Nevada

Environmental

Restoration

Project

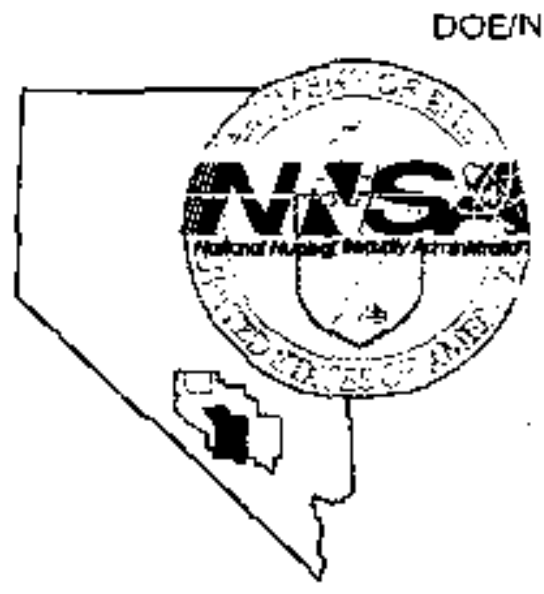

Closure Report for

Corrective Action Unit 254:

Area 25, R-MAD Decontamination

Facility,

Nevada Test Site, Nevada

Controlled Copy No.:

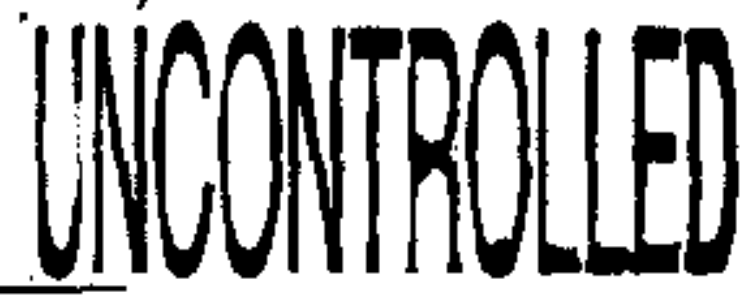

Revision: 0

February 2002

This report contains information that is protected by the Privacy Act of 1974.

Environmental Restoration

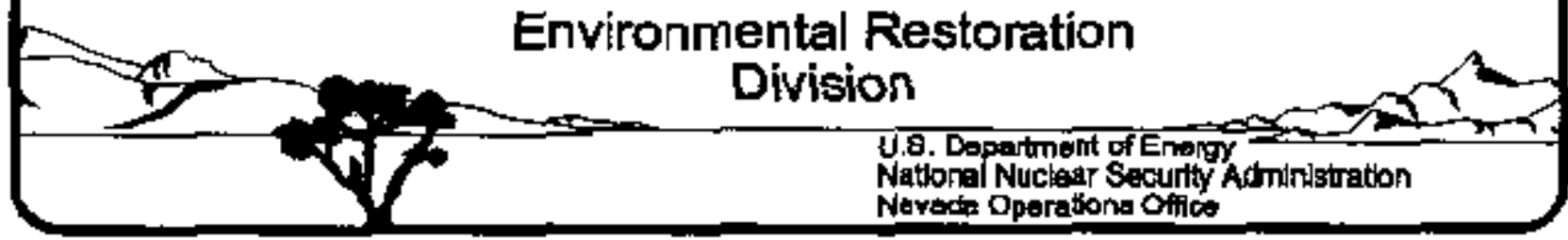




\section{DISCLAIMER STATEMENT}

Reference herein to any specific commercial product, process, or service by trade name, trademark, manufacturer, or othetwise, does not necessarily constitute or imply its endorsement, recommendation, or favoring by the U.S. Government or any agency thereof or its contractors or subconiractors.

\section{AVALABILITY STATEMENT}

Available for sale to the public from-

U.S. Department of Commerce

National Technical Information Service

5285 Port Royal Road

Springfield, VA 22161

Phone: 800.553 .6847

Fax: 703.605 .6900

EmaiI: orders@ntis.fedworld.gov

Online ordering: hthp:/\%ww,ntis, goviordering.htm

Available electronically at htp:/iwww.doe.gov.bridge

A vailable for a processing fec to U.S. Departnent of Energy and its contractors, in paper, fromU.S. Depariment of Energy

Dffice of Scientific and Techrical Information

P.O. Box 62

Oak Ridge, TN 37831-0062

Phonę: 865.576.8401

Fax: 865.576 .5728

Emait: teports ardanis.osti.you 


\title{
CLOSURE REPORT FOR CORRECTIVE ACTION UNIT 254: AREA 25 R-MAD DECONTAMINATION FACILITY, NEVADA TEST SITE, NEVADA
}

\author{
Prepared for: \\ U.S. Department of Energy \\ National Nuclear Security Administration \\ Nevada Operations Office \\ Under Contract No. DE-AC08-96-NV11718
}

Controlled Copy No.

Revision: 0

February 2002 
THIS PAGE INIENTIONAILY LEFT BLANK

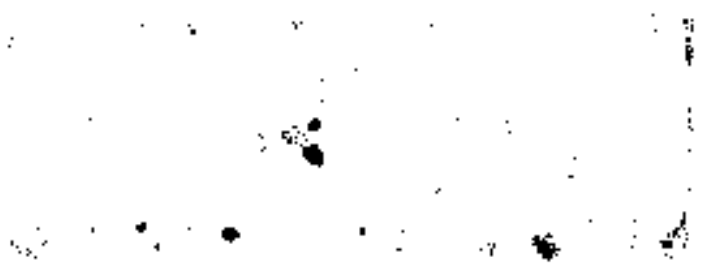




\section{CLOSURE REPORT FOR CORRECTIVE ACTION UNIT 254: AREA 25 R-MAD DECONT AMINATION FACILITY, NEVADA TEST SITE, NEVADA}

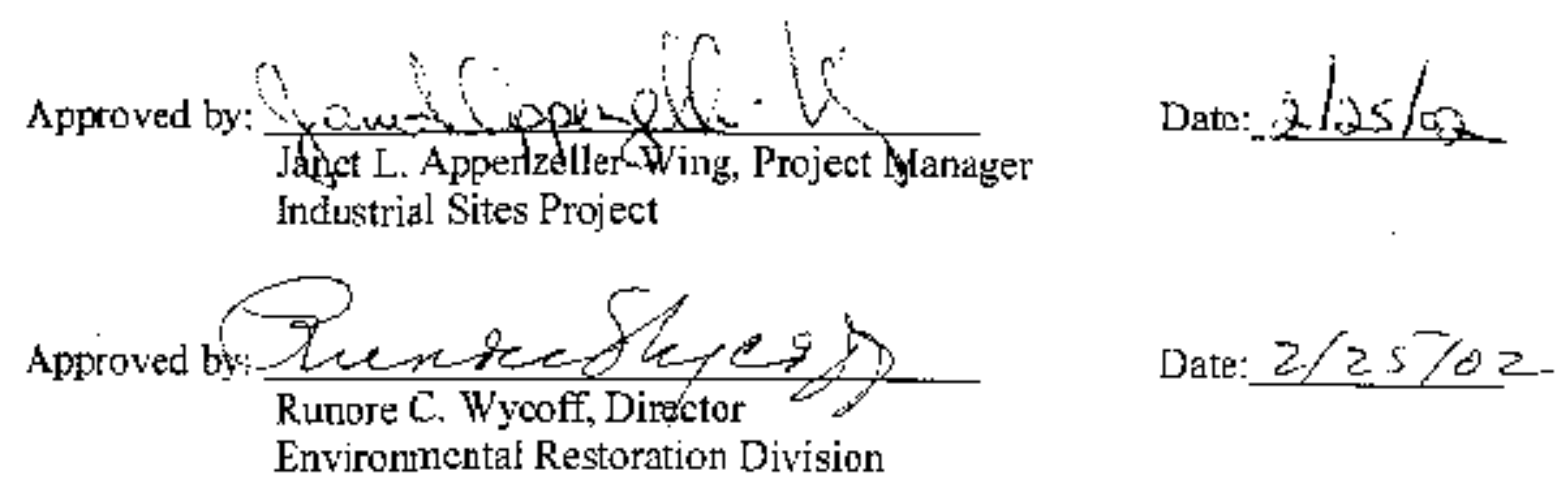


THIS PAGE INTENTIONALLY LEFT BLANK 


\section{TABLE OF CONTENTS}

EXECLTIVE SLMMARY $\ldots \ldots \ldots \ldots \ldots \ldots \ldots \ldots \ldots \ldots \ldots \ldots \ldots \ldots \ldots \ldots \ldots \ldots \ldots$

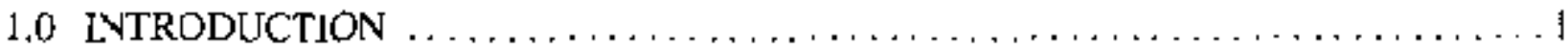

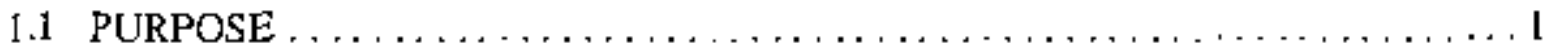

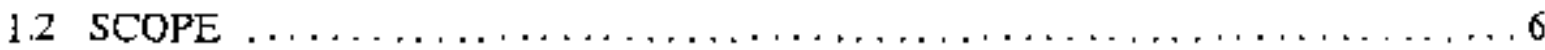

1.3 CLOSURE REPORT CONTENTS $\ldots \ldots \ldots \ldots \ldots \ldots \ldots \ldots \ldots \ldots \ldots$

2.0 STATEMENT OF WORK $\ldots \ldots \ldots \ldots \ldots \ldots \ldots \ldots \ldots \ldots \ldots \ldots \ldots \ldots$

2.1 DESCRIPTION OF CORRECTIVE ACTION ACTIVITIES $\ldots \ldots \ldots \ldots \ldots \ldots .9$

2.1 .1 Planning, Site Preparation, and Pemits $\ldots \ldots \ldots \ldots \ldots \ldots \ldots \ldots$

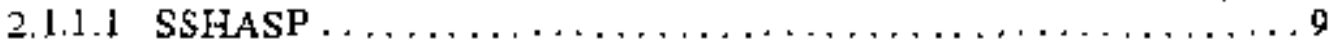

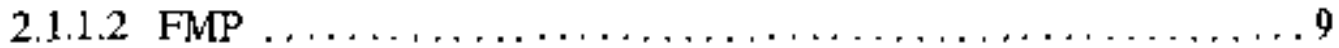

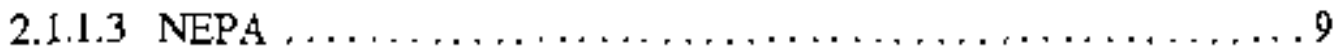

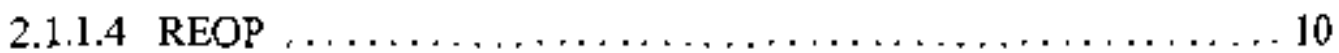

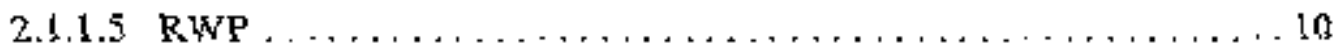

2.1.I.6 Utility Clearances and Excavation Permits . . . . . . . . . 10

2.1 .2 Field Activities $\ldots \ldots \ldots \ldots \ldots \ldots \ldots \ldots \ldots \ldots \ldots \ldots \ldots \ldots, \ldots \ldots$

2.1.2.1 Perfomed Radiological Surveys $\ldots \ldots \ldots \ldots \ldots \ldots \ldots \ldots \ldots$

2.1 .2 .2 Expanded Fenced Area and Move Debris . . . . . . . . . . . 11

2.1.2.4 Disconnected Electrical and Water Sources . . . . . . . . . 14

2.1.2.5 Identilied and Encapsulated Asbestos-Containing Materials . . . . l4

2.1.2.6 Removed and Segregated Building Materials . . . . . . . . . 14

2.1.2.7 Removed Impacted Suils and Sediments . . . . . . . . . . . 14

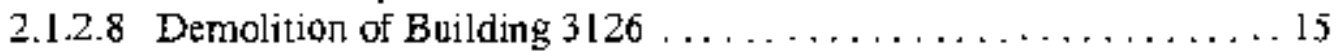

2.1.2.9 Grouted Underground Piping . . . . . . . . . . . . . 15

2.1.2.10 Removed Surface of Concrete Foundation ............ 15

2.1.2,11 Decontaminated Equípment, Removed Fence, and Released Site

2.2 DEYIATIONS FRDM CAP AS APPROVED $\ldots \ldots \ldots \ldots \ldots \ldots \ldots \ldots$

2.3 CORRECTIVE ACTION SCHEDULE AS COMPLETED . . . . . . . . . . . 19

$2.3,1$ Field Work Corrective Action Schedule $\ldots \ldots \ldots \ldots \ldots \ldots \ldots \ldots \ldots, \ldots$

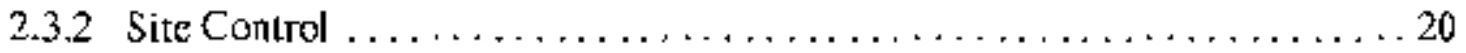

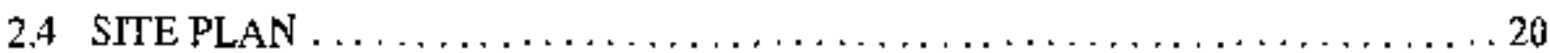

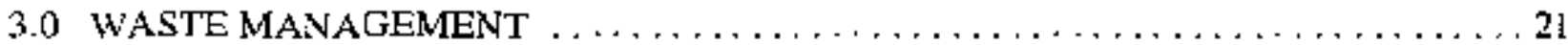

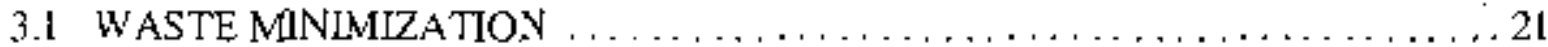

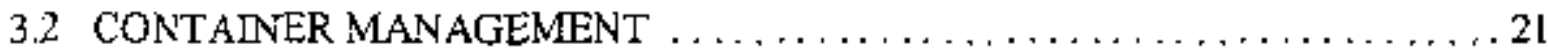

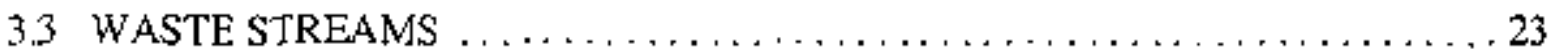

3.3.J Construction Wastes (NTS Class $\amalg$ Wasles) . . . . . . . . . . . 23

3.3.1.1 General Debris . . . . . . . . . . . . . . . . . . . . . . 23

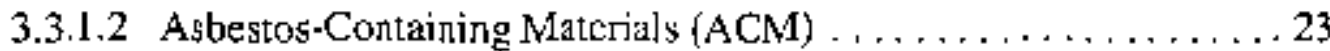

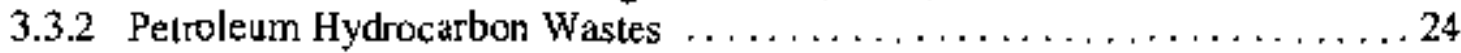

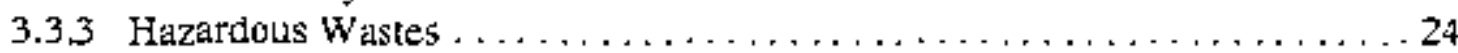

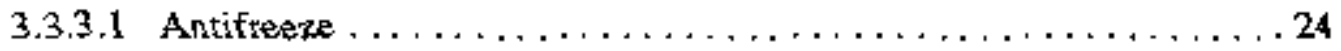




\section{TABLE OF CONTENTS (Continued)}

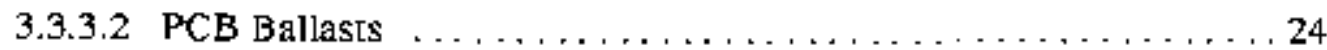

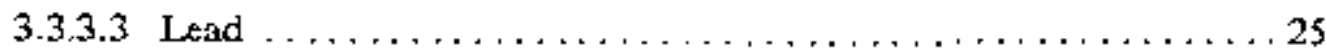

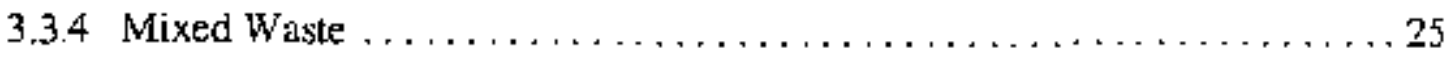

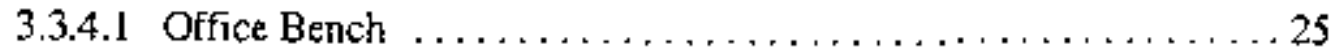

3.3 .4 .2 Decontamination Bay Air Filters $\ldots \ldots \ldots \ldots \ldots \ldots \ldots \ldots \ldots \ldots \ldots \ldots$

3.3.4.3 East Decon Bay Concreke and Decan Bay Floor Cuncrete . . . . . 25

3.3.4.4 Compressor Conerete Pad . . . . . . . . . . . . . . 26

3.3.4.5 Compressor Room Drain Sediments ............... 26

3.3.4.6 Railroad Ties South of Building $3126 \ldots \ldots \ldots \ldots \ldots \ldots \ldots . \ldots 26$

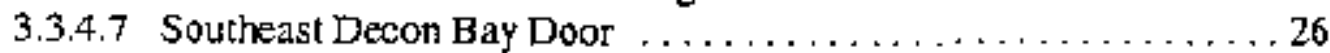

3.3.4.8 South and Northwest Decon Bay Door $\ldots \ldots \ldots \ldots \ldots \ldots \ldots 26$

3.3 .4 .9 Northwest Decon Bay Door $\ldots \ldots \ldots \ldots \ldots \ldots \ldots \ldots \ldots \ldots$ ?

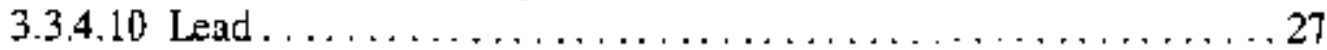

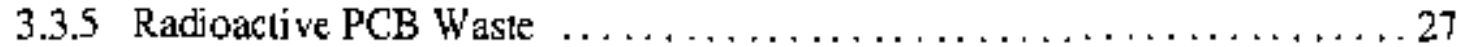

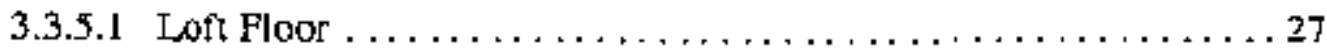

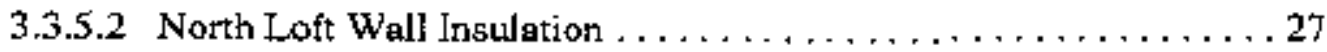

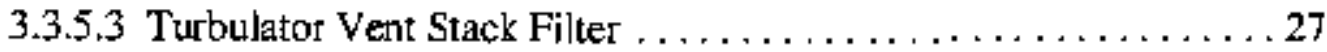

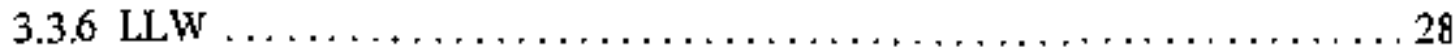

3.3.6.1 Demolition Debris and Equipment $\ldots \ldots \ldots \ldots \ldots \ldots \ldots \ldots 28$

3.3.6.2 Decontamination Pad Concrete $\ldots \ldots \ldots \ldots \ldots \ldots \ldots \ldots \ldots \ldots . \ldots \ldots 28$

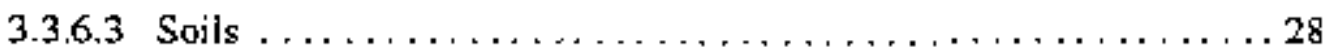

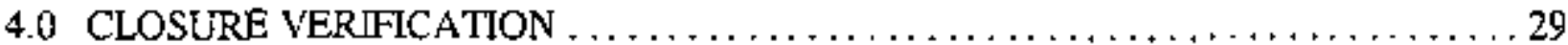

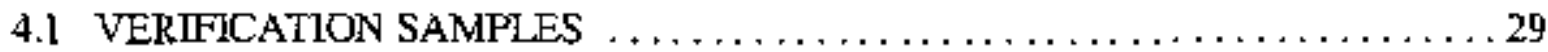

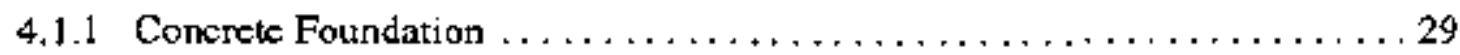

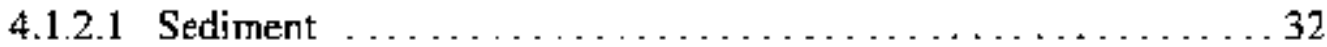

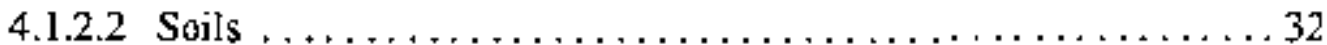

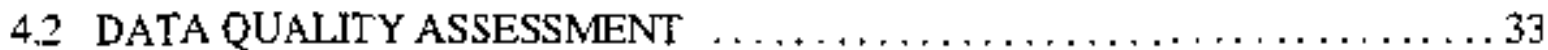

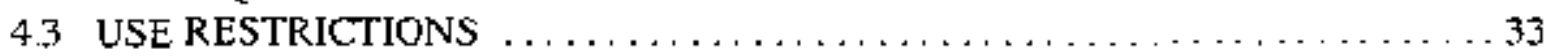

5.0 CONCLUSIONS AND RECOMMENDATIONS $\ldots \ldots \ldots \ldots \ldots \ldots \ldots \ldots \ldots \ldots . \ldots \ldots$ 


\title{
TABLE OF CONTENTS (Continued)
}

\section{APPENDICES}

\author{
APPENDIX A AS-BUILT DRAWINGS \\ APPENDLX B WASTE PROFILES \\ APPENDIX C VERFICATION SAMPLES ANALYTICAL DATA \\ APPENDIX D WASTE DISPOSITION DOCUMENTATION \\ APPENDIX E RECORD OF TECHNTCAL CHANGES (ROTCs) \\ APPENDIX F USE RESTRICTION INFORMATION \\ APPENDIX G COPIES OF FEID NOTES \\ APPENDIX H PROIECT ORGANIZATION \\ APPENDIX I COMMENT RESPONSE DOCUMENTATION \\ DISTRIBUTTON LIST
}

\section{FIGURES}

FIGURE 1 LOCATTON OF THE NTS, AREA 25. AND CAU 254. R-MAD

DECONTAMNATHON FACILITY $\ldots \ldots \ldots \ldots \ldots \ldots \ldots \ldots \ldots, \ldots$

FIGURE 2 LOCATION OF THE AREA 25 R-MAD COMPOUND $\ldots \ldots \ldots \ldots \ldots \ldots$

FIGURE 3 SITE PLAN OF CAU 254 IN THE R-MAD COMPOUND $\ldots \ldots \ldots \ldots \ldots 4$

FIGURE 4 SITE PLAN OF BUILDING 3126, CAU 254, AREA 25 R-MAD

DECONTAMINATION FACILITY $\ldots \ldots \ldots \ldots \ldots \ldots \ldots \ldots \ldots \ldots, 5$

FIGURE 5 FINAL RADIOLOGICAL VERIFICATION SURVEY; SOLLS $\ldots \ldots \ldots \ldots, 12$

FIGURE 6 FINAL RADIOLOGIC VERIFICATION SURVEY; CONCRETE $\ldots \ldots \ldots 13$

FIGURE 7 AREAL EXTENT AND VOLUMES OF EXCAVATED SOILS, RADIOLOGIC VERIFICATION SAMPLE LOCATIONS, AND GAMMA SPECTOMETRY AND ISOCS ANALYTICAL RESULTS $\ldots \ldots \ldots \ldots \ldots \ldots \ldots \ldots, 16$ 


\section{TABLE OF CONTENTS (Continued)}

\section{FIGURES (Continued)}

FIGLRE 8 VERIFICATION SAMPLE LOCATIONS AND ANALYTICAL RESULTS:

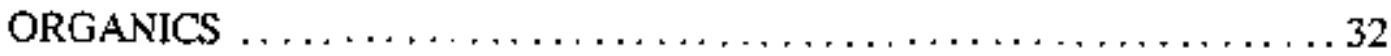

FIGURE 9 VERIFICATION SAMPLE LOCATIONS AND ANALYTICAL RESULTS:

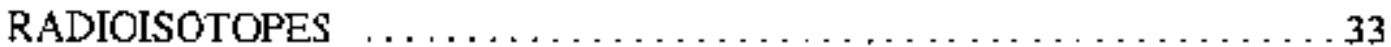

\section{TABLES}

TABLE 1 ALLOWABLE TOTAL RESIDUAL SURFACE CONTAMINATION

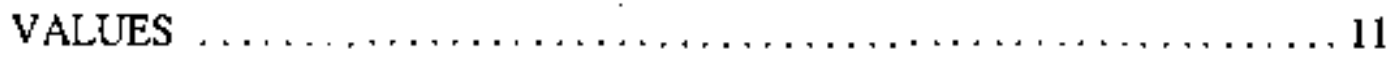

TABLE 2 GAMMA SPECTOMETRY ANALYTICAL RESULTS; RADIOLOGICAL

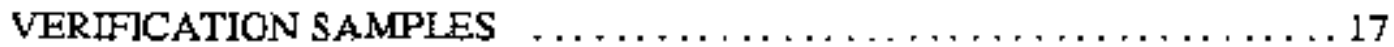

TABLE 3 ANALYTICAL RESULTS FOR RADIOLOGIC VERIFICATION SAMPLES 18

TABLE 4 MLXED AND LOW LEVEL WASTE STREAMS GENERATED DURING CLOSURE ACTIVITIES 


\section{ACRONYMS AND ABBREVIATIONS}

\begin{tabular}{|c|c|}
\hline $\mathrm{ACM}$ & Asbestos-containing Material \\
\hline AST & Above-ground Storage Tank \\
\hline $\mathrm{BN}$ & Bechtel Nevada \\
\hline BGS & Below Ground Surface \\
\hline${ }^{\circ} \mathrm{C}$ & degrees Celcius \\
\hline CADD & Corrective Action Decision Document \\
\hline $\mathrm{CAP}$ & Corrective Action Plan \\
\hline CAS & Corrective Action Site \\
\hline CAU & Corrective Action Unit \\
\hline $\operatorname{cm}$ & centimeter \\
\hline $\operatorname{cm}^{2}$ & square centimeter \\
\hline CR & Closure Report \\
\hline Cs & Cesium-137 \\
\hline CSS & Construction Site Superintendent \\
\hline DOENV & U. S. Department of Energy, Nevada Operations Office \\
\hline dpri & disinuegrations per minute \\
\hline EPA & U.S. Environmental Protection Agency \\
\hline ER & Enyironmental Restoration \\
\hline $\mathrm{EZ}$ & Exclusion Zone \\
\hline FFACO & Federal Facility Agreement and Consent Order \\
\hline FIDLER & Field Instrument for the Detection of Low Energy Radiation \\
\hline EMP & Field Management Plan \\
\hline $\mathrm{ft}$ & feet/foot \\
\hline $\mathrm{ft}^{2}$ & square feet \\
\hline gal & gallon \\
\hline $\mathrm{HSO}$ & Health and Safety Officer \\
\hline in & Inches \\
\hline $\operatorname{in}^{2}$ & square inches \\
\hline ISOCS & In-Situ Object Counting System \\
\hline IT & Interiational Technologies \\
\hline K & thousand \\
\hline $\mathrm{Kg}$ & kilogran \\
\hline $\mathrm{km}$ & kilometers \\
\hline
\end{tabular}


L

lbs

LDR

LLW

$\mathrm{m}$

$\mathrm{m}^{2}$

$\mathrm{m}^{3}$

MDA

$\mathrm{mg} / \mathrm{kg}$

MW

NDEP

NEPA

NNSA

NTS

PAL

PCB

$\mathrm{pCi} / \mathrm{g}$

PPE

PRG

QC

R-MAD

RadCon

RCRA

REOP

RMA

ROTC

RWMS

RWP

SSHASP

SZ

TPH

TRU

TSCA liter

pounds

Land Disposal Restrictions

low-level waste

meter

square meter

cubic meter

Minimum Detectable Activity

milligram per kilogram

Mixed Waste

Nevada Division of Environmental Protection

National Environmental Policy Act

National Nuclear Security Administration

Nevada Test Site

Preliminary Action Level

Polychlotinated Biphenyls

picocuries per gram

Personal Protective Equipment

Preliminary Remediation Goal

Quality Control

Reactor Maintenance, Assembly, and Disassembly

Radiological Control

Resource Conservation and Recovery Act

Real Esrate/Operartons Permit

Radioactive Materials Area

Record of Technical Change

Radioactive Waste Management Site

Radiological Work Permit

Site-Specific Health and Safety Plan

Support Zone

totat petroleum hydrocarbons

TransUranic

Toxte Substance Conlrol Act 


\section{ACRONYMS AND ABBREVIATIONS (Continued)}

T'SD

UTS

VOC

WMA

$y d^{3}$
Treatment, Storage, and Disposal Factity

Universal Treatment Standard

volatile orgaric compound

Waste Maragement Area

cubic yard 
CLOSURE REPORT - CAU 254

Section: Acronyms

Revisian: 0

Febrairy 200 ?

THIS PAGE LEFT INTENTIONALLY BLANK 
The Area 25 Reactor Maintenance. Assembly, and Disassembly (R-MAD) Decontamination Facility is identified in the Federal Facility Agreement and Consent Order of 1996 (FFACO) as Corrective Action Unit (CAU) 254. CAU 254 is located in Area 25 of the Nevada Test Site (NTS) and consists of a single Corrective Action Sice (CAS), CAS 25-23-06. CAU 254 was closed in accordance with the Comective Action Plan (CAP) for CAU 254, R-MAD Decontamination Facility (U. S. Department of Energy, Nevada Operations Office [DOE/NV]. 2000a).

CAU 254 was historically used to perfom radiological decontamination. The facility consisled of Building 3126, two outdoor decontamination pads, and surrounding soil within an existing perimeter fence. The site was used to decontaminate nuclear rocket test-car hardware and tooling from the early 1960 s through the early 1970s, and to decontaninate a military tank in the early 1980s.

Site characterization data indicated that, in places, the surficial soil and building materials exceeded clean-up criteria for organic compounds, metals, and radionuclides. Closure activities getnerated waste streans consisting of nonhazardous construction waste, petroleum hydrocarbon waste, hazardous waste, low-level radioactive waste (LLW), and mixed waste (MW). Some of the wastes exceeded land disposal restriction (LDR) limits and required off-site treament before disposal.

The recommended corrective action was revised from Alternative 2, Untestricted Release Decontamination and Verification Survey to Corrective Action Alternative 3 - Unrestricted Release Decontamina(ion, Verification Survey, and Dismantle Bujlding 3126 , in an addendum to the Correction Action Decision Document (CADD) (DOENV, 2000c). 
CLOSURE REPORT - CAU 254

Section: Execuive Summary

Revision: 0

Fetruary: 2001

THIS PAGE INTENTIONALLY LEFT BLANK 


\subsection{INTRODUCTION}

Corrective Action Unit (CAU) 254 is located in Area 25 of the Nevada Test Site (NTS), approximately 100 kilorbeters (km) (62 miles [mi]) northwest of Las Vegas, Nevida (Figure 1). The site is located within the ReactorMaintenance. Assernbly and Dissassembly (R-MAD) compound (Figute 2) and consists of Building 3126, two outdoor decontamination pads, and surrounding areas within an existing fenced area measuring approximately $50 \times 37$ meters (m) $(160 \times 120$ feer [ft]) (Figures 3 and 4). The site was used from the early 1960 s to the ear]y [970s as patt of the Nuclear Rocket Development Station program to decontaminate test-car hardware and tooling. The site was reactivated in the early 1980 s to decontaninate a radiologically contaminated military tank.

\subsection{PURPOSE}

This Closure Report (CR) describes the closure activities performed to allow un-restricted release of the R-MAD Decontanination Facility. The site is identified in the Federal Facility Agreement and Consent Order (FFACO) as CAL 254, which consists of Corrective Action Site (CAS) 25-23-06, Decontamination Facility. Remediation of CAU 254 and CAS 25-23-06 is required under the FFACO (EFACO, 1996). The CR also provides the analytical and radiological survey data to confirm that the closure activities were performed as specified in the Conective Action Plan (CAP) (U. S. Department of Energy, Nevada Operations Office [DOE/NV], 2000a).

The Comective Action Investigation. Plar (DOENV, 1999a) described the site histery, outlined a site characterization plan, and proposed Preliminary Action Levels (PAIs) as clean-up goats to achieve restricted release. Site characterization acti vities were perfomed in January and February 2000, and reported in the Corrective Action Decision Document (CADD) (DOE/NV, 2000b). The Nevada Division of Ervironmema Protection (NDEP) approved the CADD (DOE/NV, 2000b), which recommended Corrective Action Alternative 2 - Unrestricted Release Decontamination and Verification Survey. This decision to leave Building 3126 standing was changed to removal of Building 3126 in an addendum (DOE $\mathrm{NV}, 2000 \mathrm{c}$ ), which recommends Corrective Action Alternative 3 - Unrestricted Release Decontamination, Verification Survey, and Dismantle Building 3126. Use restrictions will include prohibiting intrusive activities into, and bencath, the concrete foundation and surrounding soil. 


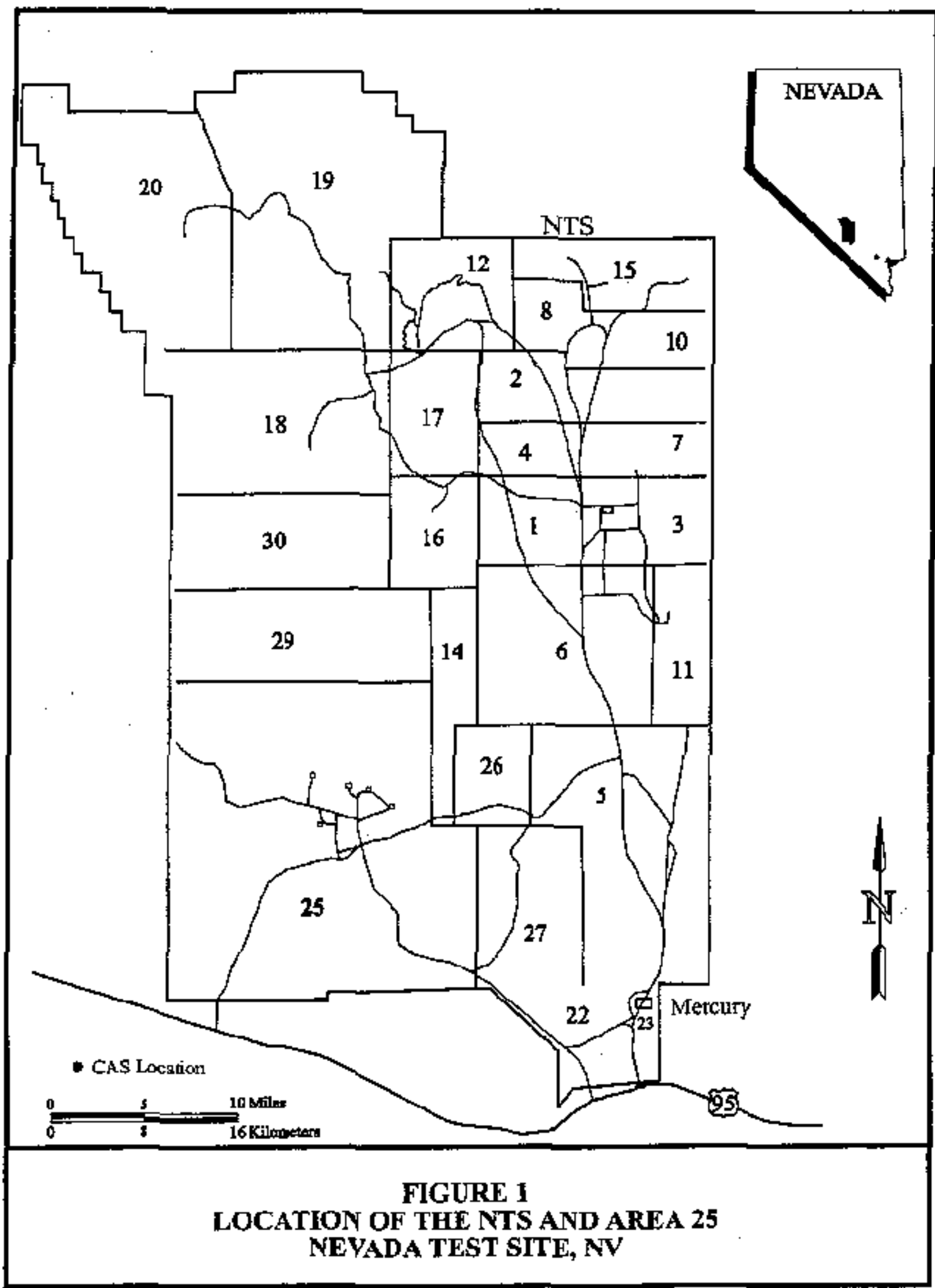




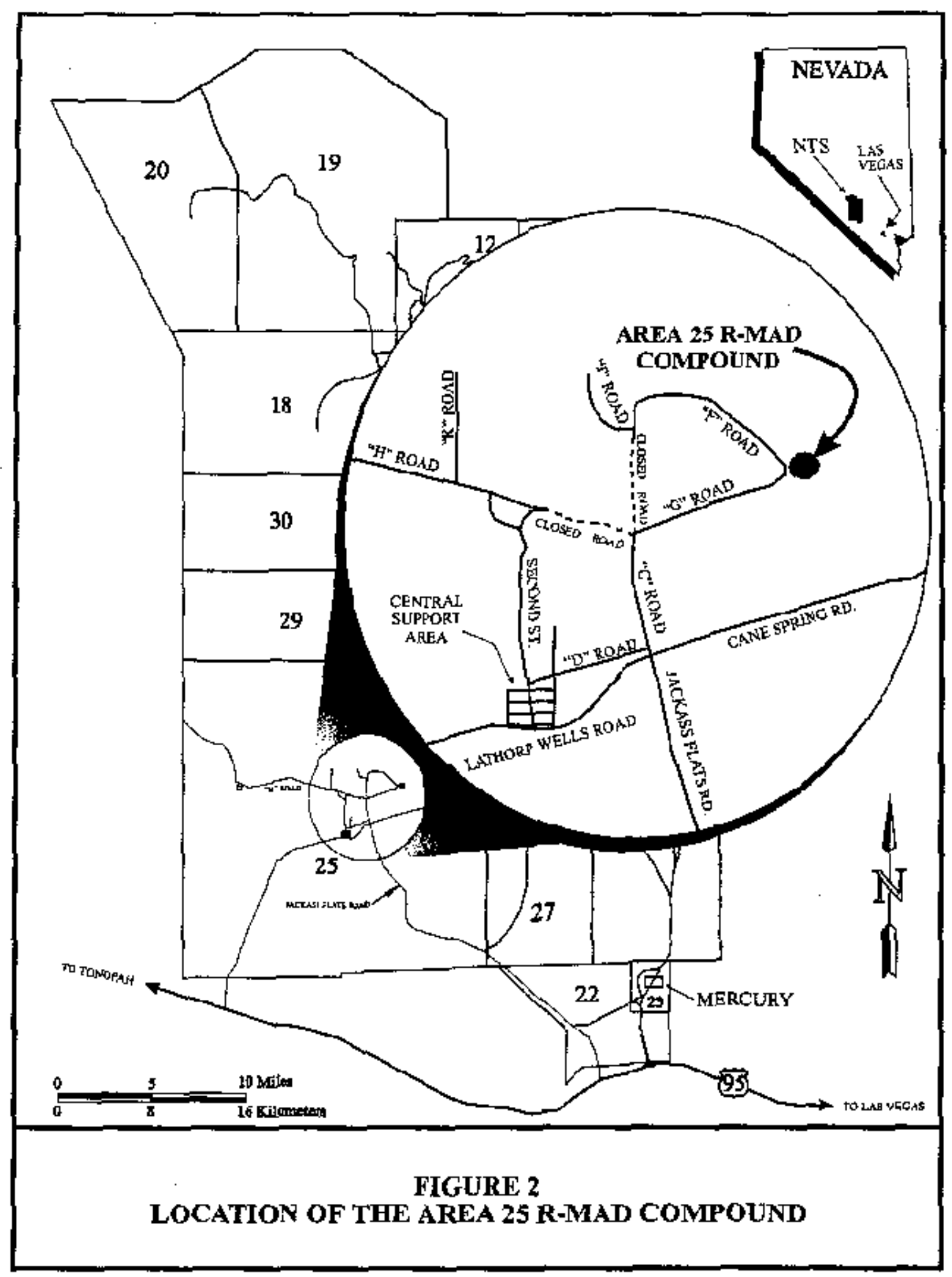




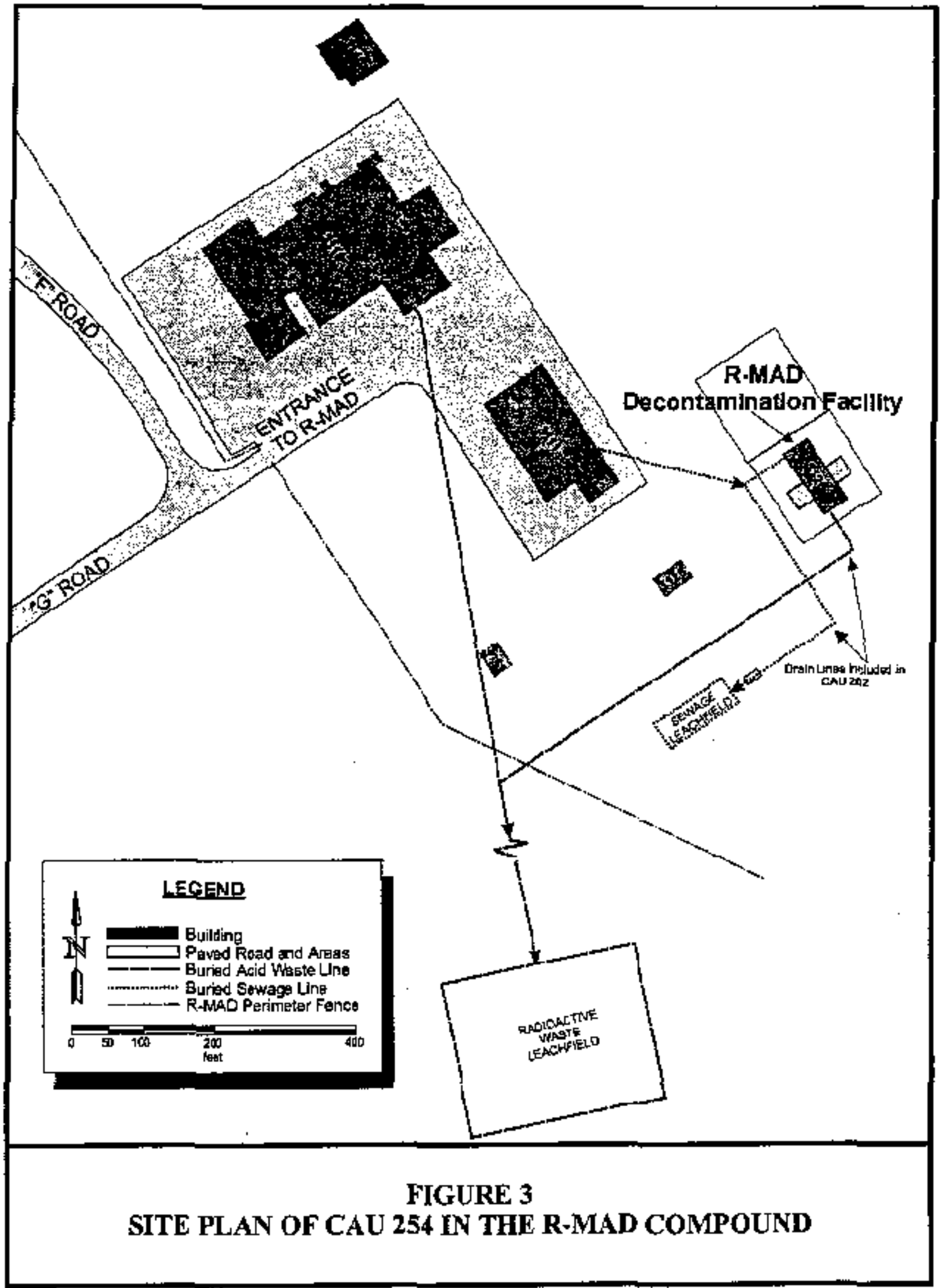




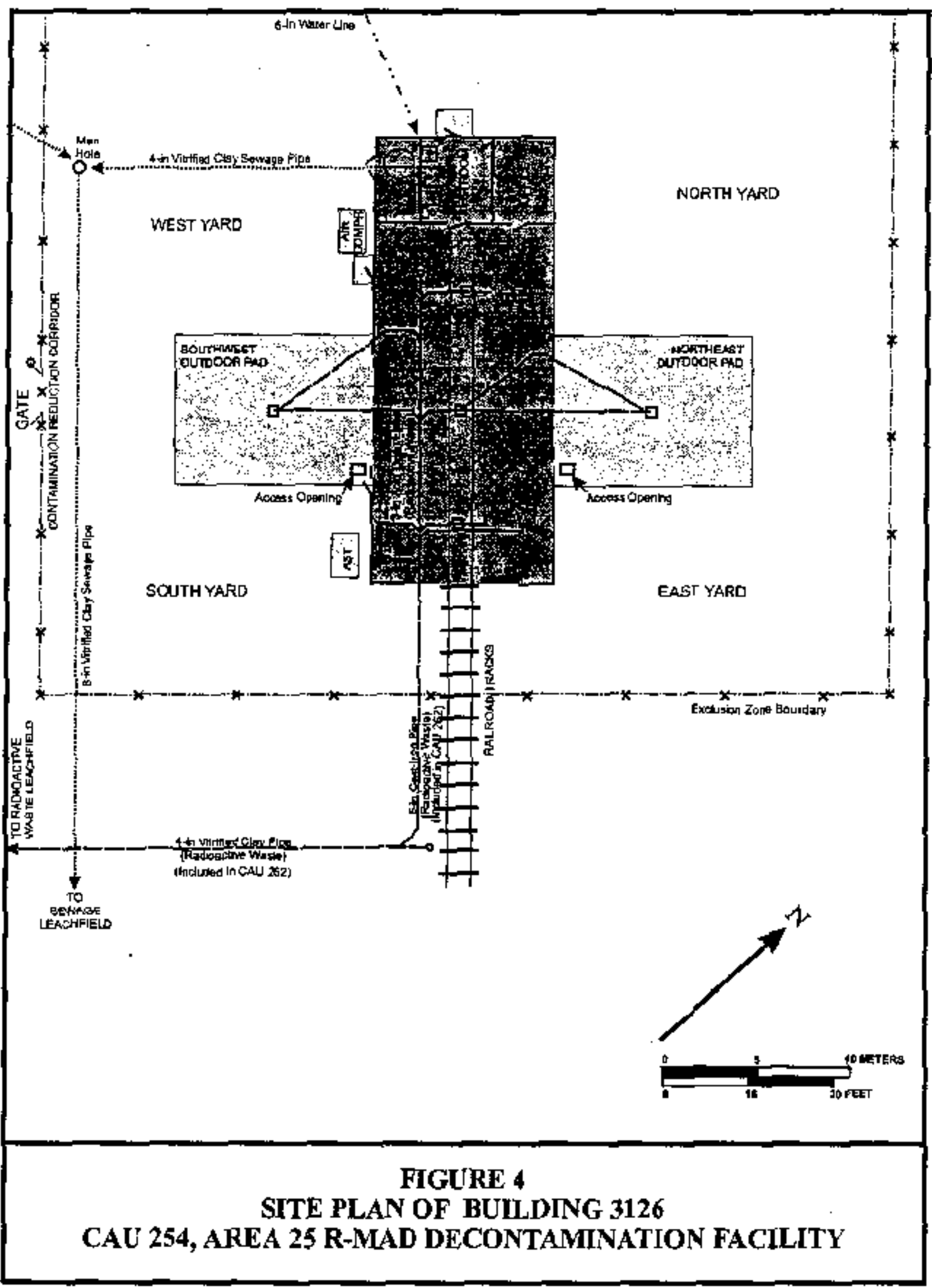




\subsection{SCOPE}

The purpose of Conrctive Action Altentative 3, as reconmended in the CADD Addendum (DOE/NV, 2000b), was to achieve closure through the following activities:

- Removal and disposal of contaminated soil and building materials.

- Verification that all contaminated soil and building materials have been removed.

The scope of work for closure of CAU 254 included the following fieid activities:

- Performed initial radiological surveys.

- Expanded fenced area and moved debris.

- Performed Hantavirus cleanup and removed roots.

- Disconnected electrical and water sources.

- Removed and encapsulated asbestos-containing materials (ACMs).

- Removed and segregated building materials.

- Removed impacted sediment and surficial soil.

- Demolished Building 3126.

- Grouted underground piping.

- Removed the radiologically contaminated surface of concrete foundation.

- Disposed of all waste generated during closure activities.

- Perfonned final radiological survey.

- Decontaminared equipment, removed fence, and requested release of site.

The soil beneath the concrete foundation was not investigated in the site charactetization nor was it included in the approved altexnative (DOE/NV, 2000a). The acid drain lines in the concrete foundation were grouted in the site characterization investigation (Bechtel Nevada [BN], 2000b) and are not included in the amended approved alternative (DOE/NV, 2000c). Site closure will, therefore, allow unrestricted access and use of the site above the ground surface but will include use restrictions to prohibit intrusive activittes into, and bepearth, the concrete foundaion. 


\section{CLOSURE REPORT CONTENTS}

This CR is divided into the following sections:

- Section 1.0 - Ineroduction

- Section 2.0-Statement of Wotk

- Section 3.0-Waste Management

- Section 4.0-Closute Verification Results

- Section 5.0-Use Restrictions

- Section 6.0-References

The following sections and appendices, as outlined in the FFACO, have not been included:

- Section 4.0 - Post-Closure Plan (Inspections, Monitoring, Maintenance and Repair)

This section is not necessary pending approval of closure in place. Site closure will ailow unrestricted access and use of the site above the ground surface, but will include use restrictions to prohibit intrusive actirities into, and beneath, the concrete foundation.

- Appendix A - Engineering Speciffcations and Drawings.

This appendix is not warranled for the site as there are no construction or engineered cover requirements for closure.

- Appendix B - Sampling and Analysis Plan

The sampling and anziysis requirements for the site are detailed in Section 4.0, Closure Verification Results. A separate sampling and analysis plan, therefore, is not included as an appendix.

The appendices included in this document ate provided as follows:

Appendix A

AS-BUILT DRAWINGS

Appendix B

WASTE PROFHES

Appendix C

VERIFICATION SAMPLES ANALYTICAL DATA
WASTE DISPOSITION DOCUMENTATION 
Appendix E RECORD OF TECHNICAL CHANGES (ROTCs)

Appendix F $\quad$ LSE RESTRICTION INFORMATION

Appendix G COPIES OF FIELD NOTES

Appendix H PROJECT ORGANIZATION

Appendix $1 \quad$ COMALETT RESPONSE DOCUMENTATION

Distribution List

This report was primarily developed using information and guidance frotn the following documents:

- Bechtel Nevada, 2000. Waste Management Plan for Conective Action Unit 254. Area 25 R-MAD Decontamination Facjlity, Nevada Test Site, Nevada, Las Vegas, NV.

- Federal Facility Agreement and Consent Order, 1996. Agreed to by the Nevada Division of Environmental Protection, the U.S. Department of Energy, and the U.S. Department of Defense.

- U.S. Depattment of Energy, Nevada Operations Office, 1999a. Corrective Action Inyestigation Plan for Corrective Action Unit 254: Area 25 R-MAD Decontamination Facility Nevada Test Sire Nevada, DOE/NV--557, Las Vegas, NV.

- U.S. Department of Energy, Nevada Operations Office, 2000a, Corrective Action Plan for Corrective Action Unit 254: Ares 25 R-MAD Decontamination Facility Nevada Test Site, Nevgda, DOENV--678, Las Yegas, NV.

- U.S. Department of Energy, Nevada Operations Office, 2000b. Corrective Action Decision Document for Corrective Action Unit 254: Area 25 R-MAD Decontamination Faciljt, Nevada Test Sje, Nevada DOENV--619, Las Vegas, NV.

- U.S. Department of Energy. Nevada Operations Oftice, 2000c. Addendumio Correcive Action Decision Document for Corrective Action Unit 254: Area 25 R-MAD Decontamination Facility, Nevada Test Site, Nevada, DOENNV--619-ADD, Las Vegas, NY. 


\subsection{STATEMENT OF WORK}

\subsection{DESCRIPTION OF CORRECTIVE ACTION ACTIVITIES}

This section describes how the approved corrective action altemative, unrestricted rejease decontamination and verification survey, was implemented.

As previously discussed, the correction action altemative recommended in the CADD (DOE/NV, $2000 \mathrm{~b}$ ) was changed to Altematfe 3 in an addendum (DOE/NV, 2000a) which added the remoyal of Building 3126. The scope of the approved altenative consisted of the following activities.

\subsubsection{PlannIag, Site Preparation, and Permits}

Prior to beginning corective action field activities, planning documents and permits were prepated. These documents include the Site-Specific Health and Safety Plan (SSHASP), Field Management Plan (FMP), National Envirommental Policy Act (NEPA) Checklist, Real Estate/Operations Pemit (REOP), Radiological Work Permit (RWP), utility clearance, and excavation permit.

\subsubsection{SSHASP}

A SSHASP (including a Preliminury Hazard Analysis and Hazard Assessment) was prepared and a copy was kept at the site by the BN Environmental Restoration (ER) Health and Safety Officer (HSO). The SSHASP was reviewed and signed by all workers priot to begining work. The HSO also maintained a material safety data sheet file for all chemicals brought to the site. The SSHASP provided a detailed, job-specific plan covering physical and environmental hazards, protection against accidents, and exposure of workers to contamination. It also discussed weather and air monitoing, accident reponing, and emergency procedures. Additional copits of the SSHASP are filed in the BN ER and Environment, Safery, and Health Division offices in Mercury, Nevada.

\subsubsection{FMIP}

A FMP was prepared for the closure activities. The FMP oudlined how the work was to be performed and inciuded an integraced safecy manngement plan and a detailed schedule for the project. In addition, the FMP identified responsible parties for each aspect of the project and indicated how decisions were be made. Copies of the FMP were available at the site and are inled in the BN ER office in Mereury, Nevada.

\subsubsection{NEPA}

A NEPA Checklist was completed prior to and after all excayation activities at the sine. Based on the findings of these strveys, excavation acivities followed all applicable federal, state, and local lats, regulations, and pennits for protection of the environment. 


\subsubsection{REOP}

A REOP was obtained prior to beginning closure activities. The permit established DOE/NV as the prime autbority possessing control of the site and accomplished the following:

- Established a sole governing organization responsible for safety.

- Identified hazards and controls associated with field operations pertinent to the site.

- Identified the hazardous materials located al the site for emergency response purposes.

- Ensured that DOENV reviewed and approved all work conducted in association with the site.

- Identified DOE/NV`s responsibility to plan and schedule activitles.

- Provided a mechanism to recover applicable infrastructure support costs.

\subsubsection{RWP}

RWPs were prepared and approved for the purpose of informing workers of the specific personal protective equipment (PPE) necessary to protect them while performing their tasks. The workers were required to read the permits and acknowledge their understanding of the requirements before entry into the exclusion zone. The RWPs were maintained by the radiological control personnel at the entrance to the site. All site workers were requlred to be Radiation Worker $I$ trained in order to perform any work on-site.

\subsubsection{Utility Clearances and Excavation Permits}

A utility clearance was performed and an excavation permit was obtained prior to beginning excavation activities. A copy of the permit was filed on-site throughout the duration of the project.

\subsubsection{Field Activities}

\subsubsection{Performed Radiological Surveys}

Radiological surveys were performed continuously during closure activities to determine the presence and/or location of radiological impact, verify cleanup, monitor worker exposures, and determine waste disposition. Pre- and post-remediation radiological surveys were performed using the NE Electra (alpha/beta), Field Instrument for the Detection of Low Energy Ratiation (FWLER), and the Ludlum 101and Geiger-Mueller Pancake detectors. The Tennelec LowBackground Counter, and In-Situ Objec1 Counting System (ISOCS) technologies were used to obtain quantitative measurements from verification sample locations in remediated areas.

Hand-held survey instruments were calibrated to background levels by obtaining an integrated background reading in a similar environment, on similar materials to be remediated (i.e., background calibration was performed on a concrete surface free of impact when the day's activities required surveying the slab). These readings were acquatred by identifying an area 
known to be frec of radiological contamination and marking ofs a 1-square meter $\left(\mathrm{m}^{2}\right)$ (10.6- square feet $\left[\mathrm{ft}^{2} \mathrm{l}\right.$ ) grid. The instrument was ther continuously moved over the grid for one minute. This procedure produced an average (integrated) reading of the background radiation present outside of the CAS boundaries. Instrments were also source-checked on a daily busis.

Radiological surveys were pertormed by demarcating the area to be remediated in $4 \mathrm{~m}^{2}\left(43-\mathrm{ft}^{2}\right)$ grids for soil excavations, and $1-\mathrm{m}^{2}$ grids $\left(10.6-\mathrm{ft}^{2}\right)$ for the concrete pad. Both the FIDLER and the Ludium 101 Pancake instruments were used to perfom an initial radiological survey. Data produced from this survey was compared to the values listed in Table 4-2 of the Radiological Control (RadCon) Manual (Table 1). Comparison of the initial survey data to those listed in Table 1 identified several "hotspots" (areas of activity greater than 15 thousand (K) disintegrations per minute [dpm]). After "holspots" werc identified and rcmoved, the areas were resurveyed. A final post-remedialion survey was then performed for both excavated areas and concrete surfaces (Figures 5 and 6 , respectively). These figures present the final net beta count recorded in dpm/100 square centimeters ( $\mathrm{cm}^{2}$ ) (15.5 square inches [in']) over background levels. Alpha counts were not performed with portable instruments due to analytical results exhibiting a 10:1 beta-to-alpha ratio. The surface contamination limits for the alpha-emitting uranium nuclides are equivalent to the beta-gamma limits for Cesium-137 and Strontium-90. Therefore, if the beta values are less than 1 hose presented in Table 1, the alpha limits cannot be exceeded. A separate alpha count is, therefore, urneccssary.

Further discussion of radiologic survey methodologies is presented in Sections 2.1,2.7, Removed Impacred Soils and Sediments, and 2.1.2. 10, Removed Surface of Concrete Foundation.

TABLE 1 ALLOWABLE TOTAL RESUDUAL SURFACE CONTAMINATION VALUES (TABILE 4-2; RADCON MANUAL)

\begin{tabular}{|c|c|c|c|}
\hline RADIONUCLIDE & 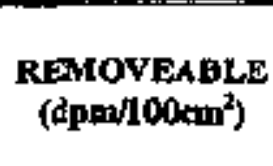 & $\begin{array}{l}\text { TOTAL (TIXED/ } \\
\text { REMOVEABLE) } \\
\text { (dpa/HODcm) }\end{array}$ & $\begin{array}{l}\text { MAXTMUM FLXED \& } \\
\text { REMOVEABLE } \\
\text { (dpm/lOAkmr') }\end{array}$ \\
\hline 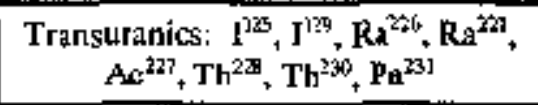 & 20 & 100 & 300 \\
\hline 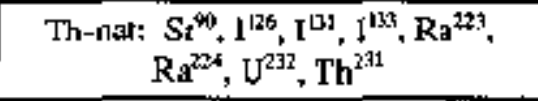 & 200 & 1,000 & 3,000 \\
\hline $\begin{array}{l}\text { U-nkt: } \mathrm{U}^{23.5}, \mathrm{U}^{2,36} \text { \& asschiated decay } \\
\text { products ensitexs }\end{array}$ & $1,000 \mathrm{a}$ & $5,0100 \alpha$ & $15,000 \propto$ \\
\hline 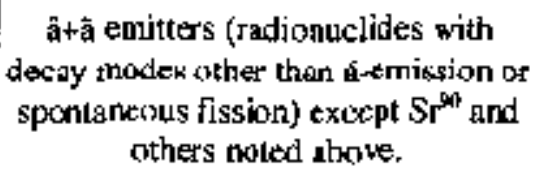 & $1,000 \alpha+\beta$ & $5,001 \alpha+\beta$ & $15,000 \alpha+\beta$ \\
\hline
\end{tabular}

\subsection{Expanded Fenced A rea and Move Debris}

In onler to provide additional room to facilitale remcdial activities, the existing fenced area was expanded to the northesi by approxinately $60 \mathrm{~m}$ ( $200 \mathrm{ft}$ ). Existing debris, located outside the northwest fence, was removed and appropriately disposed with general construction waste. 


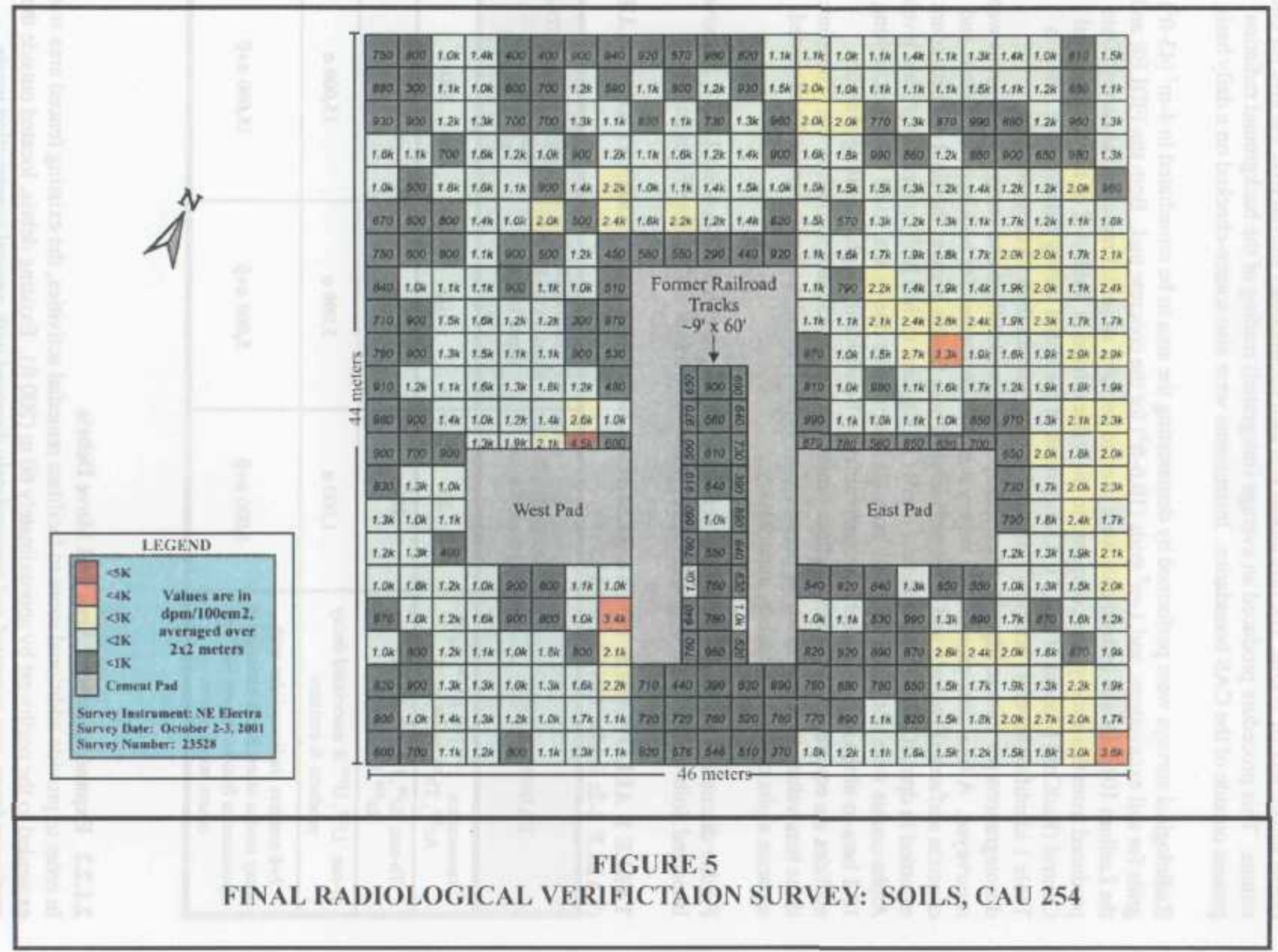




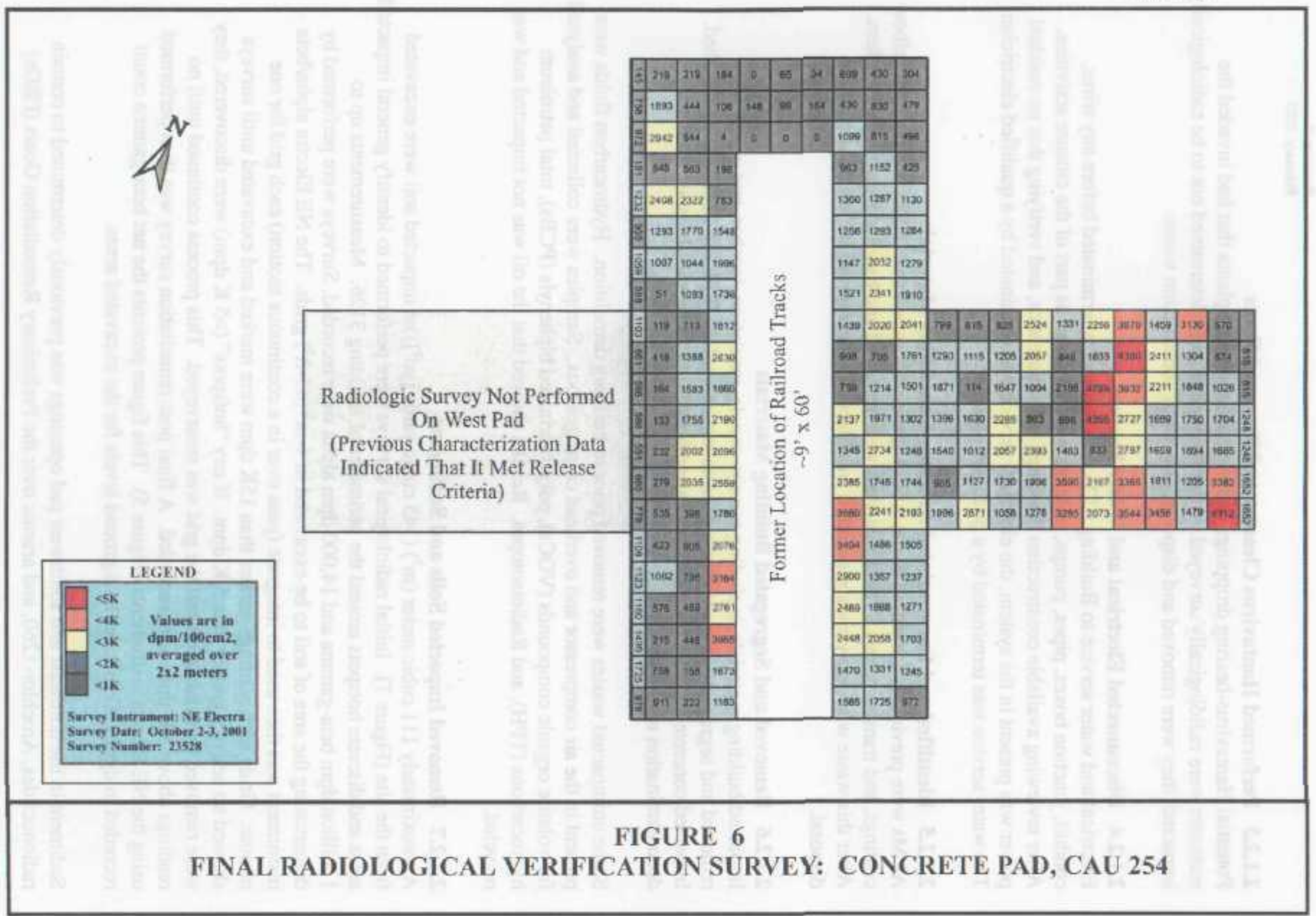




\subsubsection{Performed Hantavirus Cleanup and Removed Roots}

Fotential Hantavinus-hearing droppirigs and roots from outside plants chat had invaded the restroom were radiologically surveyed. After the wastes were determined not to be radiologically impacted, they were removed and tisposed as general construction wastc.

\subsubsection{Discomnected Electrical and Water Sources}

Electrical and water service to Building 3126 was verified as terminated before any wires, conduit, junction boxes pipes, pumps, or tanks were temoved as part of the closure activities. After reviewing available construction drawings and schematics, and verifying that no residual power was present in the system, the electrical service was terminated by a qualified electrician. The water service was terminaled by a qualified plumber.

\subsubsection{Identified and Encapsulated Asbestos-Containing Materials} ACMs were previously identified in the Above-ground Storage Tank (AST) coating, pipe-elbow coatings, and transite pancis. These materials were removed and handled by qualified workers. After this waste was safely encapsulated, it was placed in the appropriate waste strearn for disposal.

\subsubsection{Removed and Segregated Building Materials}

Impacted building materiais, including transite panels, insulation, lumber, and pipes, were removed and segregated into appropriate waste strearns before Building 3126 was demolished. Impacted concrete surfaces were removed after demolition using shot-blast or similar decontaminution methods.

Somc unimpacted wastes were removed prior to bullding demolicion. Hydrocarbon fluids were present in the air compreseor and overhead crane gearbox. Samples wcre collected and analyzed for volatile organic compounds (VOCs), polychlorinated biphenyls (PCBs), total petroleum hydrocarbons (TPH), and Radioisotopes. Results showed that the oil was not impacted and was recycled.

\subsubsection{Removed Impacted Soils and Sedinents}

Approximately 11 I cubic meter $\left(\mathrm{m}^{3}\right)\left(145\right.$ cubic yards [ $\left.\left.\mathrm{yd}^{3}\right]\right)$ of impacted soil werc excavated from the site (Figure 7). Initial radiological surveys were performed to idenlify general impacted areas and discrete holspots around the perimeter of Building 3126. Measurements up to 1 million dpm beta-gamma and $14,000 \mathrm{dpm}$ alpha were recorded. Surveys were performed by demarcating the area of soil to be excavated in $4-\mathrm{m}^{2}\left(43-\mathrm{fl}^{2}\right)$ grids. The NE Electra alpha/betal instrument was then used to integrate (pass over in a continuous molion) each grid for one minute. Grids with readings greater than $15 \mathrm{~K}$ dpm were marked and excavated until surveys showed no acti vity greater than $5 \mathrm{~K} \mathrm{dpm}$. If any "hotspots" $(>5 \mathrm{~K} \mathrm{dpm})$ were discovered, they *erc removed by excavation and the grid was resurveyed. This process conlinued until no readings above $5 \mathrm{~K}$ dpm were recorded. A final post-remediation survey was then performed using the NE Electra instruments (Figure 5). This figure presents the net beta-garnma count recorded in $\mathrm{dpm} / 100 \mathrm{~cm}^{2}$ over background levels for the excavated areas.

Sediment in the northeast and southwest pad openings was previously determined to contaip radionuclides, Atochlor-1260, and arsenic over the Preliminary Remediation Goals (PRGs) 
(Table 2, Figure 7). The sample was also detemined not to contain hazardous waste. Samples of the underlying soil only exceeded the PRG for Arochlor-1260. Sediment and underlying soil in the northeast and southwest pad openings were excavated and disposed.

\subsubsection{Demolition of Building 3126}

After removal of hazardous waste and impacted materials, the remaining building shell was demolished using a hydraulic shear attached to an excavator. Approximately 198,425 kilograms $(\mathrm{kg})(440,945$ pouthds [lbs]) of general construction debris were generated (Appendix D). All debris was radjologically surveyed and found to be below the RadCon Manual surface contamination release limits. The waste was disposed as general construction waste.

\subsubsection{Groufed Underground Piping}

The acid drain lines were previously grouted closed (BN, 2000b). Underground piping associated with fresh water inlet, outflowing sewage, and decontamination fluid supply was grouted closed with a fast-curing chemical grout. Some piping, such as the outflowing sewage lines, was completely clogged with rootlets. The upper-most vegetative matter was removed to allow the dtains to be grouted with ar least 5 centirneters (cm) (2 inches [in]) of grout. Subsurface drain lines beyond the concrete foundation were not addressed in closure activities described in this CR. These drains are included in CAU 262.

\subsubsection{Removed Surface of Concrete Foundation}

The surface of the concrete pad was previously characterized by the International Technologiess (T) Corporation. The NE Electra alphabeta instrument was used to confirm "fixed" contamination areas before remediation began. The west outside decontaminarion pad was determined to meet surface contamination release limits and, therefore, required no further action. Any remaining areas with a reading greater than $5 \mathrm{~K} \mathrm{dpm}$ were marked for remediation. The upper-most sufface (approximately $0.3 \mathrm{~cm}[1 / 4 \mathrm{in}]$ ) of the remaining concrete foundation was then removed using the shotblast decontamination method. Periodic surveys were then performed to identify remaining "hotspots". After remediation began, it was discovered that contamination was more deeply embedded in the concrete surface. Electric hand-chippers were then used to remove additional material. In several locations, the depth of impact was greater than what the hand-chippers could efficiently remove. At these locations, a hoe-rim (hydraulic hammer) was used to temove the remaining impacted material to depths not exceeding $7.6 \mathrm{~cm}$ ( 3 in) (Figure 9).

The center section of the sleb containing the rails could not be casily remediated due to recessed areas and cracks that restricted access to impacted material. This area of the pad, approximately $49.5 \mathrm{~m}^{2}\left(540 \mathrm{ft}^{2}\right)$ was demolished and removed (Figure 9). Removal activities generated a volume of approximately $3 \mathrm{~m}^{3}\left(4 \mathrm{yd}^{3}\right)$ of MW. This waste was transferred to B-25 boxes and accumulated in the radioactive materials area (RMA). Approximately $\left(30 \mathrm{~m}^{3}[31.3 \mathrm{yd}]\right.$ ) of additional soil and base material ware then excavated to an average depth of $61 \mathrm{~cm}$ (24 in). The material was placed in B-25 boxes and aceutnulated in the RMA. Radiological surveys were then performed throughout the excavation to verify that no "hotspots" reruained. A source of clean backfill was identified and the excavation was backfilled and wheel-compacted to slab grade. 


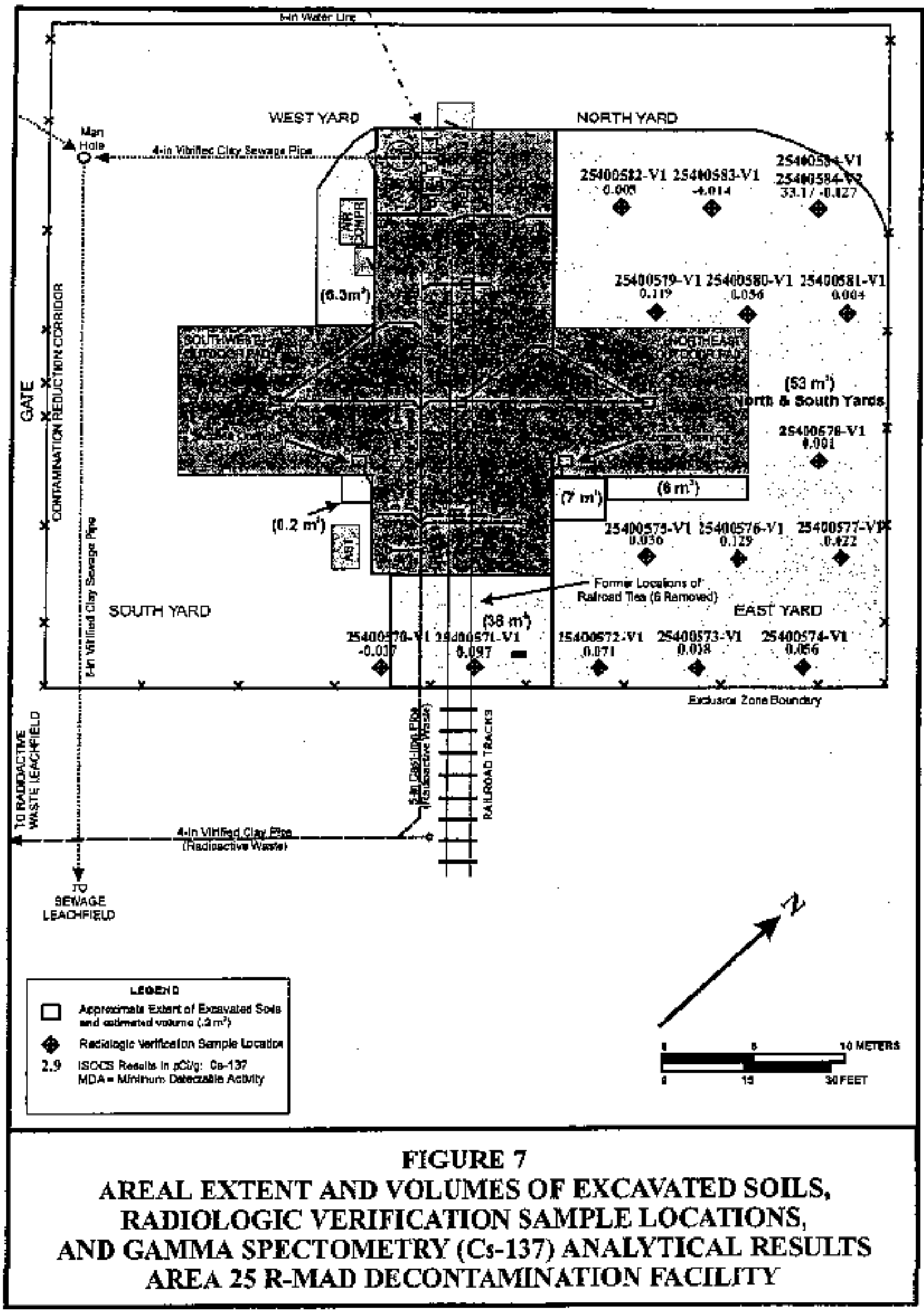


TABLE 2 GAMMA SPECTOMETRY ANALYTICAL RESULTS; RADIOLOGICAL VERIFICATION SAMPLES

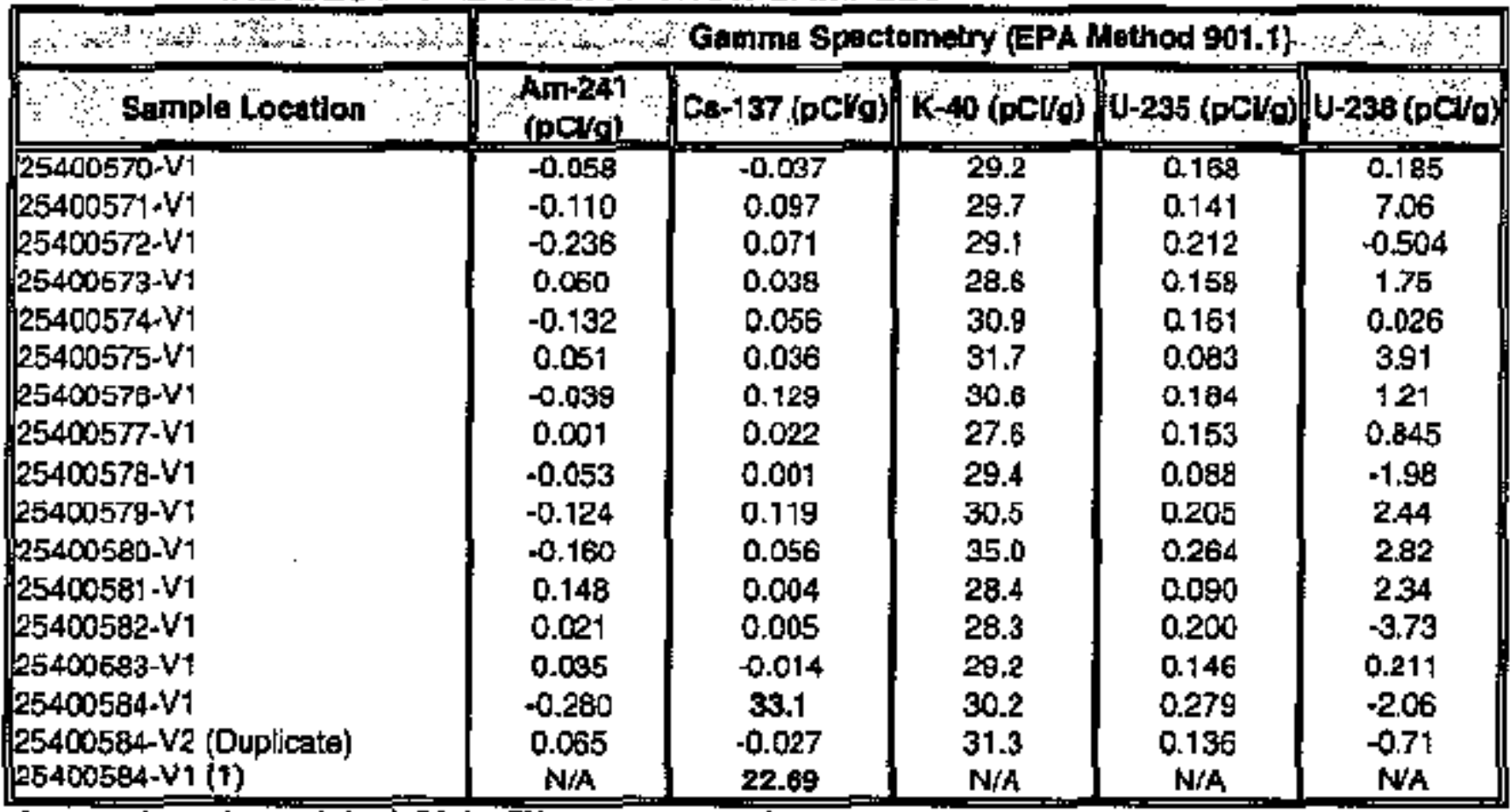

Average based on origlnal: $33.1 \mathrm{pC} / \mathrm{q}$

2.1

Average based on recount; $22.69 \mathrm{pCV} / \mathrm{g}$

1.5

Noten:

N/A $=$ Not Applicable

$\mathrm{pCl} / \mathrm{g}=$ PicoCuries per gram

ISOCS = Inaltu Object Counting System; Cesium-137 (Cs-137)

MDA = Minimum Detectable Actilty

Am-241 = Americium 241

Cs-137 = Cestium 1\$7

K-40 = Potassium 40

U.235 $x$ Urandum 235

$\mathrm{U}-2338$ = Uranium $238 \mathrm{~s}$

(1) = Cs-137 recount of sample 2540058d. $V 1$, averaged concentration of 8 alliquants

Only radioisotopes of interest are reported. For a full ist of radioisotopes analyzed, refer to Appendix C. 
TABLE 3 ANALYTICAL RESULTS FOR VERIFICATION SAMPLES

\begin{tabular}{|c|c|c|c|c|c|c|c|c|c|c|c|c|c|c|c|c|c|c|}
\hline \multicolumn{4}{|c|}{ 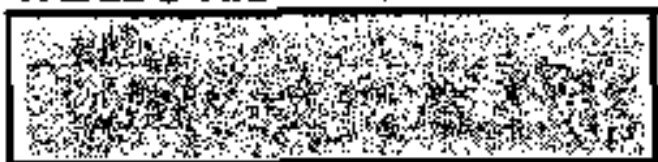 } & \multicolumn{2}{|c|}{ (n) } & 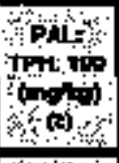 & (gind & \multicolumn{5}{|c|}{ 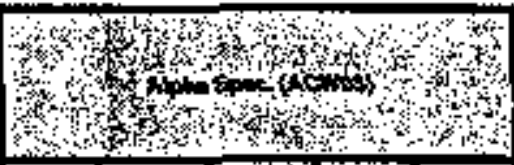 } & \multicolumn{5}{|c|}{ 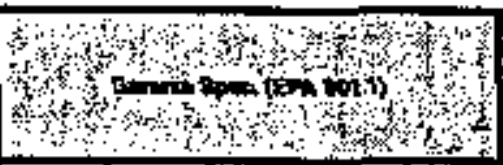 } & 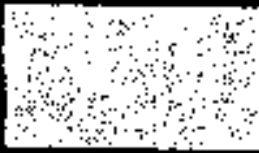 \\
\hline & 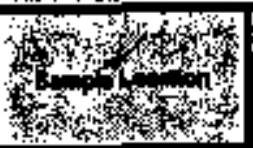 & & & Stom & 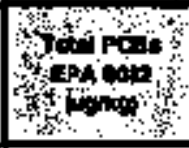 & (1) & 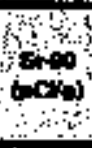 & ingin & 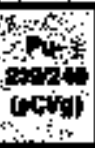 & (4) & actis & 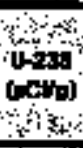 & 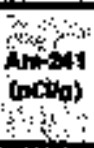 & 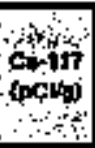 & (1) & (pingis & is & \\
\hline 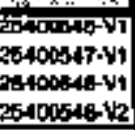 & 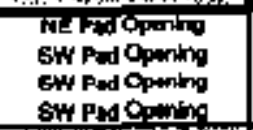 & $\begin{array}{l}\text { som } \\
\text { Soll } \\
\text { Sod } \\
\sin \\
\end{array}$ & 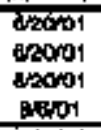 & $\begin{array}{l}\dot{-} \\
\dot{-} \\
-\end{array}$ & 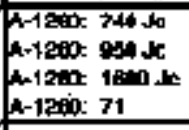 & : & $\begin{array}{l}\text { E.06 } \\
\text { ND } \\
\text { ND }\end{array}$ & $\begin{array}{c}0.015 \\
0.000 \operatorname{sen} \\
\text { No } \\
- \\
\end{array}$ & 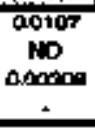 & $\begin{array}{l}0.49 \\
\text { ifa } \\
1.54\end{array}$ & $\begin{array}{r}0.106 \\
0.104 \\
0.119 \\
-\quad \\
\end{array}$ & $\begin{array}{r}1.724 \\
0.581 \\
2754 \\
\end{array}$ & No & $\begin{array}{l}7.65 \\
\text { D.a18 } \\
\text { now }\end{array}$ & 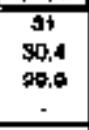 & NDO & 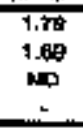 & 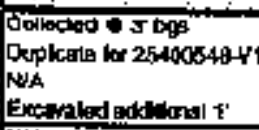 \\
\hline 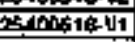 & Foncon of & Songent & 而同口 & Anelmer 110 & - & $\therefore$ & $=$ & 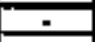 & - & $=$ & - & - & 7 & 二 & $=$ & & $=$ & WHA \\
\hline 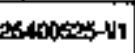 & Horness toy floor & Doncente & 旅 & $\begin{array}{l}\text { Acalono: } 220 \mathrm{E} \\
\text { Theres } 78\end{array}$ & - & - & - & r & $\cdot$ & - & - & - & r & - & - & - & - & NiA \\
\hline 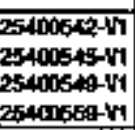 & 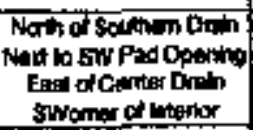 & 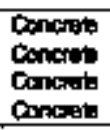 & 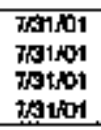 & 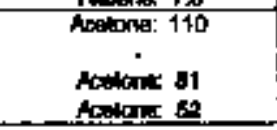 & $\begin{array}{c}- \\
\dot{m}\end{array}$ & $\sin (4)$ & $\begin{array}{l}107 \\
0903 \\
0.528 \\
1.118 \\
\end{array}$ & $\begin{array}{c}0 \\
0.008 \\
0.000 \\
-0.004 \\
\end{array}$ & $\begin{array}{c}0.014 \\
0.013 \\
0.014 \\
0 \\
\end{array}$ & $\begin{array}{r}073 \\
0.03 \\
0.52 \\
\end{array}$ & $\begin{array}{l}0.0 \% 5 \\
0.00 \% \\
0.003 \\
0.03 \% \\
\end{array}$ & 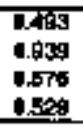 & $\begin{array}{l}0.002 \\
0.658 \\
0.015\end{array}$ & \begin{tabular}{c|}
19.6 \\
0.009 \\
0.778 \\
1.06 \\
\end{tabular} & $\begin{array}{l}- \\
- \\
- \\
-\end{array}$ & : & $\dot{5}$ & $\begin{array}{l}\text { NJA } \\
N \in A \\
N+A \\
N / A\end{array}$ \\
\hline $400505-14$ & 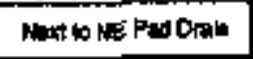 & Concterts & J Hot & 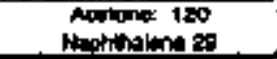 & - & s4 & 5.13 & -0.011 & 0.020 & 292 & 0.178 & 0.021 & 0.202 & 2.38 & . & o & - & NA \\
\hline
\end{tabular}

\section{Wote:}

$=$ Hot Aratyzed

A- $1260=$ Avodor 1280 in ug/kg

E = Conkembation exceded calbriton range

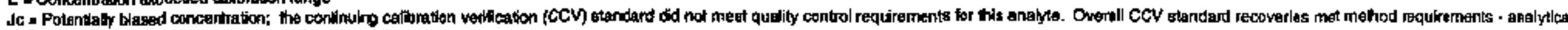
ND = Not Detecked

N/A x Nol Applicable

Pu a Plutonum

Sr-s0 = Birontum 90

U = Urantum

1 = Soll Samples Intude U-235 a u-23a

2 = Applies orly to wot malicha; Analytes resutis are for conerete matrix

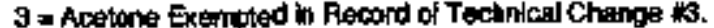

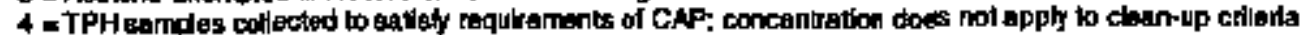

tom a disent orations per minule por $100 \mathrm{cme}$

PAL $x$ Puelminary Action Levd (US EPA) 
After surface remediation was complete, removeable contamination was assessed by taking one swipe sample per grid and analyzing the samples with the Tennelec low-backeround counter. No grids failed the swipe test. The final radiological survey was then performed using the $\mathrm{NE}$ EJectra instrument (Figure 6); the pat' was verified to be below RadCon Manual surface contamination release limits. After the site was verified clean, the perimeter fence was removed and disposed and warning signs were posted stating "Underground Radioactive Material."

\subsubsection{Decontaminated Equipment, Removed Fence, and Released Site}

Equipment used during remediation was decontaminated on-site by hand decontamination methods as necessary. No wet decon was required for large equipment. Hand-held equipment wes cleaned with wet cloths or Masslin cloths.

\subsection{DEVIATIONS FROM CAP AS APPROVED}

Closure activities followed the methodologies speciffed in the CAP (DOENN, 2000a). Three exceptions existed as documented in the Record of Technical Change (ROTC) (Appendix E) numbers one through thee:

- $\quad$ ROTC \#1:Specified that verification soil samples would be collected from the excavated areas next to the pad and analyzed using Gamma Spectrometry; average radionuclide concentrations would not exceed 7 picocuries per gram (pCi/g) for Cesium-137, with no individual sample exceeding $21 \mathrm{pCi} / \mathrm{g}$.

- $\quad$ ROTC \#2: Specifjed an updated schedule for waste management outlining actual waste disposal time frames.

- ROTC "3: Specified a modification to the CAP to allow U. S. Envisonmental Protection Agency (EPA) Region 9 PRGs for acetone in soil to be used as the closure criteria for acetone concentrations remaining in the concrete pad.

One other deviation from the CAP occurted when dernolishing the Iead-impacted concrete compressor pad. The CAP originally specified that the concrete compressor pad would be decontarninated and the material removed from the pad was to be managed as hazardous waste. Calculations were performed by BN Waste Management that determined that lead levels would fall below the UIOC Industrial Landfill Permit levels if the entire concrete pad was sized as one unit Therefore, the entire concrete pad was sized and disposed as construction waste.

\subsection{CORRECTIVE ACTION SCHEDULE AS COMPLETED}

Ficld work was performed in the safest and most efficient manner possibie. Sufficient flexibility was incorporated in the project schedule to account for minor difficulties (weather, equipment breakdown, etc.). The schedule required several modifications due to unexpected site conditions that were outside the assumptions on which the schedule was developed. In the event that the project schedule required modifications, the U.S. Department of Energy, National Nuclesr 
Security Administration Nevada Operations Oftice (NNSA/NV) consulted with NDEP personnel prior to initiating any changes.

\subsubsection{Field Work Corrective Action Schedule}

The following schedule was followed for field work:

- Prepare for Field Work

- Remediation Field Work

- Maragement and Disposal of Waste
February-May 2001

May-September 2001

May-Jonuary 2002

\subsubsection{Site Control}

Closure activities for CAU 254 involved establishing a controlled work area that only qualified personnel could enter after being granted permission by the Construetion Site Superintendent (CSS) or the HSO. Only personnel essential to the immediate task were allowed to enter the exclusion zone (EZ). All personnel were required to wear appropriate PPE. Personnel qualifications and required PPE for the EZ were downgraded or upgraded by the HSO as site conditions changed. Personnel entering or exiting the EZ would pass through the hot line where they would don or doff appropriate PPE and receive radiological frisking, if necessary. The atea outside the EZ was considered the support zone (SZ). Warting signs were posted at key locations in the $\mathrm{SZ}$ cirrecting all personnel arriving at the site (including visitors) to report to the CSS or HSO. Additional signs were posted along the EZ boundary to wam personnel not to enter without proper training and authorization.

Unintentional release of contarninants beyond the EZ was reduced though use of PPE. radiological frisking, equipment decontamination, and dust suppression. All equipment and materials were radiologically surveyed prior to removal from the EZ. Waste management areas (WMA), including the RMA, were located in the support zone, adjacent to the EZ.

\subsection{SITE PLAN}

The final, post-remediation site drawing is presented in Appendix A. 


\subsection{WASTE MANAGEMENT}

This section discusses the wastes generated and waste matragement practices used during closure activities at CAU 254. Waste streams included construction waste, petroleum hydrocarbon waste, hazardous waste, MW, radiologically impacted PCB waste, and LIW. Table 4 presents waste stream data, Appendix B presents waste profiles, and Appendix D provides waste disposal documentation.

All waste characterization sampling and analysis, unless otherwise noted, was perforned in accordance with the CAU 254 Sampling and Analysis Plan (BN 2001).

\subsection{WASTE MINIMIZATION}

All work activities followed the BN Waste Minjmization and Pollution Prevention Program. Special care was given to segregate the waste streans to avoid the generation of additional waste. Contamination was removed from the majority of concrete surfaces to redice the volume of LLW and or MW prior to disposal.

\subsection{CONTAINER MANAGEMENT}

All wastes were accumulated, stored, analyzed, and disposed of in accotdance with applicable state and federal regulations, U.S. Department of Energy (DOE) Orders, BN Weste Mantagement procednres, and the CAU-254, Area 25, R-MAD Decontamination Facility, Deactivation and Decommissioning Waste Management Plan (BN, 2001).

Staging areas for the various waste streams were located to the northwest portion of the site and were enclosed by the expanded perineter fence. All waste accumulation areas were identified with appropriate signs, and boundaries were established to restrict unauthorized entrance. The waste accumulation areas were frequently inspected to ensure that all containers were intact and not leaking.

Standard 208 Liter (L) (55 gallons [gal]) drums were used for limited volumes of petroleum hydrocarbon waste, hazardous waste, and investigation-derived decontamination fluids.

B-25 boxes were used for LLW and MW and were filled to meet their weight capacity $(-3,600$ $\mathrm{kg})(8,000 \mathrm{lbs})$. Demolition debris was first placed in the B-25 boxes, followed by sediment. soil, and compactable waste, such as.PPE and trash, to fill roid spaces. After a box was filled, the waste packrge was closed according to BN Organization Procedure OP-2151304, Radioactive Waste Tracking. Hatdling, and Management at the NTS (BN. 2000a). If a tox was not completely filled at the end of a workday, the lid was closed without securing the clips and tamper-indicating tape was placed on the box. Dums containing free liquids were stored on spill containment pallets, Appropriate labels were used and relevant information was marked on each container with an indelible tnarker. The information was legible and clearly visible for inspections. Conrsiners were labeled with information including: 


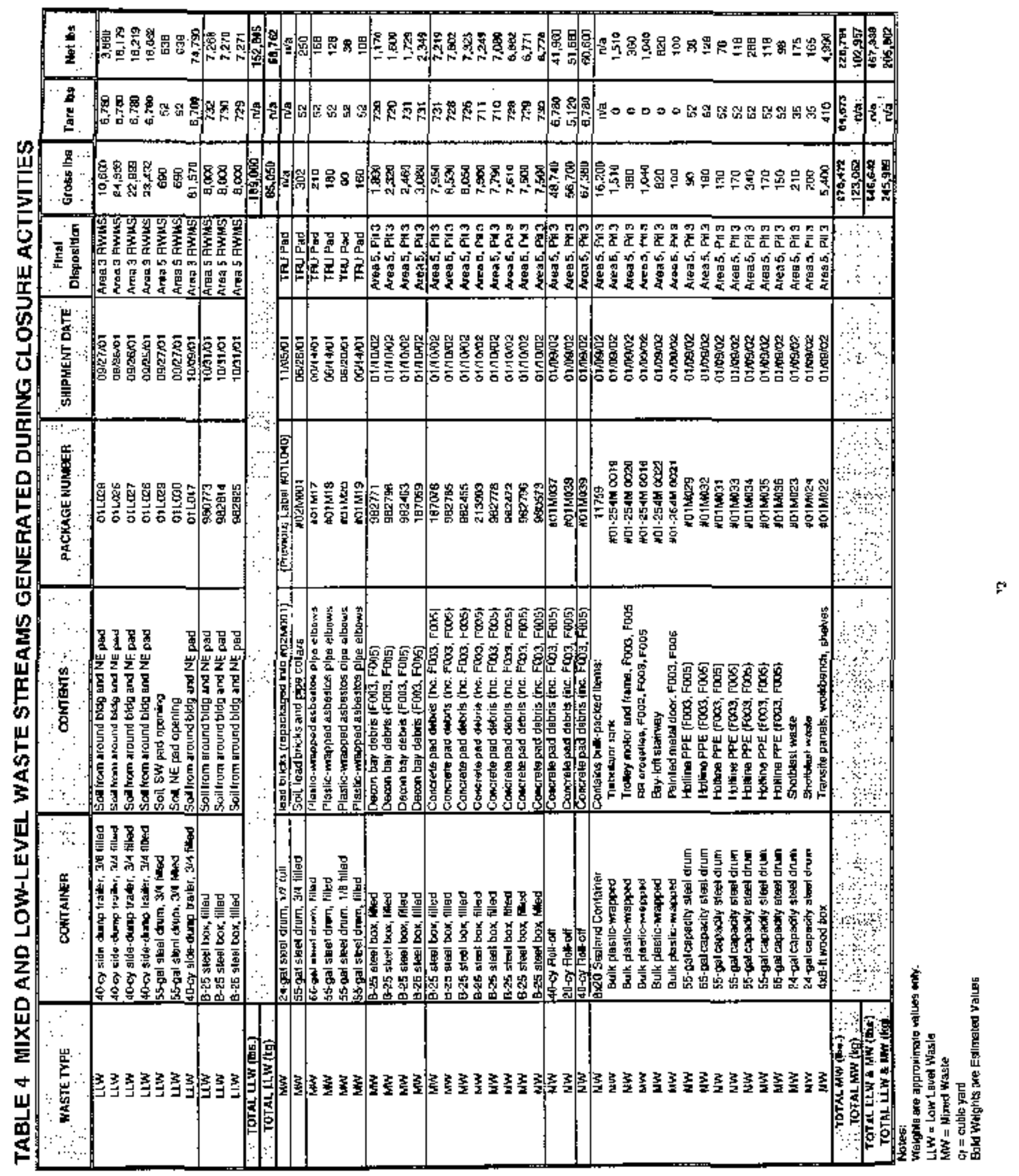


- RAD track label, hazardous waste label, or drum identification number, as appropriate.

- Waste type in container.

- Waste origin.

- Accumatation dates.

- Awaiting/pending anaiysis sticker if sampling was required.

- The words "Hazardous Waste" on containers of hazardous and mixed waste. To assure container integrity, all containers were physically inspected prior to being shipped off-site and at the time of unloading at the disposal designation.

\subsection{WASTE STREAMS}

\subsubsection{Construction Wastes (NTS Class III Wastes)}

\subsubsection{General Debris}

Approximately $219,086 \mathrm{~kg}(486,858 \mathrm{lbs})$ of construction waste in the form of demolition debris was generated from closure activities (Appendix D). Specific items include structural beans, exterior walls and roof, hot water tark, air compressor, the AST (including pipe elbow insulation), insulation, and nonhazardous PPE.

Building debris was segregated based on surface radjological survey data. Radiological surveys verified that the material did not exceed the "sum of the fractions" limits. Site characterization data were used as process knowledge to determine that building debris was not hazardous, and was not a Toxic Substances Control Act (TSCA) regulated waste, It was also detennined that debris was not radiologically impacted at concentrations greater than specified in the Area 9 , U-10c Industrial Landfill Pernit (DOENV, 1997). This waste was transported to the Area 9, C10c Industrial Landfill for disposal.

\subsubsection{Asbestos-Containing Materials (ACM)}

Both friable and non-friable ACM wastes were generated during closure activities. Inspection, sanpling, and laboratory analysis identified ACM in the interior transite panels of the decontamination bay, on some pipe elbows, and on the exterior of the AST tank coating. Transite panels composed of non-friable ACMs were encapsulated and removed from the interior walls of Building 3126. These panels were then radiologically surveyed to deternine which panels were intpacted with radiological contamination above the "surn of the fractions" limits. Panels were segregated by radiological activity into two categories: waste with radiological activity that had a "sum of the fractions" less than or equal to one, and waste that had a "sum of the fractions" greater than one. According to the level of contamination, "construction waste" or "LLW" were marked on each paneI, Low-level ACM panels were accumulated in B-25 boxes with other building debris with similar radiological activity. The waste was stored in the RMA and were disposed in the Area 5. Pit 3 Radioactive Waste Management Site (RWMS). Transite 
parels with "sum of the fractions" less than or equal to one were burrito-wrapped and disposed in the Area 23 Saritary Landfill asbestos disposal cell.

An unknown weight of friable ACM waste was generated during closure activities. Friable wastes (pipe elbow insulation) were accumulated in the AST which weighed approximately $2,637 \mathrm{~kg}(5,860 \mathrm{lbs})$. Both pipe elbows and the AST coated with friable ACMs were radiologically surveyed to determine which irems were radiologically impacted. Both the AST and the pipe elbows were determined to have radionuclide "sum of the fractions" less than or equal to one. After being surveyed, the pipe elbows were encapsulated, removed, and accumulated inside the AST. The AST was then wrapped with plastic and placed inside a wooder box. Upon receipt of the approved waste profile, the waste was shipped to the Area 23 Sanitary Landfill Asbestos disposal cell. Elbows with radionuclide "surn of the fractions" greater than one were accumulated in a 55-gal drum and were disposed as ZLW in the Area 5 Pit 3 RWMS. Information regarding this waste stream is presented in Appendix B, Asbestiform LLW, Waste Profile LRYSMWFY01021.

\section{3,2 Petroleum Hydrocarbon Wastes}

Less than $15 \mathrm{~L}$ (4 gal) of petroleum hydrocarbon waste was collected from the air compressor and overhead crane gearbox. Each waste stream was containerized separately. BN sampled each waste to detemine if tecycling was possible. The waste was then stored in the waste accumulation area pending review of analytical results. Upon teviewing the analytical results, the waste was deteminined not to be impacted. The waste was then recycled. Analytical results are not provided in this report, but are available upon request.

\subsubsection{Hazardous Wastes}

Information regarding the various hazardous wastes generated during closure activities at $\mathrm{CAU}$ 254 are presented in Appendix B, Hazardous Waste. Specifics on each component of the Hazardous Waste strears are discussed in the following sections.

\subsection{Antifreeze}

Approximately $15 \mathrm{~L}$ (4 gal) of compressor antifreze was collected in a approved 38-L (10-gal) container. This waste was previously determined to contain arsenic (D004) above the Toxicity Characteristic Leaching Procedure (TCLP) and Universal Treatment Standard (UTS) limits and, thereby classified as hazardous waste requiring treatment. The waste was transported to BN Hazardous Waste and stored on the "Haz Pad" in Area 5 until recejpt of an approved waste profile. The waste was shipped to an off-site treatment, storage, and disposal (TSD) facility for treatment and disposal in December $200 \mathrm{l}$. Information regarding this waste stream is presented in Appendix B, Hazardous Waste, (Material Profile number 3015183).

\subsubsection{PCB Ballasts}

Two PCB ballasts were removed from the building that had the potential to contain PCB concentrations greater than 500 milligrams per kilogram (mg/kg). Surface radiological surveys determined that the ballasts were not radjologically impacted. The ballasts were wrapped in a 
plastic bag, contained in a 19-L (5-gal) bucket, and stored in the WMA until being shipped to the Area 5 "Haz Pad" in June 2001. This waste was shipped to an off-site TSD facility for reatment and disposal in July 2001. Information regarding this waste stream is presented in Appendix B, Hazardous Waste, (Hazardous Waste Manifest 1065742).

\subsubsection{Lead}

Approximately 136.2 ( $300 \mathrm{lbs}$ ) of lead bricks and collars and $0.9 \mathrm{~kg}$ (2 lbs) of anti-seize lead compound was removed from the facility. The waste was surveyed and found not to be radiologically impacted. This waste was properly containetized and transferted to the 90 -day storage area. The waste was shipped to arl off-site TSD facility for treatment and disposal in December 200I. Ifformation regarding this waste stream is presented in Appendix B, Hazardous Waste, (Material Profile 3015192).

\subsubsection{Mixed Waste}

Approximately $102,824 \mathrm{~kg}(228,492 \mathrm{lbs})$ or $165-\mathrm{m}^{3}$ (2]5.8 $\left.\mathrm{yd}^{3}\right)$ of MW were generated during closure activities (Table 4). The waste stream consisted of hot-line trash, building debris in the form of transite parels, friable asbestos pipe elbows, non-ACM insulated pipes, wood and insulation, electrical equipment, conduit, a turbulator tank, concrete, and rebar. Building debtis that was not characteristic or toxic characteristic hazardous waste and contained listed hazardous waste codes at concentrations below Land Disposal Restrictions (LDR) treatmen standards was classified as MW. All MW, unless otherwise noted, was transported to and disposed in the Area 5 Pit 3 MW disposal cetl on January 9-10, 2002. Information regarding this waste stream is presenied in Appendix B, Mixed Waste, Waste Profile LRY 5 MWY01020.

\subsubsection{Office Bench}

The office bench was previously determined to contain acetone (F003) and toluene (F005) below the RCRA Section 268.40 UTS for Hazardous Waste, and was radiologicaliy impacted. Site characterization data were used as process knowledge to complete a waste profile and classify this waste as MW that met the $\mathrm{LDR}$. The waste was sized and contained in a $4 \times 8 \mathrm{ft}$ wooden box along with other MW. The waste was stored in the waste accumulation area until disposal in the Area 5 Pit $3 \mathrm{MW}$ disposal cell.

\subsubsection{Decontamination Bay Air Filters}

The decontamination bay air filters were previously consumed during site characterization activities. No ftlters were observed as being present in Building 3126 at the time of project startup.

\section{3,4.3 East Decon Bay Concrete and Decon Bay Floor Concrete}

The east decontamination pad and the decontamination bay floor concrete were previously detemined to contain acetone (FO03) and benzene (F005) below the RCRA Section 268.40 UTS for hazardous waste, TPH greater than $100 \mathrm{mg} / \mathrm{kg}$, and to be radiologically impacted. Sile characterization data were used es process knowledge to classify this material as MW that met the LDRs. Impacted concrete surfacas were removed by shot blast, electric chisels, on hoe-raras (hydraulic hammers). Contatminated matertal was accumulated in B-25 boxes. The waste was stored in the RMA until disposal in the Area 5 Pit $3 \mathrm{MW}$ disposal cell. 


\subsubsection{Compressor Concrete Pad}

The compressor concrete pad was previously determined to contain toxic levels of lead on the concrete surface (D008). As noted in Section 2.2, Deviations Ftom CAP As Approved, the entire concrele pact was sized to lower the average lead concentrations to below the PRGs. Surface radiological survey data wete used to detemine that the concrete pad was not radiologically impacted above the "sum of the fractions" limit. Process krowledge and radiological survey data were used to complete a waste profile classifying the material as construction waste. The waste was disposed in the U10c Industrial Landfill.

\subsubsection{Compressor Room Draln Sediments}

The compressir room drain sediments were previously consumed during site characterization sampling performed by the IT Corporation. After samples were collected, the drains were also grouted by IT. Surface radiological surveys performed by BN did not indicate any impacted material as being present. No action was taken for this waste strearn.

\subsubsection{Railroad Ties South of Bullding 3126}

The first railroad tie south of Building 3126 was previously determined to be contaminated with several "FLisled" wastes and radionuclides above the Class II landfill standards. Site characterization data were used as process knowledge to re-classify this material as MW that met LDRs. Howeyer, surface radiologic surveys indicated that mote than just the first railroad tie was contaminated. Therefore, all railroad ties were removed and disposed up to the fence line (Figure 7). This material was bulk-wrapped in plastic, placed in a transportainer, and stored in the RMA pending receipt of an approved waste profile. The waste was disposed in the Area 5 , Pit 3 MW disposal cell.

\subsubsection{Southeast Decon Bay Door}

The waod from the southeast decontamination bay door contained acetone (F003) below the RCRA Section 268.40 UTS for hazardous waste, cadmium greater than the UTS limit, TPH above $100 \mathrm{mg} / \mathrm{kg}$, and volumetric radjonuclide contamination greater than the "sum of the fractions" limit. This material was sized and accumulated in a B-25 box. The door was and sampled by randomly drilling approximately 100 holes across the door. Wood shavings were collected and analyzed for RCRA TCLP Metals. Analytical results were used to classify this material as MW that met the LDRs (Appendix B, Mixed Waste Profile). The waste was disposed in the Area 5 Pit $3 \mathrm{MW}$ disposal cell without treatment.

\subsubsection{South and Northwest Decon Bay Door}

The insulation from the south decontamination bay door contained carton disulfide (F003) and toxic characteristic cadmium (D006) levels, and was impacted with radionuclides less than the "sum of the fractions" limit. Site characterization and analytical data were used as process knowiedge to re-classify this waste as a non-RCRA characterlstic MW that met the LDRs. The material was sized, placed in 209-L (55-gal) drums, and accumulated in the waste accumblation area. The waste was disposed in the Area 5 Pit $3 \mathrm{MW}$ disposal cell without treatment.

The insulation from the northwest decontamination bay door contained toxic characteristic cadnium (D006) levels, and was impacted with radionuclides less than the "sum of the 
frations" limit. Site charactetization data were used as process knowledge to classify this material as MW. This material was sized and accumulated in a B-25 box. The wastc was disposed in the Area 5 Pit $3 \mathrm{MW}$ disposal cell.

\subsubsection{Northwest Decon Bay Door}

The wood from the northwest decontamination bay door contained TPH greater than $100 \mathrm{mg} / \mathrm{kg}$ and was impacted with radionuclides greater than the "sum of the fractions" release limit. Site characterization data were used as process knowledge to classify this waste as MW that met LDRs. The material was sized and accumalated in a B-25 box with other LLW impacted with TPH. The waste was disposed in the Atta 5 Pit $3 \mathrm{MW}$ disposal cell.

\subsubsection{Lead}

Approximately $138 \mathrm{~kg}$ ( $308 \mathrm{lbs}$ ) of radiologicaliy impacted lead waste consisting of lead-bricks and pipe collars was generated during closure activities. The waste was collected in a $209 \cdot \mathrm{L}$ (55-gal) steel drum and stord in the RMA. The waste was clessified using process knowledge as MW requiring treatment prior to disposal. The waste was then transported to and stored on the Area 5 Transuranic pad. The waste will be stored until either onsite or offsite treatment and disposal altematives are identified. The NDEP will be informed of the actual shipment date soon as the waste leaves the "Haz Pad".

\subsubsection{Radioactive PCB Waste}

\subsubsection{Loft Floor}

The wood from the loft floor was previously determined to contain acetone (F003), xylene (F003), and toluene (FOO5) below the RCRA Section 268.48 UTS for hazardous wastes, and TSCA regulated PCBs. The impacted area was examined but no evidence of a spill was found and no radiological impact was observed. Observations and analytical data were used to conclude that the impacted area originated from dried PCB paint applied to the floot. In November 2001, the NDEP granted permission for this waste to be managed as PCB bulk product waste, for which TSCA limits do not apply. This waste was classified as bulk-product waste that met the LDRs. The waste was disposed in the Area 9 U10C Industrial Landfill. Information regarding this waste stream is presented in Appendix D, Area 9 U10C Industrial Landfill Load Verification Forms.

\subsubsection{North Loft Wall Insulation}

The north loft wall insulation was previously determined to contain TSCA regulated PCBs and radionuclides less than the "sum of the fractions" limit thus requiring off-site treatment for PCBs. However, anajytical results did not indicare any remaining contamination. Site characterizaion and analytical data wore used to te-classify this waste as MW that meet the LDRs. The waste was disposed in the Area 3 Bulk RWMS in December 2001. Information regarding this waste stream is presented in Appentix D, Area 9 U10C Industrial Landfill Load Verification Fortis.

\subsubsection{Turbulator Vent Stack Filter}

The turbulator vent stack filter was initially analyzed by Paragon Laboratories of Fort Collins, Colorado during site characterization activities performed by IT. The filter was determined to contain PCBs, lead, and radionuclides greater than the "sum of the fractions" limit. The residual 
sample was returned from the laboratory and stored on the Area 5 Transuranic (TRL) Pad. This sample weighed approximately one pound. It was later detemined that analytical dara wete insufficient to determine treatability, so the remaining sample was sent to NFT Laboratories in Oak Ridge. Tennesses for subsequent analysis where the sample was totally consumed duting analysis. A "Certificate of Destruction" letter is included in Appendix D.

\subsubsection{LLW}

Approximately $68,762 \mathrm{~kg}(152,805 \mathrm{lbs})$ or $70 \mathrm{~m}^{3}\left(91.5 \mathrm{yd}^{3}\right)$ of LLW was generated during closure activities (Table 4). The waste stream consisted of dry contaminated soil and sampling and holline compactible trash. Ptocess knowledge and site characterization data were used to classify the waste as nonhazardous, not TSCA regulated PCBs, and radiologically impacted at concentrations greater than the "sum of the fractions" limit. The waste was managed as LLW. The bulk of the waste consisted of excavated soils and sediments but also included some equipment, piping, shotblast waste, and associated demolition debris. This waste was accumulated in B.25 boxes and shipped to the Area 3 Eulk RWMS in December 2001. Information regarding this waste stream is presented in Appendix B, LLW, Waste Profile LRYFY01022.

\subsubsection{Demolition Debris and Equipment}

Demolition debris and equipment, including piping, structural members, and miscellaneous materials with radionaclide constituents that exceeded the "sum of the fractions" limits, were managed as bulk LLW. Surface radiological survey data were used to complete the waste profiles. This waste was accumulated in B-25 boxes interspersed with soil, PPE, and other derived waste. The waste was stored in the RMA and later shipped to the Atea 5 Pit 3 RWMS in December 2001.

\subsubsection{Decontamination Pad Concrete}

The decontamination pad concrete was radiologically surveyed and classified as LLW being impacted with a "sum of the fractions" greater than one and was not a RCRA waste. Shotblast waste was stored in the RMA. The waste was shipped to the Area 5 Pit 3 RWMS in December 2001 .

\subsubsection{Soils}

Radiologically impacted soils with a "sum of the fractions" greater than one were excavated from the northeast area of Euilding 3126, the perimeter of the decontamination building, and from around the perimeter of the outside cast decontamination pad (Figure 7). This material was accumulated and stored in the RMA. Site characterization data was used as process knowledge to determine that the soil was not hazardous waste snd not TSCA regulated. This material was shipped to the Area 5 RWMS for disposal in December 2001. Radiologic survey data were used to determine that impacted soils with a "sum of the fractions" less than one net disposal requirements as specified in the Area 9 U-10c Industrial Landfill Permit. This material was shipped to the Area 9 U-10c Industrial Landfill For disposal in December 2001. 


\subsection{CLOSURE VERIFICATION}

\subsection{VERIFICATION SAMPLES}

Verification sarnples were collected after corrective actions were performed to verify removal of impacted material (Tables 2 and 3; Figures 8 and 9). Appendix C presents the Form I data sumnaries; complete data packages are available upon request. Verification samples were collected using decontaminated staitless-steel scoops and placed into laboratory-supplied containers. Samples were inmediately logged on Chain of Custody forms and chilled to 4 degrees celcius $\left({ }^{\circ} \mathrm{C}\right.$. Samples were then transferred to the BN Analytical Services Group under strict Chain of Custody procedures.

Samples were identified using the sample-naming convention used in previous investigations with the additional suffix "-V1" (25400546-V1). Samples begin with sample number "25400546-V1" and end with sample number "25400586-VI". If one sample exceeded an action level, further excavation was performed and a second sample was collected. For example, when verification sanple "25400548-V]" was delermined to exceed the PRGs for PCBs, additional soil was excayated and sample "25400548-V2" was collected and unalyzed.

Relatively impervious surfaces, such as concrete, that were radiologically contaminated were remediated to radiological activity release levels as indicated in Table 4-2 of the RadCon Manual (DOENV, 1999b) (Table 1). Porous materials, such as wood and soil, that were radiologically contaminated or potentially contaminated were removed or remedisted to "sum of the fractions" levels.

\subsubsection{Concrete Foundation}

The concrete foundation was sampled at seven locations after the uppermost impacted surface was removed and radiological surveys no longer indicated remaiting "hot spots" (Table 3).

- Six samples were analyzed for YOCs. Four locations showed acetone concentrations above the detection limits. ROTC \#3 specified a modification to the CAP to allow EPA Region 9 PRGs for acetone in soil to be used as the acetone action levels for the concrete pad (Appendix E).

- Two samples were analyzed for PCBs; both locations were reported as non-detects.

- Two samples were aralyzed for TPH. Sample location 25400549 -V1, east of the eenter drain, was reported as $840 \mathrm{~m} g / \mathrm{kg}$. Sample location $25400563-\mathrm{V} 1$ was reported as $54.0 \mathrm{mg} / \mathrm{kg}$. While the NDEP action level for TPH is $100 \mathrm{mg} / \mathrm{kg}$ it is only applicable to soil. These samples were collected to meet the requirements specified in the CAP $(B N, 2000 a)$. No regulatory drivers exist that require any additional removal of concrere from the area. 


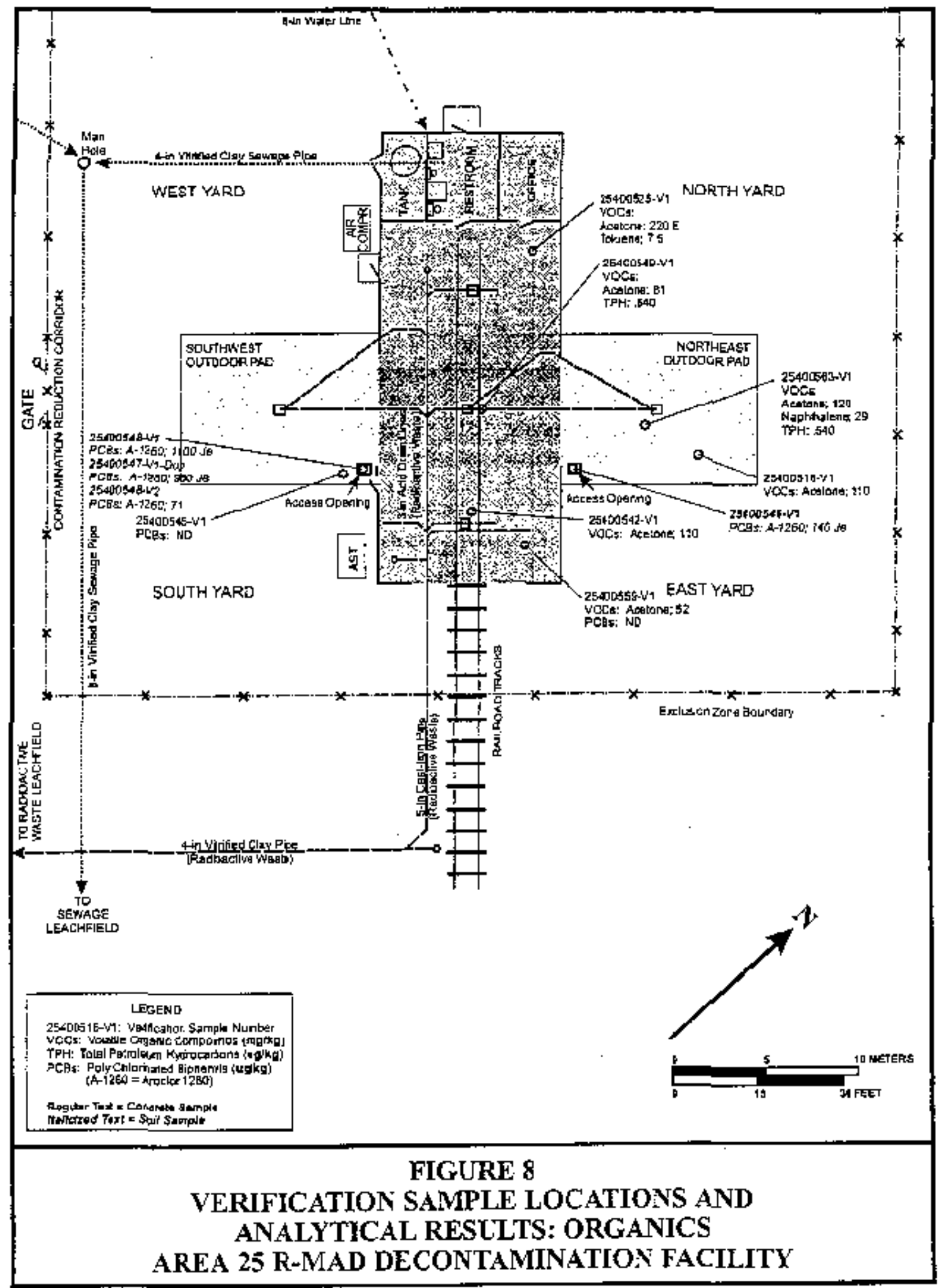




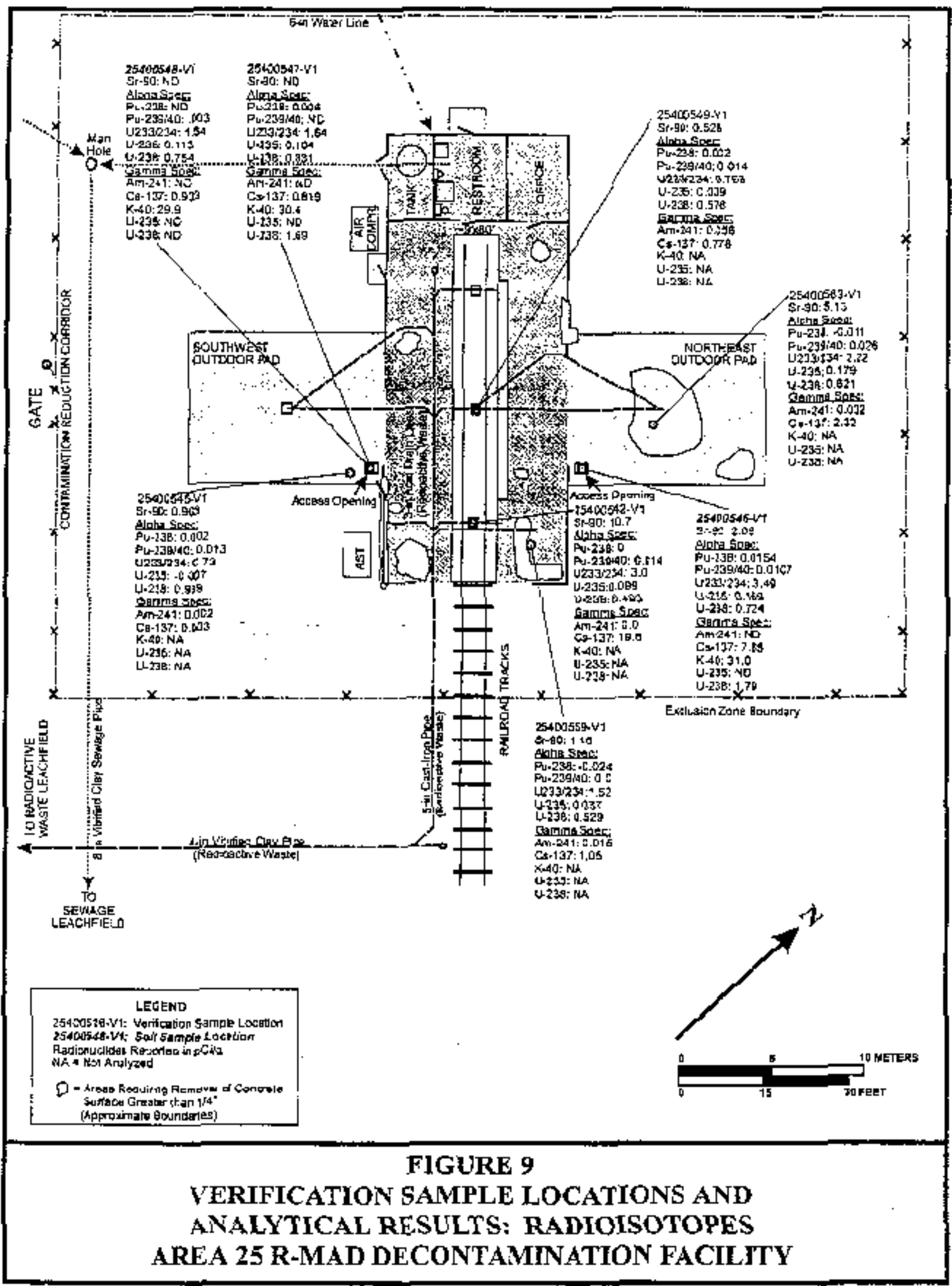


- Five sample locations were analyzed for radioisotopes. The analytical data was not used to determine if remediation was complete. Only sufface contamination limits from Table 4-2 of the Radcon Manual are applicable.

\subsubsection{Sediment and Soils}

\subsubsection{Sediment}

The sediment beneath the northeast and soulhwest pad openjugs was excavated to approximately $0.9 \mathrm{~m}$ (3 ft below ground surface [bgs]) and $0.6 \mathrm{~m}$ ( $2 \mathrm{ft} b \mathrm{bs}$ ), respectively. The locations were then radiologically surveyed and sampled after surveys no longer indicated remaining "hot spots". Two verification samples $(25400548-\mathrm{V} 1,25400546-\mathrm{V} 1)$ were collected and analyzed for PCBs and radioisotopes (Table 3, Figure 8).

- Both lacations were analyzed for PCBs; concentrations were below the PRGs at location 25400546.V1. Location 25400548-VI (SW pad) showed PCB cottcentrations (Aroclor 1260; 1,600 micrograms per kilogram) as exceeding the PRGs. An additional foot of soil was excavaled and the location resampled (25400548-V2). Results showed no PCB's above the PRGs.

- Bolh locations were analyzed for radioisotopes. Neither location exceeded the sum of fractions level for radionuclides.

\subsubsection{Soils}

As specified in ROTC \#1, samples were collected from soil excavation areas and analyzed for Cesiun-137 (Cs-137) using gamma spectrometry (Table 2, Figure 7). Individual samples could not exceed $21.0 \mathrm{pCi} / \mathrm{g}$, with the average of all samples not to exceed $7 \mathrm{pCi} / g$. Samples were field screened for Cs-137 using ISOCS analysis; data indicated that no sample exceeded $21.0 \mathrm{pCi} / \mathrm{g}$ (Table 2). Samples were transfered to an off-site laboratory and analyzed by gamma spectometry. Analytical results showed one sample exceeded $21.0 \mathrm{pCi} / \mathrm{g}$ of Cs-137 (25400584V1 $[33.1 \mathrm{pCi} / g])$. The average concentration of all samples was $2.1 \mathrm{pCi} / \mathrm{g}$, well below the 7.0 pCi/g limit.

Since ISOCS field sereening data indicated that no samples were above $21.0 \mathrm{pCi} / \mathrm{g}$, a recount of sample 25400584-V1 was requested. The sample was divided into 8,40 milliliter (mL) alliquots and recounted (Appendix $\mathrm{C}$ ). The average concentration of $\mathrm{Cs}-137$ for seven of the eight alliquots was $1.79 \mathrm{pCi} / \mathrm{g}$, with the low concentration of $1.34 \mathrm{pCi} / \mathrm{g}$ and a high concentration of $3.10 \mathrm{pCi} / \mathrm{g}$. The eighth alliquot reported a concentration of $169.0 \mathrm{pCi} / \mathrm{g}$. The mass-weighted average concentration of Cs-137 for the 8 alliquots, based upon the mass submitted to the laboratory, is $19.81 \mathrm{pCi} / \mathrm{g}$. The high concentration of the ejthth altiquot is jikely due to a discrete fuel particle. This fuel particle was likely shielded by the surrounding matrix during the initial count. The average concentration of all samples, based upon the recount of sample 25400584$\mathrm{VI}$, is $1.5 \mathrm{pCi} / \mathrm{g}, 0.6 \mathrm{pCi} / \mathrm{g}$ less than the average for the initial sample.

If more than one alliquot had an elevated count, there would be reason to believe that more impacted material temained on-site. However, due to the fact that only one of eight alliquots reported an elevated value, and that the duplicate sample showed no activity, no evidence exists to suggest that the remidiation goals for the site have not been met. 


\subsection{DATA QUALITY ASSESSMENT}

Accurate and defensible analytical data were collected to verify that closure activities met the project-specific t'equirements as outlined in the CAP (DOE-NV, 2000a). Closure activities consisted of removing sediment, soil, building materials, and concrete surfaces that were above action levels for organic compounds and radioisotopes. Verification oonsisted of perforning radjological surveys and laboratory analysis to confirm that the remaining concrete foundation and soils were below surface contamination release levels. Seven concrete and three sediment sumples were collected and analyzed for organic compounds and tadioisotopes of interest (Table 3). In addition, 15 samples were collected and analyzed using gamma spectonetry and ISOCS (Table 2). Samples were collected, cooled to $4^{\circ} \mathrm{C}$, logged onto the Chain of Custody, and transported to the BN Analytical Services Group under strict chain-of-cusfody procedures. Samples were analyzed by EPA-approved laboratories. Analytical results were validated at the laboratory using stringent quality control (QC) procedures. All sample data were also internally validated by $\mathrm{BN}$ personnel using Tier Il validation procedures. No anomalies were discovered in the dats.

QC samples were collected and analyzed to aid in detemining the validity of regular sample results. These samples included two blind duplicates, one matrix spike/matrix spike duplicare, one rinse blank, and one rip blank for each VOC shipment. QC data are not presented with the analytical results. These data are maintained in the BNER files and are ayailable upon request.

\subsection{LSE RESTRICTIONS}

Site closure will allow utorestricted access and use of the site above the ground sunface, but will include use restrictions to prohibit activities into and beneath the concrete foundation, surtouncling soils, and grouted drain lines contuined in CAU 262. Future use of any land related to this CAU is restricted from any intrusive activity unless concurzence is obtained in advance and in writing from NDEP. Such intrusive activities would alter and/or modify the established containment controls as approved by NDEP.

The site shall be monitored on an annual basis to ensure that posted waming signs stating "Underground Radioactive Material" remain intact and that the text does not become unieadable due to fading from exposure to ultraviolet radiation. Refer to Appendix F for additional use restriction information.

Based upon the completion of site activilies, it is requested that a notice of completion be provided by the NDEP for CAU 254, R-MAD Decontanination Facility, Building 3126. Upon closure approval, CAU $2 \$ 4$ will be promoted from Appendix II to Appendix $N$ of the FFACO, Closed Corrective Action Linits. 
Februile: 2001

THIS PAGE INTENTIONALLY LEFT BLANK 


\subsection{CONCLUSIONS AND RECOMMENDATIONS}

Al] cleanup activilies specificd in the Corrective Action Plan for CAC 254, Area 25 R-MAD Decontamination Facility (DOE/NV, 2001) were successfully performed. All cleanup activities are documented in this Closure Report. Any deviations from the approved CAP (DOE/NV, 2001) were documented in Section 22, DEVLATIONS FROM CAP AS APPROVED.

Based upon the analytical data presented in Appendix $C$ and the radiological survey data presented in Figures 5 and 6, all site-specific cleanup goals, as established in the CAP (DOENV. 2001) have been meet The National Nuclear Security Administralion (NNSA) hereby requests that the site be closed in accordance with the FFACO Agreement of 1996. The NNSA hereby requests inat CAT 254 be moved from Appendix W. Corrective Action Trvestigations Cortective Actions, to Appendix $\Gamma$, Closed Corrective Aclion Units. 
Jadromat: 200 ?

\section{THIS PAGE INTENTIONALLY LEFT BLANK}




\subsection{REFERENCES}

Bechtel Nevada, 2001. "CAU-254, Area 25, R.MAD Decontamination Facility, Deactivation and Decomrissioning Waste Maragement P]an." Revo.

Bechtel Nevada, 2001. Sampling and Analysis Plan, Nevada Test Site, CAU 254, Area 25 R-MAD Decontamination Facility. May 2001 Rev 0.

Bechtel Nevada, 2000a. "Radioactive Waste Tracking, HandIing, and Management at the NTS," Rev. 2, Organization Procedure OP-2151.304, Las Vegas, NV.

Bechtel Nevada, 2000. Waste Marngement Plan for Corrective Action Lirti 254, Area 25 RMAD Decontamination Facility, Nevada Test Site, Neyada,

Bechtel Nevada, 2000b. Record of Communication between Curtis Obi (BN) and Jeff Johnson (IT Corporation) regarding sampling and grouting of acid waste floor drains (e-mail), Las Vegas, NV.

Federal Facility Agreement and Consent Order, 1996. Agreed to by the Nevada Division of Environmental Protection, the U.S. Department of Energy, and the U.S. Department of Defense.

U.S. Department of Energy, Kevada Operations Office, 1997. Permit for Area 9 Uloc Disposad Site Class [II Industuia] Solid Waste Disposal Site, Permit SW/13/097/03 (revised June 2000), Las Vegas, NV.

U.S. Department of Energy Nevada Operations Office, 1999a. Corrective Action Investigation Plan for Corrective Action Unit 254: Area 25 R-MAD Decontamination Facilitv, Nevada Test Site Nevada, DOE NV-557, Las Vegas, NV.

U.S. Department of Energy, Nevada Operations Oflice, 1999b. NV/XMP Radjological Conirol Manual, DOENV/11718--079, Las Vegas, NV.

U.S. Department of Energy, Nevada Operations Office, 2000a, Corective Action Plan for Corrective Action Linit 254: Area 25 R-MAD Decontamination Facility, Nevada Test Site, Nevada, DOE/NV--678. Las Vegas, NV.

U.S. Department of Energy, Nevada Operations Office, 2000b. Conective Action Decisjon Degument for Concelive Action Unit 254: Area 25 R-MAD Decontamination. Facility. Neviada Test Site. Nerada. DOENV--619, Las Vegas, NV.

U.S. Department of Energy, Nevada Qperations Ottice, 2000c. Addendum to Corective Action Decision Document for Corrective Action Unit 254: Area 25 R-MAD Decontrimination Eacility.Nevada Test Site Nevada, DOE/NVB619-ADD, Las Vegas, NV.

U.S. Department of Energy, Nevada Operations Office, 2001. Waste Management Plan for CAU-254, Area 25.R-MAD Decontamination Facility, Nevada Test Site, Nevada. 
APPENDIX A

AS-BUILT SITE DRAWING 
THIS PAGE LEFT INTENTIONALLY BLANK

A-ij 


\section{APPENDIX A}

\section{TABLE OF CONTENTS}

As-Built Site Drawing $\ldots \ldots \ldots \ldots \ldots \ldots \ldots \ldots \ldots \ldots \ldots$ A-5

A-iij 
THIS PAGE LEFT INTENTIONALLY BLANK

A-iv 


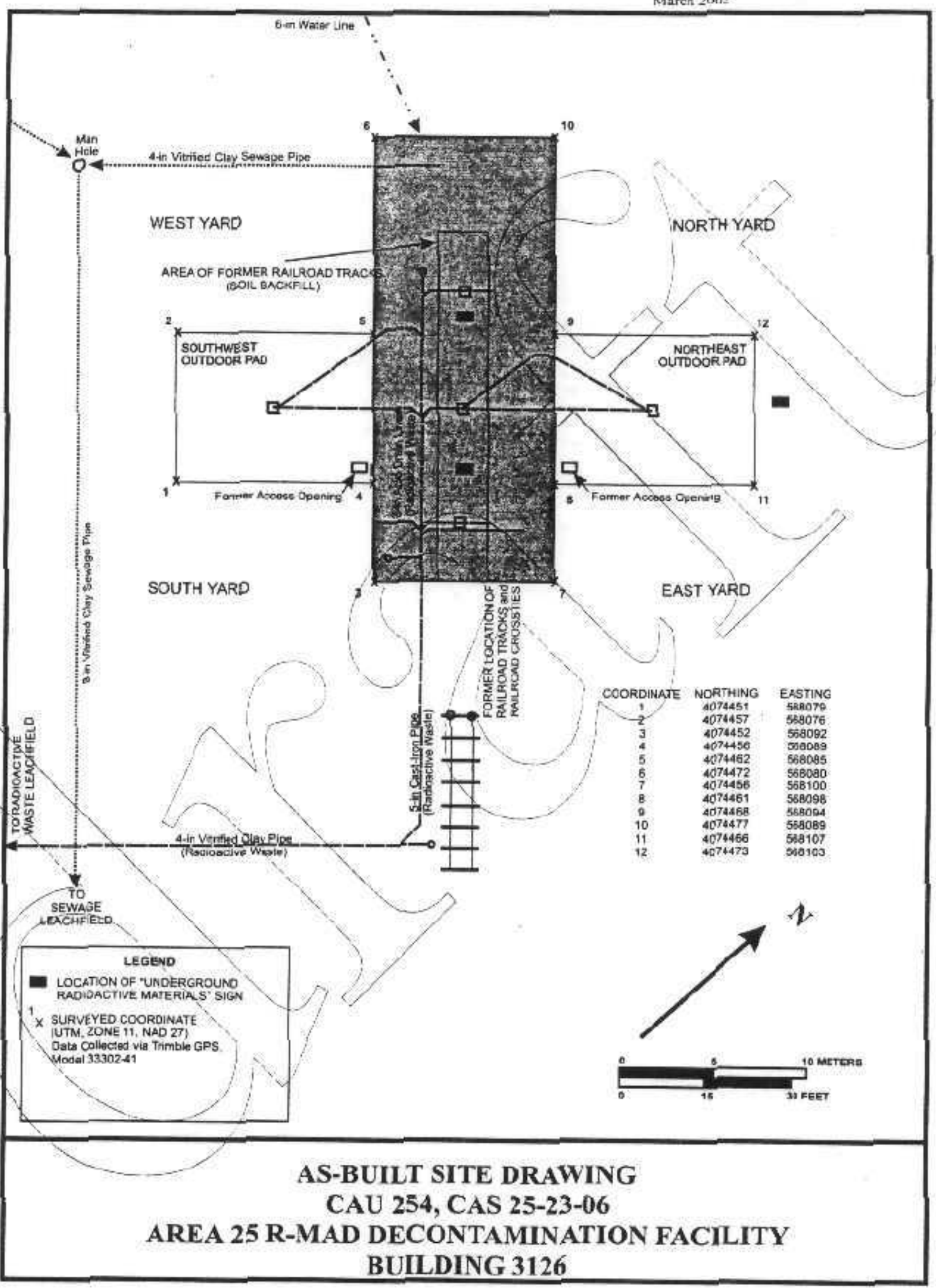


APPENDIX B

WASTE PROFILES 
THIS PAGE LEFT INTENTIONALLY BLANK 


\section{APPENDIX B}

\section{TABLE OF CONTENTS}

Asbestiform LLW Waste Profile $\ldots \ldots \ldots \ldots \ldots \ldots \ldots \ldots$. B-5

Hazardous Waste Profile $\ldots \ldots \ldots \ldots \ldots \ldots \ldots \ldots \ldots \ldots$, B-24

Low-level Waste (LLW) Profile $\ldots \ldots \ldots \ldots \ldots \ldots \ldots \ldots$, B-4l

Mixed Waste (MW) Profile $\ldots \ldots \ldots \ldots \ldots \ldots \ldots \ldots \ldots$ B-54 
THIS PAGE LEFT INTENTIONALLY BLANK

B-iv 


\section{ASBESTIFORM LLW WASTE PROFILE (LRY5MWFY01021)}

B-5 
THES PAGE LEFT INTENTIONALLY BLANK

B-6 


\section{Waste Characterization Summary \\ Waste Stream LRY5MWFY0102I \\ Revision 0}

\subsection{Origin of the Waste}

This waste strean consists of remediation waste from Corrective Action Unit 254 (CAU 254), Area 25 Reactor-Mainrenance Assembly and Disassernbly (R-MAD)

Decontamination Facility. The facility was used for decontamination of test-car hardware and tooling used in 1963 through 1973 as part of the Nuclear Rocket Development Station prograun. Subsequently the facility was used to decontaminate a military tank in the eatiy 1980's. Contemination of the interior of the decontamination facility resulted from decontamination fluids on the insice and exterior concrete pads. Overspray of decontamination fluids contaminated the astestiform insulated pipe elbows and joints.

The waste generation processes include hot line operations and friable asbestiform instlated pipe elbow and joint removal. These materials were removed by asbestos trained workers. The elbows and joints were wetted with a water and suffactant mixture, wrapped in 6-mil plastic and taped before removal. Following removal, the elbows and joints were enclosed in 6-mil plastic bags and packed in 55 -galion drums.

\subsection{Quantity of Waste}

The quantity of wasta for FYZ002 is approximately 1 cubic meters.

\subsection{Waste Description}

The waste strearn consists of hotline compactible trash (e.g., personal protection equipment [PPE], tape, kimwipes, paper, plastic, plastic bags, etc.) ACM insulated pipe elbows and joints.

\subsection{Waste Characterization Detemination}

\subsection{Hazardons Waste Constituents}

Process knowledge (inc. sampling and analysis data) resulting from the corrective action investigation is used to characterize raaterial for this waste strean. The U.S, Department of Energy Nevada Operations Office (DOENV) report DOENV-619. Corrective Action Decision Document for Corrective Action Unit 254: Area 25 R-MAD Decontamination Facilth, Nevada Test Sile, Nevada, June 2000 (CADD) contains analytical results of the corrective action investigation. 
The ACM insulated pipe elbows and joints were not sampled for RCRA constituents to prevent unnecessary exposure of sampling worker to asbestos fibers. A BN IH subject matter expent made the friable asbestos determination. Analytical results from associated building debris (wood, concrete and non-ACM insulation) are used to determine the waste characteristics.

The results of this investigation are summarized in the Executive Sumrnary on pages ES2 through ES-4 of the CADD. Analytical data for building materials (debris) are found in Appendix $D$ of the CADD. Tier I, II and III data evaluation were completed by IT Corp. and are documented in Appendix $A$ of the $C A D D$.

The analytical data from the CADD were used to characterize each type of waste material sampled (e.g., concrete, wood, and insulation) for this waste stream. The average concentrations for potential constituents of concern were determined for each type of material (see Table 1). The following paragraphs summerize the results of the hazardous waste deternination for this waste stream.

\section{Toxicity Characteristic Waste}

Total metals, total volatile organic compounds (VOCs), and total semi-volatile organic compounds (SVOCs) data found in Appendix A of the CADD are used primarily for toxicity characteristic determinations of the building debris.

The analytical results from buildings samples presented in the CADD were well below toxicity characteristic concentrations established in 40 CFR 261.24 for all materials with the exception of cadmium. The TCLP results for cadmium from a single wood sample taken from the south decon bay door was $4.7 \mathrm{mg} / \mathrm{L}$ (the results from the other wood samples were well below $1 \mathrm{mg} / \mathrm{L}$ ). Two insulation samples (one sample from the south decon bay door and one from the northwest decon bay door) had reported calculated TCLP results of $0.95 \mathrm{mg} / \mathrm{L}$ (just below the regulatory limit of $1.0 \mathrm{mg} / \mathrm{L}$ ). Since these were the only samples that indicated toxicity concentrations greater than or close to regulatory linits, confirmatory samples of associated non-ACM materisl were collected and analyzed for TCLP metals.

Confirmatory samples of wood and insulation were taken in accordance with the Sampling and Analysis Plon, Nevada Test Stte, CAU 254, Area 25 R-MAD Decontamination Facility, Rev. O, May 2001. The cotifurnatary samples consisted of a composite sample of wood taken from the south decon bay door and two composite insulation samples, one from the south decon bay door and one from the northwest decon bay door. These confirmatory samples were collected from the material and locations that indicated the highest cadmiun concentrations from the site investigation results. The TCLP cadmium analytical results for the wood sample from the south decon bay door was $0.0105 \mathrm{mg} /$, while the TCLP cadmium results from the insulation samples were 0.407 and $0.117 \mathrm{mgL}$ (see Table 1). The results of these samples were used to generaie the mean and ugper confidence limit for TCLP metals presented in the NTSWAC Waste Profile \#IRY SMWWYO1020 and associated MEF \# F01020. 
Since the confirmatory sample results from associated, non-ACM materials were below the RCRA toxicity concentration linit for cadmium, and all other toxicity constituent concentrations were well below the toxicity concentration limits in the site investigation samples, the wagte siream does not exhjbit the toxicity characteristic.

\section{Listed Waste}

The waste generator (BN Environmental Remediation) docunened the anticipated listed waste codes in the NNSANV Corrective Action Ptan for Corrective Action Unif 2,54: Area 25 R-MAD Decontamination Facility, Nevada Test Site, Nevada, Rev0, December 2000 (DOE/NV-678) section 2.3.6 Mixed Waste. These codes include acetone (F003), carbon disulfide (F005), ethylbenzene (F003), toluene (F005), 1,1,1-trichloroethane (F002), trichioroethene (F002), and zylenes (F003).

In accordance with the Technical Guidance Momorontum, Sepiember 7, 1999, Interpretation of Hazardous Waste Regulations as They Apply to Potential Solvent Contominated Waste from $C A U 254$ (RMAD Decon Factlity), the following componds are the hazardous waste codes to be assigned:

$\begin{array}{ll}\text { Carbon Tetrachloride } & \text { F001 } \\ \text { Trichlorothylene } & \text { F001 } \\ \text { 1,1,1-Trichloroethylenc } & \text { F001 } \\ \text { 1,1,2-Tticholo-1,2,20Ttrfluotethane } & \text { F002 }\end{array}$

The Corrective Action Plan for Corrective Action Unit 254: Decontamination Facility, Nevada Test Site, Nevada, December 2000 (DOENV-678 (CAP) section 2.3.6, Mixed Waste, lists acetone (F003), carbon disulfide (F005), theylbenzene (FO03), toluene (F005), 1,1,1-trichloroethane (F002), trichloroethene (F002), and xylene (F003) as listed waste. The F002 listed code compounds are also listed as F001 codes. The F001 code is used in this waste profile (LRYSMINFY01020).

Not all of the listed codes discussed above are detected in each type of brifiding materials removed from the Decontamination Facility. All listed code compounds contained in builting debris for this waste strears are at concentrations below the 40 CRF 268.40 treatment standards. The CADD site investigation analytical results are summatized in Table I.

The first railroad tie outside and south of the decon bay door contains the following organic compounds (CADD, Appendix D) and waste codes from the above two lists:

$\begin{array}{ll}\text { Carbon Tetrachloride } & \text { F0OI } \\ \text { Trichloroethylene (Trichloroethene) } & \text { F001 } \\ 1,1,1-\text { Trichloroethane } & \text { F001 } \\ \text { Acetone } & \text { F003 } \\ \text { Ethylbenzene } & \text { F003 }\end{array}$


M+P-Xylene

F003

O-Xylente

F003

Carbon Disulfide

F005

Toluene

$\mathrm{F} 003$

Benzene is reported in the CADD from one concrate sample taken from the east decon samples. This constituent is assumed to be an F005 code.

Not all of the building materials (debris) have each of these whste codes. Separation of the building debris into several waste streams is not practical. The reported concentrations of all of these organic compounds in the CADD, Appendix D, are below the 40 CRF 268.40 Treatment Standards for Hazardous Waste and are not Land Disposal Restricted. The waste codes assigned to the LRY5MWFY01020 waste stream include F001, F003 and F005.

\subsection{Radionuclide Constituents}

Frocess knowledge from an extensive concetive action investigation is used to characterize material for this waste stream. The CAU 254 CADD Appendix D contains the results (strontium 90, gamma spectrometry, isotopic plutonium and isotopic uranium analytical data) of the corrective action investigation. The reported radionuclides include Cs-137, Sr-90, NB-94, Eu-154, U-234, U-235, U-238 and PU-239. A sumnary of the site investigation process knowledge in found Table 2.

The transite wall board and the friable asbestos covered pipe elbows and joints were not sampled during the site investigation or during waste characterization. Sampling of this waste material may have resulted in generation of asbestos frbers to the working environment and unnecessary exposure of workers to asbestos fiber. The transite wallboard and friable asbestos insulated pipe elbows and joints are on vertical interior surfaces of the decontanination facility. Overspray from decontamination activities are expected to tesult in higher concentration of contaminants in the concrete floor than the interior wall and pipe surfaces. The snalytical results from the other building materials are used to characterize the materials.

Results shown in Table 2 are used as process knowledge to calculate the radionuclide activities reported in profile \#LYR5MWFY01020.

\subsection{Free Liquids}

The material consists of dry building debris and compactible hotline trash that does not contain free liquids. The waste was packaged in accordance with BN organization procedure, $O P-2151,304$, Radiaactive Waste Tracking, Hondling, and Management at the NTS (OP-2151.304) assuring no fre liquids are contained in this waste. As waste is packaged, it is visually inspected for free liquids. 


\section{4,4 Fine Particulates}

The material consists of dry building debris and compactible hotine trash that does not containing fine particulates. The waste was packaged in accordance with BN ongarization procedure, OP+2151.304, Radioactive Waste Tracking, Handling, and Management at the NTS (OP-2151.304) assuring no free liquids are contained in this waste. As waste is packaged, it is visually inspected for fine particulate.

45 Gases, Etlologic Agents, Chelating Agents, Explosives, Pyrophorics, Beryutum and PCBs

Process knowledge for this waste stream generated during site investigation (as documented in the CADD) does not indicate the presence of any of these materials. Also, the waste was packaged in accordance with BN organization procedure, $O P$ 2J51.304, Radioactive Waste Tracting Handling, and Management at the NTS (OP. 2 (51304) assuring none of the above were included in with this waste. 


\section{Nevada Test Site Waste Profile, Revision 3, 12/2000}

\section{A. Gederator Information}

1. WCO

Phjllip Ratchs Phone 295-5685 FAX

$295-6569$

2. Techrical Contact

3. DOE COntact

Harry Perry Phone

4. Faciliry Name Kenneth Small Phonte

295-0685 FAX

$295-4815$

Address Bechtel Nevgda City P.O. Bax 9852! Las Veras Starle 295-1933 FAX 295-1153

5. EPA dentification Number NV3890090001

B. General Waste Stream Information

1. Waste Stream Identification Number LRY5MWFY0102I Profile Revision Nuraber 0 Profile Revision Date

Decentiba 12,200$]$

2. Title of Worte Stream Area 25, R-MAD Decontamination Facility - Asbestiform Mixed Low-Level Waste

3. Waste Category

4. Generating Process Description

This waste streans is a result of remediation of Corrective Action Unit 254 (CAU 254), Area 25 Reactor-Maintenanee Assernbly and Disassembly (R-MAD) Decontemination Facility. This facility was used for the decontamination of test-cor hardware and tooling used in I961 through 1973 as part of the Nuclear Rockel Deyelopment Station program. Subsequenty the facility was used to decontaminate a militery tank in the early 1980 s. Specific processes from which this waste strearn are generated include removal of contaminated material from the deoontaminetion building and the exterior dooontsminstion peds, end hotime and CA operations. The wagte strean consitos of compectible trash (including, personal protection equiprnent [PPE], tape, kimwipes, paper, plastic, plastic bags, dc.), and bullding debris, (inctuding, asbestifom insulated pipe eflows and joints).
$\square$ Yes
No
Proess description contiruztion page attached?
$\square$ Yes
No
Flow diagram attarhed?

5. Extmated Rare of Oenerarton
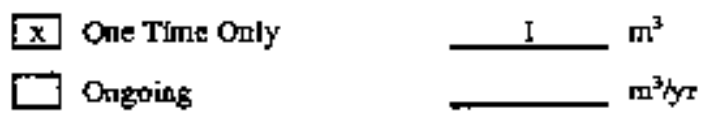

6. Reasous for Submitral (specify one)

国 New Wast Stream

$\square$ Modification to Waste Stran

7. $\square$ Yes $\mathbf{Q}$ No

Dons this waste atream require a WAC deviation? Atrach infotnation.

C. Physical Properties

1. Waste Fom Description

目 Solid $\square$ solidified $\square$ Encapsnlated $\square$ Sludge

2. List Waste Strearn Components

Estimatex Percent by :

Asbestiform pipe elbous and ivints

\begin{tabular}{ll}
\hline$x$ Volnme & $\square$ Weight \\
\hline
\end{tabular}




$$
\text { DYes } \quad \text { No Conponent continuation page attached? }
$$

3. The final waste form must cornply with the following critorta as defined in the WAC. List docurrentation that demonstrates WAC complianse for tach.

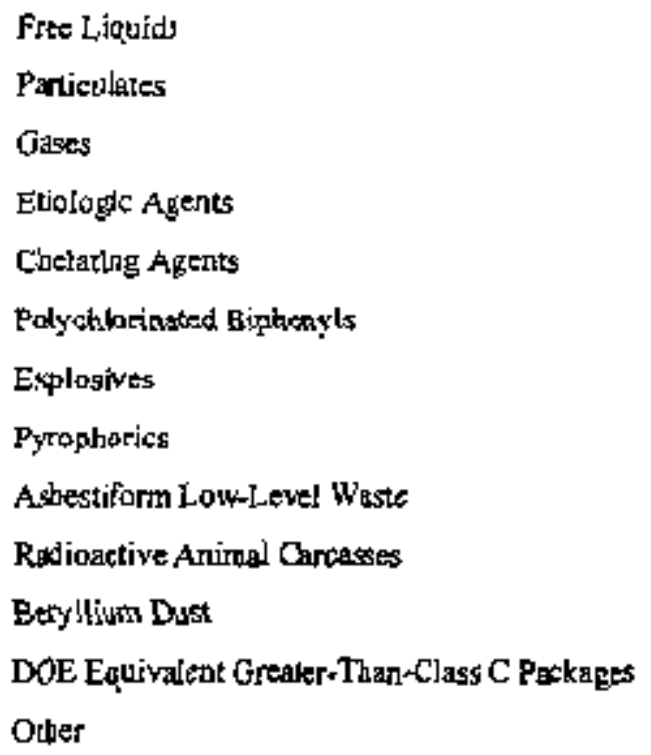

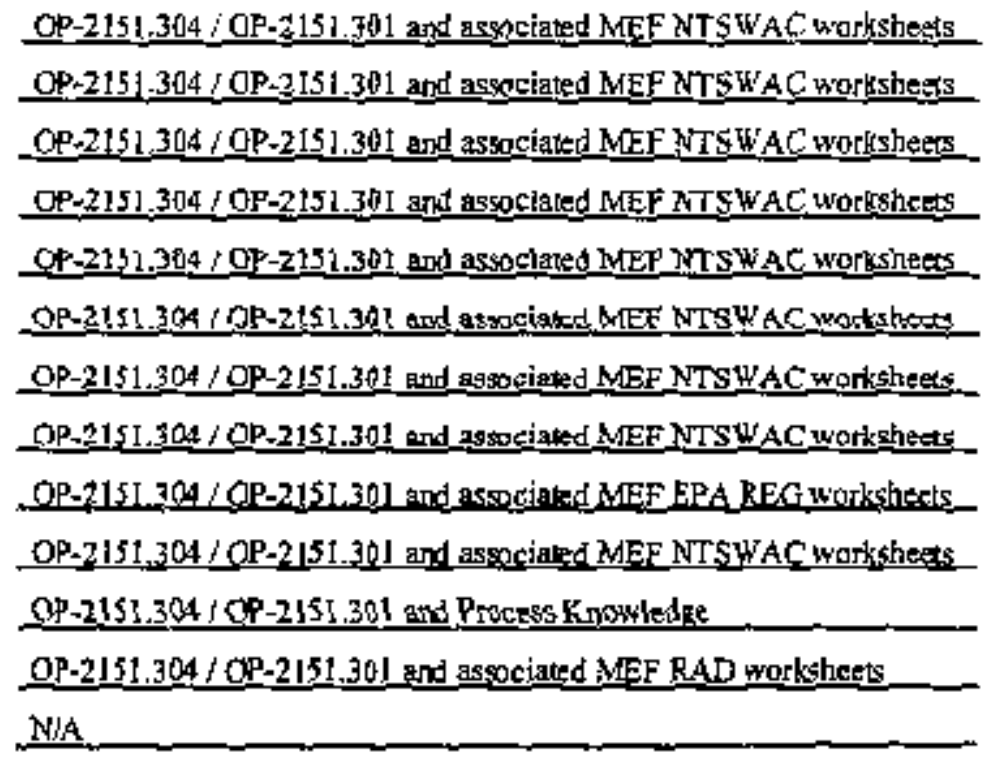

\section{RCRA Characterization}

1. RCRA ctarscterization by:

Check all that apply

$$
\begin{aligned}
& \text { 区 Proctes Kupwledze } \\
& \square \text { Sanpling and Analysis for complete characterzation } \\
& \square \text { Confiftlatory Sanpiling and Analysis }
\end{aligned}
$$

List documents that crotroi RCAA deteminatlons.

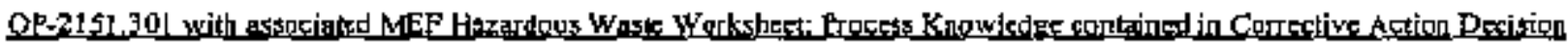

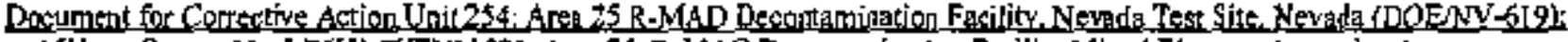

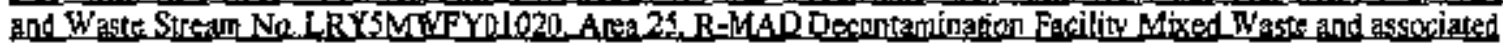
characterization documentesing in MEE HEY 01022

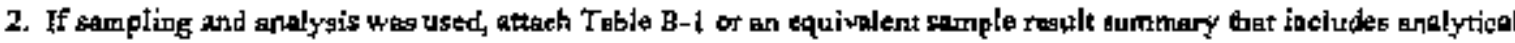
results, upper confidence limits, and explanntions of anomialies for all analytes analyzed. include any state-specific analyte results.

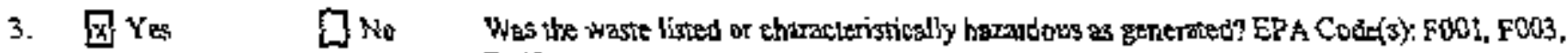
Foos

4. Docs the final waste form cabibit any characteristics of hacadous waste as defined in Tite ,40 CFR 26t?

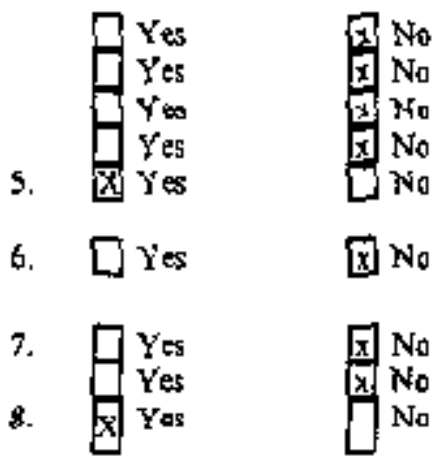

Isitzbility

Corrosivity

Reactivity

Toxicity

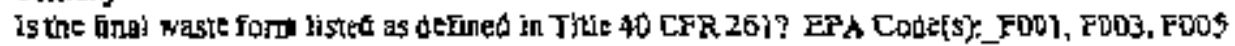

Wo Is the wasie hazardous per state-of-generation regulations? if yes, idertify hazardous oompoants and stote regulatious.

Has the waste baen trated? Attach information which vorifies WAC conpliance If yes, was the waste trated sfur August 24, 1998 ?

Is the final waste form mixed waste? If yes, attach inforration which verifies LDR compliance Waste net treetment stapdards at the point of geberation. Therefore, no furtber trestment is necessery to naeet LDR complibence. 


\section{E. Radiological Properties}

1. Radiplagional characterizstion by (check all that apply)
X Process Knowiledge
$\square$ Sampling \& Analysis
Materiaks Control \& Accountability
$\square$ Direct Measurement
$\square$ Gross Radiation Measurement
$\square$ Scoling Factors
$\square$ Other

2. Reference documeats that destibe the radiological characteriation process.

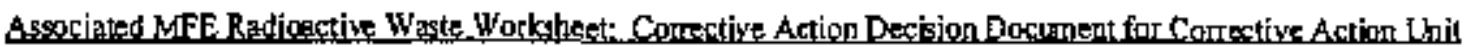

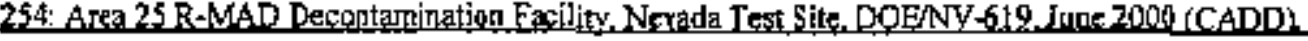

3. Reference documents that describe the method of detemining package activity.

\section{Associated MFe Radipactive Waste Workthest}

4. List reportable radionuclites as defened in the WAC.

Rartionuclide

C.137

St-90

$\mathrm{U}=734$

U-23:5

[1-238

Pu-239

Eu-154

Nh-94
Activity Range ( $\left(\mathrm{gq} / \mathrm{m}^{\mathrm{j}}\right)$

$\frac{4.68 \mathrm{E}+03}{3.22 \mathrm{E}+04}$ to $\frac{2.01 \mathrm{E}+07}{2.67 \mathrm{E}+07}$
$\frac{3.47 \mathrm{E}+03}{5.39 \mathrm{E}+03}$ to $\frac{4.86 \mathrm{E}+06}{1.21 \mathrm{E}+05}$
$\frac{3.51 \mathrm{E}+03}{9.84 \mathrm{E}+02}$
$\frac{1.76 \mathrm{E}+04}{2.10 \mathrm{E}+05}$ to to $\frac{3.03 \mathrm{E}+04}{2.90 \mathrm{E}+05}$
$-2.69 \mathrm{E}+03$

Activity Replesentative of Finu Waste Farm (Bq $\left./ \mathrm{m}^{3}\right)$

\begin{tabular}{l}
\hline $.43 \mathrm{E}+06$ \\
\hline $3.76 \mathrm{E}+06$ \\
\hline $9.01 \mathrm{E}+06$ \\
\hline $3.85 \mathrm{E}+04$ \\
\hline $3.31 \mathrm{E}+04$ \\
\hline $6.89 \mathrm{E}+03$ \\
\hline $9.27 \mathrm{E}+04$ \\
\hline $1.58 \mathrm{E}+04$ \\
\hline
\end{tabular}

X] No

Reportable Radionaclide continuation page altached?

Attach chemical form of radionuctide list if tnown. Page attached?

5. $\square$ Yes $\mathrm{Q}$ No

Does the wigte contrin any alpha-emitting tranguranic madionucIides with a half-life greater than 5 years

6. $\mathrm{Y} Y$ 吅 $\square$ No (Pu-141 a Cm-242)? If yes, list below.

Transuranic Nuclides

Pu -239

$\frac{P u-239}{\square \text { Yes } \quad \text { No }}$

Activity Range (nCifg)

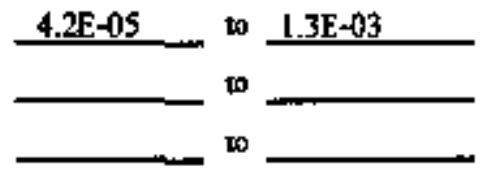

Transuranic guxlfde contisuation pagc attached?
Activity Represenbalive of Final Waste Form (nCig)

2.95-0.4

7. List documents thet deseribe process(es) that controls TRU determinations and ensofes TRU waste is not shipped

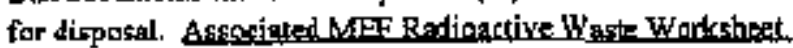

8. $\mathrm{x}$ Y $\rightarrow \mathrm{No}$

Is entiched uraniturn present? lf yex grovide enrichment of ${ }^{\mathrm{DS}} \mathrm{U}$ by whightpercent $15 \%$ Providt maximum mass of ${ }^{212} \mathrm{U}$ per package 0.05 g/packnge. Referenos ontrolling docoments. See MEF \# F01021 Radioactive Waste Wukshetet and C alculations 


\section{F. Packaging Description}

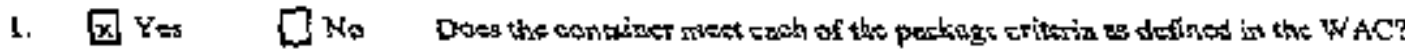

List docomentation that demonstrates WAC compliance.

Waste will be pactaged and prepared for slipment aecorting to procedure Op-2 is1.304. Waste packares will be inspected prior to certification and shipment according to procedure L-A20.014 and L-A20.0IS.

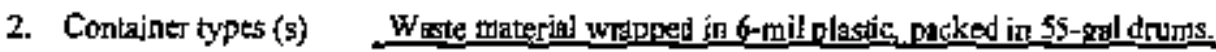

DOr Specification(s)/Descriptions(s) Strong Tight

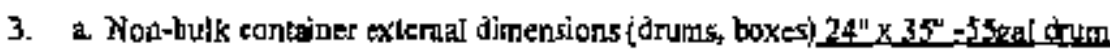

Does box meet 3,375 it/fit staength test?

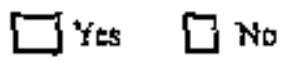

Weight Range $\mathrm{NA}$ - $\mathrm{kg}$ to $\mathrm{NA} \mathrm{kg}$

b. Bulk package externd dimensions (cargo containers, soli-offs) Wis

-

Weight Range NA_ $\mathrm{kg}$ to NA__ $\mathrm{kE}$

c. Bulk shiprpent dimeasions NA

Weight Range NA_ $\mathrm{Ng}$ to NA_ kg

4. Estimated radiation dqse rite of firposil packige:

Surtace Q.coot to 0.045 asvih

One meter 0.0002 to 0,005 mSv/h

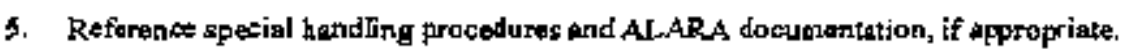

G. \$lensturt

To the besc of my knowledgc, the information in this docutrient and artachmefts is crue and acturate. Wulful and delixerate omissiors have nol been made. All known and suspated hazardous materials have been disclosed.

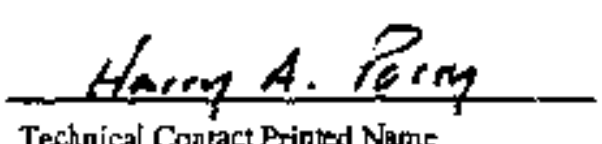

Technical Contact Printed Name

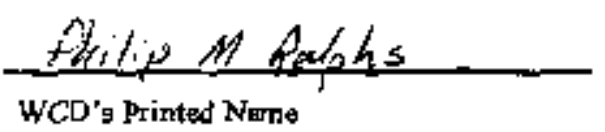

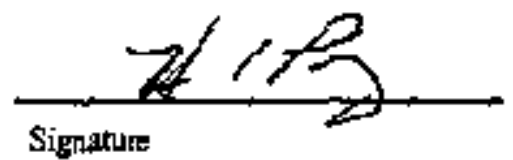

Sigrature

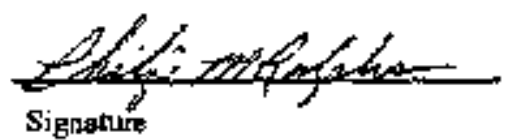

$12 / 13 / 01$

Date

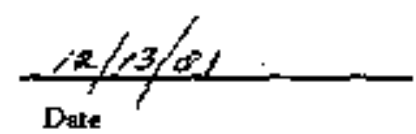


Table B-1

Analytical Resules

$\begin{array}{cc}\text { Statistical } & \text { Upper } \\ \text { Mean } & \text { Confldence } \\ \text { (mgL) } & \text { Leve] }\end{array}$

TCLP Metols:

Arseric

Befium

Cadmitun

Chrominm

Lead

Mentury

Scleqium

Şilyer

TCLP Volatiles:

Beozene

Casbon Tetrachloride

Chbrobenzene

Chlorotorm

1,4-Dictlombenzene

1,2.Dichlorothane

Methyl ethyl ketone

Pyridine

Tetachiloroethelyne

Triehlorwethylenc

Virvl chloride

Dichloroethylene

\begin{tabular}{l}
$\frac{0.036}{0.347}$ \\
\hline 0.178 \\
\hline 0.0345 \\
\hline 0.0535 \\
\hline 0.00043 \\
\hline 0.0349 \\
\hline 0.0032 \\
\hline
\end{tabular}

0.04

$0.670 \quad$ p-Cresol

$0.5899 \quad \mathrm{~m}-\mathrm{Cr} \mathrm{ses} \mathrm{I}$

0.0927 Cresol

0.0970 Diritrotoluege

$0.00124 \quad$ Hexwdhlorobenzente

0.0349 Hexachloro-1,3-butadiene

$0.0040 \cdot$ Nitrobenzene

Pentachlorophenol

PK/CADD

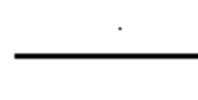

2,4,5-Trichtoroptenol 2,4,6-Trichlorophenol

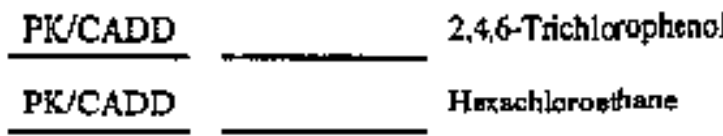

TCIP Pestleldes

TCLP Pestjcides and Herbletdes:

PK/CADD

PK/CADD

PK/CADD

PK/CADD

PR/CADD

PK/CADD

PK/CADD

PK/CADD

PW/CADD

PKVADD

PKJCADD

PK/CADD

PK/CADD

PKJCADD

PK/CADD

PK/CADD

PKJCADD

Chlordane

PKVADD

2,4 - D

Endrin

Feptachlor and Hydroxide

Lindane
Statistical

Mean

(mp/L)

Lpper Confidence Level

\section{TCL.P Somivalatllest}
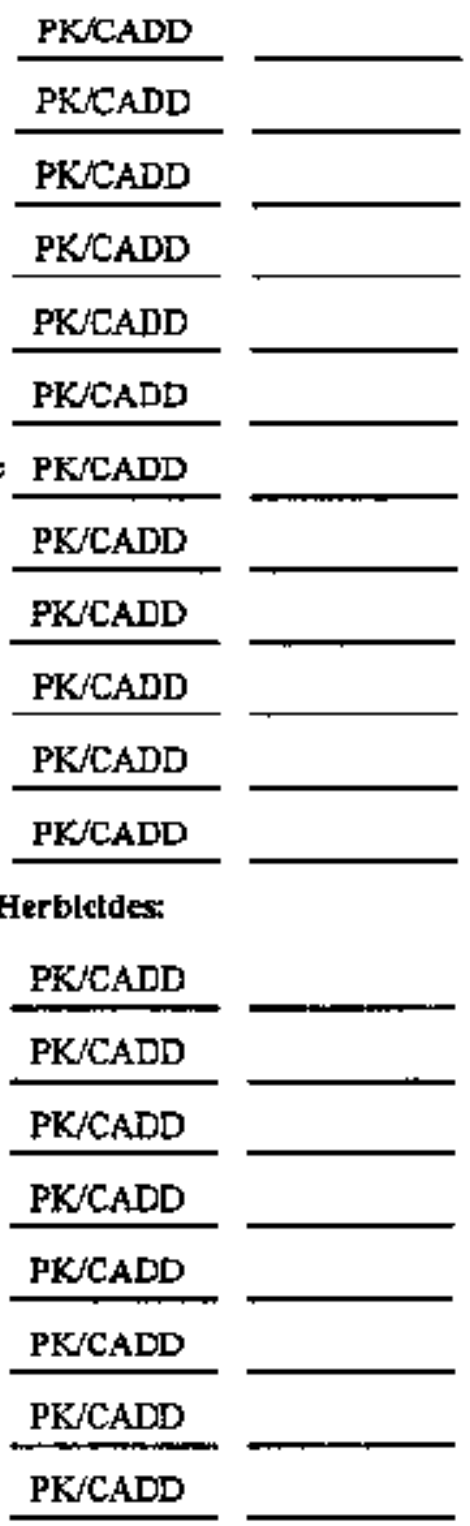

Note: See attached table, (CAU 2SA CADD, Builfing Debris Analytical Results Sumnary . Waste Stream ID \#'s LRY 5MWFY01020 and LRY SMWFY01021) for a summary of CADD process knowledge information. 


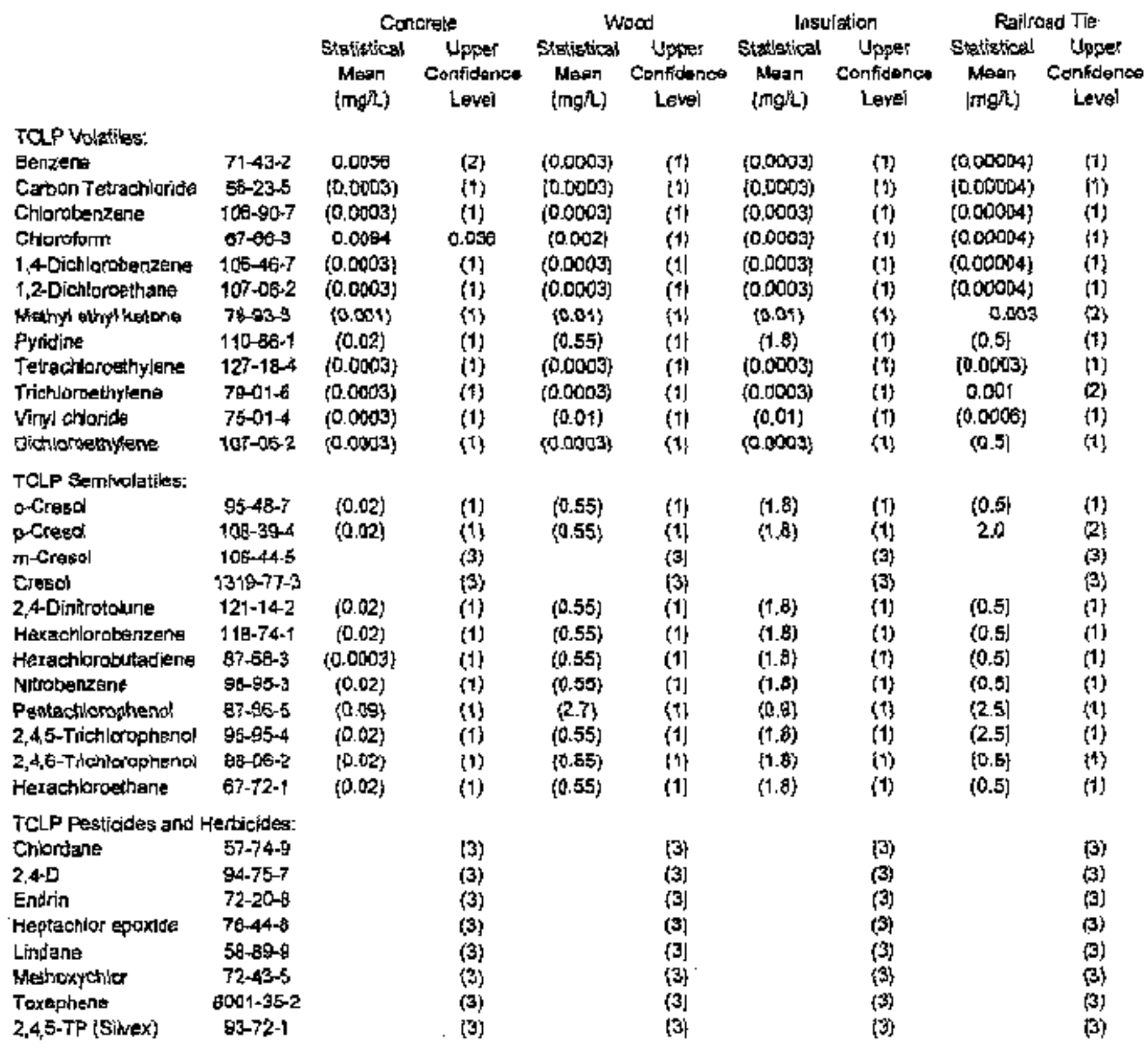

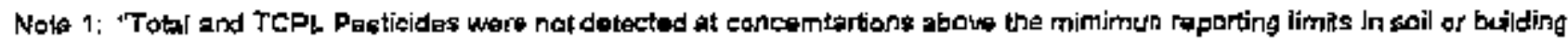
material sampled" during the site inwestigation CAU, 254 CADO, Executive Summar, page EA-3.

Now 2: The anatytical data snown in this table (mg/L) were determined by dividing the totals data in ugikg by 20.

(1) dotection linht .

(2) detected in anly one sample

$3-17$

(3) not analyzed 


\section{Land Disposal Restrictions Notification and Restriction Waste Stream \# LRY5MWFY01021 \\ Area 25, R-MAD Decontanination Facility - Mixed Waste}

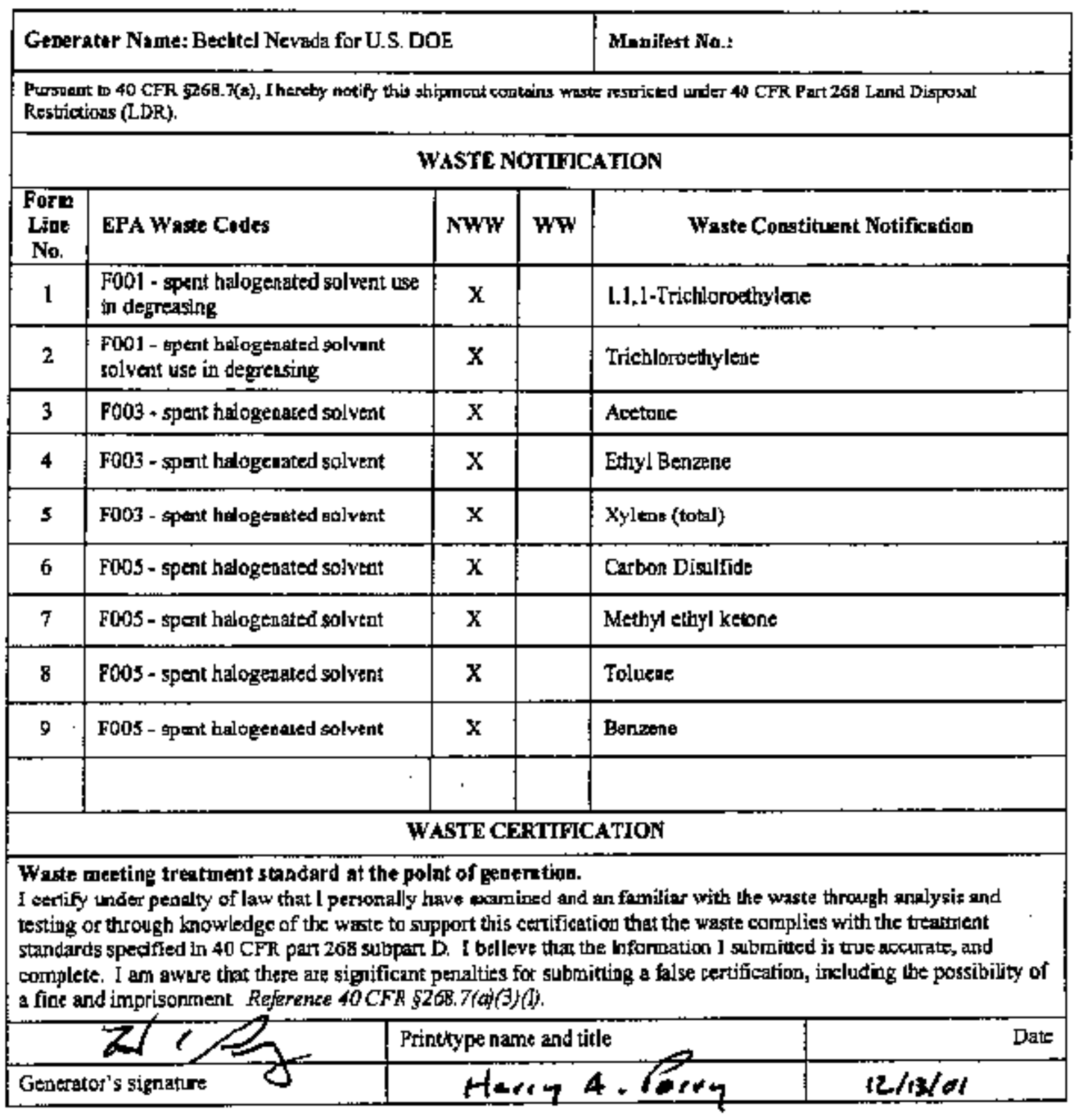




\section{Waste Stream Nomber LRYSMWFY01021 \\ References}

Bechtel Nevada Organization Procedure, OP-2151 301, Fadionetive Waste Evahuation, Rev, 0.

Bechtel Nevada Organization Procedure, OP-2151.304, Radioantive Waste Tracking, Handiling, and Management at the NTS, Rev. 2.

Material Evaluation Form Folder No. F01021.

Material Evaluation Form Folder No. Fo1020.

NTSWAC Profile Number LRY5MWFY01020, CAU 254, Area 25, R-MAD Decontamination Facility - Mixed Waste.

U.S. Department of Energy Report DOE/NV-619, Comective Action Decision Document for Corrective Action Unit 254: Ares 25 R-6AD Decontamination Facility, Nevada Test Sile, Nevada, June 2000. 


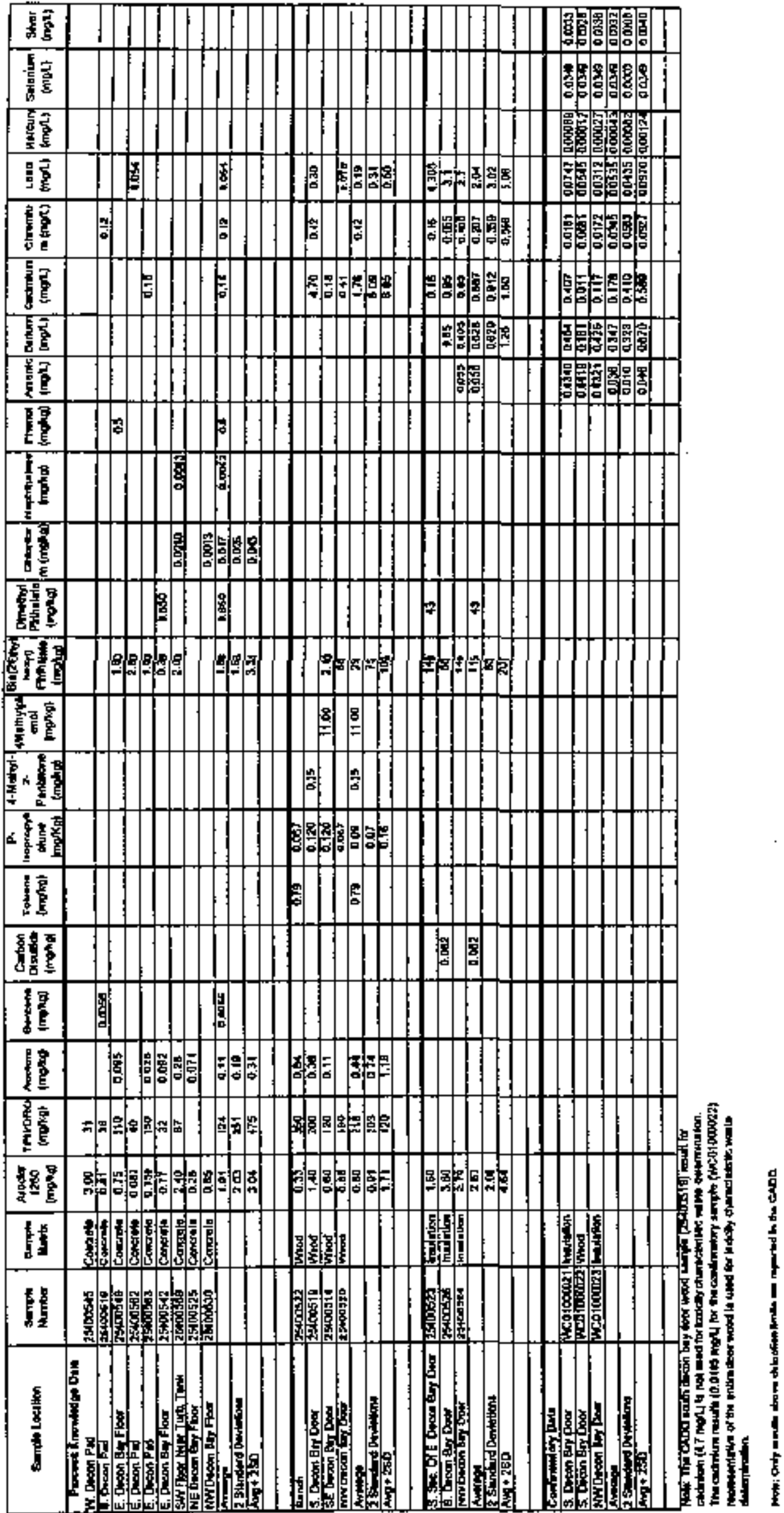




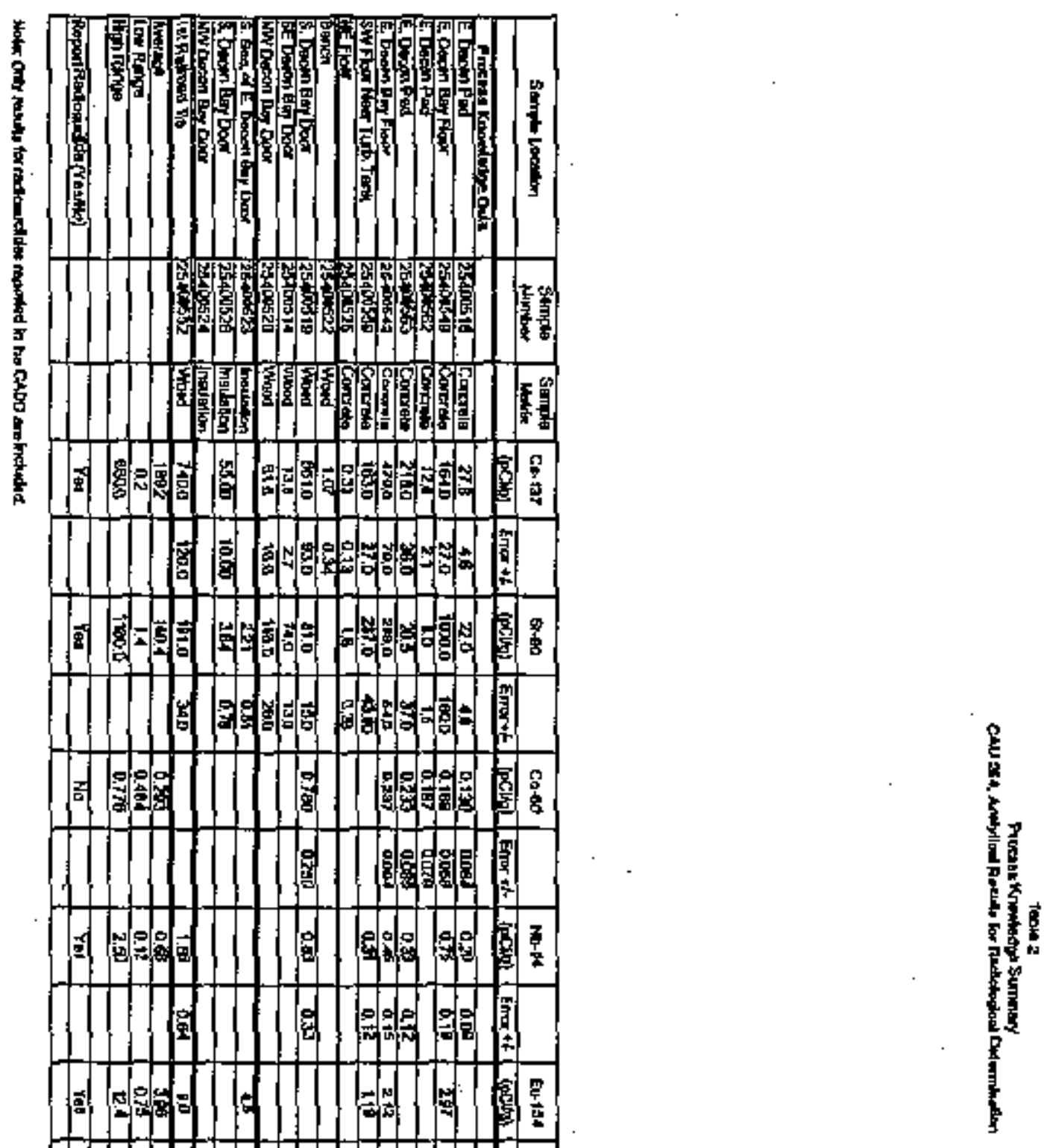

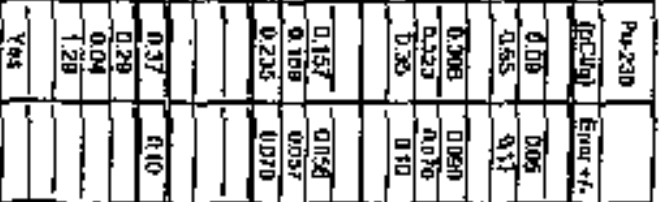




\begin{tabular}{|c|c|c|c|c|c|c|c|c|c|c|c|c|c|c|c|c|c|c|}
\hline & $\begin{array}{l}\text { Wasta } \\
\text { Lass } \\
(\mathrm{kg})\end{array}$ & 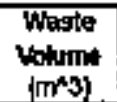 & C5-137 & & $s+80$ & & Not4 & & Eu-154 & & y-234- & & U235 & & U-23: & & Put-239 & \\
\hline & & & 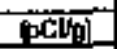 & Eghr's & (pclol & $8 q / m^{2} 3$ & 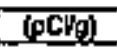 & 부 $\mathrm{m}^{2} 3$ & $(\mathrm{p} C \mathrm{C} / \mathrm{\rho})$ & Bq/n $m^{2} 3$ & $\left(\mathrm{gcl} \mathrm{Ll}_{\mathrm{g}}\right)$ & Bngrem & {$[\mathrm{p}(\mathrm{i} / \mathrm{j})$} & 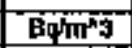 & $(p-d y)$ & 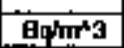 & (1) $\mathrm{Cug}^{\prime}$ & $\mathrm{By}^{\prime} \mathrm{m}^{\mathrm{N}} \mathbf{3}$ \\
\hline & $9719+1$ & 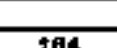 & & & & & & & & & & & & & & & & \\
\hline Areanos & $1039+5$ & & T但? & 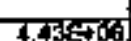 & 160.4 & 376 & 0.676 & 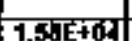 & 3,86 & 8270 & 36.5 & 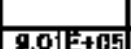 & 1.8 & 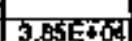 & 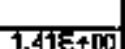 & 33 & 0304 & 8 月 \\
\hline 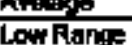 & & & $-\overline{\mathrm{a}}$ & . & Dent & $\frac{3,650}{3.23 E+04}$ & $\frac{0.070}{\mathrm{D} 116}$ & $\frac{\mid}{269 \mathrm{gE}+03}$ & 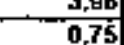 & $\frac{1.25}{17}$ & 0.148 & 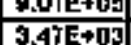 & 6.20 & $\frac{3,695+144}{5.39 \mathrm{E}+93}$ & 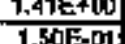 & $\frac{3.31 E+04}{365}$ & 0,294 & 8. $80 \times+60$ \\
\hline L & & & 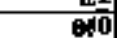 & 201EAp? & $\pi$ & $2.7 \mathrm{~B} \leqslant \cdot d \gamma$ & 25.5 & $5.66=2+04 \mid$ & 12.4 & $2.80+05$ & 207.6 & $\mid 4,76 E+06$ & 5.16 & $1,30 \mathrm{E}+06$ & 4. & $1.1 \mathrm{BE}+106$ & 1.293 & $3.03 \mathrm{E}+0 \mathrm{~d}$ \\
\hline & & & & & & & & & & & & & & & & & & \\
\hline Detion & plese 9 & $\bar{A}=\overrightarrow{A C}$ & thy $\left(\mathrm{p}^{\mathrm{C}} \mathrm{p}\right)$ & Wasing & {$[\mathrm{k} \nabla]^{2}+100$} & $0, g / g^{*} 0.0$ & $97 \mathrm{Gq}$ & 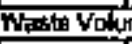 & 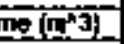 & & & & & & & & & \\
\hline & & & & & & & & & & & & & & & & & & \\
\hline
\end{tabular}




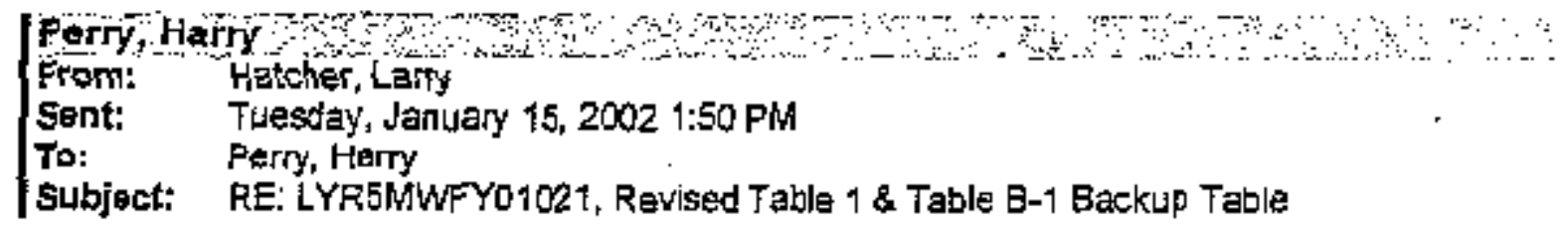

I have reviewed the contents of cells which perform calculations. The discrepencies I identifited have been corrected and the spreadsheat appears correct.

Larry

n-Original Hessago-

From porry Hary Sent: Tuesday, January $15,20021,21 \mathrm{PM}$

To: Hatcher, Larry

Gubject: LYR5MWFY01021, Ravised Tabla 1 \& Table B-1 Backup Table

Please review the calculations for the altached. Table 1.

I have reviewed the calculations and revised the calculations in Table 1.

in Table 1, note the changas in the "Avg + 2SD" insulation values for cadrnium and lead values. These values are greater than the regulatory limits. This the reason we had the waste material resarrole. Representative samples were taken from materlal of concern and analyzed for TCLP matals. The results for the insulation were determined by dividing total metals by 20 as a conservative estimate for TCEP metals. As you can see the confimnabry tesults are much lower and were used for waște determination.

$\ll$ F |te: Table 1.xls $>$ 


\section{THIS PAGE LEFT INTENTIONALLY BLANK}


HAZARDOUS WASTE MATERIAL PROFILES 
THIS PAGE LEFT INTENTIONALLY BLANK

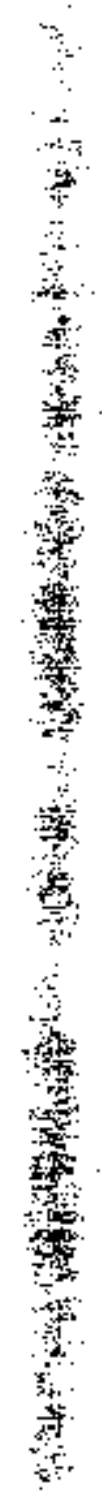




\section{Material Profile}

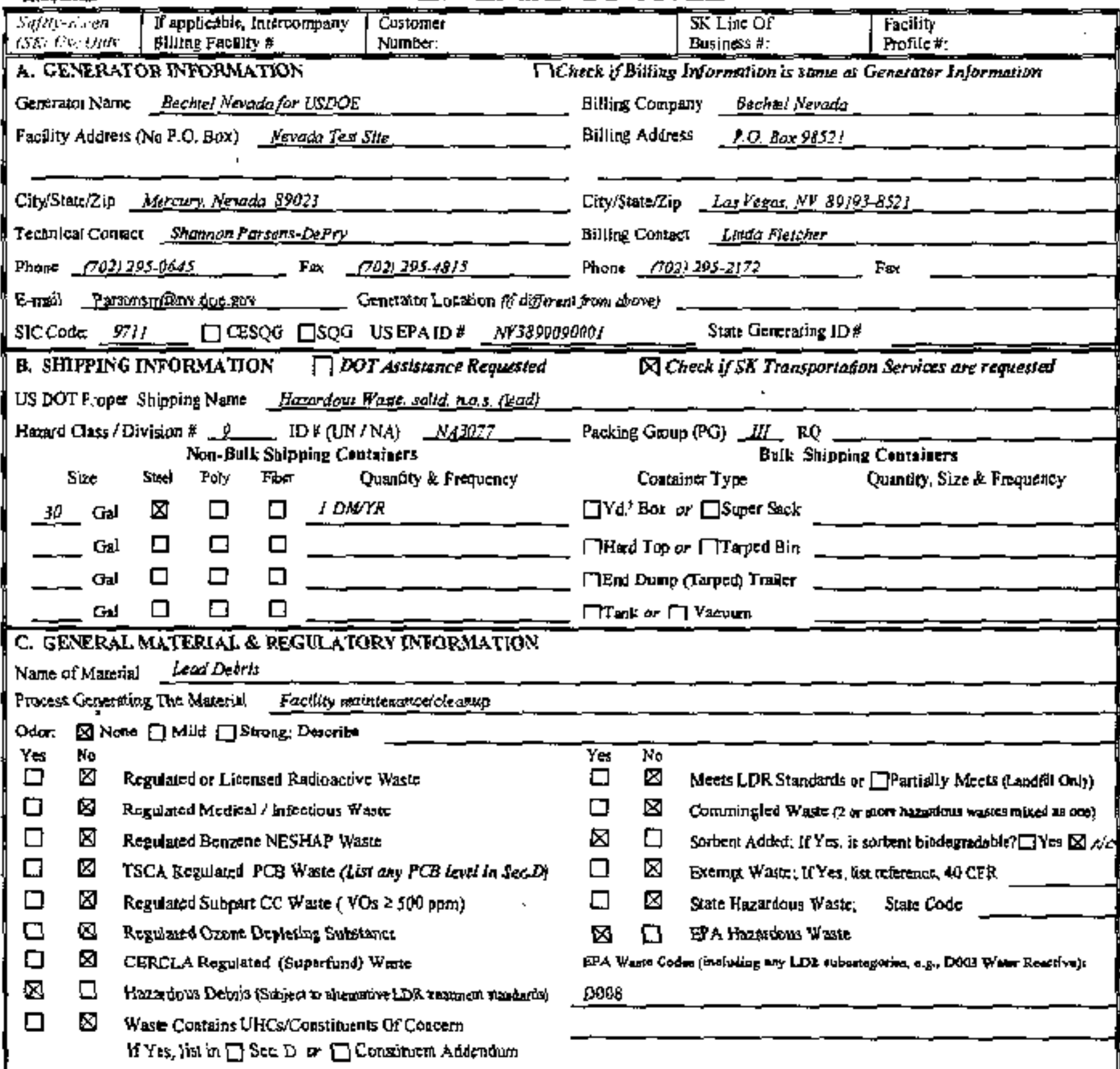

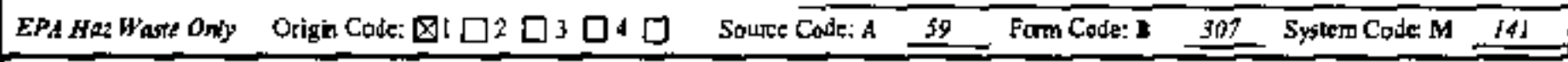

D. MATERLAL COMPOSETTON

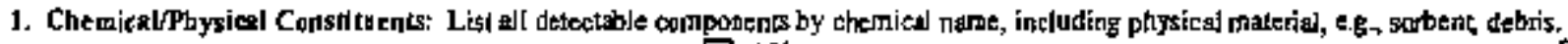

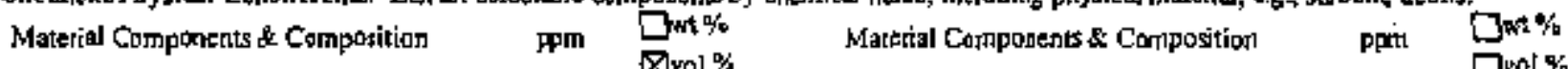

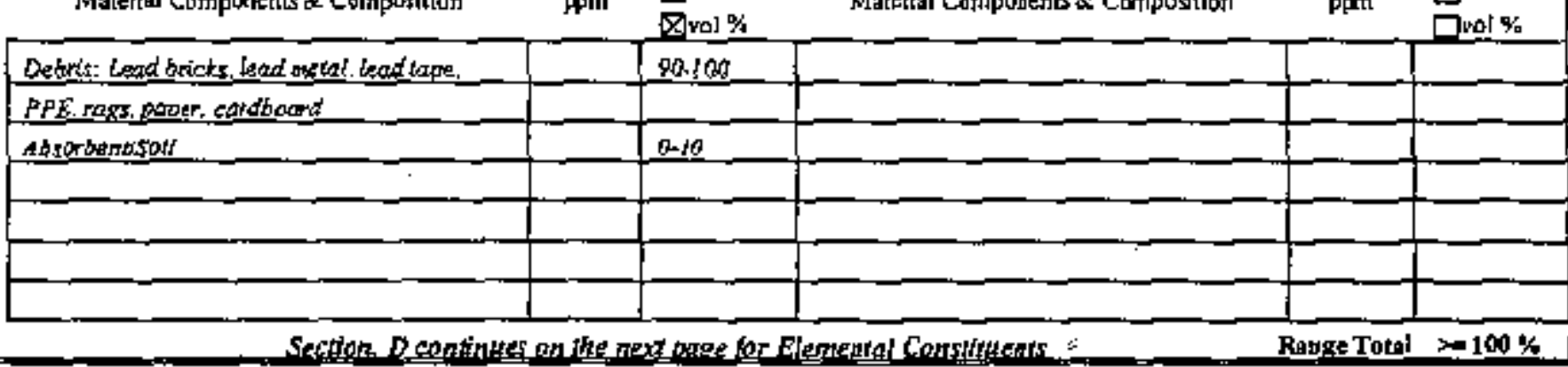

1999.All Rights Reseved.Safray-KLeen Cos. 
Shatry-Kleen Material ProfiLe (continued);

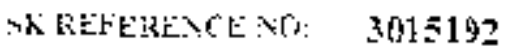

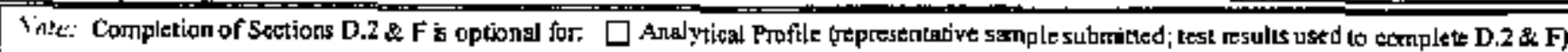

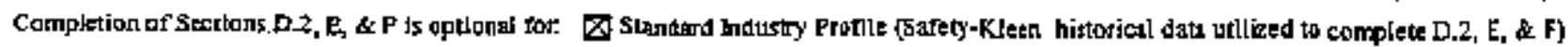

D. MATERLAL COMPOSTION (Contimed)

7. Elemental Constitarn's $\square$ Check if this wasts cantains No Detectable Elements / Matah, uriess lised balow.

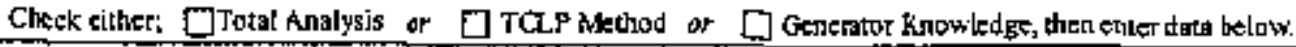

\begin{tabular}{|c|c|c|c|c|c|c|c|c|c|}
\hline Constituent & ppm & Constìnent & ppti & Constituent & ppth & Conscintent & ppu & Constituent & ppm \\
\hline Atuminutr & & Codmiturn & & Flupisis & & Nixkel & & Sodium & \\
\hline Anfimony & & Chlorine & & Lead & & Photphorequs & & Sulfiar & \\
\hline Arsenic & & Chromjium & & Líthíuna & & Poxassilum & & Thalling & \\
\hline Barium & & Cobalt & & Mangamere & & Stettonium & & Trtanilum & \\
\hline Beryllium & & Copps & & Mesifuy & & Silies & & Veradiam & \\
\hline Bromine & & lodine & & Malybatevum & & Silver & & Zine & \\
\hline
\end{tabular}

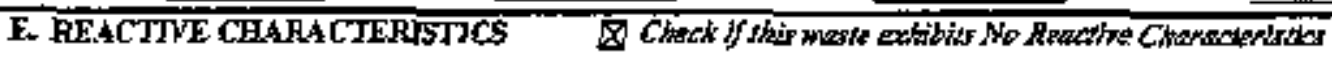

Yea No

$\square \square$ Explostve

Yas No

$\square \square$ Shock Sensifive

$\square \square$ Dxidizt:

ㅁ Pyrophoric

$\square \square$ Wulter Reactive

Pyophoric $\square \square \quad$ Air Regltive

Yot to

[ $\square$ Rextive Cyanide

ppm

[] $\square$ Reative Sulfide

[] $\square$ Polymerisable

ppm

Other Ineomputibles; Describe

F. MATERIAL PHYSICAL CHARACTERISTICS @ $70^{\circ} \mathrm{F}$.

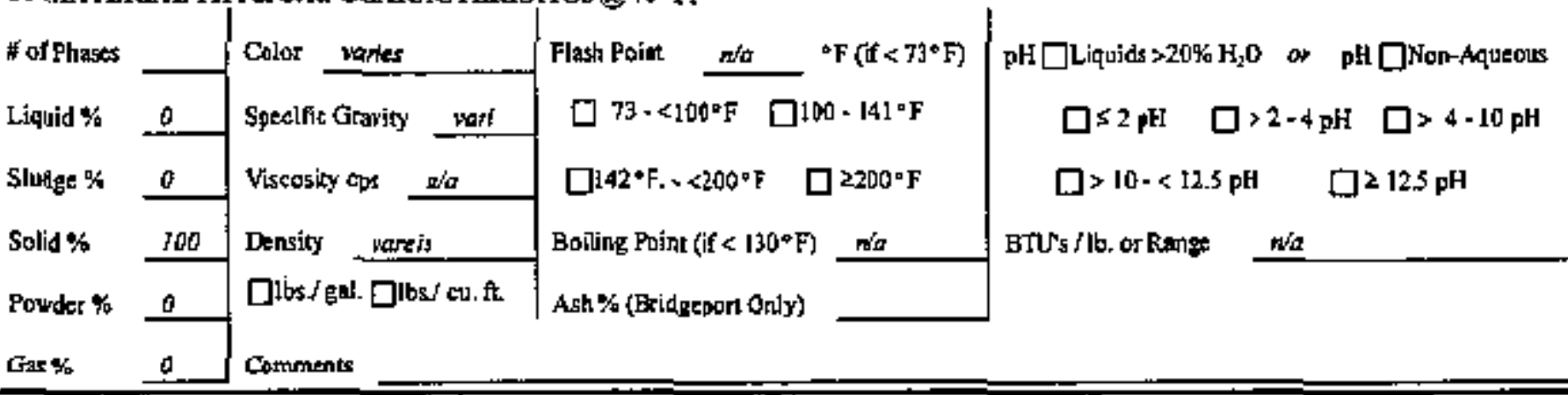

G. GENERATOR PROFLLE CERTIFICATION

I hereby certify that I an an whthorized agent of the generuor, and warant on behalf of the generator that the information supplied on this torm

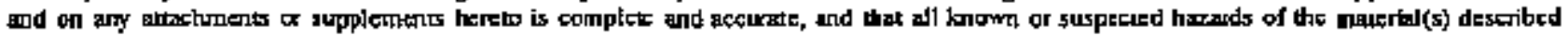

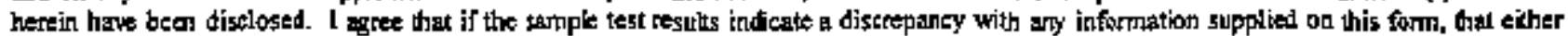

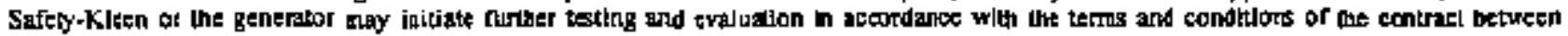

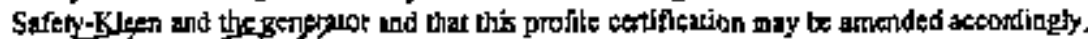

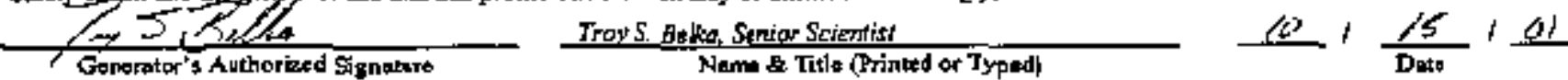

Comments

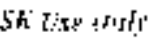

SK Sales Rxp. Name

Pricess Approvel H

Fiste Appromil \& Cerijlection

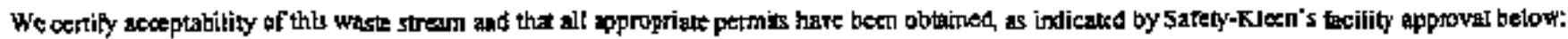

П SKOS $\mathrm{C}$ sKvs $\neg$ Non-bsz Eviluation 7 Standerd Industry Profile: SIP lodex * Employe: \# TRI Flowpati I" Tustitory/armoli \# Pricin: 
Date 9/12/01.

\begin{tabular}{|c|c|c|c|c|c|}
\hline & Compe & - Sute L & $-\mathrm{FY}$ & Smbe & \\
\hline $\begin{array}{l}\text { Contniner } \\
\text { Xomber: }\end{array}$ & $\mathbf{B N}$ & NTS & 01 & 025 & \\
\hline $\begin{array}{l}\text { Dơ's Ship } \\
\text { Yamt: }\end{array}$ & ine & & & & PE-IJ] \\
\hline $\begin{array}{l}\text { Ilorroni Ct } \\
\text { Dividein: }\end{array}$ & 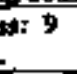 & $\begin{array}{l}\text { UNA } \\
\text { Niumb }\end{array}$ & & FE: & RQ: $\overline{\text { Ha }}$ \\
\hline Contriner & ye: & $1 \times \sqrt{40}+9$ & & & $30-\mathrm{G}, 300$ \\
\hline
\end{tabular}

X Mixed Lab $\quad$ Mantrest \#

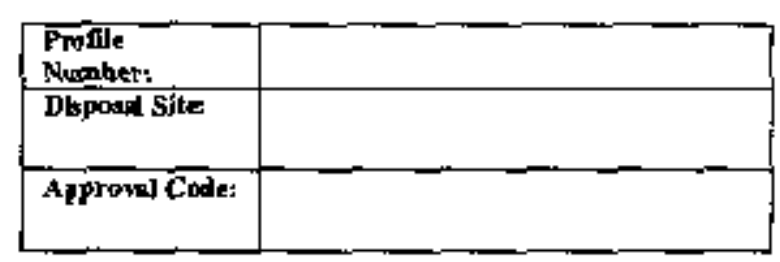

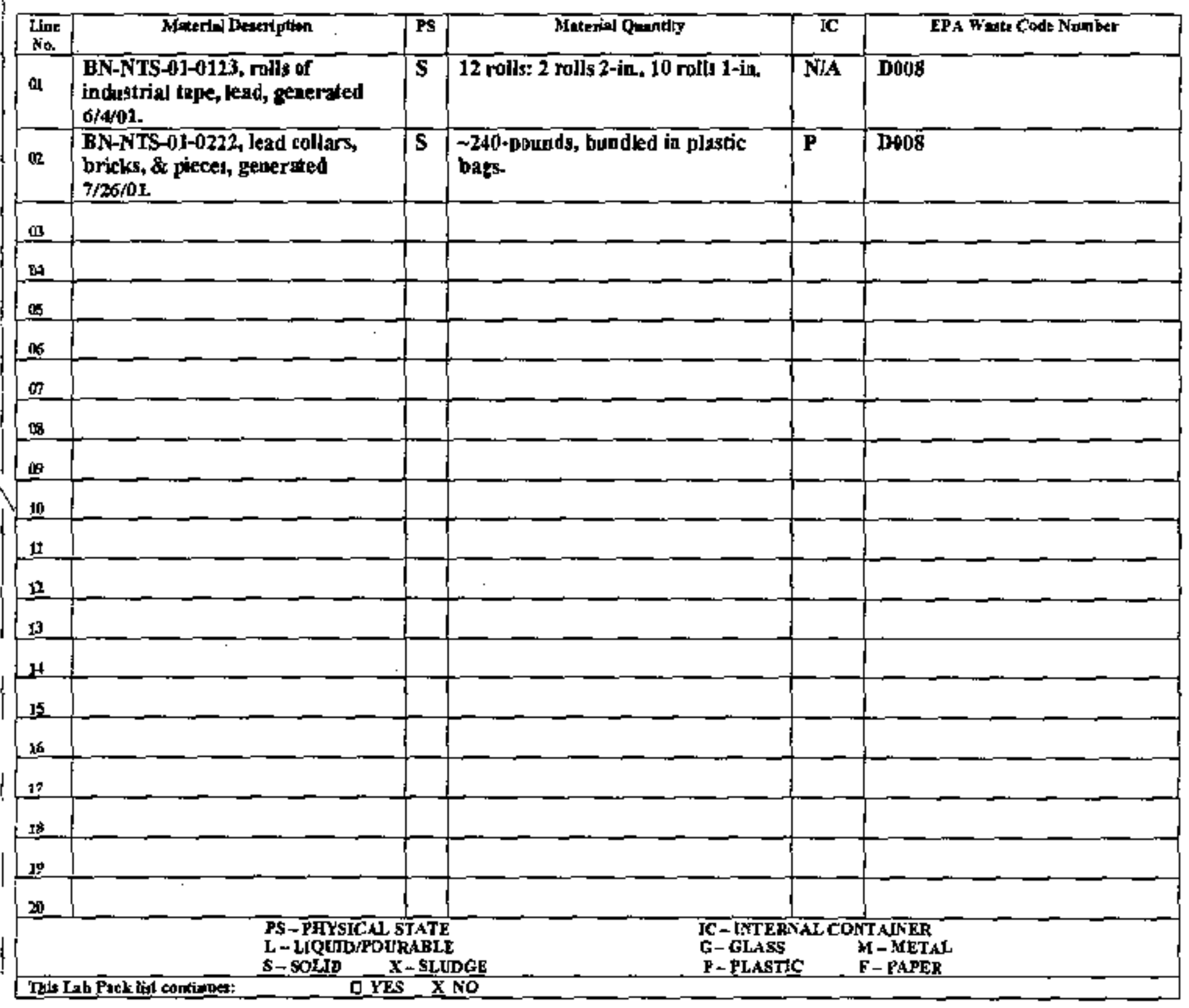

PIOTOURA

QYYS XNO 
Antifreeze Documentation

$3-30$ 


\section{Material Profile}

customer

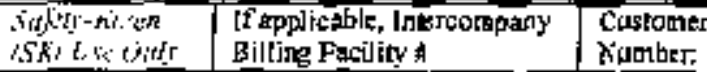

A. GENERATOR INFORALTTON

Gederator Name Becticel hievado far USbaE Business \#:

Facility Probile \#:

Fadilty Addross (No P.O. Box) Nevada Tete Sitz

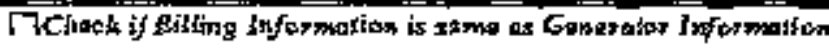

Billing Conpany Becher Nevado

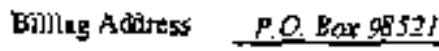

City/StakiZip Mercind Mevado 89023

Tequilea Contact Shatnonforgoss-DePry

Phoile DO21 205-06+5

Far rroty 205-1815

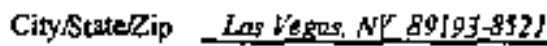

Bltling Contact Lindit Fercher

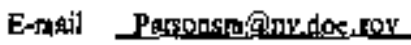
Generator Location af didorem, from sbovel

SIC Codk: $27 I I=\square \mathrm{CESQG}$ 口SSQG US EPAID\# AV389009000I

Stak Geserating ID \#

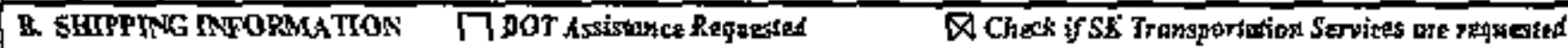

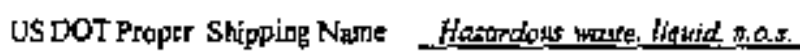

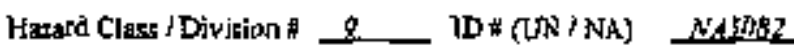

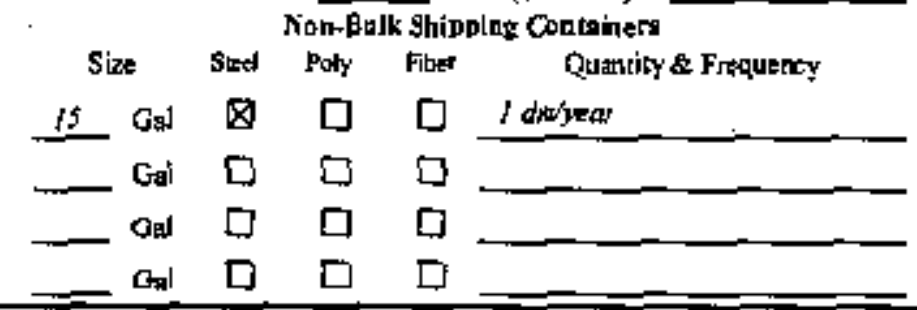

Packing Group (PG) III RC

$$
\text { Containes Type Bolk shipping Contajotry }
$$

$\square \mathrm{Yd}^{3}{ }^{3} \mathrm{Bdx}$ or $\square$ Super \$ack

Therd Top oy Tryerped Bin

ПE⿺𠃊t Dump (Tarped) Tradler

ПTank ar ח vacuom

\section{GENERAL MATERIAL \& REGULATORY INFORHLTION}

Name of Marerial Antiffeers with or granic VHCs

Procets Generating The Materis maintendor
Odor: $x_{\text {Neno }} \square$ Mild $\square$ Stratz; Describe
$Y=\quad N o$
$\square \quad$ Regolated of Licensed Radiondire Waste

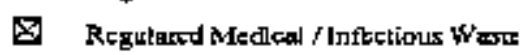

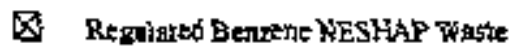
凶 TSCA Regulared PCB Waste (Likt anj PCB level in Sec. D)
区 Reguiated Subpart CC Wuste ( VOs $2500 \mathrm{ppm}$ )
$\otimes \quad$ Regulated Ozone Depleting Substarice
Q CERCLA Rogulated (Svyterfund) Whate

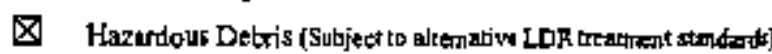

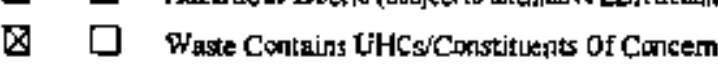
If Yes, list in $\square$ Sce. D or $\square$ Conitiunent Addendum

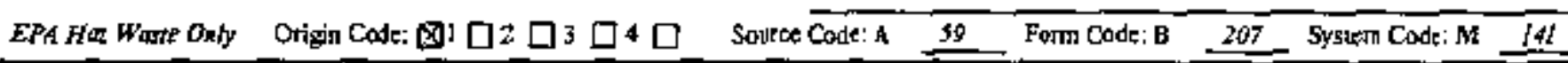

D. MATEJAL COMPOSTTON

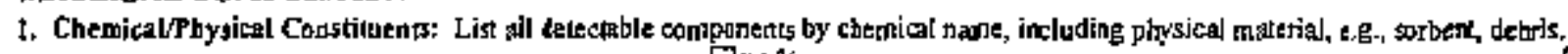

Material Components \& Composition Ppr $\square$ we $\%$ Material Components \& Composition ppm $\square$ wt \%

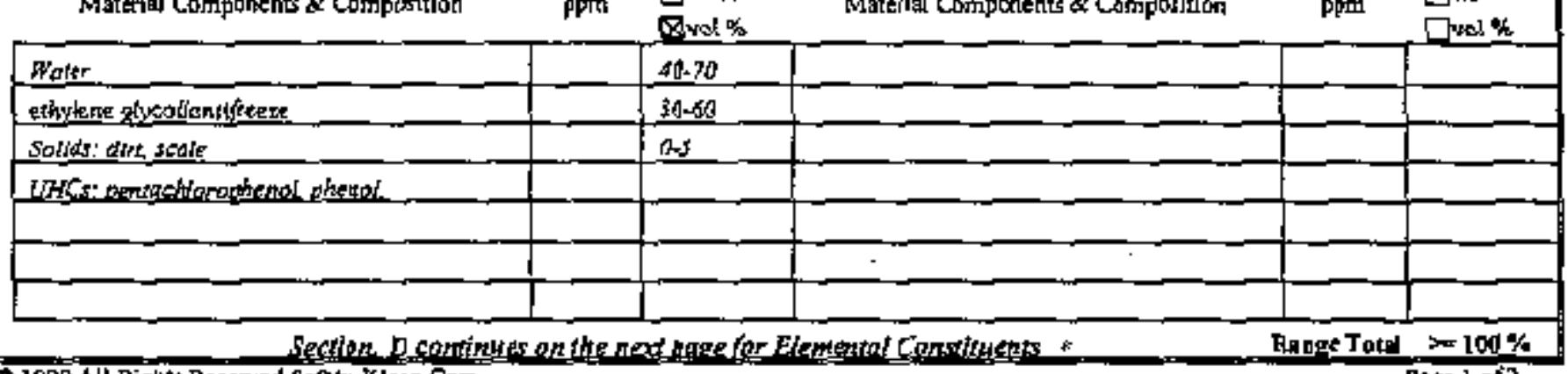

\begin{tabular}{|c|c|c|}
\hline $\begin{array}{l}\text { Yes } \\
\square\end{array}$ & 圈 & 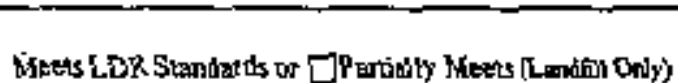 \\
\hline 口 & Q & 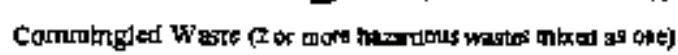 \\
\hline$\square$ & 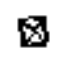 & 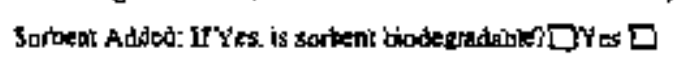 \\
\hline 口 & $\bigotimes$ & Extmpl Watc; if Yes, list Teferentec, 40 CFR \\
\hline$\square$ & $\mathbb{1}$ & State Hazadous Waste; State Code \\
\hline$凶$ & [] & EPA Hazardous Waste \\
\hline
\end{tabular}

Q1999. All Rights Resertred.Safaty-XIeen Coxp.

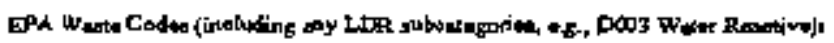
DOOADODI 


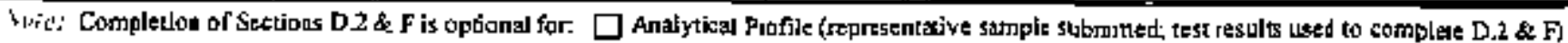

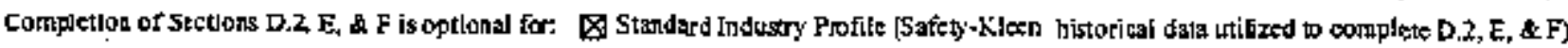

D. MATERIAL COMPOSFTION (Cominused)

2. Elemental Constituents $\square]$ Check if thit wate cokfains No Detecteble Elemests / Metas, whless listed delow.

Check either, $\square$ Total Anglysis on D TCLP Method or XGtnerator Knowdedge then enter dala below.

\begin{tabular}{|c|c|c|c|c|c|c|c|c|c|}
\hline Constemant & ppris & Conststimitnt & ppro & Congtimisn & $\mathrm{ppm}$ & Constiruente & $\mathrm{ppm}$ & Consikueni & ppm \\
\hline Aluminutr & & Cadmitum & $0+100$. & Flyprine & & Nicks! & & soding & \\
\hline Artimaty & & Chlorine & & Leart & 0,500 & Phospterous & & Sulfur & \\
\hline Aredic & 0.500 & Chromium & 0.500 & Lithium & & Potascitum: & & Thadlium & \\
\hline Ввінт & Q. 1000 & Cobalt & & Mknganese & & Selenium & 1.200 & Titanium & \\
\hline Beryllium & & Coppe & & Macury & 0.70 & Șilieon & & VanadiumI & \\
\hline Brosgine & & lodine & & Mdybdentum & & Silver & 0.500 & Zlte & \\
\hline
\end{tabular}

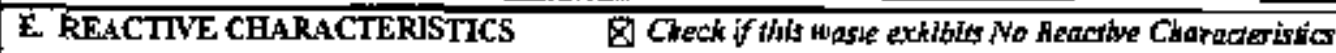

Yal No

$\mathrm{Yas}$ No

Yer No

$\square$
$\square \square$

Explosive

$\square \square \quad$ Oxldizer

Shack Sensitive

$\square \square$ Water Reactive

口 $\square$

Reactive Cyanlde

D

$\square \square \quad$ Pyrophorle

$\square \square \quad$ Alr Rextive

口 [ Rective Sulfide

口 C. Potymerizabic

Other Insompatibles; Dscribe

F: MATERIAL PHYSICAL CHARACTERISTICS $Q 30^{\circ} \mathrm{F}$.

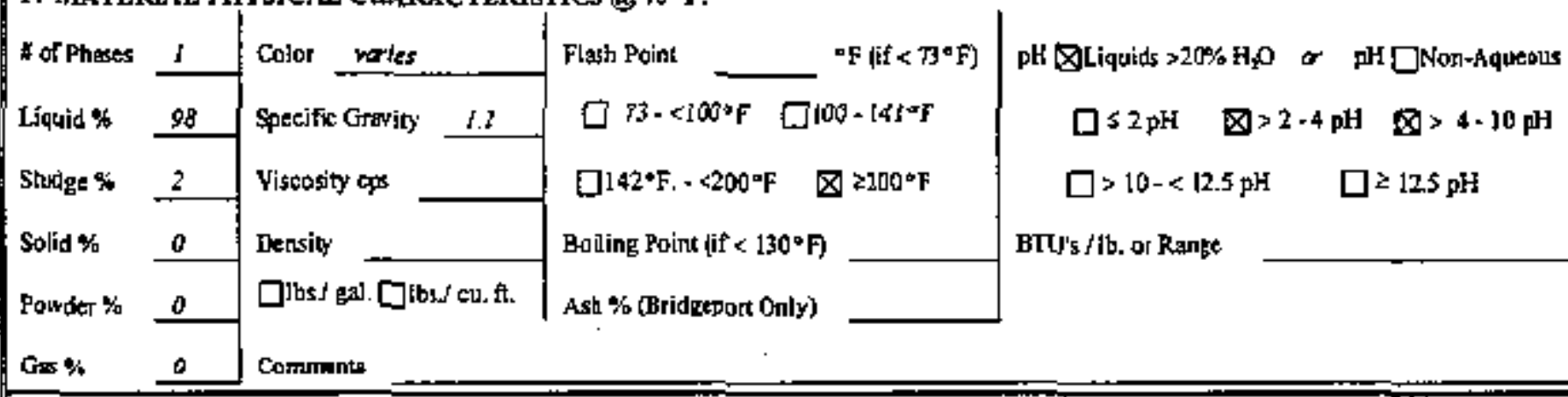

G. GENERATOR PROFILE CERTIFICATION

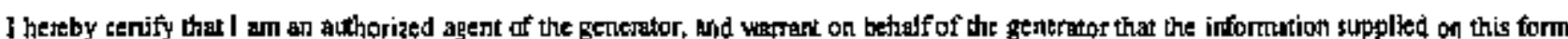

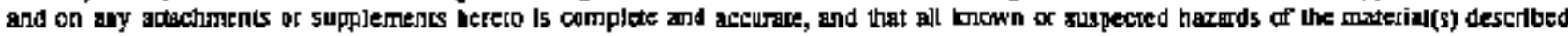
hereis have teen disclosed. I ugree that if the sample test results indicate a dkserepancy with any intormalion stpplied on this form, that eilher

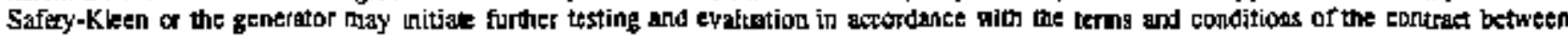
Safy-Kken and the generator and that this profile etrification thay be arended aecordingly.

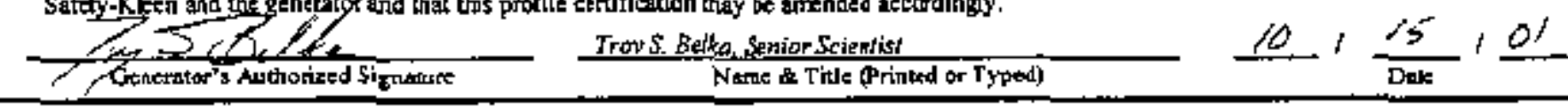

Commoners

Sif

SK Soles Rep. Nare

Ptocess Approval *

Frege Approval \& Certiflection

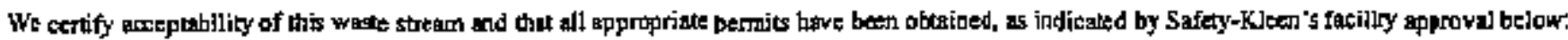

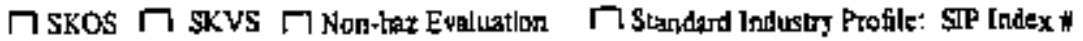
Employes * TRIFlowpath * Tartitory/Brinoh : Prician Praduet Code or Pant \# $t$ Daste

\section{SK Authorized Factlity Signatse}

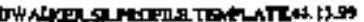

Name \& Titte (Printed of Typed)

Pege 2 of 2 
PCB Ballasts Documentation

$B-33$ 


\section{Bechtel Nevada}

Environmental Operations'

Hazardous Waste Operations

Dat of Requssl: Jung 7, 2001

EAX to S-48t5 or send to 94/S NTS1 10

Requester Nama:

Cutis Obi

Date Nended: June 14,2004

Secondary Contact:

Dennis Gustafson

Fhone Number: (702) 295-55/7

Charge : C C7FidDi1

EP Number:

Phone Number:_(702) 295-0684 Mail Stop:

NT5306

Section A - Services Requested

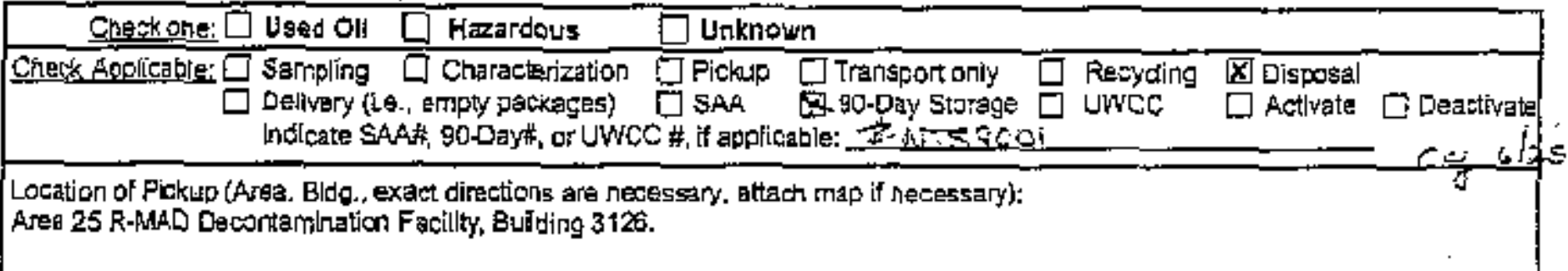

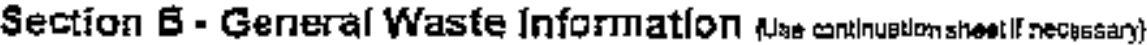

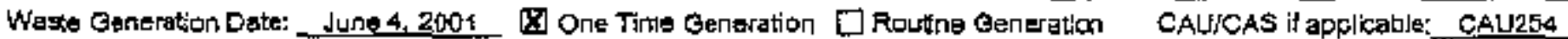

Radiologiea: Clearance prorided: $\square$ BN-0121, Clearance Slicker $\mathbf{X}$ BN-0488, Green Tag $\square$ BN-0002, Hazardous Waste Certification QNane

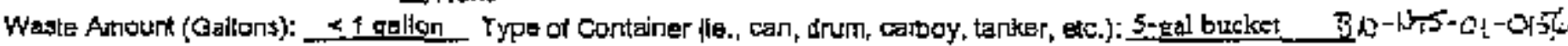
Number of Containers: 1

Detaled Descr|ptiof Process Knqwledge fie., Liquid, Soljd, Gas; Name ol material; Physical descripton; How waste was generated, Suspected contantinanis, sto.): (Attach appilcable MSDSs.)

Two brich-sized ballasts from fiubrescent-fight fixtures from office In Euitding 3126. Way contain PCBB. The balasts have a date of

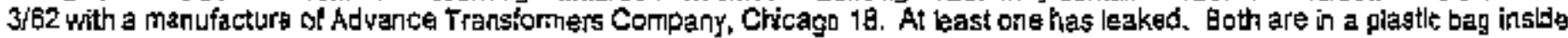

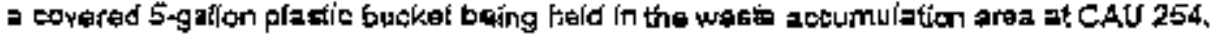

l certify tunder penalty of law the above information is corract and additiongl informstion required is aralfable as indicalad.

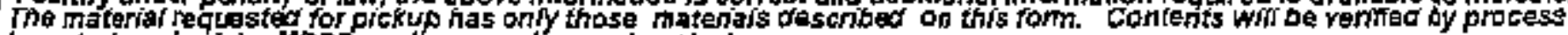
knowledge of ofigin, MSDS, andior sampling and asalysis.

(sperity) 圆Gonerator $\square$ Facilty Owner $\square$ Prolect Manager

Signature:

Section C . Work Location Informatlon

Facility Paint of Conact (Name, Phone, Pagen:

Curts Obi, 295-5577, 794-8859

Who will sign the Work Package Traveler? (Name, Phone, Pager): Curtls Obl, 295-5977, 7\$4+6e59

Facility Aesoss Raquiramank:

Need to check in at R-MAD entrance. Access limited to waste storage arga.

Known hazards in the requested service arga:

none

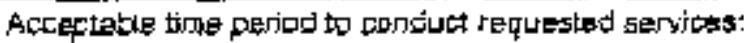

Hours (AMSIPM): 08:00 - 16:00

Qav(s): Mon - Thu

Section D. Services Completed

Waste characterized br: Frocess knowledge MSDS Sampling \& Anaiysis Dther:

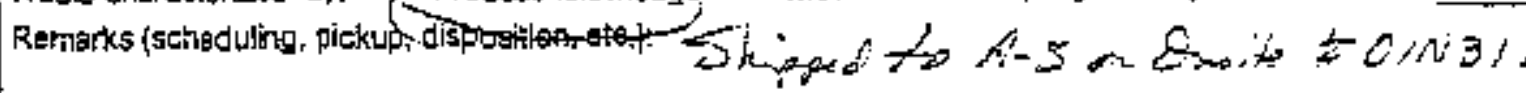

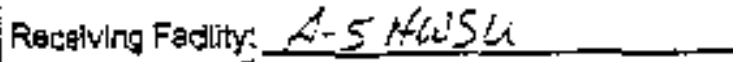

signature:

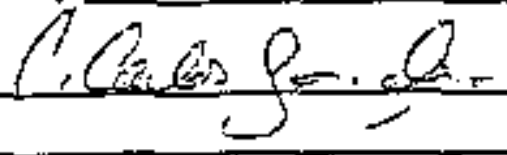

Dere: $1 / 26 / 8$ 


\section{ONSITE WASTE TRANSPORT MANIFEST}

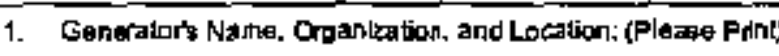
EN Env. Rem, Curtis Obi, HWAA HNTS9001 CTF44011, org. \#2152

Area 25 R-MAD Bldg. 3126

Generator's Pnone:t 702$\rfloor 295-5577$

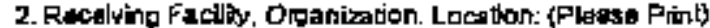
BN Hazardous Waste Storage Unit Hax Waste Ops, org. \#2151

Area 5 E!dg. 5 -20

Fadtly Phong: ( 702) 295-7669

\section{3, Trantporter Name; BN Haz Waste Ops Trangort Dala:}

\{Fiazes Pins

Trateport Dala: 6/2801

\section{[30. Venicis J.D. Number,}

$\Rightarrow 6300731$

5. Contsiners ]6. Total 1 7. Linil

4. U.S. O.O.T. Dessriptlen. Include: EPA Waste Code and Packego idenlificatan Nurnbers.

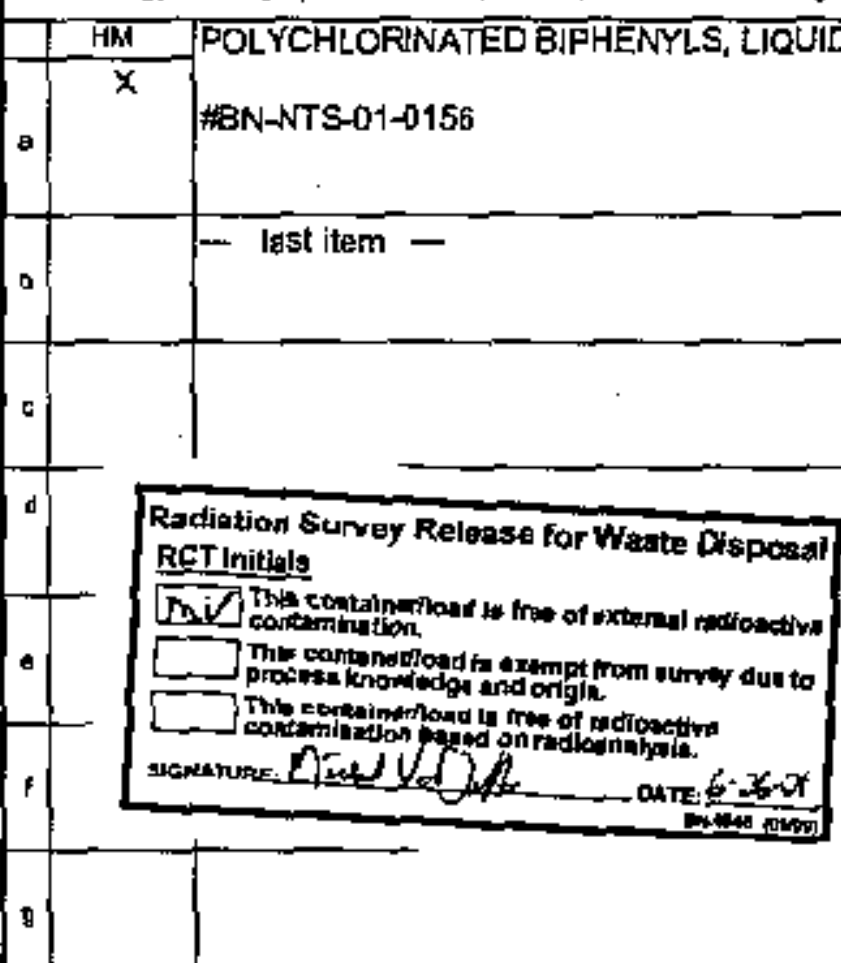

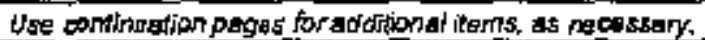

8. Special Handling Instructions and Adtliarol lffomglon: 24 How emargency contact $702-2955400$

ERG \#171

$$
\text { Oit of sperife blate - 6/4/zool }
$$

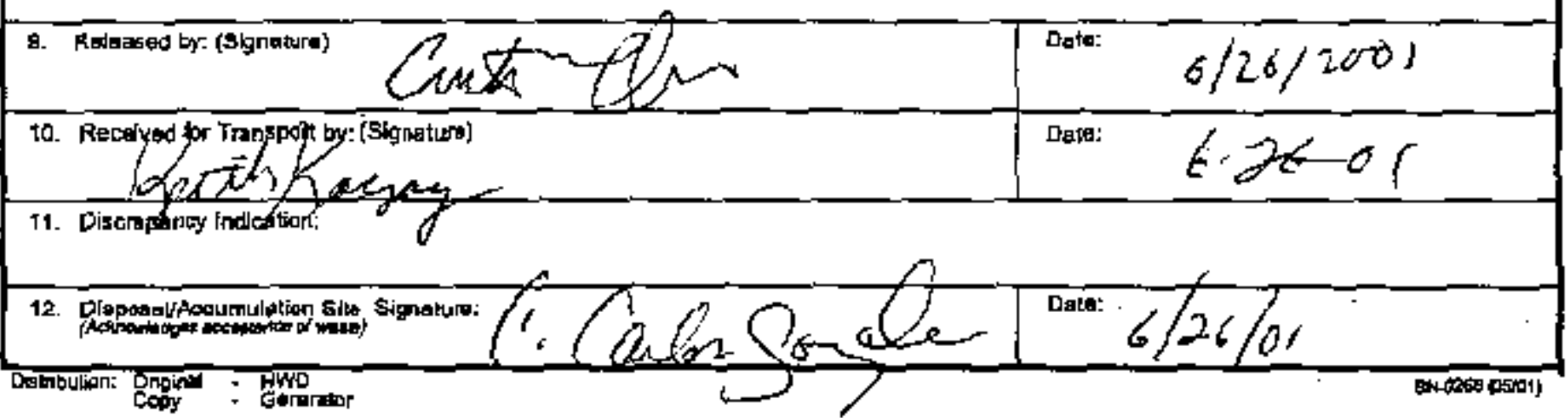


Contificate of Dostraktion is required

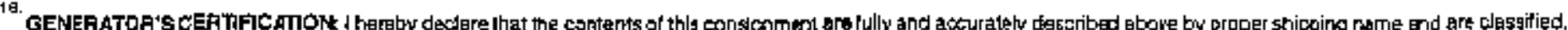

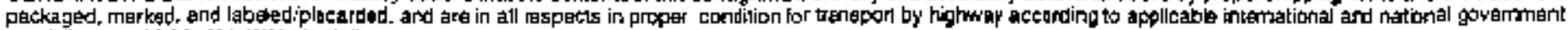
ragulaturons and Arkanase stals régulations.

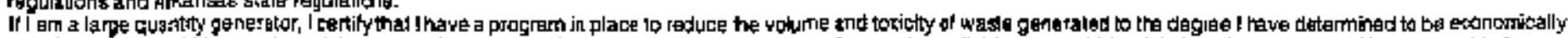

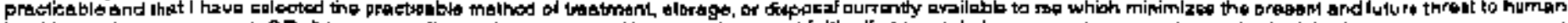

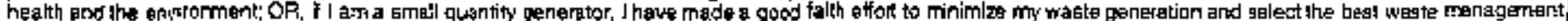
method the is availabe to mes and that l car attord.

Prnted Typed lamp

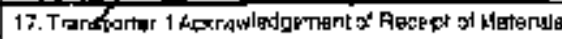

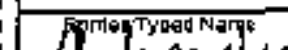

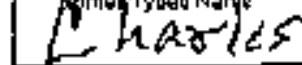

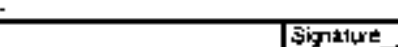

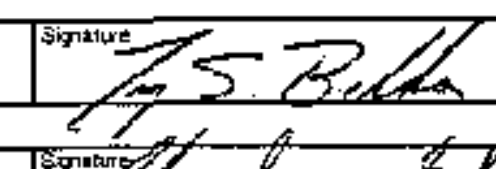

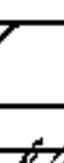
Förm Aaproved. ONE No. 205:Loc'r 


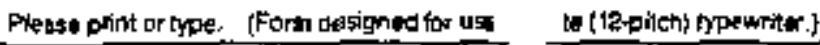

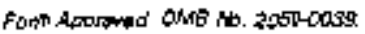

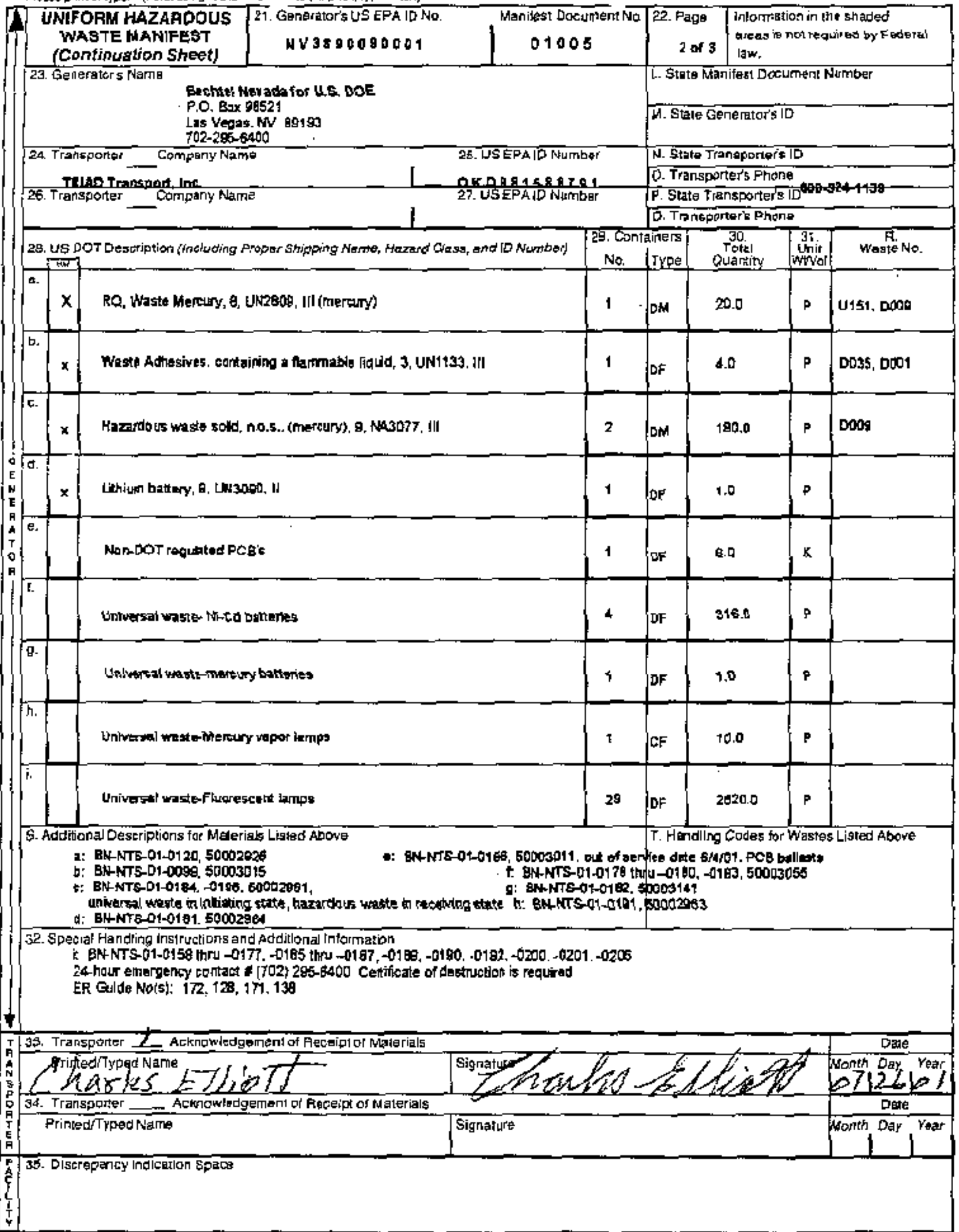

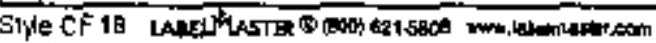




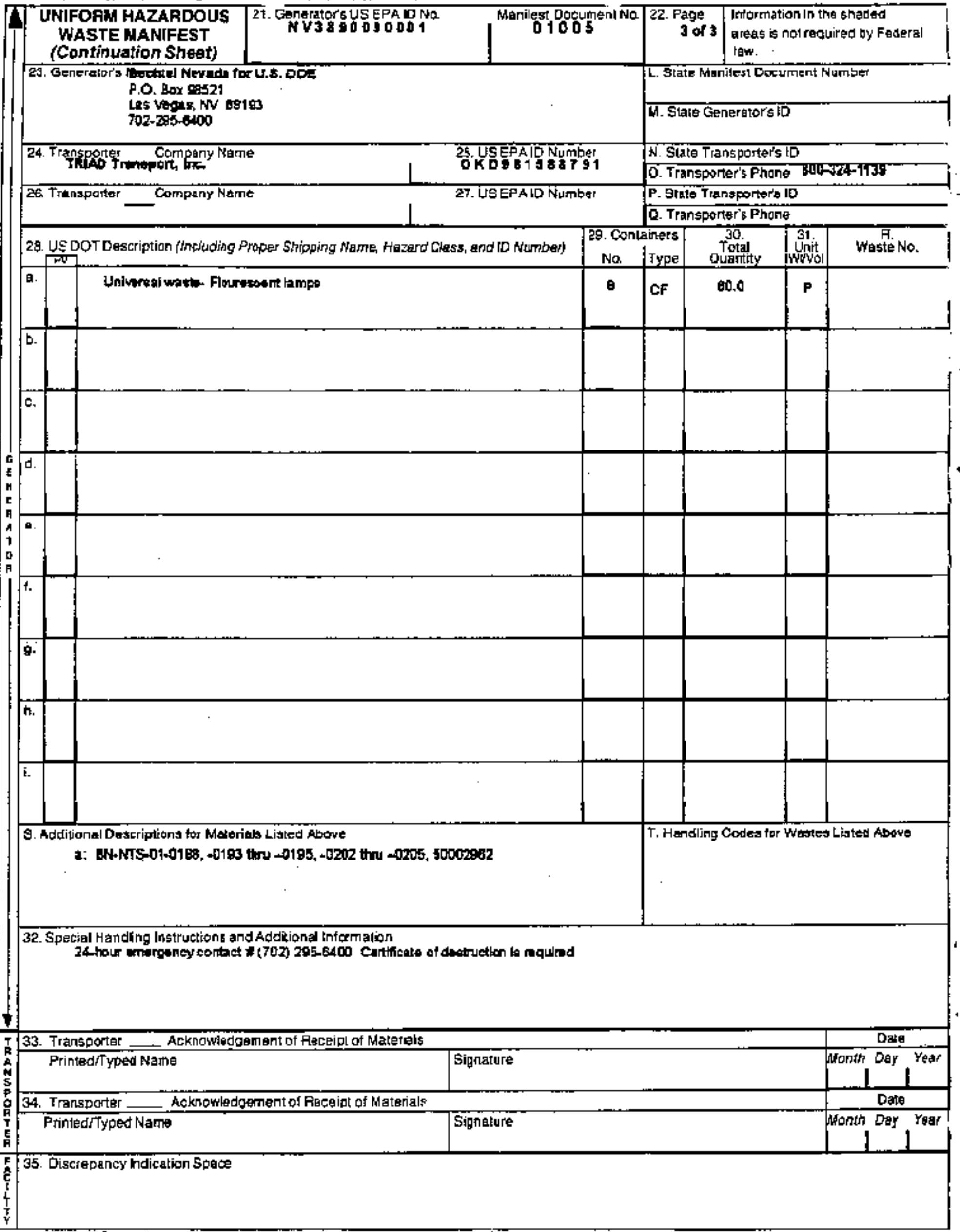




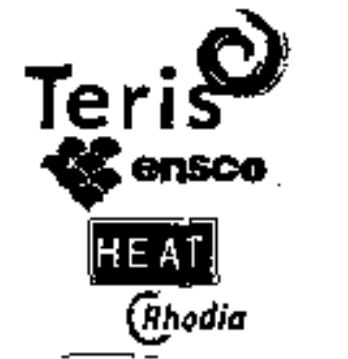

区

$$
\text { Enseo }
$$$$
\text { HOORADO AR }
$$

Technicai Approvals

30 Ambrican Circie

EI Dordo, AR 71730

$A R D 069748192$

(a70) 863-7173
WULMAGTON; CA

Ensor

Teehnital Approvals

IT'Y Ext Derni

Wilmington, CA 90744

CAD 044229835

(\$10) 835-\$775

Indicate which ENSCO Facillties may be used and send this WMDS to your chotce as prinary facllity

Choose an Action

Edil WMDS | Retum To I ist

50003011

7 RECERT INFORAATION

\begin{tabular}{|c|c|}
\hline Contact & ATTN: ACCOUNTS PAYRBLE \\
\hline Customer Name & BECHTEL NENADA \\
\hline Address & P.O. BOX $98521 \mathrm{MS}$ NLVO25 \\
\hline Address 2 & REFERENCE: SUBCONTRACT \# 20401 \\
\hline Cly & LAS VEGAS \\
\hline State & NV \\
\hline Zip & 89150 \\
\hline Shano \$ & $702285-4780$ \\
\hline
\end{tabular}

SHIPPING FACILTY

Contact

ATTN: SHANNON PARSONS DEPRY

Shipper Hame

Address

Atdress 2

City MERCLPY

State NV

Zip $\quad B 9023$

Phore: 702295-8491

USEPA ID\# N N3890090001

USEPA ID*

Wasto Name LEAKING PCQE LIGHT

Es

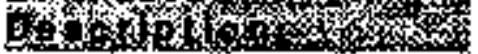
ALLASTS

50003011

Contralled Document Mo. R.tho01 Bra?

is a fepressentutive sample Providad?

Eves 这 No

Source Code 619

Form code h/219

Process Generating Waste SiC\#

9711

Ptorats Description

NATIONAL SECIJRITY

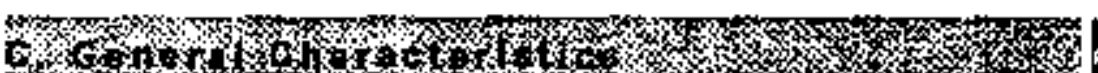

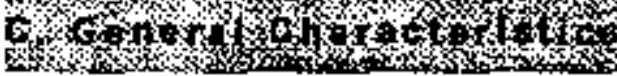

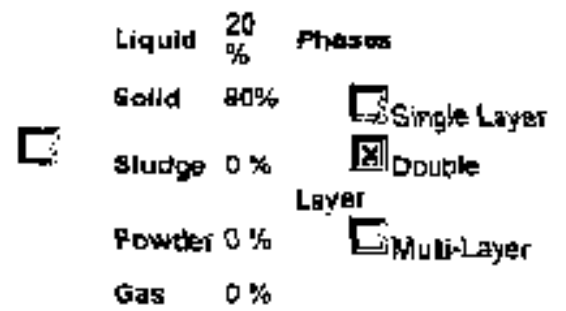

xis Sitits

Golor varies

Otar

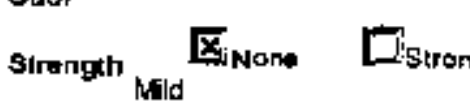

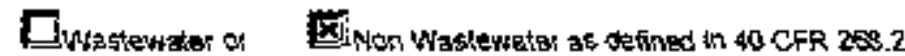

EIncinerotion Dnly

들ecycle Onty

Difuel Substitution

区iprast Appropriate Method

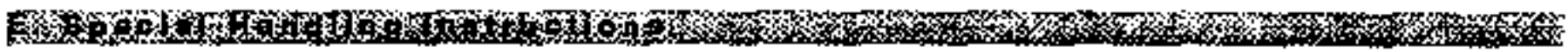

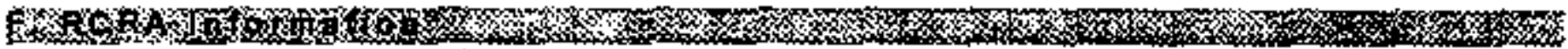
Is this a USEPA hazardous waste? 口 प 区 $\underline{\text { No }}_{\text {No }}$

List the USEPA harardous waste codes, specty the nature of any Dod3 waste in gact|on H 1: NA PCB

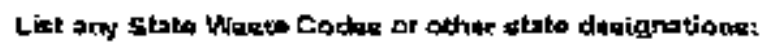

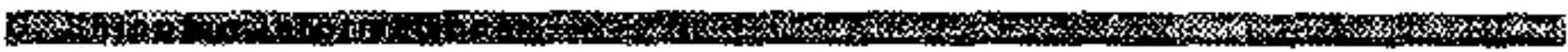
Proper Shipping Description: POLYCHLORIMATED EIPHENYLS, Loruts

$$
\begin{array}{lll}
\text { Poigon Inhalation Hazard } & {[]_{\text {Yes }}} & {[]_{\mathbb{N}}} \\
& {[]_{N b}}
\end{array}
$$


Marins Follutant $\quad\left[\right.$ Yes []$_{\text {No }}$

RQ

Hazand Class: 9

Truek or Rail? †

Pounds: 0
IDN: UNN2315

Contalnegr Type; $P$

Gallon: 1

$P G: 11$

Technical N.O.S. desciptlons:

Container Size: 1

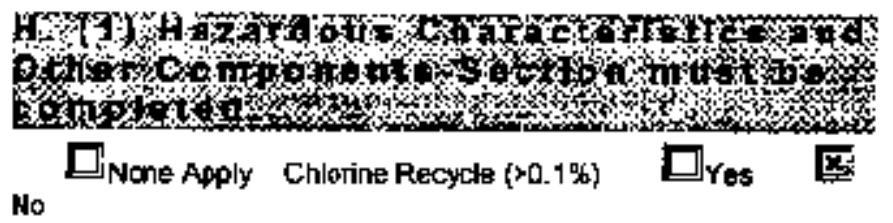

Metal Objects: $\quad[\text { Yes } \quad \mathrm{X}]_{\text {No If Yes, describe, include }}$ dimensions:

F Fumirg/Smoking

Waste

Water Reactive

C. Dloxirs and Furans

Ozona Deplotion 40 CFR 82

口 Chlorine 0.00\%

D Eromine $0.00 \%$

D lodine $0.00 \%$

ㅁ Flourine 0.00\%

Cyanides 0.00 pm

Ei: Sulfides 0.00 ppm

Fi Phendlcs $0.00 \mathrm{ppm}$

婧

\section{Air Rearactwe}

Explosite

D Radioactive

Diogog|cal

[ل] Shoch Sengilive

[D Asbestos

D Affected Berzene Waske Cortrolled Benzene Waste 40 CFR 01 Subport FF

Oxidzer

Minimum Maximum Awg/Actua

\begin{tabular}{|c|c|c|c|c|}
\hline (4) & $\begin{array}{l}\text { Totpl } \\
\text { (ppm) }\end{array}$ & $\begin{array}{l}\text { TCLP } \\
\text { (mal) }\end{array}$ & $\begin{array}{l}\text { STLC } \\
\mid \mathbf{m g} f\} \mid\end{array}$ & img \\
\hline NחMCNY(SB) & 0.0000 & 0.0000 & 0.0000 & 0.00 \\
\hline ZSENIC(AS) & 0.0000 & 0.0000 & 0.0000 & \\
\hline ARIUM(EA) & 0.0000 & 0.0000 & 0.00000 & \\
\hline ERYLLIUM(BE) & 0.00000 & 0.000 & 0.0000 & \\
\hline ADMIUM(CD) & 0.0000 & 0.0000 & 0.0000 & \\
\hline CHROME VI(CA6) & 0.0000 & 0.0000 & 0.0000 & \\
\hline CHROMAUM[CR) & 0.0000 & 0.000 & 0.0000 & \\
\hline $\operatorname{COBAL} T(C O)$ & 0.0000 & 0.0000 & 0.0000 & \\
\hline COPPER(CU) & 0.0000 & 0.0000 & 0.0000 & \\
\hline LEAD (PB) & 0.0000 & 0.0000 & Q & \\
\hline MANGANESE(MN) & 0.0000 & 0.0000 & 0.0000 & \\
\hline NEERCURY(HE) & 0.0000 & 0.0000 & 0.0000 & \\
\hline MOLYGDENUM\{KK\} & 0.0000 & 0.0000 & 0.0000 & \\
\hline NICKEL(NI) & 0.0000 & 0.0000 & 0.0000 & \\
\hline SELENIUM(SE) & 0.0000 & 0.0000 & 0.0000 & \\
\hline SILVER(AG) & 0.0000 & 0.0000 & 0.0000 & \\
\hline THALLA相 & 0.0000 & 0.0000 & 0.0000 & \\
\hline . & 0.0000 & 0.0000 & 0.0000 & \\
\hline$f(Z N)$ & 0.0000 & 0.0000 & 0.0000 & 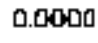 \\
\hline
\end{tabular}

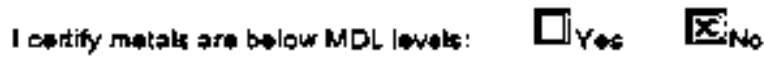

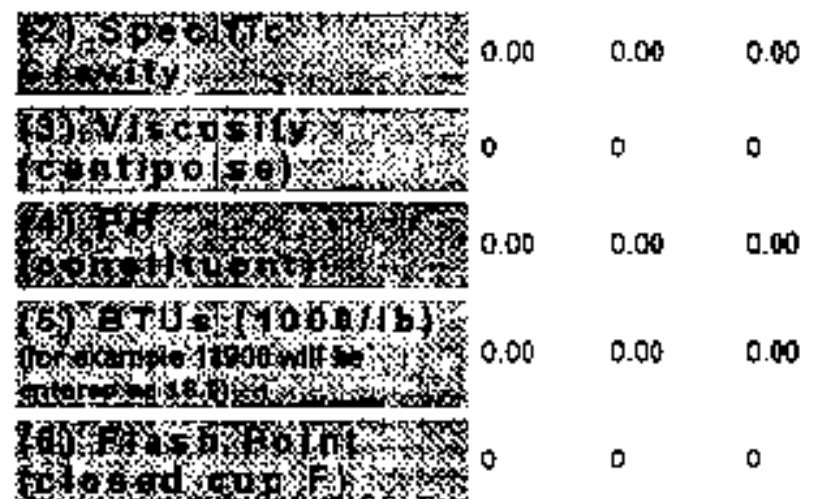

19. (il actual percentages are not known. use ranger.] Total should be at lesst 100\%.
All Constituents must be spectically idențflad and
physital composition llotod oeparatoly.
Mnimum
Mraximum
AvolActual
CAS Number
POLYCHLORINATED BIPHENYLS (PCBS)
$5.000 \%$
$50.000 \%$
$20.000 \%$
$1336 \cdot 36-3 \%$

L25;

I hereby cently thet al Infomation in this and all attached documems is complete and acoulate and thel ab known or sespected hazarts,

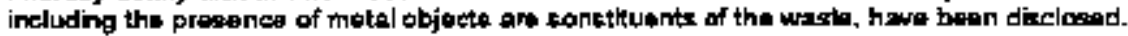

Original Authorized Signeture: Troy \$ Belka

Recertification Date: 06-21-02
Authoring Signature Date: 06-21-01

Recertlifeation Lotter Sent Date: 


\section{LOW-LEVEL WASTE (LLW) PROFILE}

(LRYFY01022) 
THIS PAGE LEFT INTENTIONALLY BLANK

B-42 


\section{Waste Characterization Summary \\ Waste Stregm LRYFY01022 \\ Revision 0}

\section{I.0 Origin of the Waste}

This wastc stream consists of remedialtion watste from Corrective Action Unit 254 (CAL 254), Area 25 Reactor-Maintenance Assenbily and Disassembly (R-MAD) Decontannination Facilicy. The facility was used for decontamination of test-car hardware and tooling used in 1963 through 1973 as part of the Nuclear Rocket Development Station program. Subsequerity the facility was used to decontaminate a military tank in the early 1980's. Contarnination of the inlerior of the decontarnination facility resulted from over spray of decontamination flujds from the outside pads onto the surrounding soil and decontarnination pad openings. The waste generation processes include lot line opcrations and excavation of soil surounding the decontatnination pads, decontamination building and decontamination pad openings.

\subsection{Quartity of Waste}

This is an angoing waste gtream. The initivl quantity of waste for FY2001 is approximately 70 cubic meters. Additional soil may be excavated in following riscal years as the excaration sites are verified to meet the cleanup standards.

\subsection{Waste Deswiption}

The waste stream consists of dry contaninaled soil, and sampling and hotline compactible trash (e.g., personal protection equipment [PPE], tape, kimwipes, paper, plastic, plastic bags, etc.).

\subsection{Waste Characterization Determination}

\section{Hazirdous viaste Constil uents}

Process knowledye from an extensive corrective action investigation is used to characlerize miaterial for this waste stream. The U.S. Department of Energy Ncvada Operations Office (DOE/NV) report $D O E / N Y-619$. Corrective Action Decision Doctiment for Corrective Action Unit 254: Area 25 R-MAD Decontaminarion Facility, Nevada Test Site. Nevada. Jame 2000 (CADD) contains the results of the corrcclive action investigation. The results of this unvestigation ate summarized in the Executive Summary on pages ES-2 through ES-4 of the DOENV-619 report. Aralytical data are found in Appendix A and Appendjx D of the DOL/NV-619 report. Tier 1 . II and III data evaluation were conjpleted and are documunted in Ajpendix A or the DOE/NV-619 report.

\section{B- 43}


The site invesligation reports toral cluomiun at $100 \mathrm{mg} / \mathrm{kg}$ in the east deconlamination sump soils (Appendix D, page D-2). TCL.P metals confirmatory sampling and analysis (presented in Wasle Streand Profile LRYSLLFY01022. Table B-1) resulted in chromium below the RCRA characteristic level. Mixed low-level waste is segregated from this waste stream and will be handled separately.

\section{Radion uclide Constituents}

Process knowledge from an extensive corrective action investigation is used to characterize material for this waste siceam. The CAU 254 CADD Appendix A contains the results (strontium 90, gamma spectrometry, isotopic plutonium and isotopic uranium analytical data) of the corrective action investigation.

The initial low-level waste generated from CAU254 consists of dry soils from the facility yard and decoutamination pad opening soil. The characterization methods for these materials are summarized below. Detailed characterization documentation is foumd the appropriate Material Evaluation Form (MEF) worksheets.

Site investigation radionuclide concentrations reported in the CAU 254 CADD for bore hole and soil samples are used to develop scaling ractors. Composite samples were taken for material excavated from the yard soil and analyzed according to the Sampling and Altulysis Ptan, NTS. CAU 254, R-MAD

Decontamination Facility, Rev. O. Gamma spectrometry for cesium 137 and scaling factors are used to characterize the soll excayated from the decuntanination facility yard. Radionuclides with concentrations at background jevels or less than one percent of the total activity are not reported on the waste stream proile.

The CAU 254 CADD analytical results are used to characterize the decontamination pad opering soil.

Remediation of this site is ongoing and additional waste forms will be cluatacterized per the Bechtel Nevada (BN) organization procchure, $O P$ 2157.301, Ralioactive Waste Evaluasion (OP -2151.301) and the appropriate waste characterization worksheets. Characterization details will be documented in the MEF records.

\section{Free Liquids}

Materiat consists of dry soils and compactible hotline trash that do not containing free liquids. The waste will be packaged in accordance with $\mathbf{B N}$ organization procedure, Of-2/5/.304, Rationctive Wuste Trothing, Handing, and Managemetr at the NTS (OP-2151.304) assurjug no free liquids are contained in this waste. As wasle is packaged, it will be visually inspecred for free liquids.

$$
\text { B. } 4.4
$$




\section{Particulutc}

The curtent soils consist of dry sand and gravel. Since the soil may contain fine particulate material an exception to the NTSWAC is needed. Waste from the decomaminution pad openings are contained in wo 55 -gallor drums and will be overpacked in 85 -gallon drums in accordance witl paragraph 3.1.6 of the NISWAC.

Gases, Etiologic Agcnts, Chelating Agents, Explosives, Pyrophorics, and PCBs

None of the above are associaled with this waste. The waste will be packaged in accordance with OP-251.304. 


\section{Nevada Test Site Waste Profile, Revision 3, 12/2000}

\section{A. Generator Information}

I. WCO

Phillin Raphes Phone

$\frac{295.5675}{295-0665}$
rAX

2950509

3. Technical Conteal

Harry Perry Phone

1. DOF Cortact Kolyreah Simal! + Phure $205-1033$ six

+ Faviloty Nasc

Addrex [escintce Nerada P.Q. AOx 9B5?

3. EPA Identification Numbut Las Veuas Suste

$\underline{N Y}$
$\mathrm{Zip}$

$89193-852]$

\section{B. General Waste Stream Information}

1. Waste Stram Identification Number Profile Revision Nun:ter

LRYSLLFYORLIIZ

1. Tinle of hriside Sitcars

3. Waste Categrory

Low-Lerel
"Classified W'asit"
CERCLA wase

\section{Generalusg Process Descripton}

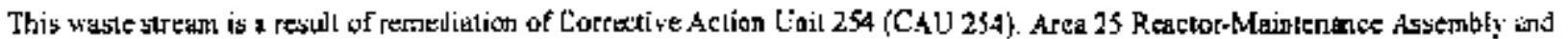

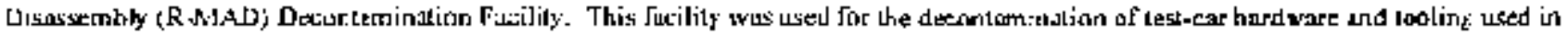

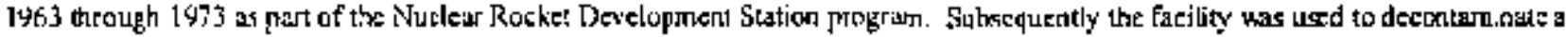

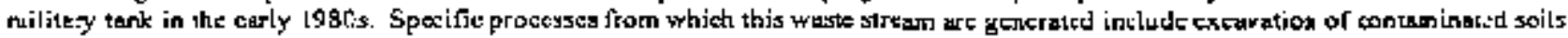

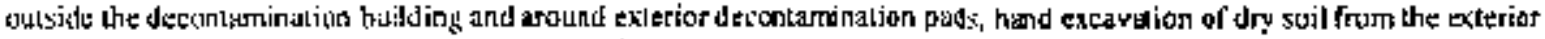

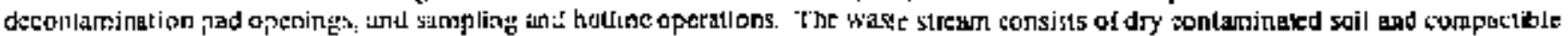

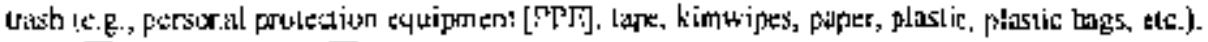

$$
\begin{array}{ll}
D \text { Yes } & \text { 区 X } \\
\square \text { Yes } & \text { 区 : }
\end{array}
$$

5. Estimated Ruale of Generaltion

6. Ressous tor Stcomital (specity ane)

8 Ncw Waste Suciam

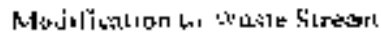

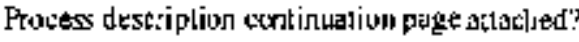

Flow diagran attoshed?
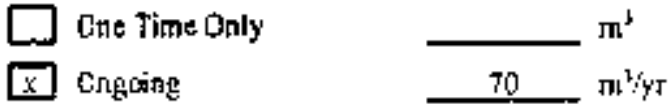

7. X Yos DNin C. F'hysical l'ropertiets

1. Vistc Jonin Description

2. List Wiaste Strean Componcnis

will

Compenphile Trosils

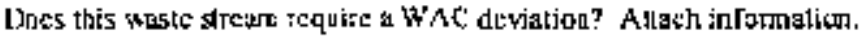

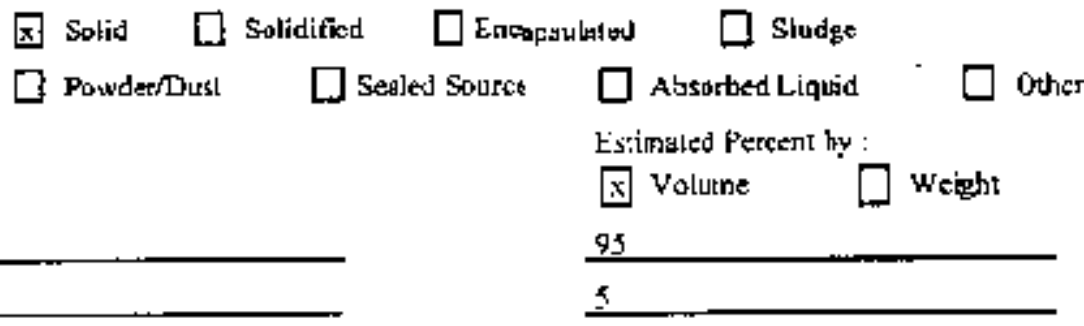


[ Y Y

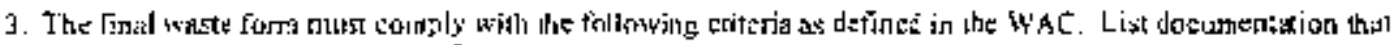
derixus sintes in'AC' complianes for each

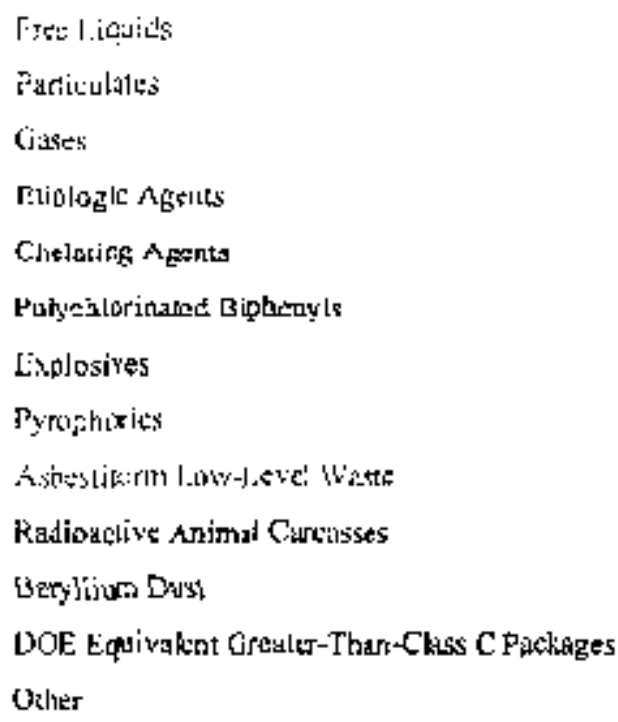

\begin{tabular}{|c|}
\hline \multirow{2}{*}{ 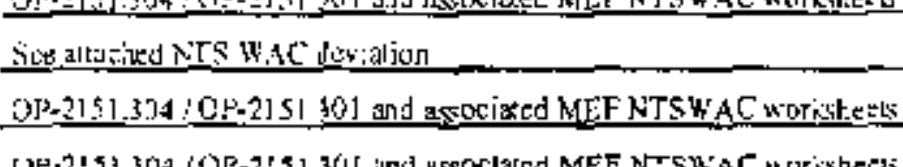 } \\
\hline \\
\hline \\
\hline$\left.\left[3 P_{-2} \mid \overline{7} 1,3\right] 4 / O P=2151.5,3\right]$ and and \\
\hline p.2151,304 /OP.2L51.? \\
\hline 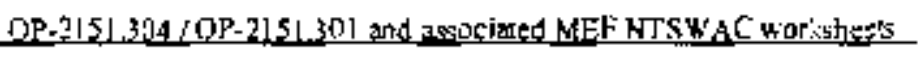 \\
\hline 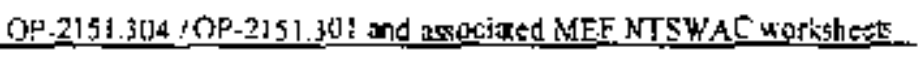 \\
\hline 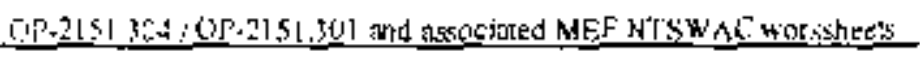 \\
\hline 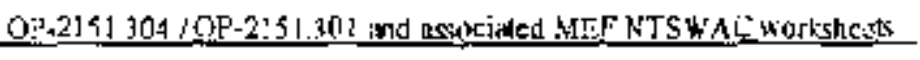 \\
\hline 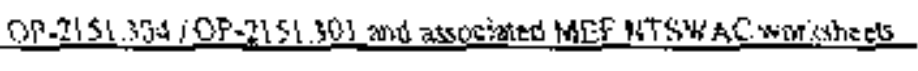 \\
\hline 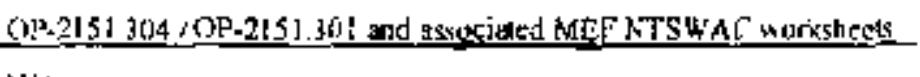 \\
\hline
\end{tabular}

\section{RCRA Churacterization}

?. RCRA ténucieriztion by Cleck inl that upply

$$
\begin{aligned}
& \text { Proctss Knowituet }
\end{aligned}
$$

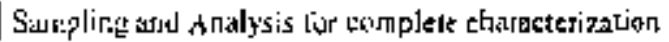

$$
\begin{aligned}
& \text { x] Confirthatory Sampling and Anelysis }
\end{aligned}
$$

LIsl betemer:s that control RCRA dettetritrations.

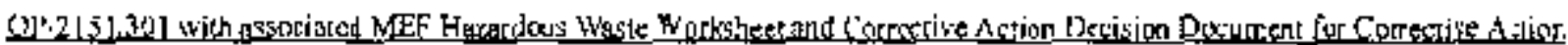

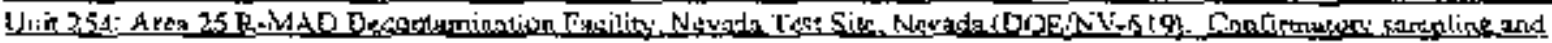

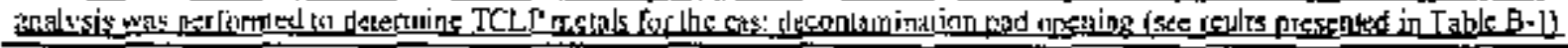

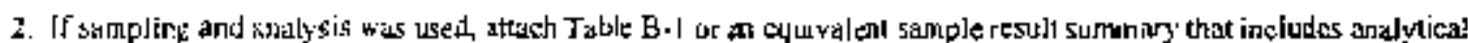

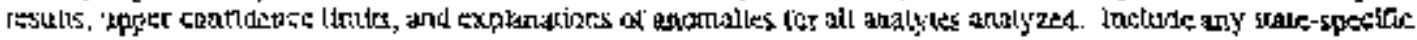
artolyte tesulis.

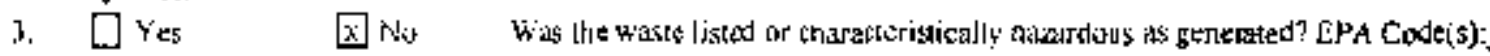

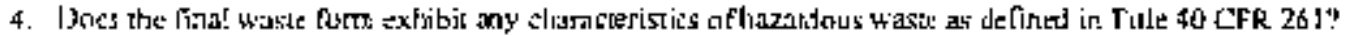

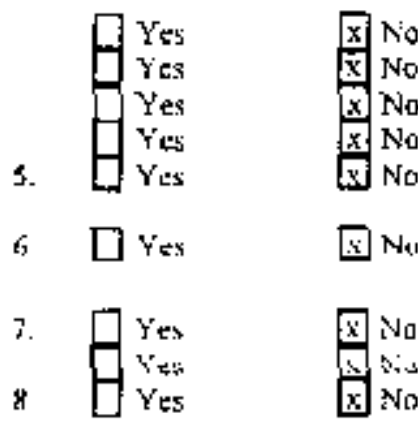

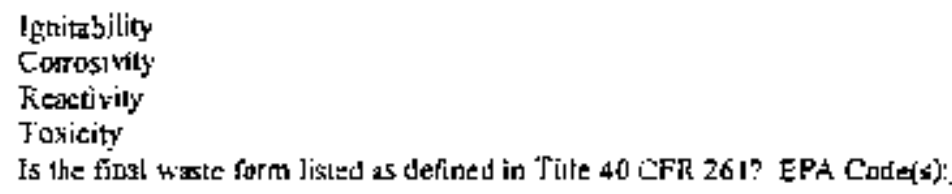

\section{E. Radiological Properties}


1. ResfioJogicat characterizatas by tchesk all liat applyh
Q Process Knaruledgu

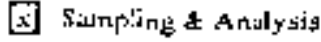
Meteriak Control \& Axounatililin

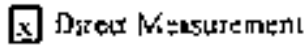
国 Gross Hadiation Metsureraent
ख) Scaling factors
$\square$ Dither

2. Reference docuntents that ieserithe the radiologion characterizalion pucess.

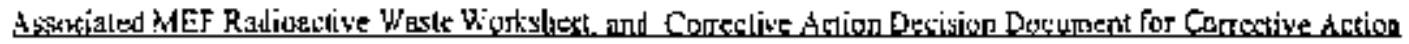

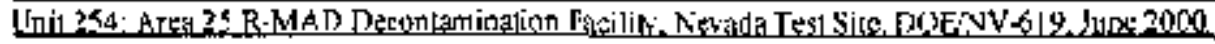

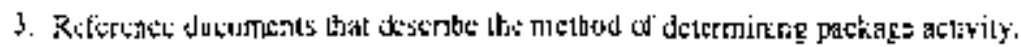

\section{Assoriated MEF Radioszijoc Wasce Wothshet}

4. List reportatic radionwelide as detined in the thac.

\begin{tabular}{|c|c|c|c|}
\hline Hadignuelkte & Activity $R$ & 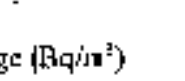 & $\begin{array}{l}\text { Activily Represcntative of } \\
\left.\text { Final Weate Fonn (Bg } g^{\prime} \mathrm{m}^{3}\right)\end{array}$ \\
\hline$C=137$ & $5.09 \sqrt{1}-06$ & $19 . \leq 3 \mathrm{E}-04$ & $2.65 \mathrm{E}+07$ \\
\hline Sr-90 & $1,99 E-76$ & {$[\quad] .42 E=08$} & $3.32 \mathrm{E}+0 \mathrm{~T}$ \\
\hline $1 !-2.34$ & $3.67 \Gamma: x] 6$ & $6 \quad 2.15 \mathrm{E}-07$ & $1.02 \mathrm{E}+07$ \\
\hline$[1-23]$ & 2.14ETUS & $\begin{array}{ll}t & 1.32 E+06 \\
a & \end{array}$ & $0.19 E+Q 95$ \\
\hline Pu-239 & $4.28 \mathrm{E}+\mathrm{J} 1$ & $1.955 \div 01$ & 1.12E-05 \\
\hline Eu-154 & $1.50 \mathrm{E}+36$ & $\int_{0}^{1} 1.13 E+07$ & $3.79 E+06$ \\
\hline $\mathrm{Nb}-\mathrm{OS}$ & $2.36 \mathrm{E}+0.5$ & i $117 \mathrm{~F} \div \mathrm{a}$ & $1.71 \mathrm{E}+06$ \\
\hline
\end{tabular}

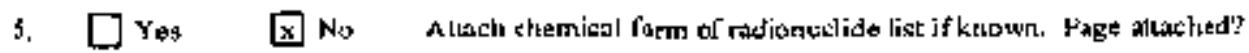

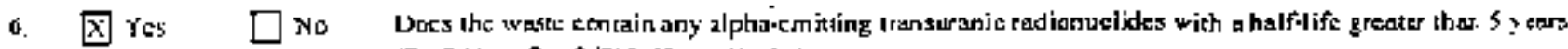
(Tu-24l or $\mathrm{Cm}-2-12)$ ? IF yes tist below.

Transitraniç Nucliftes

$146-239$

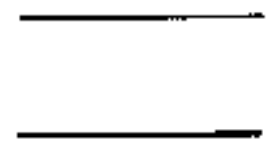

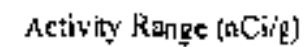

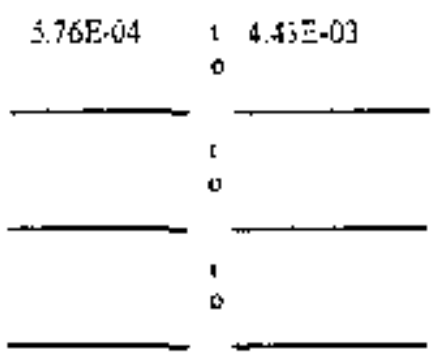

l'ransuroie nuclide sontinustion paste anached?
Acriłity Representative of Find bite form (nCiv)

2.010-03

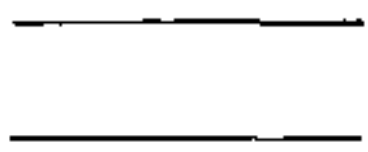




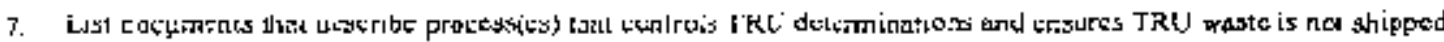

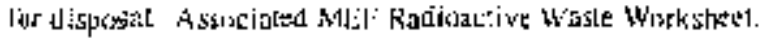

8. $\mathrm{x}$ Y cs $\square \mathrm{Ni}$

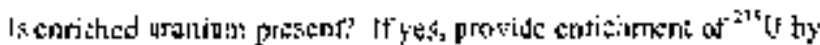

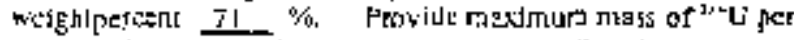

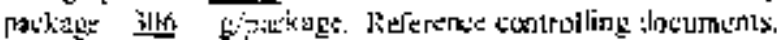

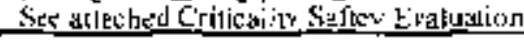

\section{F. Packaging Description}

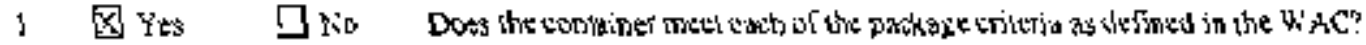

List do:umentation thal demonstralns WAC corapliarice.

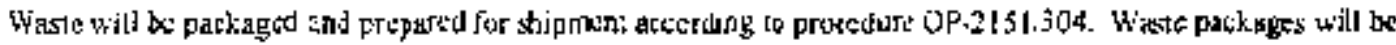

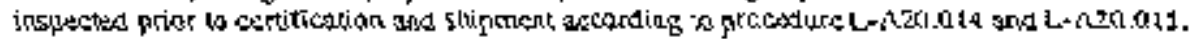

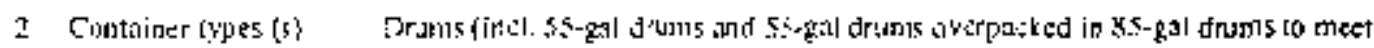

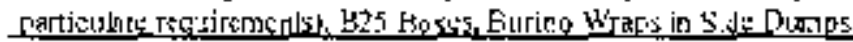

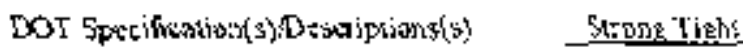

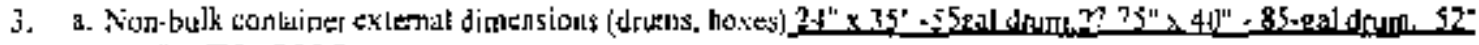

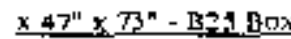

Dos box une: 3,375 lb/tt' sttcngtì rest?

凤 Yes $\square \mathrm{No}$

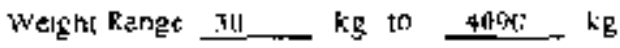

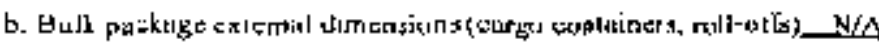

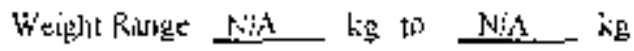

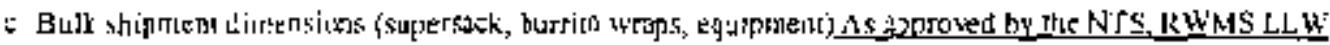

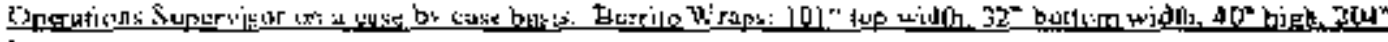
lenlle.

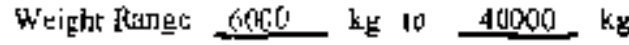

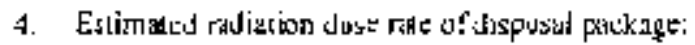

Strface 0.0002 in 0.005

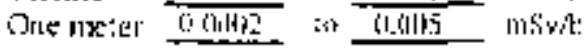

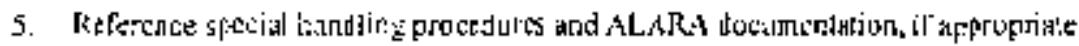

\section{Signature}

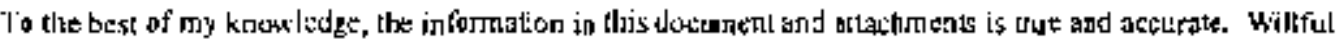

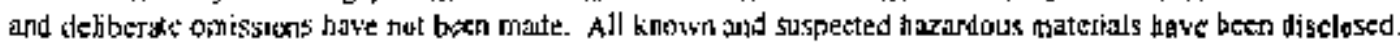

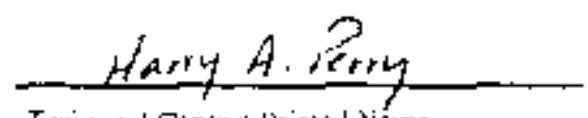

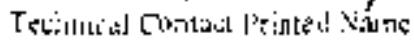

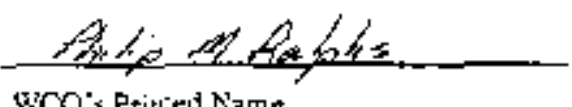

WCO's Pritled Name

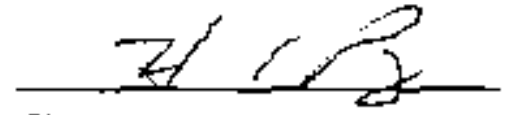

Sịnoture

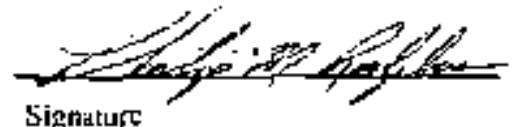

Sig̣naturc

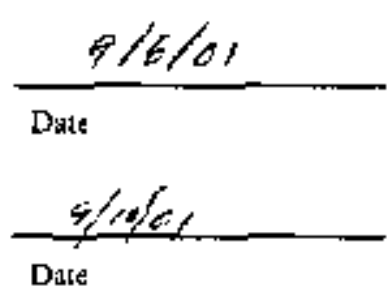


Tabie B-1

Wiste \$tream Number [RYTYO]U22

Analytical Results

East Dccontamingtion Pud Sump Soil

Confirmatory Analysis

\begin{tabular}{|c|c|c|c|c|}
\hline & & $\begin{array}{c}\text { Resułts } \\
\text { Mg/L }\end{array}$ & $\begin{array}{l}\text { Upper } \\
\text { Contydence } \\
\text { levei }\end{array}$ & \\
\hline Harium & & 1]..352 & $N / A$ & One sampie taken. \\
\hline Cadminm & & 0.218 & $\mathrm{~N} / \mathrm{A}$ & One sarmple taken. \\
\hline Chratijum & & 0.0437 & N/A & One siample saken. \\
\hline Lead & & 9377 & $\mathrm{~N} / \mathrm{A}$ & One sanple taken. \\
\hline Merelay & & 0.0001 & $N / A$ & One sample taken. \\
\hline 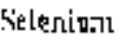 & - & 4.7302 & NiA & One sample taken. \\
\hline Situer & & 0.006 & $M / A$ & Ore sample taken. \\
\hline
\end{tabular}


NTSWAC DEVIATION, B.7.

Area 35, R-MAD Decontamination Fucility

Particulates

Requirement: NTSWAC, Revision 5, Sxtion 3.1.6, Particulates, requirs that any waste containing more than i weight percent of less-than-10-micrometers-diameter particles, or 15 weight percent of less-thar-200-micrometers-dianeler particles be intmobilized or placed in $\mathrm{s}$ socure package. Exampies of acceptable packaging (i.e, $55-\mathrm{gal}$ drums inside 85 -gal drums) and steel boxes. Drums and wooden boxes with seaked 6-nil (minimum) incrs and disposal containers with contents individually wrapped and seated in plastic are accepteble.

Justification: The soil excuvated from the Area 75, R-MAD, decontarmination facility consist of a sandy gravel mixture of unknown weight percent of minus I0-micrometer and ninus 200 . nicrometers diameter particies. The soil will be shipped in side dump uruck trailers lined with plastic burito wraps. The materia! in the four loaded side dunp trock trailers was sprayed with water dyring the excavation and loading processes to control rclease of dust. This material was wrapped in 10 mil plastic burrito wraps which should retain this noisture, Additional moisture will be added to hiture loads. Visual ìnspection of the soil material during excavation and packing into burrito urap fined trailers verifies that addition of moisture to dry soil for dust control does not result in free liquids.

Duration: 1his deriation is to encompass the duration to complete the remediation of the Area 25. IR-MAD decontominstion focility in FY2001. This project is also anticipated to canty orew into :he subsequent fiscal ycar. Additional waste may be generated during the cleanup verification phase of the project, requiring an exiension in to FY2002.

Corretive Action: There is no corrective action require. 


\section{Examination of Criticality Safety Issues Associated With the Disposal of Contaminated Soil from $\mathrm{CAU}-254$}

The following points are made in regart to the criticality safery of the contaminated soil from CAU.254:

- The soil is packaged in four bulk containers with a total volume of 145 cubic meters.

- The concentration of U-235 tanges from 3.5E-06 to $1.1 \mathrm{E}-05$ gures/goil per package.

- The highest cencentration of $U-235$ in a package, on a volume basis is $0.022 \mathrm{~g} / \mathrm{L}$, well below the DOT fissile exempt shipping evel of $5 \mathrm{~g} / \mathrm{L}$.

- If the sane soil were packaged in seyenty 55 -gal drums, the amount of U-235 per drum would te $4.4 \mathrm{~g}$, and the drums could be disposed together with no concems for criticality safety.

- Since the soil is packaged in a single container, slthough with the sane volume as the seventy drums, the amount of U-235 in the package is $305 \mathrm{~g}$, which triggers this examinalion of criticality safety.

- No amount of neutron moderation or reflection could make the $658 \mathrm{~g}$ iotal mass of $\mathrm{U}-235$ dispersed in 145 cutic meters of soit a criticality safety concem.

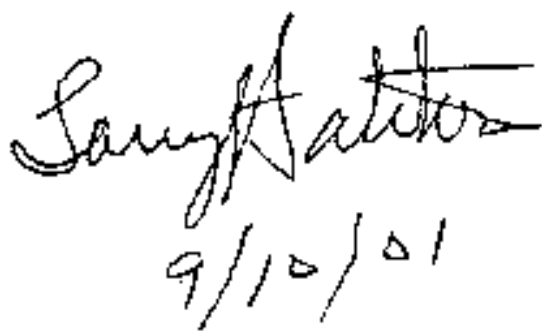


Wastc Stream Number LRYFY01022

References

Bechte! Nevada Organization Procedure, OP-2151,301, Radioaclive Waste Evaluation, Rev. 0.

Bechtel Nevada Drganization Procedure, OP-2151.304, Radioactive Waste Tracking, Hardling, and Management at the NTS, Rev. 2.

Malerial Evaluation Form Folder No. F01022.

U.S. Department of Energy Report DOE/NY-619, Corrective Action Decision Document for Corrective Action Unit 254: Area 25 R-MAD Decontamination Facility, Nevada Test Site, Nevada, June 2000. 
THIS PAGE LEFT INTENTIONALLY BLANK 


\section{MIXED WASTE (MW) PROFLE (LRY5MWFY01020)}




\section{Waste Characterization Summary \\ Waste Stream LRY5MWFY01020 \\ Revision 0}

\subsection{Origin of the W*ste}

This waste stream consists of remediation waste from Corrective Action Unit 254 (CAU 254), Area 25 Reactor-Maintenance Assembly and Disassembly (R-MAD) Decontamination Facility. The facility was used for decontamination of uest-car hardware and tooling used in 1963 through 1973 as part of the Nuclear Rocket Development Station program. Subsequently the facility was used to decontaminate a military tank in the early 1980 's. Contamination of the interior of the decontamination facility resulted from decontamination fluids on the inside and exterior concrete pads. Overspray of decontamination fluids contamingted the interior walls (transite wallboard), doors (wood and metal), piping, pipe elbows (friable asbestos), and equipment.

The waste generation processes include hot line operations, friable asbestos elbow: removal, pipe removal, door removal, transite wallboard removal, door wood and insulation removal, and decontamination pad concrete debris/rebar.

\subsection{Quantity of Waste}

This is an ongoing waste stream. The initial quantity of waste for FY 2002 is approximately 170 cubic meters.

\subsection{Waste Description}

The waste stream consistb of hotline compactible trash (e.g.. personal protection equipment [PPE], tape, kimwipes, paper, plastic, plastic bags, etc.) and building debris. The bujiding debris consists of transite wallboard; friable asbestos insulated pipe elbows; non-ACM insulated pipes; wood and insulation removed from dours; metal doors; electrical equipment, conduit and wire; a turbulator tank; miscellaneous equipment; and concrete rubble and rebar.

\subsection{Waste Characterization Determination}

\subsection{Hazardous Waste Constituents}

Process knowledge (inc. sampling and analysis data) resulting from the corrective aclion investigation is used to characterize material for this waste stream. The U.S. Department of Energy Nevada Operations Office (DOENV) report DOE/NV-619. Corrective Action Decision Document for Corrective Action Unit 254: Area 25 R-MAD Decontamination 
Facility, Nevado Test Site, Nevada, June 2000 (CADD) contains analytical results of the corrective action investigation.

The results of this inyestigation afe summarized in the Executive Summary on pages LS2 through ES-4 or the CADD. Analytical data for building materials (debris) are found in Appendix D of the CADD. Tier I, II and III data evaluation were completed and are documented in Appendix $A$ of the CADD.

\section{Toxicity Characteristic Waste}

Total metals, tolal volatile organic compounds (VOCs), and total semi-volatile organic compounds (SVOCs) data found in Appendix A of the CADD are used primanily tor toxicity characteristic detenminations of the building debris.

Confinatory samples of wood and insulation were aken in accordance with the Sampling and Analysis Plan, Nevada Test Sile, CAU 254, Area 25, R-MAD

Decontaminatton Facility, Rev. 0 , May 2001 (SAP). The confirmatory analytical results are summarized in Table B-1 of the LYR5MWFY01020 waste profile.

Calculated TCLP cadmium results for the south decon bay door and northwest decon bay door insulation sampies are both reported at $0.95 \mathrm{mg} / \mathrm{L}$ cadmium (see attached Table 1). Confirmatory samples were taken from each door and analyzed for TCLP metals. The confirmatory sample TCLP analytical results are 0.407 and $0.117 \mathrm{mg} / \mathrm{L}$ (sce attached table), respectively. Insulation from these two doors does not exhibit toxicity characteristic for cadmium per the 40 CFR 261.24, Table 1 regulatory levels.

The south decon thy door wood was sampled at a single location on the door during the site investigation and analyzed for TCLP metals. The TCLP cadinium result reported for the south decon bay door wood in the CADD is $4.7 \mathrm{mg} / \mathrm{L}$. A representative sample of the entire dDor was taken and analyzed for TCLP to confirm the CADD reported value. The confintory semple TCLP analytical result is $0.0105 \mathrm{mg} / \mathrm{L}$ (see attzched Table 1). Wood from this door does not exhibit toxicity characteristic for cadmilum per the $40 \mathrm{CFR}$ 261.24, Tahte 1 regulatory levels.

\section{Listed Waste}

The waste generater documented the anticipated listed waste codes in the DOE $\wedge \mathrm{V}$ Corrective Action Plan for Corrective Action Unit 254: Area 25 R-MAD Decontamination Faciliry, Nevada Test Site, Nevada, Revo, December 2000 (DOE/NY678 ) section $2.3 .6 \mathrm{Mixed}$ Waste. These codes include acetone (F003), carbon disulfide (F005), ethylbenzene (F003), toluene (F005), 1,1,1-trichloroethane (F002), trichloroethene (F002), and zylenes (F003).

In accordance with the Technical Guidance Menorandum September 7, 1999, Interpretation of Hazardous Waste Regulations as They Apply to Potential Solvent 
Contaminated Waste from CAU 154 (RMAD Decon Facility). If detected the hazardous waste codes are to be assigned as follows:

$$
\begin{array}{ll}
\text { Carbon Tetrachloride (2-Butanone) } & \text { F001 } \\
\text { Trichloroethylene } & \text { F001 } \\
\text { 1,1,1-Trichloroethylene } & \text { F001 } \\
\text { 1,1,2-Tricholo-1,2,20Trifluorethane } & \text { F002 }
\end{array}
$$

The Corrective Action Plan for Corrective Action Unit 254: Decontamination Facility. Nevada Test Site, Nevada, December 2010 (DOE/NV-678 (CAP) section 2.3.6, Mixed Waste ists acetone (F003), carbon disulfide (FO05), etheylbenzene ( $F 003$ ), toluene (F005), 1,1,1-trochloroethane (FO02), trichloroethene (FO02), and xylene (FO03) as listed waste. The F002 listed code compounds are also listed as F001 codes. The F001 code is used in this waste profile (LRY5MNFY01020).

Not all of the listed codes discussed above are detected in each building materials. All listed code compounds contained in building debris for this waste stream are at concentrations below the $40 \mathrm{CRF} 268.40$ treatment standards. The CADD site investigation analytical results are summarized in Table lof this WCS.

The first railroud tie outside and south of the decon bay door contains the following organic compounds (CADD, Appendix D) and waste codes from the above two lists:

$\begin{array}{ll}\text { Carbon Tetrachloride (2-Butanone) } & \text { F001 } \\ \text { Trichlorocthylene (Trichlotoethene) } & \text { F001 } \\ \text { 1,1,1-Trichloroethane } & \text { F001 } \\ \text { Acetone } & \text { F003 } \\ \text { Ethylbenzene } & \text { F003 } \\ \text { M+P-Xylene } & \text { F003 } \\ \text { O-Xylene } & \text { F003 } \\ \text { Carbon Disulfide } & \text { F005 } \\ \text { Toluene } & \text { F003 }\end{array}$

Benzene is reported in the CADD from one concrete sample taken from the east decon samples. Benzene may canry a F005 waste code.

Not all of the building materials (debris) have each of these waste oodes. Separation of the building debris into several waste streams is not practical. The reported concentrations of all of these organic compounds in the CADD, Appendix D are below the 40 CRF 268.40 Treatment Standards for Hazardous Waste and are not Land Disposal Restricted. The waste codes assigned to the LRY 5MWFY01020 waste stream include F001, F003 and F005.

\subsection{Radionuclide Constituents}


Process knowledge from an extensive corrective action investigation is used to characterize material for this waste stream. The CAU 254 CADD Appendix D contains the results (strontium 90, gamma spectrometry, isotopic plutoniun and isotopic utaninm amalytical data) of the corrective action investigation. The reported radionuclides includi Cs-137, Sr-90, NE-94, Eu-154, U-234, U-235, U-238 and Pu-239. A sunimary of the site investigation process knowledge in found Table 2 of this WCS.

The transite wallboard and the fiable asbestos covered pipe elbows and joints were not sampled during the site investigation or during waste characterization. Sampling of this waste material may have resulted in goneration of asbestos fibers to the working environment and unnecessary exposure of workers to asbestos fiber. The transite wallboard and friable asbestos insulated pipe elbows and joints are on vertical interior surfaces of the decontanination facility. Ovenspray from decontamination activities arc expected to result in higher concentration of contaminants in the concrete floor than the interior wall and pipe surfaces. The analytical results from the other building materials are used to characterized the materials.

Results shown in Table 2 of this report are used as process knowledge to calculate the radionuciide activities reported in profile \#LYR5MWFY01020.

\subsection{Free Liquids}

The material consists of dry building debris and compactible botline trash that does not containing free liquids. The waste was packaged in accordance with BN organization procedure, $O P-2151.304$, Radioactive Waste Tracking, Handling, and Management at the NTS (OP-215l.304) assuring no free liquids are contained in this waste. As waste is packaged, it is visually inspected for free liquids.

\subsection{Fine Particulates}

The material consists of dry building debris and compactible hotline trash that does not containing fine particulates. The waste was packaged in accordance with BN organization procedure, OP-2151.304, Radioactive Waste Tracking, Handling, and Management at the NTS (OP-2151.304) assuring no free liquids are contained in this waste. As waste is pack ged, it is visually irspected for fine particulate.

\subsection{Gases, Etiologic Agents, Chelating Agents, Explasives, Pyrophorics, and PCDs}

The waste was packaged in accordance with $B N$ organization procedure, $O P-2151.304$, Radiaactive Waste Tracking. Handling, and Management at the NTS (OP-2151.304) assuring none of the above were included in with this waste. 


\section{Nevada Test Site Waste Profile, Revision 3, 12/2000}

\section{A. Generator Information}

1. WCO

2. Technical Contact

3. DOE Contact

4. Facility Name Phillin Ralohs Phone

295.5685 FAX 295-6569

Adoress

City

Harry Perry
Phone

295.06859

FAX

$295-4815$

\begin{tabular}{ll} 
Kenneth Small & Phone \\
Bechtel Nevada & \\
\hline
\end{tabular}

295-1933

FAX

$295-153$

5. EPA Identification Number P.O. Box 98521

B. General Waste Stream Information

1. Waste Srean Idantifiation Number Profile Revision Number $\underline{0}$

2. Tide of Waste Stream Profle Revision Date

Deceniber 12,2001

3. Waste Category Area 25, R-MAD Decontumination Facility -Mixed Weste

D. Low-Leve]
cClossified Waste"
CERCLA waste

X Mixed Low-Level (Generated within Nevada only)

CERCLA waste

4. Generating Frocess Description

This waste stream is a resolt of remediation of Comrective Action Unit 254 (CAU 254), Area 25 Reactor-Maintenance Assembly and Disassembly (R.MAD) Deconjarnination Faclity. This facility was useo for the decontarnination of test-car hardware and tooling used in 1963 through 1973 a part of the Noclear Rodket Development Siation program. Subsequently the facility was used to decontaminate a rnilitary tank in the early 1980s. Specific processes from which this waste stream are generated inchude rernowal of contaminated material

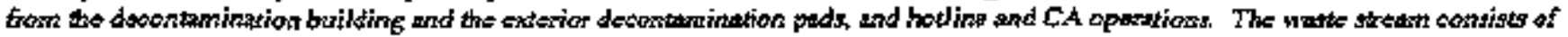
compactible trash (ineluding, personal protection equipment [PPE], tape, kinwipes, papet, plastic, plastic bags, etc), and building debris (including, concrete tubble w/ rebar and soil, wood doors and office benches, nort-ACM insulation from the doors, non-ACM insulated piping. elestrical equiprent with associated conduit and wire, \& turbulator tank, metal staiss, an overhead crane, and transite wallboard

$\begin{array}{ll}\square \text { Yes } & \text { 目 } \\ \square \text { Yes } & \text { 林 }\end{array}$

5. Estimated Rate of Gentration

6. Reasons for Subriittal (specify one)

圆 New Waste Strean

Modificarion to Waste Stream
Process description continuation page altached?

Flow diagram attached?

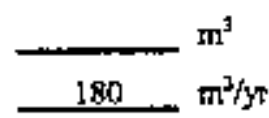

7. 口 Yes $\mathrm{x}$ No

C. Physical Properties

I. Waste Form Description

冈 Solid

Powder/Dust

2 List Waste \$treara Comporents

Sese arach list.
Does this waste stream requirt a WAC devietion? Attach information.

Solidified $\square$ Encapsulated $\square$ sludge

$\square$ Scaled Source $\square$ sbsorbed liquid $\quad \square$ Other

Estimated Percent by :

a Yolume $\square$ Weight 
园 Yes $\square$ No Compencent continuation page attached?

3. The finti watt form mus compdy with the folbwing crilerla us defined in the WAC. List documenuation that damonstrates WAC compliance for each.

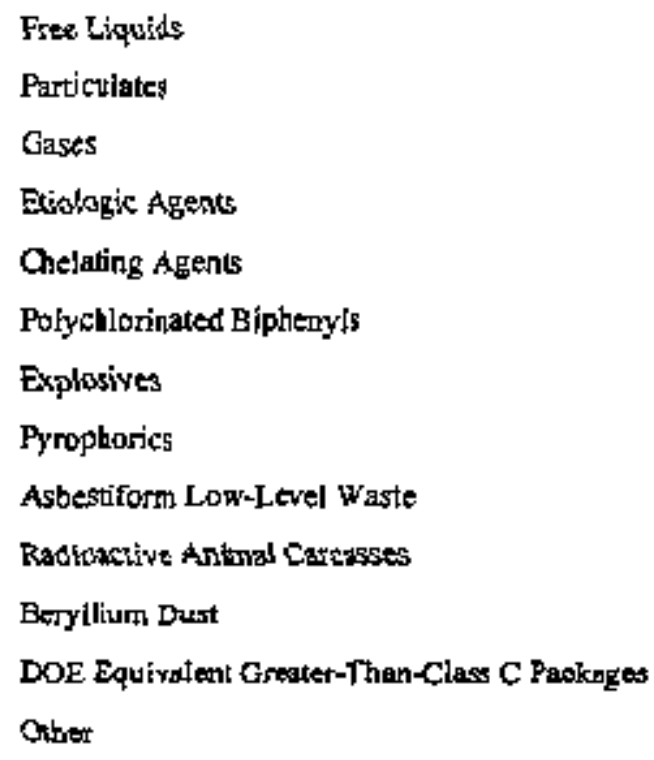

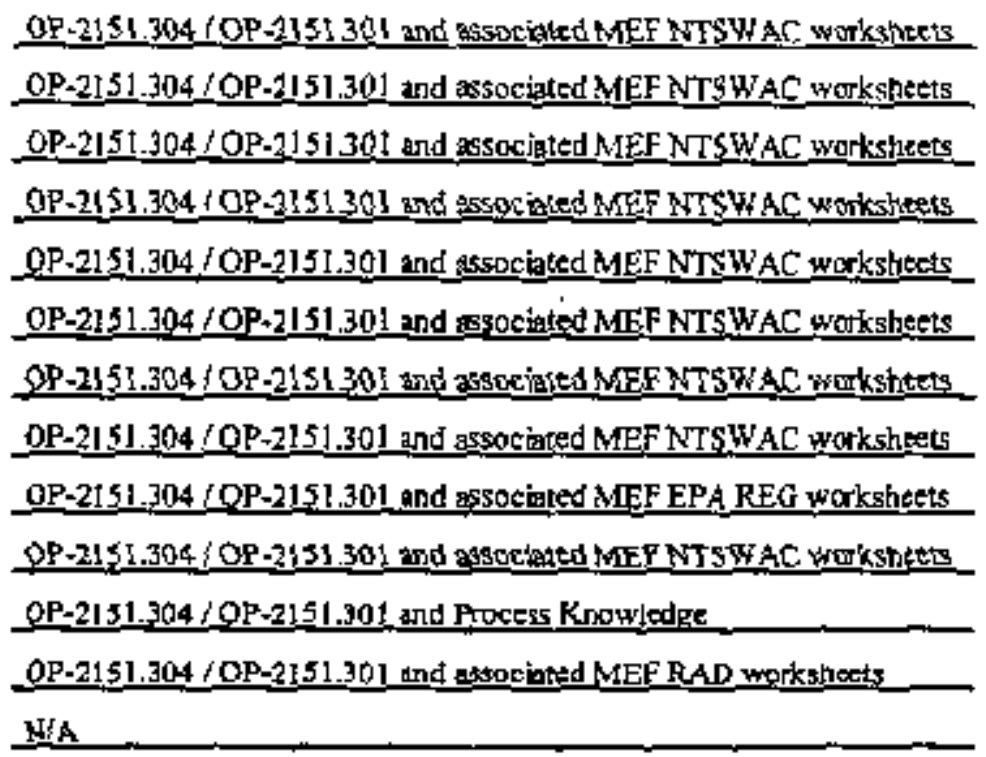

\section{RCRA Characterization}

1. RCPA, charascetization by : Check all thrt apply

Q Process Krowledge

$\square$ sampling and Analysis for complete characterizasion

冈 Confinmatory Sampiting and Aralysis

List decumente that control RCRA determinations

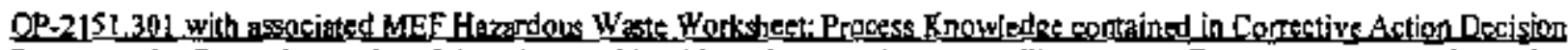

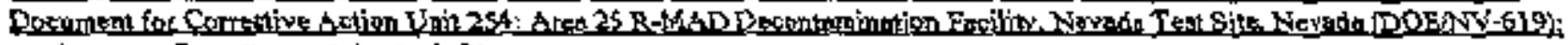
contimpaton Samoling and Analysis Plige

2. If sampling and analysis was used, ettach Table $\mathrm{B}-1$ or arl oquivalent sample resulf sumrnary that includes analytical results, upper confidence limits, and explanations of anomalies for all analytes antlyzed. Include eny state-specific analyte results. Confirmntory samples worn anolyzod for TCLP motals onfy. The rosuts are reported in Table B-1. Procose knowledge results, bound in the CAU CADD Appendix D, are used for other hazardous constituent. A saminary of the PK data

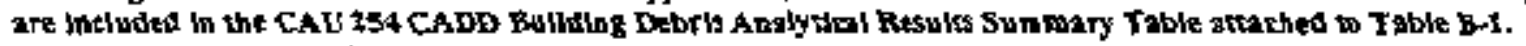

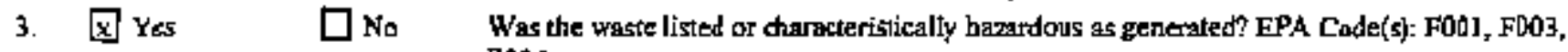
Foos.

4. Does the final waste form exhibit ang charactetistics of hazardous waste as defined in Title 40 CFR 261?
5. 园Yes
No
$\mathrm{No}$
No
No
6. $\square$ Yes 중 No
8. $\begin{array}{ll}\text { Yes } & \text { Yes } \\ \text { 8es } & \text { No } \\ \text { No }\end{array}$

Ignitapillty

Corrosivity

Reardivity

Toxícity

Is the final waste form listed as defined it Tikie wo CFR 26[? EPA Code(s):_FoOI, F003, Foos

Is the waste hazardous per stare-of gencration regulations? If yes, identify hazardous components and state regulations.

Has the waste been teated? Amach infotrailion wilch verfles WAC compltance. If yed, was the waste treated atter August 24, 1958?

Is the find waste ford trixed waste? If yes, attach information which verifies

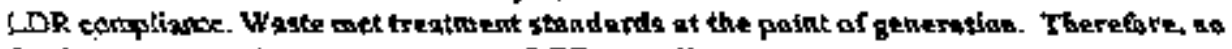

further treatinent is besessary to meet LDR compliance. 


\section{E. Radiological Properties}

I. Radiological characterization by (chtck all that apply)
X Process Knowledge
$\square$ Sampling \& Analysis
Matcials Control \& Accountability
$\square$ Direct Mesurement
Gross Radiation Measujement
Scaling Factors
$\square$ Other

2. Reference documents that describe the radioloqical characterization process.

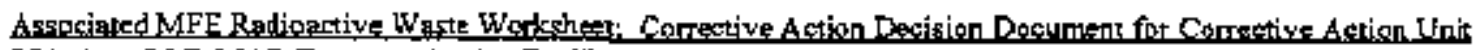

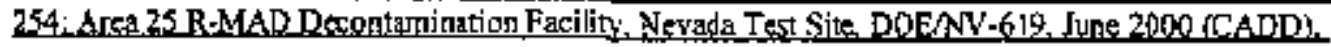

3. Reference documents that describe the melhad of deternining package activity.

\section{AssociatedMFE Radionctive Waste Woxkstherl}

4. Ligk reportable radipnuclides as definext in the WAC.

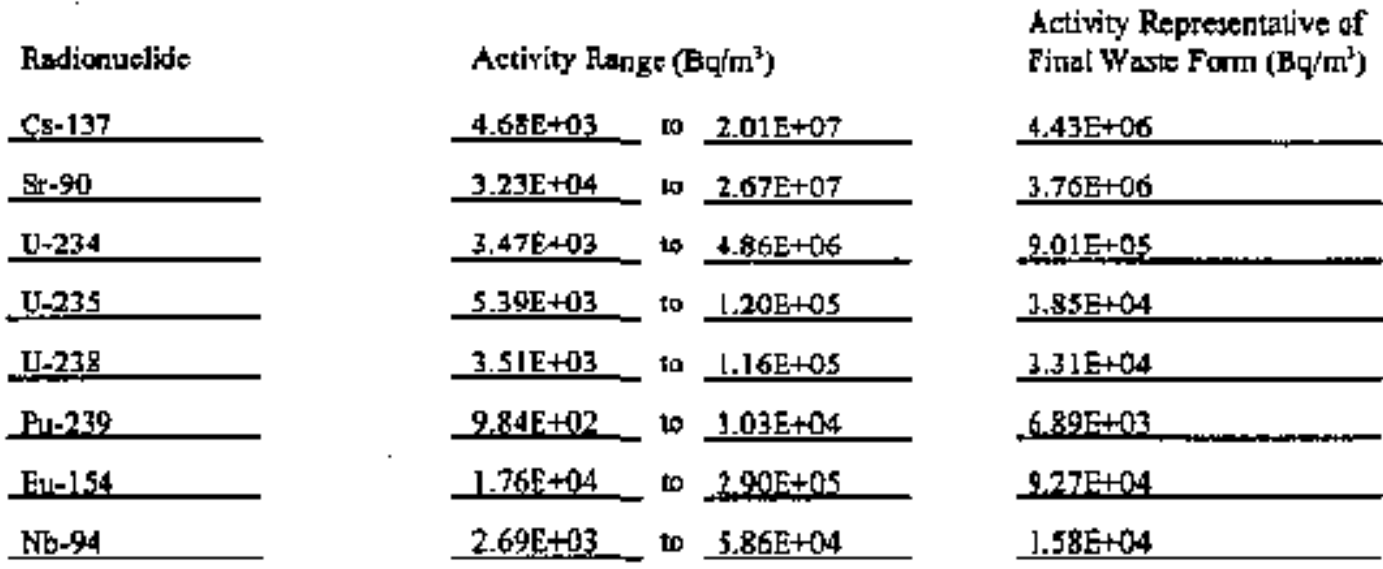

Reportable Radienualide continuation page altached? $\square$ Yes $邓$ No

5. $\square$ Yes $\quad$ No Attach chemical form of radiometide list if known. Page attached?

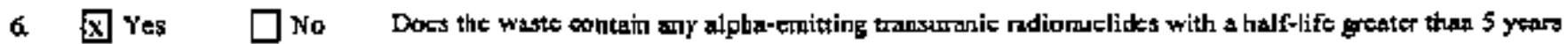
(Ph-241 or Cin-242)? If yes, list below.

Tranșuranic Nuclides

Pบ-239
Actirity Range ( $\mathrm{nCl} / \mathrm{g}$ )

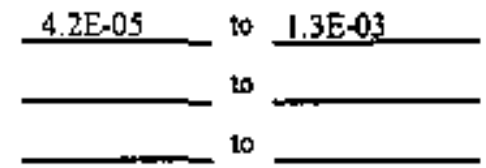

Activity Representalive of Final Waste Form (nCíg)

2.9E-A4

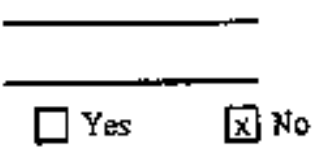

Transeranic nuclide contituation page athached?

7. List docurents that describe mocess(es) that controts TRU determintations and ensures TRU waste is not shipped

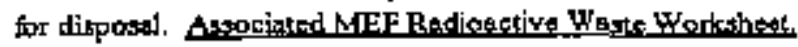

8. 国 Yes $\square$ No Is enriched uranium present? lf yes, provide enrichment of ${ }^{21 \mathrm{IJ}}$ by

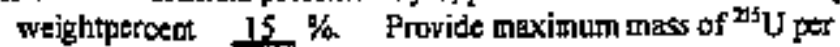
package 21 g/package Reference controlling documents. See attached Criticaliey Saftey Evaluation 
F. Packaging Description

1. $\square$ Yes $\square$ No Does the contains met each of the package criteria as defined in the WAC? Lust agcumencalion chat demonstrates WAC compitance.

Waste packaged and prepared far shipment according to procedure Op-2131 304. Waste packages will be inspected

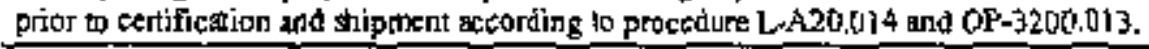

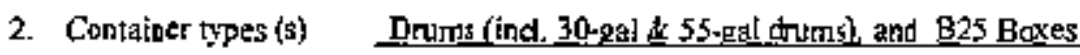
DOT Specification(s)/Descriptions(s) Strong Tight

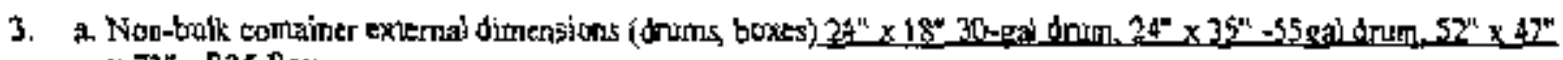
$\times 73^{\prime \prime}-\mathrm{B} 25 \mathrm{~B}$ B.

Does bor met t 3,375 it/ ft 5 strength test?

$[x$ Yes $\square$ No

Wright Range 30 _ $\mathrm{kg}$ to 4090 - $\mathrm{kg}$.

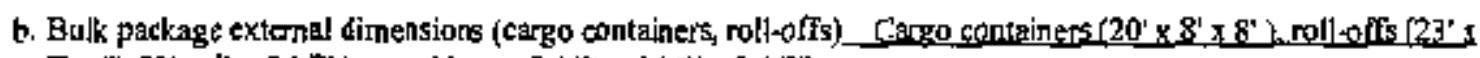

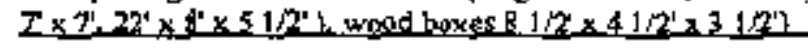

Weight Range 225 $\mathrm{kg}$ to $280 \mathrm{gh} \mathrm{kg}$

c. Bulk shipment dimensions._....NA

Weight Range NA_ $\mathrm{kg}$ to $\mathrm{NA}$ - $\mathrm{kg}$

4. Estimated radiation dose rate of disposal package:

$$
\begin{aligned}
& \text { Surface } \\
& \text { One meter } \\
& 0.00002
\end{aligned} \text { to } \frac{0.005}{0.005} \mathrm{mSvh}
$$

5. Refetace special handling procedures and ALARA documentation, if appropriate.

G. Signature

To the best of my knowledge, the information in this document and attachments is tree and accurate. Willful and deliberate omissions have not been made. All known and suspected hazardous materials have been disclosed.

Harry 4. Pesty

Technical Contact Printed Name

Dist; A Re 64

WCO's Printed Name

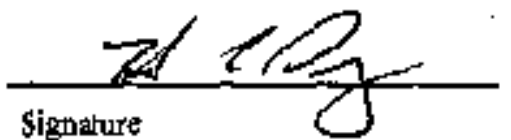

Signature

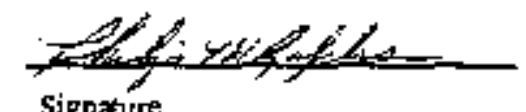

Signature

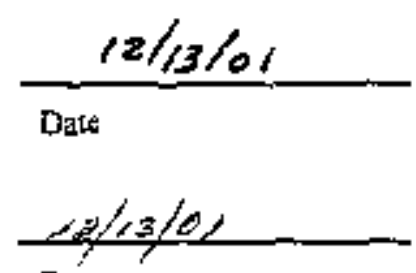

Dare

$B-63$ 
Table B-1

Amalytical Resuits

$\begin{array}{cc}\text { Staristical } & \text { Upper } \\ \text { Mean } & \text { Confidence } \\ \text { (mgl) } & \text { Level }\end{array}$
Statistical
Mean
$(\mathrm{mg} / \mathrm{L})$

Upper

Confidence

Level

TCLP Metals:

TCLP Semivolatiles:

\begin{tabular}{|c|c|c|c|c|}
\hline Arseric & 0.036 & 0.046 & $0-$ Cresol & PK/CADD \\
\hline Barium & 0.347 & 0.670 & p-Cresol & PK/CADL \\
\hline Cadmium & 0.178 & 0.589 & m-Cresol & $\mathrm{PK} / \mathrm{CADD}$ \\
\hline Chromium & 0.0345 & 0.0927 & Cresol & PKICADD \\
\hline lead & 0.0535 & 0.0970 & Dinitrotoluane & PK/CADD \\
\hline Mercury & 0,00043 & 0.00124 & Hexachlorobenzene & PK/CADD \\
\hline Selenium & 0.0349 & 0.0349 & Hexachlon-1,3-butadiente & PKCADD \\
\hline Silver & 0.0032 & 0.0040 & Nitrobenzente & PK/CADD \\
\hline TCLP Volatiles: & & & Pentachloriphenol & PK/CADD \\
\hline Benzane & PK/CADD & & 24,5-Trichlorophenol & PK/CADD \\
\hline Carbon Tetrachlorids & PK/CADD & & 2,4,6-Trioblerophenel & PK/CADD \\
\hline Chlorobenzene & PKJCADD & & Hexachloroethane & PK/CADD \\
\hline Chloroform & PKCADD & & TCLP Pestlcides and & erbicides: \\
\hline 1,4-Dichlorobenzent & PKJCADD & & Chlordane & $\mathrm{PK} / \mathrm{CADD}$ \\
\hline 1,2-Dichlorottlane & PKJCADD & & $1,4-D$ & $\mathrm{PK} / \mathrm{CADD}$ \\
\hline Methyl ettyl ketane & PK/CADD & & Endrin & PKJCADD \\
\hline Fyridine & PKCADD & & Geparctilor and Hydroxide & $\mathrm{PK} / \mathrm{CADD}$ \\
\hline Tetrachlorvethelyne & PKCADD & & Lindane & PKJCADD \\
\hline Trichloroethylene & PK/CADD & & Methoxychlor & PK/CADD \\
\hline Yinyl chloride & PK/CADD & & Toxaphent & PK/CADD \\
\hline Dichloroethylene & PK/CADD & & $2,4,5-$ TP (Silve $x)$ & PK/CADD \\
\hline
\end{tabular}

Note: See attached table (CAU 254 CADD, Building Debris Analytical Results Sumuary, Waste Stream ID \#'s LRY5MWFY01020 and LRY5MWFY01021) for a summary of CADD process knowledge information. 


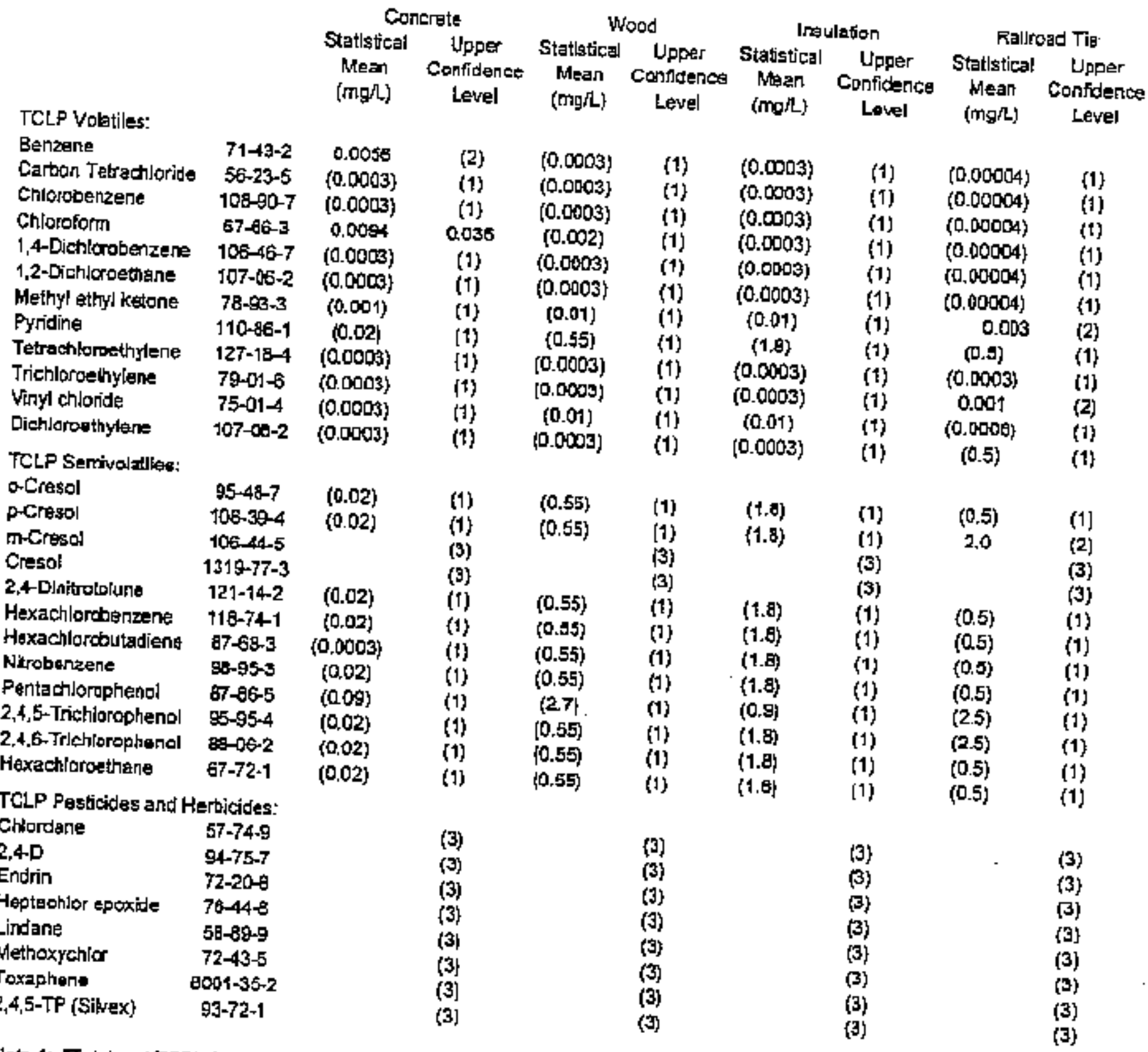

Note 1: 'Total and TCPL Peaticides were not detected at concemtarions above the minimun reporting lirrits in solt or bujilting material sarmpled' during the site inwastigation CAU 254 CADD, Exocutive Summery, poge EA-3.

Note 2: The ansiytical data shown in this table (mg/L) were detemlned by diwiding the totals data in ugkg by 20.
[1) detection Init
(2) detected in only ane sample
(3) not analyzad 


\section{C.2 Table}

Area 25, R-MAD Decontamination Facility

Proftle \#LRYSMWFY01020

List of Waste Stream Components

Estimated Percent by Volume

\section{Waste Stream Component}

Concrete debris w/ rebar and gravel

Wood debris

Non-ACM insulation

Hotline trasth, PPE

Scrap metal, inc. Non-ACM insulated pipe

Transite wallboard

\section{Percentby Volume}

65

9

5

7

12

2 
Waste Stream Number LRYSMWFY01020

References

Bechtel Nevada Organization Frocedure, OP-2151.301, Radioactive Waste Evaluation, Rev, 0.

Bechtel Nevada Organization Procedure, OP-2151.304, Radioactive Waste Tracking, Handling, and Management at the NTS, Rev. 2.

Material Evaluation Focm Folder No. F01020.

U.S. Department of Energy Report DOENV-619, Corective Axtion Decision Document for Corrective Action Unit 254: Area 25 R-MAD Decontamination Facility, Nevada Test Site, Nevada, June 2000 . 


\section{Examination of Criticality Safety Issues Associated With the Disposal of Contaminated Debris From CAU-254}

The following points are made in regard to the criticality safety of the contaminated building debris from CAU-254:

- The debris is packaged in containers with a total volume of 164 cubic meters.

- The concentration of U-235 ranges from $1.1 \mathrm{E}-07$ to $2.4 \mathrm{E}-06 \mathrm{gu}-23 \mathrm{~s} / \mathrm{g}_{\mathrm{geb}} \mathrm{s}$ per package.

- The highest concentration of $\mathrm{U}-235$ in a package, on a volume basis is $6.7 \mathrm{E}-07$ $\mathrm{g} / \mathrm{L}$, well below the DOT fissile exempt shipping level of $5 \mathrm{~g} / \mathrm{L}$.

- If the package of debris with the highest amount of U-235 was packaged in 55 . gal drums, the amount of U-235 per drum would be $1.4 \mathrm{E}-04 \mathrm{~g}$, and the drams could be disposed together with no coneens for criticality safety.

- Since the debris is packaged in a single container, although with the same volume as the drums, the amount of U-235 in the package is $21 \mathrm{~g}$, which triggers this examination of criticality safety.

- No amount of neutron moderation or reflection could make the $78 \mathrm{~g}$ total mass of U-235 tispersed in 164 cubic meters of debris a criticality safety concem.

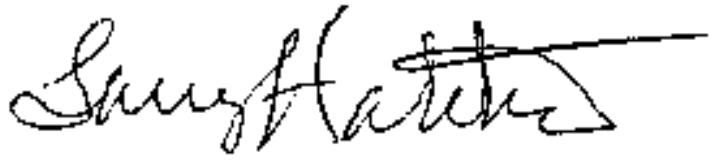

Larry Hatcher, CHP

$11 / 12 / 01$ 


\section{Land Disposal Restrictions Notification and Restriction Waste Stream \# LRY5MWFY01020 \\ Area 25, R-MAD Decontamination Facilly - Mixed Waste}

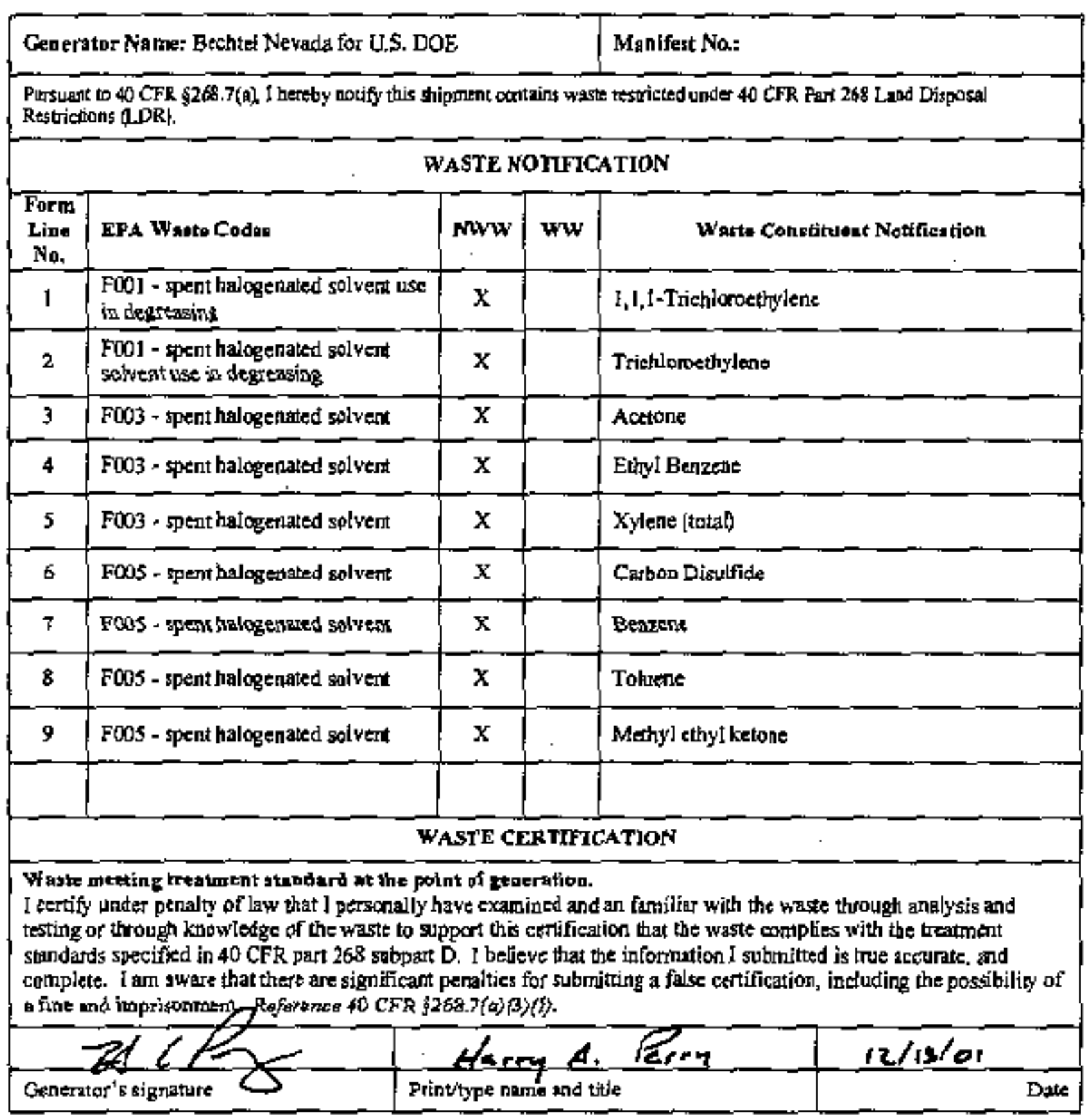




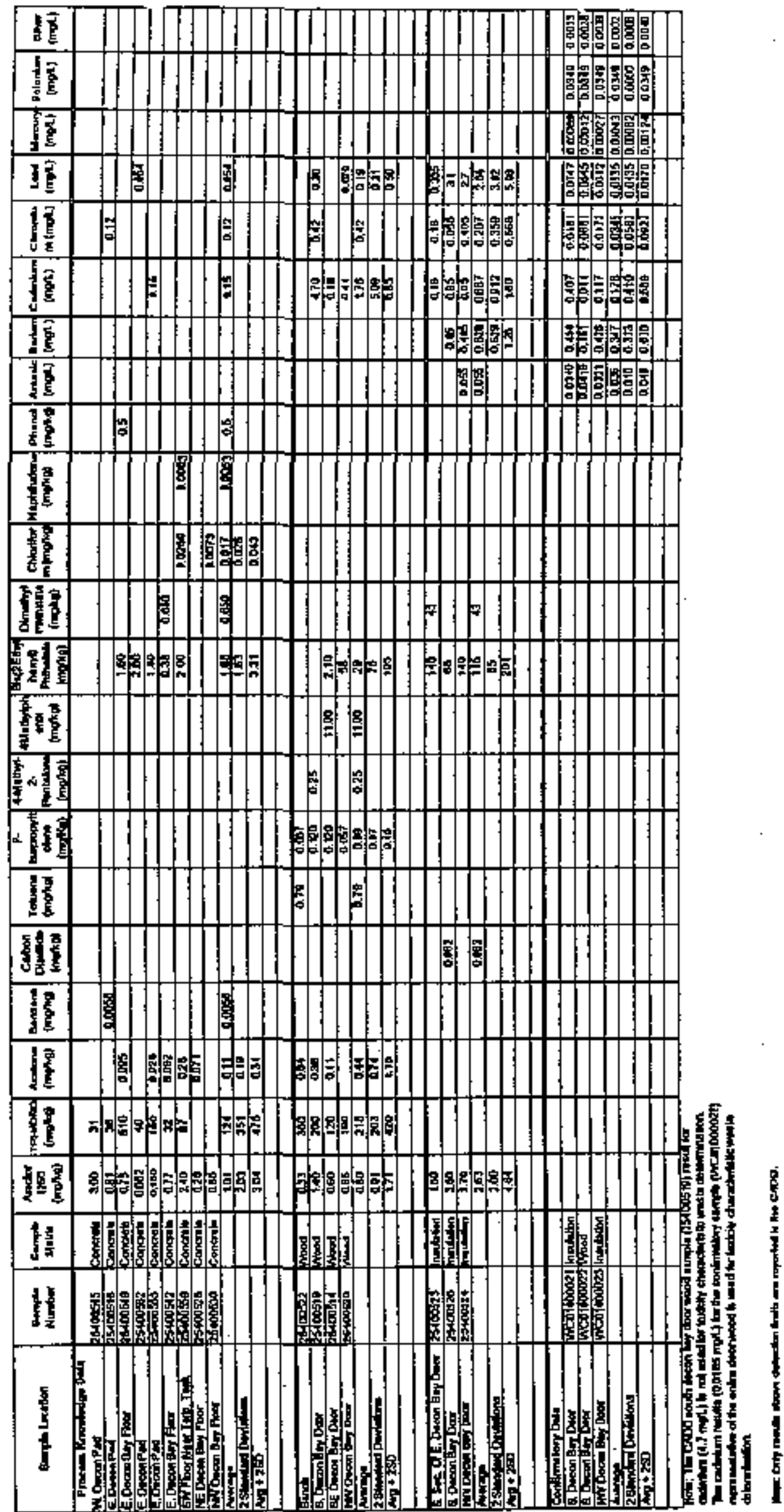




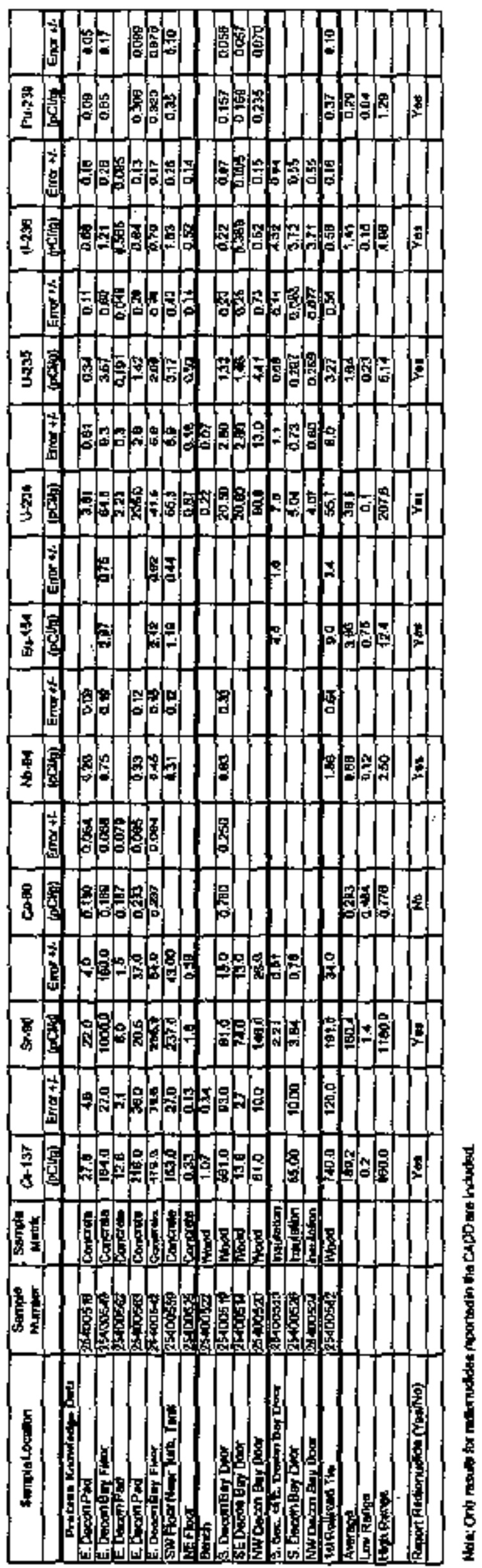




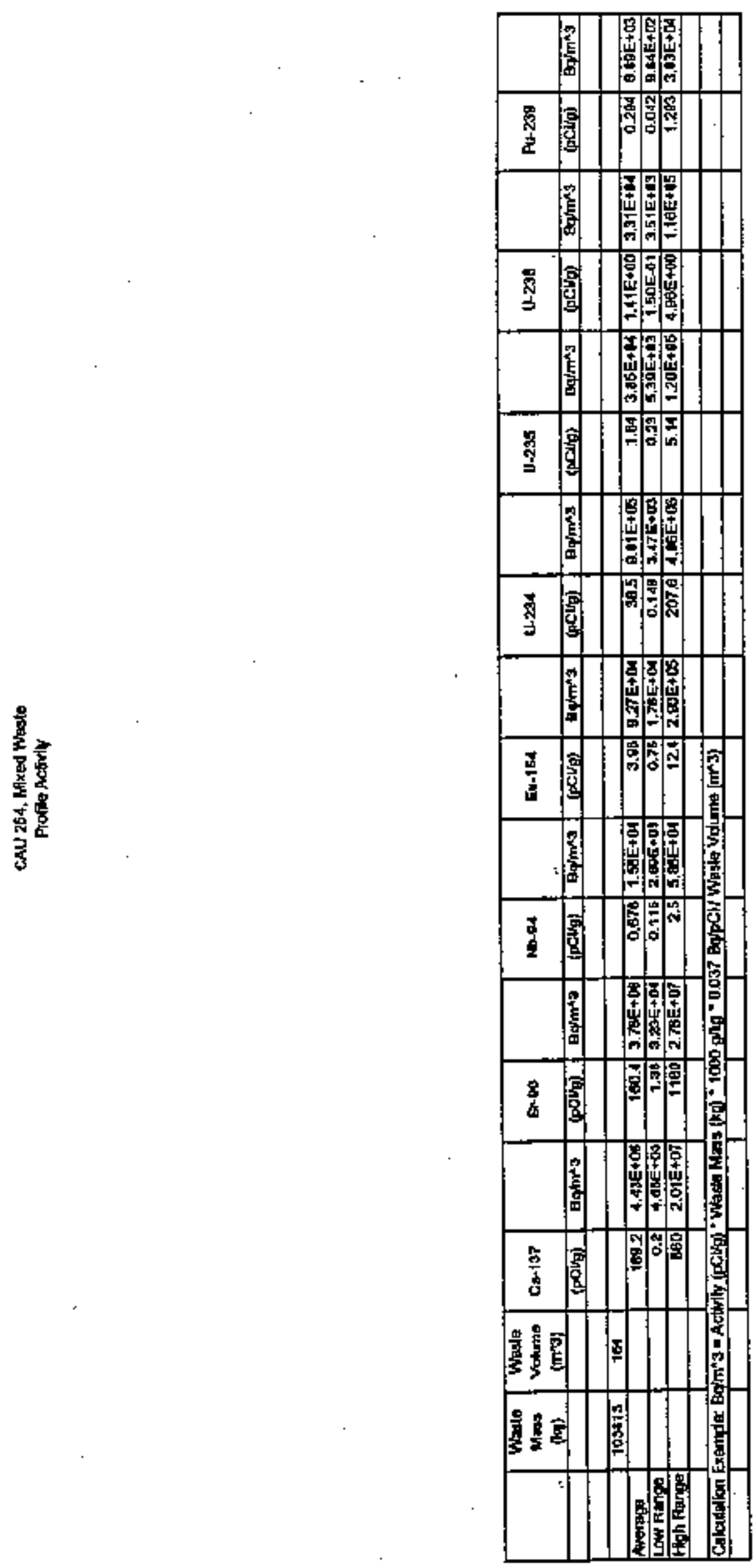


First Rail Road Tie South of the Decontanination Bay CAU 234, Area 25 R-MAD Decontamination Facikity Sample \#25400552

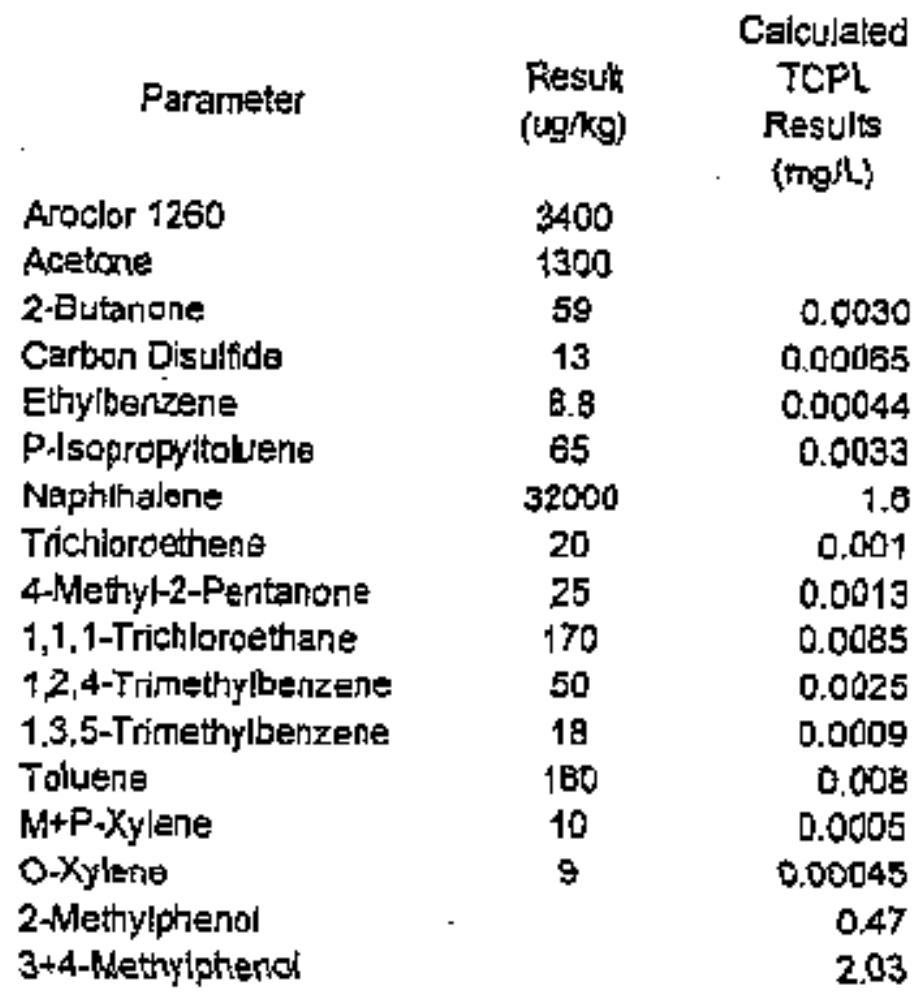

Noke: All of the above resuts have a " $r$ qualifyer, meaning estimated. 
THIS PAGE LEFT INTENTIONALLY BLANK

B-74

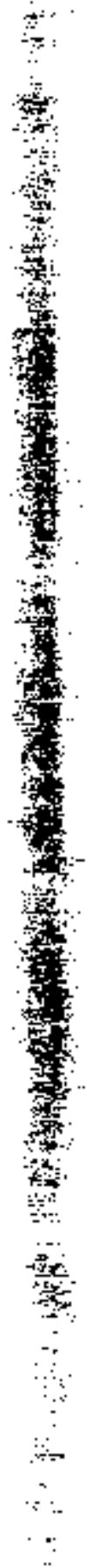




\section{APPENDIX C}

\section{VERIFICATION SAMPLES ANALYTICAL DATA}


THIS PAGE LEFT INTENTIONALLYY BLANK

Cij 


\section{APPENDIX C}

\section{TABLE OF CONTENTS}

Concrete and Sediment Verification Samples $\ldots \ldots \ldots \ldots \ldots \ldots \ldots \ldots$, C-6

Sample Delivery Group V1173 $\ldots \ldots \ldots \ldots \ldots \ldots \ldots \ldots$ C-8

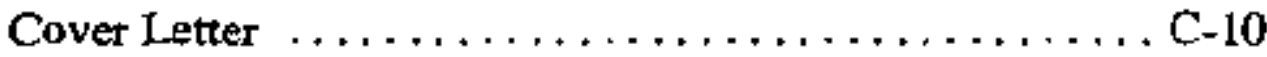

25400548-V1 (PCB's) $\ldots \ldots \ldots \ldots \ldots \ldots \ldots \ldots \ldots$ C-11

$25400547-V 1$ (PCB's) $\ldots \ldots \ldots \ldots \ldots \ldots \ldots \ldots \ldots . \ldots \ldots$ - 12

25400546-V1 (PCB's) . . . . . . . . . . . . . . . C-13

Method Blank ...........................

Chain of Custody $\ldots \ldots \ldots \ldots \ldots \ldots \ldots \ldots \ldots \ldots, C-15$

Sample Delivery Group V1226 $\ldots \ldots \ldots \ldots \ldots \ldots \ldots \ldots$ C- 16

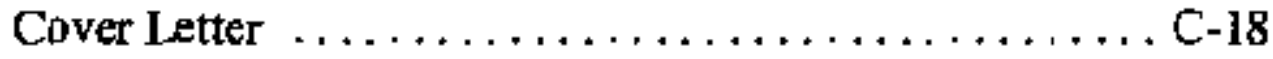

25400000-V1 (VOCs) ..................... C-19

25400525-V1 (VOCs) . ................... C-20

25400559-V1 (VOCs) , ................... C-21

$25400549-V 1$ (VOCs) $\ldots \ldots \ldots \ldots \ldots \ldots \ldots \ldots \ldots \ldots$ C-22

25400542-V1 (VOCs) . . . . . . . . . . . . . . . C-23

25400516-V1 (VOCs) ..................... C-24

25400563-VI (VOCs) $\ldots \ldots \ldots \ldots \ldots \ldots \ldots \ldots \ldots$ C-25

Method Blank (VOCs) . . . . . . . . . . . . . . . . . C-26

Method Blank (VOCs) $\ldots \ldots \ldots \ldots \ldots \ldots \ldots \ldots \ldots \ldots$ C-27

25400545-V1 (PCBs) . . . . . . . . . . . . . . . C-28

25400559-V1 (PCBs) . . . . . . . . . . . . . . . . . . . . . C-29

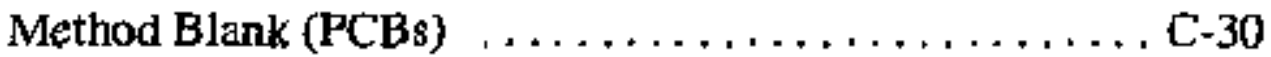

25400549-V1 (TPH) . . . . . . . . . . . . . . . C-31

25400563-V1 (TPH) ..................... C-31

Quelity Control Data (PCBs) ................. C-32

Quality Control Data (VOCs) .............. C-33-40

Chain of Custody ..................... C-41

Sample Delivery Group V1232 $\ldots \ldots \ldots \ldots \ldots \ldots \ldots \ldots \ldots$ C-42

Cover Letter . . . . . . . . . . . . . . . . . . . . C C-44

25400548-V2 (PCBs) . . . . . . . . . . . . . C 45

25400001-V1 (PCBs) . . . . . . . . . . . . . . C-46

Method Blank (PCBs) $\ldots \ldots \ldots \ldots \ldots \ldots \ldots \ldots \ldots \ldots$ C-47

Quality Control Data(PCBs) ............ C-48-49

Chain of Custody

C-50

C-iji 
Concrete and Sediment Verification Samples (Continued) . . . . . . . . C-51

Radioisotopes $\ldots \ldots \ldots \ldots \ldots \ldots \ldots \ldots \ldots \ldots \ldots \ldots \ldots \ldots \ldots \ldots \ldots \ldots$

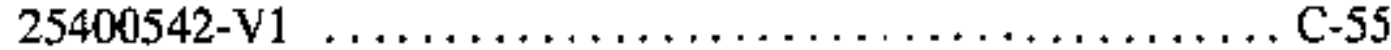

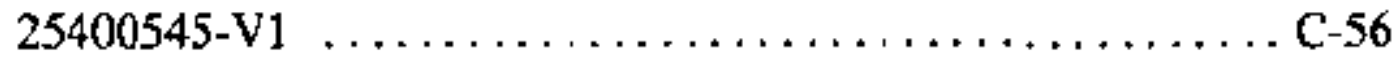

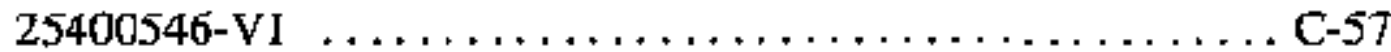

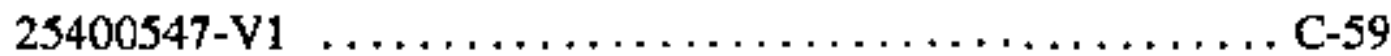

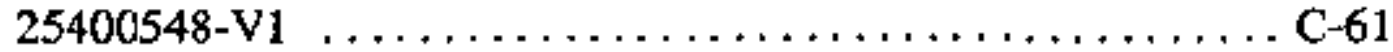

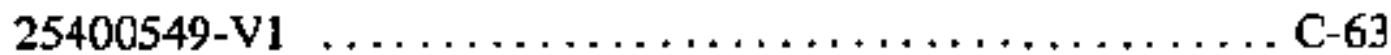

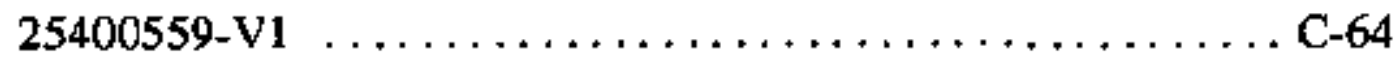

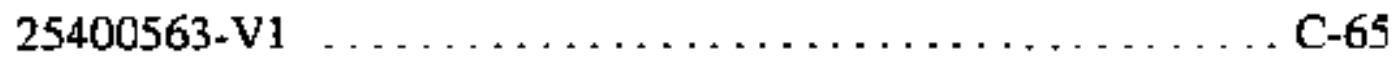

Excavation Verification Samples $\ldots \ldots \ldots \ldots \ldots \ldots \ldots \ldots \ldots \ldots \ldots \ldots$ C-66

Gamma Spectometry . . . . . . . . . . . . . . . . . . . . C-68

25400570-V1 .......................... C-70

$25400571-\mathrm{V} 1 \ldots \ldots \ldots \ldots \ldots \ldots \ldots \ldots \ldots \ldots \ldots \ldots, C_{-71}$

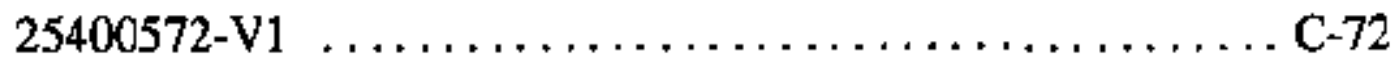

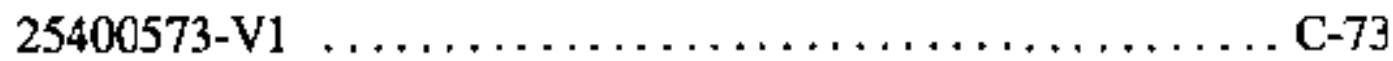

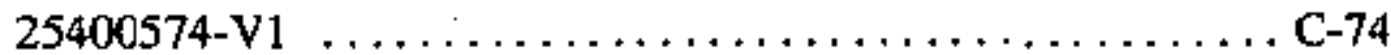

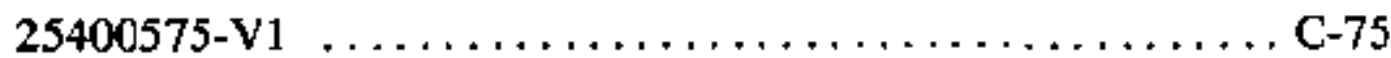

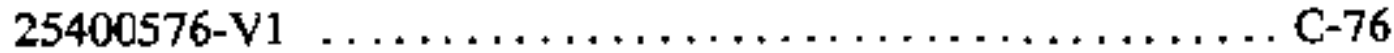

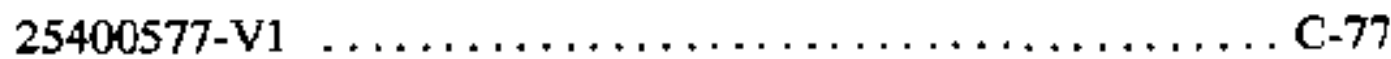

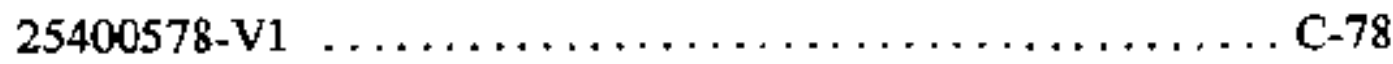

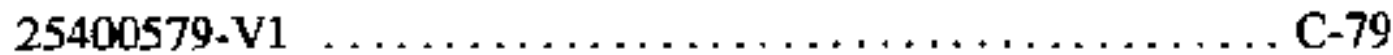

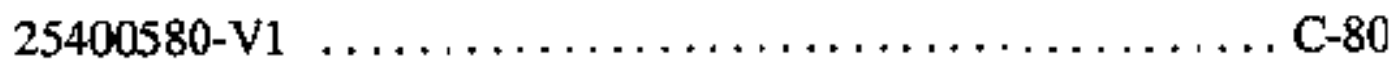

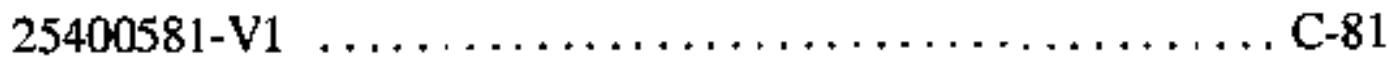

$25400582-\mathrm{V} 1 \ldots \ldots \ldots \ldots \ldots \ldots \ldots \ldots \ldots \ldots \ldots \ldots \ldots$ C.82

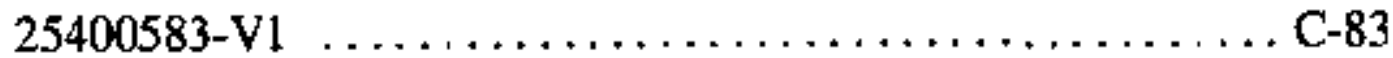

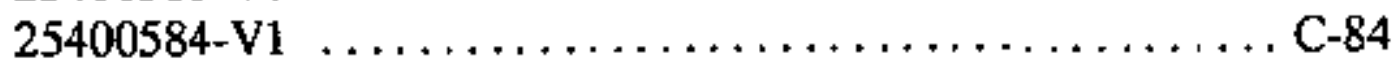

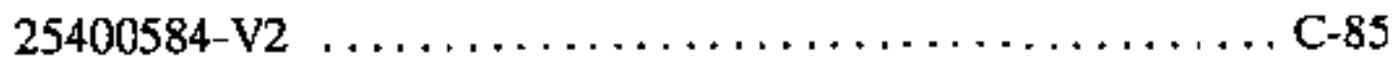

Recount of Sample 25400584-V1(2669-15) ........... C-86

$2669-15 \ldots \ldots \ldots \ldots \ldots \ldots \ldots \ldots \ldots \ldots \ldots . \ldots \ldots$. . . . . . . . . . 


\section{CONCRETE AND SEDIMENT VERIFICATION SAMPLES}


THIS PAGE LEFT INTENTIONALLY BLANK

C-vi 
Sample Delivery Group 1173

Ch 


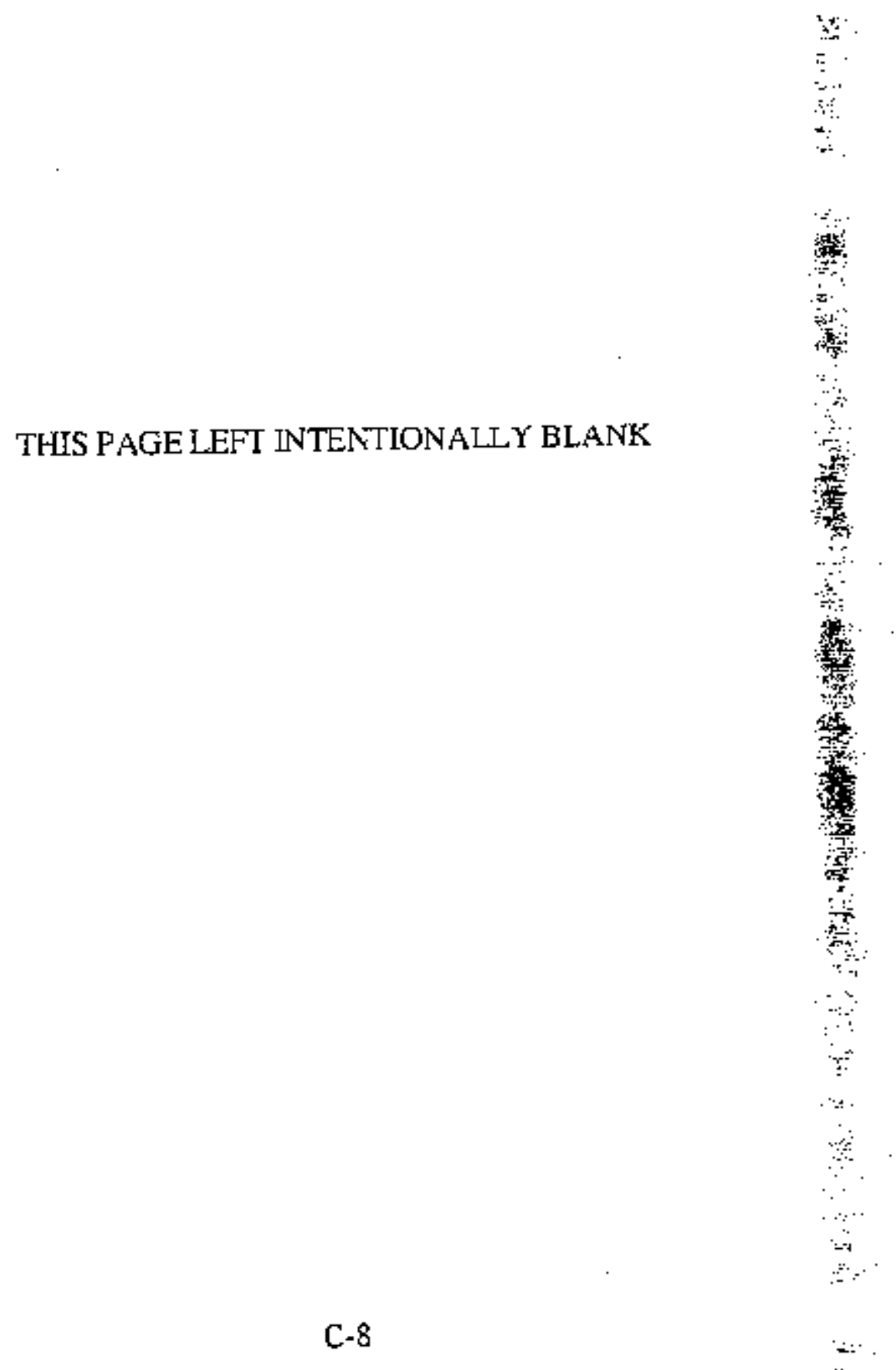


PolyChlorinated Biphenyls (PCBs)

C.9 
CLIENT: Bechtel Nevada

P.O. Box 98521 , M/S NTS273

ATTN: Ted Fedding

PROTECT NAME: V1179

NEL OROER DO: L0106265

PROJECT NUMBER: 23081

Atteched are the analyital resuls for samples in suppor of the above referenced project.

Samples submitted for this project rert not sampled by NEL Laboratories. Samples were received by NEL in good condition under chain of eustody on 6/21/01.

Should you have any questions or comments, please feel free to contatt our Client Services department at (702) $657-1010$.

\section{Some results have been flagged as folows:}

Je - This concentration may be biased besause the continuing calibation verification (CCV) standard did not meet QC requirements for tris analyte: Bowever, overall CCV'standard resoveries meet method requirements and antalytical restults are in confrol.
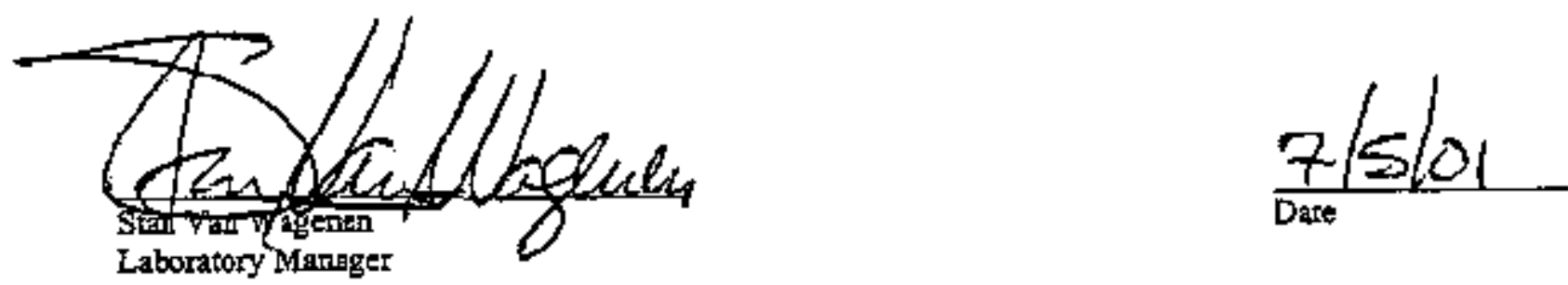

\section{CERTIFICATIONS:}

\begin{tabular}{llll}
\hline & Reao & Las Vegas & S. Califonis \\
\cline { 2 - 4 } Arizona & AZ0520 & AZ0518 & AZ0605 \\
California & 1707 & 2002 & 2264 \\
US Anry Corps & Certiried & Corified & \\
of Engineers & & &
\end{tabular}

$\begin{array}{llll} & \text { Rena } & \text { Las Vorgs } & \text { S. Californias } \\ \text { Idatio } & \text { Certified } & \text { Certified } & \\ \text { Montana } & \text { Certified } & \text { Cerifled } & \\ \text { Nevade } & \text { NV033 } & \text { NV052 } & \text { CA084 } \\ \text { L.A.C.SD. } & & & 10228\end{array}$


NEL LABORATORIES

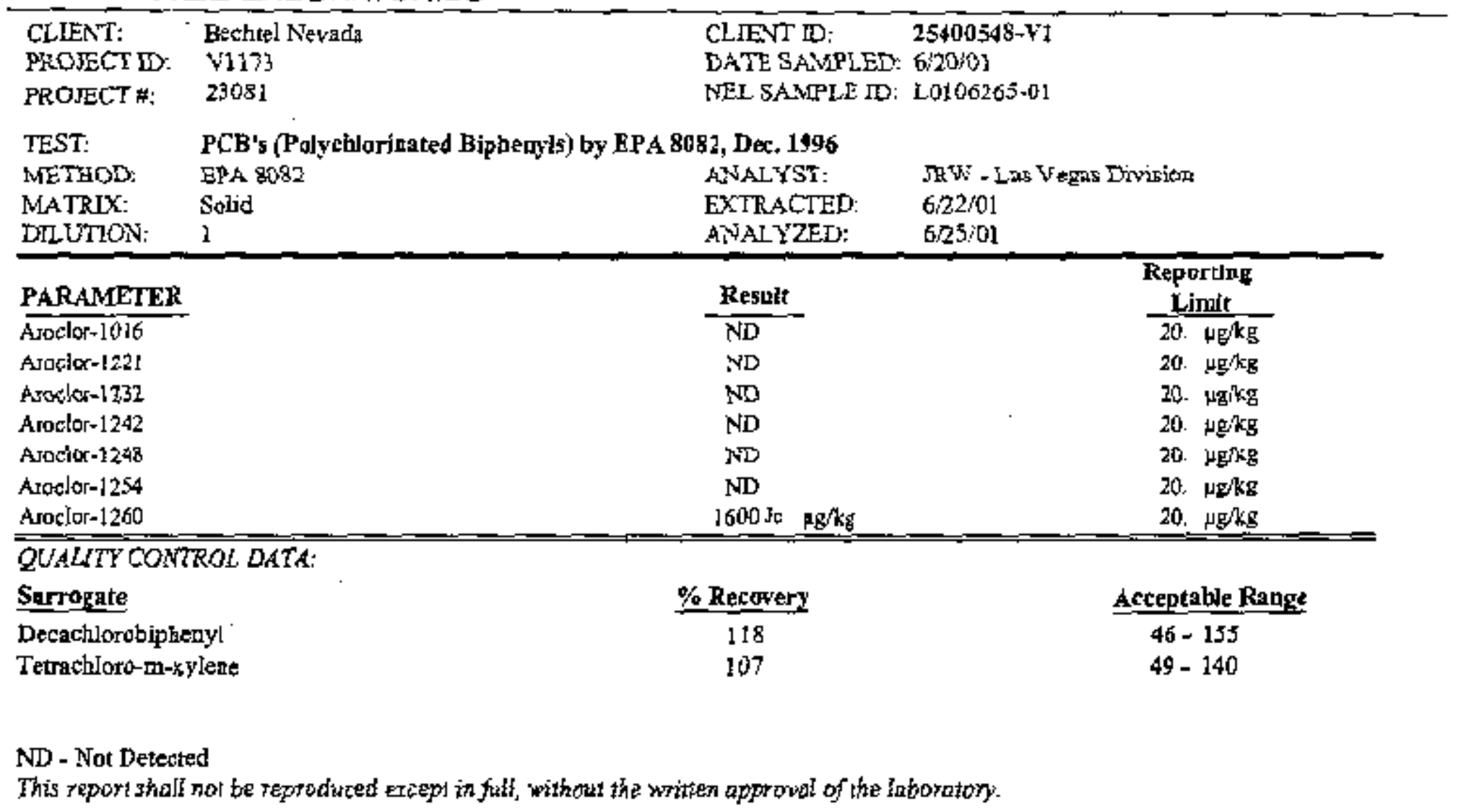




\section{NEL LABORATORIES}

\begin{tabular}{|c|c|c|c|}
\hline $\begin{array}{l}\text { CLIENT: } \\
\text { PROJECT ID: } \\
\text { PROJECT \#: }\end{array}$ & $\begin{array}{l}\text { Bectatel Nevada } \\
\text { V1 } 173 \\
23081\end{array}$ & $\begin{array}{l}\text { CLIENT ID: } \\
\text { DAIE SAMPLED: } \\
\text { NEL SAMPLE ID: }\end{array}$ & $\begin{array}{l}25400547-V 1 \\
620 / 01 \\
L 0106265-02\end{array}$ \\
\hline TEST: & FCB's (Polych) & D82, Doc. 1996 & \\
\hline $\begin{array}{l}\text { METHOD: } \\
\text { MATRLX: } \\
\text { DIUTHON: }\end{array}$ & $\begin{array}{l}\text { EPA } 8082 \\
\text { Solid } \\
\text { ] }\end{array}$ & $\begin{array}{l}\text { ANALYST: } \\
\text { EXTRACTED: } \\
\text { ANALYZED: }\end{array}$ & $\begin{array}{l}\text { JRW - Las Vegas Divisio } \\
6 / 22 ; 01 \\
625 \% 01\end{array}$ \\
\hline
\end{tabular}

\begin{tabular}{|c|c|c|}
\hline PARAMETER & Retwult & $\begin{array}{c}\text { Reporting } \\
\text { Lynit }\end{array}$ \\
\hline$\overline{A r D c} 10 \pi-1016$ & N & $20 . \mu \mathrm{g} / \mathrm{gg}$ \\
\hline Aroclor -1221 & $\mathrm{ND}$ & 20. $\mathrm{Ha} / \mathrm{tg}$ \\
\hline Aroclor -1232 & $\mathrm{ND}$ & 20. $\mu \mathrm{g} / \mathrm{kg}$ \\
\hline Arocldpr-1242 & $\mathrm{ND}$ & 20. $\mu \mathrm{g} / \mathrm{kg}$ \\
\hline Aroclor-1248 & $\mathrm{No}$ & 20. $\mu \mathrm{g} / \mathrm{Ag}$ \\
\hline Arodor-1254 & ND & 20. $\mu \mathrm{g} / \mathrm{kg}$ \\
\hline Aroctor- 1260 & $950 \mathrm{Jc} \mu \mathrm{g} / \mathrm{kg}$ & 20. $\mu \mathrm{g} / \mathrm{kg}$ \\
\hline \multicolumn{3}{|c|}{ QUALTY CONTROL DATA } \\
\hline Surrogate & \% Recovery & Acceptable Rante \\
\hline $\begin{array}{l}\text { Decachlorobiphemyl } \\
\text { TetrachIoro-m-xylens }\end{array}$ & $\begin{array}{l}110 \\
104\end{array}$ & $\begin{array}{l}46-155 \\
49-140\end{array}$ \\
\hline
\end{tabular}


NEL Laboratories

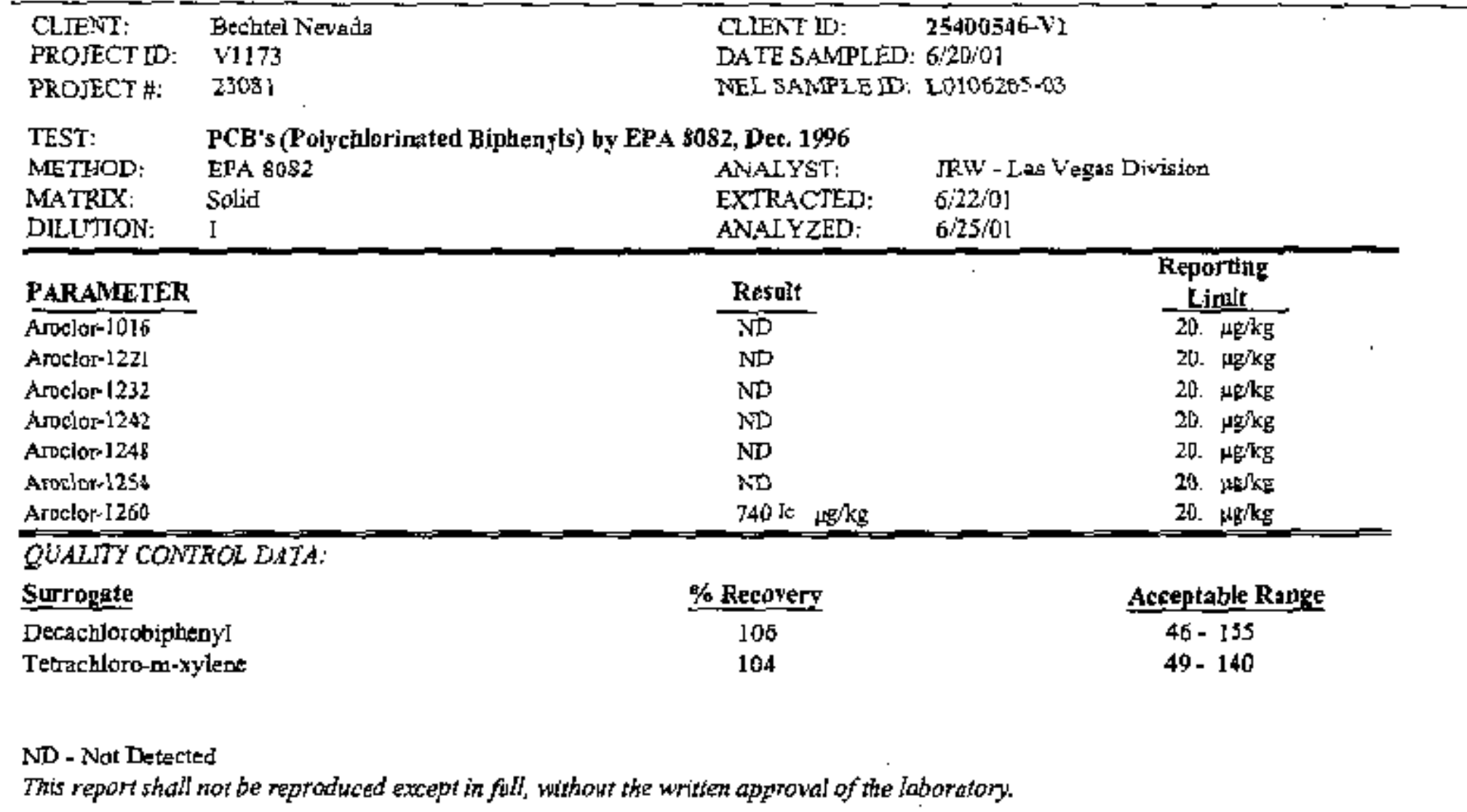


NEL LABORATORIES

\begin{tabular}{llll}
\hline CLIENT: & BechtelNevada & CLIENT ID: & Mrethod Blank \\
PROJECT D: & V1 173 & DATE SAMPLED: NA \\
PROIECT \#: & $2308 \mathrm{t}$ & NEL SAMPLE IN: & 010622 PCBS-BLK
\end{tabular}

TEST: $\quad$ PCB's (Polychlorinated Biphenyla) by EPA 8082, Dec. 1996

METHOD: EPA BO82

MATRIX: Solid

ANALYST: JRW - Las Vegas Division

EXTRACTED: $\quad 6 / 22 / 01$

ANAL YZED: 6/25/01

\begin{tabular}{|c|c|c|}
\hline PARAYETER & Result & $\begin{array}{c}\text { Reporting } \\
\text { Ltmit } \\
\end{array}$ \\
\hline Aroclor-1016 & $\overline{N D}$ & $20 . \mu g / 1 g$ \\
\hline Aroclor-1221 & ND & 20. $\mu \mathrm{g} / \mathbf{L E}$ \\
\hline Aroclor- 1232 & ND & 20. $\mu g / \mathrm{h}_{\mathrm{B}}$ \\
\hline Arocler-1242 & $\mathrm{ND}$ & 20. $\mathrm{kg} / \mathrm{kg}$ \\
\hline Aroctor-1248 & $\mathrm{ND}$ & 20. Ho/ks \\
\hline Aroclor- 1254 & ND & 20. $\mu \mathrm{g} / \mathrm{kg}$ \\
\hline Aroclor-1260 & $\mathrm{ND}$ & 20. $\mathrm{\mu g} / \mathrm{kg}$ \\
\hline
\end{tabular}

QUALTY CONTROL DATA:

Surrotenate

Decachlorobiphenyl

\section{\% Recovery \\ 112}

109

\section{Acceptable Range}

$46-155$

$49-140$

ND - Not Detected

This report shall not be reproduced excepr in fult, without the written approval of the laboratory. 


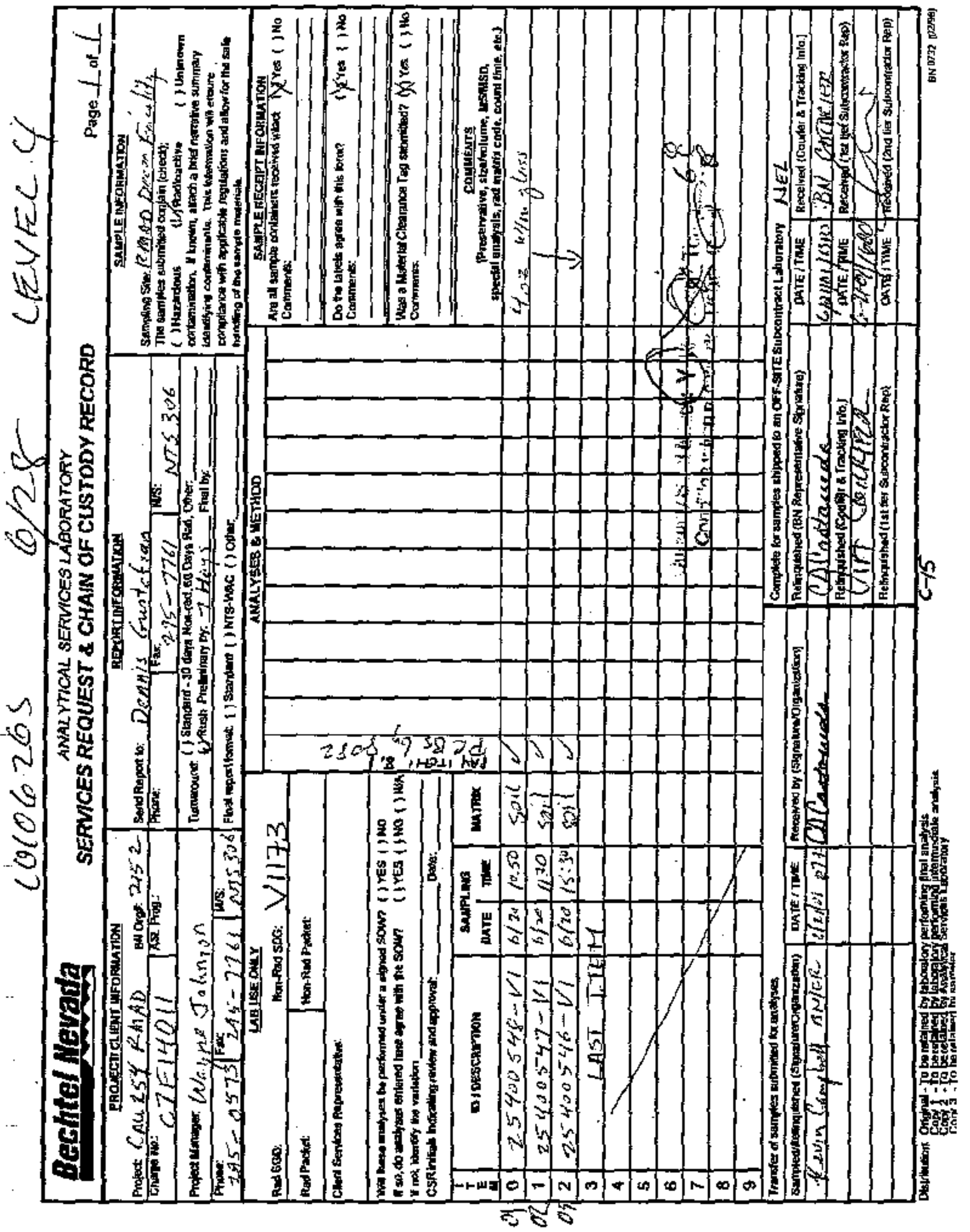


THIS PAGE LEFT INTENTIONALLY BLANK

C-16 
Sample Delivery Group 1226 


\section{CLIENT: BechteI Nevada}

P.O. Box 98521 , M/SNTS273

ATTN:

Las Vegas, NV $89193-8571$

Ted Redding

PROJECT NAME: VI226

PROFECT NUMBER: 23081

Attached are the analytical results for samples in support of the sbove referenced project.

Samples submitted for this project were not sampled by NEl Laboratories. Samples were received by NEL in good condition, under chain of eustody on $8 / 2 / 01$.

Should you have any questions or eomraents, pleage feel free to contast our Client Bervices departunent at (702) 65?-1010.

Some results have been dagged as follows:

E Concentration exceeded calibration tange.

Some QA resilts have been flagged as foilows:

J - This concentation should be considered an estimate due laboratory control sample failure.

I1 - The bateb MS and or MSD were outgide aeceptance fimits. The batch LCS was acceptable.

Some surrogate resuits bave been Ilagged as follows:

Sf - This surrogate was outside aceeptance limits.

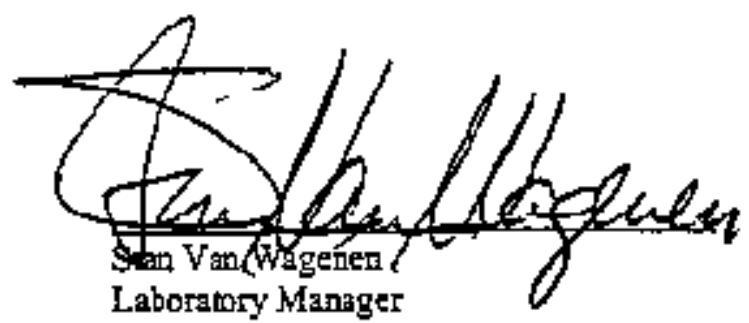

CERTIFICATIONS:

\begin{tabular}{|c|c|c|c|}
\hline & Respo & Las Vegas & S. Callfomia \\
\hline Arizot & $\overline{A Z O 520}$ & AZO518 & A20605 \\
\hline California & 1707 & 2002 & 2264 \\
\hline $\begin{array}{l}\text { US Army Corps } \\
\text { of Enginters }\end{array}$ & Certified & Certifled & - \\
\hline
\end{tabular}

NEL ORDER ID: L0108017

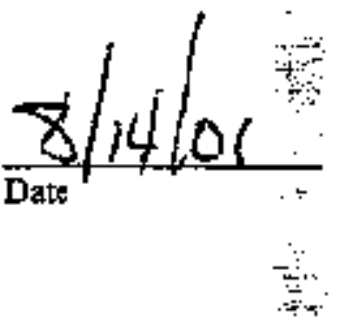

Idaho

Mortana

Nevada

R.en:

Q

L.A.C.S.D.

$\begin{array}{llc}\text { Certified } & \text { Certified } & \cdots \\ \text { Certified } & \text { Centified } & \ddots \\ \text { Nvo33 } & \text { Nv0s2 } & \text { CA084 } \\ & & 10228\end{array}$




\begin{tabular}{|c|c|c|c|c|c|c|c|}
\hline $\begin{array}{l}\text { CLIENT: } \\
\text { PROJECT ID: } \\
\text { PROJECT : }\end{array}$ & $\begin{array}{l}\text { Bechted Nevada } \\
\text { Y1226 } \\
23081\end{array}$ & & & $\begin{array}{l}\text { CLIENT ID: } \\
\text { DATE SAMLLED; } \\
\text { NEL SAMELE DO: }\end{array}$ & $\begin{array}{l}25400000-\mathrm{Vl} \\
7 / 30 / 01 \\
\mathrm{~L} 0108017.01\end{array}$ & & \\
\hline $\begin{array}{l}\text { TEST: } \\
\text { METHOT: } \\
\text { MATRIX: } \\
\text { DLUTTOA: }\end{array}$ & $\begin{array}{l}\text { Volatile Organic } \\
\text { EPA. } 8 z 60 \\
\text { Aqueous } \\
1 \\
\end{array}$ & Compoas & सY ЕР 8260B & $\begin{array}{l}\text { December } 1996 \\
\text { EXTRACTED: } \\
\text { ANALYZED: } \\
\text { ANALYST: }\end{array}$ & $\begin{array}{l}\text { NA } \\
8 / 6 / 01 \\
\text { DMH - Las Ve }\end{array}$ & as Division & \\
\hline \multicolumn{2}{|l|}{ PARAMETER } & $\begin{array}{l}\text { Result } \\
\mu \mathrm{g} / \mathrm{L} \\
\end{array}$ & $\begin{array}{c}\text { Reporting } \\
\text { Litnit }\end{array}$ & \multicolumn{2}{|l|}{ PARAMLTER } & $\begin{array}{l}\text { Result } \\
\mu \mathrm{g} / \mathrm{L}\end{array}$ & $\begin{array}{c}\text { Reporting } \\
\text { Limit } \\
\end{array}$ \\
\hline \multicolumn{2}{|l|}{ Acetans } & $\overline{\mathrm{ND}}$ & 25.40 & \multicolumn{2}{|l|}{ 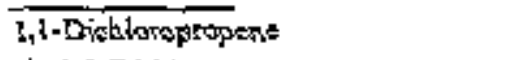 } & ब⿰冫 & $5 . \mu \mathrm{g} / \mathrm{C}$ \\
\hline \multirow{2}{*}{\multicolumn{2}{|c|}{$\begin{array}{l}\text { Benzene } \\
\text { Bnondetrizene }\end{array}$}} & $N D$ & $5 . \mu g / L$ & \multicolumn{2}{|c|}{ cis-1,3-Dichloropropene } & ND & 5. $\mu \mathrm{g} / \mathrm{L}$ \\
\hline & & $N D$ & $5.4 \mathrm{H} / \mathrm{L}$ & \multicolumn{2}{|c|}{ tans-1,3-Dichlinoprepent } & ND & 5. $4 \mathrm{~g}^{2} \mathrm{~L}$ \\
\hline \multicolumn{2}{|c|}{ Bromochlaroftethanc } & ND & S. $\mu \mathrm{L} / \mathrm{L}$ & \multicolumn{2}{|l|}{ - Ecthylbentanc } & D & 5. $\mu g / \mathrm{L}$ \\
\hline \multicolumn{2}{|c|}{ Bromodichloromethene } & $N D$ & $5.48 / 2$ & \multicolumn{2}{|l|}{ Hexactiorobatabiene } & $N D$ & 5. $\mu \mathrm{gg} / \mathrm{L}$ \\
\hline \multicolumn{2}{|l|}{ Eromoform } & ND & S. $\mu g / L$ & \multicolumn{2}{|l|}{ 2.Hexanone } & ND & 25. \\
\hline \multicolumn{2}{|l|}{ Bromornethane } & ND & 3. $\mu g / L$ & \multicolumn{2}{|l|}{ Iodometanane } & $\mathrm{No}$ & 5. $\mathrm{pg} / \mathrm{L}$ \\
\hline \multirow{2}{*}{\multicolumn{2}{|c|}{$\begin{array}{l}\text { 2-Butarone } \\
\text { ת-Butylbenzene }\end{array}$}} & $\mathrm{ND}$ & $25 \cdot \mu \mathrm{b} / \mathrm{L}$ & \multicolumn{2}{|l|}{ Isoprwoylbenzente } & $\mathrm{MD}$ & $5 . \mu g / L$ \\
\hline & & ND & $5 . \mu \mathrm{g} / \mathrm{L}$ & \multicolumn{2}{|l|}{ p-lsopropyltoldene } & No & 5. $\mu \mathrm{g} / \mathrm{L}$ \\
\hline \multicolumn{2}{|l|}{ sex-Burytberzente } & ND & S. $\mu E / L$ & \multicolumn{2}{|c|}{ Methylene chiotide (Dichlofornethane) } & ND & 5. $\mu D / L$ \\
\hline tert-Butylberzene & & ND & $5, \mu g / L$ & \multicolumn{2}{|l|}{ 4.Methyl-2-penlanone } & ND & 25. $\mu g / L$ \\
\hline \multicolumn{2}{|l|}{ Carbon disulfide } & ND & $5 . \mu \mathrm{g} / \mathrm{L}$ & \multicolumn{2}{|l|}{ MTBE } & NII & S. $\mu F^{\prime} / \mathrm{L}$ \\
\hline \multicolumn{2}{|c|}{ Carbon tetrachioride } & $N D$ & 5. $\mu E^{\prime} \mathrm{L}$ & \multicolumn{2}{|l|}{ NaphthaItene } & MD & $10 \cdot \mu / L$ \\
\hline \multicolumn{2}{|l|}{ Chloroberzene } & ND & 5. $\mu v / L$ & . M.Propylbenzene & & ND & 5. $\mu g / \mathrm{L}$ \\
\hline Chiorocthane & & ND & 5. $\mu \mathrm{g} / \mathrm{L}$ & Styrene & & $\mathrm{ND}$ & $5 . \mu \mathrm{g} / \mathrm{L}$ \\
\hline ChJoroform & & $\mathrm{ND}$ & 5. $4 \mathrm{~g} / \mathrm{L}$ & 1,1,1,2-Tetrachloroeth & tane & ND & 5. $\mu g / L$ \\
\hline Chloromethane & & 6.4 & 5. $\mu \mathrm{g} / \mathrm{L}$ & I,1,2,2-Tetrachloroeth & lane & ND & S. $\mu \mathrm{g} / \mathrm{L}$ \\
\hline 2-Chlorotoluene & & $N D$ & 5. $\mu \# / L$ & Tetrachlorocthene (PC & & $\mathrm{ND}$ & 5. $\mu \mathrm{g} / \mathrm{L}$ \\
\hline 4-Chlorotoluere & & $N D$ & 5. $\mu \mathrm{gL}$ & Tolutere & & ND & 5. $\mu g / L$ \\
\hline Dibromochloromet. & thane & $N D$ & $5.45 / 2$ & 1,2,3-Trichlarabenzed & . & ND & S. $\mu \mathrm{g}^{\prime} / \mathrm{L}$ \\
\hline 1,1-Dibrotno-3-ch] & loropropatte (DBCP) & $N D$ & $10 . \mu g / L$ & 1,2,4-Trithlorobenzes & & $\mathrm{ND}$ & 5. $\mu g^{\prime} \mathrm{L}$ \\
\hline 1,2-Dibromsethane & $(\mathrm{E}) \mathrm{B})$ & ND & 5. $\mathrm{L} \mathrm{L} / \mathrm{L}$ & $1,1,1-$ Trichlorecthane & $(1,1,1-T C A)$ & $\mathrm{ND}$ & $5 . \mu g^{\prime} t$ \\
\hline Dibmomomethane & & ND & 5. $\mu \notin L$ & 1,1,2-Trichlorookhand & $(1,1,2-T C A)$ & ND & 5. $\mu g / L$ \\
\hline 1,2-Didulorobenzer & $n e(D-D C B)$ & 30 & 5.48L & Trikhlorsethene (TCE) & & $\mathrm{no}$ & 5. $\mu \mathrm{g} / \mathrm{L}$ \\
\hline 1,3-Dichlorobenzes & $n e(m-D C B)$ & $\mathrm{ND}$ & 5. $\mu \mathrm{L} / \mathrm{L}$ & Triehlorofleoronethar & (Freon 11 ) & ND & to. $\mu \mathrm{g} / \mathrm{L}$ \\
\hline 1,4-Dithlorobonati & $\lambda \in\{(p-D C B\}$ & $\mathrm{ND}$ & S. $n \mathbb{t}^{\pi / L}$ & 1,2,3-Triefturopkopan & & 30 & 5. $\mathrm{pg}^{\prime} \mathrm{L}$ \\
\hline Dichlowdiffurom & ethane (Freor 12) & ND & 5. $\mu \frac{1}{2} \mathrm{~L}$ & 1,2,4-Trimethylorenzex & & $\mathrm{ND}$ & 5. $\mu g / \mathrm{L}$ \\
\hline 1,t-Dichloroethane & $(1,1-D \in A)$ & $\mathrm{ND}$ & 5. $\mu z \pi$ & 15,5-T rimethylbenze & & No & S. $\mu \mathrm{g} / \mathrm{h}$ \\
\hline 1,2-Dishlorgethane & $=(1,2-D C A)$ & ND & 5. $\mu g / L$ & Vunyl chloride & & ND & 5. $\mu g / \mathrm{L}$ \\
\hline 1,1-Dichioroethene & $(1,1-D C E)$ & ND & 5. $4 \mathrm{~g} / \mathrm{L}$ & $0 . x y]_{\text {enge }}$ & & ND & 3. $\mu g / 1 /$ \\
\hline cis-1 2-Dichtoroeth & & $\mathrm{ND}$ & S. $\mu \mathrm{g} / \mathrm{L}$ & $m p-X y l e n f$ & & ND & $10 . \mu \mathrm{g} / \mathrm{L}$ \\
\hline тrans- $t$,2-Dichloroe & ethene & ND & $5 . \mu g / L$ & & & & \\
\hline 1,2-Dichlordpropar & & $N D$ & S. $\mu \notin L$ & & & & \\
\hline 1,3-Dich|orapropar & & ND & 5. $14 \mathrm{~L}$ & & & & \\
\hline 2,2-Dichloroproper & & ND & $10 . \mu 8 / L$ & & & & \\
\hline
\end{tabular}

QUALIY CONTROL DATA:

\section{Surrogate}

4-Bromofluorobenzıne

Dibromofluoromethane

Toluene-d8
$\%$ Recorery

97

98

98
Acceptable Ragte

$76-111$

$88-114$

$95-108$

ND - Not Detected

This report shap not be reproduced except in full, withcal the written approval of the laboratory. 


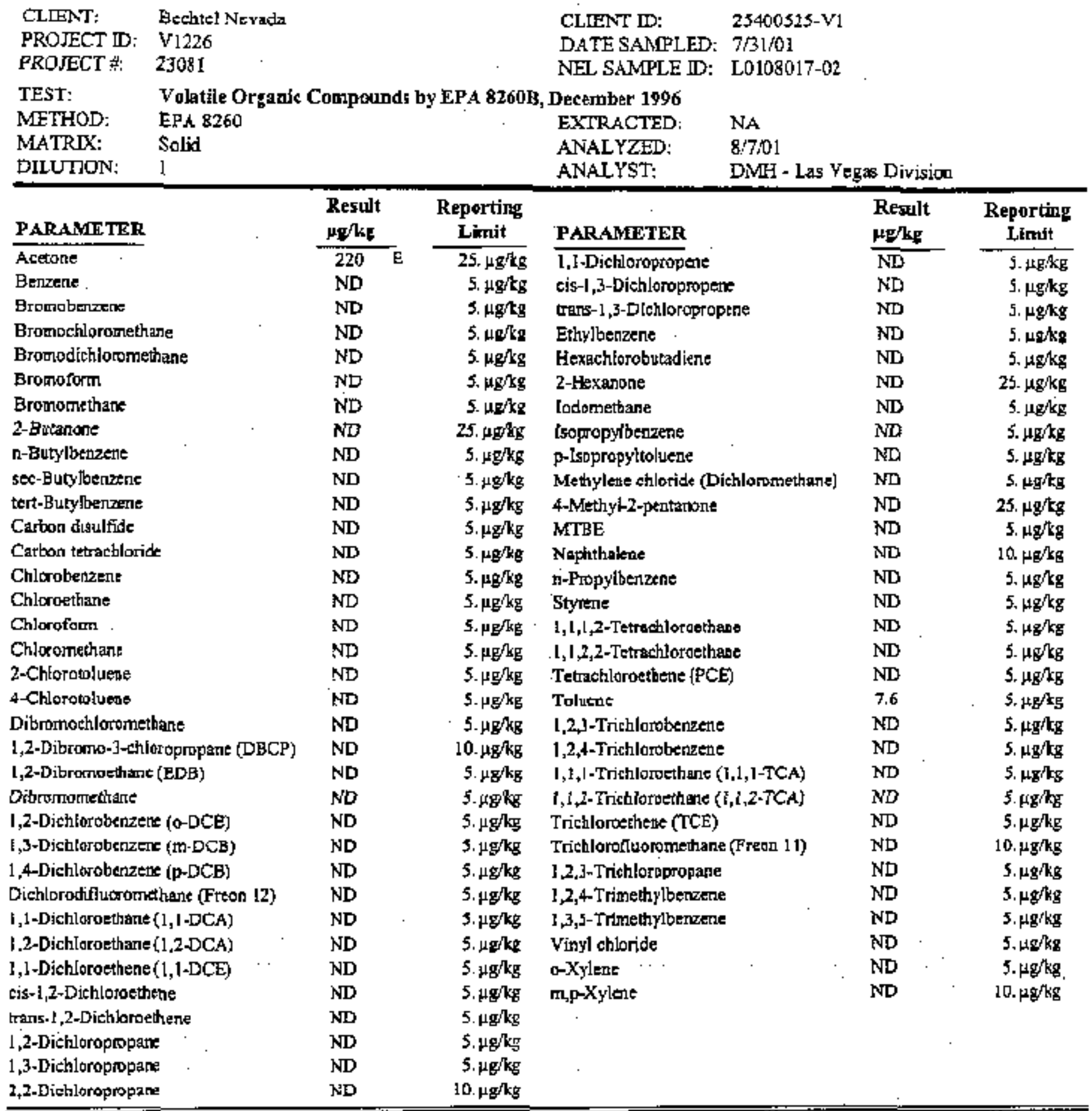

\section{DUALITY CONTROL DATA:}

\section{Surrogate}

4-Bromofluorobenzene Dibromoflutoromethane Toluene-d8
\% Recovery

98

10

\$7
Acceptable Ranke

$74+121$

$80-\$ 20$

$81-117$

\section{ND - Nol Deseted}

This report shall nor be reproduced except in full, wittout the wittent approval of the laboratory. 


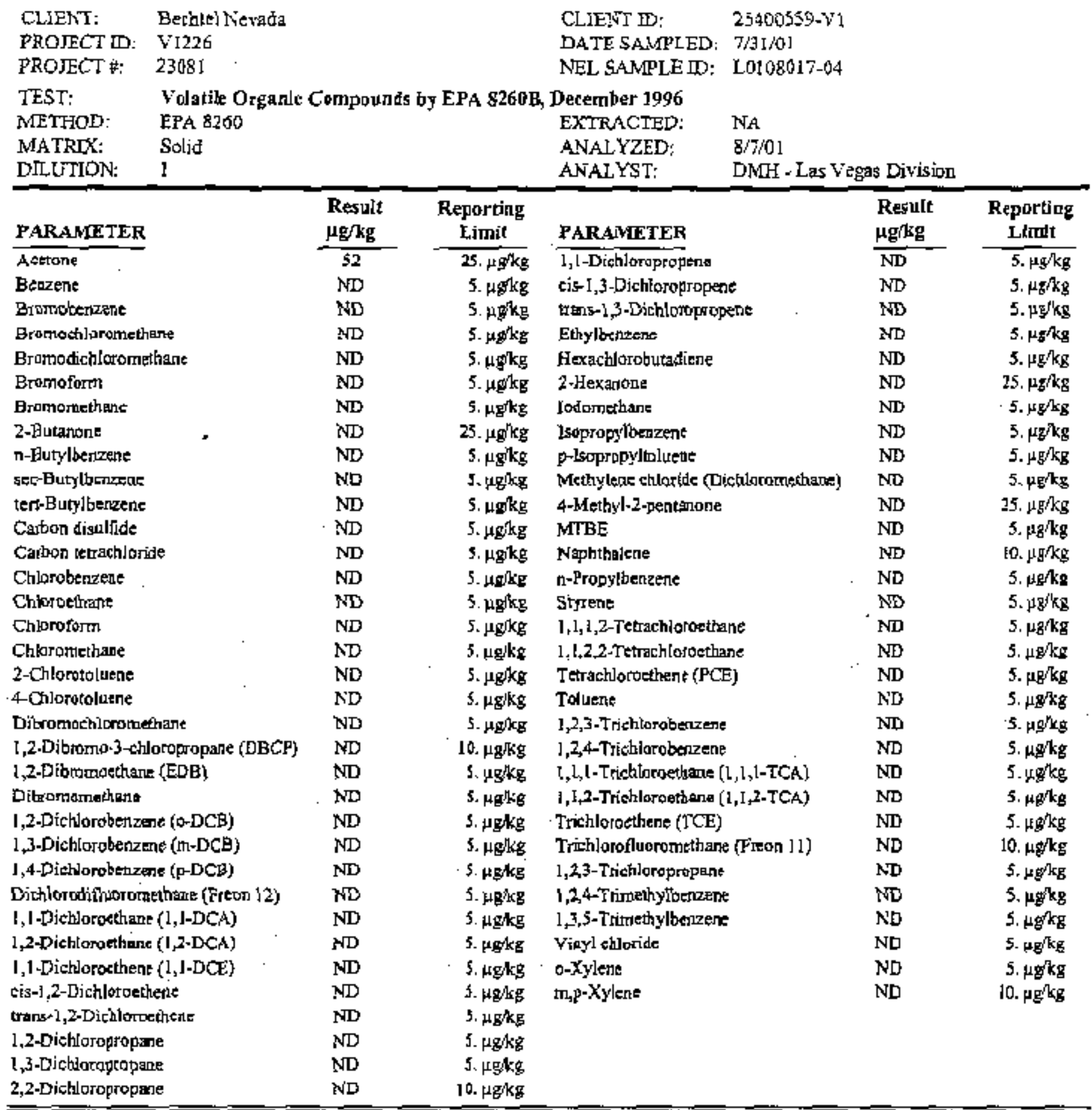

QUALI'Y CONTROL OATA:

Surrogate

4-Bromofuprobtrzere

Dibromoflumomethane

Tolueneds
$\% \mathbf{R e c o v e r y}$

95

$3 . \quad$ \$1

97
Aeceptable Range

$74-121$

$80-.120$

$81-117$

ND - Not Detected

Thit report shall not be reproduced except in full, without the written approval of the laboratory. 


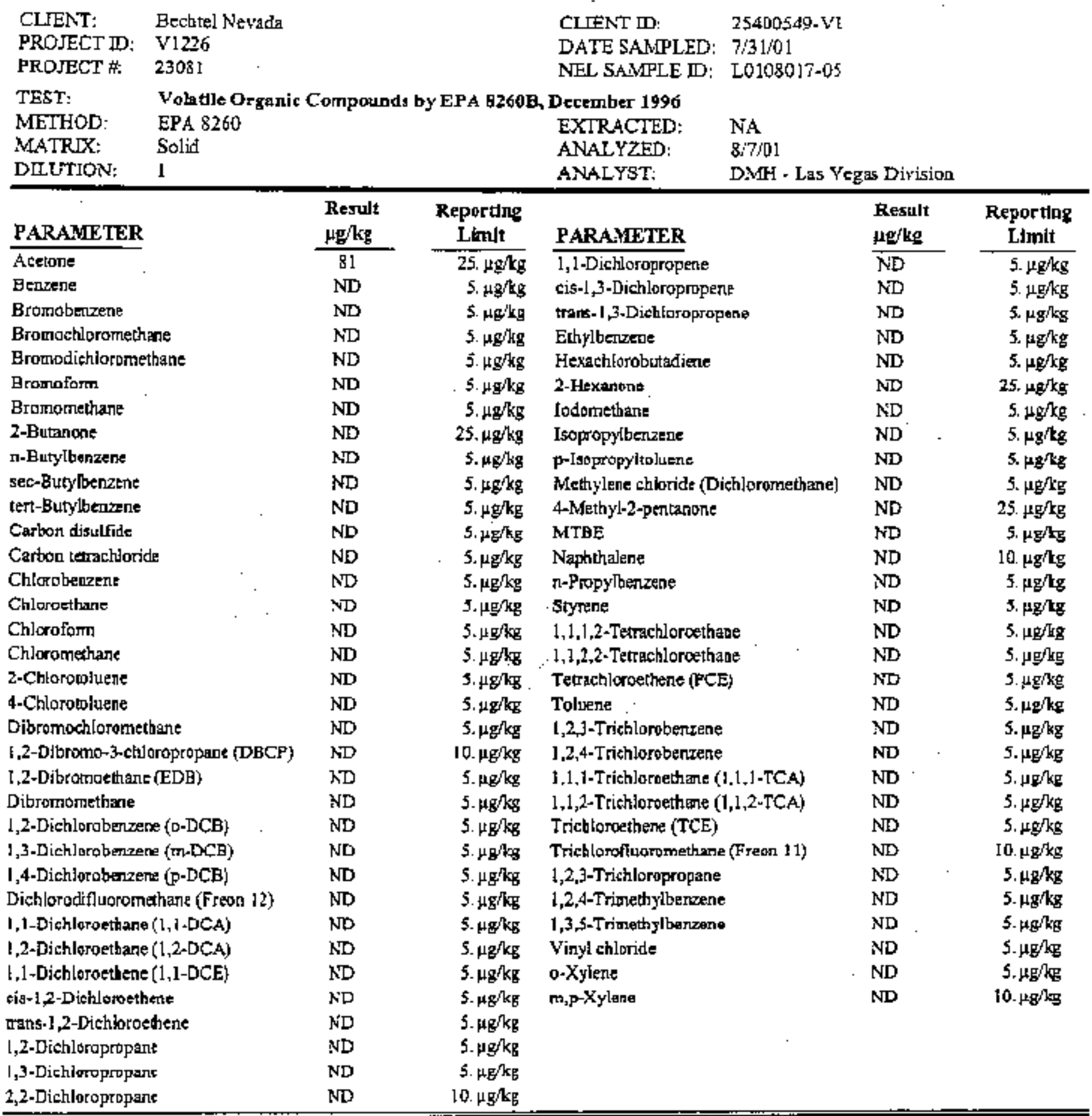

QUALITY CONTAOL DATA:

\section{Surrogate}

4-Bromofluorobenzene Dibromoftroormethane Toluene-18

$\frac{\text { \% Recovery }}{78}$

88
Acceptable Range

$74+121$

BO - 120

B1 - 117

ND - Nol Detected

This report shall nat be repnoduced except in full. without the written approval of the laboratory. 
CLIENT: Bechrel Neyada

PROJECT D: VI226

PROJECT: 23081
CLIENT ID: $\quad 25400542-V 1$

DATE SAMPLED: 7/31/01

NEL SAMPLE D: LO1OS017-06

TEST: Volatile Organic Compounds by EPA 8260B, December 1996

METHOD: ЕPA $82 E 0$ EXTRHCLED: FA

MATRIX: Solid

DRUTTON: 1

ANAIYZED:

$8 / 7 / 01$

ANALYST:

DMH - Las Vegas Divisjon

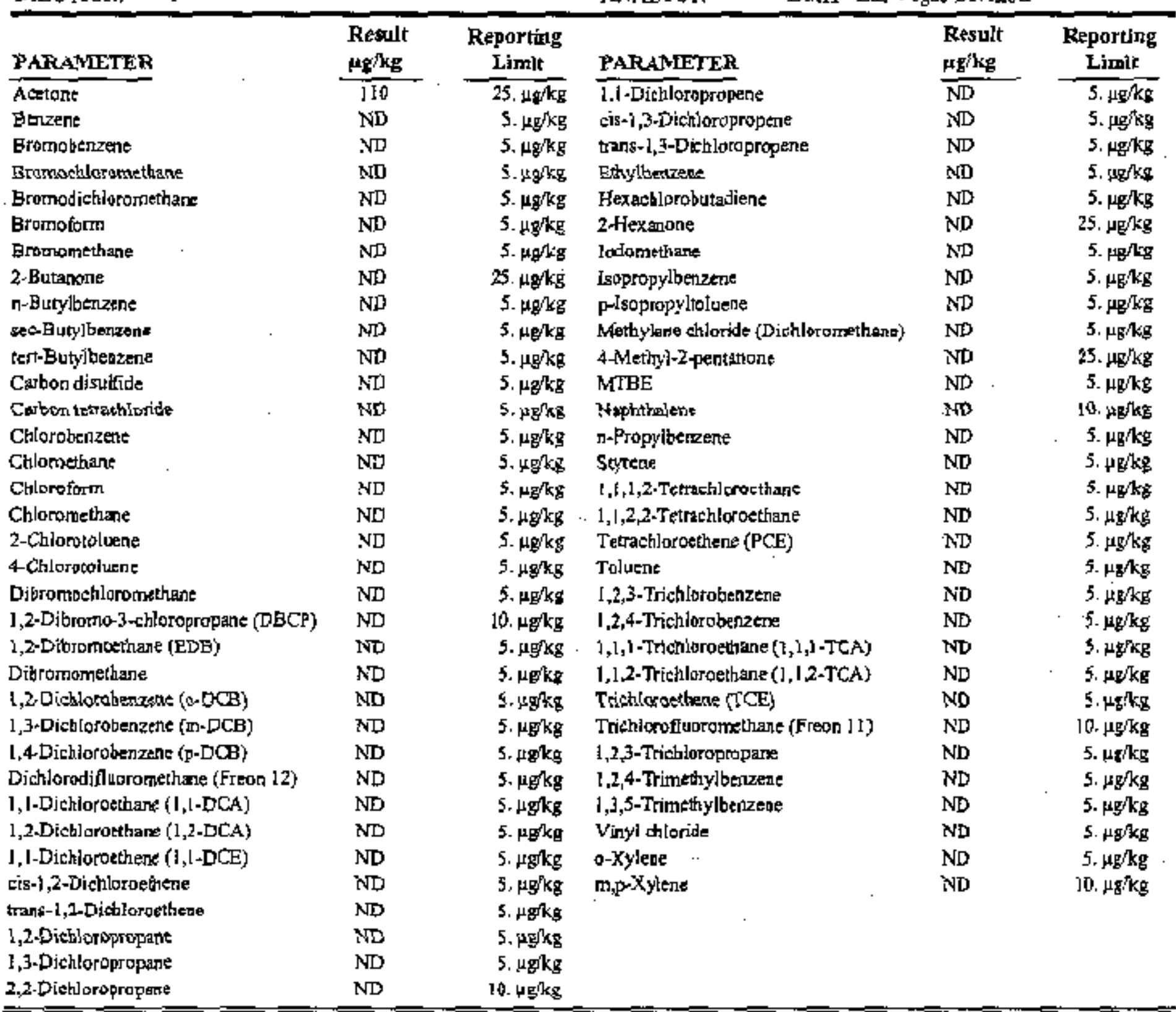

QUALITY CONTROL DATA:

\section{Sitrogate}

4-Bromofluprobejzene

Dibramofluromethane

Tọluent-d8

\section{$\%$ Recopery}

84

I

91
Sf

Acceptable Ranate

74 - 121

$80-120$

$B 1=1.17$

ND - Not Detected

This report shall not be reproktuced except in ytul, whout the writen approwal of the laboratory. 

CLIENT: BechteI Nevada
PROJECT ID: V1226
CLIENT ID: $\quad 254005] 6-\mathrm{V}]$
PROJECT : 23081
DATE SAMPLED: $7 / 31,01$
NEL SAMPLE ID: L0108017 $\div 07$

TEST: Valatile Organir Compounds by EPA 8260B, December 1996

METHOD: EPA 8260 EXTRACTED: NA

MATRIX: Solid

ANALYZED: $\quad 8 / 701$

DILUTION: $\quad 1$

ANALYST:

DMH - Lag Vegas Divigion

\begin{tabular}{|c|c|c|c|}
\hline PARAMETER & $\begin{array}{l}\text { Resudt } \\
\text { rg/kg }\end{array}$ & $\begin{array}{c}\text { Reperting } \\
\text { Limit }\end{array}$ & PARAMETER \\
\hline Actane & 110 & $\overrightarrow{25 . \mu g / \mathrm{kg}}$ & $\overline{1,1 \text {-Dichloropropere }}$ \\
\hline Benzene & ND & $5 . \mu g / k g$ & cis-1,3-Dishloroptopene \\
\hline Bromobenzens & $\mathrm{ND}$ & 5. $\mu \mathrm{g} / \mathrm{tg}$ & trass-1,3-Diebloroproperte \\
\hline Bromochloromethane & ND & 5. $\mu \mathrm{g} / \mathrm{kg}$ & Ethylbeszene \\
\hline Bromodichlomernethane & ND & $5 . \mu \mathrm{g} / \mathrm{kg}$ & Hexach]orobutadiene \\
\hline Brotinoform & ND & 5. $\mu \mathrm{g} / \mathrm{kg}$ & 2-Hexanone \\
\hline Bromornethane & ND & 5. $\mu \mathrm{g} / \mathrm{kg}$ & Jodomethene \\
\hline 2-Batanone & ND & $25 . \mu \mathrm{g} / \mathrm{kg}$ & Isopropylberuzene \\
\hline n-Butylbenzene & ND & 5. $\mu \mathrm{gg} / \mathrm{kg}$ & p-isopropyltoluetre \\
\hline sec-Butybenzene & $\mathrm{ND}$ & 5. $49 / \mathrm{kg}$ & Methylene chloride (Dichlonmethane) \\
\hline tert-Butylbenzent & ND & 5. $\mu \mathrm{g} / \mathrm{kg}$ & 4-Methyl-2-pentanone \\
\hline Cartion disulfife & ND & 5. $\mathrm{Pg} / \mathrm{kg}$ & MTBE \\
\hline Carbon tetrackloride & ND & 5. $\mu \mathrm{g} / \mathrm{kg}$ & Naphthalene \\
\hline Chloroberzene & ND & $5 . \mathrm{Hg} / \mathrm{kg}$ & n-Propyibenzene \\
\hline Chloroethane & ND & S. $\mu \mathrm{g} / \mathrm{kg}$ & Styrene \\
\hline Chloroform & ND & $5 . \mu \mathrm{g} / \mathrm{kg}$ & 1,1,1,2-Tetrachlorothant \\
\hline Chlóromethane & ND & $5 . \mu g / \mathrm{kg}$ & 1,1,2,2-Teradhlorocthane \\
\hline 2-ChlorotaLuene & ND & 5. $\mu \mathrm{g} / \mathrm{kg}$ & Tetrachlondethene (PCE) \\
\hline 4-Chlorotoluene & $\mathrm{ND}$ & 5. $\mu \mathrm{g} / \mathrm{kg}$ & Toloene \\
\hline Dibremochloromethant & ND & $5 . \mu \mathrm{H} / \mathrm{kg}$ & $1,2,3$-Trichiorobenzene \\
\hline 1,2-Dibromo-3-ch[oropropane (DBCP) & $\mathrm{ND}$ & 10. $\mu \mathrm{g} / \mathrm{kg}$ & $1,2,4$ Trich:lorobenzenę \\
\hline 1,2-Dibrocronethane (EDB) & ND & 5. $4 \mathrm{~g} / \mathrm{kg}$ & 1,1,1-Trichlowethane $(1,1,1-\mathrm{TC} \mathrm{A})$ \\
\hline Dibromtonethane & ND & 5. $\mu g / \mathrm{kg}$ & 1,1,2-Trichlonethane $(1,1,2-T C A)$ \\
\hline 1,2-Dichlarobenzene (0-DCB) & ND & $3 . \mu \mathrm{g} / \mathrm{kg}$ & Trichloroethene (TCE) \\
\hline 1.3-Dichlorobenzene $(\mathrm{m} \cdot \mathrm{DCB})$ & ND & $5 . \mu g / \mathrm{kg}$ & Trichlorofiuonomethane (Freon 11) \\
\hline 1,4-Dichlorobenzene (p-DCB) & ND & $5 . \mu g / \mathrm{kg}$ & 1,2,-Trichlompropane \\
\hline Dietlorodjfluoromethane (Freon I2) & ND & $5 . \mu \mathrm{g} / \mathrm{kg}$ & 1,2,4-Trimechylbetizent \\
\hline 1.1-Dichloroethane (1.1-DCA) & ND & 5. $\mu \mathrm{g} / \mathrm{kg}$ & 1,3,5-Trimethylberzene. \\
\hline 1,2-Dichlorosthane $(1,2-D C A)$ & ND & $5 . \mu \mathrm{g} / \mathrm{kg}$ & Vinyl chloride \\
\hline 1,1-Dichloroethene (1,1-DCE) & ND & $5 . \mu \mathrm{g} / \mathrm{kg}$ & o-Xylente. \\
\hline cis-1,2-Diehlototherie & $\mathrm{ND}$ & 5. $\mu \mathrm{g} / \mathrm{kg}$ & m,p-Xylene \\
\hline trars-1,2-Dichlorothenc & $\mathrm{ND}$ & $5 . \mu \mathrm{g} / \mathrm{kg}$ & \\
\hline 1,2-Dichloropropare & ND & $5 . \mu \mathrm{g} / \mathrm{kg}$ & \\
\hline 1,3-Díchioropropare & MD & 5. $\mu g / k g$ & \\
\hline 2,2-Dichloropsopars & $\mathrm{ND}$ & $\mathrm{I} 0 . \mathrm{Hg} / \mathrm{kg}$ & \\
\hline
\end{tabular}

\begin{tabular}{|c|c|}
\hline $\begin{array}{l}\text { Result } \\
\text { Hg/kg }\end{array}$ & $\begin{array}{c}\text { Reporting } \\
\text { Limit }\end{array}$ \\
\hline $\mathrm{ND}$ & $3 . \mu \mathrm{g} / \mathrm{kg}$ \\
\hline $\mathrm{ND}$ & 5. $\mu \mathrm{g} / \mathrm{kg}$ \\
\hline $\mathrm{ND}$ & S. $40 \mathrm{k}$ \\
\hline ND & 5. $\mu g \mathrm{~kg}$ \\
\hline ND & 5. $\mu \mathrm{g} / \mathrm{kg}$ \\
\hline ND & 25. $\mu \mathrm{g} / \mathrm{kg}$ \\
\hline $\mathrm{ND}$ & 9. $\mu \mathrm{gg} / \mathrm{kg}$ \\
\hline ND & 5. $\mu g k g$ \\
\hline $\mathrm{ND}$ & 5. $\mu$ g $/ \mathrm{kg}$ \\
\hline ND & 5. $\mu g / k g$ \\
\hline $\mathrm{ND}$ & 25. $\mu \mathrm{g} / \mathrm{kg}$ \\
\hline $\mathrm{ND}$ & 5. $\mu \mathrm{g} / \mathrm{kg}$ \\
\hline $\mathrm{ND}$ & 10. $\mu \mathrm{g} / \mathrm{kg}$ \\
\hline ND & 5. $\mu \mathrm{g} / \mathrm{kg}$ \\
\hline ND & .5. $\mu g / \mathrm{kg}$ \\
\hline ND & 5. $\mu \mathrm{g} / \mathrm{kg}$ \\
\hline ND & 5. $\mu g \mathrm{~kg}$ \\
\hline ND & 5. $\mu g / \mathrm{kg}$ \\
\hline $\mathrm{ND}$ & 5. $\mu g / \mathrm{kg}$ \\
\hline ND & 5. $\mu \mathrm{g} / \mathrm{kg}$ \\
\hline ND & 3. $1 \mathrm{~g} / \mathrm{kg}$ \\
\hline ND & 5. $\mu \mathrm{g} / \mathrm{kg}$ \\
\hline ND & 5. $\mu \mathrm{g} / \mathrm{kg}$ \\
\hline ND & 5. $\mu g / \mathrm{kg}$ \\
\hline ND & $10.4 \mathrm{~L} / \mathrm{kg}$ \\
\hline $\mathrm{ND}$ & 5. $\mu \mathrm{g} / \mathrm{kg}$ \\
\hline ND & s. $\mu \mathrm{g} / \mathrm{kg}$ \\
\hline ND & 5. $\mu \mathrm{g} / \mathrm{kg}$ \\
\hline ND & 5. $\mu \mathrm{g} / \mathrm{ks}$ \\
\hline ND & 5. $1 \mathrm{Hg} / \mathrm{tg}$ \\
\hline ND & 10. $\mu \mathrm{g} g / \mathrm{kg}$ \\
\hline
\end{tabular}

QUALIT CONTROL DATA:

\section{SurTogate}

4-Bromcfluorobenzene

Dibromafluoromethane

Toluene-dB
\% Retavery

93

3 Sf

98
Acceptabie Range

$74 \cdot 121$

$80-120$

$81-117$

ND - Not Derecred

This report shall tot be reproduced except in full, without the written approval of the laboratory.

$$
\text { C. } 2.4
$$




\begin{tabular}{|c|c|c|c|c|c|c|c|}
\hline $\begin{array}{l}\text { CLIENT: } \\
\text { PROJECT ID: } \\
\text { PRONCT \#: }\end{array}$ & $\begin{array}{l}\text { Bechtel Nerada } \\
\text { V1226 } \\
23081\end{array}$ & & & $\begin{array}{l}\text { CLSEFTT } \\
\text { DATE SAMPLED: } \\
\text { NEL SAMPLE ID: }\end{array}$ & $\begin{array}{l}25400563 \times 1 \\
7 / 31 / 01 \\
20108017-08\end{array}$ & & \\
\hline IEST: & \multicolumn{7}{|c|}{ Volatile Organic Compounds by EPA 8260B, December 1996} \\
\hline METHOD: & EPA 8260 & & & EXTRACTED: & & & \\
\hline MATRTX: & Solid & & & AN,ALYZED: & $8 / 7 / 0 \mathrm{I}$ & & \\
\hline DRUTTON: & 1 & & & ANALYST: & DMH - Las Ve & as Division & \\
\hline \multicolumn{2}{|l|}{ PARAMETER } & $\begin{array}{l}\text { Result } \\
\mu g / k g\end{array}$ & $\begin{array}{c}\text { Reporting } \\
\text { Limit }\end{array}$ & \multicolumn{2}{|l|}{ PARAMETER } & $\begin{array}{l}\text { Reswl } \\
\mu \mathrm{g} / \mathrm{kg}\end{array}$ & $\begin{array}{l}\text { Reporting } \\
\text { Limit }\end{array}$ \\
\hline \multicolumn{2}{|l|}{$\overrightarrow{\text { Acetore }}$} & $\sqrt[120]{30}$ & $25 . \mu \mathrm{g} / \mathrm{kg}$ & \multicolumn{2}{|l|}{ 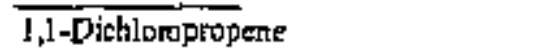 } & $\sqrt{\mathrm{ND}}$ & 5. $\mu \mathrm{g} / \mathrm{kg}$ \\
\hline \multicolumn{2}{|l|}{ Bonzene } & ND & 5. $\mu g / \mathrm{kg}$ & \multicolumn{2}{|l|}{ cis-1,3-Dichloropropente } & ND & 5. $\mu_{\mathrm{E}} \mathrm{kg}$ \\
\hline \multicolumn{2}{|c|}{ Bromobenzene } & ND & 5. $9 \mathrm{gg} \mathrm{kg}$ & \multicolumn{2}{|c|}{ canss-l,J-Dichloropropene } & TD & 5. $\mu g / k g$ \\
\hline \multicolumn{2}{|c|}{ Bromochloromethane } & $\mathrm{ND}$ & 5. $48 / \mathrm{kg}$ & \multicolumn{2}{|l|}{ Ethylbenzene } & ND & 5. $\mu g / \mathrm{kg}$ \\
\hline \multicolumn{2}{|c|}{ Bromadichloromethane } & ND & 5. $4 \mathrm{~g} / \mathrm{ks}$ & \multicolumn{2}{|l|}{ Hexachlotothutadiene } & ND & 5. $1 / \mathrm{kg}$ \\
\hline \multicolumn{2}{|l|}{ Eromolorm } & ND & 5. $\mu g / \mathrm{kg}$ & \multicolumn{2}{|l|}{ Z-Hexanone } & ND & $25 . \mu \mathrm{g} / \mathrm{kg}$ \\
\hline \multicolumn{2}{|l|}{ Bforromethane } & ND & 5. $\mu \mathrm{F} / \mathrm{kg}$ & \multicolumn{2}{|l|}{ Iodomethane } & $\mathrm{MD}$ & 5. $\mu / \mathrm{g} / \mathrm{kg}$ \\
\hline \multirow{2}{*}{\multicolumn{2}{|c|}{$\begin{array}{l}\text { 2-Butarone } \\
\text { ti-Butybenzenc }\end{array}$}} & ND & $25 . \mu \$ / k g$ & \multicolumn{2}{|l|}{ Isopropy]benzens } & $\mathrm{ND}$ & $5 . \mu \mathrm{g} / \mathrm{kg}$ \\
\hline & & ND & $5 . \mu g / \mathrm{kg}$ & \multicolumn{2}{|l|}{ p-Isopropy]tolutic } & $\mathrm{ND}$ & 5. $\mu g / \mathrm{kg}$ \\
\hline \multicolumn{2}{|l|}{ stc-Eumyibenzene } & ND & 5. $\mu g k_{\mathrm{Kg}}$ & \multicolumn{2}{|c|}{ Methylene chloride (Dichiorontethane) } & ND & 5. $\mu g / k 8$ \\
\hline \multirow{2}{*}{\multicolumn{2}{|c|}{$\begin{array}{l}\text { tert-Butylbeazene } \\
\text { Csathothdisuriftede }\end{array}$}} & ND & 5. $\mu \mathrm{g} / \mathrm{kg}$ & \multicolumn{2}{|c|}{ 4-Methyi-2-pentenone } & $\mathrm{ND}$ & 25. $\mathrm{\mu g} / \mathrm{kg}$ \\
\hline & & ND & 5. $4 \mathrm{~g} k \mathrm{~kg}$ & MLBE & · & ND & 5. $\mu g k g$ \\
\hline \multicolumn{2}{|c|}{ Caban tetrarbloxide. } & ND & 5. $\mu, 1 / \mathrm{kg}$ & Naphthalene & . & 29 & 10. $\mu g / \mathrm{kg}$ \\
\hline Chlorobedzene & & ND & 5. $\mu g / \mathrm{kg}$. & n-Propylbenzente & & ND & 5. $\mu g / \mathrm{kg}$ \\
\hline Chiloroethane & & ND & 5. $15 \mathrm{f} / \mathrm{kg}$ & Stytent & & $\mathrm{ND}$ & 5. $\mu g / \mathrm{kg}$ \\
\hline Chtorofonn & & ND & $5 . \mu \mathrm{g} / \mathrm{kg}$ & $1,1,1, \#$ Tetrachlorootba & & $\mathrm{ND}$ & 5. $\mu \mathrm{g} / \mathrm{kg}$ \\
\hline Chotomethane & & ND & 5. $\mu \mathrm{m} / \mathrm{kg}$ & I, $1,2,2$ Tetrachlotocth & & $\mathrm{ND}$ & 5. $\mathrm{XE} / \mathrm{kB}$ \\
\hline 2-Chlorotoluene & & $\mathrm{ND}$ & 5. $\mu g / \mathrm{kg}$ & Tetracblorothene (PCE & & $\mathrm{ND}$ & 5. $140 / \mathrm{kg}$ \\
\hline 4 Chlorotol hente & & ND & 5. $4 \mathrm{~g} / \mathrm{kg}$ & Toluete & & ND & 5. $\mathrm{Ng} / \mathrm{kg}$ \\
\hline Dibromochlorome & thane & ND & $5 . \mu q / \mathrm{kg}$ & 1,2,3-Trichlorobtnzene & & ND & 5. $4 \mathrm{~g} / \mathrm{kg}$ \\
\hline 1,2-Dibromo-3-cht & Ioropropane (DBCP) & ND & 10. $\mu \mathrm{g} / \mathrm{kg}$ & 1,2,4-Trichlorobenzene & & ND & 5. $\mu g / \mathrm{kg}$ \\
\hline 1,2-Dibrom10ethan & (EDB & $\mathrm{ND}$ & 5. $\mu \mathrm{g} / \mathrm{kg}$ & $1,1,1$-Trithbjoethane & $(1,1,1-T(A)$ & $\therefore \mathrm{ND}$ & $5: 40 / k g$ \\
\hline Dibrontomethate & & $\mathrm{ND}$ & 5. $\mu \mathrm{g} / \mathrm{kg}$ & $1,1,2-\tau$ tichloroethane & {$[1,1,2-T C A)$} & $\mathrm{ND}$ & 5. $\mu \mathrm{g} / \mathrm{kg}$ \\
\hline 1,2-Dichiorobenze & efte $(0-D C B)$ & ND & 5. $\mu \mathrm{g} / \mathrm{kg}$ & Tritholoroe'sese (TCE) & & $\mathrm{ND}$ & 5. $\mu y / \mathrm{kg}$ \\
\hline I,3-Dichlarobenzs & me $(\mathrm{m}-\mathrm{DCB})$ & ND & 3. $\mu g / \mathrm{kg}$ & Trichloroflugromethane & e (Freon 11$)$ & $\mathrm{ND}$ & $10 . \mu \mathrm{g} / \mathrm{kg}$ \\
\hline 1,4-Dichlorobenżt & ane $(\mathrm{p}-\mathrm{DCB})$ & $\mathrm{ND}$ & 5. $4 \mathrm{~g} / \mathrm{kg}$ & 1,2,3-Trichloropropare & & $N D$ & 5. $14 \mathrm{~g} / \mathrm{kg}$ \\
\hline Dichlorodifl noror & gethate (Freor !2) & ND & 5. $\mu g / \mathrm{kg}$ & 1,2,4-Trimethyfbenzene & & ND & S. $\mu \mathrm{g} / \mathrm{kg}$ \\
\hline 1, I-Dictroroethan & $e(1, i-D C A)$ & ND & 5. $\mathrm{Hg} / \mathrm{kg}$ & . 1,3,5-TAmethylbenzene & & $\mathbb{N D}$ & 5. $\mu \mathrm{H} / \mathrm{kg}$ \\
\hline I,2-Dichloroethen & $(12-D C A)$ & $\mathrm{ND}$ & 5. $\mu 2 / \mathrm{kg}$ & Vinyl chloride & & ND & 5. $\mu \mathrm{a} / \mathrm{kg}$ \\
\hline 1,1-Dichloroethen & $(1, i-D C E)$ & ND & $5 . \mu \mathrm{g} / \mathrm{kg}$ & o-Xylene & & No & S. $\mu g^{\prime} / \mathrm{kg}$ \\
\hline cis-1,2-Dichloroe & hent & $\mathrm{MD}$ & 5. $\mu g \mathrm{~g} \mathrm{~kg}$ & mip-Xylene & & ND & 10. $22 \mathrm{~g} / \mathrm{kg}$ \\
\hline trans-1,2-Dichloro & ethene & ND & ร. $\mu \mathrm{q} / \mathrm{kg}$ & & & & \\
\hline I,2-Dichloropropa & & ND & 5. $\mu g / k g$ & & & & \\
\hline 1,3-Dichloropropz & & $\mathrm{NDF}$ & 5. $\mu \mathrm{g} / \mathrm{kg}$ & & . & & \\
\hline 2,2-Dichlortpropa & & ND & 10. $\mu \mathrm{g} \mathrm{kg}$ & & & & \\
\hline
\end{tabular}

OUAITYCONTROL DITA:

Surrogate

4-Bromofluorabenzene

Dibrombfluoromerbane

Toluene-d8

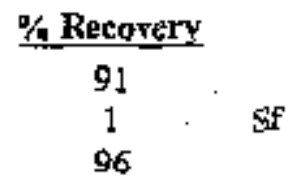

Atcentable Range

$74-121$

$80 \cdot 120$

$81-117$

ND - Not Detecled

This report shall not be reproduced except in full, without the written approval of the laboratory. 


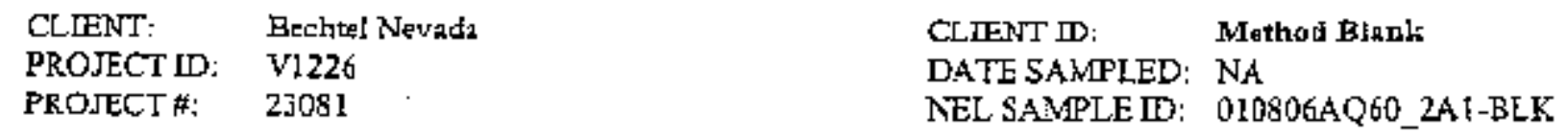

TEST: Volatike Organic Cotapounds by EPA 8260B, December 1996

METHOD: EPA 8260

MATRD: Aqueons

ANALYST: DMH - Las Vegas Division

EXTRACIED: NA

ANALYZED: $\quad 8 / 6 / 01$

\section{PaRameter}

\section{Actone}

Benzert

Bramobenzene

Bromachloramethene

Bromodichloromethane

Bromoform

Bromomethane

2-Batanome

r-Butylbenzede

sec-Butylbenzene

tert-Butylbenzene

Carbon disulfade

Carbon trachiouride

Chloroburizent

Chtoroethane

Chloroform

Chloromethare

2-Chlorololuene

4-Chtorololuene

Dibromochlortinethane

1,2-Dibromo-3-chloroproparx (DBCP)

1,2-Dibromoethane (EDB)

Dibrotmamethatre

1,2-Dichlorobenzeue (o-DCE)

1,3-Dichlorobenzete (m-DCB)

1,4-Dichlordbenzede (p-DCE)

Dichlorodifluoromethane (Frton 12)

1,1-Dichiordethane ( $1,1-D C A)$

1,2-Dichlarosthone (1,2-DC.A)

1,1-Didtloroethene (1,1-DCE)

cis-1,2-Dichlorpethene

trang-1,2-Dichloroethene

I,2-Dichloropropare

\section{Resulx}

$\frac{\mu \mathrm{g} / \mathrm{L}}{\mathrm{ND}}$

$\mathrm{ND}$

ND

ND

ND

ND

ND

ND

ND

जD

ND

ND

ND

ND

ND

ND

ND

ND

ND

ND

ND

ND

ND

ND

ND

ND

ND

$\mathrm{ND}$

$N D$

ND

ND

ND

ND

Reporting

$25 \mathrm{\mu g} / \mathrm{L}$

s $\Perp g / L$

s $1 \mathrm{~g} / \mathrm{l}$

s $\mu \mathrm{g} / \mathrm{L}$

$5+8 / 2$

$5 \mu \delta /$

$5 \mu \mathrm{g}$

$25 \mu \mathrm{g} / \mathrm{L}$

$5 \mu \mathrm{g} / \mathrm{L}$

$3 \mu \mathrm{gL}$

$5 \mu \mathrm{gL}$

$5 \mu g^{\prime L}$

$s \mu g / L$

5 19 $/$ L

$5 \mu \mathrm{g} / \mathrm{L}$

$3 \mu \mathrm{H} /$

$5 \mu \mathrm{g} / \mathrm{L}$

$5 \mu \mathrm{g} / \mathrm{t}$

$5 \mathrm{Hg} / \mathrm{L}$

$5 \mu \mathrm{g} L$

10 म

$5 \mu \mathrm{g} / \mathrm{L}$

$5 \mu g /$

$5 \mu g / \mathrm{L}$

$5 \mu \mathrm{g} /$.

$5 \mu \mathrm{g} L$

$5 \mu \mathrm{g} L$

$\$ \mu \mathrm{g} / \mathrm{L}$.

$5 \mu \dot{\sigma}^{2}$

$5 \mu \mathrm{g} / \mathrm{L}$

$5 \mu g / \mathrm{L}$

$5 \mu \mathrm{g} / \mathrm{L}$

$5 \mu \mathrm{g} / \mathrm{L}$

\section{PARAMETER}

I,3.Dichloropropane

2,2-Dichloropropare

1, I-Dichlosopropent

sis-1,3-Dichloropropene

trars-1,3-Dichlorcpropene

Ethylbenzene

Hexuchiorobutadiere

2-Hexarione

Iodomethane

Isapropylbentere

p-Isopropyltoluens

Meffylene chloride (Dithlomenthatne)

4-Methyl-2-pentanore

MTBE

Naphthatene

n-Fropylbenzane

Styrene

1,1,1,2-Tetratilardethane

1, 1,2,2-Tetratiloroethatic

Tetrathloroethene (PCE)

Tolvene

1,2,3-Trichlarobeizene

1,2,4-Trichloroberzene

1,1,1-Trichlorothane (1,1,1-TCA)

1,1,2-Trichlorethane (1,1,2-TCA)

Tridilordethene (TCE)

Trictloroftuotomethane (Freor 11)

1,2,3-Trichloropropane

1,2,4-Trimethylberzane

1,3,5-Trimechylbenzene

Vinyl cbloride

o-Xylene

m.p.XYlene
Result

Reporting

rtg/L

ND

ND

$\mathrm{ND}$

ND

ND

ND

$\mathrm{ND}$

ND

ND

ND

ND

ND

ND

ND

ND

ND

$\mathrm{ND}$

ND

ND

ND

ND

ND

ND

ND

ND

ND

ND

ND

ND

ND

ND

ND

$\mathrm{ND}$
Limit

$5 \mu \mathrm{g} 2$

$10 \mu \mathrm{g} / \mathrm{L}$

5 틴ㄷ

5 rgi

$5 \mu \mathrm{gl}$

5 ugh

$5 \mu \mathrm{g} h$.

$25 \mu g h$

$5 \mu \mathrm{g} t$

5 애

5 山해

$5 \mu g / L$

$25 \mu \mathrm{g}$

5 pgt

I0 $\mu \mathrm{g} / \mathrm{k}$

$3 \mu \mathrm{g} / \mathrm{L}$

$5 \mu \mathrm{g} / \mathrm{L}$

$5 \mu \mathrm{g} / \mathrm{L}$.

$5 \mu \mathrm{g} /$.

$5 \mathrm{gg} /$

$s_{\mu \mathrm{g} / \mathrm{L}}$

s $\mu \mathrm{g} / \mathrm{L}$

$5 \mu \mathrm{g} / \mathrm{L}$

s $\mu \mathrm{g} / \mathrm{L}$

$5 \mu \mathrm{g} / \mathrm{L}$

$5 \mu \mathrm{g} /$

it $\mu \mathrm{g} / \mathrm{l}$,

$s \mu \mathrm{g} /$.

$5, \mu \mathrm{g} /$

5 pgit.

$5 \mu g / L$

$5 \mu g^{/ L}$

$10 \mathrm{Hg} / \mathrm{L}$

QUALITY CONTROL DATA:

\section{Surtorate}

4-Bromofluorobenzente

Dibromofiucromethane

Tolnene-d8

$\frac{\% \text { Recovery }}{98}$

Acteptabte Range

$76-111$
$8 B-114$
$95-108$

ND - Nox Detected

This report shall as be reproduced except in full, without the writen approval of the laboratory. 


$\begin{array}{llll}\text { CLIENT: } & \text { Becbtel Nevada } & \text { CLIENT D: } & \text { Method Blank } \\ \text { PROJECT ID: } & \text { V17\%6 } & \text { DATE SAMPLED: NA } \\ \text { PROIECT \#; } & 23081 & \text { NEL SAMPLE ID: 010807SD60_LA1-BLK }\end{array}$

TEST: Vola :Organic Compounds by EPA 82608, December I996

METHOD: EPA ...60 ANALYST: DiYH - La Vagas Division

MATRTX: SOLIA EXTRACTED: NA ANALYZED: $\quad 87 / 01$

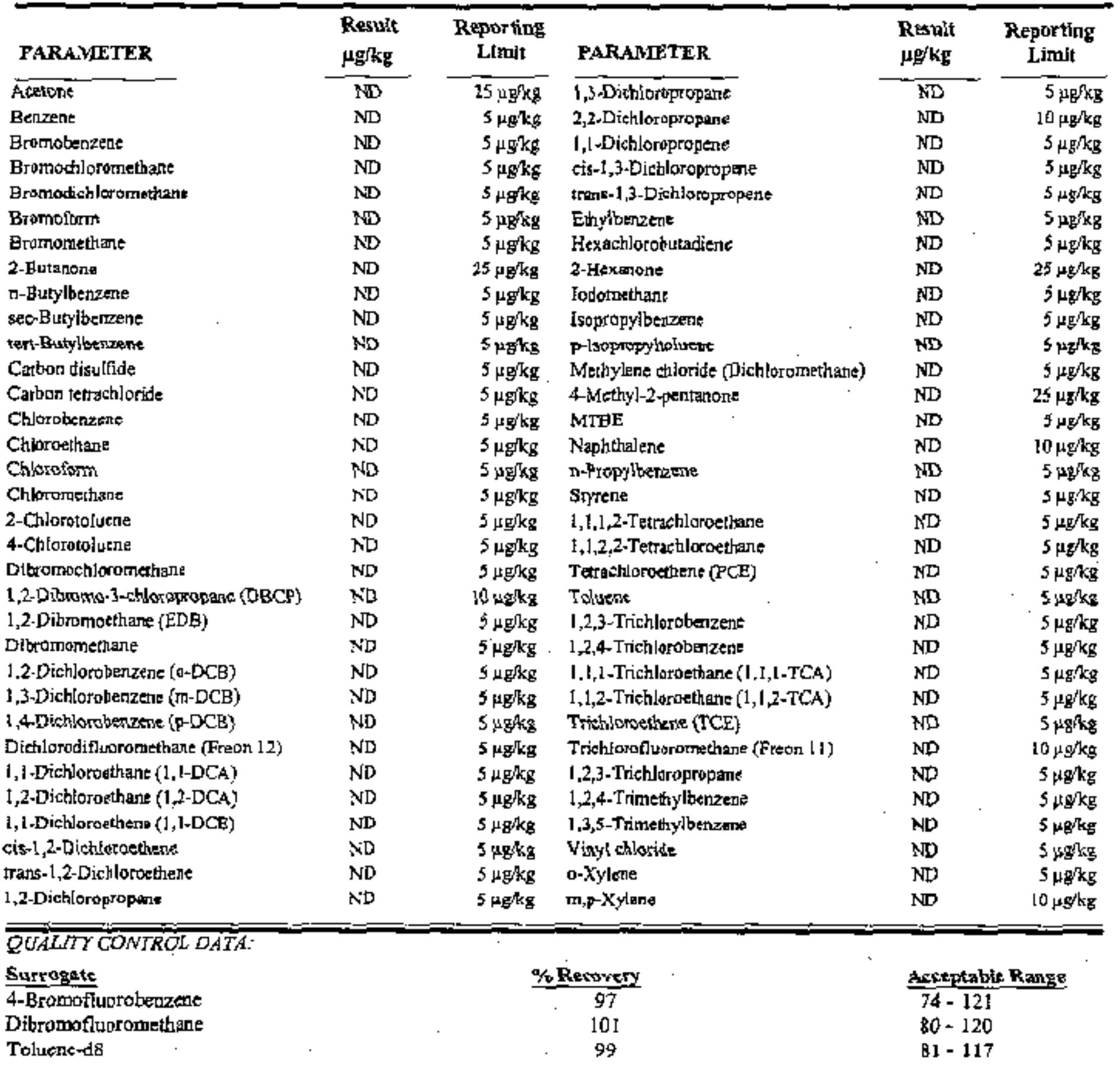

ND-Not Detected

This report shall not be reproduced extept in full, withoul the wrimen approval of the laboratory. 


$\begin{array}{lll}\text { CLIENT: } & \text { Bechtel Nevada } & \text { CLENT ID: } \quad \text { 25400545-V1 } \\ \text { PROJECT ID: } & \text { V1226 } & \text { DATE SAMPLED: } 7 / 31 / 01 \\ \text { PROJECT H: } & 23081 & \text { NEL SAMPLE D: } \text { L0108017-03 }\end{array}$

\begin{tabular}{llcl} 
TEST: & PCB's (Polychlorinated Biphenyls) by EPA 8082, Dec 1996 & \\
METHOD: & EPA 8082 & ANALYST: & JRW - Las Vegas Division \\
MATRL: & Solid & EXTRACTED: & $8 / 3 / 01$ \\
DILUTION: & 1 & ANALYZED: & $8 / 9 / 01$ \\
\hline
\end{tabular}

\begin{tabular}{|c|c|c|}
\hline PARANETER & Result & $\begin{array}{l}\text { Reporting } \\
\text { Limit }\end{array}$ \\
\hline Arocior-1016 & $\mathrm{ND}$ & 20. $1 \mathrm{~g} / \mathrm{kg}$ \\
\hline Aroclor- $\mid 221$ & ND & 20. $\mu \mathrm{g} / \mathrm{kg}$ \\
\hline Arodlor- 1232 & ND & 20. $\mu \mathrm{g} / \mathrm{kg}$ \\
\hline Aro:ler-1242 & ND & 20. $\mu \mathrm{g} \mathrm{kg}$ \\
\hline Aroklor-]248 & $\mathrm{ND}$ & 20. $\mu \mathrm{g} / \mathrm{kg}$ \\
\hline Aroclor-1254 & $\mathrm{ND}$ & 20. $\mu \mathrm{g} / \mathrm{kg}$ \\
\hline Aroclior-1260 & $N D$ & 20. $\mu \mathrm{\omega} / \mathrm{kg}$ \\
\hline
\end{tabular}

QUALITY CONTROL DATA:

Surrogate

Decachlorobipheny!

Tetrachloro-m-xylene
\% Recovery

78

76
Acceptable Range

$46-155$

$49 \cdot 140$

ND - Not Detected

This report shall tot be reproduced excapt is full, without the written approwal of the laboratory. 


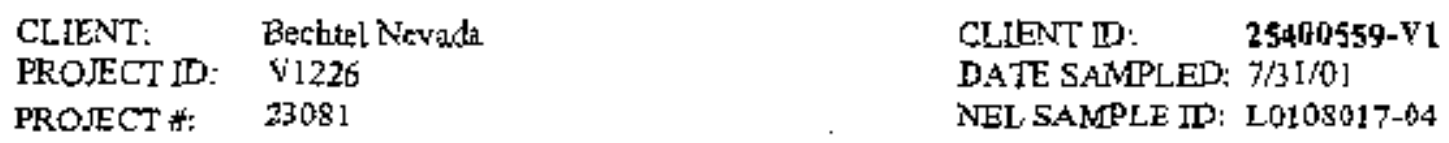

TEST: $\quad$ PCB's (Potychloringted BJpheryls) by EPA 8082, Dec. $1 \$ 96$

WETHOD: EPA 8082 ANALYST:

MATRD: Solid EXTRACTED:

DILUTTON:

ANALYZED

Rin - Las Vegas Division
$8 / 3 / 01$
$8 / 6 / 0 !$

Reporting

\section{PARAMETER}

Aroclor-10

Aracler-1221

Aroclor-1232

Asdeloc- 1242

Arocl $x-1248$

Aroclor-1254

Arociox-1260 1

\section{QUALTYCONTROL DATA:}

\section{Surrogatc}

Decachlorobipheayl

Tetrachloro-mb-xylene

\begin{tabular}{l} 
Rewalt \\
\hline ND \\
ND \\
ND \\
ND \\
ND \\
ND \\
ND \\
\hline
\end{tabular}

\% Recovery

101

91
Limit

20. $\mu \mathrm{g} / \mathrm{kg}$

20. $\mathrm{Ng} / \mathrm{kg}$

20. $\mu \mathrm{Hg} / \mathrm{kg}$

20. $\mu \mathrm{g} / \mathrm{kg}$

20. $\mu \mathrm{g} / \mathrm{kg}$

20. $\mu \mathrm{g} / \mathrm{kg}$

20. $4 \mathrm{~g} / \mathrm{kg}$

\section{Acceptable Ragge}

$45-155$

$49-140$

ND - Not Detected

This report shall not be reproduced ercept in full, without the written approval of the laboratory. 

CLIENT: BechteiNevada
PROJECT ID: VI226
CLIENT D: Melhod BJank
PROJECT 年: 23081
DATE SAMPLED: NA
NEL SAMPLE D： 010\$03PCBS.BLK

$\begin{array}{llll}\text { TEST: } & \text { PCB's (Polycblorinated Bipheayls) by EPA 8082, Dec. 1996 } & \\ \text { METHOD: } & \text { EPA 8082 } & \text { ANALYST: } & \text { JRW - Las Vegas Division } \\ \text { MATRDX: } & \text { Solid } & \text { EXTRACTED: } & 8 / 3 / 01 \\ & & \text { ANALYZED: } & 8 / 601\end{array}$

\begin{tabular}{|c|c|c|}
\hline PARANETER & Result & $\begin{array}{c}\text { Reporting } \\
\text { Lifult } \\
\end{array}$ \\
\hline Aroclor-1016 & $\overline{\mathrm{ND}}$ & $20 . \mu g / k g$ \\
\hline Aroclor-L221 & ND & $20 . \mu \mathrm{g} / \mathrm{kg}$ \\
\hline Asdior -1232 & ND & 20. $\mathrm{Hg} / \mathrm{kg}$ \\
\hline Aroclor- $\mid 242$ & ND & 20. $\mu \mathrm{g} k \mathrm{~kg}$ \\
\hline Aroclor- 1248 & ND & 20. $\mu \mathrm{gkg}$ \\
\hline Aroclor- 1254 & ND & 20. $\mu g / \mathrm{kg}$ \\
\hline Aroctor-1260 & $\mathrm{ND}$ & 20. $\mu \mathrm{g} / \mathrm{kg}$ \\
\hline
\end{tabular}

QUALITY CONTROL DATA:

Surrogate

Decachlotobiphenyl

\% Recovery

84

92

Acceptible Range

$46-155$

$49-140$

ND - Not Detected

This repert shall not be reproctaced except in full, without the written approval of the laboratory. 


\begin{tabular}{|c|c|c|c|c|c|c|c|c|}
\hline $\begin{array}{l}\text { CLIENT: } \\
\text { PROJECT DD: } \\
\text { PROJECT H: }\end{array}$ & $\begin{array}{l}\text { Bechtel Nevada } \\
\text { Vi226 } \\
23081\end{array}$ & & & & & & - & . \\
\hline $\begin{array}{l}\text { TEST: } \\
\text { METHOD: } \\
\text { ORDER D: }\end{array}$ & $\begin{array}{l}\text { Total Extractabie } \\
\text { EPA } 8015 \mathrm{M} \\
\text { L0108017 }\end{array}$ & Petroleum ay & trocafbons & $y$ EPA & Method $801 \mathrm{jM}$, & December & 1996 & \\
\hline MATRLX: & Solid & & & & AN & ALYYS: & PXC - Division & \\
\hline $\begin{array}{l}\text { CLIINT } \\
\text { SAMPLE ID }\end{array}$ & $\begin{array}{c}\text { SAMPLE } \\
\text { DATE }\end{array}$ & $\begin{array}{c}\text { NEL } \\
\text { SAMPLE ID }\end{array}$ & $\begin{array}{l}\text { RESUIT } \\
\text { mgikg }\end{array}$ & C.R. & $\begin{array}{l}\text { Reparting } \\
\text { Limit } \\
\end{array}$ & $\begin{array}{l}\text { Surrogate } \\
\text { Recovert } \\
\end{array}$ & EXTRACTED & ANALYZED \\
\hline $25400549-\mathrm{Vl}$ & $7 / 31 / 01$ & L0108017.05 & 840 & 0 & $20 . \mathrm{mg} / \mathrm{kg}$ & $78 \%$ & $8 / 9 / 01$ & $8 / 9 / 01$ \\
\hline 25400563-v1 & $7 / 31 / 01$ & $20108017-08$ & 54 & D & $20 . \mathrm{mg} / \mathrm{kg}$ & $56 \%$ & $\mathrm{~B} / \mathrm{O} / \mathrm{Ol}$ & $8 / 9 / 01$ \\
\hline
\end{tabular}

\section{G.R.: Eartion Rarge}

D Diesel Range Organics (C10 to C28).

$O$ Oil Range Organics (C1 8 to C34).

QUALITY CONTROL OATA (TOTAI for DIeEPl Range):

\section{Sampie ID}

Blenk, 010808TP -BLK

LCS, 010808TPHS-LCS

LCSD, 010808TPHS-LCSD

MS, 010808TPHS-MS

MSD, 010808\%HS-MSD

- Surrogate used was Ottacosane, acceptance linuits 55-130\%.
Result Acceptablc Range Surrogatc Recorery* Sample Number

\begin{tabular}{|c|c|c|c|c|c|c|}
\hline \multicolumn{2}{|c|}{ ND } & $<$ & $20 \mathrm{tag} / \mathrm{kg}$ & 90 & $\%$ & $N / \mathbf{A}$ \\
\hline 58 & $\%$ & 54 & $-91 \%$ & 82 & $\%$ & NA \\
\hline 6] & $\%$ & 54 & $-93 . \%$ & 82 & $\%$ & NiA \\
\hline 52 & $\%$ & 34 & $-110 \%$ & 74 & $\%$ & L010\$047-02 \\
\hline 58 & \% & 34 & $-110 \%$ & 89 & $\%$ & L0108047.02 \\
\hline
\end{tabular}


CLIENT: Bechkel Nevads

PROJECT T: VI226

PROJECT H: 23081

TEST: $\quad$ PCB's (Polychlorizated Biphenyls) by EPA 8082, Dec 1996 MATRDX: Solid

\section{PARAMETER}

Aroclor-1016

Aroclor-1016

Aroclor-1016

Aroclor-1016

Arocior- 1260

Aroclor-1260

Aroclor- 1260

Aroclor-1260

\begin{tabular}{|c|c|c|c|c|c|}
\hline NEL Sample DD & 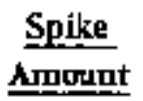 & $\frac{\text { Spike }}{\text { Resutitit }}$ & $\frac{\text { Percent }}{\text { Recovery }}$ & $\frac{\text { Acceptable }}{\text { Range }}$ & $\underline{R P D}$ \\
\hline 010803PCBS-LCS & 333 & 301 & 90 & $63-127$ & \\
\hline 010803PCBS-LCSD & 333 & 337 & 101 & $63-127$ & 11.3 \\
\hline L0108017-03-MS & 333 & 277 & 83 & $55-j 42$ & \\
\hline L0108017-03-MSD & 333. & 290 & 87 & $55-142$ & 4.6 \\
\hline 010803 PCBS-LCS & 333 & 277 & 83 & $57-138$ & \\
\hline $010803 \mathrm{PCES}-\mathrm{LCSD}$ & 333 & 313 & 94 & $57-138$ & 12.2 \\
\hline L0108017-03-MS & 333 & 222 & 67 & $48-129$ & \\
\hline LO108017-03-MSD & 333 & 238 & 71 & $48-129$ & 7. \\
\hline
\end{tabular}




\begin{tabular}{ll} 
CLIENT: & Bechtel Nevsda \\
PROSCT D: & V1226 \\
PROJECT \#: & 23081 \\
TEST: & Volatite Organic Compounds by EPA 8260B, December 1996 \\
MATRL: & Aqueors \\
\hline
\end{tabular}

\begin{tabular}{|c|c|c|c|c|c|c|}
\hline PARAMETER & NEL Sample II & $\begin{array}{c}\text { Spike } \\
\text { Amgunt }\end{array}$ & $\frac{\text { Spike }}{\text { Resudt }}$ & $\begin{array}{l}\text { Percent } \\
\text { Recovery }\end{array}$ & $\begin{array}{l}\text { Acseptable } \\
\text { Range }\end{array}$ & $\underline{\mathbf{R P}} \underline{\underline{D}}$ \\
\hline Actone & 010806 AQ60_2A1.LCS & 50 & 39.11 & 78 & $70-130$ & \\
\hline Acetone & L0108030-01 MS & 50 & 45.07 & 90 & $70-130$ & \\
\hline Asetone & L0102030-01-MSD & 50 & 47.69 & 95 & $70 \cdot 130$ & 5.6 \\
\hline Benzene & $\left.0] 0806 \mathrm{AQ} 60 \_2 \mathrm{~A}\right]-\mathrm{LCS}$ & 50 & 46.24 & 92 & $70-130$ & \\
\hline Beazene & L0108030-01-MS & 50 & 52.68 & 105 & $70-130$ & \\
\hline Benzege & L0108030-01-MSD & 50 & 50,82 & 102 & $70-130$ & 3.6 \\
\hline Bromobenzerte & 010806AQ60_2A1-LCS & 50 & $46.4 B$ & 93 & $70-130$ & \\
\hline Bromobenzene & Lo108030-01-MS & 50 & 51.39 & 103 & $70-130$ & \\
\hline Bromoberizene & L0108030-01-MSD & 50 & 50.83 & 102 & $70-130$ & 1.1 \\
\hline Bramochloromethane & 010806AQ60_2A1-LCS & 50 & 41.88 & 84 & $70-130$ & \\
\hline Brompchlotomethane & L0108030-01-MS & 50 & 43.62 & 87 & $70-130$ & \\
\hline Bromochloromethane & L0108030-01-MSD & 50 & $\$ 0.05$ & 100 & $70-130$ & 13.7 \\
\hline Bromodichloromethane & 010806AQ60_IA1-LCS & $5 \theta$ & 45.87 & 92 & $70-130$ & \\
\hline Bromodichlorongetharie & L0108030-01-MS & 50 & .50 .77 & 102 & $70-130$ & \\
\hline Eromodictubromethane & L0108030-01-MSD & 50 & 51.53 & 101 & $70-130$ & 1.5 \\
\hline Bromoform & 010806AQ60_1A1-LCS & 50 & 41.82 & 84 & $70-130$ & \\
\hline Bromoform & L0108030-01-kS & 50 & 49.84 & 100 & $70-130$ & \\
\hline Bremoform & L0108030-0I-MSD & 50 & 49.76 & 100 & $70=130$ & 0.2 \\
\hline Bromomethane & 010806AQ50_2A1-LCS & 50 & 50.54 & IOI & $70-130$ & \\
\hline Bromomethane & L0108030-01-MS & 50 & 54.86 & 120 & $70-130$ & \\
\hline Bromomethane & L01080 $0-01 \cdot M S D$ & 50 & $\$ 2.6$ & 105 & $70-130$ & 4.2 \\
\hline 2-Butanone & 010806AQ60_2A1-LCS & 50 & 44.1 & 88 & $70-130$ & \\
\hline 2-Butanone & L0108030-0I-MS & 50 & 54.95 & 110 & $70-130$ & \\
\hline 2-Butanone & $10108030-01-M 5 D$ & 50 & 53.11 & 106 & $70-130$ & 3.4 \\
\hline n-Butylbenzene & 010806AQ60_2Al-LCS & 30 & 43.9 & 88 & $70-130$ & \\
\hline n-Butyloenzene & L0108t30-D1-MS & 50 & 45.99 & 92 & $70-130$ & \\
\hline n-Butybenzene & Lo108030-D1-.MSD & 50 & .45 .17 & 90 & $70 \cdot 130$ & 1.8 \\
\hline sec-Batylbefzene & 010806AQ60_2AJ-LCS & 50 & 46.09 & 92 & $70-130$ & \\
\hline sec-Butylbenzene & LOI08030-01-MS & 50 & 49.73 & 99 & $70-130$ & \\
\hline sec-Butylbelaexe & L0108030-O1-MSD & 50 & 48.37 & 97 & $70-130$ & 2.8 \\
\hline tent-Elutylbenzene & 010806AQ60_2A1-LCS & 50 & 45.99 & 92 & $70-130$ & \\
\hline teri-Dustylbersene & Lo108030-31-10s & 50 & 50.35 & 101 & $70-130$ & \\
\hline tent-Butylbeazene & $10108030-01-M S D$ & 50 & 48.69 & 97 & $70-130$ & 3.4 \\
\hline Carbon disulfide & 010\$06AQ60_2ALLCSS & 50 & 44.64 & 89 & $70-130$ & \\
\hline Carbon disulfide & L0108030-01-MS & 50 & 50.9 & 102 & $70-130$ & \\
\hline Cartonn disulfide & L0108030-01-MSD & 50 & 47.18 & 94 & $70-130$ & 7.5 \\
\hline Carbor tetrachtoride & $010806 \mathrm{AQ50} 2 \mathrm{~A} 1-\mathrm{LCS}$ & 50 & 39.86 & 80 & $70-130$ & $\cdot$ \\
\hline Catbon tetrachloride & L0108030-01-MS & 50 . & 46.45 & 93 & $70 \cdot 130$ & \\
\hline
\end{tabular}

ND - Not Detected

This report shall not be reproduced except in full, without the writert approval of the laboratory. 
CLIENT: Bechte1 Nevada

PROIECT ID: V1226

PROJECT H: 23081

TEST: $\quad$ Volatile Organic Compøunds by EPA 8260B, December 1996

MATRIX: Aqueous

\section{PARAYIETER}

Cartorn tetrachloride

Chlorobenzmite

Chlorobenzene

Chloraberizene

Chloroethant

Chtoroethane

Chlorgethane

Chloraterm

Chloroform

Chloroform

Chloromethane

Chloromethane

Chloromethane

2-Chlorotoluene

2-Chlorotolutene

2-Chlorotoluene

4-Chlorotoluene

4-Chlorotoluene

4-Chlorotoluene

Dibromochloremethane

Dibromochloromethane

Dibromachloromethate

1,2-Dibromo-3-chloropropane (DBCP) 010806AQ60_2A1-LCS

1,2-Dibromo-3-chioropropane (DBCP) Lo108030-01-MS

1.2-Dibromo-3-chloropropane (DBCP) L0108030-01-MSD

1,2-Dibromothane (EDB)

1,2-Dibromoethane (EDB)

1,2-Dibromoethane (EDB)

Dibromomethane

Dibromomethone

Dibromonethane

1,2-Dichlorobenzene (o-DCB)

1,2-Dichlorobenzene (O-DCB)

1,2-Dichlorobenzene ( 0 -DCB)

1,3-Dichlorobenzene (m-DCB)

1,3-Dichlorobenzene (m-DCB)

1,3-DichIorobenzene (m-DCB)

1,4-Dicblorobenzene (p-DCB)
NEL Sample ID

L0108030-01-MSD

010806AQ60_2A1-LCS

L0108030-01-MS

LO108030-01-MSD

010806AQ60_2A1-LCS

L0108030-01-MS

L0108030-01-MSD

010806AQ60_2A1-LCS

L0108030-01-MS

L0108030-01-MSD

010806AQ60_2A1-LCS

L0108030-01-MS

L0108030-01-MSD

010806AQ60_2A1-LCS

L0108030-01-MS

L0108030-01-MSD

010806AQ60_2A1-LCS

LO10B030-01-MS

L0108030-01-MSD

010806 AQ60_2A1-LCS

L0108030-0l-MS

L0108030-0i-MSD

010806AQ60_2A1-LCS

L0108030-01-MS

L0108030-01-MSD

010806AQ00_2A1-LCS

L0108030-01-MS

L0108030-01-MSD

010806AQ60_2A1-LCS

Lo108030-0]-MS

L0108030-01-MSD

010806AQ60_2A1-LCS

L0108030-01-MS

L0108030-01-MSD

010806AQ60_2A1-LCS

\begin{tabular}{ccccc}
$\frac{\text { Spike }}{\text { Ampunt }}$ & $\frac{\text { Spike }}{\text { Result }}$ & $\frac{\text { Percent }}{\text { Recovery }}$ & $\frac{\text { Acceptnble }}{\text { kange }}$ & RPD \\
\cline { 1 - 2 } & $\frac{44.06}{50}$ & $\frac{88}{70-130}$ & 5.3 \\
50 & 46.13 & 92 & $70-130$ & \\
50 & 50.94 & 102 & $70-130$ & \\
50 & 51.16 & 102 & $70-130$ & 0.4 \\
50 & 45.1 & 90 & $70-130$ & \\
50 & 49.19 & 98 & $70-130$ & \\
50 & 47.72 & 95 & $70-130$ & 3.
\end{tabular}

50

50

47,1

49.98

94

$70-130$

$70 \cdot 130$

$70-130$

12.6

$70-130$

$70-130$

$70-130$

3.9

$70 \cdot 130$

$70-130$

$70-130$

0.1

$70-130$

$70-130$

$70-130$

0.8

$70+130$

$70-130$

$70 \cdot 130$

$70-130$

$70-130$

$70-130$

14.4

$70-130$

$70-130$

$70-130$

$70-130$

$70-130$

$70-130$

0.2

$70+130$

$70-130$

$70-130$

0.2

$70-130$

$70-130$

$70-130$

0.1

\section{3}

4

3.

9

93

$70-130$ 
CLENT: Bechte] Nevada

PROECT D: V1226

PROJECT\#: 21081

TEST: $\quad$ Volatjle Organic Compounds by EPA 8260B, December 1996

MATRIX: Aqueous

\begin{tabular}{|c|c|c|c|c|c|c|c|}
\hline PARAVETER & NEL Sample W & $\underset{\text { Ampolke }}{\text { Smont }}$ & Spike & $\begin{array}{l}\text { Percent } \\
\text { Recover }\end{array}$ & & $\frac{\text { Acceptable }}{\text { Range }}$ & $\underline{\mathrm{RPD}}$ \\
\hline 1,4-Dichlorobenzene (p-DCB) & L0108030-01-MS & 50 & 50.45 & 101 & & $70-130$ & \\
\hline 1,4-Dieflatobenzene $(\mathrm{p}-\mathrm{DCB})$ & LOLOR030-0I-MSD & 50 & 53 & 102 & & $70-130$ & 1.1 \\
\hline Dichlorodifluorouethane (Freon 12) & $010806 \mathrm{AQ60 \_ 2A1-LCS}$ & 50 & 47.9 & 96 & & $70-130$ & \\
\hline Dichloradifluorotaethane (Fiton 12) & LO106030-01-MS & 50 & 49.28 & 99 & & $70-130$ & \\
\hline Dichiorodifluoromethane (Freon 12) & LO108030-0I-MSD & 50 & 47.41 & 95 & & $70-130$ & 3.9 \\
\hline 1,1-Dichroroetrane $\{1,1-D C A\}$ & 010806AQ60_2A1-LCS & so & 42.94 & 86 & & $70 \cdot 130$ & \\
\hline 1,1-Dichloroettane $(1,1-D C A)$ & L0108030-01-MS & 50 & 39.75 & 80 & & $70 \cdot 130$ & \\
\hline 1,1-Dichloroedane $(1,1-D C A)$ & L0108030-61-MSD & 50 & 38.75 & 78 & & $70-130$ & 2.5 \\
\hline 1,2-Dichlorothane $(1,2-\mathrm{DCA})$ & 010806AQ60_2A1-LCS & 50 & 45 & 90 & & $70-130$ & \\
\hline 1,2-Ditblomethane (1,2-DCA) & L0108030.01-MS & 50 & 49.81 & 100 & & $70 \cdot 130$ & \\
\hline 1,2-Dichloroethane $(1,2-D C A)$ & L010\$030-01-MSD & 50 & 49.66 & 99 & & $70-130$ & 0.3 \\
\hline 1, I-Dichlongethene (1,1-DCE) & 010806AQ60_2A1-LCS & 50 & 47.59 & 95 & & $70 \cdot 130$ & \\
\hline 1,1-Dichloroethene (1,1-DCE) & L0t08030-0]-MS & 50 & 55.81 & 112 & & $70 \cdot 130$ & \\
\hline 1,1-Dichlorocthene (1,1-DCE) & L0108030-01-MSD & 50 & 51.73 & 103 & & $70-130$ & 7.6 \\
\hline cis-1,2-Dichlorotherse & 010806AQ60_2A.1-LCS & 50 & 41.93 & 84 & & $70 \cdot 130$ & \\
\hline cis-1,2-Dichlorothene & L0108030-0]-MS & 50 & 43.48 & 87 & & $70 \cdot 130$ & \\
\hline cis-1,2-Dichlorot thene & L $0108030-01-M S D$ & 50 & 42.35 & 85 & & $70-130$ & 2.6 \\
\hline traps-1,2-Dichloroethene & 010806AQ60_2A1.LCS & 50 & 32.5 & 65 & 」 & $70-130$ & \\
\hline traps-12-Dichloroethene & L0108030-01-MS & 50 & 32.02 & 64 & $\mathbf{I}$ & $70-130$ & \\
\hline traps-1 2-Dichlorothene & L0108030-01-MSD & 50 & 31.2 & 62 & $\mathbf{J}$ & $70 \cdot 130$ & 2.6 \\
\hline 1.2-Dichloropropane & 0.0806AO60_1A.1-LCS & 50 & 47.27 & 95 & & $70-130$ & \\
\hline 1,2-Dichloropropane & L010803001-MS & 50 & 52.74 & 105 & & $70-130$ & \\
\hline 1,2-Dichloropropare & L0108030-41-KSD & 50 & $\$ 2.22$ & 104 & & $70-130$ & 1. \\
\hline 1,3-Dichloropropane & 010806AQ60_2A1-LCS & 50 & 44.91 & 90 & & $70-130$ & \\
\hline 1,3-Dichoropropane & L0108030-01-MS & 50 & 31.15 & 102 & & $70-130$ & \\
\hline 1,3-DichIoropropane & L0108030-01-MSD & 50 & 51.06 & 102 & & $70-130$ & 0.2 \\
\hline 2,2-Dichloropropane & 010806AQ60_2A1.LCS & 50 & 33.8 & 68 & J & $70-130$ & \\
\hline 2,2-Dichiloroprapane & L0108030-01-MS & 50 & 32.75 & 66 & J & $70-130$ & \\
\hline 2,2-Dichloropropane & $20108030-01-M S D$ & 50 & 28.64 & 57 & J & $70-130$ & 13.4 \\
\hline 1,1-Dichloropropene & 010806AQ60_2A]-LCS & 50 & 47.44 & 95 & & $70-130$ & \\
\hline 1,1-Dichloropropene & L0108030-01-MS & 50 & 54.55 & 109 & & $70-130$ & \\
\hline ],1-Dichloropropene & L0108030-01-MSD & 50 & 51,03 & 102 & & $70-130$ & 6.7 \\
\hline cis-1,3-Dichloropropene & 010806AQ60_2A1.LCS & 50 & 42.73 & 85 & & $70-130$ & \\
\hline cis-1,3-Dichloropropene & L0108030-01-MS & 50 & 46.67 & 93 & & $70-130$ & \\
\hline cis-1,3-Dichloropropene & L0108030-01-MSD & 50 & 46.57 & 93 & & $70-130$ & 0.2 \\
\hline trans-1,3-Dichloropropene & 010806AQ60_2A1-LCS & 50 & 41.93 & 84 & & $70-130$ & \\
\hline trans-1,3-Dichloropropen & L0108030-01-MS & 50 & 45.91 & 92 & & $70-130$ & \\
\hline tans, 1,3-Dichloropropent & L0105030-01-MSD & 50 & 45.41 & 91 & & $70-130$ & 1.1 \\
\hline
\end{tabular}

ND - Not Detected

This report shall not be reproduced except in full, without the whthes approval of the laboratory: 
CLIENT:

Bechtel Nevada

PROJECT ID:

V 1226

PROJECT H:

23081

TEST:

Volatile Organic Cornpounds by EPA 8260B, December 1996

MATRE:

Aqueous

\begin{tabular}{|c|c|c|c|c|c|c|c|}
\hline PARAMETER & NEL Sample II & $\frac{\text { Bpike }}{\text { Alnkount }}$ & $\frac{\text { Spike }}{\underline{\text { Rtsult }}}$ & $\frac{\text { Percent }}{\text { Recovery }}$ & & $\frac{\text { Acceptable }}{\text { Range }}$ & $\underline{\text { RPD }}$ \\
\hline Ethylbenzene & 010806 AQ60_2A1-LCS & 50 & 44.7 & 89 & & $70-190$ & \\
\hline Ethylbenzene & $20108030-01-\mathrm{MS}$ & 50 & 51.7 & 503 & & $70+130$ & \\
\hline Ethylbenzene & L0108030-01-MSD & 50 & 49.88 & 100 & & $70-130$ & 3.6 \\
\hline Hexachlorobutadiene & 010806AQ60_2A1-LCS & 50 & 46.9 & 94 & & $70-130$ & \\
\hline Hexacthlorobutadiene & L0108030-01-MS & 50 & 41.49 & 83 & & $70+130$ & \\
\hline Hexachlorobutadiene & L0108030-0l-MSD & 50 & 45.32 & 91 & & $70-130$ & 8.8 \\
\hline 2-Hexamone & 010806AQ60_2A1-LCS & 50 & 44.62 & 89 & & $70-130$ & \\
\hline 2-Нехаполе & L0108030-01-MS & 50 & 55.25 & 111 & & $70-130$ & \\
\hline 2-Hexanone & L0108030-01-MSD & 50 & 56.23 & 112 & & $70-130$ & 1.8 \\
\hline Iodomethane & 010806AQ60_2A1-LCS & 50 & 37.2 & 74 & & $70-130$ & \\
\hline Iodomethane & L0108030-01-MS & 50 & 37.21 & 74 & & $70-130$ & \\
\hline Iodomethane & L0]08030-01-MSD & 50 & 37.95 & 76 & & $70=130$ & 2. \\
\hline Isopropylbemene & 010806AQ60_2A1-LCS & 50 & 47.29 & 95 & & $70-130$ & . \\
\hline Isopropylbenzene & L0108030-01-MS & 50 & 51.98 & 104 & & $70-130$ & \\
\hline Isopropytbenzenc & L0108030 01-MSD & 50 & 50.16 & 100 & & $70-130$ & 3.6 \\
\hline p-Isopropyltoluerit & $010806 \mathrm{AQ60} 2 \mathrm{~A} 1-\mathrm{LCS}$ & 50 & 48.02 & 96 & & $70-130$ & \\
\hline p-Isopropyltoluene & L0108030-01-MS & 50 & 50.01 & 100 & & $70-130$ & \\
\hline p-Isopropyltoluene & L0108030-01-MSD & 50 & 49.63 & 99 & & $70-130$ & 0.8 \\
\hline Methyleme chloride (Dichloromethane) . & $010806 \mathrm{AQEO} 2 \mathrm{2A1}-\mathrm{LCS}$ & 50 & 43.47 & 87 & & $70-130$ & \\
\hline Methylene chloride (Dichloronethane) & L0108030-01-MS & 50 & 31.27 & 63 & Л & $70-130$ & \\
\hline Methylene chloride (Dichloromethane) & L0108030-01-MSD & 50 & 46.52 & 93 & & $70-130$ & 39.2 \\
\hline 4-Metbyl-2-pentanone & 010806AQ60_2AI-LCS & 50 & 44.66 & 89 & & $70-130$ & \\
\hline 4-Methyl-2-pentanoue & L0108030-01-MS & 50 & 53.76 & 108 & & $70-130$ & \\
\hline 4-Methyl-2-pentanone & L0108030-01-MSD & 50 & 55.03 & 110 & & $70-130$ & 2.3 \\
\hline MTBE & $010806 \mathrm{AQ60 \_ 2A1-LCS}$ & 50 & 37.14 & 74 & & $70 \cdot 130$ & \\
\hline MTEE & L0108030-01-MS & 50 & 60.32 & 91 & & $70-130$ & \\
\hline MTBE & L0108030-01-MSD & 50 & 57.19 & 76 & & $70-130$ & 17.1 \\
\hline Naphthalene & 010806AQ60_2Al-LCS & 50 & 31.73 & 63 & $\mathbf{J}$ & $70-130$ & \\
\hline Naphthalene & L0108030-01-MS & 50 & 35.61 & 71 & & $70-130$ & \\
\hline Naphthalene & L0108030-01-MSD & 50 & 44.95 & 90 & & $70-130$ & 23.2 \\
\hline n-Propylbenzede & 010806AQ60_2A1-LCS & 50 & 45.76 & 92 & & $70-130$ & \\
\hline n-Propylbenzene & L0108030-01-MS & 50 & 50.3 & 101 & & $70-130$ & \\
\hline n-Propylbenzene & LoI08030-01-MSD & 50 & 49.6 & 99 & & $70 \cdot 130$ & 1.4 \\
\hline Styrene & 010806AQ60_2A1-LCS & 50 & 48.69 & 97 & & $70-130$ & \\
\hline Styreme & Lo108030-01-MS & 50 & 49.76 & 100 & & $70-130$ & \\
\hline Srytene & L0108030-01-MSD & 50 & 47.8 & 96 & & $70-130$ & 4. \\
\hline $1,1,1,2$-Tetrachloroethane & 010806AQ60_2A1-ICS & 50 & 46.51 & 93 & & $70 \cdot 130$ & \\
\hline 1,1,1,2-Tetrachlorothane & L0108030-01-MS & 50 & 52.21 & 104 & & $70-130$ & \\
\hline \multicolumn{7}{|l|}{ ND - Not Detected } & \\
\hline
\end{tabular}


CLIFNT: Bechrel Nevada

PROJECT D: V1226

PROJECT \#: $\quad 23081$

TEST: Volatile Organic Compounds by EPA 8260B, December 1996

MATRL: Aqueous

\section{PARAMETLR}

$1,1,1,2$-Tetrachloroethane

$1,1,2,2$-Terachlorow thane

1,1,2,2-Terachlorothane

1,1,2,2-Tetrachloroethane

Tetrachloroethene (PCE)

Tetractloroethene (PCE)

Tetrachlotiethene (PCE)

Toluene

Toluene

Tolatene

1,2,3-Trichlorobenzane

1,2,3-Trichlorobenzene

1,2,3-Trichlorobenzene

I, 2,4-Triclloroberezente

1,2.4-Trichlorobenzerie

1,2,4-Trichlorobenzene

1,1,1-Trichlorothane (1,1,1-TCA)

1, 1,1-Trichloyothane (1,1,1-TCA)

1, 1, I-Trichlorothane (1,1,1-TCA $)$

$1,1,2-T_{\text {Tit }}$ hlor opthane $(1,1,2-T C A)$

1,1,2-Trichloroethane (1,1,2-TCA)

1,1,2-Trichloroethane (I,1,2-TCA)

Trichloroethene (TCE)

Trichloroethene (TCE)

Triblugoethene (TCE)

Trishlorofluoromethan (Freon II)

Trichlorofluoronethane (Freon 11)

Trichlorofluoromethane (Ereon 11)

1,2,3-Trickibroproprase

1,2,3-Trichloropropane

1,2,3-Trichloropropane

1,2,4-Trimethylbenzene

$:, 2,4$-Trimethylbenzene

1,2,4-Timethylbenzene

1,3,5-Trimethylbenzene

1,3,5-Timethylbenzene

1,3,5-Trimethylbenzene

Vinyl chloride
NEL Sample W

L0108030-01-MSD

0I 0806AQ60_2AI-LCS

L0108030-01-MS

L0108030-01-MSD

010806 AQ60_2A 1-LCS

L0108030-01-MS

L0108030-01-MSD

010806AQ60_2A1-LCS

L0108030-01-MS

L0108030-0I-MSD

OLDB06AQ60_2A]-LCS

LOI08030-01-.MS

L0103030-01-MSD

010800AQ60_2A]-LCS

LO108030-01.MS

L0108030-01-MSD

010806AQ60_2AI.LCS

U108030.01-MS

L0I 08030-01-MSD

D10806A060_2A1.LCS

L0108030.01-MS

L0108030-01-MSD

010806AQ60_2A1-LCS

L0108030.0I-MS

L0108030-01-MSD

010806AQ60_2A1.LCs

L0108030-0I-MS

L0108030-01-MSD

010806AQ60_2A1-LCS

L0108030-01-MS

LO108030-01-MSD

010806AQ60_2A1-LCS

L0108030-01-MS

L0108030-01-MSD

010806AC60_2A1-LCS

L0108030-01-MS

L0108030-01-MSD

010806AO60_2A1-LCS
Spike

Amoun$$
50
$$

50

50

50

50

50

50

50

so

50

50

50

50

50

50

50

50

50

50

50

50

50

50

50

50

50

50

50

50

so

50

50

50

50

50

50 .

50

50

50.

\section{Spike}

Result

51.24

47,48

52.42

53.44

45.28

52.08

50.04

43.64

50.34

49.64

32.13

31.36

$\$ 9.14$

36.75

37.92

42.41

39.94

45.11

42.46

45.39

50.79

51.46

46.44

52,85

50.91

$\$ 4.44$

63.54

57.63

46.1

51.3

51.96

47.45

52.04

51.94

47.17

50.73

50.08

51.4
Fecover

102

95

105

107

91

104

100

87

191

99

64

63

78

78

74

76

85

80

90

35

91

91

102

103

93

106

I02

109

127

115

92

103

104

95

104

104

94

10)

100

103
Acceptabile

$\frac{\text { Range }}{70-130} \quad \frac{\text { RPD }}{1.9}$

$70-130$

$70-130$

$70-130$

$70-130$

$70-130$

$70-130$

4.

$70-130$

$70-130$

$70-130$

1.4

$70-130$

$70-130$

$70 \cdot 130$

$70-130$

70.130

$70+130$

$70-130$

70.130

$70 \cdot 130$

6.1

70.130

$70 \cdot 130$

$70-130$

$70-130$

$70-130$

$70-130$

3.7

$70-130$

$70-130$

$70-130$

$30-130$

$70-130$

$70-130$

$70-130$

$70-130$

$70-130$

$70-130$

$70-130$

$70-130$

1.3

$70-130$

ND - Not Detected

This report shall not be reprokuced extept in fult, withow the written approval of the laboratory. 


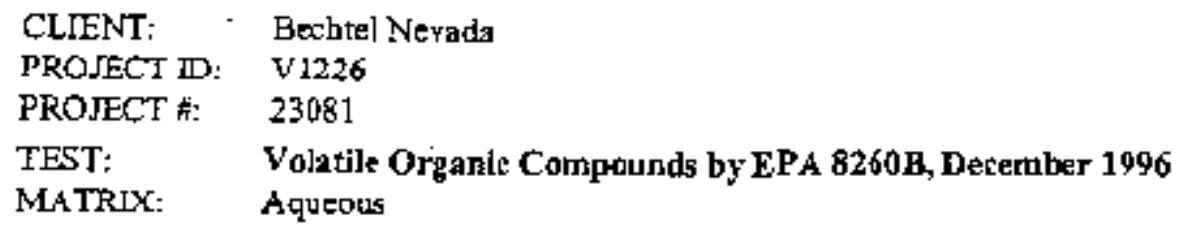

\section{PARAMETER}

Vinyl chloride

Viryl chloride

o-Xylene

a.Xylene

0 -Xylene

m,p-Xylene

$\mathbf{m}, \mathrm{F}$-Xylene

$\mathrm{m}, \mathrm{p}$-Xylene

\section{NEL Sample ID}

L0108030-01-MS

L0108030-01-MSD

010806AQ60_2A1-LCS

L0108030-01-MS

L0108030-01-MSD

010806AQ60_2A1-LCS

L0108030-01-MS

L0108030-01-MSD

\begin{tabular}{ccc}
$\frac{\text { Spike }}{\text { Amonnt }}$ & & $\frac{\text { Spike }}{\text { Result }}$ \\
\cline { 1 - 1 } 50 & & 59.26 \\
50 & & 52.61 \\
50 & 46.86 \\
50 & 53.38 \\
50 & 51.79 \\
100 & 90.4 \\
100 & 101.84 \\
100 & 99.95
\end{tabular}

\begin{tabular}{ccc}
$\frac{\text { Percent }}{\text { Recovery }}$ & $\begin{array}{c}\text { Acceptable } \\
\text { Range }\end{array}$ & FPD \\
\hline 119 & $\frac{70-130}{70}$ & \\
105 & $70-130$ & 11.9 \\
94 & $70-130$ & \\
107 & $70-130$ & \\
104 & $70-130$ & 3. \\
90 & $70-130$ & \\
102 & $70-130$ & \\
100 & $70-130$ & 1.9
\end{tabular}


CLIENT: Bechtel Nevada

PROJECT D: V1226

PROJECT H: 23081

TEST: $\quad$ Vofatila Organic Compounds by EPA 8260A, December 1996

MATRD: Solid

\begin{tabular}{|c|c|c|c|c|c|c|c|}
\hline PARAMETER & NEL Shmple TD & $\frac{\text { Spike }}{\text { Amootat }}$ & $\frac{\text { Spike }}{\text { Resutt }}$ & $\frac{\text { Percent }}{\text { Recovery }}$ & & $\frac{\text { Acceptable }}{\text { Range }}$ & $\underline{\text { RPD }}$ \\
\hline Actone & 010807SD60_IA1-LCS & 50 & $\overline{175.84}$ & 352 & $\mathbf{J}$ & $70-130$ & \\
\hline Benzene & $0108075 D 60 \_1 A I-L C S$ & 50 & 50.3 & 101 & & $70 \cdot 130$ & \\
\hline Brmobenzene & 010807SD60_1A1-LCS & so & $52.9 \mathrm{~B}$ & 106 & & $70-130$ & \\
\hline Bromochlofomethane & 010807\$D60_1A1-LCS & 50 & 52.17 & 104 & & $70-130$ & \\
\hline Bromodichloromethane & 010807SD60_LAI-LCS & 50 & 52.95 & 106 & & $70-130$ & \\
\hline Bromoform & 010807SD60_IA1-LCS & 50 & 59.31 & I19 & & $70-130$ & \\
\hline Bromomethane & 010807SD60_LAl-LCS & 50 & 53.49 & 107 & & $70-130$ & \\
\hline 2-Butanone & 0108079D60_1AT-LCS & 50 & 156.93 & 314 & J & $70 \cdot 130$ & \\
\hline n-ButyJenzene & 010807SD60_IA1-LCS & 50 & 49.86 & .100 & & $70-130$ & \\
\hline sec-Butyibanzere & 01080าSD60_1Ai-1,CS & 50 & 52.91 & 106 & & $70-130$ & \\
\hline tert-Butylbonzene & 010807SD60_LA1-LCS & 50 & 51.09 & 102 & & $70-130$ & \\
\hline Cajbondisulfide & 010807SD60_1AL-LCS & 50 & 44.58 & 89 & & $70-130$ & \\
\hline Carbon tetrachloxide & 01080TSD60_1A.1-LCS & 50 & 52.97 & 106 & & $70 \div 130$ & \\
\hline Chlorobenzase & 0108078060 IA1-LCS & so & 53.21 & 106 & & $70-130$ & \\
\hline Chloroethate & 010807SD60_1A.1-LCS & 50 & 47.83 & 96 & & $70-130$ & \\
\hline Chlorotorm & 010807SD60_LA1-LCS & 50 & 47.91 & 96 & & $70-130$ & \\
\hline Chloromethane & 010807SD60_1Ai-LCS & 50 & 46.41 & 93 & & $70-130$ & \\
\hline 2-Chlorotoluene & 010807SD60_1A1-LCS & 50 & 52.96 & 106 & & $70-130$ & \\
\hline 4-ChlorotoIrene & 010807SDO0_lA1-LCS & 50 & 41.36 & 83 & & $70-130$ & \\
\hline Ditrompchlororsethan & 010807SD60_1AI-LCS & 50 & $\$ 3.55$ & 107 & & $70-130$ & \\
\hline 1,2-Dibrome-3-cbloroprcpane (DBCP) & 01080TSD60_1A1-LCS & 50 & 62.47 & 125 & & $70-130$ & \\
\hline 1,2-Dibromotthane (EDB) & 010807SD60_1A1-LCS & so & 54.09 & 108 & & $70-130$ & \\
\hline Ditromomethane & $010807 S D 60,1 \mathrm{~A} 1-\mathrm{LCS}$ & 50 & 53.22 & $10 \dot{~}$ & & $70-130$ & \\
\hline 1,2-Dichlorobeturenc (o-DCB) & $010807 S D 60 \_1 A 1-L C S$ & 50 & 50.58 & 101 & & $70-130$ & \\
\hline 1,3-Diehlorobenrene (m-DCB) & 010807SD60_1AI-LCS & $50^{\circ}$ & 51,61 & 103 & & $70-130$ & \\
\hline 1,4-Dichloroberitene (p-DCB) & $010807 S D 60$ IA1-LCS & 50 & 53.71 & 107 & & $70-130$ & \\
\hline Dictlorodiflioramethane (Freon I2) & 010807SD60_1A1-LCS & 50 & 47.77 & 96 & & $70-130$ & \\
\hline 1,1-Dichloresthame (1,1-DCA) & 010807SD60_1Al-LCS & 50 & 48.56 & 97 & & $70-130$ & \\
\hline 1,2-Dichlorothane (1,2-DCA) & 010807SD60_1Al-LCS & 30 & $5 I .88$ & 104 & & $70-130$ & \\
\hline 1,1-Dichtoroethere (1,1-DCE) & $.010807 S D 60 \_|A|-L C S$ & 50 & 47.54 & 95 & & $70-130$ & \\
\hline cis-1, 2-Dichlorotheas & DIOSOTSD60_1AI-IKS & 50 & 47.4 & 95 & & $70-130$ & \\
\hline trans-1,2-Dichloroetwenc & 010807SD60_1A.1-LCS. & 50 & .48 .32 & 97 & & $70-130$ & \\
\hline 1,2-Dichloropropane & 010807SD60_IA1-ICS & 50 & 52.46 & 105 & & $70-130$ & \\
\hline 1,3-Dichloropropane & $010807 S D 60 \_1 \mathrm{AI}-\mathrm{LCS}$ & 50 & 54.29 & 109 & & $70-130$ & \\
\hline 2,2-Dichlowopropane & 010807SD60_IA1.LCS & 50 & 50.78 & 102 & & $70-130$ & \\
\hline 1,1-Dichloropropene & $010807 S D 60 \_1 \mathrm{~A} 1-\mathrm{LCS}$ & 50 & 53.09 & 106 & & $70 \cdot 130$ & \\
\hline cis-1, 3ૈ-Dichloropropgene & $0108075060 \_1 A 1-L C S$ & 50 & 57.33 & 115 & & $70-130$ & \\
\hline trans-1,3-Dichloropropene & 010807SD60_1A.1-LCS & 50 & 49.89 & $100^{\circ}$ & & $70-130$ & \\
\hline
\end{tabular}

ND - Not Detected

This report shall not te reproduced except in full, without the writes approval of the labonatory. 
TLIENT: Bechtel Nevada

'ROJECT ID: V1226

PROJECT 烡: $\quad 23081$

TEST: Volatile Orianic Compornds by EPA 82608 , Dectmber 1996

MATRIX: Solid

\begin{tabular}{|c|c|c|c|c|c|c|c|}
\hline PARAMETER & NEL Sample ID & $\underset{\text { Anike }}{\text { Spintant }}$ & $\underset{\text { Spike }}{\text { Sesult }}$ & $\frac{\text { Percett }}{\text { Rerovery }}$ & & $\frac{\text { Acceptable }}{\text { Range }}$ & $\underline{\text { RPD }}$ \\
\hline Ethylbenzent & 010807SD60_1A1-LCS & 50 & 50.08 & 100 & & $70-130$ & \\
\hline Hexachlorobutadiene & 010\$07SD60_1A1-LCS & 50 & 52.43 & 105 & & $70-130$ & \\
\hline 2-Hexamone & 010807SD60_1A1-LCS & 50 & 104.65 & 209 & $\mathbf{J}$ & $70-130$ & \\
\hline Iodomethane & 010807SD60_1A1-LCS & 50 & 52.59 & 105 & & $70 \cdot[30$ & \\
\hline 1sopropylbenzene & 010807SD60_1AI-LCS & 50 & 50.62 & 101 & & $70-130$ & \\
\hline p-Isopropylteluene & 010807SD60_1A1-LCS & 50 & 52.01 & 104 & & $70-130$ & \\
\hline Methylente chloride (Dichlorornethane) & 010807SD60_1A1-LCS & 50 & 51.39 & 105 & & $70-130$ & \\
\hline 4-Methyl-2-pentanone & 010807SD60_1A1-LCS & 50 & 72.18 & $144 \mathrm{~J}$ & J & $70-130$ & \\
\hline MTBE & 010807SD60_1A!-LES & 50 & 50.53 & 101 & & $70-130$ & \\
\hline Naptbalene & 010807SD60_1A1-LCS & 50 & $\$ 3.98$ & 108 & & $70-130$ & \\
\hline n-Propylbenzene & 010807SD60_1A1-LCS & 50 & 49.78 & 100 & & $70-130$ & \\
\hline \$tyrens & $0108075 D 60 \_1 A 1-L C S$ & 50 & 53.61 & 107 & & $70-130$ & \\
\hline 1,1,1,2-Tetrachlorothane & 010807SD60_1A1-LCS & 50 & 53.58 & 107 & & $70-130$ & \\
\hline 1,1,2,2-Tetrachlonoethane & $010807 S D 60 \_\{A\}-L C S$ & 50 & 56.02 & 112 & & $70-130$ & \\
\hline Tetrachloroethene (PCE) & 010807SD60_1A1-LCS & 50 & 54.85 & 110 & & $70+130$ & \\
\hline Toluene & 010807SD60_1A1-LCS & 50 & 51.17 & 102 & & $70-130$ & \\
\hline 1,2,3-Trichlorobenzene & 010807SD60_1A1-LCS & 50 & 31.26 & 103 & & $70-130$ & \\
\hline 1,2,4-Tritblotobenzente & 010807SD60_1A1-LCS & 50 & 54.66 & 109 & & $70-130$ & \\
\hline 1,1,1-Tríchloroetbane $(1,1,1-\mathrm{TCA})$ & 010B07SD60_1A1-LCS & 50 & 48.89 & 98 & & $70-130$ & \\
\hline i,1,2-Trichloroethane $(1,1,2-\mathrm{TCA})$ & 010B07SD60_1A1-LCS & 50 & 52.35 & 105 & & $70-130$ & \\
\hline Trichloroethene (TCE) & 010807SD60_1A1-LCS & 50 & 51.57 & 103 & & $70-130$ & \\
\hline Trichlarofluoromethane (Freon 11) & 010807SD60_1A1-LCS & 50 & 53.41 & 107 & & $70-130$ & \\
\hline 1,2,3-Trichloiopropane & 010807SD60_1A1-LCS & 50 & 59.72 & 119 & & $70-130$ & \\
\hline !,2,4-Trimethylbenzexe & 010807SD60_IA1-LCS & 50 & 51.49 & 103 & & $70-130$ & \\
\hline 1,3,5-Trimethylbutatene & 010807SD60_1A1-LCS & 50 & 50.68 & 101 & & $70-130$ & \\
\hline l'ingl chloride & 010807SD60_1A1-LCS & 50 & 49.51 & 99 & & $70-130$ & \\
\hline o-Xylene & 010807SD60_1Al-LCS & 50 & 53.26 & 107 & & $70-130$ & . \\
\hline mi,p-Xylene & 010807SD60_1Al-LCS & 100 & 106.78 & 107 & & $70+130$ & \\
\hline
\end{tabular}


Letite 4 Nue $8 / 9$

2008017

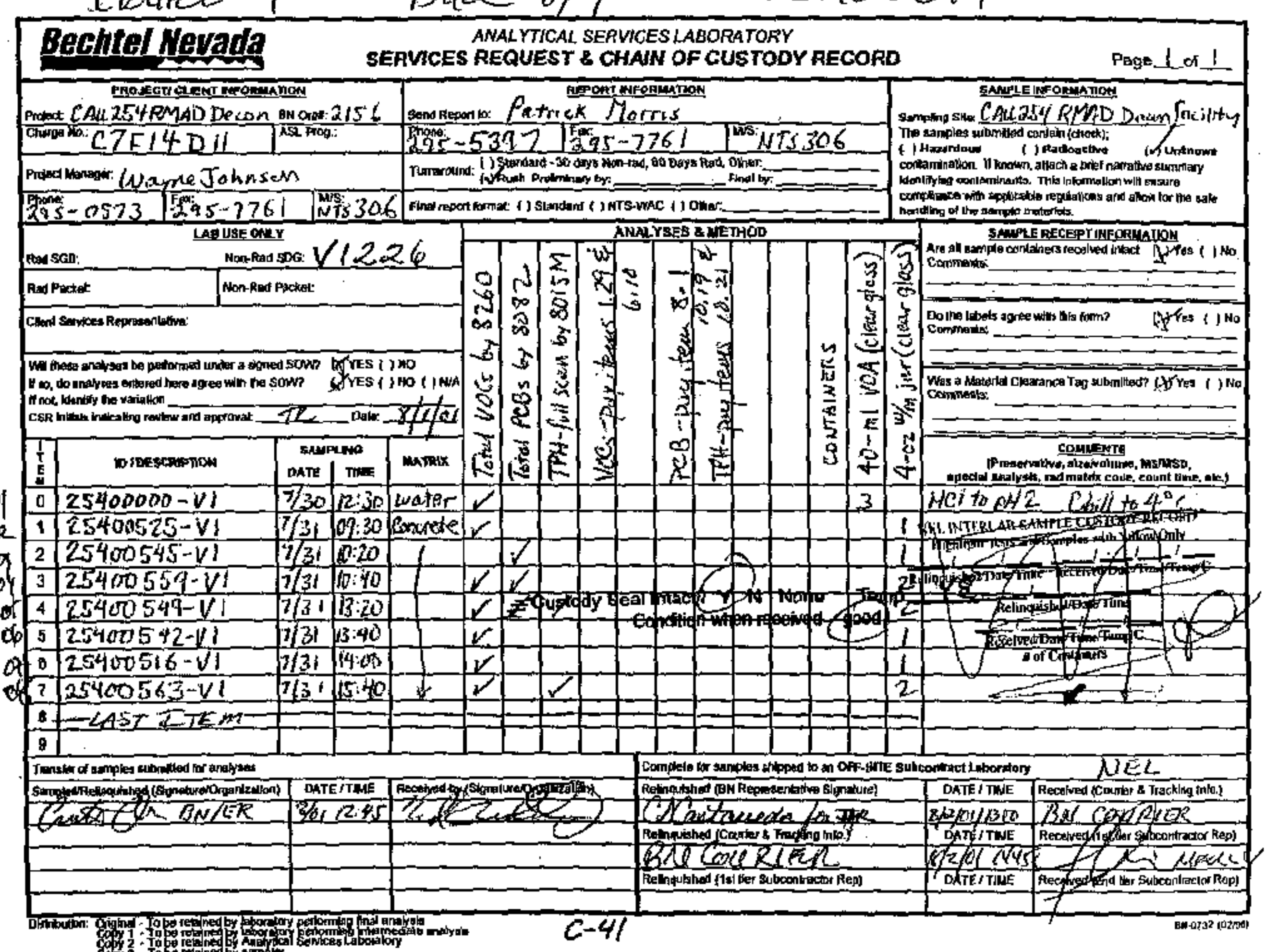


THIS PAGE LEFT INTENTIONALLY BLANK

C-42 
Sample Delivery Group 1232

C. -43 


\section{CLIENT; Bechtel Nevada \\ P.O. Box 98521, MS NTS273 \\ Las Yegas, NV 89193-8521 \\ ATTN: $\quad$ Ted Redding}

NEL ORDER ID: L0108069

PROJECT NAME: V1232

PROJECT AUMBER: 23081

Attached are the analydcal results for samples in suppor of the above referenced project.

Samples submfted for this project were not sarapled by NEL Laboratories. Samples were teceived by NEL in good condition, under chain of eustody on $8 / 8 / 01$.

Should you have any questions or comments, plense feel free to contact onr Chient Services departinent at (702) 657-1010.

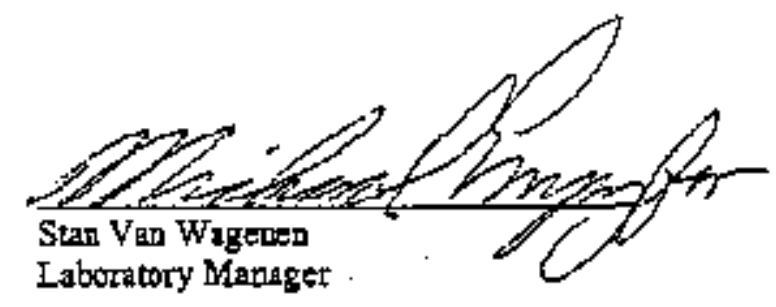

\section{CERTIFICATIONS:}

\begin{tabular}{llll}
\hline & Reno & Las Vggas & S. Califomin \\
\cline { 2 - 4 } Arizong & AZ0520 & AZ0518 & AZ0605 \\
Califordia & 1707 & 2002 & 2264 \\
USAnny Corps & Certified & Certified & \\
of Engineers & & &
\end{tabular}

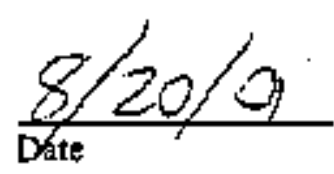

$$
c-44
$$




\begin{tabular}{|c|c|c|}
\hline C & Berhtel Nerada & CLIENT ID: \\
\hline PROJECT ID: & V1232 & DATE SAMPLED: $8 / 6 / 01$ \\
\hline PROJECT & 23081 & NEL SAMPLE D: L0108068-0! \\
\hline
\end{tabular}

TEST: $\quad$ PCB's (Polychiorinated Biphenyls) by EPA 8982. Dec. 1996

METHOD: EPA 8082 ANALYST: JRW - Las Vegas Diqision

MATRDX: SÖ̆ á EXTRACTED:

DILUTION: 1 ANALYZED: $1 / 15 / 01$

\begin{tabular}{|c|c|c|}
\hline PARAMETER & Kestut & $\begin{array}{c}\text { Reporting } \\
\text { Limit }\end{array}$ \\
\hline Anvetor-1016 & ND & 20. $\mathrm{Hg} / \mathrm{kg}$ \\
\hline Araclor-122l & ND & 20. $\mu g / k g$ \\
\hline Aroclor-1232 & ND & 20. $\mu \mathrm{g} / \mathrm{kg}$ \\
\hline Aroclor-1242 & $\mathrm{ND}$ & 20. $\mu \mathrm{c} / \mathrm{kg}$ \\
\hline Aroclor-I 248 & ND & 20. $\mu g / \mathrm{kg}$ \\
\hline Araclor -1254 & $\mathrm{ND}$ & 20. $\mu \mathrm{g} / \mathrm{kg}$ \\
\hline Aroclor -1260 & $\mu \mathrm{g} / \mathrm{kg}$ & 20. $\mu \mathrm{\mu g} / \mathrm{kg}$ \\
\hline
\end{tabular}

QUALTYY CONTROL DATA:

Surrogatie

Decachlorobiphenyl

$\%$ Recovery

Tetracbloro-m-xylene

102

82

Acceptable Range

$46-155$

$49-140$

ND - Not Detected

This report thalt not be reproduced except in full, without the wrtten approval of the laboratory. 


\begin{tabular}{|c|c|c|}
\hline NT: & Bechtel Nevada & CLIENTI D: $\quad 25400001-V 1$ \\
\hline PROJECT E: & $v_{1232}$ & DATE SAMPLED: $8 / 6 / 01$ \\
\hline PROJECT $\frac{n}{n}:$ & 23081 & NEL SAMPLE D: L0108068-02 \\
\hline
\end{tabular}

TEST: $\quad$ PCB's (Polychlorinated Bipher:yls) by EPA 8082, Dec. 1996

METHOD: EPA 8082 ANALYST: JRW - Las Vegas Division

MATRIX: Aqueous EXTFACTED: 8/11/01

DILUTON: 1 ANALYZED: $8 \% 4 \% 1$

\begin{tabular}{|c|c|c|}
\hline PARAMETEK & Result & $\begin{array}{l}\text { Reporting } \\
\text { Limit }\end{array}$ \\
\hline Arbelor.1016 & $\overline{N D}$ & !. $\mu \mathrm{g} / \mathrm{L}$ \\
\hline Areclar-122l & ND & l. $\mu g / t$ \\
\hline Aroclor. 1232 & ND & 1. $\mu \mathrm{g} / \mathrm{L}$ \\
\hline Arocior-1242 & ND & 1. $\mu g / \mathrm{L}$ \\
\hline Arociss-1248 & ND & 1. $\mu \mathrm{gg} / \mathrm{L}$ \\
\hline Araclor-1254 & ND & 1. $\mu g \mathrm{~L}$ \\
\hline Arteler.1260 & ND & l. $\mu g / \mathrm{L}$ \\
\hline
\end{tabular}

QUALTY CONTROL DATA:

Surrogate

\%ecosery

71

111

\section{Acceptable Ragee}

$32-145$

$50 \cdot 143$

\section{ND - Not Detected}

This report shall not be repreduced except in full, withous the written appraval of the laboratory. 

CLIENT:
Bechtel Nevafa
CLIENT D:
Method Blink
PROIECT D: V!232
DATE SAMPLED: NA
PROJECT H: 23081
NEL SAMPLE D: O10\$11PCES-BLK

TEST:

PCB's (Polychlorinated Biphengls) by EPA S082, Dec. 1996

METHOD; EPA 8082 ANALYST:

MATRIX: Solid EKTRACTED:

JRW - Las Vegas Division

ANALYZED:

$1 / 15 / 01$

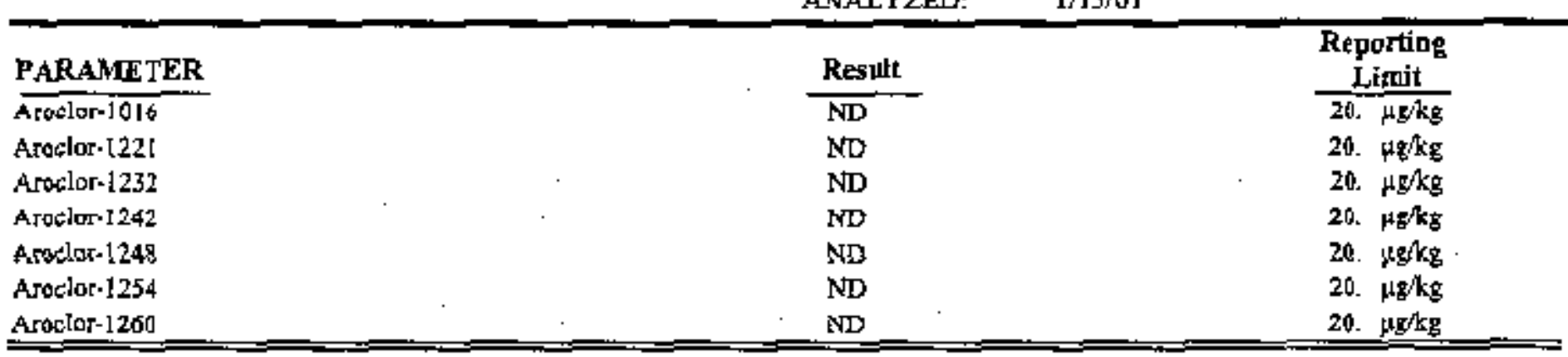

\section{QUALTY CONTKOL DATA:}

Surrogate

Decachilurobithenyl

\% Recovery

115

Tetrachtoro-øi-xylene

123

Aeceptable Ronge

$46-155$

$49-140$

ND - Not Detected

This report shall not bo reprodwced exwapt in full, withous the wrtter approval of the laboratory.

CLIEN: Becitel Nevada

PROSECT ID: V1232

CLIENT D: Method Biank

PROIECT H: 23081

DATE SAMPLED: NA

NEL, SAMPLE D: OLOBIIPCBW-BL.K

TEST: $\quad$ PCB's (Polychloringted Bjphenyls) by EPA 9082, Dec, 1996

METHOD: EPA $\$ 0 B 2$ ANALYST: · JR - Las Vegas Division

MATRIX: Aqueous

EXTRACTED: 8 8II 101

ANALYZED: $\quad 8 / 14 / 01$

\begin{tabular}{|c|c|c|}
\hline PARAMTETER & Result & $\begin{array}{l}\text { Reporting } \\
\text { Limut }\end{array}$ \\
\hline Arcior-10 & ND & I. $\mu \mathrm{g} / \mathrm{L}$ \\
\hline Aroclor-1221. & ND & 1. $\mu g / L$ \\
\hline Aroslor-i 232 & $\mathrm{ND}$ & I. $\mu g^{\prime} \mathrm{L}$ \\
\hline Aroclor-1242 & ND & 1. $\mu g \mathrm{~L}$ \\
\hline Arocldr -1248 & ND & I. $4 \mathrm{gg} \mathbf{L}$ \\
\hline Arocler-1254 & ND & 1. $\mu \mathrm{g} \mathrm{L}$ \\
\hline Aroclor 1260 & KD & 1. $\mu \mathrm{gL}$ \\
\hline
\end{tabular}

QUALIYY CONTROL DATA:

\section{Surrogate}

Decachlorobipheny

Tetrachloro-[a-xylent

$\frac{\text { \%erovery }}{46}$

63
Acceptablt Range

$32-145$

$50-143$

ND-Not Detected

This report shall not be reproduced except in full, withota the written approval of the Laboratory. 
CLEENT: Bechtel Nevada.

PROJECTID: V 1232

PROJECT \#: 2308 I

TEST: PCB's (Polychlorinzted Bipheayls) by EPA 8082, Dec. 1996

MATRX: SoII

PARAMETLE

Aroclor-1016

Afoclor-1016

Avoclot-1016

Aroclor-1016

AJoclor- 1260

Atoclor-1260

Aroclor- 1260

Aroclor-1260
NEL Sample I

010811PCBS-LCS

010811PCBS-LCSD

L0108068-01-MS

L0108068-01-MSD

010811 PCBS-LCS

OI0811PCBS-LCSD

L0108068-01-MS

L0108068-01-MSD

\begin{tabular}{|c|c|}
\hline Splke & Spike \\
\hline Amount & Result \\
\hline$\$ 33$ & 338 \\
\hline 333 & 395 \\
\hline 333 & 321 \\
\hline 333 & 335 \\
\hline 333 & 333 \\
\hline 333 & 379 \\
\hline 333 & 404 \\
\hline 333 & 428 \\
\hline
\end{tabular}

\begin{tabular}{c}
$\frac{\text { Percent }}{\text { Recovery }}$ \\
\hline 102 \\
119 \\
96 \\
102 \\
100 \\
114 \\
100 \\
107
\end{tabular}

Acceptable

Rmge 조으

$63 \cdot 127$

$63 \cdot 127$

15.6

$55 \cdot 142$

$55=142$

5.5

$57 \cdot 138$

$57 \cdot 13 \%$

129

$48-129$

$48-129$

7. 
CLIENT: Bechtel Nevada

PROJECT D: V1232

PROJECT \#: 23081

TEST: $\quad$ PCB's (Polychlorinated Biphenyls) by EPA 8082, Dec 1996

MATRLX: Aqueous

\section{PARAMETER}

ArocIor-10]6

Araclor-1016

Arocion-1260

Aroclor-1260
NEL Sample ID

O10811PCBW-LCS

01081IPCBW-LCSD

OLO81IPCBW-LCS

010811PCBW-LCSD
Spike Amout

10

10

10

10

\section{Spike}

Bestalt

8.63

10.25

10.64

10.87
Percent

Recovery

86

102

106

109
Acceptable

Romge kPD

$56 \cdot 126$

$56-126$

$44-134$

$44-134$ 
PROJECTICUENT INFBAMATLON

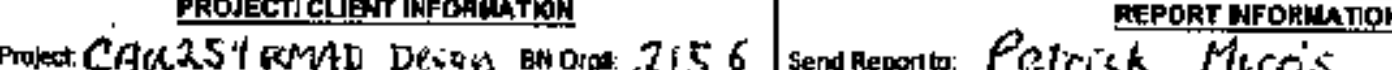

\begin{tabular}{|c|c|}
\hline 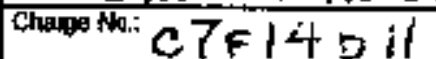 & ASL Prog:-: \\
\hline
\end{tabular}

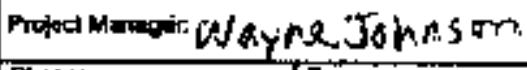

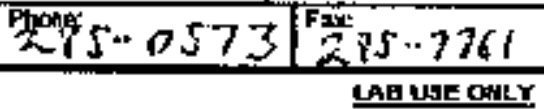

Pad SCD:

Rad Packet Nonfead sog: V1232

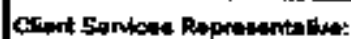

Wil hest unstyses be pertamed under a gigned SOWh ( ) VES ( ) wO

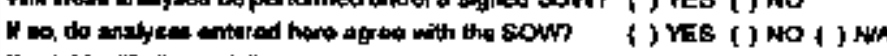

Th nok, bientily the valialon

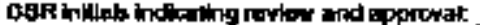

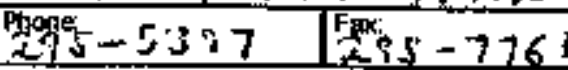

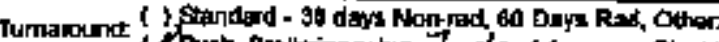

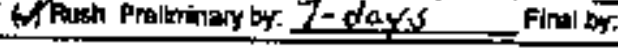

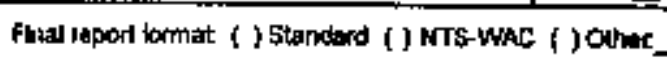

\section{ANALYSEg \& RETHDOD}

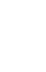

ANGLYSES \& NËTHDOB

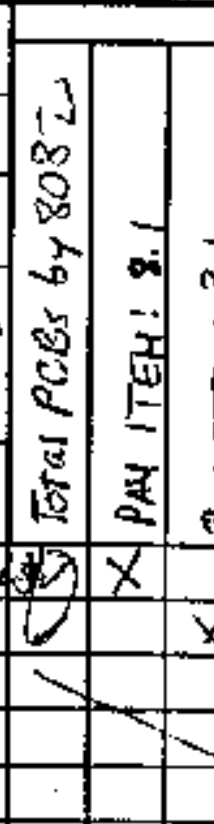

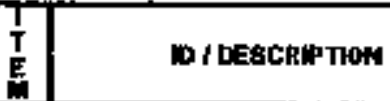

$25400548-\sqrt{2}$

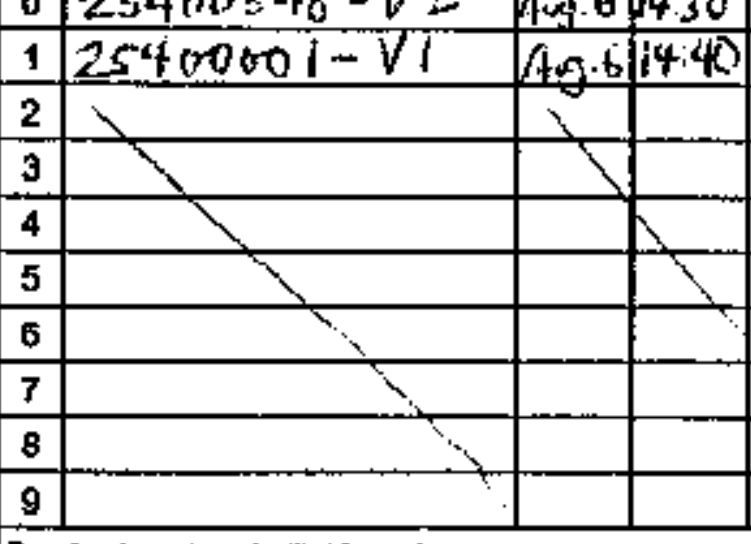

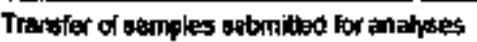

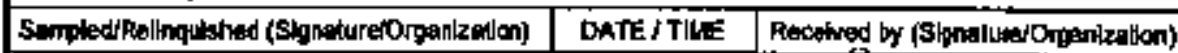

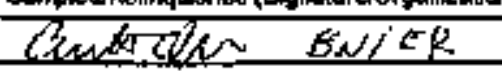

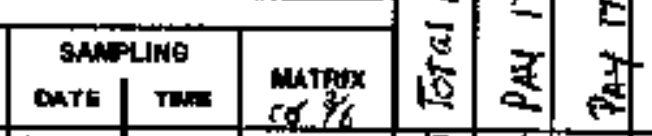

WATER
$=$

\begin{tabular}{|l|l|l|}
\hline & & \\
\hline & & \\
\hline & & \\
\hline
\end{tabular}
S5YHPLE IMFORLATION

Page__ of

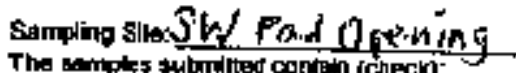

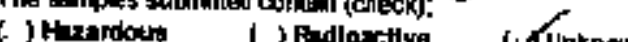
(1) J Unknown

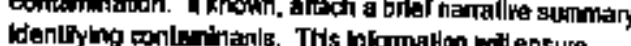
idenifying ronlenimanle. This hicomation wit ensure

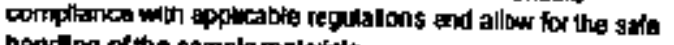
hending of the semple maleitily,

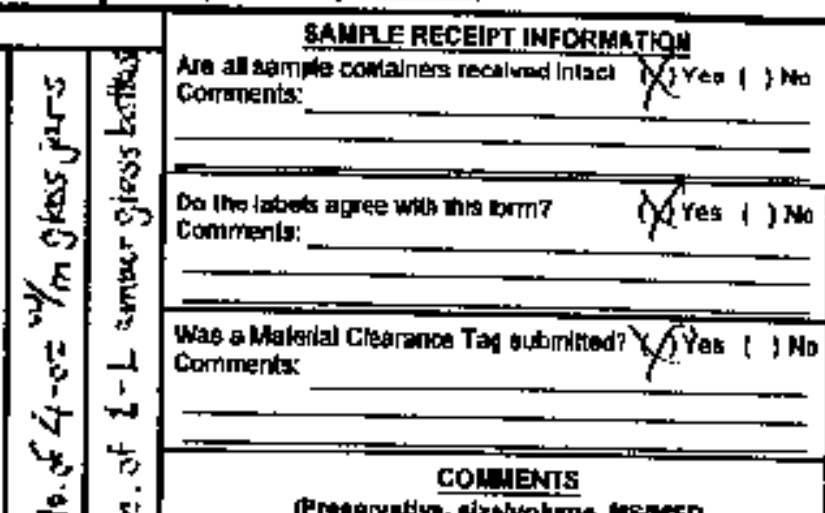

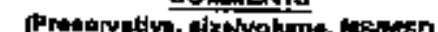

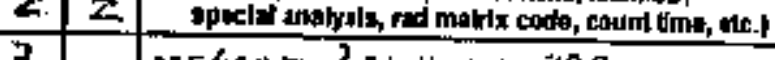

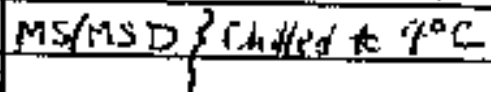

16. is ast intorded tho this metrerial be recenved unter tho audarith of a radionative

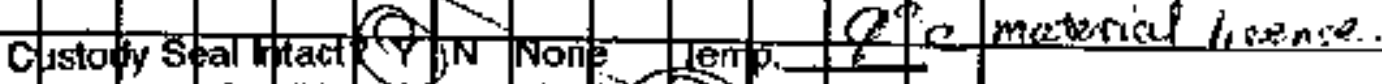

these are destre werifiratum sampliz. PCA conteritiations are?

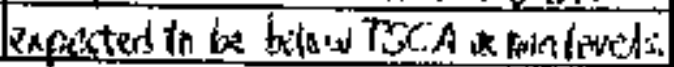

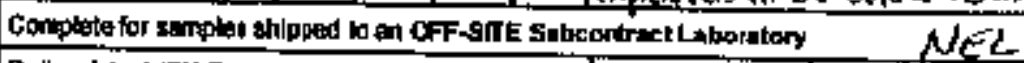

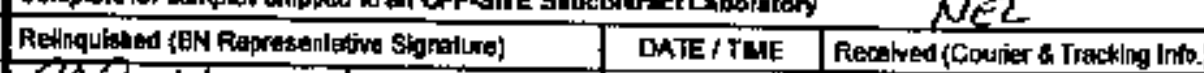

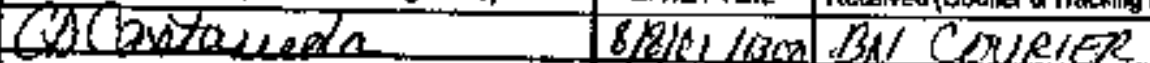

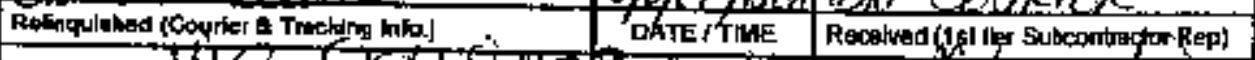

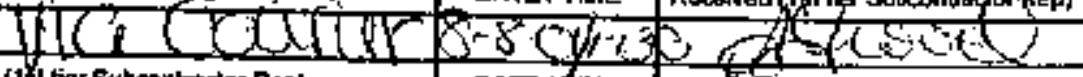
Relinqulshad (10.1 tier Subcontractor Rop) DATE I fIME Recelved (Znd Ier Subcontrador Rep) 


\section{CONCRETE \& SEDIMENT VERIFICATION SAMPLES}

(Continued) 
THIS PAGE LEFT INTENTIONALLY BLANK 


\section{Radioisotopes}

C-53 
THIS PAGELEFT INTENTIONAILY BLANK

C-54 
Sanford Cohen \& Asscciates

Southeastern Environmental Laboratory

Radioanalytical Results

Report laditivation Number: $\$ 2483$

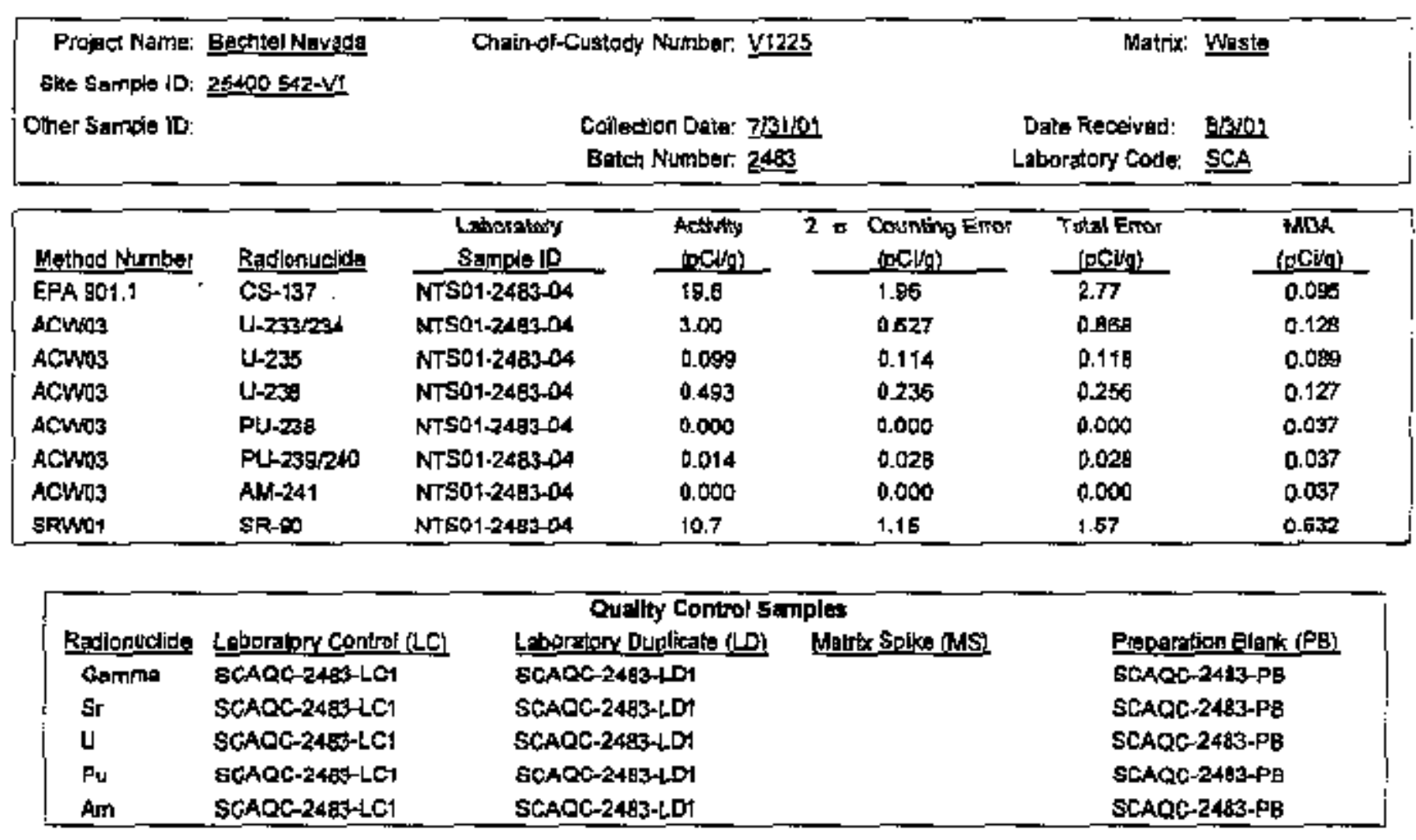




\section{Sanford Cohen \& Associates}

\section{Southeastern Environmental Laboratory}

Radloanalytical Results

Report Erentification Number, \$2483

\begin{abstract}
Project Namo: Beohtel Nexreds
\end{abstract}
Site Semple [D: 25400 545-1/1

Other Sampla ID:
Chain-of-Cuetody Number. W19es

Collection Date: $7 / 3101$

Botch Number, 2485
Matelx: Woste

Date fleceived: 8/301 Laborabry Code: 포오.

\begin{tabular}{|c|c|c|c|c|c|c|c|}
\hline Method Number & Radionuelida & $\begin{array}{l}\text { Loboratary } \\
\text { Sample ID }\end{array}$ & $\begin{array}{l}\text { Actlvity } \\
\text { ipCisplo }\end{array}$ & & $\begin{array}{l}\text { Counting Enor } \\
\text { (phifal }\end{array}$ & $\begin{array}{l}\text { Tolal Enor } \\
\text { (pCigl }\end{array}$ & $\begin{array}{l}\text { MDA } \\
\text { (DCWG }\end{array}$ \\
\hline$\overline{E P A}: 01.1$ & $\operatorname{cs}-137$ & Nis01.2493-0. & 0.003 & & 0.043 & 0.043 & 0.000 \\
\hline$A C H / 123$ & $\sqcup-233 \sqrt{234}$ & NTS01-2483-01 & 0.730 & & $029 B$ & 0.331 & 0.183 \\
\hline AChNDIB & U-235 & NTS01 2483-01 & -0.007 & & 0.080 & 0080 & 0.205 \\
\hline Achite & L-238 & NTS01-2483-01 & 1939 & & 0.330 & 0.395 & 0.182 \\
\hline ACWNOS & FU-238 & NTSO1-2483-01 & 0.002 & & 0.035 & 0.035 & 0.078 \\
\hline ACWNDS & FU-239/240 & NTSO1-2483-01 & 0.013 & & 0027 & 0027 & 0.036 \\
\hline Acrics & $\operatorname{mat}-246$ & NTSOH 2463-CH & 0.002 & & 0003 & 0.033 & $\$, 072$ \\
\hline SFWO1 & SR-90 & NTS01-2483-D1 & 0.903 & & 0.455 & 0.465 & 0.630 \\
\hline
\end{tabular}

\begin{tabular}{|c|c|c|c|c|}
\hline \multicolumn{5}{|c|}{ Qualty Control Surplas } \\
\hline 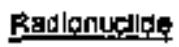 & Laboraton contra (LC) & Laporatory Dupllore (LD) & Matrtx SDike (tMS & Preprontion Blank (PE) \\
\hline Garmma & SCAQC-2493-LC1 & sCAQC-2483-1Di & & SCAQG-2433-PQ \\
\hline Sr & SCAOC-24B3-LC1 & SCAOC-2483-LD1 & & SCAQC-2483-PB \\
\hline $\mathbf{U}$ & SCACC-24BJ-LC1 & SCACC-2483-LD1 & & SCACO-24A3-PB \\
\hline $\mathrm{Pu}$ & SCAOC-24B3-LC1 & SCAQC-2483-LD1 & & SCAQC-2483PB \\
\hline Am & SCAQC-2483-LC1 & SCAQC-248S-LDI & & \$CAOC-2483-PB \\
\hline
\end{tabular}

$$
c-56
$$




\section{GENERAT ENGTWERTG LABORATORIES}

Miedring today's needs wid a wirion for tamerrow.

\section{Certificate of Analysts}

Cotnpany : Bechell Nevado

Adtrin: 2621 Loses Rord

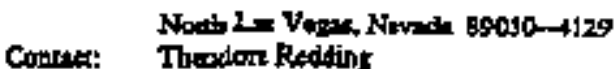

Repoxt Down July. 19.2009

Loyect: Eovironnentalkad Annlysis

Prote 1 of 2

Cliant Stanpis II).

Sngpide ID:

Matrix:

Conoct Date:

Recelve bors

Collectar.

25400546-VI Proiect NEVAODID]

4602000

Sct

20 Jun 01

22. JuN01

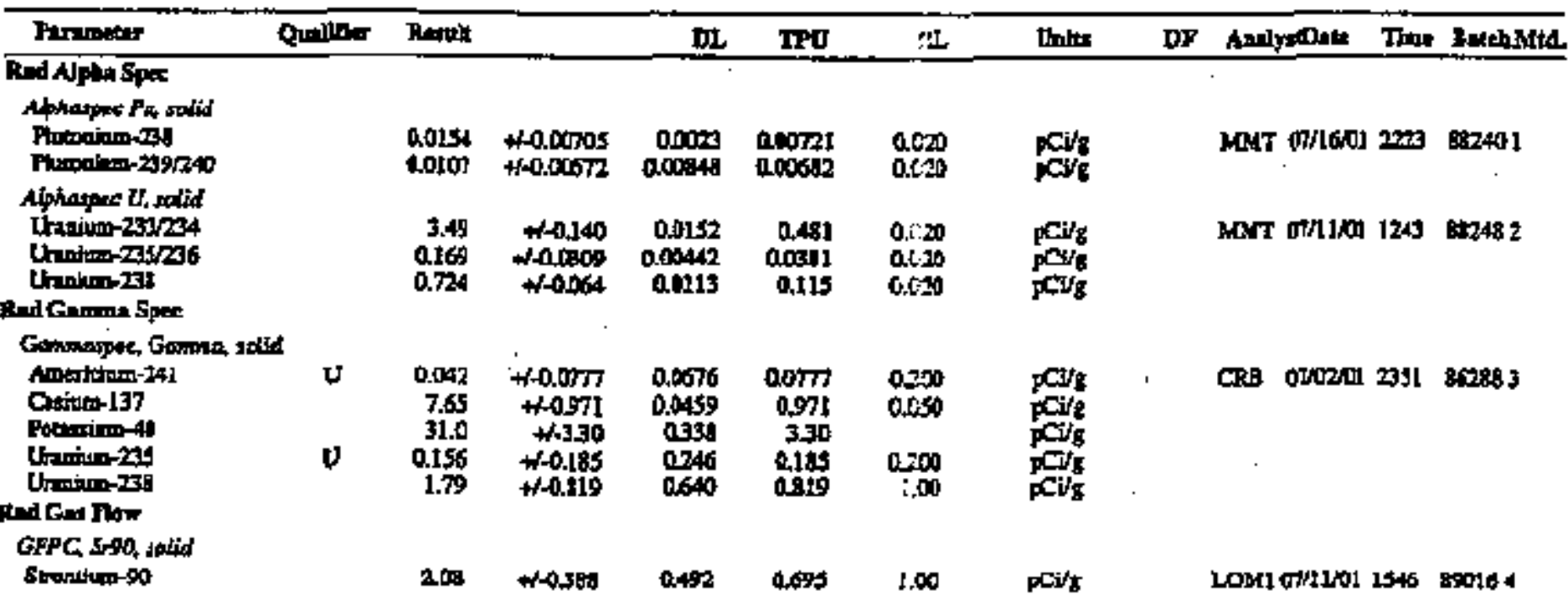

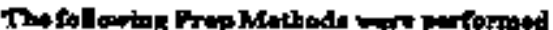

\begin{tabular}{|c|c|c|c|c|c|}
\hline Mrethod & Dexclpiton & $\overline{A+1+5 x}$ & Dat: & Thit & Fre Batel \\
\hline As Sod Prop & Avh Soll Prep RAD A-121,A03:E,A-026 & WEO & $0 ; 2501$ & 1341 & 86112 \\
\hline Dry Soli Prop & 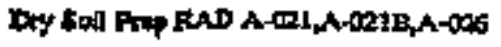 & WEO & ostingl & 2110 & 5607 \\
\hline
\end{tabular}

\begin{tabular}{|c|c|}
\hline Method & Denstiptima \\
\hline I & DOEDALHASL 300 \\
\hline 2 & DOE EMI HASL $\$ 00$ \\
\hline 3 & DOE RAL HASL 300 \\
\hline 4 & EPA 9A50 \\
\hline
\end{tabular}

Notes:

The Qulifies in this report gre defund as follows :

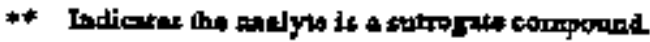




\section{GENERAL ENGINEERING LABORATORIES}

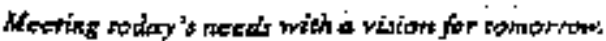

\section{Certificate of Analrsis}

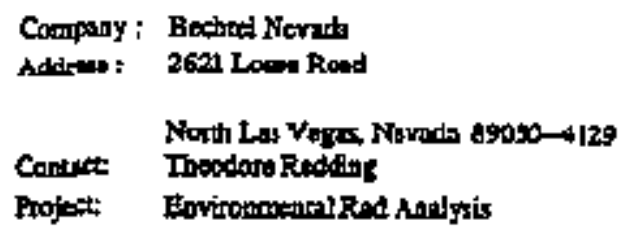

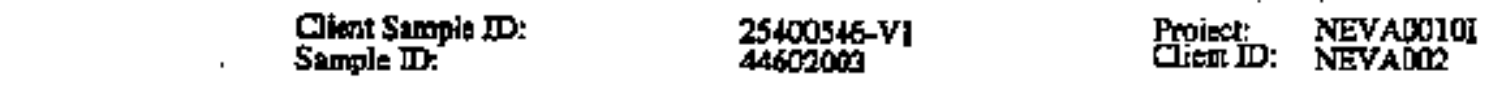

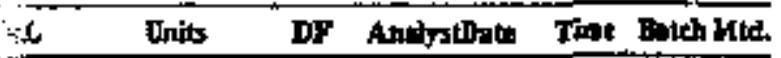

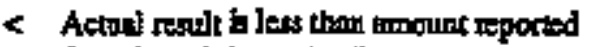

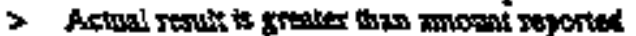

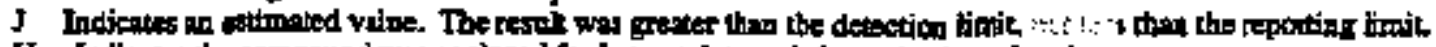

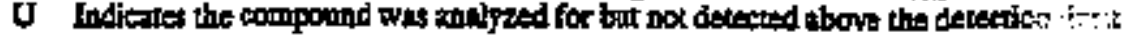

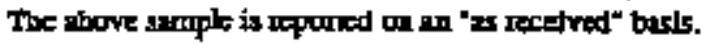

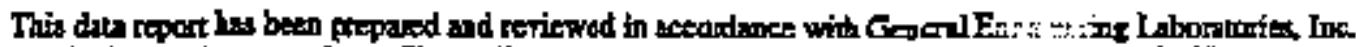

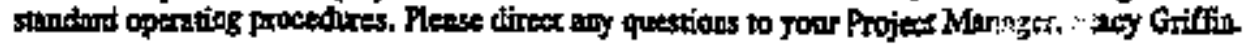

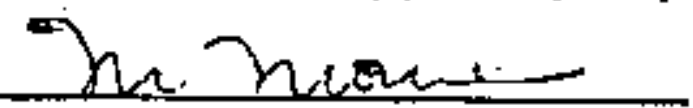

Ratiowed by 


\section{GENERAL ENGINEERING LABORATORIES}

Negring Itoday's needs wish a vision for iomorrow.

\section{Certificate of Analysis}

Company: Bechtol Nevadi

Addres: 2681 Loret Roul

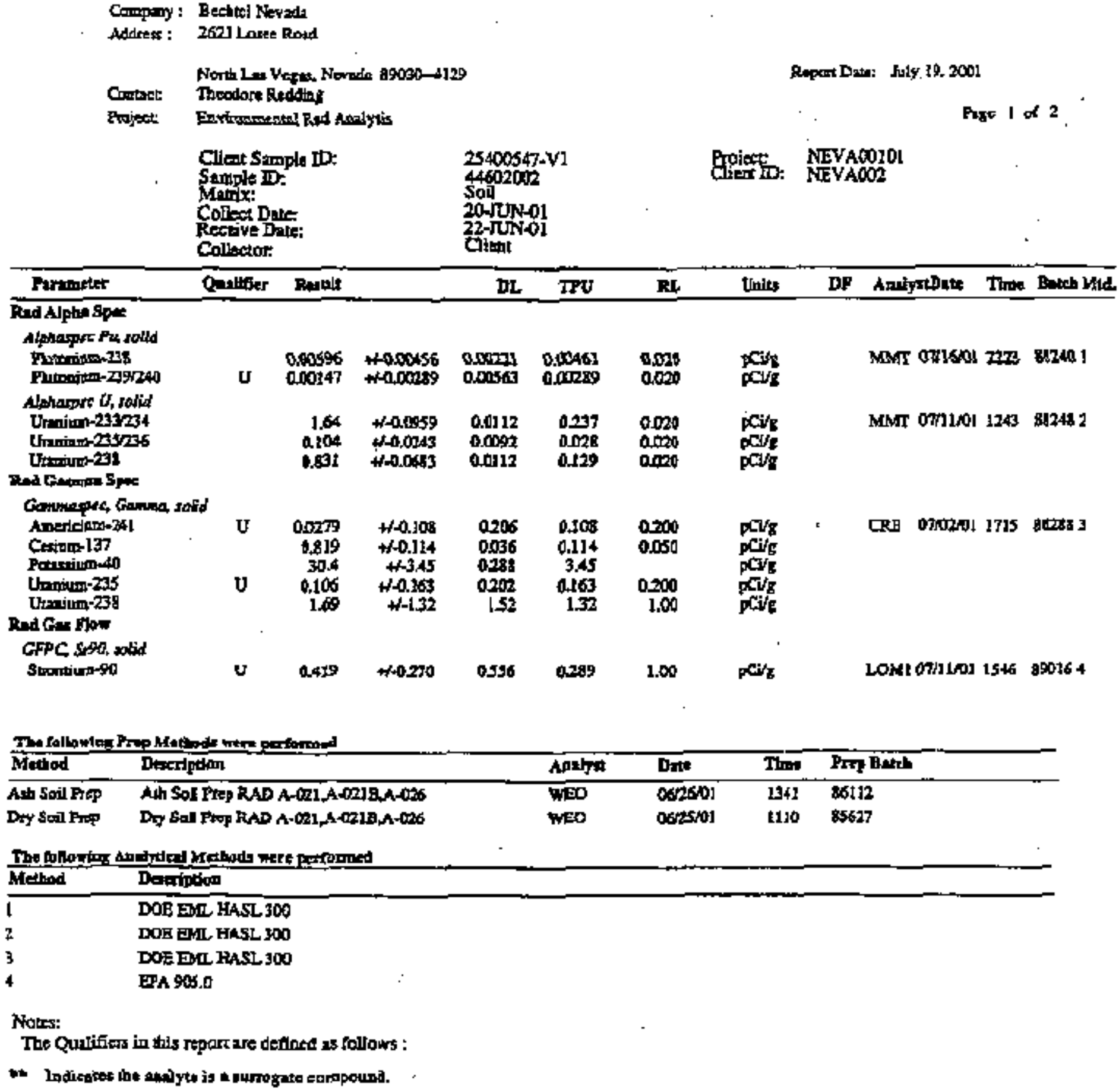




\section{GENERAL ENGINEERING LABORATORIES}

Metring laday sneedr with a virlon for rovormin.

\section{Certificate of Analysis}

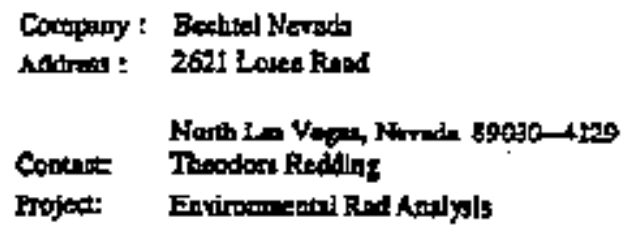

Rtpor but: July.10, 2001

bage 2 of 2

$<$ Actril rasplit is les then andont reposted

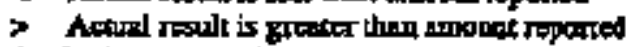

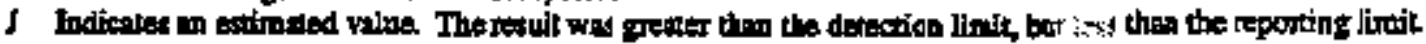

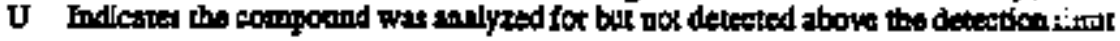

The above temple in trponted on an "as roceivod" bits.

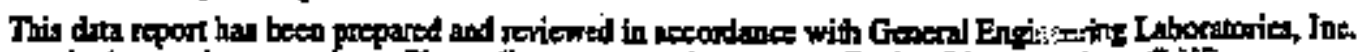

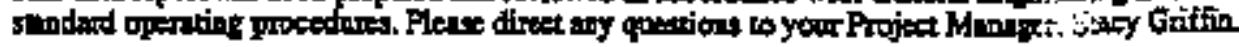

Reviewed by

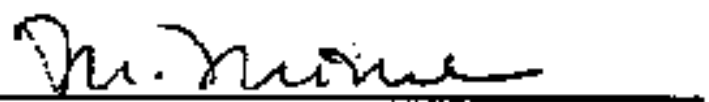




\section{GENERAL ENGINEERING I.ABORATORIES}

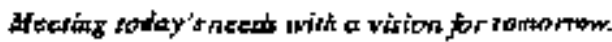

\section{Certificate of Analrsis}

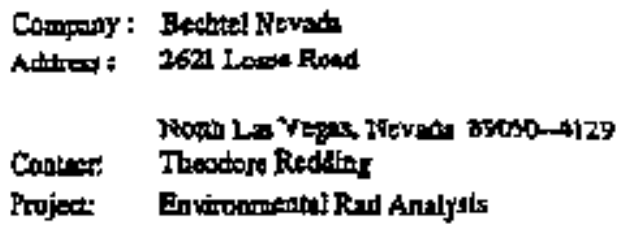

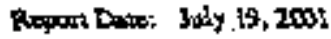

Page 1 of 2

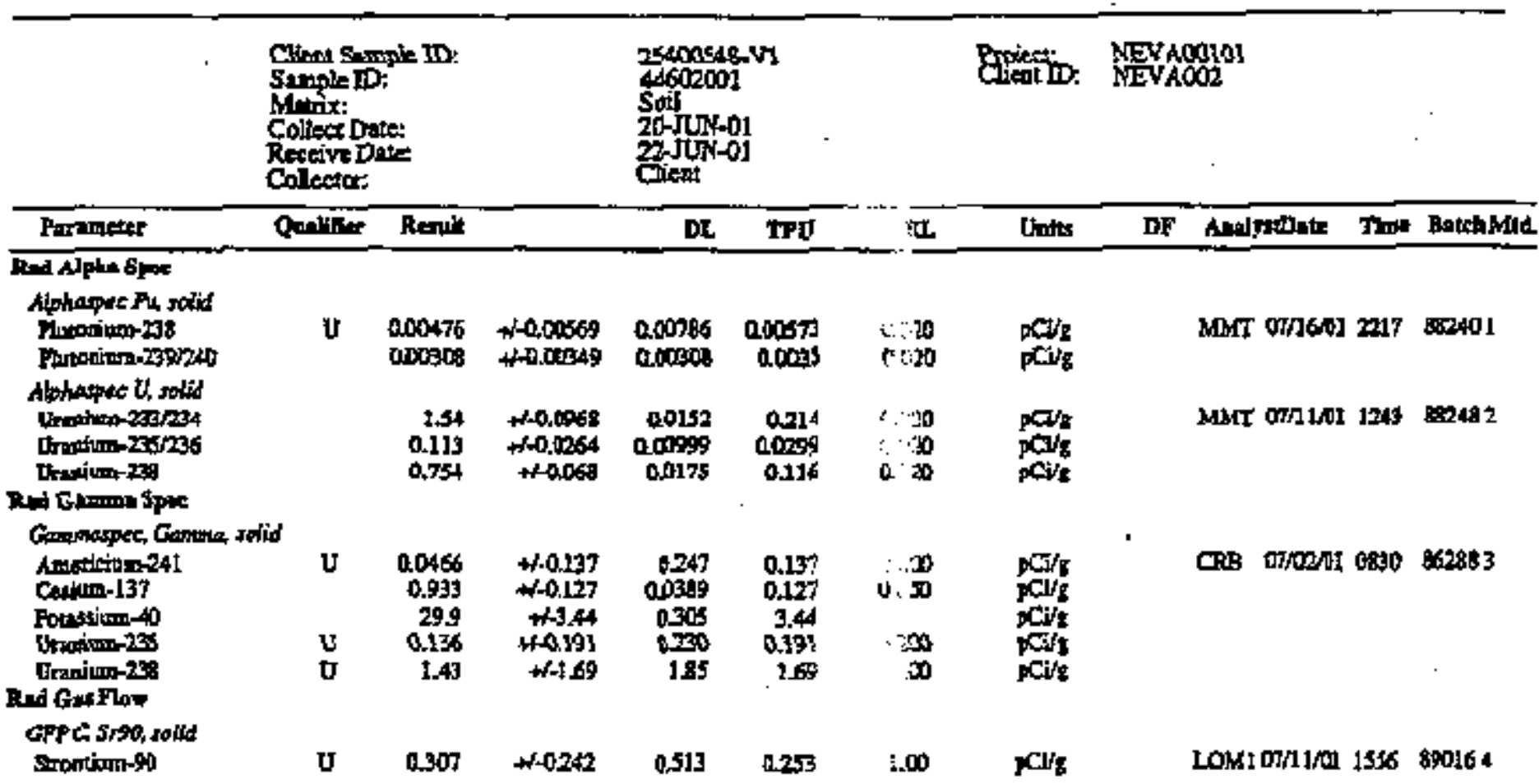

The followtin Fro Mtethods pere pertormed

\begin{tabular}{|c|c|c|c|c|c|}
\hline Mrtingor & Dexatption & Alantyit & Dante & Tin: & Butp Aake \\
\hline intherit tong & 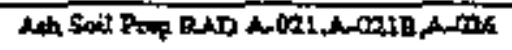 & wa & aepsial & $\overline{1342}$ & 85412 \\
\hline Dry Soil Prep & 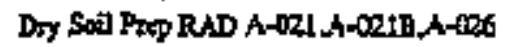 & WEO & O6RSA1 & 1110 & 15627 \\
\hline \multicolumn{6}{|c|}{ 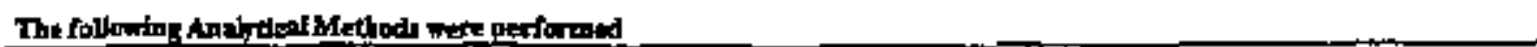 } \\
\hline Mripod & Dectiption & & & & \\
\hline I & DOE EXI, Inst 300 & & & & \\
\hline$z$ & DOEEML HASL 300 & & & & \\
\hline 3 & DOEEML EASL 300 & & & & \\
\hline 4 & EPATOS,O & & & & \\
\hline
\end{tabular}

Nates:

The Qrallifies in this repor ane defined as follows:

** Indicates the anjolyte is i surogrente componud. 


\title{
GENERAL ENGINEERING LABORATORIES
}

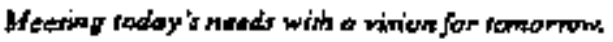

\section{Certfficate of Analysis}

\author{
Company i Beahtel Netrada

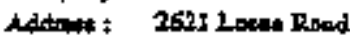 \\ Noth Lo Veras, Nevoda $8900-4129$ \\ Conter: Theodant Resting \\ Projer: Emiranoensel RodAnalyais
}

Repur Dant: July 19, 200!

Page 2 of 2 .

Clitent Sample ID. Samplio II:

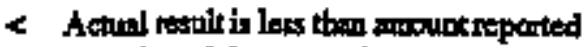

- Achial resoll is goriter thin amoint reported

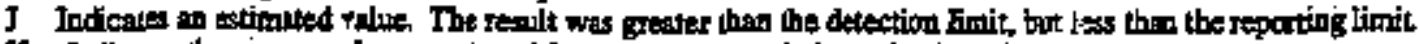

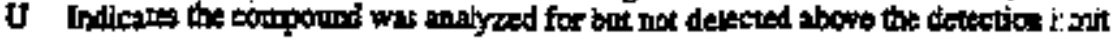

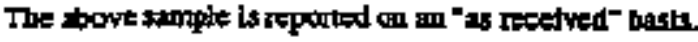

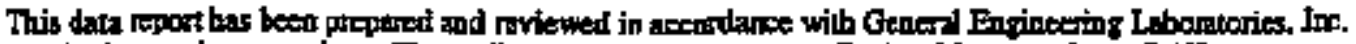

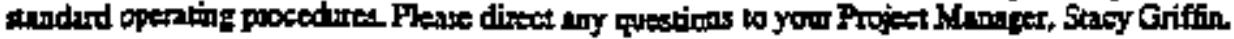

Rericwed by

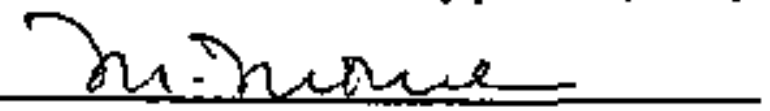


Sanford Cohen \& Associates

Southeastern Ervironmental Laboratory

Radioanalytical Results

Report denthication Number, S24B3

\begin{tabular}{|c|c|c|c|c|c|c|c|}
\hline $\begin{array}{l}\text { Propect Name: } \\
\text { slke sample to: } \\
\text { Olher sqmple ID: }\end{array}$ & $\begin{array}{l}\text { ochtel Nerect } \\
400 \text { sate-4a }\end{array}$ & Conalnor-ce & $\begin{array}{l}\text { ion Date: } \\
\text { Number: }\end{array}$ & & & $\begin{array}{l}\text { Ite Recolved: } \\
\text { oretery Code: }\end{array}$ & 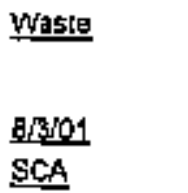 \\
\hline Method Number & Radionuclide & $\begin{array}{l}\text { Laboratory } \\
\text { Sample } 10\end{array}$ & $\begin{array}{l}\text { Activity } \\
\text { (ocidgl }\end{array}$ & & $\begin{array}{l}\text { Counting Enter } \\
\text { of Ciral }\end{array}$ & $\begin{array}{l}\text { Totill Error } \\
\text { lpCijo }\end{array}$ & MDA \\
\hline EPA 901.1 & $63-137$ & NTS01-24B3-03 & 4.778 & & 0.137 & 0.157 & 0.079 \\
\hline ACWnos & $U-233 / 234$ & NTSO1.2483-03 & 0.763 & & 0.291 & 0.329 & 0.071 \\
\hline ACHNOZ & $U-236$ & NTS01-2493-03 & 0.039 & & 0.099 & 0,100 & 0.184 \\
\hline ACWNOS & U-238 & NT $501 \cdot 2483-03$ & 0.576 & & 0.251 & 0.276 & 0.071 \\
\hline ACMNOB & PU.23B & NTS01.2483-03 & 0.002 & & 0.036 & 0.036 & $0.0 \% \mathrm{~s}$ \\
\hline ACWos & PU-Z39/240 & NTS01-2413-03 & $0.0 € 4$ & & 0.027 & 0.028 & 0.037 \\
\hline ACWOB & AM-241 & NTS01-2483-03 & 0.056 & & 0.058 & 0.057 & 0.03 \\
\hline SRWM-1 & SR-m & NTS01.2482-03 & 0.528 & & 0.377 & 0.381 & 0.558 \\
\hline
\end{tabular}

\begin{tabular}{|c|c|c|c|}
\hline \multicolumn{4}{|c|}{ Quality Control Smplas } \\
\hline Radienndide & Lenoratory Control (LC) & Laboratory Dupileste (LD) & Puppaption Elank (PB) \\
\hline Gamma & scage-24tz-LCi & Scasc-2483-104 & $\operatorname{scacc-2443-PB}$ \\
\hline Sr & SCAQG-24BS-LC1 & SCACR-2483-LD1 & SCAOC-2483PG \\
\hline 是 & SCACG-248S-LCI & SCAQC-2483-LD1 & SCAQC-2483-PB \\
\hline$p_{u}$ & SCAPC-7483-LCI & SCAMC-ZA83-LD & SCAOA-2A83PU \\
\hline An & SCAQC-2483-LCI & SCAQC-2463-LD1 & SCAQC-2403.PB \\
\hline
\end{tabular}




\section{Sanford Cohen \& Associates \\ Southeastern Environmental Laboratory \\ Radioanalytical Regults}

Report kentincetion Number: $\$ 2493$

\begin{tabular}{|c|c|c|c|c|c|c|c|}
\hline \multicolumn{2}{|c|}{ 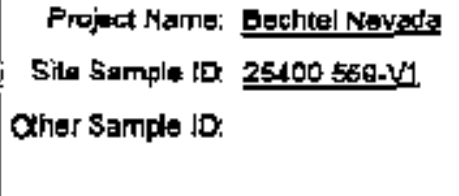 } & \multicolumn{3}{|c|}{ Chaln-or-Custody Numbar, Vizes } & \multicolumn{3}{|c|}{ Matrix Waste } \\
\hline Hethod Number & Rodionuedida & $\begin{array}{l}\text { Laboratory } \\
\text { Sample 10 }\end{array}$ & $\begin{array}{l}\text { Acthity } \\
\text { frowiti }\end{array}$ & 20 & $\begin{array}{l}\text { Counting Error } \\
\text { (ofolfol }\end{array}$ & $\begin{array}{c}\text { Total Error } \\
\text { (nCikg) } \\
\end{array}$ & $\begin{array}{c}\text { MDA } \\
\text { pCival }\end{array}$ \\
\hline EPA 901,1 & $\operatorname{cs}-137$ & NTS01-2483-02 & 1.05 & & 0.167 & 0.107 & 0.088 \\
\hline ACWA3 & $U-233 / 234$ & NTS01-2483-02 & 1.52 & & 0.418 & 0.518 & 0.143 \\
\hline ACANOS & U.235 & NTSBt-2483-02 & 0.037 & & 0.095 & 9.085 & 0.178 \\
\hline ACWNo3 & U-238 & NTS01-24B3-02 & 0.529 & & 0.250 & 0.272 & 0.186 \\
\hline ACWN3 & PU-23B & NTSO1-2483-D2 & -0.024 & & 0.034 & 0.034 & 0.100 \\
\hline ACWNO3 & PU-Z39/240 & NTSO1.2483-02 & 0.000 & & 0,000 & 0.000 & 0.039 \\
\hline ACWNO3 & AM-241 & NTSO1.2483-02 & 0.015 & & 0.030 & 0.030 & 0.040 \\
\hline SRWN1 & SR-gO & NTS01-2483-02 & 1.18 & & 0.455 & 0.470 & 0.555 \\
\hline
\end{tabular}

\begin{tabular}{|c|c|c|c|c|}
\hline \multicolumn{5}{|c|}{ Gualty Contrel Stiples: } \\
\hline Radlonuclide & Labaratery Control ac) & Ltorabar: Duplizate (D) & Moticix Soike (MS) & Propartion Blenth PE: \\
\hline Gamina & SCACA-24EB-LC1 & SCAOC-24gF-10 & & SCAQC.24BOPB \\
\hline Sr & SCAOC-24BS-LC1 & SCAOC-24B-101 & & SCAQC-2483-PB \\
\hline $\mathbf{U}$ & SCAOC-2480-LC1 & SCAQC-24:3-LD1 & & SCACG-2483-PB \\
\hline Pu & SCAQC-24B3-LC: & SEACC-24B3-10 & & SCAOC_2AEB-PB \\
\hline Am & SCAQC-2,45-LCl & SCAOC-24B3-LDI & & SCAOC-24LB-PB \\
\hline
\end{tabular}




\section{Radioanalytical Results}

Repart ldentrification Number: 52493

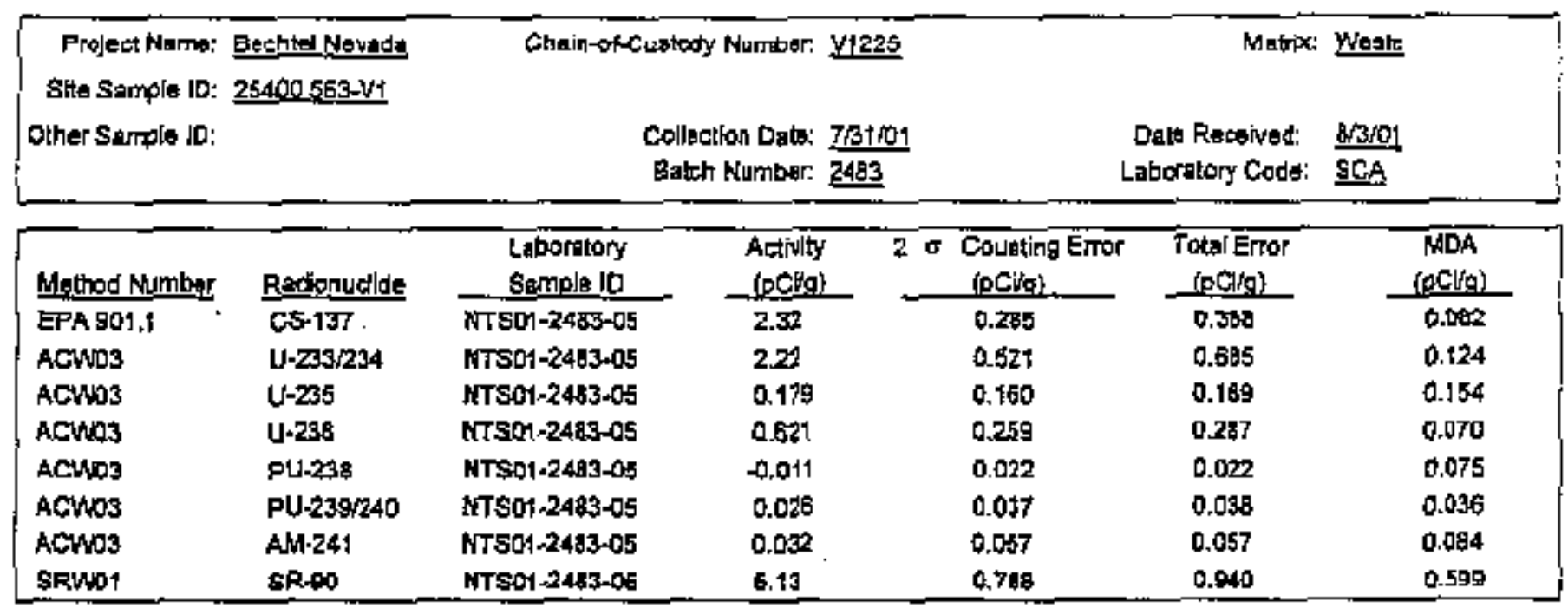

\begin{tabular}{|c|c|c|c|}
\hline \multicolumn{4}{|c|}{ Otullky Confrol Sermples } \\
\hline Radionucills: & Lebortatgry Control (the) & Labogetory Dsplicate (LD) Matrk Spike (HS) & Preparglion Blank (PB) \\
\hline Oaminam & achoc-2483-LCr & ACAQC-2493-101 & SCADC-2485-PB \\
\hline $5 r$ & SCACC-2483-LCI & SCAQC-2483-D1 & SCAOC-2483-PB \\
\hline$\Downarrow$ & $\operatorname{senco-2483-LA1}$ & SCAQC-24e3-104 & SCAOC-2483-PR \\
\hline Pu & SCACC-2403-LO1 & SCAQC-2403-61 & SCADC-2A43-PB \\
\hline $\mathbf{A m}$ & SCACC-2483-LC1 & $\operatorname{sc4} 40 \cos 243-101$ & SCACC-2493-PB \\
\hline
\end{tabular}




\section{THIS PAGE LEFT INTENTIONALLY BLANK}




\section{EXCAVATION VERTICATION SAMPLES}


THIS PAGELEFT INTENTIONALI,Y BLANK

$C-68$ 
Gamma Spectometry

C-69 
Sanford Cohen \& Associates

Southeastern Envirommental Laboratory

Radloanalytioai Results

Report Identhication Nuniber. S2e6s

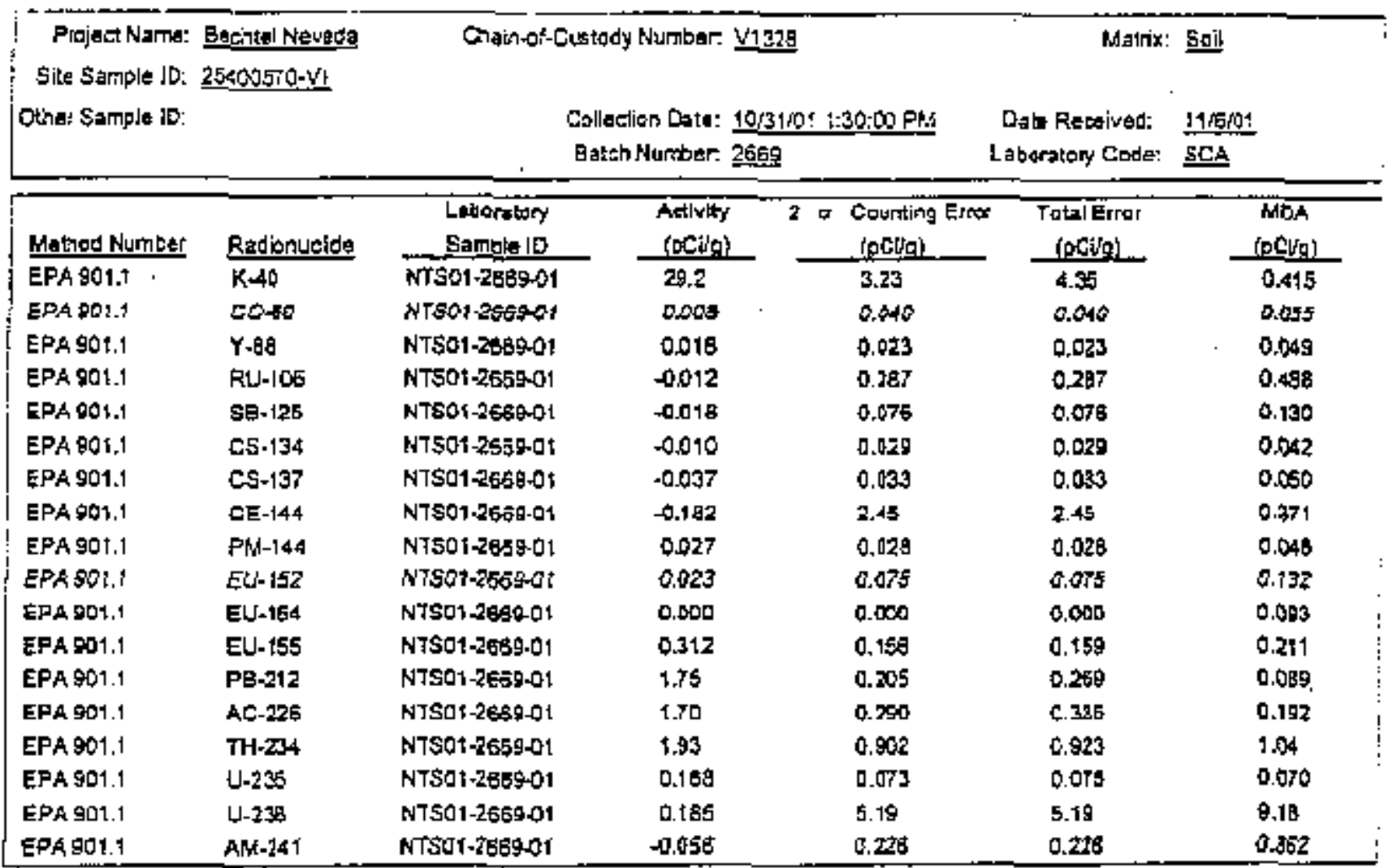

\begin{tabular}{|c|c|c|c|c|}
\hline \multicolumn{5}{|c|}{ Gually Controb Samplas } \\
\hline Redionuelids & LEborekary Contmet iLCI & Lethotatery Duplifeter. (L) & Matux Epike (MNS) & Rieparatlan Elonk (목) \\
\hline Gartant & SCAGQ-26ES-LCI & 5CADC-2669LD1 & & SCAQC-2459+PB \\
\hline
\end{tabular}


Radloanalytical Results

R.eport Identritation Number, S26ẹ

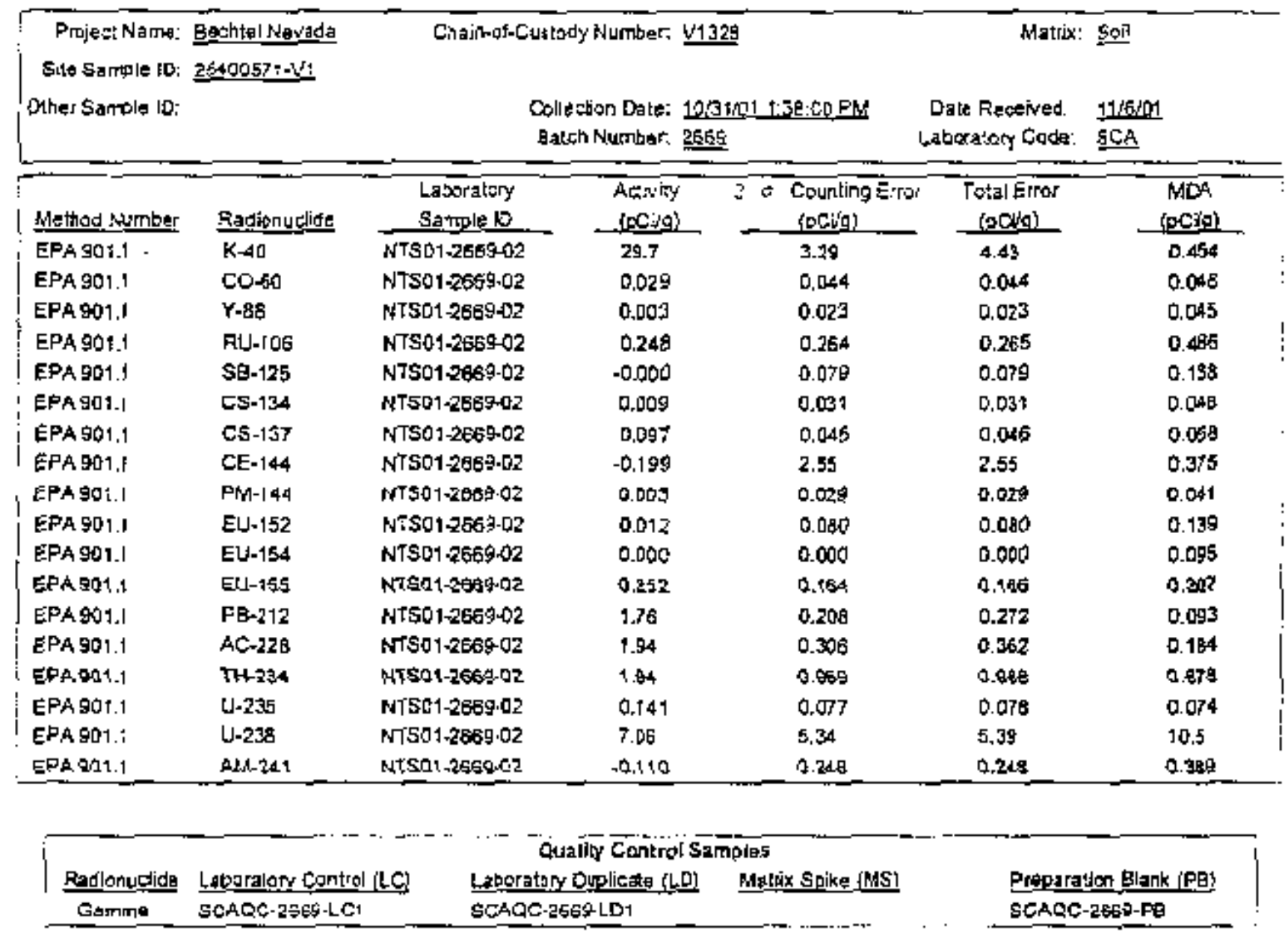




\section{Southeastern Environmental Laboratory}

\section{Radioanalytteal Results}

Report Identitication Number: 52 seg

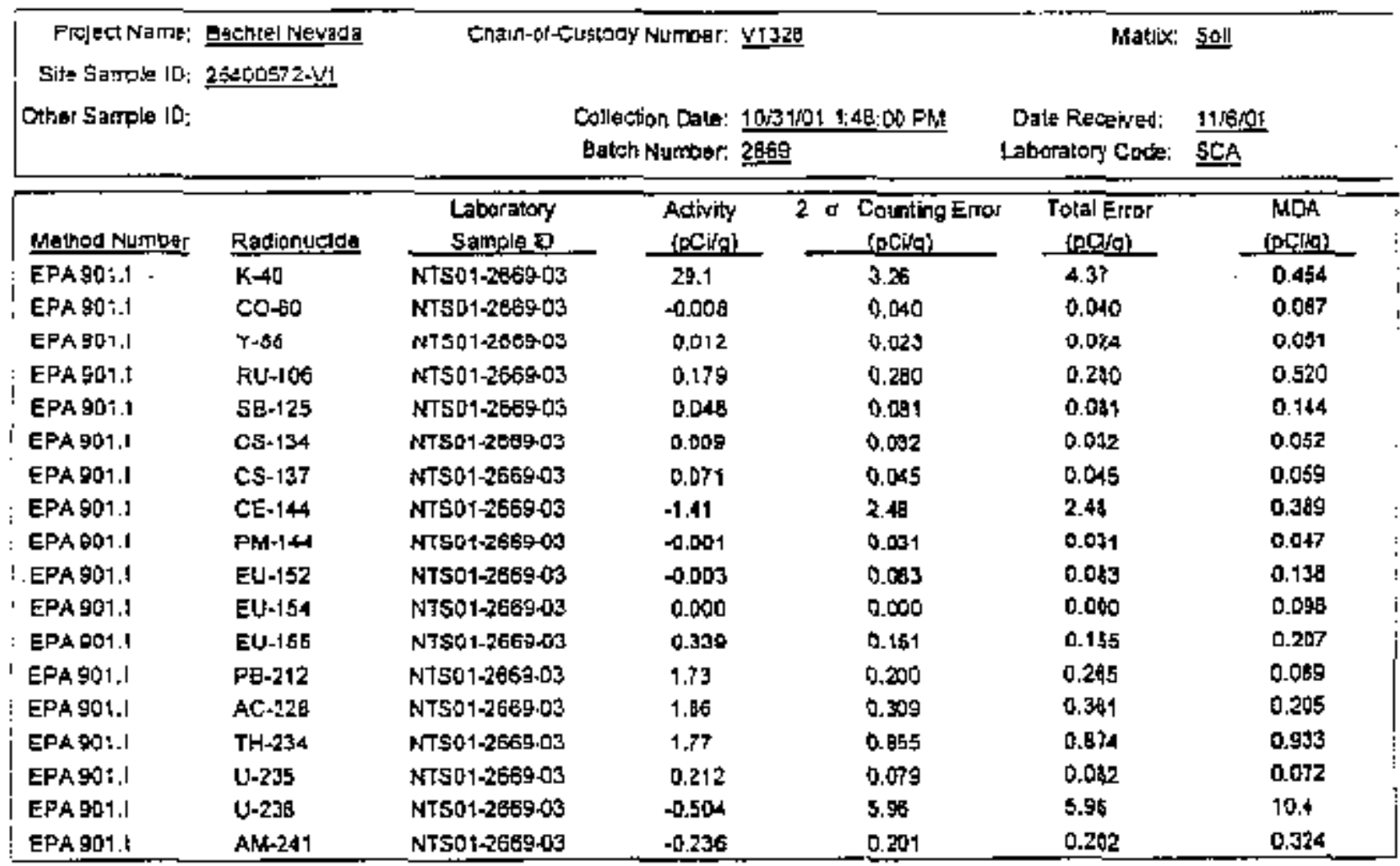

\begin{tabular}{|c|c|c|c|c|}
\hline \multicolumn{5}{|c|}{ Qualiy Controt Samples } \\
\hline 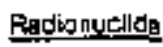 & Laboratory Control (LC) & 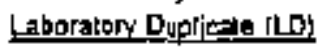 & Maldx Spike (MS) & Pregaratıon Blank [PS] \\
\hline Garme & SCAOC.2689-LCI & SCROC.2659LO1 & & SCAOC-2659.FI \\
\hline
\end{tabular}




\section{Sanford Coher \& Associates \\ Southeastem Envir ormental Laboratory}

Radloanalytical Results

Repart Idantlication Nursber: 52569

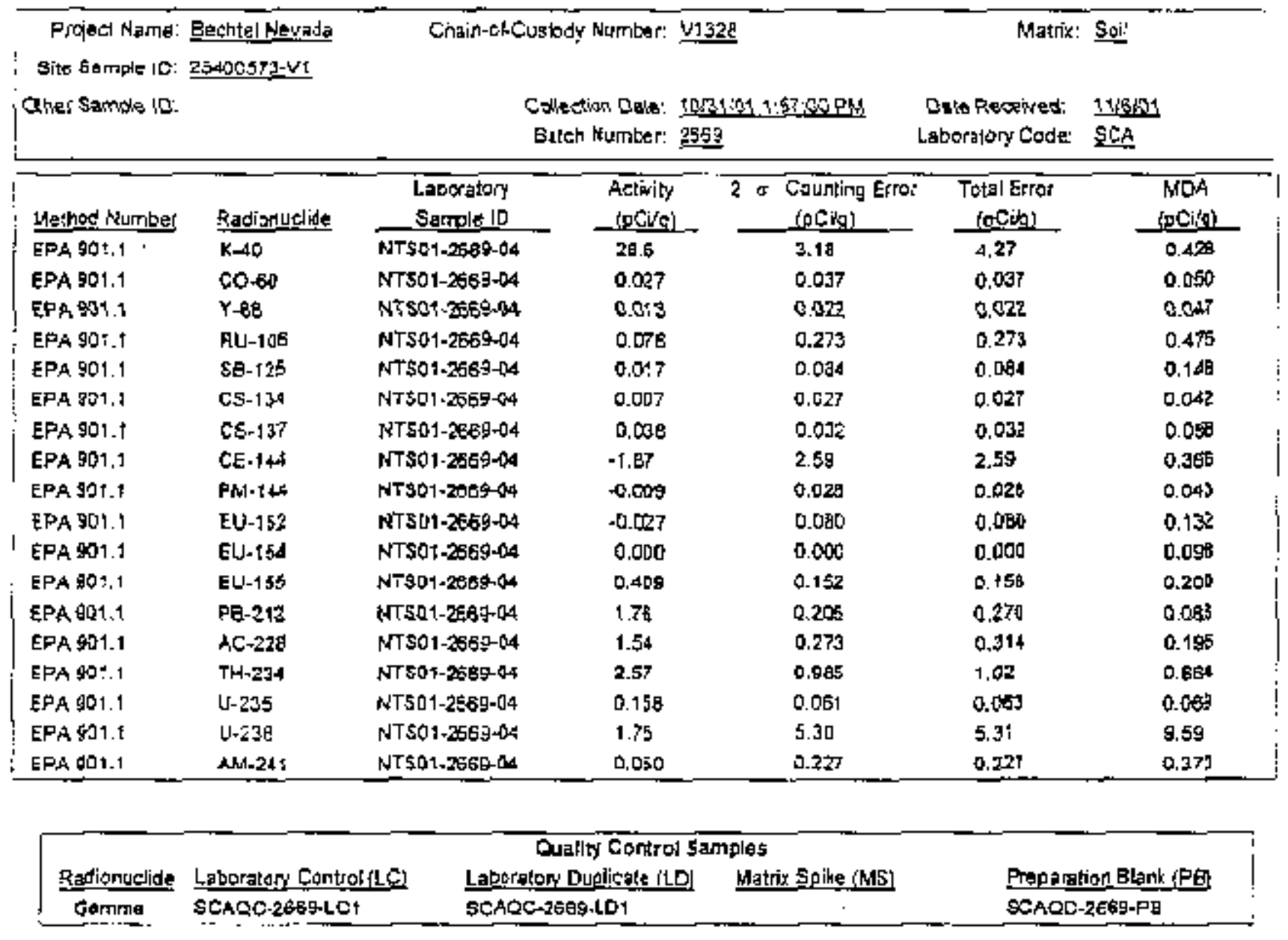




\section{Southeastern Envlronmental Laboratory}

Radioanalytical Results

Report Identiácatlon Nunber. \$2ógg

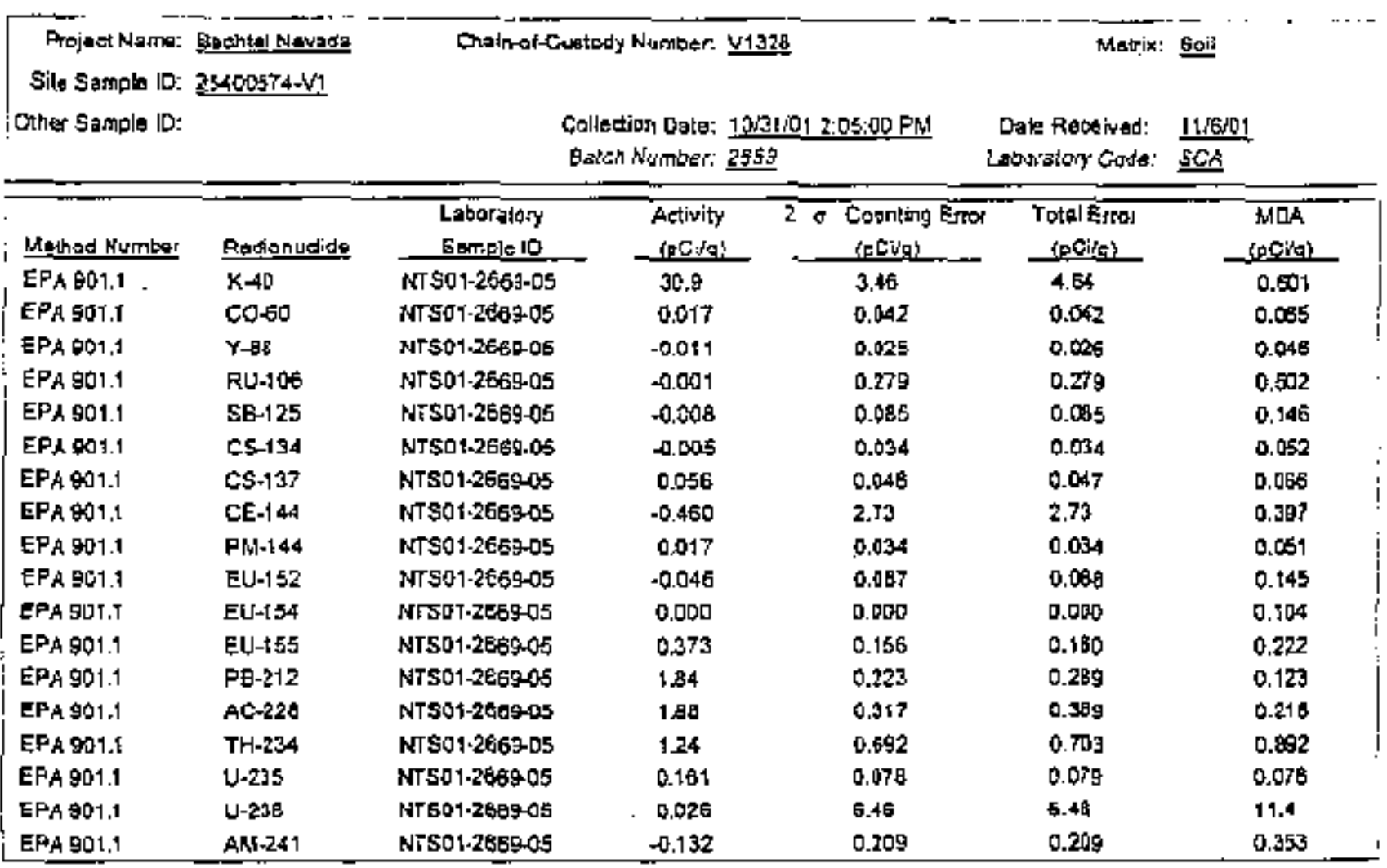

\begin{tabular}{|c|c|c|c|c|}
\hline & & Duafity Centrol 5 & Ales & \\
\hline Radonucalde & baboratory Contro: [LC] & 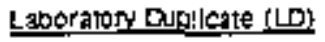 & Matix Solke (MS) & Fregration Blank i $P$ De \\
\hline Gamma & SCACE.2559-LE1 & SCAOC-2B6\%LD1 & & SCAOC-2B69-FB \\
\hline
\end{tabular}


Sanford Cohen \& Associates

\section{Southeastern Environmental Laboratory}

Radioznalytical Results

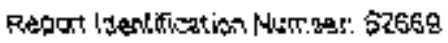

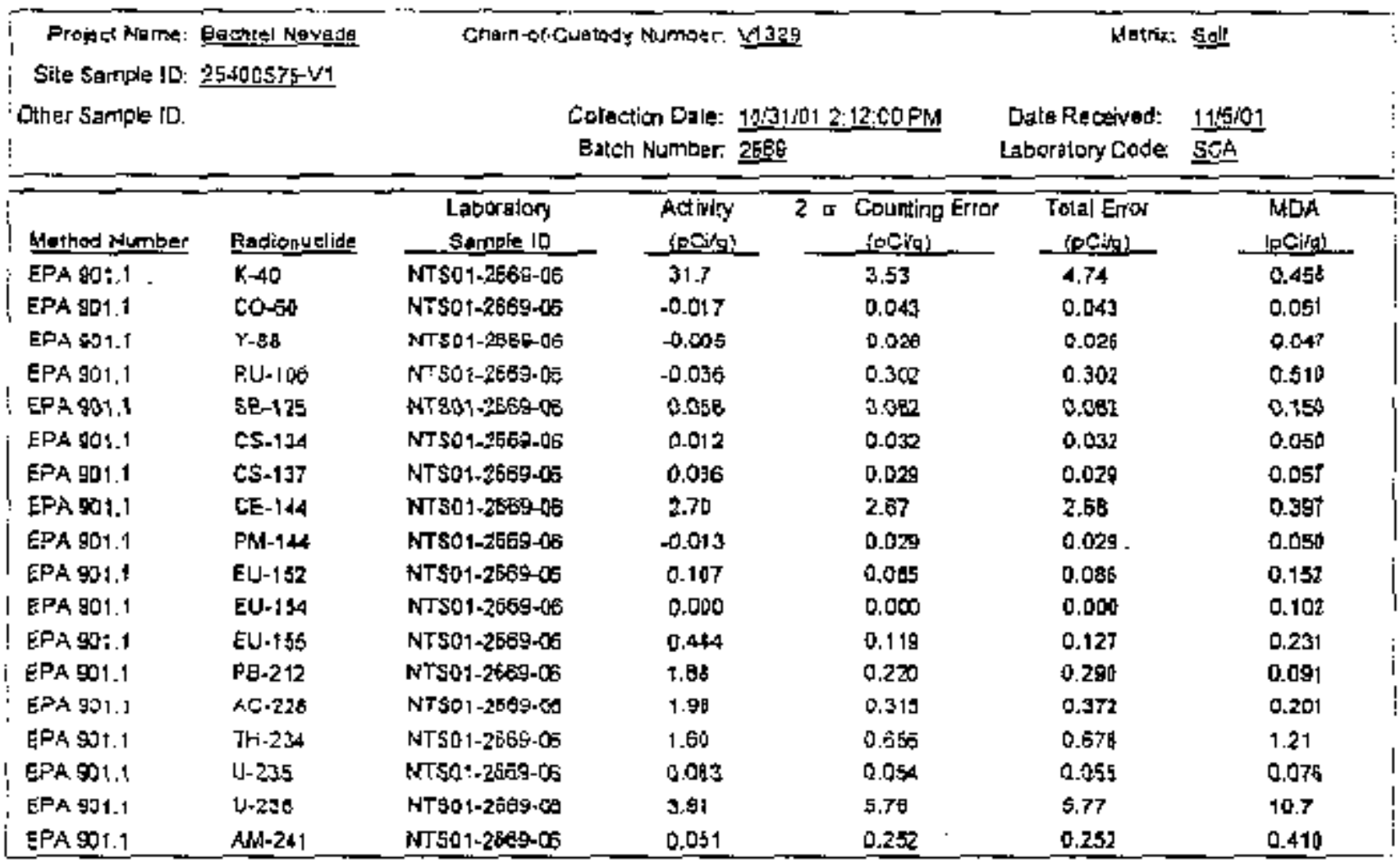

\begin{tabular}{|c|c|c|c|c|}
\hline \multicolumn{5}{|c|}{ Gualdty Control Sumples } \\
\hline Eisgiontueinge & 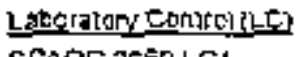 & 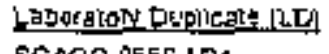 & Matinx spike imbi & 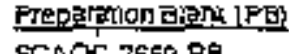 \\
\hline
\end{tabular}


Sanford Cohen \& Assoclates

Southeastern Environmental Laboratory

Radtoanalytical Fesults

Report Idankifieation Nurnter, \$2659

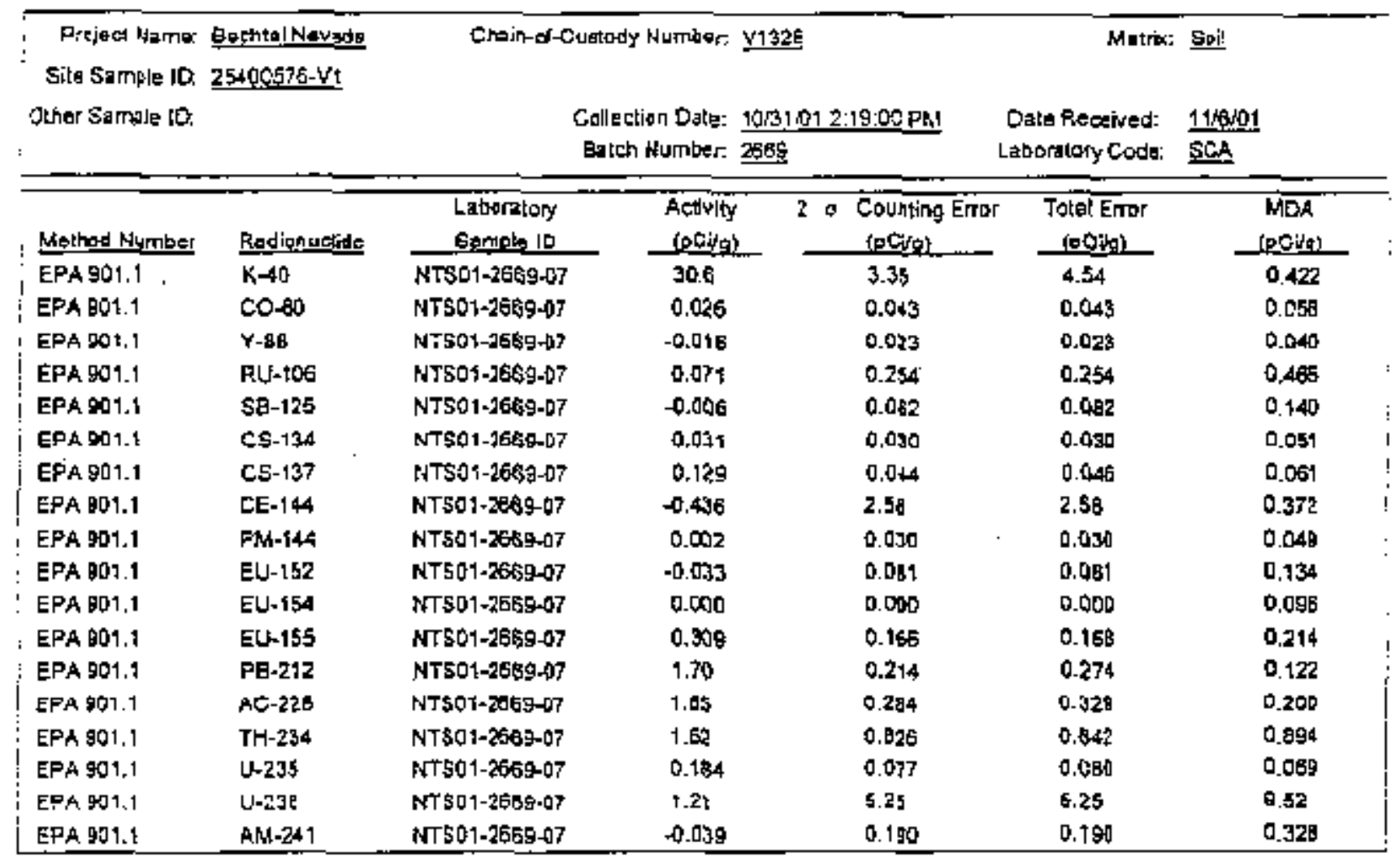

\begin{tabular}{|c|c|c|c|c|}
\hline \multicolumn{5}{|c|}{ Cuality Control Samples } \\
\hline Rodianuellda & Laboralury Control ( $(5)$ & Laporaton ㅁypllesk & Matrly Splke (MS) & Brepalation Blank fFG \\
\hline Gamma & SCAQC 2689-LC1 & SCAOC-20GOLDI & & SCAQC-2650.PB \\
\hline
\end{tabular}




\section{Southeastern Environmental Laboratory}

Radioanalytical Res ults

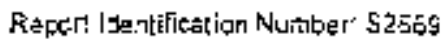

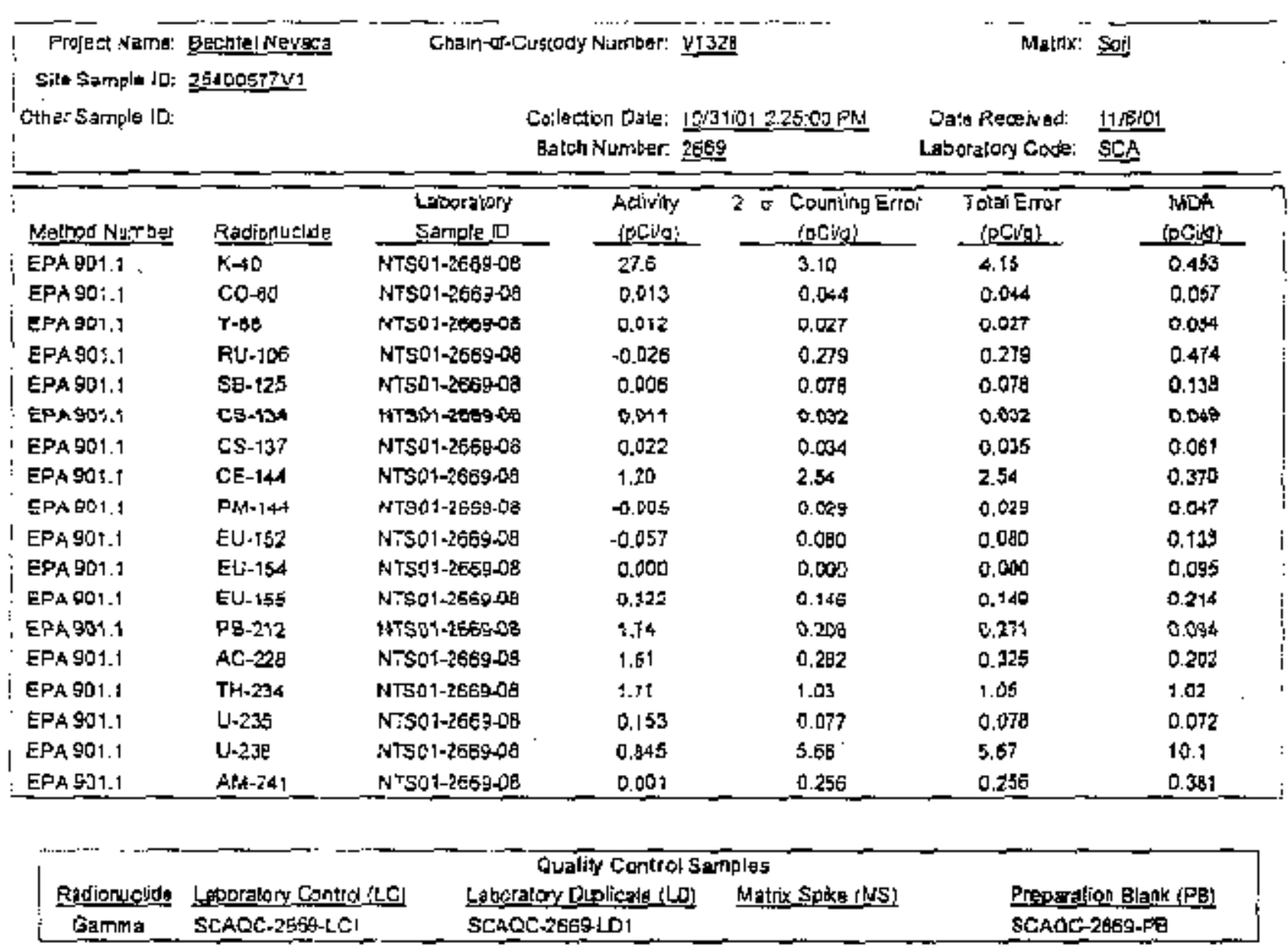


Sanford Conen \& Associates

Southeasstern Environmental Laboratory

Radioanalytical Results

Reppott tontiffiction Number 52559

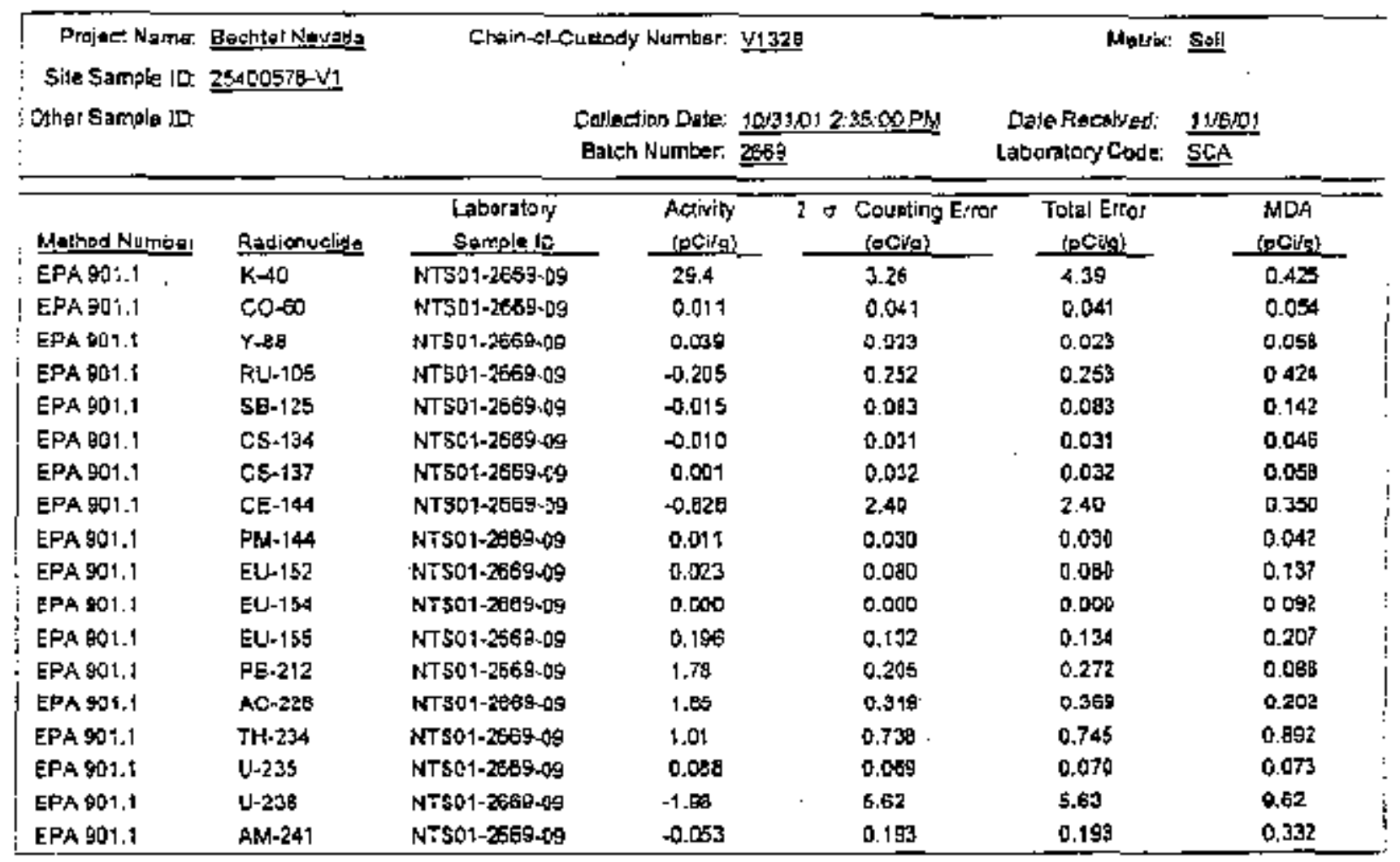

\section{Quallty Contrisl Samples}

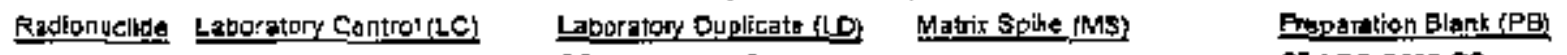

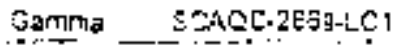
SCACC-2669EO1 
Radioanalytical Results

Regort itentification Number: S20̄6g

\begin{tabular}{|c|c|c|c|c|c|c|c|}
\hline 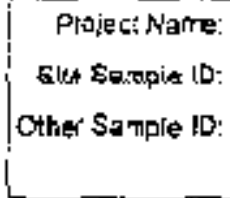 & $\begin{array}{l}\text { Eepchtel Nepuaca } \\
254005 ? 9-41\end{array}$ & \multicolumn{3}{|c|}{ Chain-of-Custody kumber. V1328 } & :A1:COPH & \multicolumn{2}{|c|}{ Matrix: 些il } \\
\hline Mathed Number & Radionudide & $\begin{array}{l}\text { Lasoratory } \\
\text { sampine ID }\end{array}$ & $\begin{array}{l}\text { Adtivity } \\
\text { ipcivel }\end{array}$ & 20 & $\begin{array}{l}\text { Countirsy Error } \\
\text { (ocitgl }\end{array}$ & 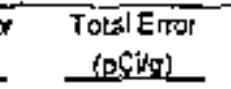 & $\begin{array}{r}\text { MDA } \\
\text { fPCVal } \\
\end{array}$ \\
\hline EPA 901.1 & $k-8$ & NTS01-25BO-10 & $30 . \overline{6}$ & & 3.39 & 4.56 & 0.483 \\
\hline EPA 001.1 & 6060 & NTSOL-266g-10 & 0.002 & & 0.042 & 0.042 & 0.055 \\
\hline EFA & $\gamma-8$ & סוי. & 2000 & & D.D20 & 0.023 & 0.048 \\
\hline EPA OD1.J & RU-10B & NTS01-2859.10 & 0.111 & & 0.284 & 0.284 & 0.500 \\
\hline EPA $901 . \dagger$ & \$B-125 & NTS01-2669-10 & 0.002 & & 0.085 & 0.065 & 0. 149 \\
\hline EPA 901.1 & ES-13 & NTSO1-2609-10 & -0.014 & & 0.034 & 0.094 & 0.040 \\
\hline EPA 901,1 & 65.137 & MT\$01.2669-40 & $0.1 f 9$ & & 0.053 & 0.065 & 0.059 \\
\hline EPA SO1.1 & CE-1 44 & NTSO1-256 -40 & -219 & & 2.35 & 2.6 & 0.397 \\
\hline EPA No1, 1 & PM-144 & NT\$01-2609-10 & 0.027 & & 0.030 & 0.000 & 0.045 \\
\hline EPA $\$ D_{1} 1.1$ & EU-152 & NTSO1-28姆10 & -0.018 & & 0.082 & 0.082 & 0.141 \\
\hline$E P A 901.1$ & EU-15i & NTSO 1-2589-10 & 0.000 & & 0.000 & 0.000 & 0.088 \\
\hline EPA & Eบ-155 & NTS01-2EEg-10 & 0.420 & & 0.168 & 0.182 & $0.21 \theta$ \\
\hline EPACOS.1 & PB-2:2 & NTSOY-2589-10 & 4.87 & & 0.220 & 0.283 & 0.101 \\
\hline EPA $\$ 0 \uparrow .1$ & $A C-228$ & NTSD1.26Eg-10 & 9.86 & & 0.319 & 0.369 & 0.170 \\
\hline EPA DD1.1 & THH.23A & NTSO1-2669-10 & 1 es & & 0,964 & 0.6865 & 1.21 \\
\hline EPA GO:.T & U.235 & NTS01.2669.10 & 0.205 & & 0.085 & 0.067 & 0.076 \\
\hline EPA g01.1 & 0.230 & NTS01-26e8-10 & 2.44 & & 5.44 & 5.45 & 9.99 \\
\hline EOAO91.1 & Am-241 & 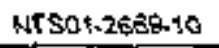 & -0.124 & & 0.248 & $0.24 \mathrm{~B}$ & 0.385 \\
\hline
\end{tabular}

\begin{tabular}{|c|c|c|c|c|}
\hline \multicolumn{5}{|c|}{ ouryly comion 5 ampias } \\
\hline Rafioneddde & Lesboratory Control \{LC] & Llaborabry Duol|cite tinh & Matrx Solke (HS) & Preparat|on alank (FE) \\
\hline Gammo & SCAOC-ZESD-LC1 & GCAOC-2660-LD1 & & ECAQC-2560-8日 \\
\hline
\end{tabular}


Radioanabytical Results

Rapert Iseantîication Wumber: Sz669

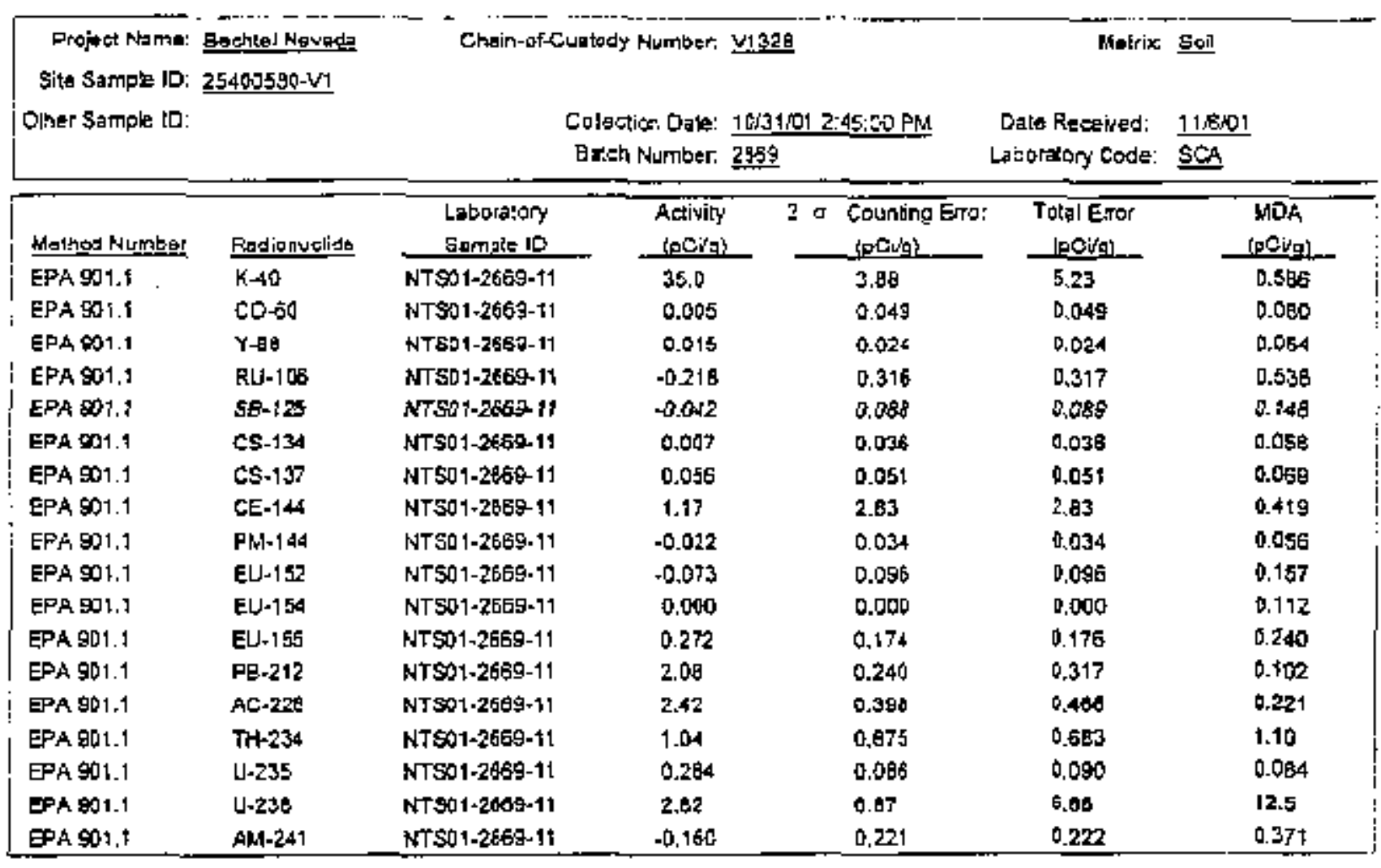

\begin{tabular}{|c|c|c|c|c|}
\hline \multicolumn{5}{|c|}{ Quality Contral Samples } \\
\hline Ragionufdatd & Laboralon Centrel [LC) & Leaboratory Gupdctcate $[\in \square\}$ & platrly splke [MS] & Prepararlon Bank $\{P B\}$ \\
\hline Gamma & SCAOC-2GEQ-LCI & SCADC-2669-LD1 & & SCAOC-26EDPB \\
\hline
\end{tabular}


Sanford Cohen \& Associates

Southeastern Environmental Laboratory

Radloanalytlat Results

Repor Jdentifleation Number: SiEeg

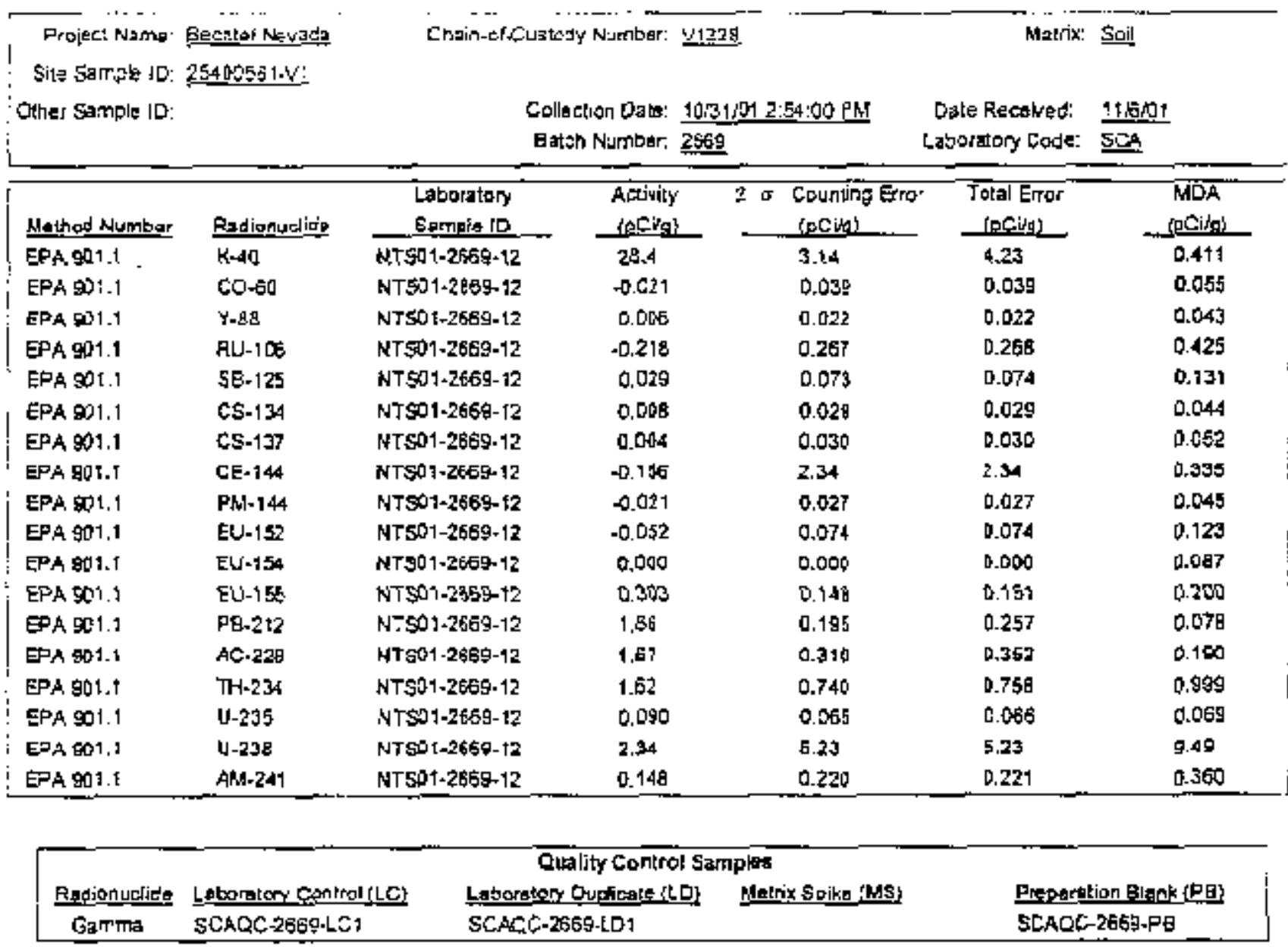

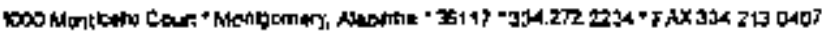

12

$c-81$ 
Sanford Cohen \& Associates

\section{Southeastem Environmental Laboratory}

Radioanalytical Rẹsults

Rewart tdenliflaction Number: 32559

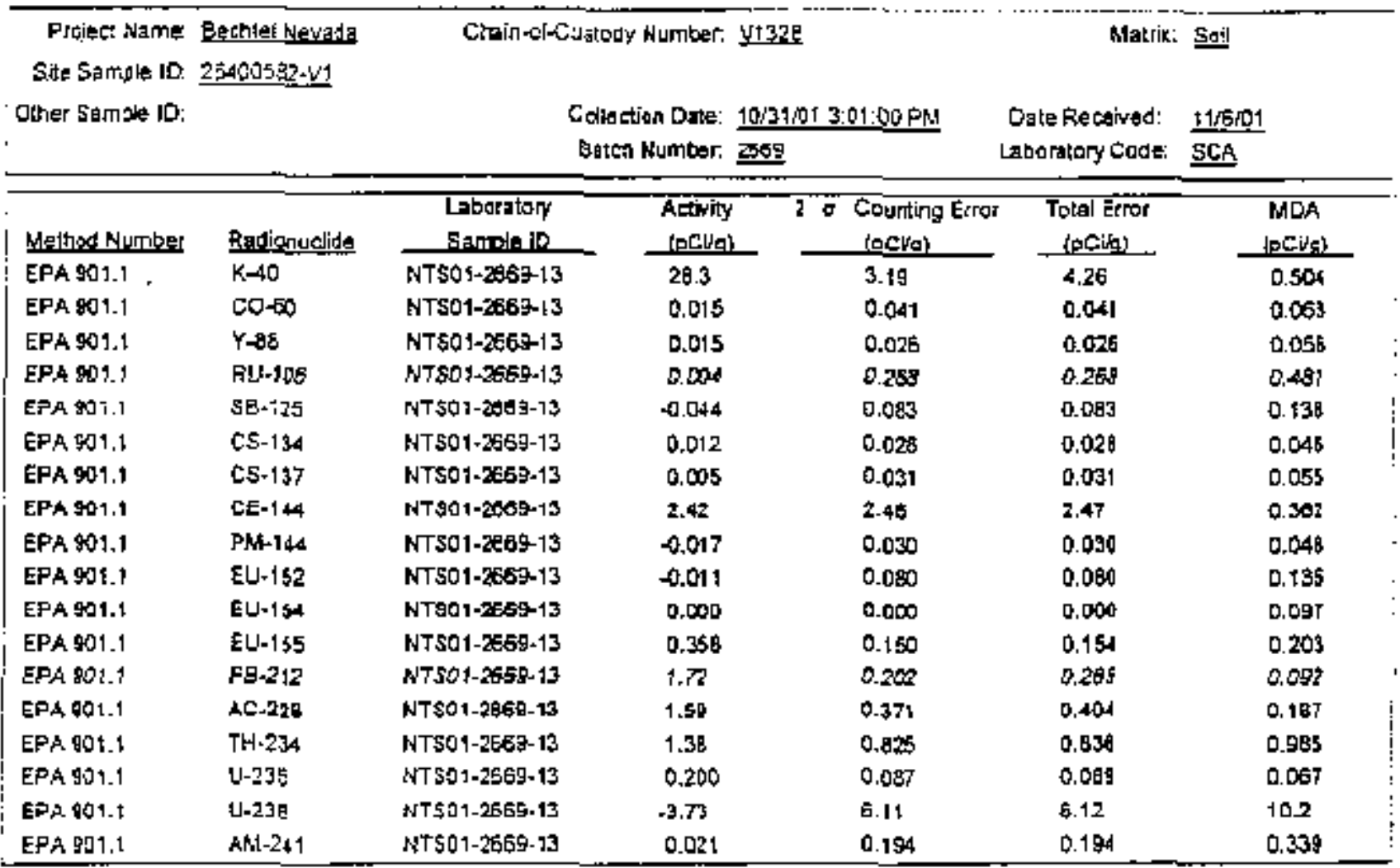

\begin{tabular}{|c|c|c|c|c|}
\hline \multicolumn{5}{|c|}{ Duality Controd \$amphs } \\
\hline Rodjonuldede & Lleboratory EontrolithC) & Leborkby Dyogicats in & Mstrix Spike !MS! & Propernolyon Blank \{PB] \\
\hline Gaturng & SCADC-2665:-C1 & SCADC-2669-101 & & $\mathrm{SC} \cdot \mathrm{AOC}-2 \mathrm{~B} 89 . \mathrm{PA}$ \\
\hline
\end{tabular}

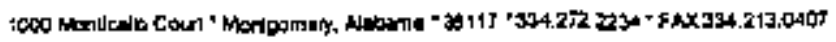


Sanford Cohen \& Associates

\section{Southeastem Environmental Laboratory}

Radiognalytlodd Results

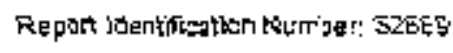

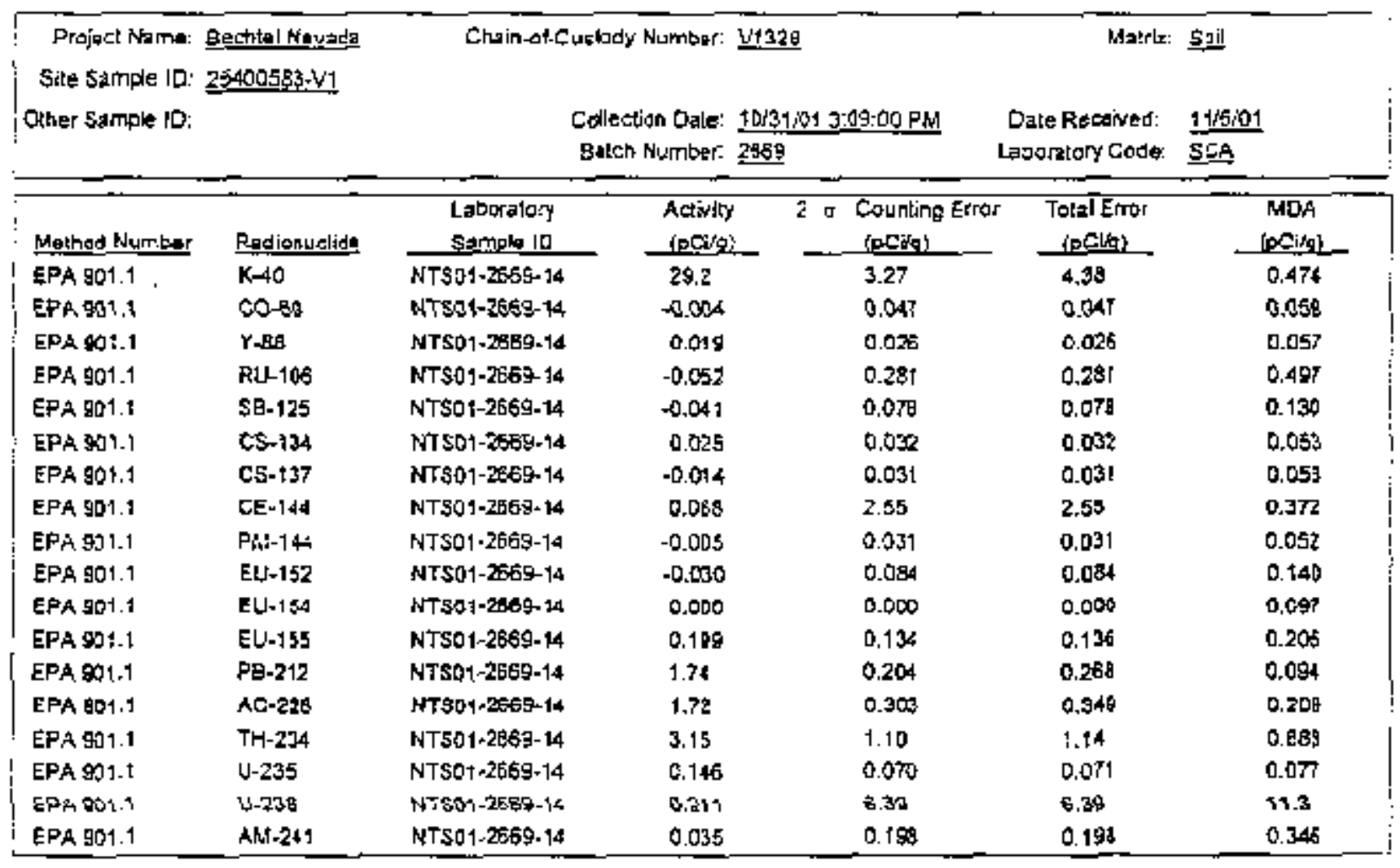

\begin{tabular}{|c|c|c|c|c|}
\hline \multicolumn{5}{|c|}{ Wolity Contud Samples } \\
\hline Radlonudide & 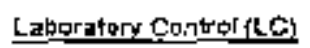 & 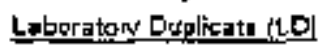 & Matrix Fpihe \{MS & Preparation Riank (Pa) \\
\hline Gampa & इCAOC-25694Ct & SCAOC-268D-LD1 & & SCACC-2ES\%-PG \\
\hline
\end{tabular}


Sanford Cohen \& Associates

Southeastern Environmental Laboratory

Radioanafytical Rosults

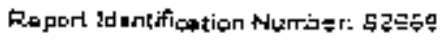

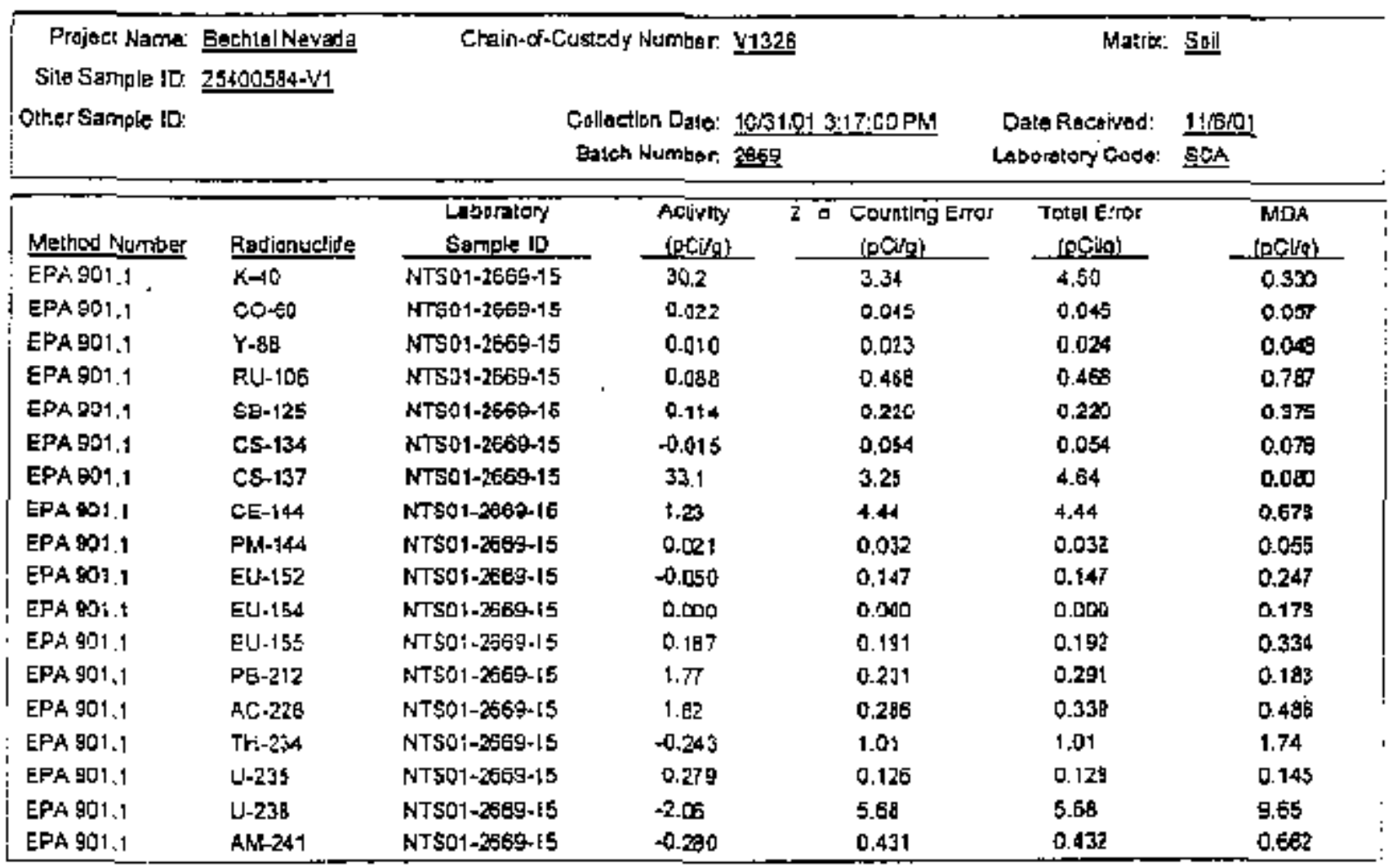

\begin{tabular}{|c|c|c|c|c|}
\hline \multicolumn{5}{|c|}{ Duallt Gontrol Gamples } \\
\hline Radionuctide & Lesporatory Control (LC) & Laboratorc Qund laste (LC) & Matrix Soire thisl & Econaration Blark $\left\{\mathrm{P}^{2}\right.$, \\
\hline Gamma & SCAQC-2Дag-LCI & SCACC-2665LC1 & & SCAOC-26B9-PB \\
\hline
\end{tabular}


Sanford Cohen \& Associates

Southeastern Environmental Laboratory

Radibamalytika! Results

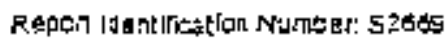

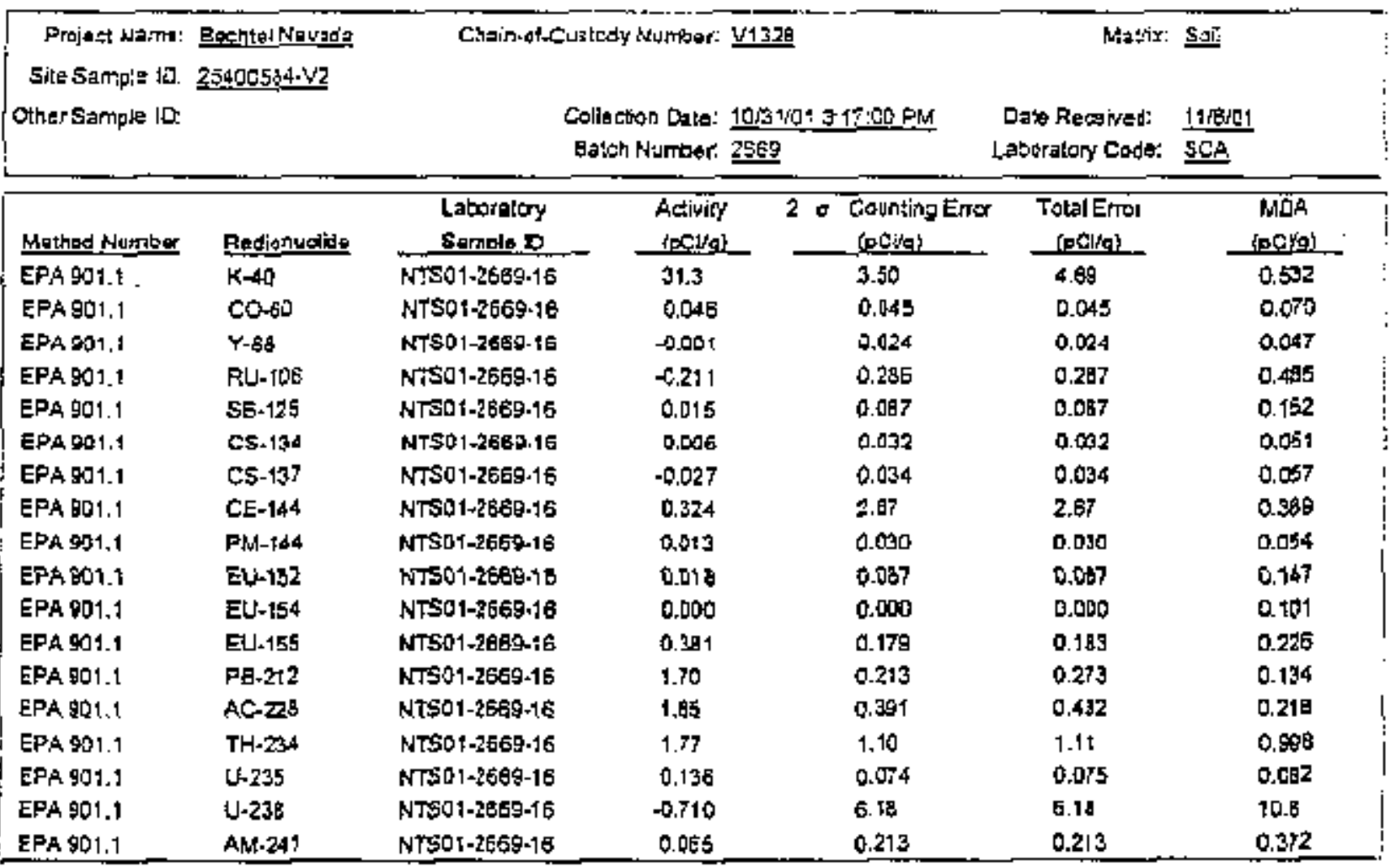

\begin{tabular}{|c|c|c|c|c|}
\hline \multicolumn{5}{|c|}{ oually Control Samples } \\
\hline Radlonychlide & Lahoralgor Control [LC] & Lahoratory Duplleale (LD) & Malrix Spike (MST) & Prepegation Blank (PBd \\
\hline GArrume & SCAOC-565G-LC1 & $50 A 0 C-2550201$ & & SCAPC-2680.PB \\
\hline
\end{tabular}


THIS PAGE LEFT INTENTIONALLY BLANK

C-86 


\section{Recount of Sample 25400584-V1}


Sanford Cohen \& Associates

\section{Southeastern Environmental Laboratory}

Radiloanalytical Rasults

Repord Identification Numbe: 52557

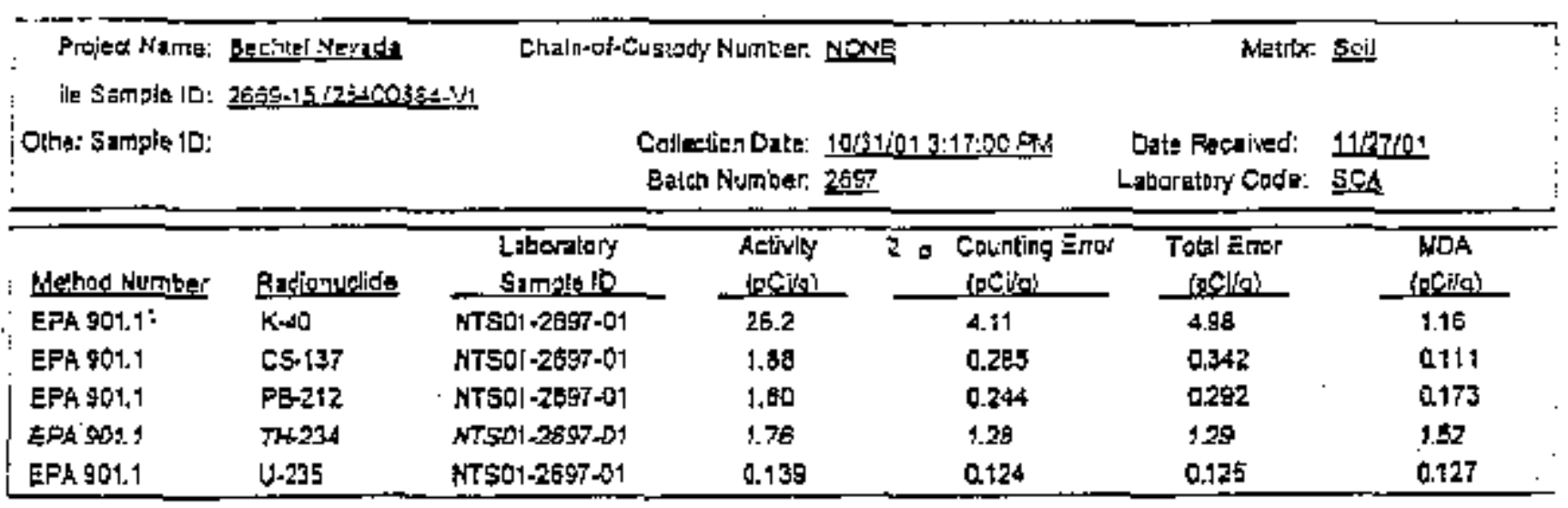


Santord Cohen \& Assocjates

Southeastern Environmental Laboratory

Radioanalytical Results

Risport deanification Nuriber. \$2eg7

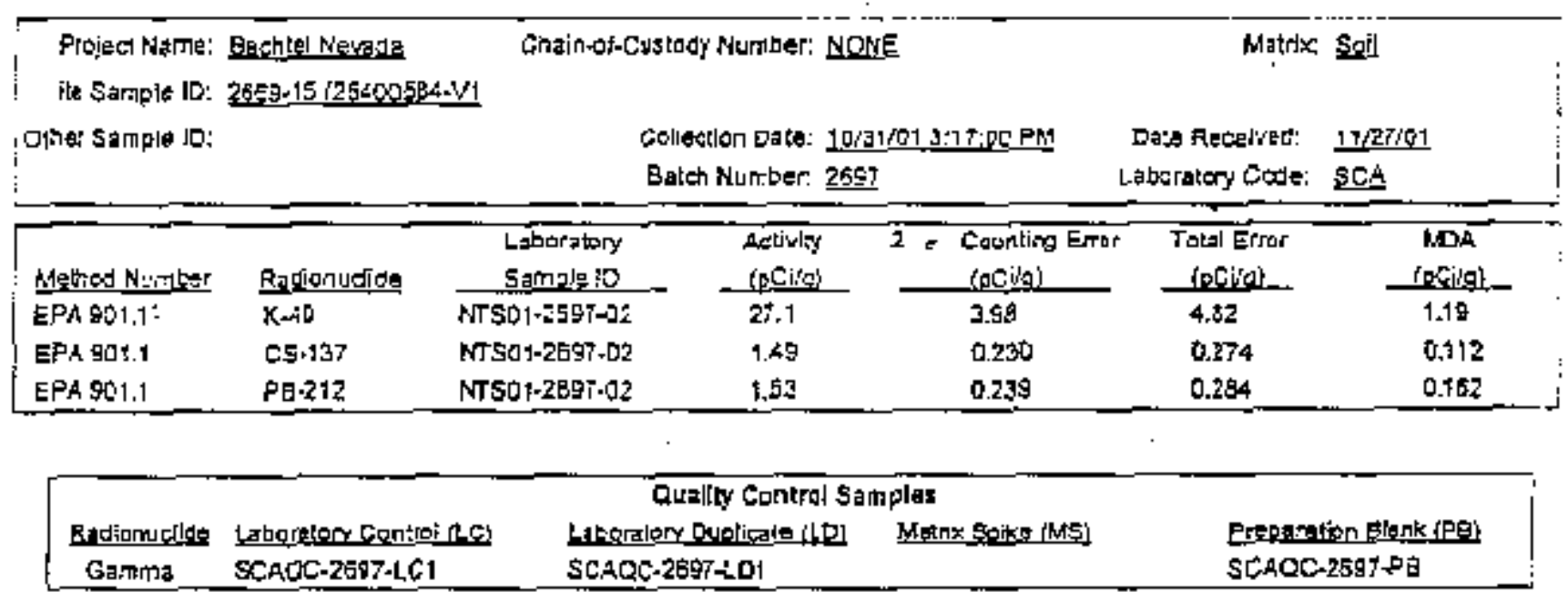




\section{Southeastern Environmental Laboratory}

Rađloanalytical Results

Report Hertilication, Number. Steg7

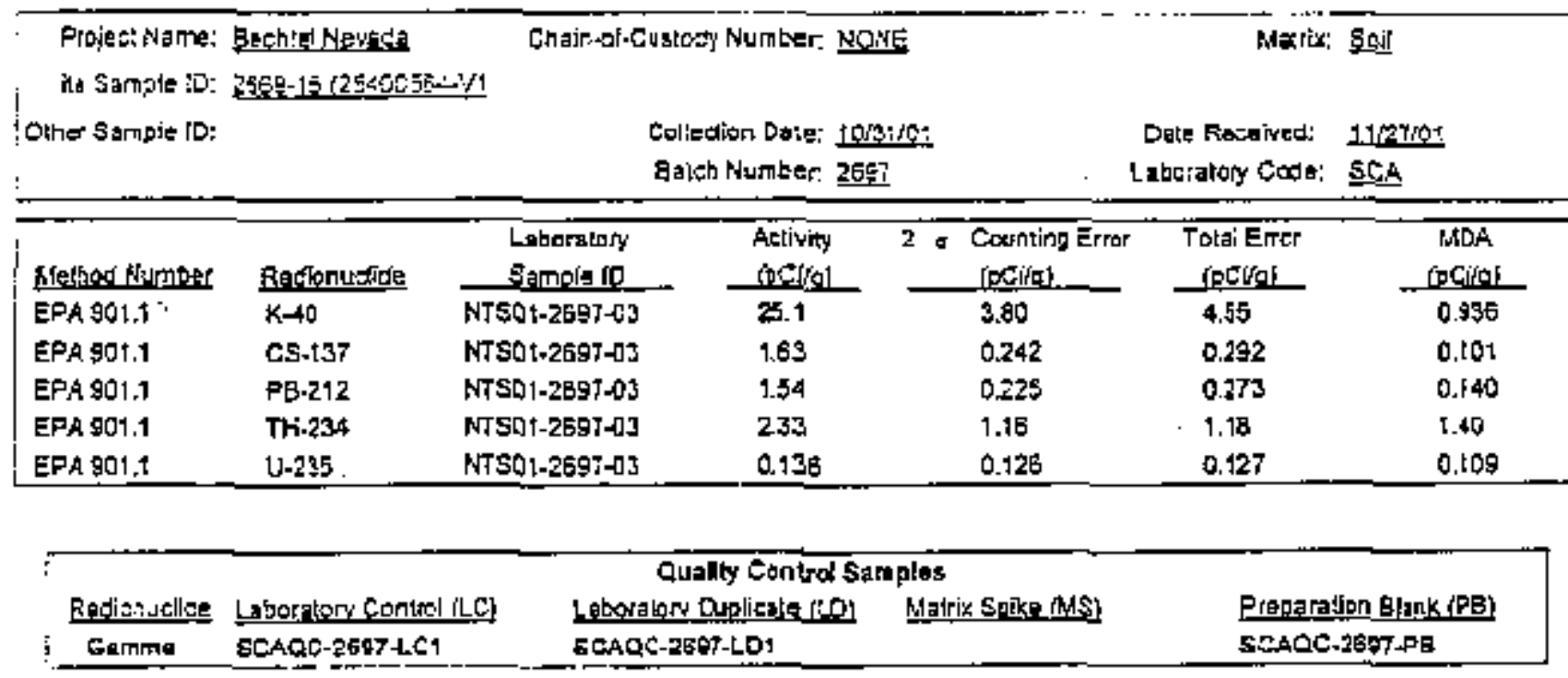


Sanford Cohen \& Associates

Southeastern Enviromental Laboratory

Radionalytical Results

Report ddentifitation Nurter $52 \equiv 97$

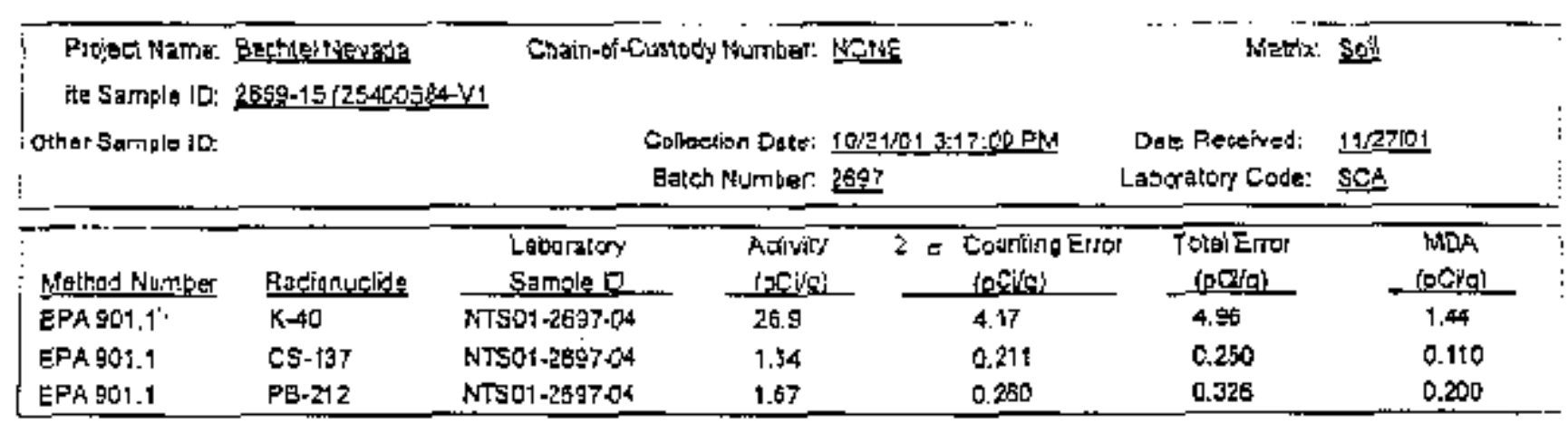

Guafity Con trol Samples

\begin{tabular}{|c|c|c|c|c|}
\hline \multicolumn{4}{|c|}{ lily Eon tro| Samples } & \\
\hline Radiant & 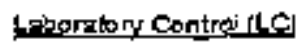 & LLabereton Buplicala f나마 & Matrix Setxh (MS) & 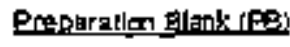 \\
\hline Gamrag & SCA,QC-259T=LC1 & SCAOC-26974LD & & SCAQC-2Bg $\vec{t}-\mathrm{PB}$ \\
\hline
\end{tabular}

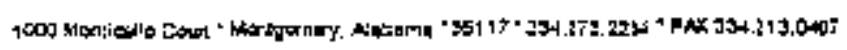

$$
-9
$$




\section{Saniord Conen \& Associates}

Southeastern Environmental Laboratory

\section{Radioanalytical Results}

Report dentllneation Nurnjer, S2eg7

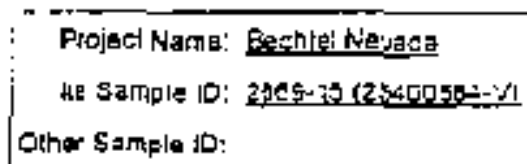

\begin{tabular}{|c|c|c|c|c|c|c|}
\hline Method Mermigar & Brofontullde & $\begin{array}{l}\text { Labrably } \\
\text { Sample } 10\end{array}$ & $\begin{array}{l}\text { Activity } \\
\text { cocilot }\end{array}$ & $\begin{array}{c}2 \text { ocounting Etror } \\
\text { focing }\end{array}$ & $\begin{array}{l}\text { Tota Enor } \\
\text { Cecers: }\end{array}$ & 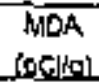 \\
\hline EPA S01.1: & $K-40$ & Nrs01-2Agi-os & 25.0 & 2.05 & 4.42 & 0.710 \\
\hline EPA $\$ 01.1$ & CS+137 & NTS01-249J-0S & 3.10 & 0.379 & 0.489 & 0.098 \\
\hline EPA 901.1 & PQ-212 & NTS01-2637-05 & 1.35 & 0.206 & 0.246 & 0.158 \\
\hline EFA 901.1 & $T H=234$ & NTS01-299]-DS & $1,8 \mathrm{~d}$ & 1.10 & 1.12 & 1.15 \\
\hline
\end{tabular}

\begin{tabular}{|c|c|c|c|}
\hline \multicolumn{4}{|c|}{ Dually Contral Samplat } \\
\hline Ridionutide & Laboralory Contro: [C & 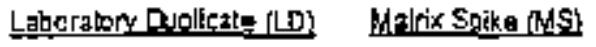 & 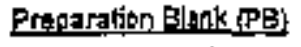 \\
\hline Gamma & SCAOC-2597-LC1 & SCAOC-2697-LOI & SCACC-2697+P \\
\hline
\end{tabular}


Sanford Coher \& Associates

\section{Southeastern Environmental Laboratory}

Radloanalytical Results

Reperidentification Number. $\$ 2 \_97$

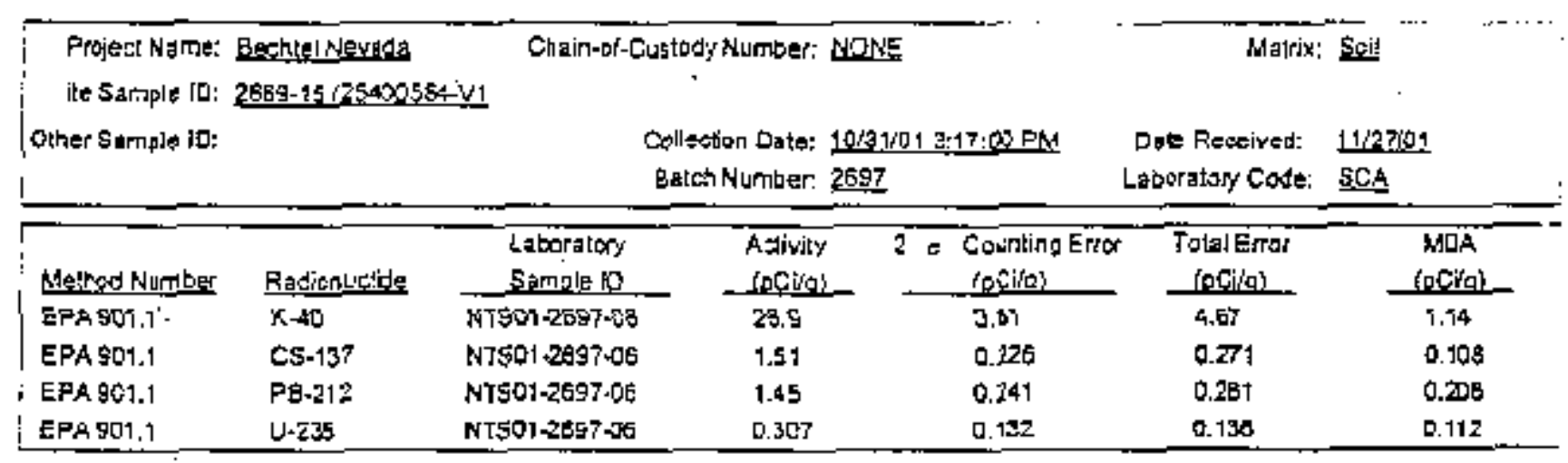

\begin{tabular}{|c|c|c|c|c|}
\hline & \multicolumn{4}{|c|}{ Rujizy Control \$amples } \\
\hline Ris fioruct & Laboralory Conifol $(\mathrm{CC}$ & Eeqberaton Duolleste (LD) & Matrix Spke (MASl & Preparatlon 81gnk (PA) \\
\hline Gamma & SCAQCL-2B97-LC1 & SCAQ6.259tor & & SCADC-2097+PB \\
\hline
\end{tabular}


Radioanalytical Results

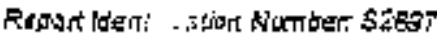

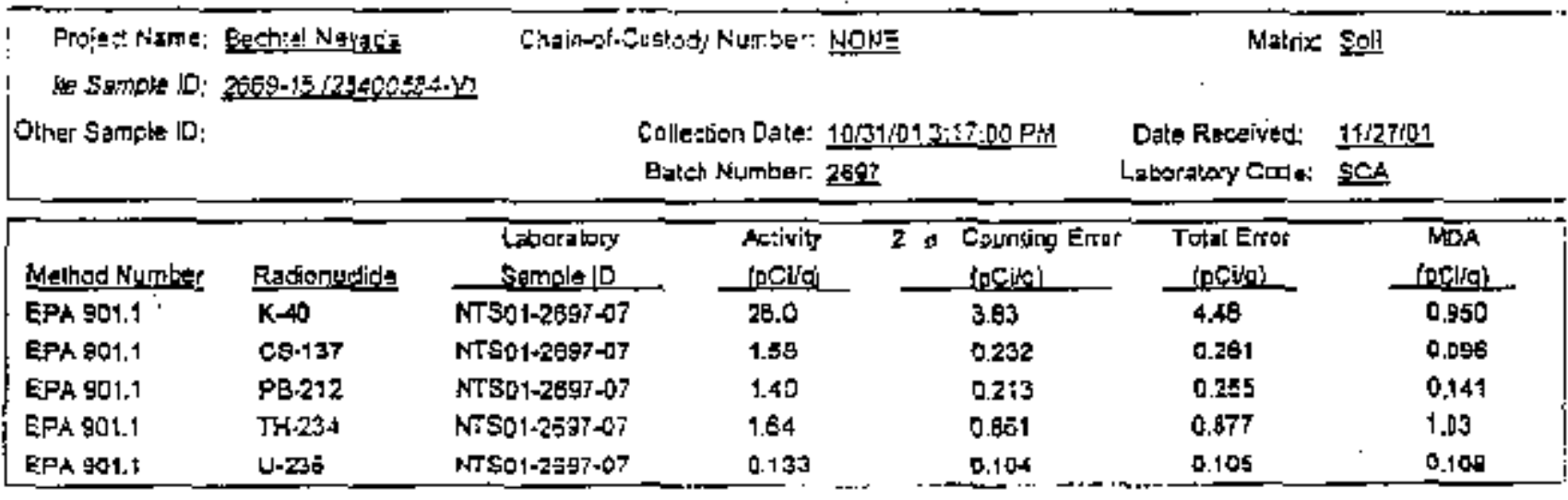

\section{Qualty Contrat Somplos}

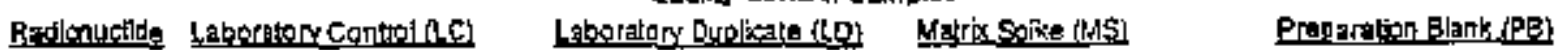

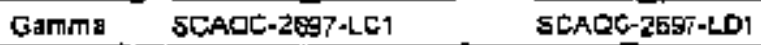


Sanford Cohen \& Associates

Southeastern Environmental Laboratory

Radioanalytical Results

Report Hentification Nunter. $53 a 57$

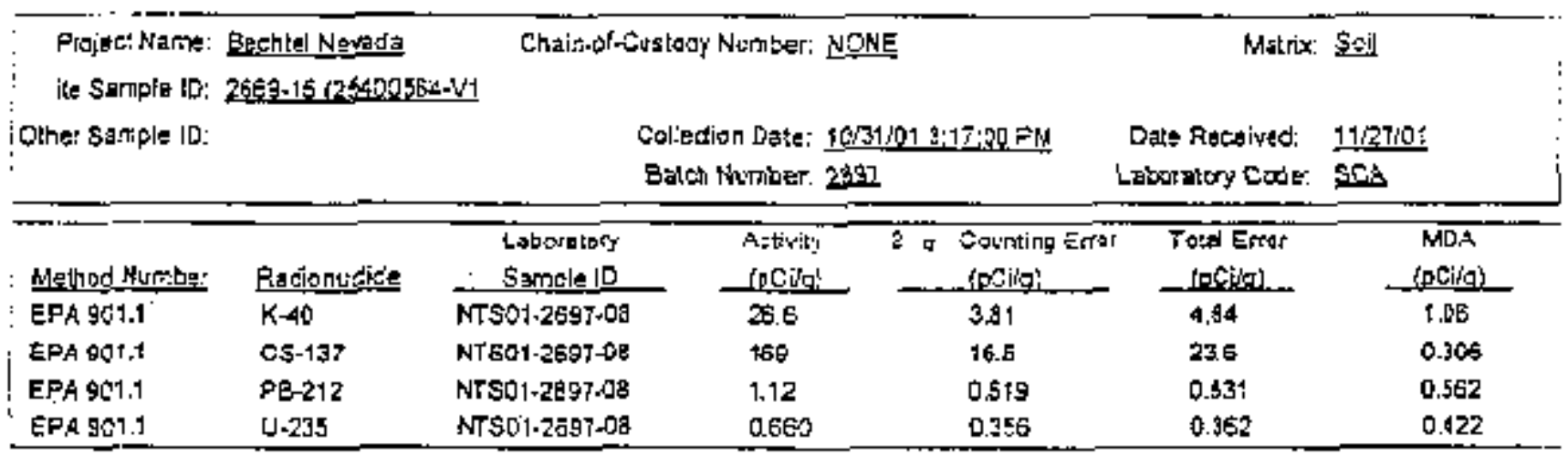

\begin{tabular}{|c|c|c|c|c|}
\hline \multicolumn{5}{|c|}{ qualry Conirol samples } \\
\hline Radschructide & Laboratery contal (C) & 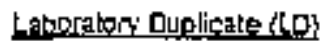 & Marrix Spike WS & Preparalien Blrnk \{PAl \\
\hline Gamma & SCAOC-2697-LC1 & SCAQE-2697-LD1 & & SCAOC.2597P9 \\
\hline
\end{tabular}




\section{APPENDIX D}

\section{WASTE DISPOSITION DOCUMENTATION}

This section contains infomation prolected by the Privacy net of 1974 and is withheld in this intormational copy. 
THIS PAGE LEFT INTENTIONALLY BLANK

D-ji 


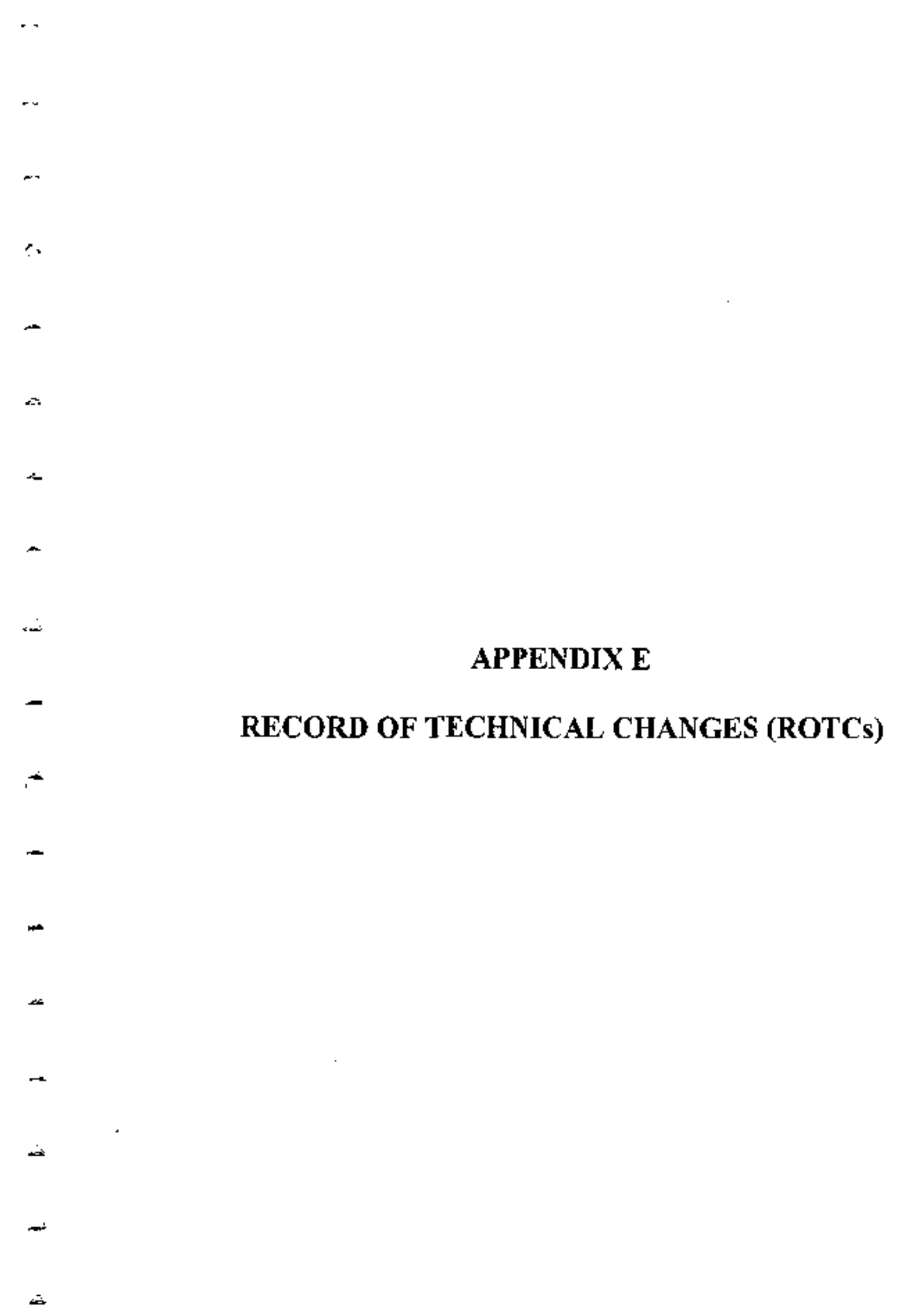


THIS PAGE LEFT INTENTIONALLY BLANK

E-ji 


\section{APPENDIX E}

\section{TABLE OF CONTENTS}

Record of Technical Change $\# 1 \ldots \ldots \ldots \ldots \ldots \ldots \ldots \ldots$ E-5

Record of Technical Change $\# 2 \ldots \ldots \ldots \ldots \ldots \ldots \ldots \ldots . . \ldots$ E-15

Record of Technical Change $\# 3 \ldots \ldots \ldots \ldots \ldots \ldots \ldots \ldots$ E-22 
THIS PAGE LEFT INTENTIONALLY BLANK

E-iv 


\section{RECORD OF TECHNICAL CHANGE \#1}

E-5 
THIS PAGELEFT INTENTIONALLY BLANK 


\section{Department of Energy \\ Nevada Operations Office \\ P.O. Box 98518 \\ Las Vegas, NV 89193-8518

$\sin 012001$

Paul J. Liebendorfer, P.E., Chief

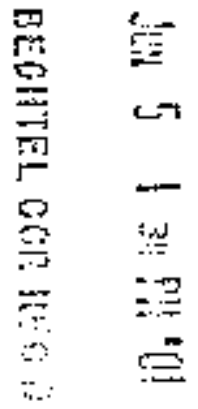

Department of Conservation and Natural Resources

Division of Environmental Protection

333 W. Nye Lane, Room 138

Carson City, NV 89706-0851

SUBMITTAL OF THE RECORD OF TECHNICAL CHANGE (ROTC) NO. 1 FOR THE CORRECTIVE ACTION PLAN FOR CORRECTIVE ACTION UNIT 254: AREA 25 DECONTAMDATION FACILTTY, NEVADA TEST SITE, NEVADA

Please find enclosed for your information and files two controlled copies of the subject ROTC. If you have any questions, please contact Sabine $T$. Curtis, of my staff, at (702) $295-0542$.

ERD:STC

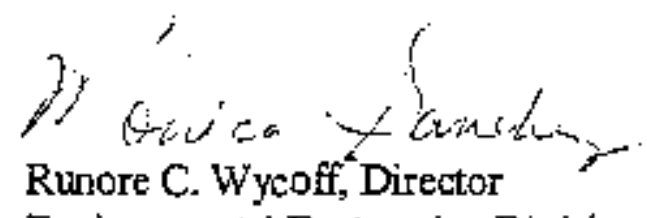

Environmental Restoration Division

Enclostre:

As stated

ce w/encl. (controlled):

M. D. McKinnon, NDEP, Las Yegas, NV

S. D. Lawrence. EM Records Center, NNSANV, Las Vegas, NV 
ce w/encl. (uncontrolled):

BN Correspondence, Las Vegas, NV

Environmental Management Library, BN; Las Vegas, AV

D. L. Gustafson, BN, Las Vegas, NVin? a :

A. M. Heidema, BN, Las Vegas, NV

W. F. Johnson, BN, Mercury, NV

S. J. Nacht, BN, Mercury, NV

C. M. Obi, BN, Mercury, NV

J. L. Cowley, BN, Mercury, NV

L. E. Wille, IT, Las Vegas, NV

f. L. Appenzeller-Wing, ERD, NNSANV, Las Vegas, NV

S. T. Curtis, ERD, NNSA/NV, Las Vegas, NV

cc w/o encl:

K. K. Beckley, NDEP, Carson City, NV

M. A. DeBurle, NDEP, Carson City, NV

L. J. Gabriel, DTRA, Mercury, NV

DTRA Environmental, MS 645, Mercury, NV

G. M. Romano, IT, Las Vegas, NV

K. A. Hoar, ESHD, NNSANV, Las Vegas, NV

P. L. Hall, EM, NNSANV, Las Vegas, NV 


\section{RECORD OF TECHNICAL CHANGE}

Testuisal Choriene Nto.

ProjectiJob No.

PtojecuJob Nama

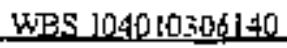

CAU 254. Area 25 RMAD Decontamination Facilitr
Page

Dale_ $5 / 18 / 2001$

The following tenimical clanges (íntuding justificatisn) are reguessed by:

Denris Gistaftron

(Name)
Task Mangser

(Title)

The project time will be Unchanes).

Applicable Project-Specific Docıntent(s): Corrective Action Plart for Correclive Action Unit 254, Area 25

Decontanioation Facility Nevada Test Site, Nerada

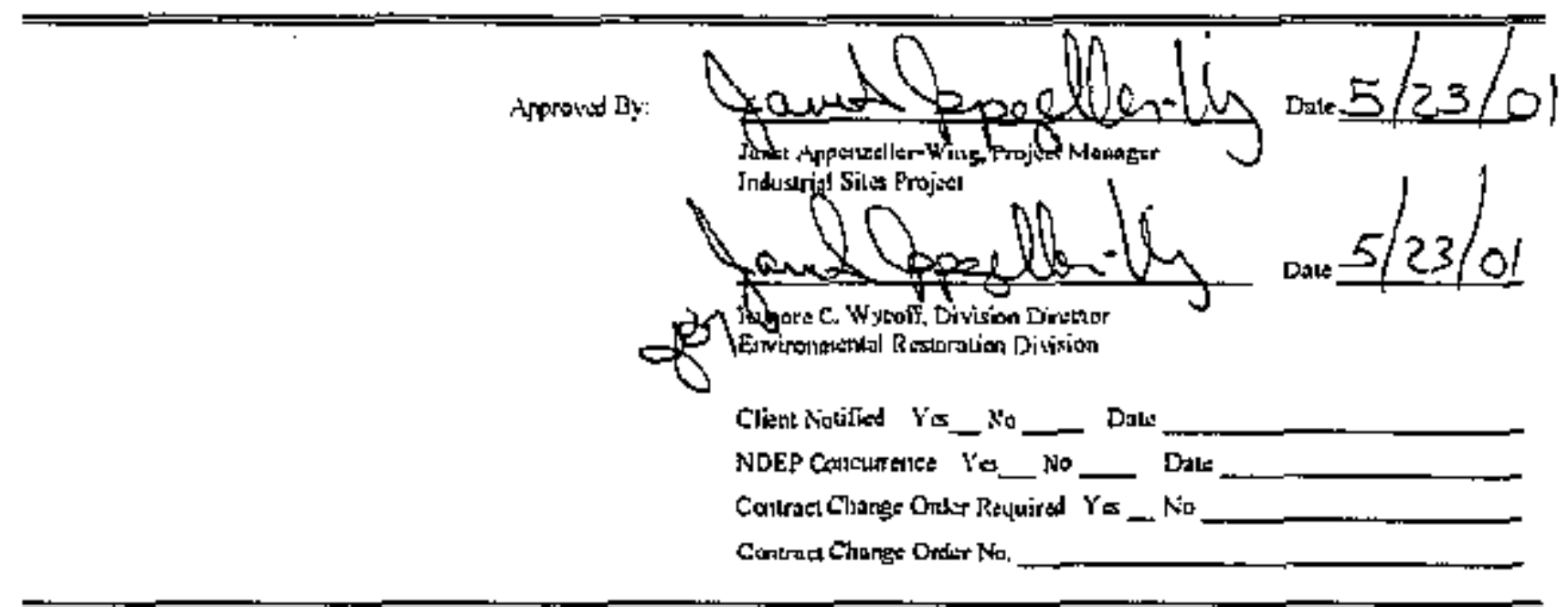


This Record of Technical Change describes additional remediation verification work to be performed at CAT 254 unter Section 244, Remediation Verification, of the CAP to ensure clean closure of this CAD. The following paragraph deseribes the additional work to be performed:

Radioactive impacted sotl adjucent to the decontaningtion jads (see attached figure) will be excavated and dilsposed at the apropriate Nevada Test Site pertitted land fill. Soil samples will be collected for anatysis to verify clean-ug eriteria bave been met. The soil samples will be analyzed by Ganma Spectrometry since Cesimu-137 (Cs-137) is the predominate radionuclide in the soil and can be easihy quantified using Garama Spectromerry, All other radionuclides are a fraction of the Cs-137 activity and can be calculated from scaling factors developed from Aren 25 Denctivation and Ditunntling (D\&D) waste streams. The average radionuclide concentrations of all soll samples collected will sot excet 7 pico Curies per gram (pCV/g) for Cs-137, and no individual sample will exceed $21 \mathrm{pCi} / \mathrm{g}$ for Cs-137. If this criteria is not met, gdditiongl excavatios and verification sampling will be donte. 


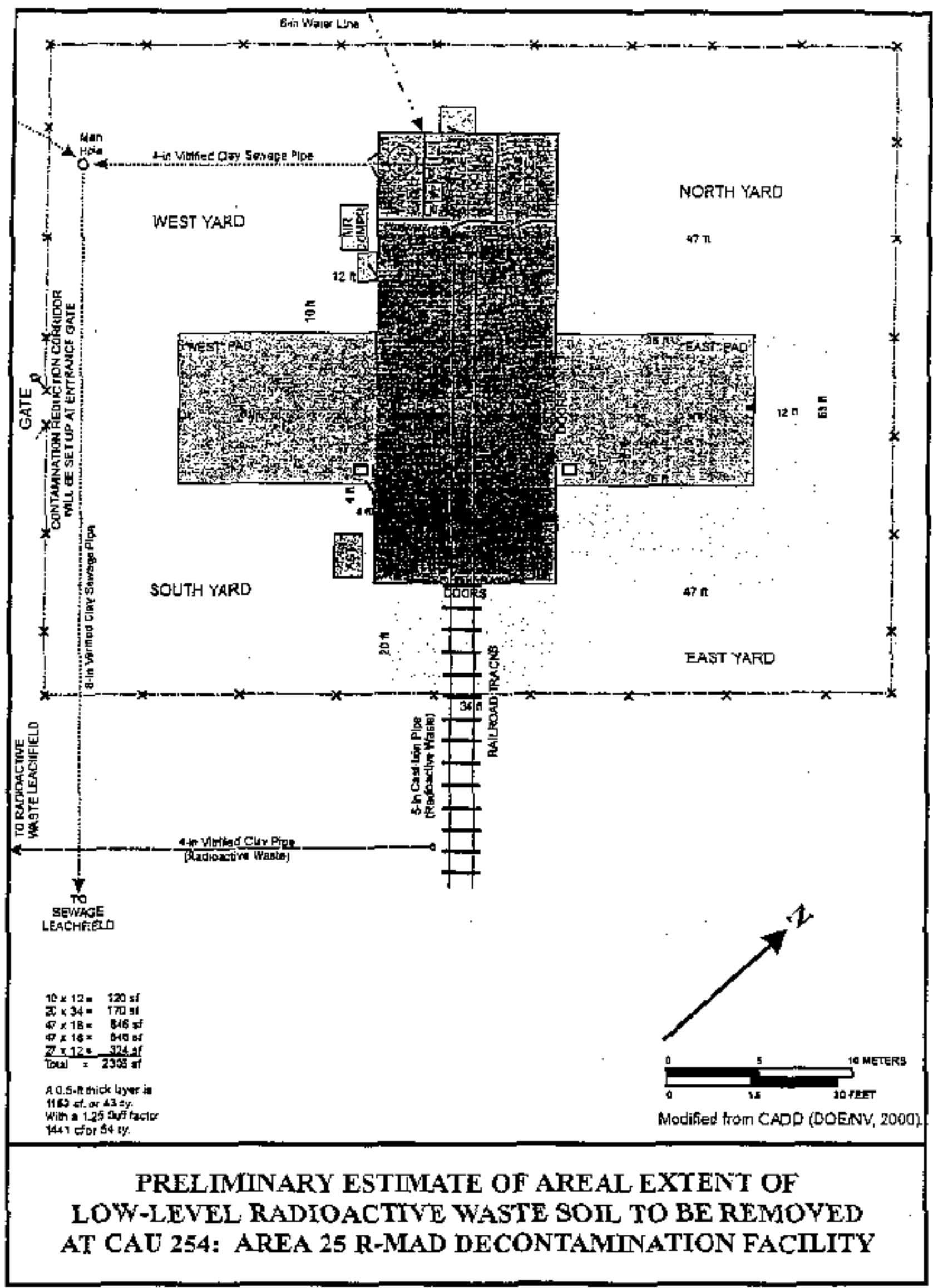




\section{RECORD OF TECHNICAL GHANGE}

Ioxingal Ganes No.

rojoctis Wo.

HS . 101010\%140

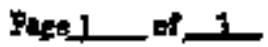

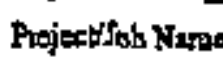

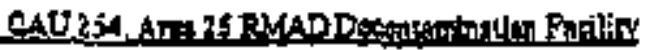

\begin{tabular}{|c|c|}
\hline Denrin Contafteon & Torkyanger \\
\hline (Ningte) & (tidte) \\
\hline
\end{tabular}

$=$

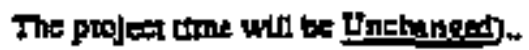

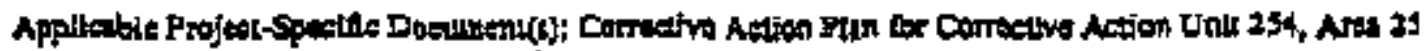

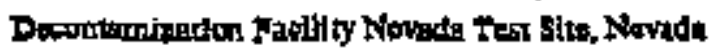

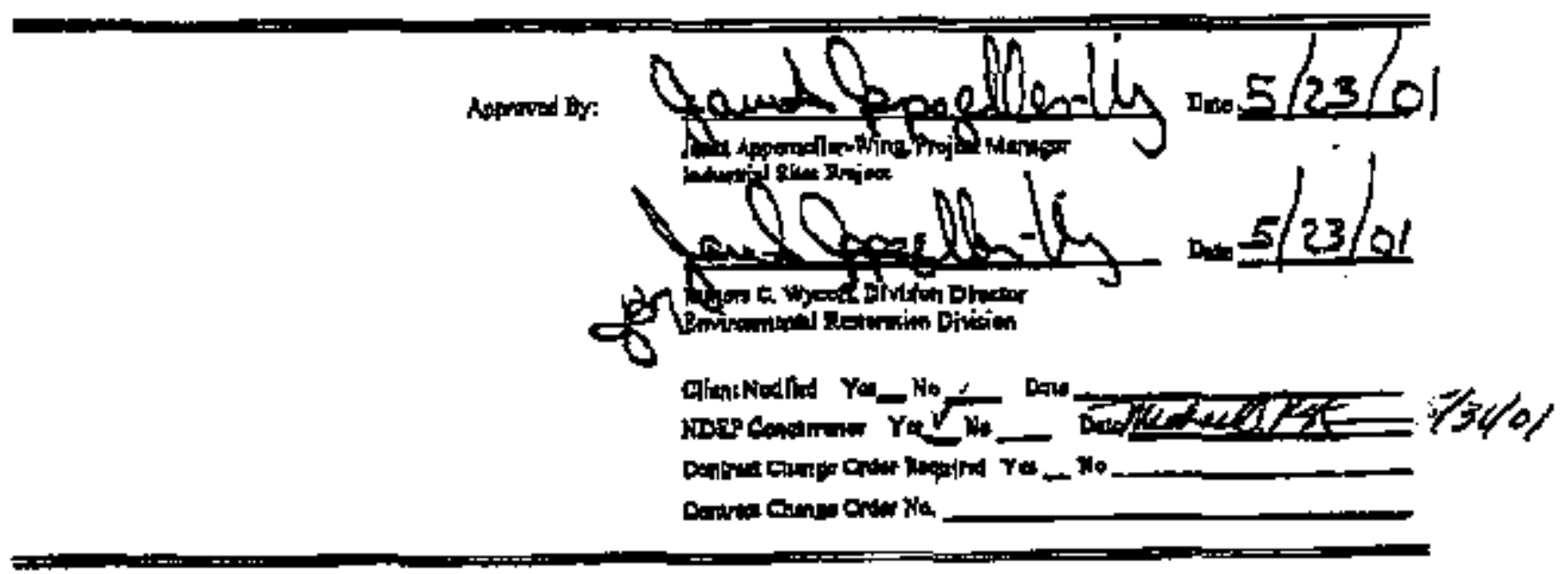

$E-12$ 
Telabet Cherse No.

Properab Na, 1
Fue 2 ar 3

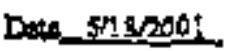

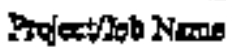
7981700040035

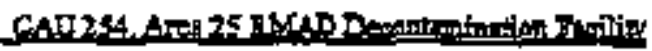

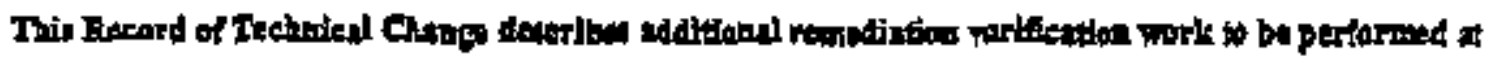

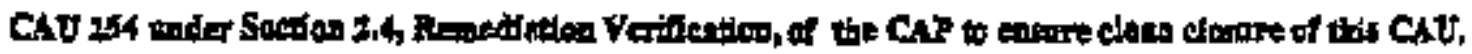

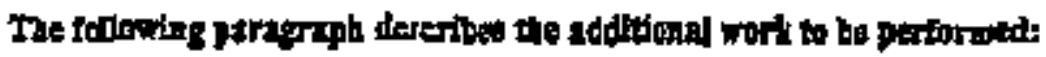

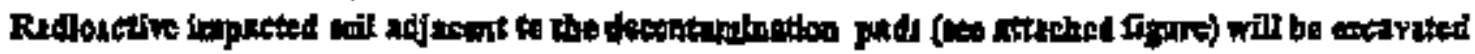

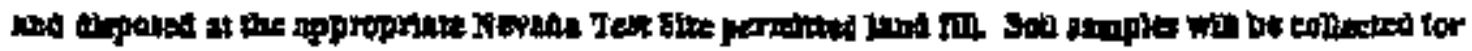

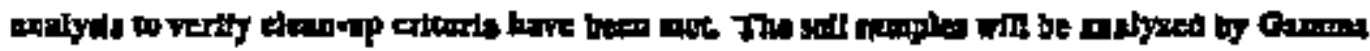

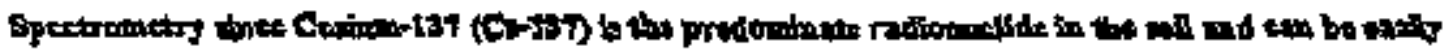

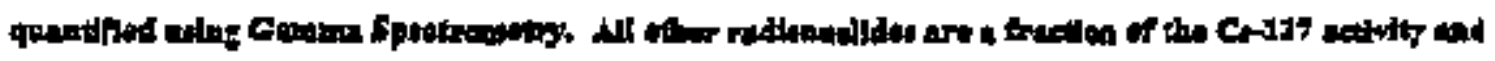

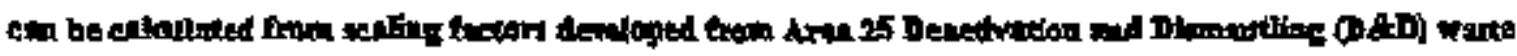

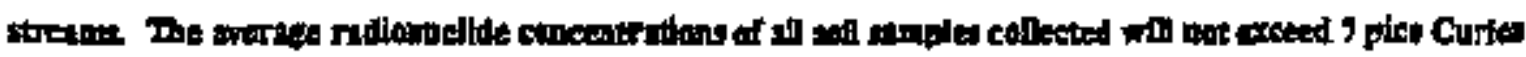

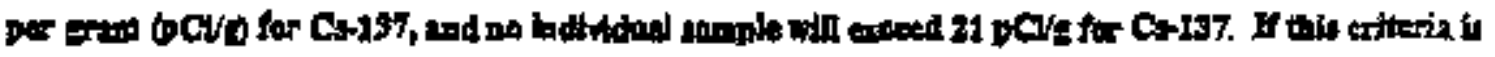

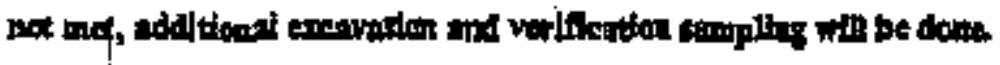

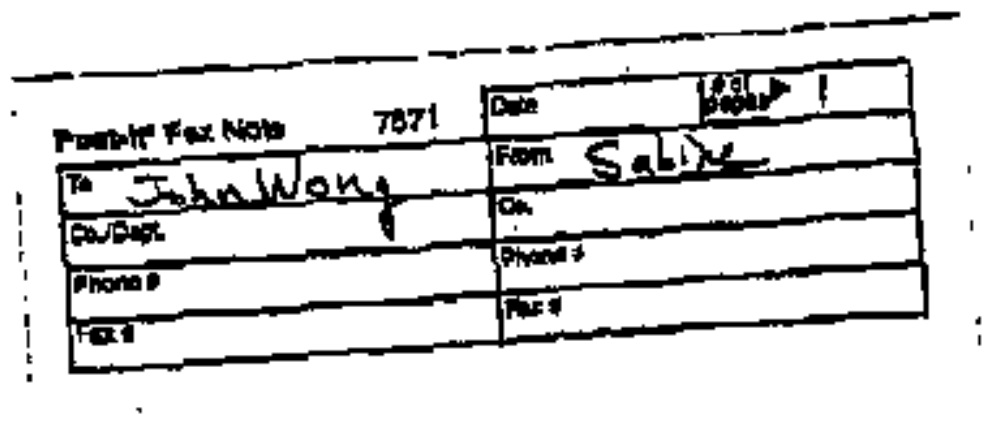




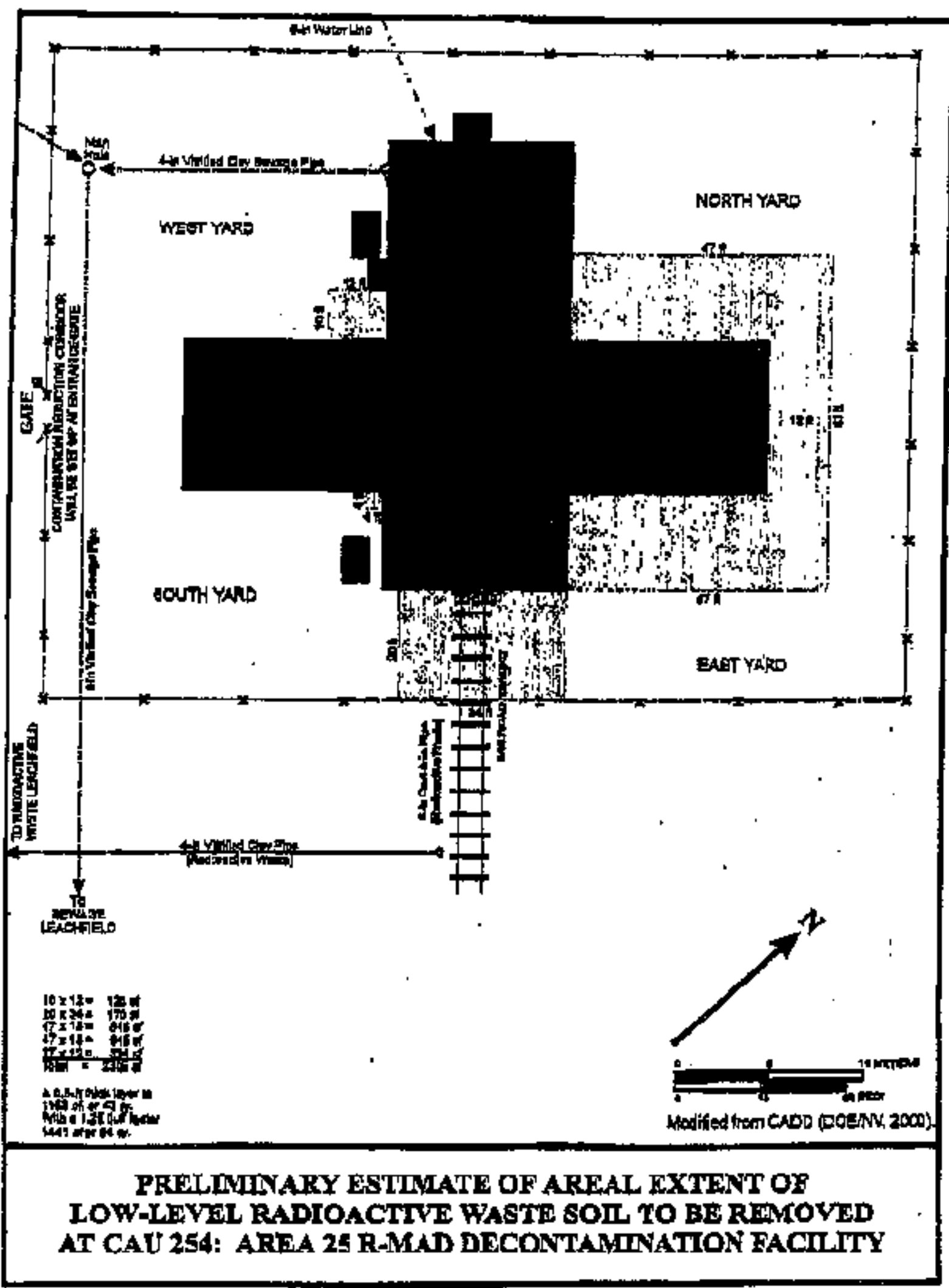




\section{RECORD OF TECHNICAL CHANGE \#2}

E-15 
THIS PAGEIEFT INTENTIONALLY BLANK

E-16 
Paul J. Liebendorfer, P.E., Chief

Department of Conservation and Natural Resources

SEF 1 J 2001

Division of Enyironmental Protection

333 W. Nye Lane, Room 138

Carson City, NV 89706-0851

SUBMITTAI OF RECORD OF TECHNICAL CHANGE (ROTC) NO. 2 FOR THE CORRECTIVE ACTION PLAN FOR CORRECTTVE ACTION UNIT 254; AREA 23 DECONTAMINATION FACILITY, NEVADA TEST SITE, NEVADA

Please find enclosed two controlled copies of the subject ROTC for your project files. If you have any questions regarding these changes, please contact Sabine T. Curtis, of my ataff, at (702) 295-0542.

ERD:STC

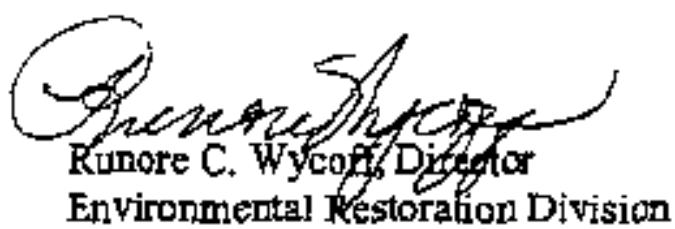

Enclosure:

As stated

cc w/encl. (controlled):

SLpervisor, NDEP, Las Vegas, NV

S. D. Lawrance, EM Records Center, NNSANV, Las Vegas, NV

Southern Nevada Public Resding Room,

Las Vegas, NV

Public Reading Room Coordinator, IT, Las Vegas, NV 


\section{RECORD OF TECHNICAL CHANGE}

Techniel Change No. 2

$\left.p_{10}\right]$ 45

Projoct/Job No. WBS 104010306140

Date 82금이닌

Projeci'Job Name CAU 254 AreB 25 RMAD Desontamination Fecility

The following technical chenges (induding justifation) are requestod by:

Greg Doyle

(Name)
TeskMpngger

(Title)

The project time will be Uincherposit.

Applissble Project-Specific Document(s): Corrective Attion Plan for Corrective Action Thit 254, Area 25 Decontamination Facility Nevada Test Site, Nevada

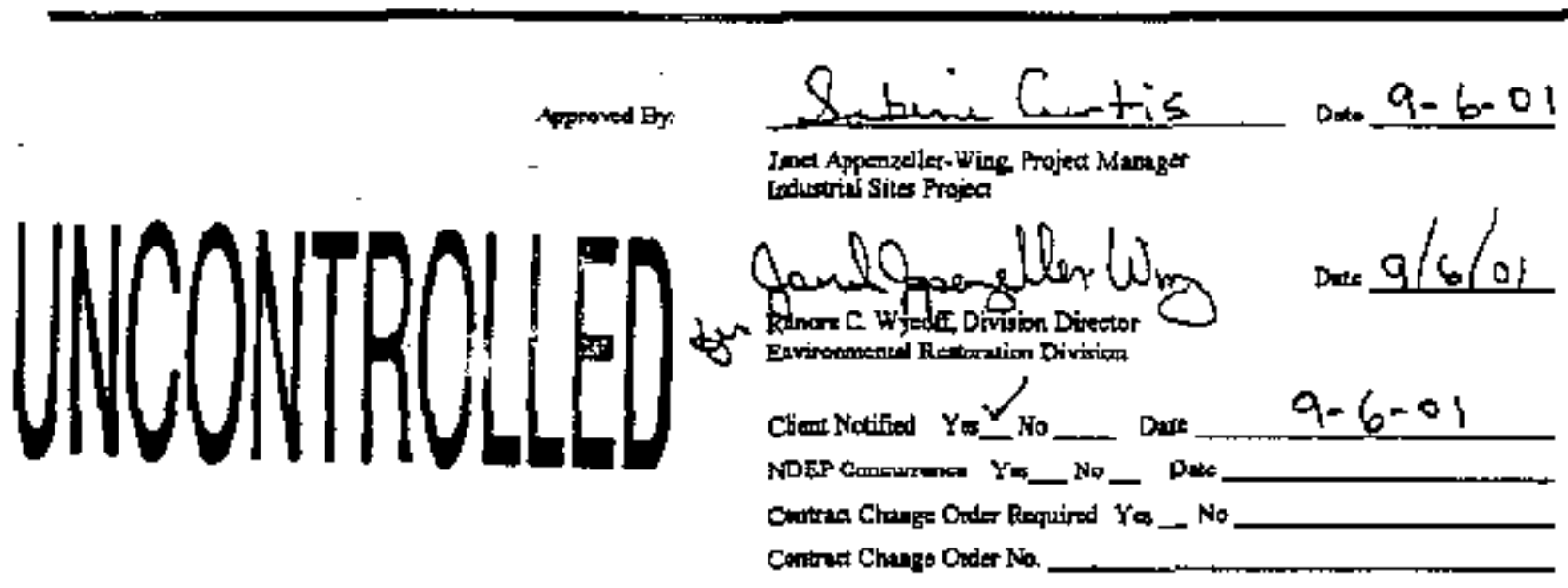

Mixed haxardous and radionetive waste and low level radioactive waste accumulated during closure activitits at CAU 254 is currently being stored onsite while awaiting characterization, profiling and disposal. 
Recent (June 25, 2001) correspondence with the Nevada Division of Environmental

Protecrion (NDEP), indicates that once the accimulation of these wastes is complete, they must be shipped to the appropriate destination within 15 days of the receipt of the final characterization data. The RWAP process involved with the waste disposal from CAU 254 will cause the storage of these wastes to extend beyond both State and RCRA limits. Additional gtidance from the State of Nevada altows for the submittal of a schedule, which outlines the actnal waste disposal timcline. Based upon our best estimate of the RWAP process currently being implemented for the CAL 254 mixed and low-level wastes, we propase the following schedule.

\section{MIXED HAZARDOUS AND RADIOACTIVE WASTES}

Compile Data Validation - 09/27/01

Submit proftle to RWAP - I0/18/OL

RWAP approval - 12/21/01

Ship Waste - 01/15/02

\section{LOW-LEVEL WASTES}

Sabmit profile to RWAP - 08/25/01

RWAP approval - 10/22/01

Ship Waste $-11 / 12 / 01$ 
Tochioul Chrmolita. $+$

Pan of 1

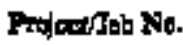

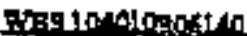

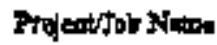

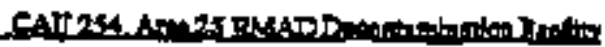

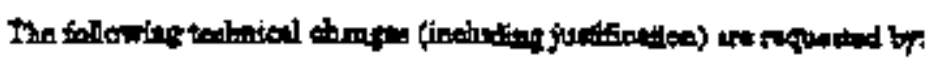

smerade

andi)
Tristidenter

(Jitis)

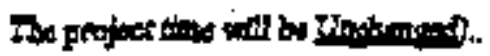

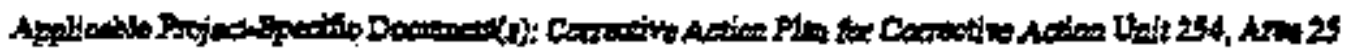

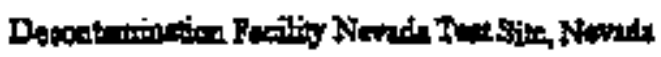

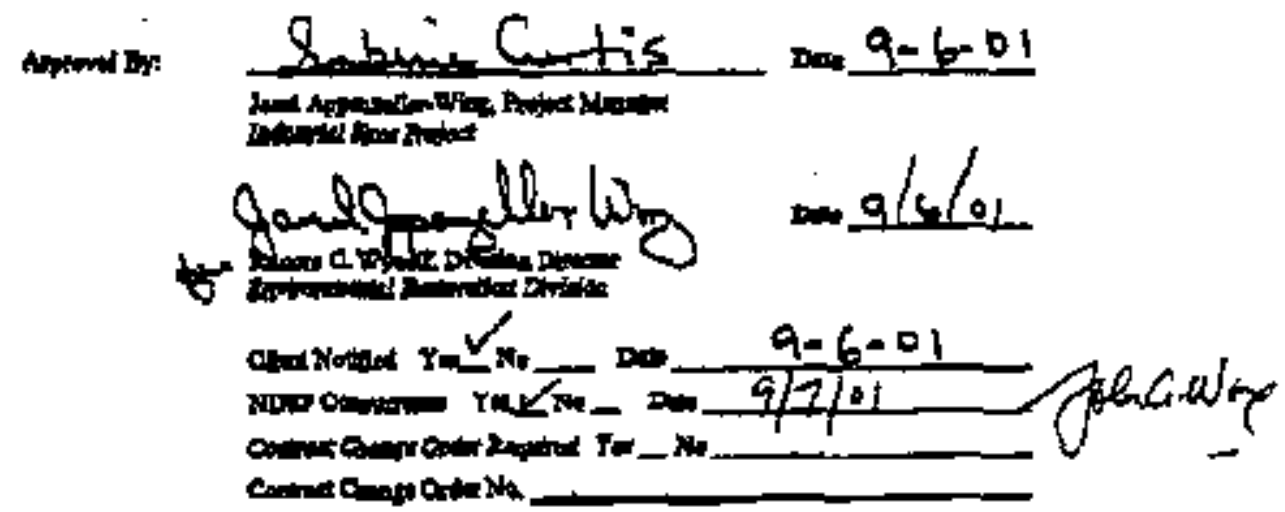

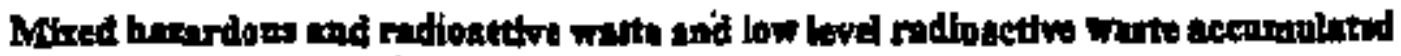

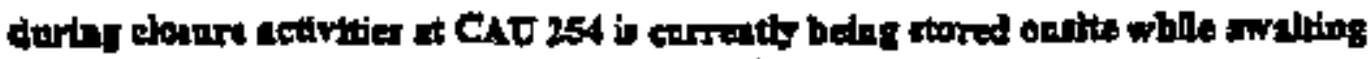
chereterientas, prointige ned dbpoul. 
Recut (Juxe 25, 2001) eorterpondenes with the Nerads Division of Environmental

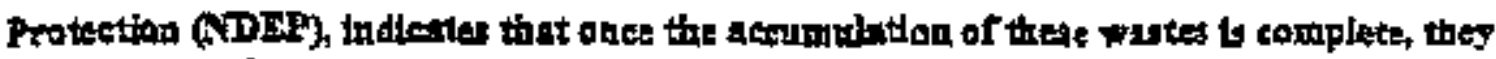

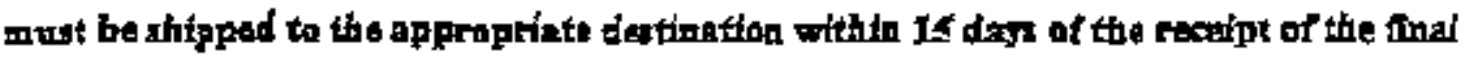

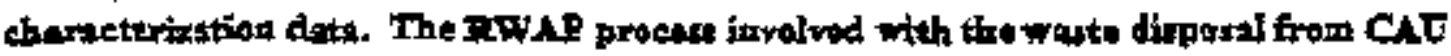

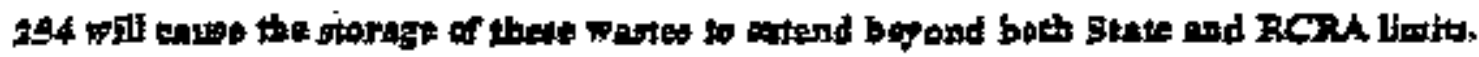

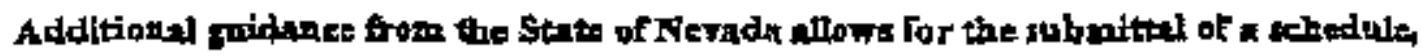

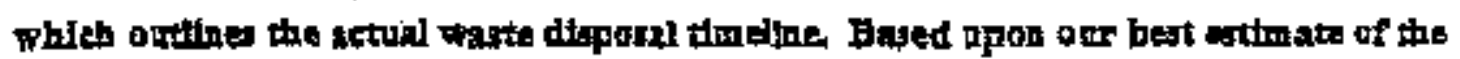

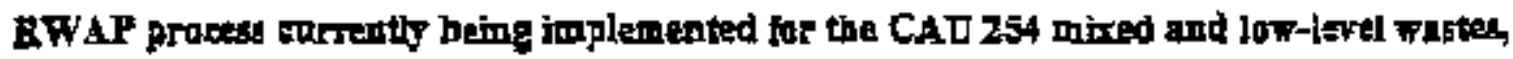
Te propase the tollowing achedale.

\section{MDED HAZARDOUS AND RADIOACTIV WASTES}

Complle Data Validation $-09 / 27 / 01$

Subrite profile to BWAP - 10/19/01

RWAP approtal - 10/31/04

Shlp Warte-01/502

\section{LOW-LEVEL WASTBS}

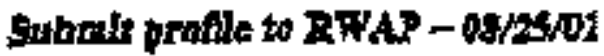

RWAP spploval - 10/29/01

chip Waite - 11/201 
THIS PAGE LEFT INTENTHONALIY BLANK

E-22 


\section{RECORD OF TECHNICAL CHANGE \#3}




\section{Department of Energy}

Nevada Operations Office

P.O. Box 98518

Las Vegas, NV $89198-6518$

Paut J. Liebendorfer, P.E., Chief

Departinent of Conservation and Natural Resources

Division of Environmental Protection

333 W. Nye Lane, Room 138

Carson City,.NV 89706-0851

SUBMTTAL OF THE RECORD OF TECFNCAL CHANGE (ROTC) \#3 FOR

CORRECTTVE ACTION UNIT 254: AREA 25 R-MAD DECONTAMINATION FACILTYY, NEVADA TEST STTE, NEVADA

Plesge find enclosed two controlled copies of the subject ROTC for your files. If you

have any questions or comments tegarding this matter, plesse contact Sabine T. Curtis, of my

stafi, at (702) 295-0542.

ERD:STC

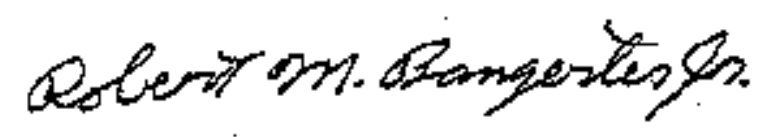

Folitiore C. Wycon, Director

Environimental Restoration Division

Enclosure:

As stated

ce w/encl (controlled):

Supervisor, NDEP, Las Vegas, NV

S. D. Lawrence, EM Reconds Center,

NNSANN, Las Vegas, NV

Southem Nevada Public Reeding Room,

Las Vegas. NV

Public Reading Room Coordinator, IT,

Las Vegas, NV 


\section{RECORD OF TECHNICAL. CHANGE}

Textrital Change No

Project/Job No.

ProjectJab Name
1

WRS.104010306240
Page 1 - of 3

Date. $9: 10,2001$

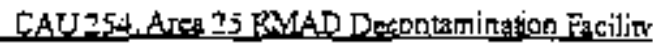

The followwing techrical changes (including jugtifestion) are requested by:

Greg Dovle

Nates)
TaskManapes

(Titilt)]

The project time will be Unchanged).

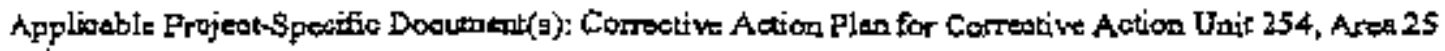

Desonterrination Faciliy Nevada Test Site Mieqada

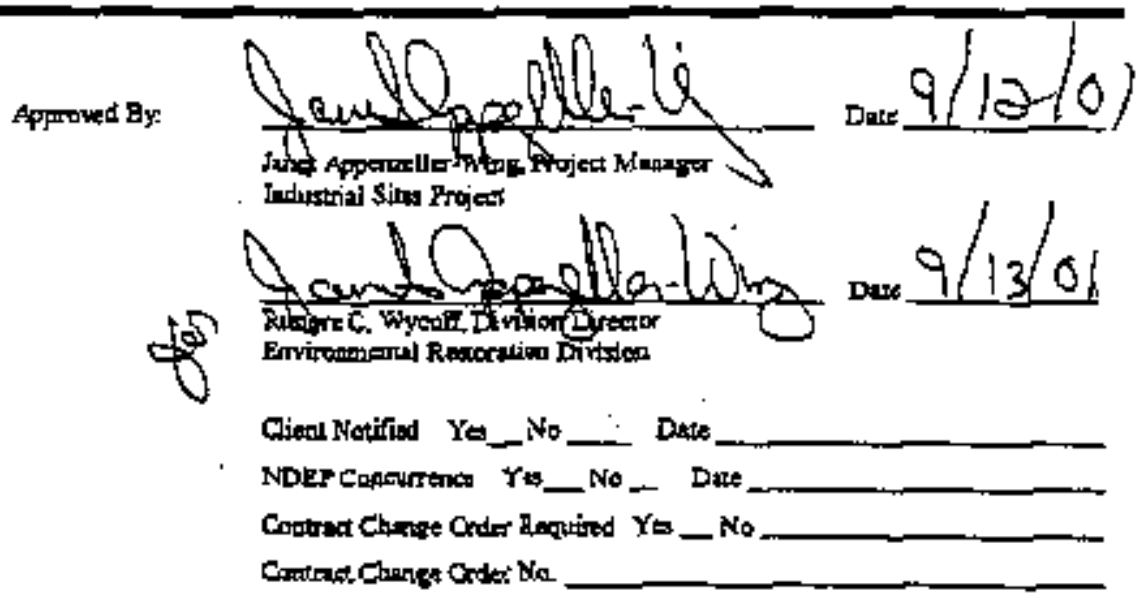


This Technical Change Notice addresses Corrective Action Unit (CAU) 254 Corrective Action Plan (CAP).

Acetone was identisied as a constituent of concern during the Corrective Action Investipation fieldwork. Based on review of past activities conducted at the Ares 25 RMAD Decontumingtion Building it was decided that acetone was used in the decontamination process and that it was a F003 Resource Conservation and Recovery Act (RCRA) listed waste. The CAV 234 CAP specified that all hazartious waste would be removed from CAU 254. It was assumed that any acetone found within CAU 254 would be associated with radiological contamination and would be remediated during the shot blast decontamination activities. Five verification samaples were collected from the remediated areas of the CAU 254 concrete floor. Four of these samples contained above detection limits of acetone. The highest detected concentration of acetone was 110 parts per billion (ppb).

The National Nuclear Security Agency Nevada Operations Office (NNSA/NV), Environnental Restoration Division (GRD) proposes that further removal of concrete from the CAU 254 foundation is not necessary. The concentrations of acetone detected within the concrete are four orders of magnitude lower than the U. S. Environuental Protection Agency (EPA) Region 9 Preliminary Remediation Goals (PRG). The EPA Region 9 PRG for acetone in residential soi is 1,600 parts per millton (ppm) or $1,600,000$ ppb. Given that the acetone within the CAU 254 concrete is not readily leachable into the surrounding soil, NNSA/NV ERD requests that the CAU 254 CAP be modified to allow the use of the EPA Region 9 PRG for acetone in soil ar the closure criteria for the acetone rensining in the concrete floor. 


\section{RECORD OF TECHNICAL CHANGE}

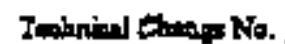

Trejsergob tio.

nojertab Nime
3

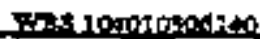

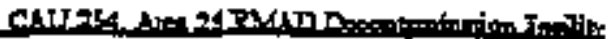

Patri ar 1

Din_onol

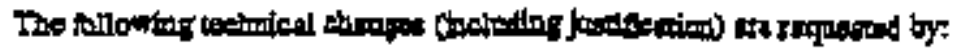

Gisthad. aime)

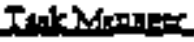

(거이)

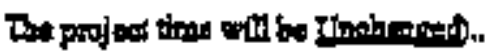

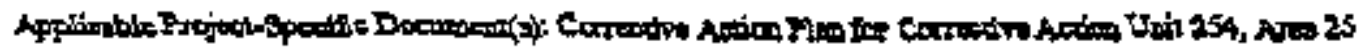

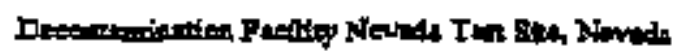

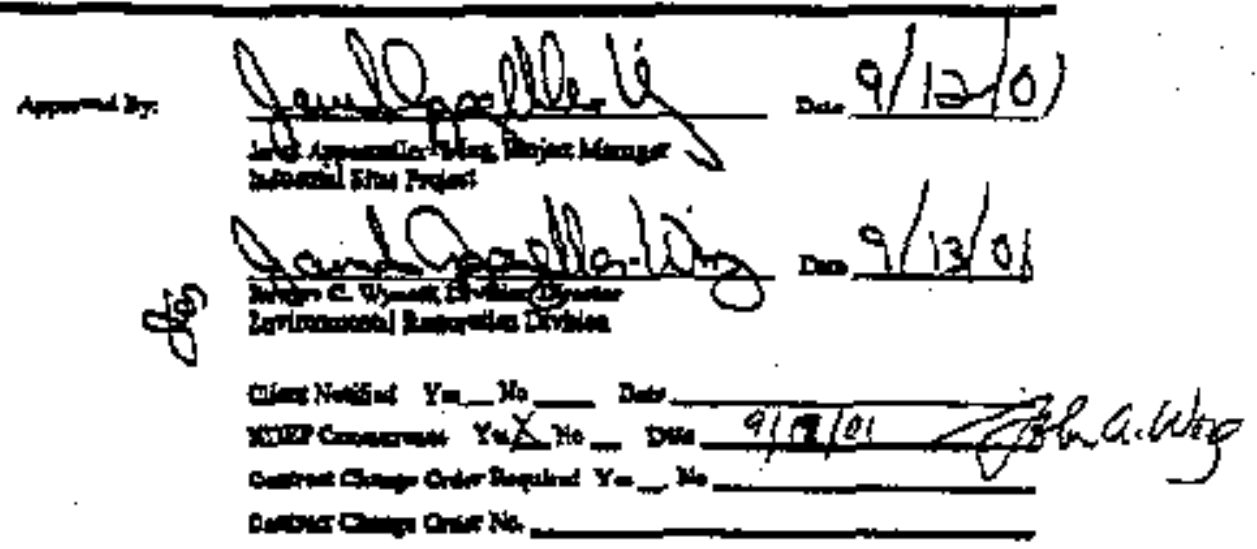




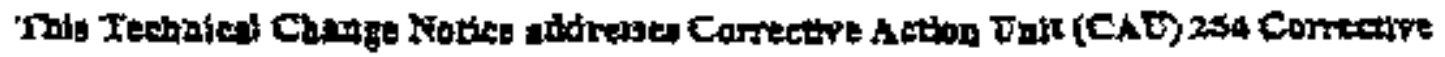
Aatsa Plon (CAF).

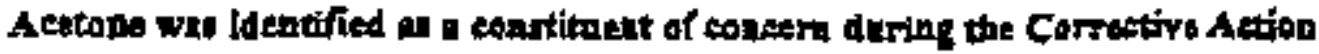

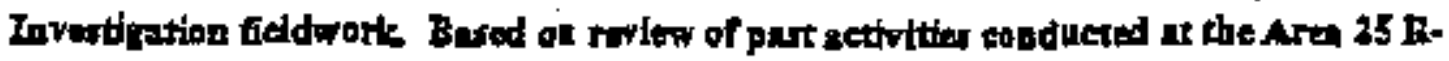

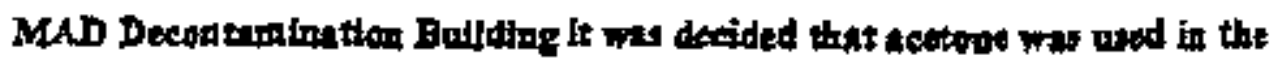

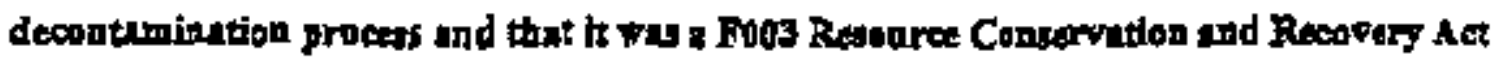
(RCRA) lifed ware The CAT 254 CAP upeified thes all bezardous woste would be

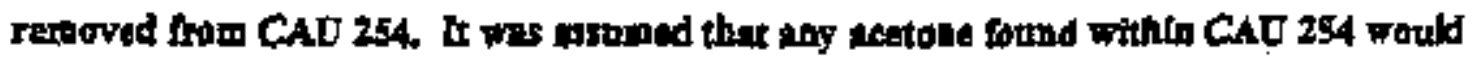

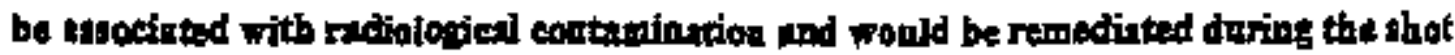

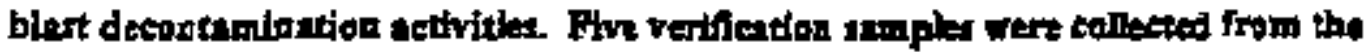

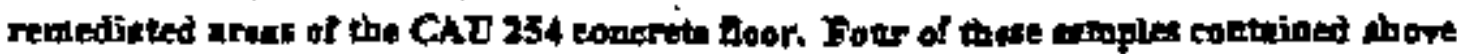

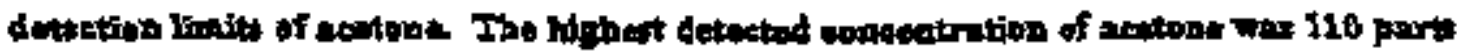
per ballon (ppb).

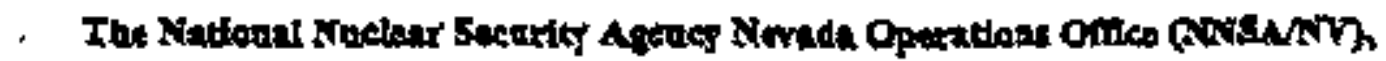

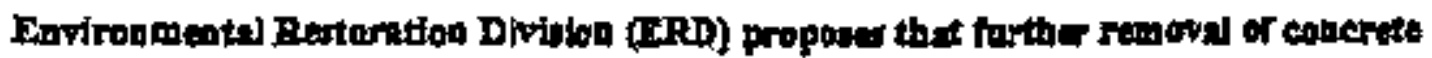

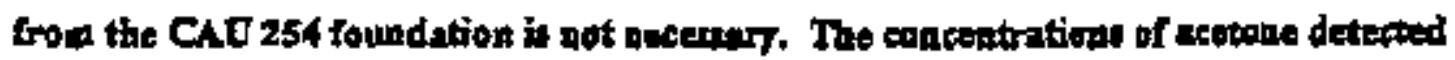

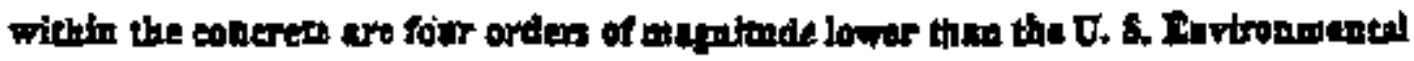

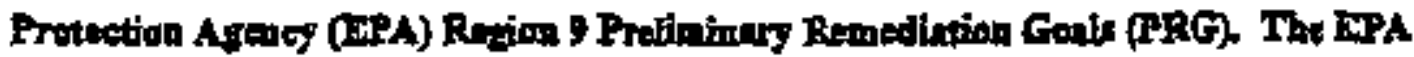

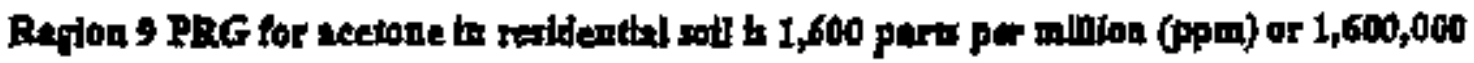

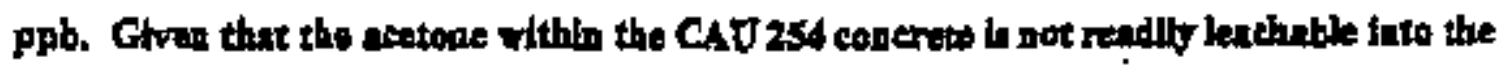
sarrouding toil, JiNSANV BXD requed that the CAD 254 CAP be modified to allow

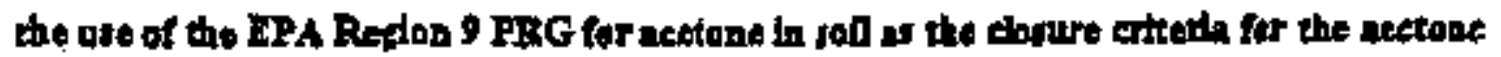
romething in the eonerute toer. 


\section{APPENDIX F}

\section{USE RESTRICTION INFORMATION}

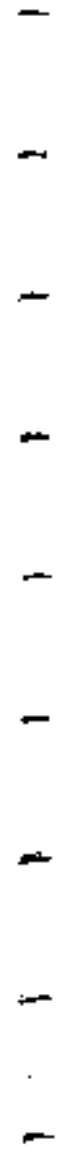


THIS PAGE LEFT INTENTIONALIY BLANK

F-ii 


\section{APPENDIX F}

\section{TABLE OF CONTENTS}

CAU Use Restriction Form $\ldots \ldots \ldots \ldots \ldots \ldots \ldots \ldots \ldots$, F-5

Surveyed Coordinate Map for CAU 254, CAS 25-23-06 ....... F-8

Raw Coordinate Data $\ldots \ldots \ldots \ldots \ldots \ldots \ldots \ldots \ldots \ldots \ldots$, F-1 1 
THIS PAGE LEFT INTENTIONALLY BLANK

F-iv 


\section{CAU USE RESTRICTION FORM}


THIS PAGE LEFT INTENTIONALLY BLANK

F-6 


\section{CAU Use Restriction Information}

CAU Number/Description: CAU 254: Area 25 R-MAD Decontamination Facilite. Buflding 3126

Applicable CAS Nambers/Descriptions: CAS 25-23-06

Contact (organization/project): DOE/NY Industual Sítes Project Manager

Surveyed Area (UTM coordinates; Zone 11, NAD 27): Refor to Artached Mat

Survey Date: 11/06/01 Surpey Method (GPS, etc): GPS, Converted to NAD 27

Site Monitoring Requirements: V'sual inspection of posted signs as spectfied bv the closure docungentation (DOE/NV 2002).

Reguired Frequency (quarterly, annually?):Anmually

If Moritoring Has Started, Indicate Last Compietion Date: N/A

\section{Use Restrictions}

The fiture use of any land related to this Corrective Action Unit (CAU), as described by the above surveyed location, is restricted from any DOE activity that may alter or modify the containment control as approved by the state and identified in the CAU Closure Report or other CAU docurnentation tunless appropriate concurrence is obtained in advance.

Comments: Radiological contamination is present below the bujlding tad at a minimum of aporoximately 15 centimeters ( 6 inches) withir the boundartes of the surreved location. Refer to the Closure Report for additional information on the condition of the site and any monitoring and br inspection requirements.

Submitted By:

Bate:

cc wlth copy of surveyed location map:

CAÜ Fites (2 copies) 
THIS PAGE LEFT INTENTIONALLY BLANK 
SURVEYED COORDINATE MAP FOR CAU 254, CAS 25-23-06 


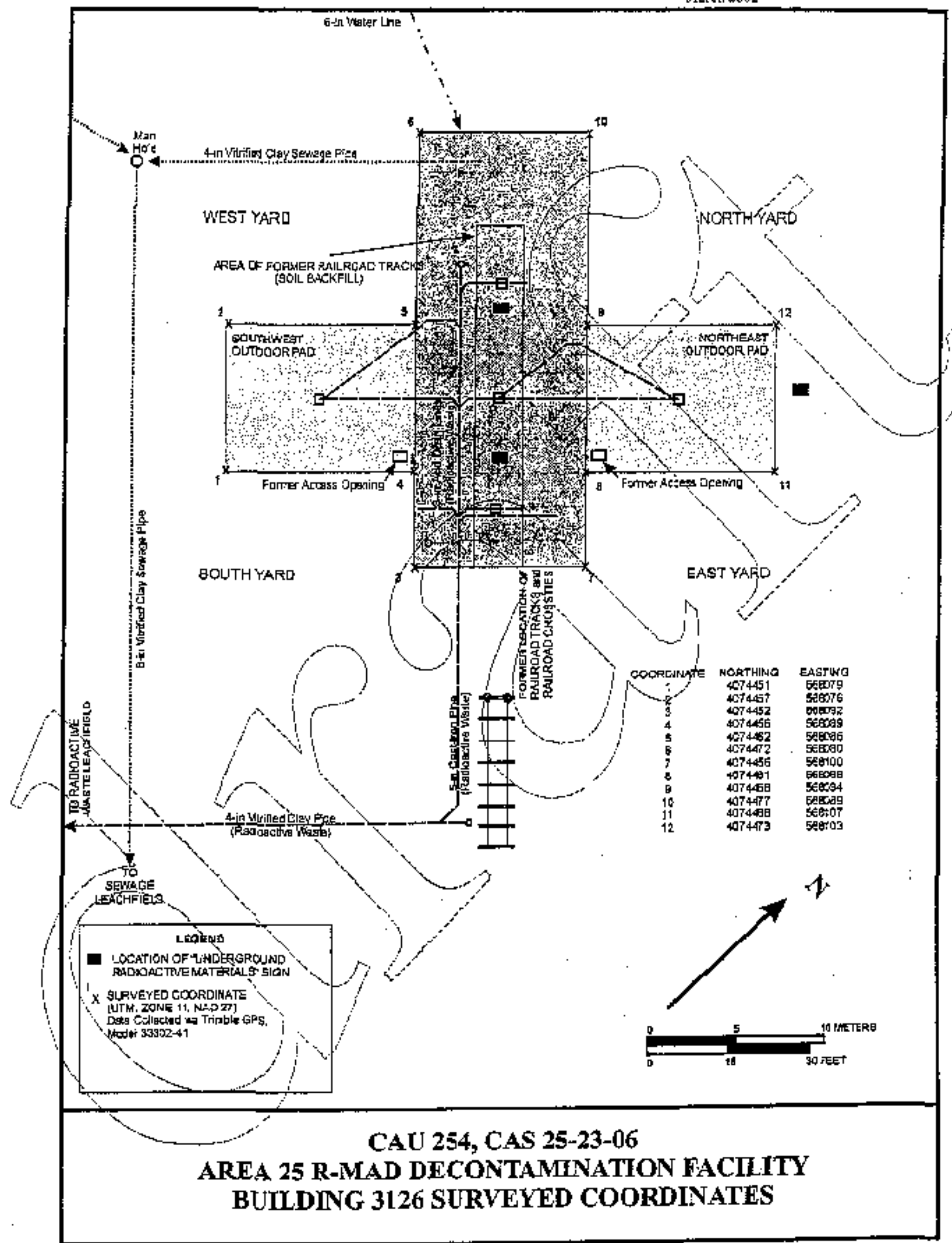


RAW COORDINATE DATA

F-11 
THIS PAGE LEFT INTENTIONALLY BLANK

F-12 


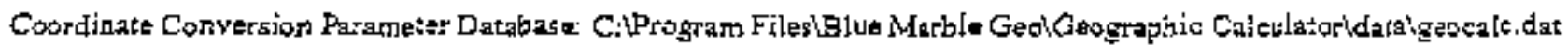

\begin{tabular}{|c|c|c|c|c|}
\hline AT & रिव्वस्त & FEt & & \\
\hline$R ?$ & DEEGMTSS & beghanise & & \\
\hline & s. & $c$ & & \\
\hline$\overline{R j}$ & "36.48513ण" & 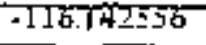 & $407+45]$ & 563059 \\
\hline Af & 36.489181 . & .116 .142578 & 4074457 & 568076 \\
\hline $\mathrm{RJ}$ & 36.489151 & +116.142474 & $4074452:$ & उदप्रण52 \\
\hline Ro & 36.489175 & $-116.12 \geq 490$ & 4074456 & 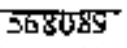 \\
\hline$R 7$ & 36.759208. & -116.142515 & 4074432 & 563045 \\
\hline$M B$ & $36.489260^{\circ}$ & -116.14235! & 4074477 & 568680 \\
\hline$R$ & 36.489176 & -Г16.1424T7: & 4074456 & 588100 \\
\hline$R N$ & 30.489200 & -116.142432 & 4074461 & उठ8098. \\
\hline 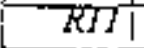 & $36.48923 \mathrm{~d}$ & -116.142458 & $4074468:$ & 568094 \\
\hline RII! & 36.1899286 & 2156142493 & 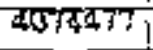 & 563085. \\
\hline$R / 3$ & 36.489230 & -116.142370 & 4074466 & 56810?: \\
\hline$R T+\mathrm{i}$ & 36.489263 & -116.142350. & 4074473 & 5ण्दार० \\
\hline \multicolumn{5}{|l|}{$R T 5$} \\
\hline$R I B$ & Notes: & $\bar{b}$ & ! & \\
\hline \multirow{3}{*}{$R I 7$} & Elevation: & & & \\
\hline & $1171.76 \mathrm{~m}$ & ! & | & \\
\hline & as & & & \\
\hline$R / 8$ & $\begin{array}{r}\text { Soupe at } \\
\text { Data: } \\
\text { Trimble } \\
\text { GPS, Modsl } \\
33302-41\end{array}$ & & & \\
\hline
\end{tabular}

\section{Foint Dalabase Canverslon Serings}

Input North/South Colurna: C1

Input Esst/West Column: $\mathrm{C}_{2}$

Intut Height Colutur:

Output Noith/South Colama: C3

Outpur East/West Column: Of

Outut Feight Columst:

Output Scale Factor Column: (tone)

Ourpur Convergence Columa; (ans)

\section{Cooritinate Systewn Groip "Geodefic Lattutie / Longltude"}

Coordinate Systerd: Lariude / Longitude

Detrm: WGS 1984

Ethipsoid: Wis 1984

Semi-major axis (meters): 6378137.0000

Semi-minor axis (meters): 6356752.3142

1st esctintaloty: 0.081819190843

and ecrentricity: 0.082094437950

Flattening: 0.003352810665

Keciprocal flatening-298.2572 


\section{Coordinate System Group "Universal Thanswerse Mercafor"}

Coordinate System: Zone $11 \mathrm{~N}(120 \mathrm{~W}$ to $114 \mathrm{WW})$

Daturn: NAD 1927 - Wentem US

Datum Transfomation Method: Molodersky

$X$ shift to WG\$ 4 (m=ters): -9.000000

$Y$ shift to WGS $\$ 4$ (meters): 159.000000

$Z$ stift to WGSBA (neters): 175.000000

Pine meridian shift (deg): 0.000000000000

Ellipsoid: Clarke 1866

Semi-major axis (mtters): 6.378206 .4000

Semi-minor axis (meters): 6356583.8000

lst acoentrioity: 0.082271854225

2nd eccentricity: 0.082551710741

Flettening: 0.003390075304

Reciprocal flartening: 294.9787

Projection: Transverse Mercator/Gauss-Kruger

Units: Meter

Orisin latitude: 1t 0 0000,0000

Origin longltude: W 1170000.0000

Falsenorthing 0

False asting: 500000

Scale factor: 0.99960000

Bine Marble Geggraphics.

The Geographie Sofhwere Conponent Congenny,"

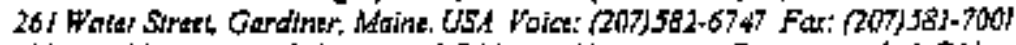

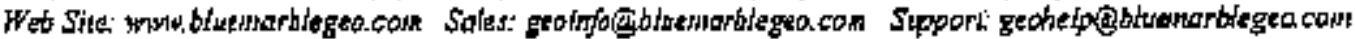




\section{APPENDIX G}

\section{COPIES OF FIELD NOTES}


THIS PAGE L.EFT INTENTIONALLY BLANK 


\section{APPENDIX G}

\section{TABLE OF CONTENTS}

Copies of Field Notes $\ldots \ldots \ldots \ldots \ldots \ldots \ldots \ldots \ldots \ldots$, G-5 
THIS PAGE LEFT INTENTIONALLY BLANK

\section{G-iv}




\section{Copies of Field Notes}

G-5 
THIS PAGE LEFT INTENTIONALLY BLANK

G-6 


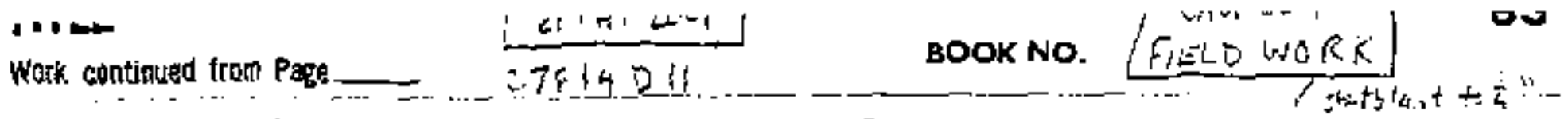

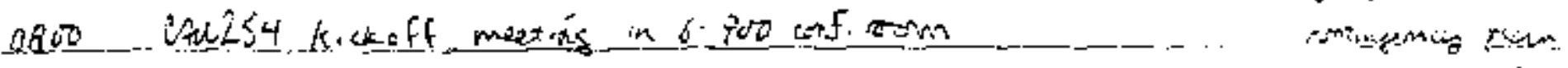

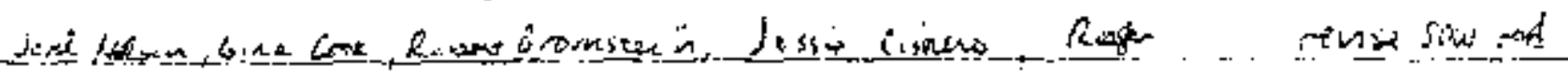

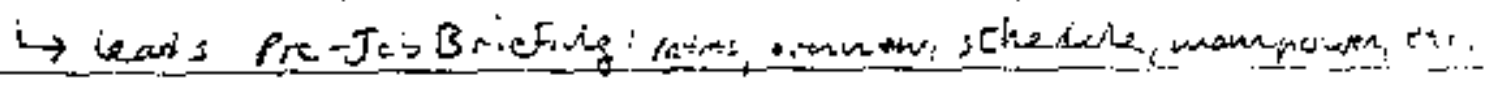

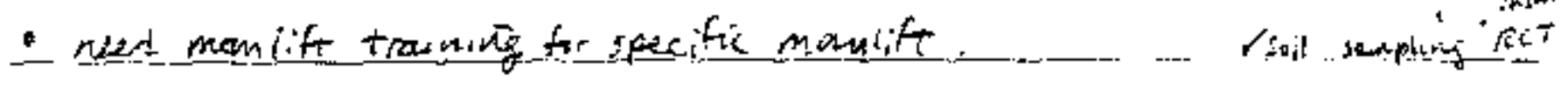
5

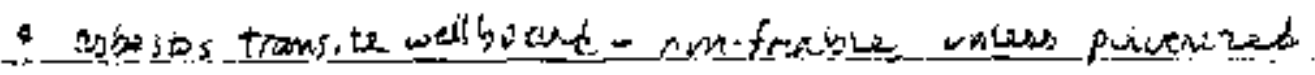

10

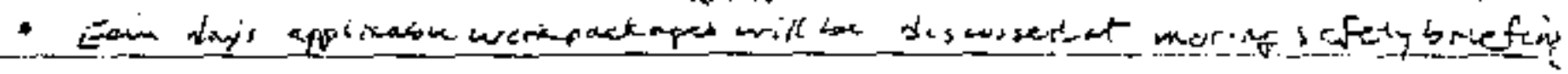

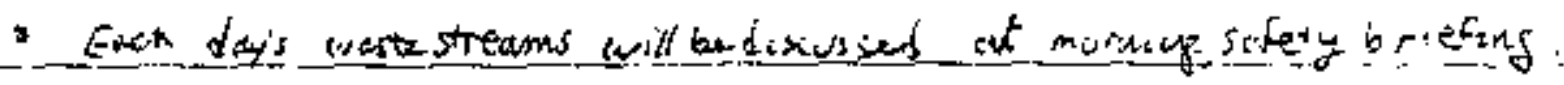

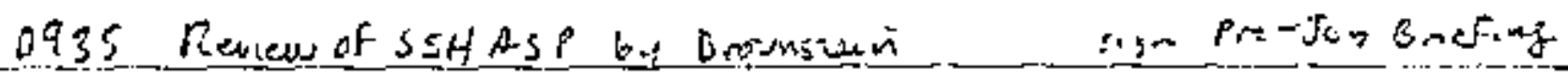

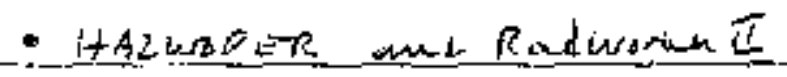

Nosprate JHAs.

15

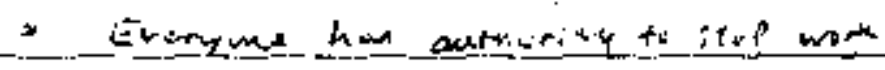

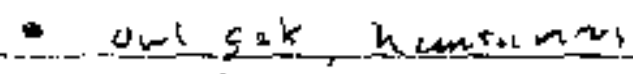

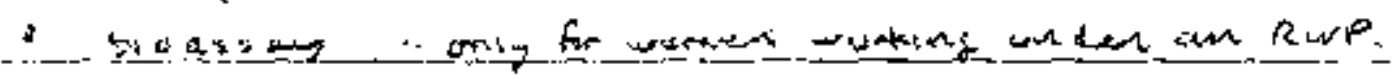

inatcom rsos

$\therefore$ -

$\therefore-$

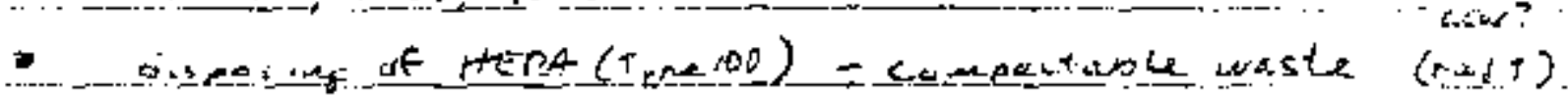

- host stress, w w

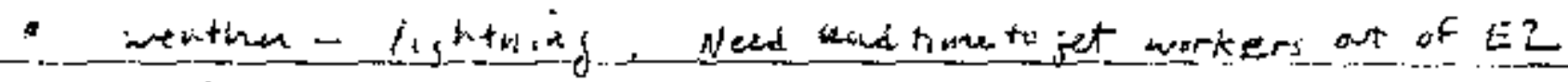

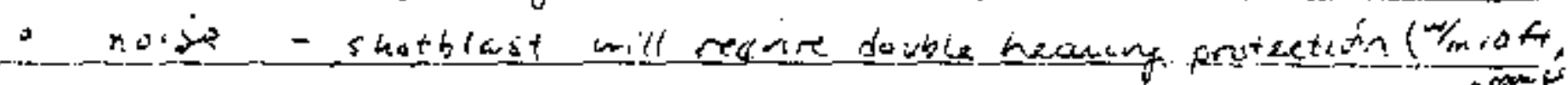

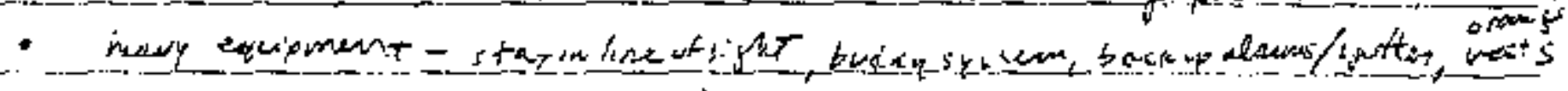

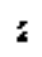

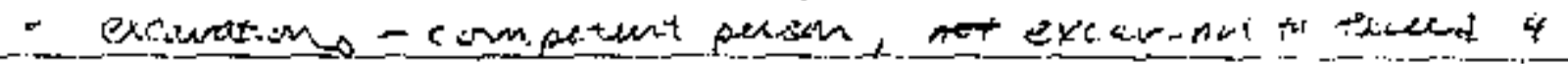

biret vtilites

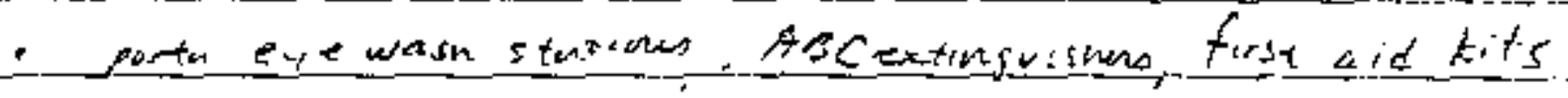

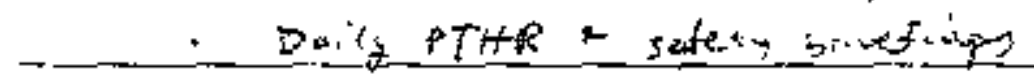

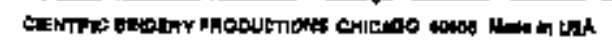

Work continued to Page

SIGRATURE

DATE

DISAOSED TO AND UNDERSTOCD UY

DATE WTNESS DATE

$6: 7$ 
84 TITLE

PRONECT NO.

Work contioued from Page

BOOK NO.

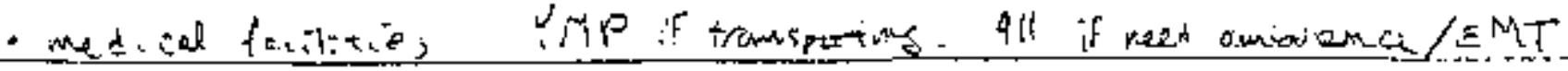

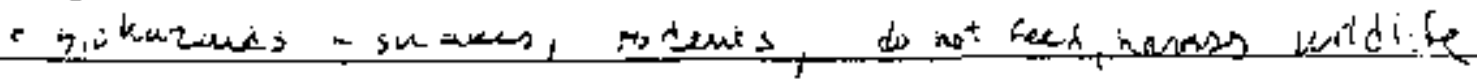

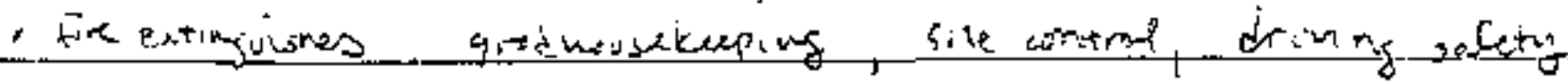

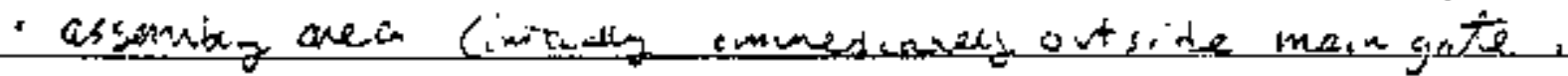

5

- $E \vec{z}$ nies

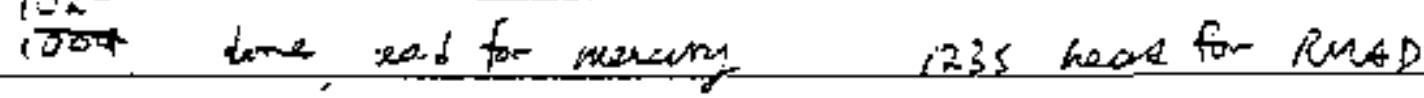

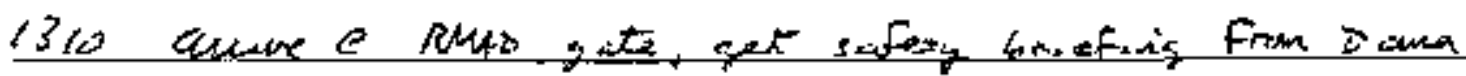

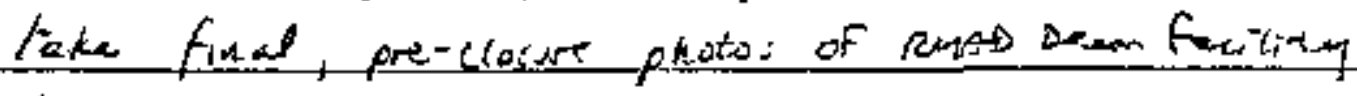

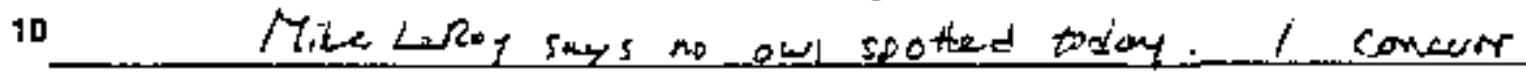

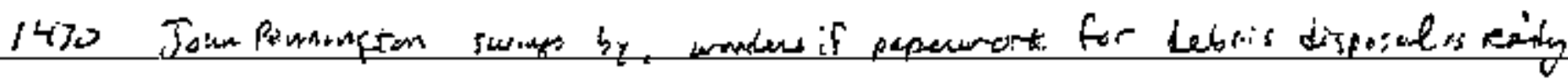

irm Hidiskey Rober Brownstien

jessis cosnent:

15
Mrite $V \cos D_{i} u_{i s}$

M, Lit Lan

Dems kolker

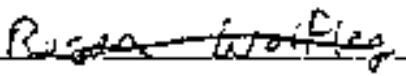

Tike withene

20

ait supecusor en liwhey.

tentifit
David Mituryte

Jounmen Grostat

Rum fartionicas

Bith Sutkention

Joum Penuningtan

Jared Langer

Ruben coarcos

6 ing Gominen

Damil Voligin.

Ropierotfleg.

1530 sepust RUAD for Mexcang

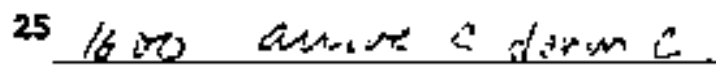

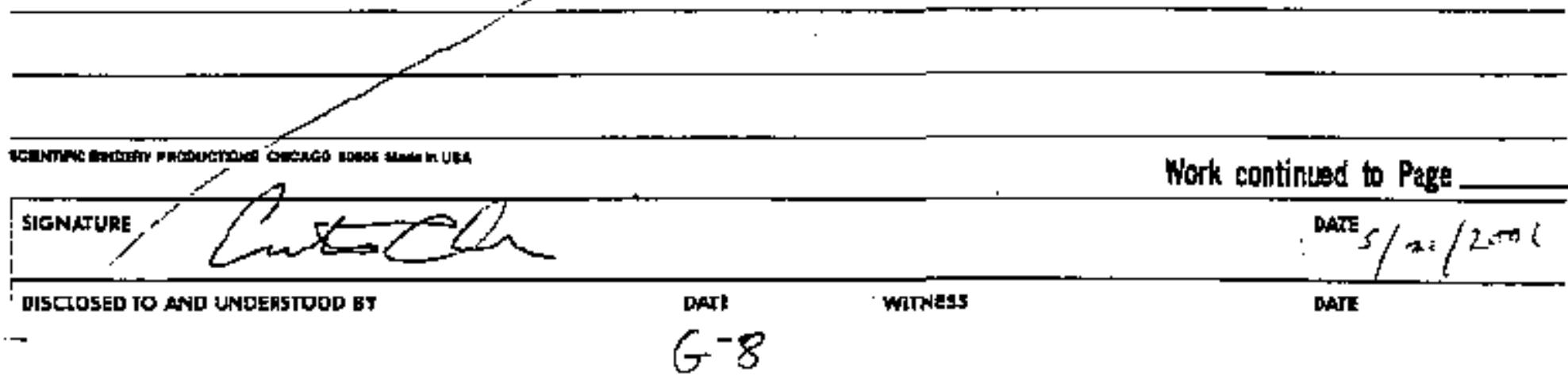


TITLE

PROJECT ND.

85

Work continue from Page sis ing ul BOOK NO.

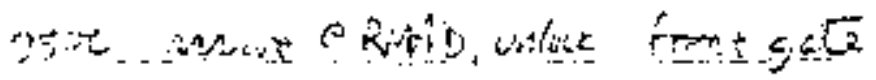

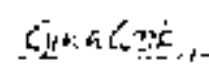

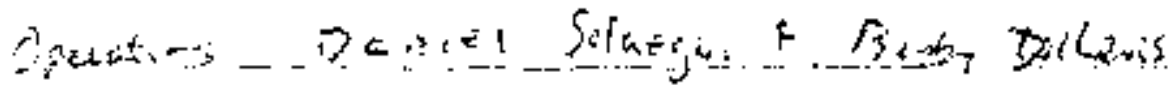

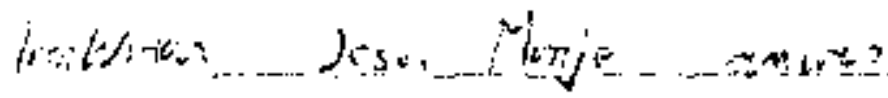

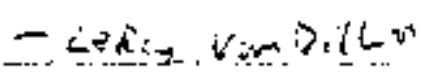

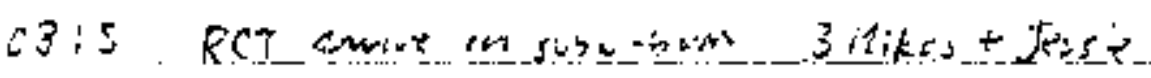

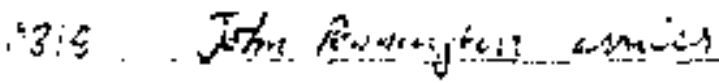
$(3-170-6-2$ $F+74$

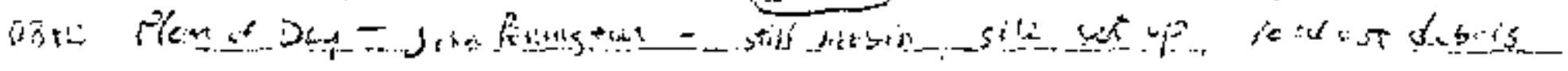

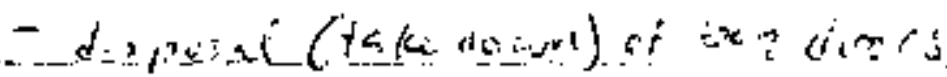

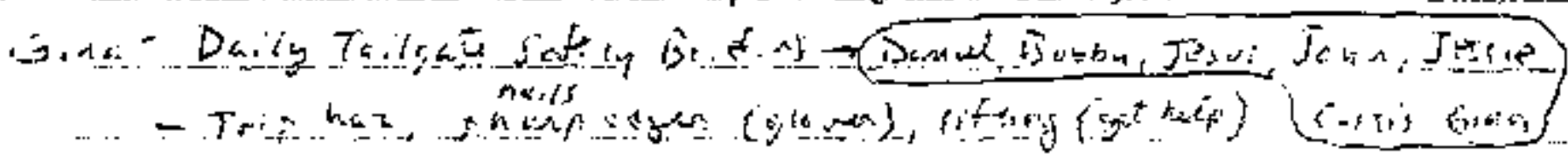

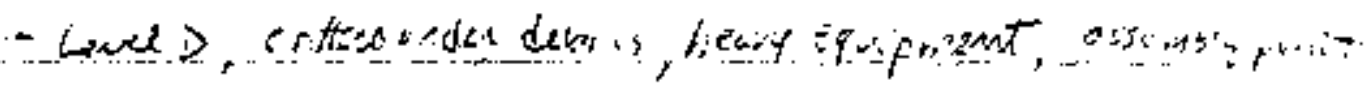

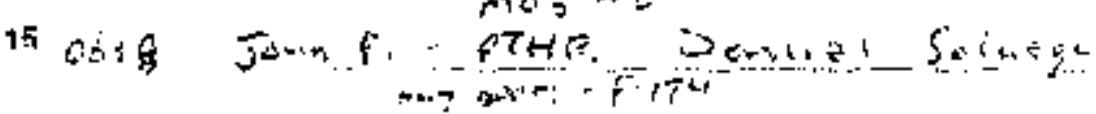

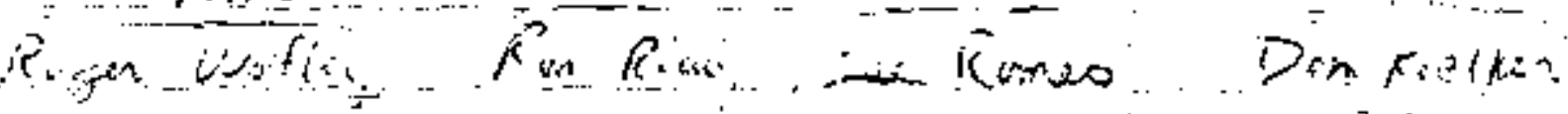

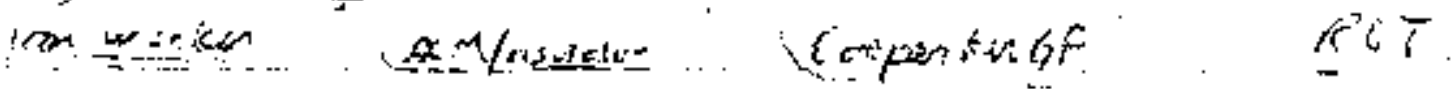

20

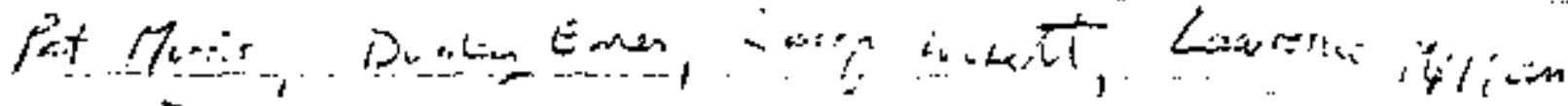

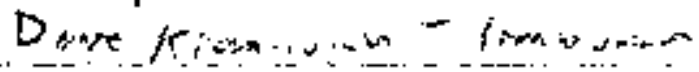

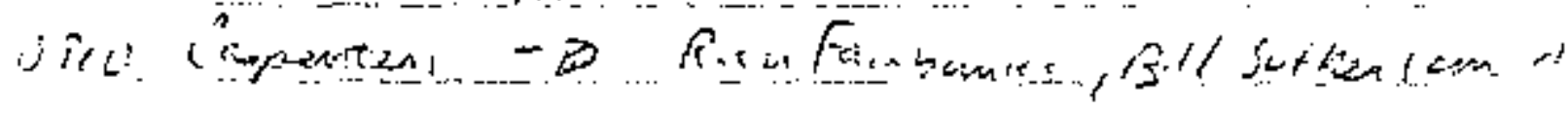

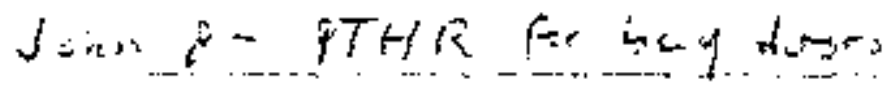

25

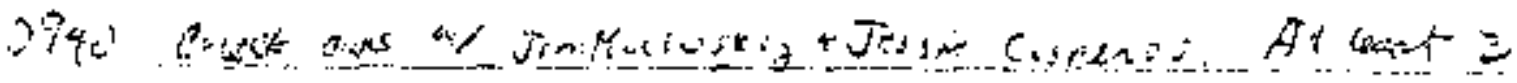

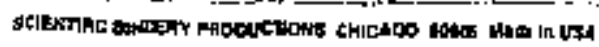

SIGNATURE

DUELLED TO AND UNDERSTOOD BY
Work continued to Page

DATE

DATE

WITNESS

DATE 
86 TITLE

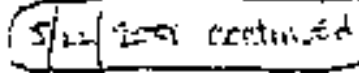

Work continued from Page
PROJECT NO.

BOOK NO.

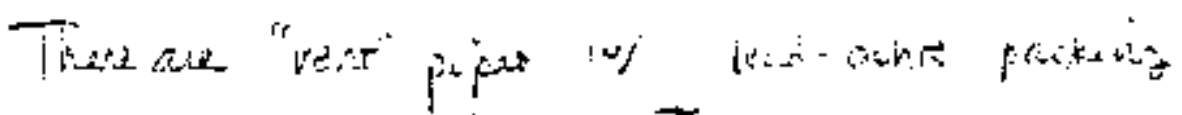

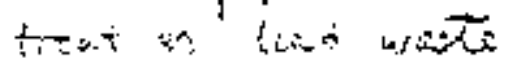

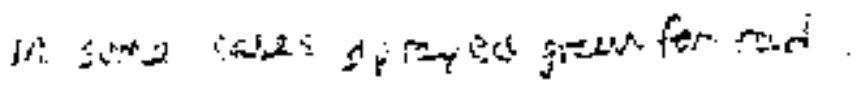

急

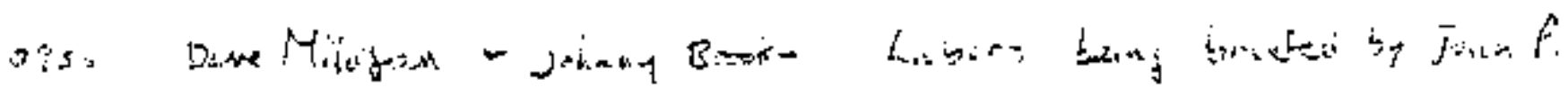

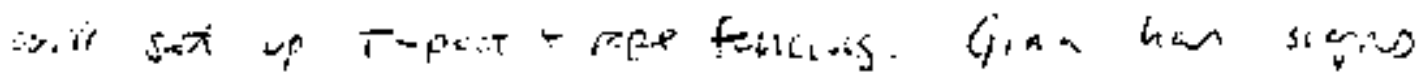

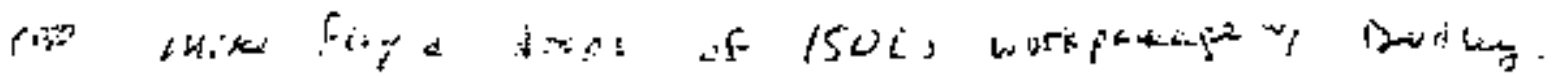

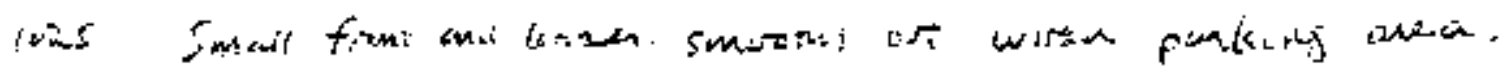

fore lift riven dizioris

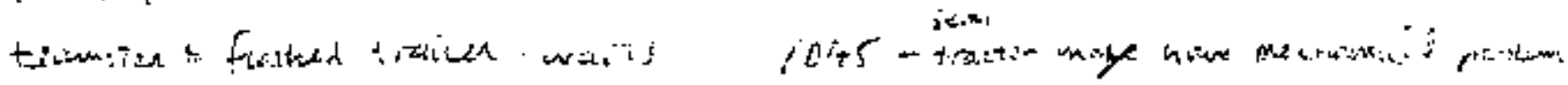

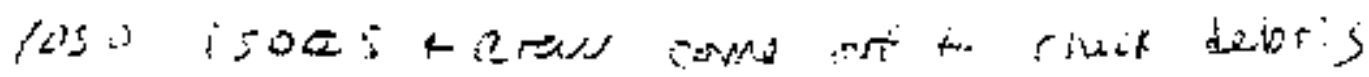

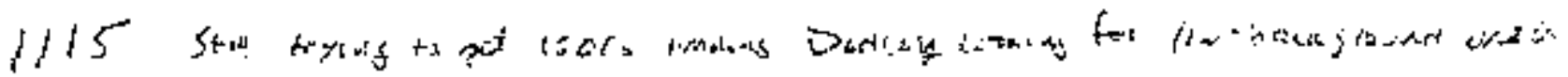

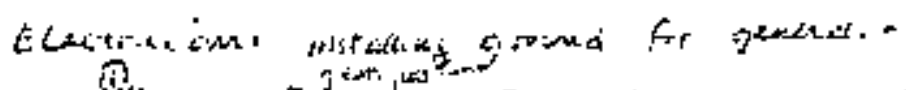

fol

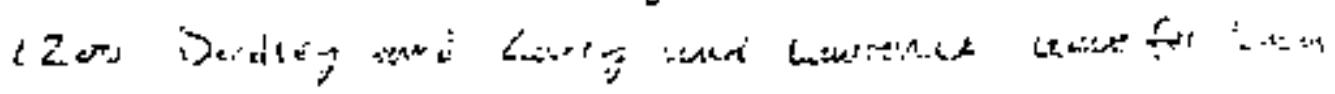

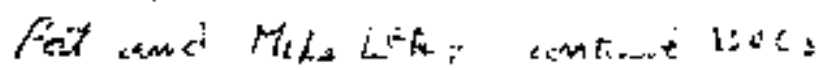

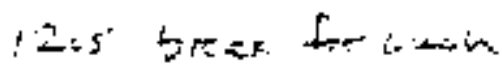

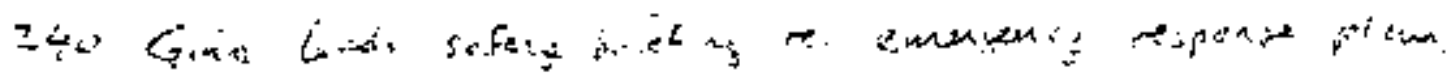

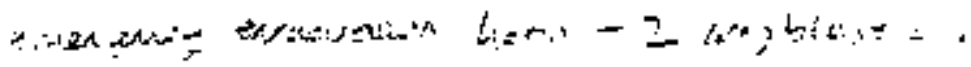

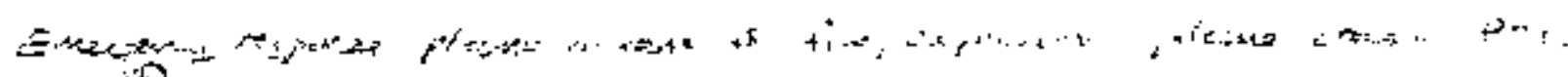

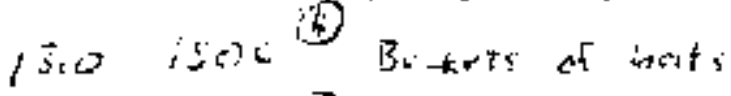

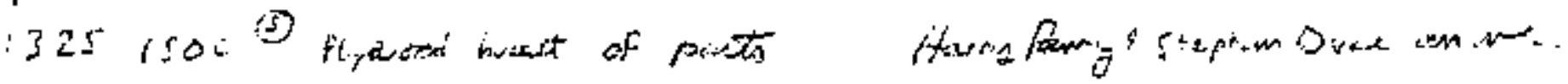

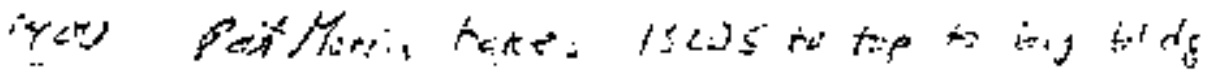

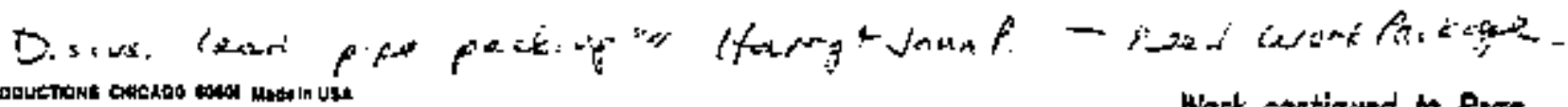

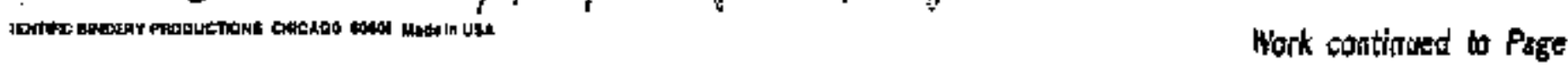

ilenatura

DATE

JISCLSED TO AND UNDERSTOOD BY

DATE

WITNESS

DATE

$6-10$ 
TITLE

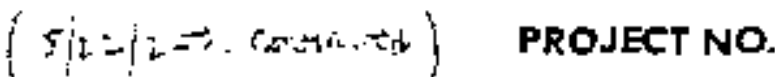

BOOK NO.

87

Work continued from Page

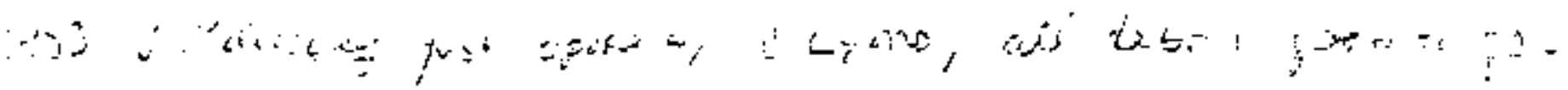

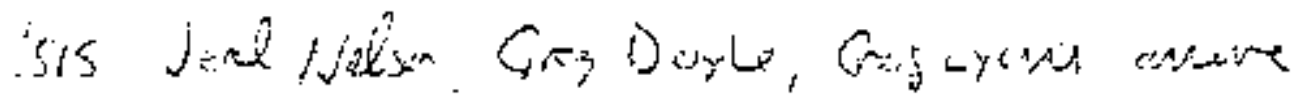

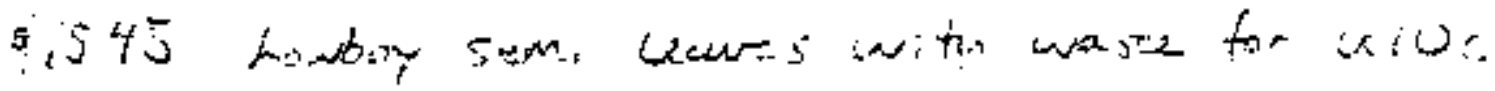

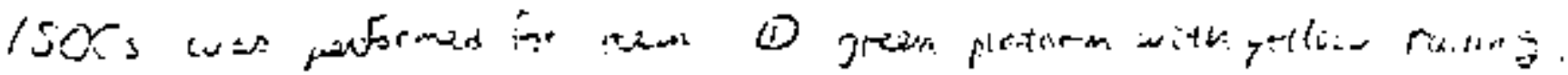

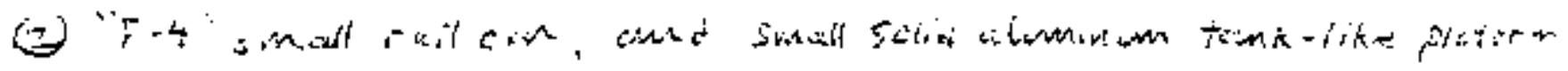

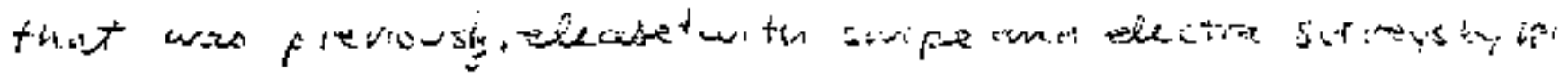

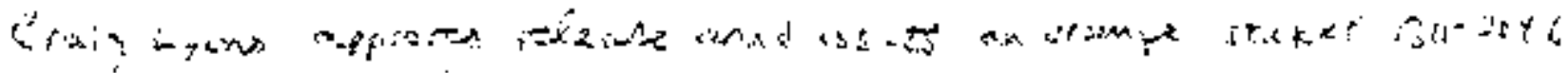

10

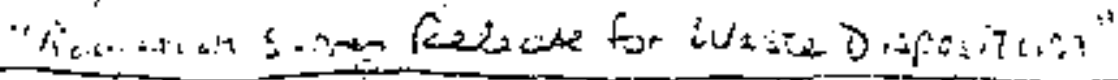

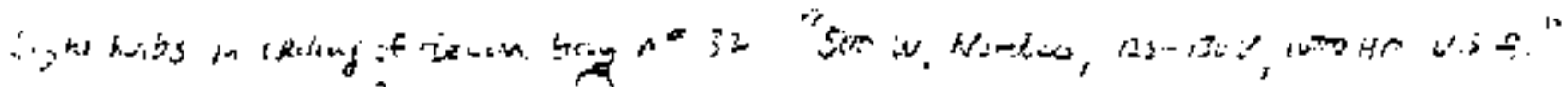

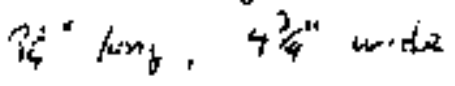

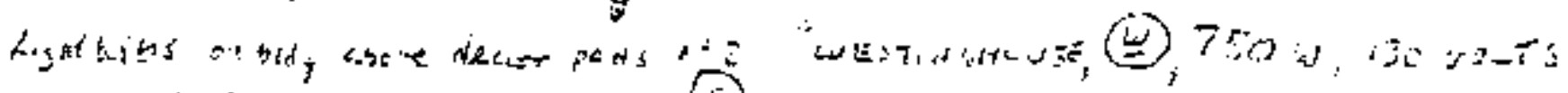
15

12 long, d" wide

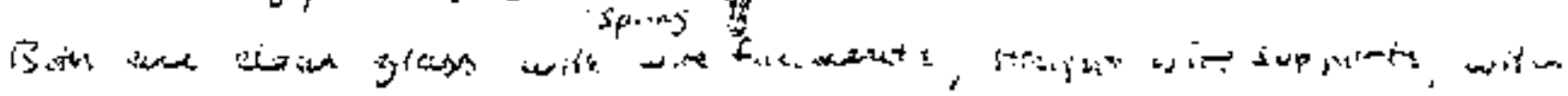

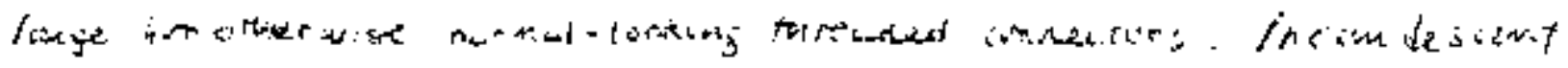

20

1430 densest $5: 0$

1700 ind ut dinah.

25

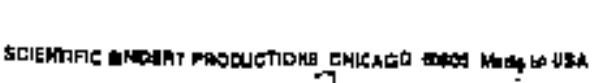

SIGNATURE

$\therefore$ is DISCLOSED TO ANE UNDERSTOOD BY
Work continued to Page

Dar

$5 / 22 / 20$

DATE

WINES 
88

TITLE

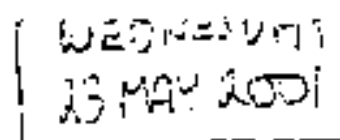

PROJECT NO.

Work continued from Page

BOOK NO.

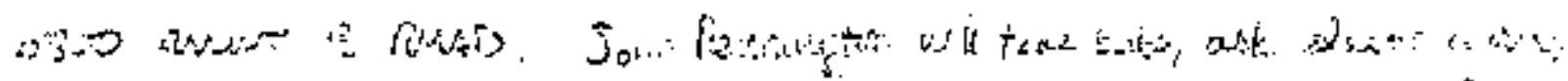

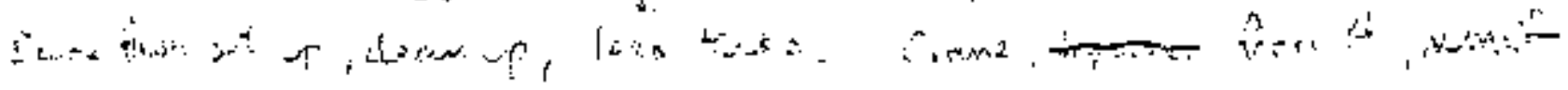

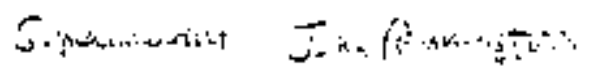

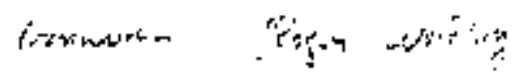

$\therefore \rightarrow$ and

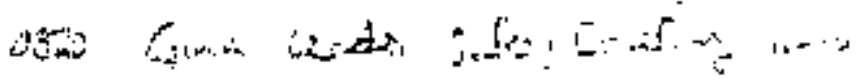

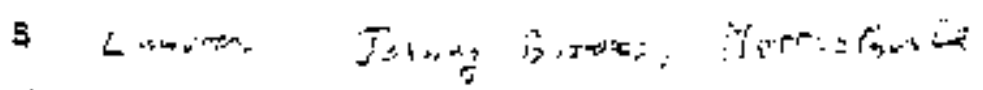

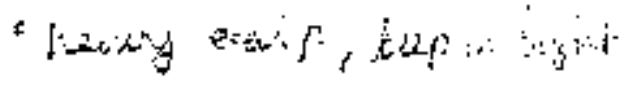

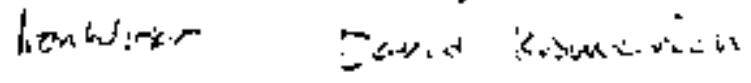

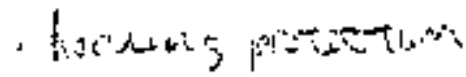

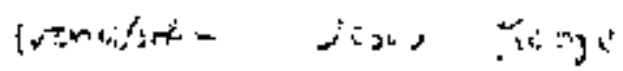

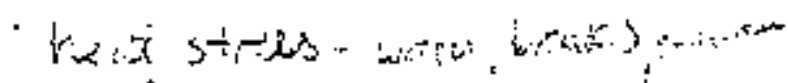

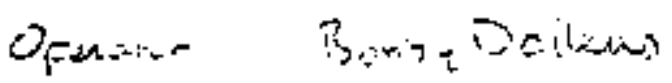

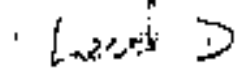

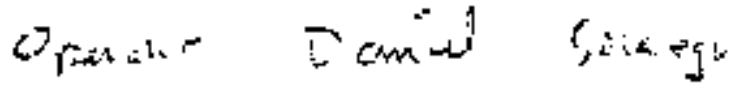

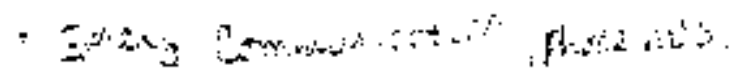

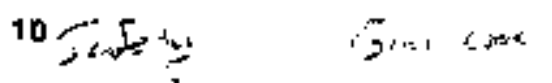

- Ins

Oinisis

1 expiation

$* y^{r}+x_{1.1}$ a

ard Pun

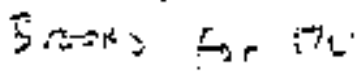

15

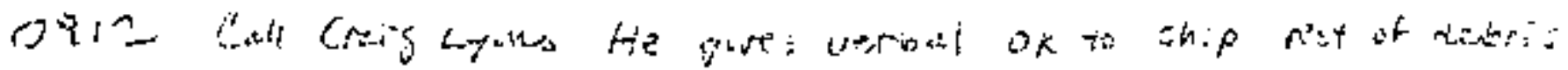

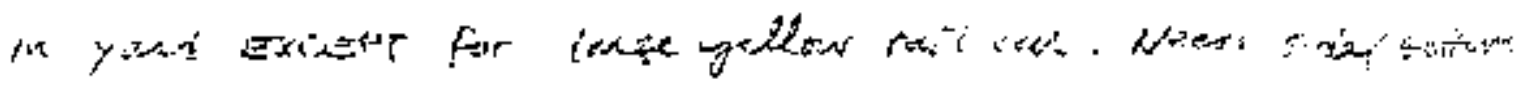

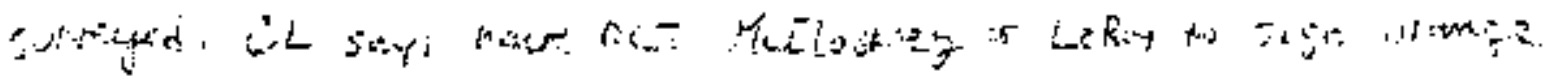

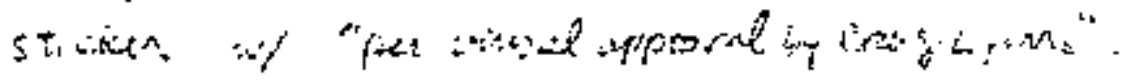

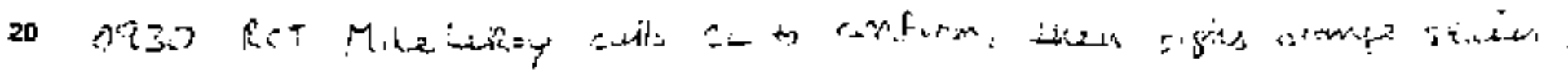

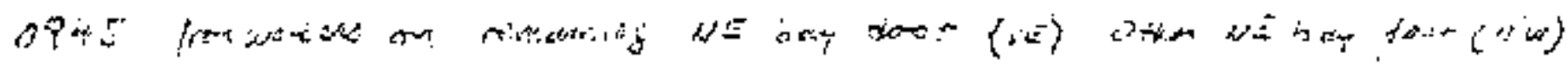

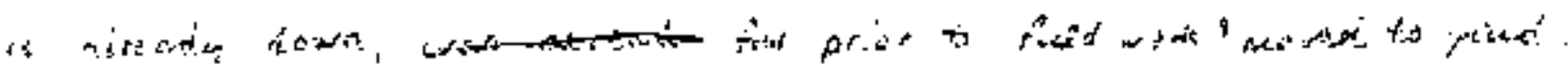

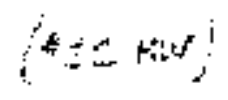

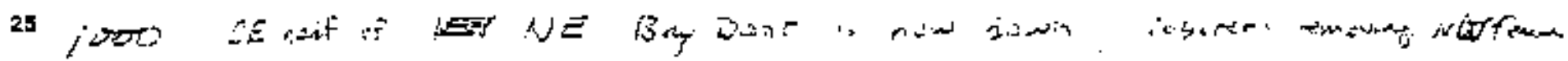

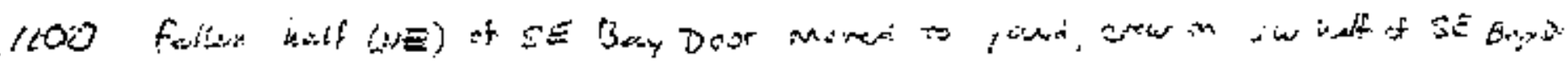

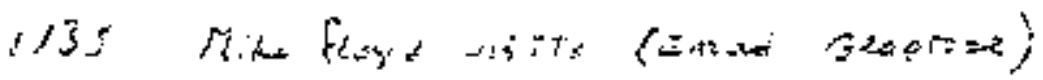

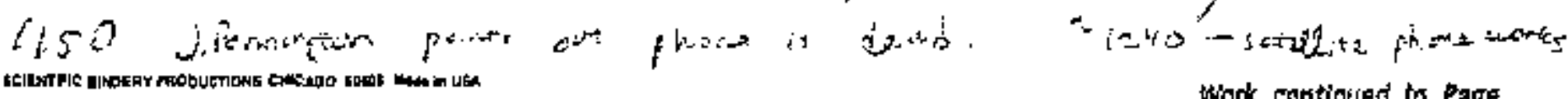

Work cortinusud to Page

SIGNATURE

DATE

DISCLOSE TO ANDUNDERSTLOD BY

$t_{t}^{\text {Daft }}=12$

WINES

DATE 
TITLE

Work continued from Page
(

BOOK NO.

89

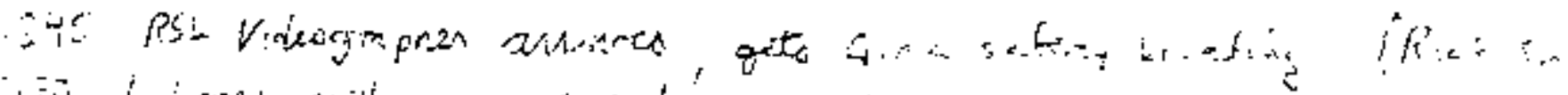

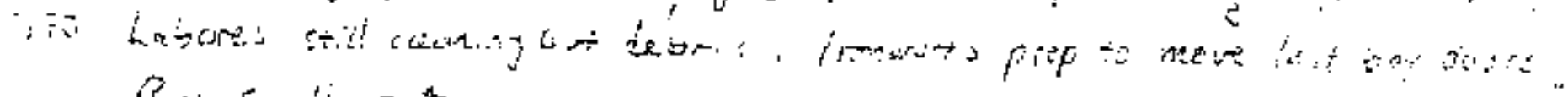

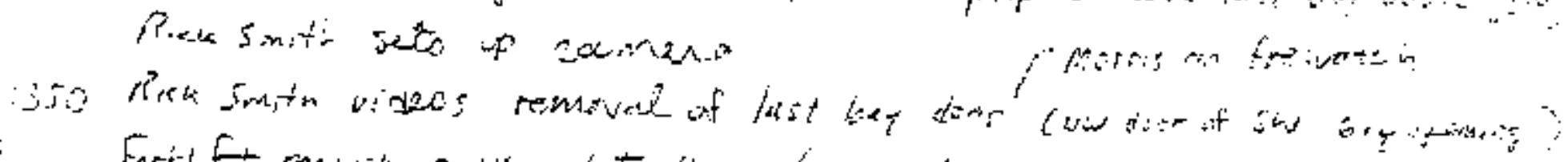

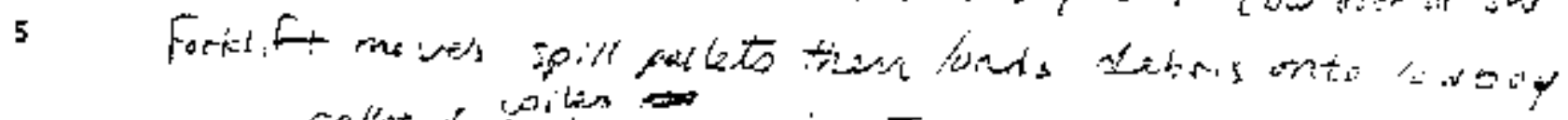

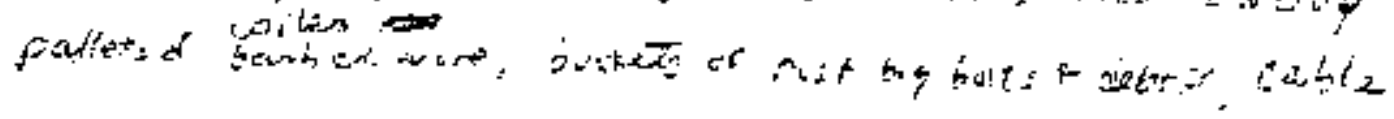

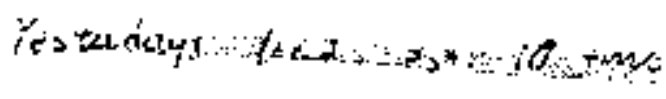

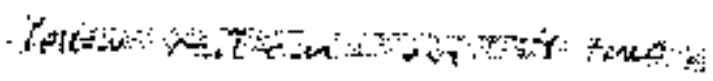

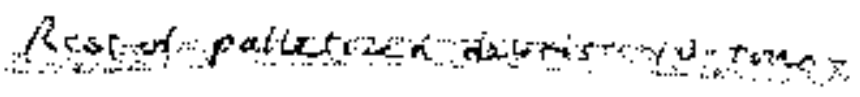

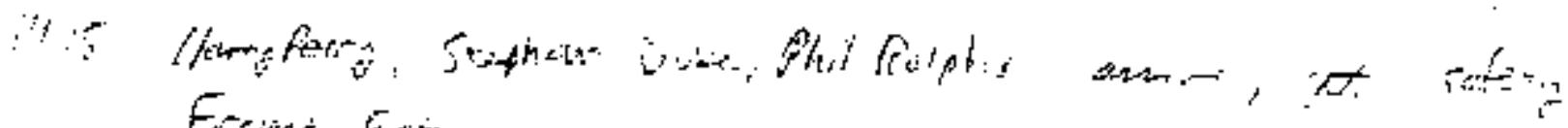
Frimit. Ex:

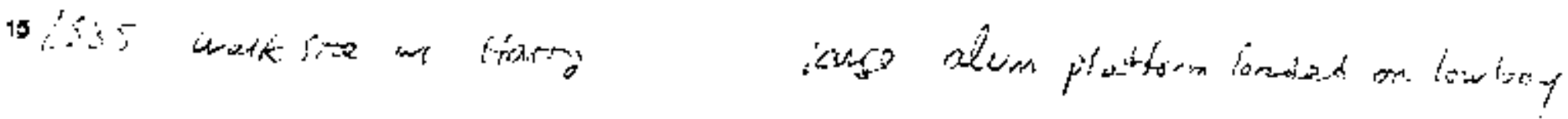

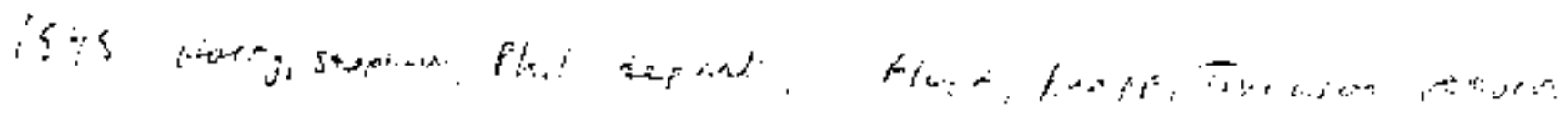

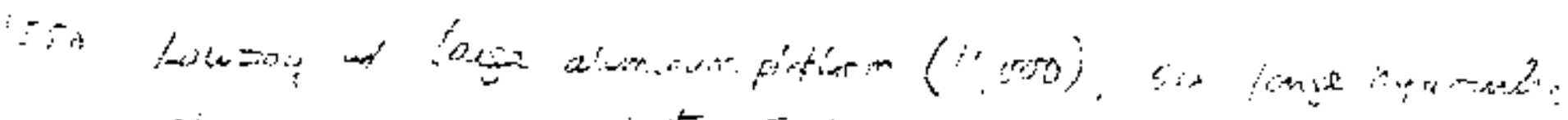

20

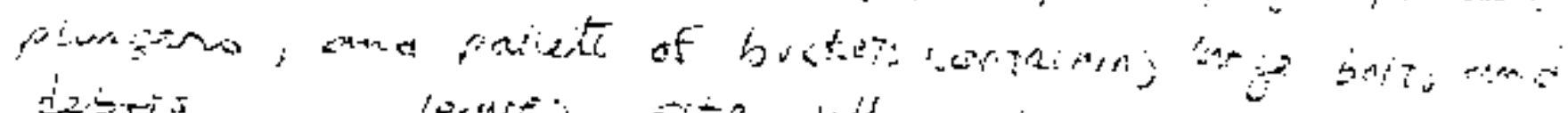

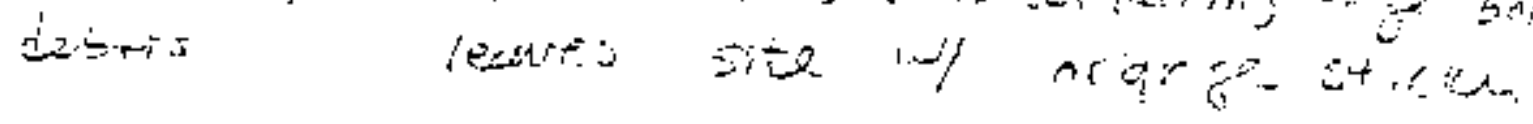

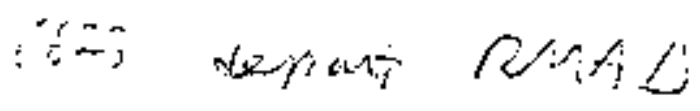

20

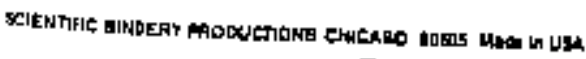

SIGNATURE

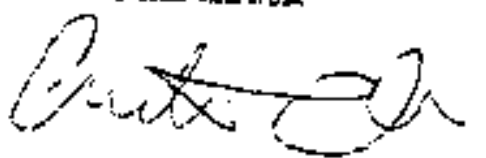

DISCLOSED TO AND UNDERSTOOD BY

$$
6-13
$$

Work continued to Page

$$
\text { DATE } Y:-7 / z=
$$

DATE 
90 TTLE

Work continyed from Page

0250 anive $S$ RAD

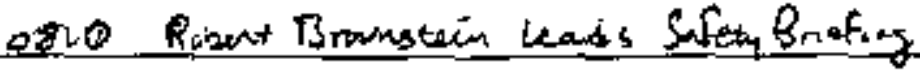

- hast strews fir/s an/pet yestmixy

breuk is min / Zur worik
PROJECT NO.

BOOKNO.

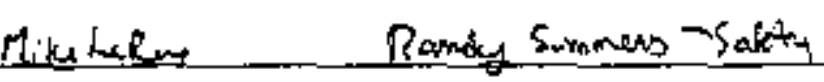

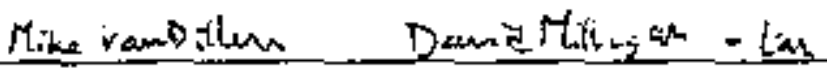

Ribut brungin

Juhway 3 rooks -las

Toming $60 m^{m} 2$

jober Pevinuigtan - sop

5

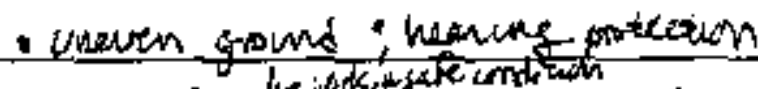

Bos Rommel

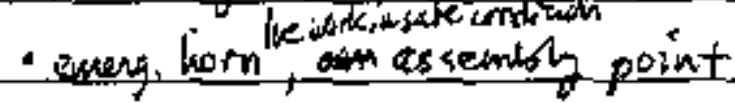

Bo'yzy.lems omi

- hoies in growd where fence posts emoved

Dammy folegri-opa

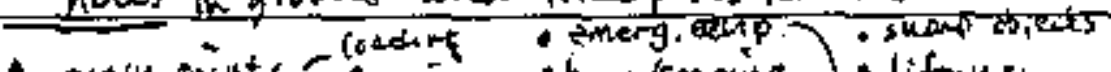

Mrrif Give - Losps

$P$ lam af Day : continue setup, more ant deicts

jestie Manje-lon

10

one workpacage to dowy,

Reseswitley Iran

fire eating, eye wasin fir il aid icil

Jack R. 3s - Team

$6 / 4$ - csobs. \& soil-resilators

Bud seguero - tab

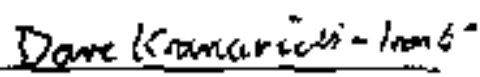

i5 \$840 losding debats onto Jese's lowboy

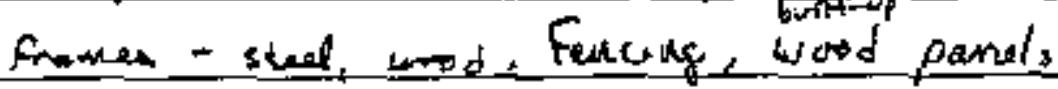

Nead

Hoso Reriew artstandine action teins

Next week

Paty bettles

20

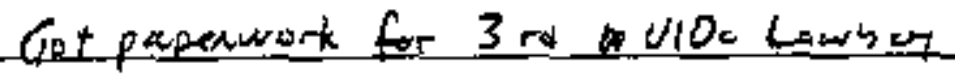

Downlead pics

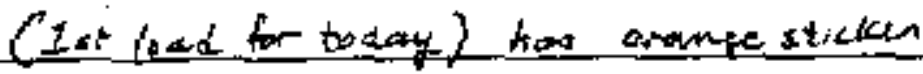

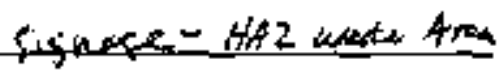

initialed by MVD per C. Lxeng

$=\operatorname{HW} A \mathrm{ma}$

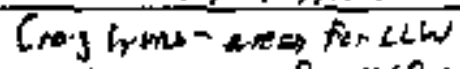
doum anes for ento

The soubue for text wrek (week 2) is:

25

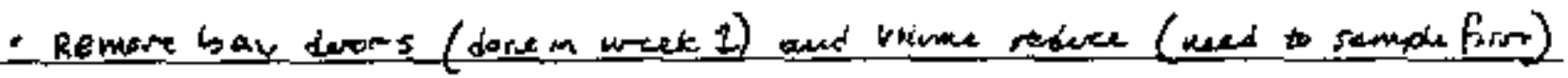

- Dram and sample adL fCors.

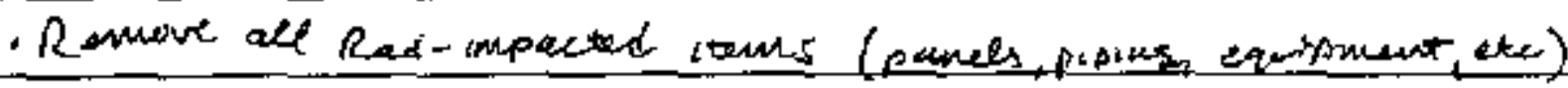

west 3 will be cemove rad sol and begin removin ACSLS.

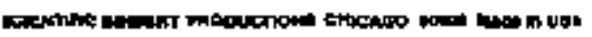

Work contimued to Page

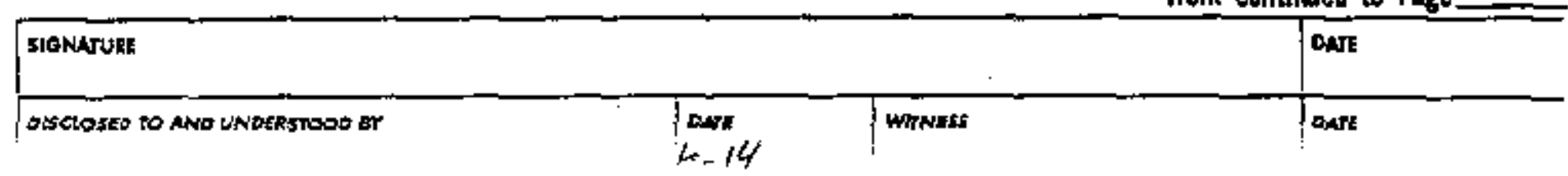


TITLE

(ripupool untinued) PROJECT NO.

BOOK NO.

91

Work continued fram PBge -

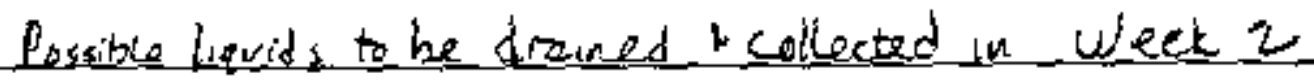
Anely

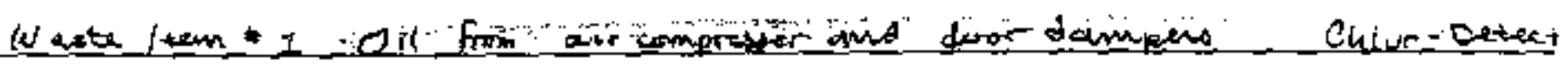

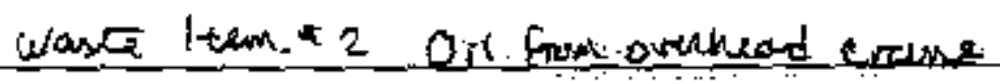

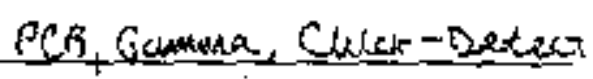

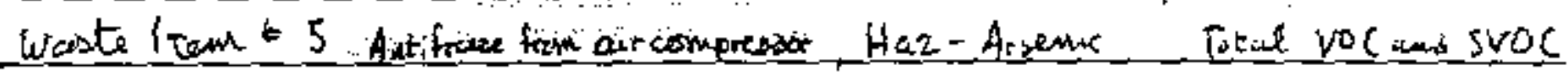

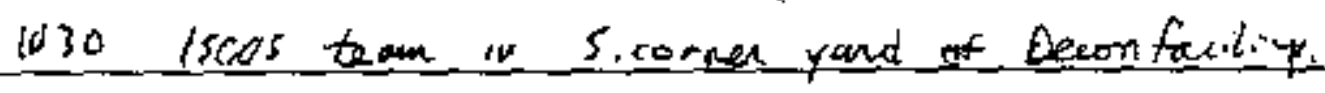

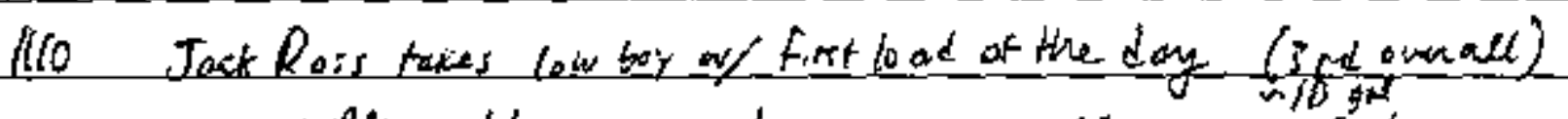

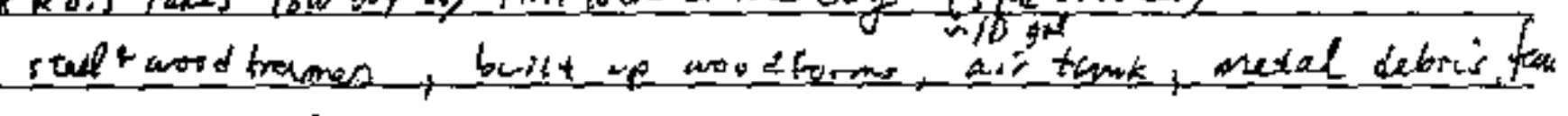
Hes liad ficm of erange stuckan.

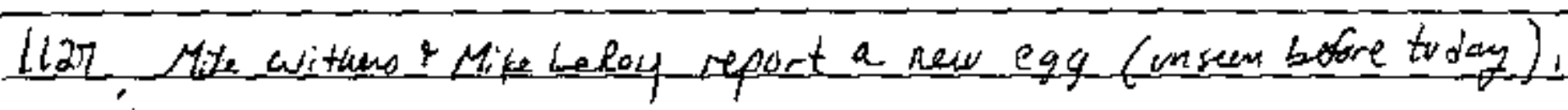

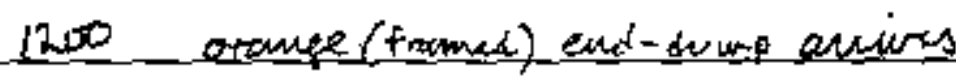
Den Dakuy. 15

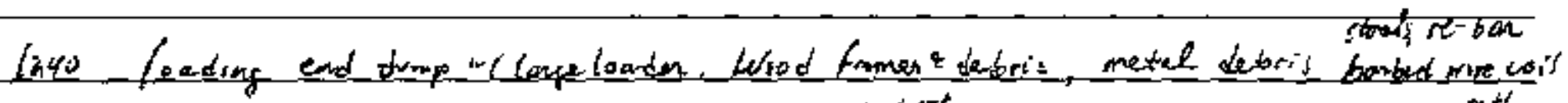

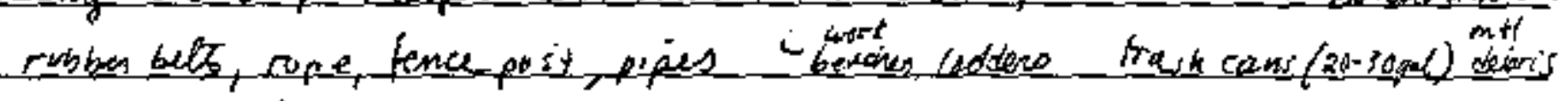

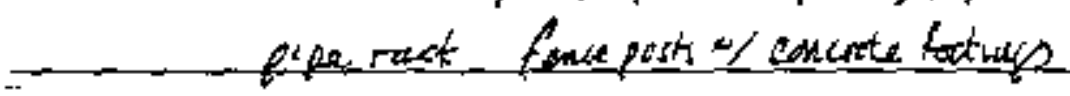

20 Liss Cina but an sib

Qtextaveta

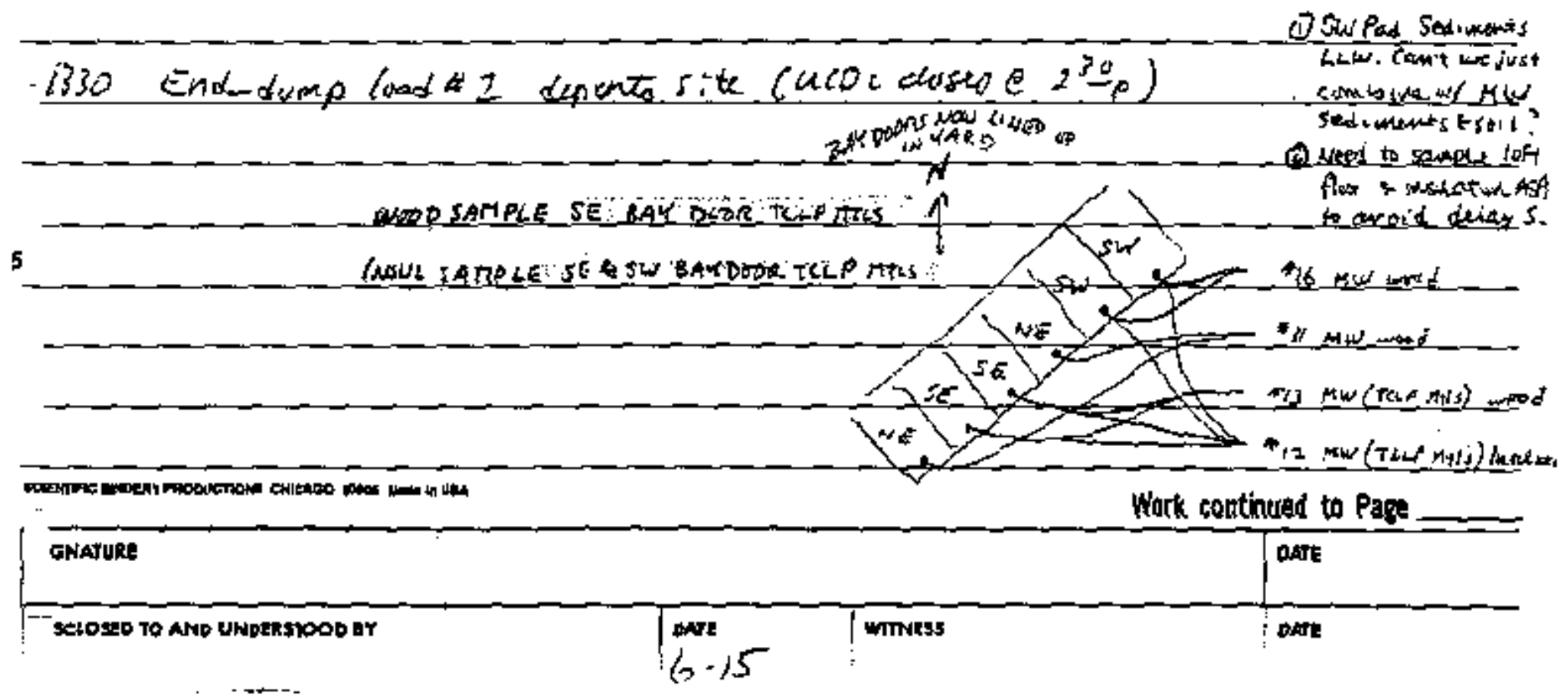


92 TITLE

TIVESDAY

PROJECT NO.

Work continued from Fage.__

BOOK No.

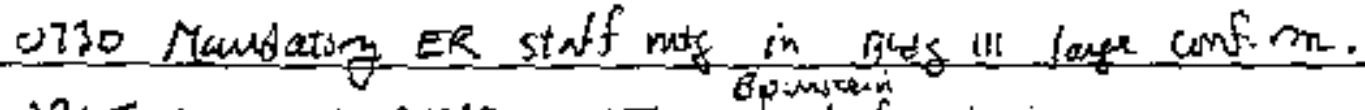

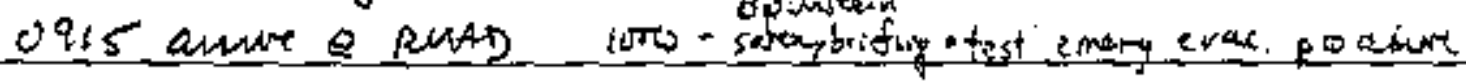

(onthosis

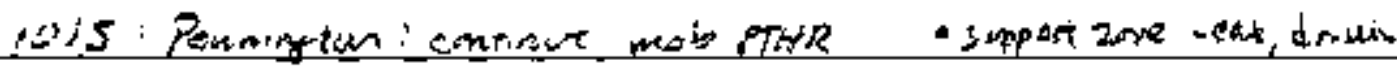

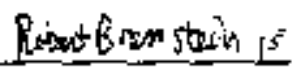

Ginater (s)

- heet stress foriss sheltes

- Ez - Arinke hatting apen

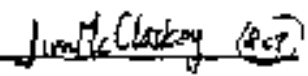

- pinat privas, trips, shasp dij.

BCT survey

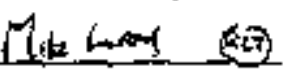

- thermal borns, metal in som _. Eir extivuguisheno

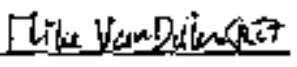

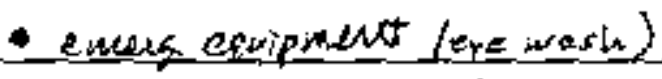

Doakgedier sat

- Girgurne pantucies

Mise bithero ac:

- heaking protetion ne equig.

jessic Cineosfor

- PPE - lave 2

Mentraxie (1)

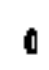

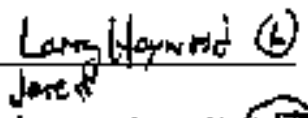

Eepowe works sot up fhomes

Nisis Monje (W)

RHIER RMAD VOX $5-0867$

Pitgenkeifler (ii)

FAx $5 \cos 73$

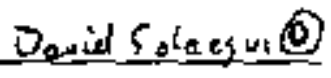

15

LackRors $(0)$

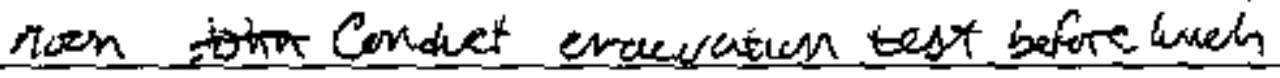

Dos Deislege 0

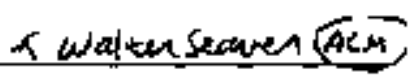

1300 Lood up flat bed semi-tratex with mare dabix, fence ports w 2 cme. footings

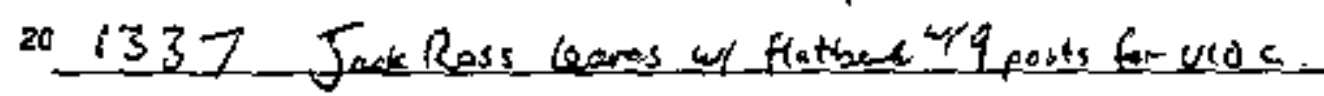

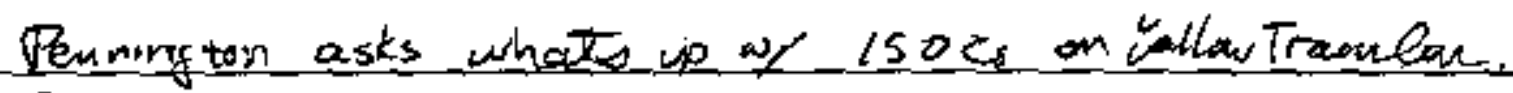

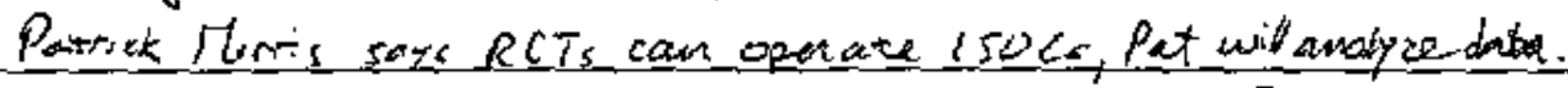

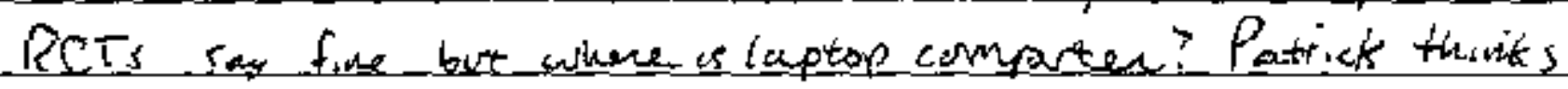
25 It is in Hensery. Can't reach Dudieg, to us.

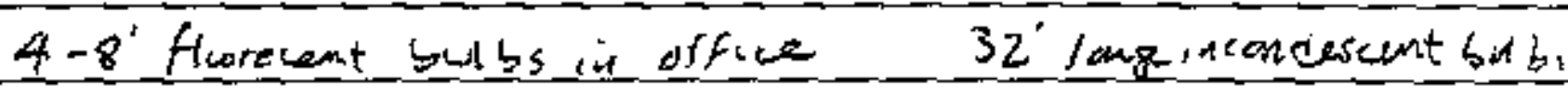

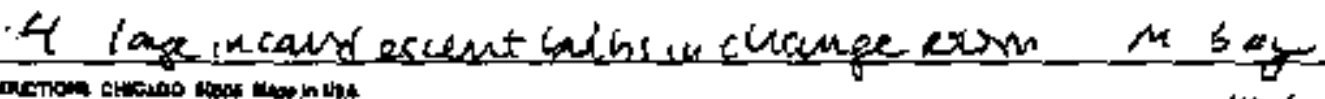

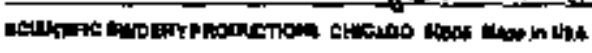

Work continued to Page

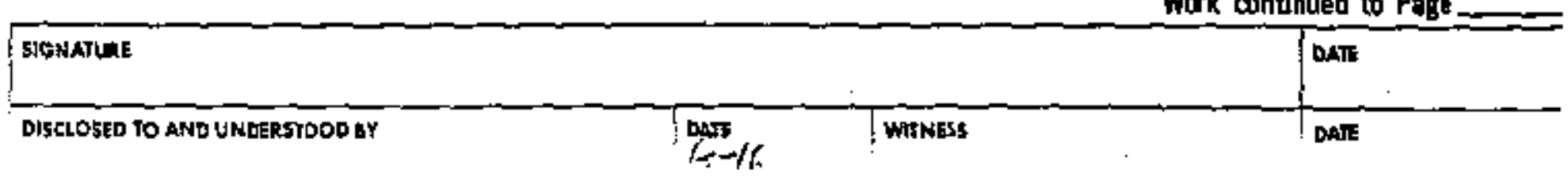


TITLE

Work continued from Page
(129) word continued

PROJECT NO.

BOOK NO.

93

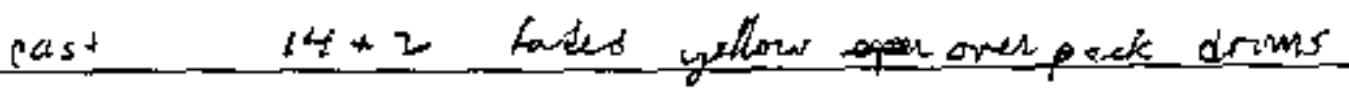

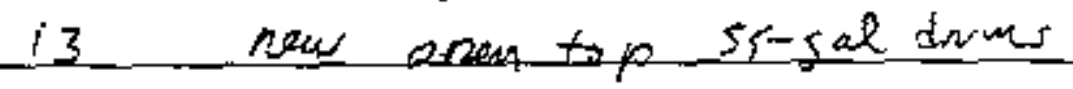

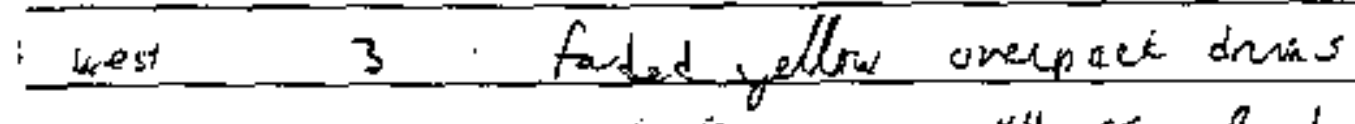

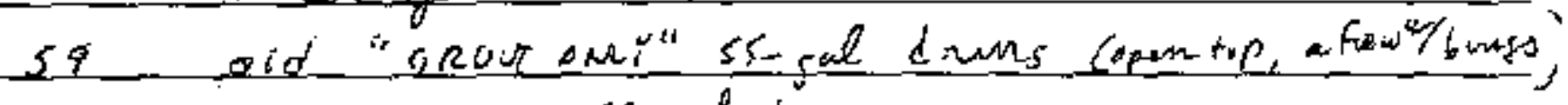

2 new open top si-gul dins

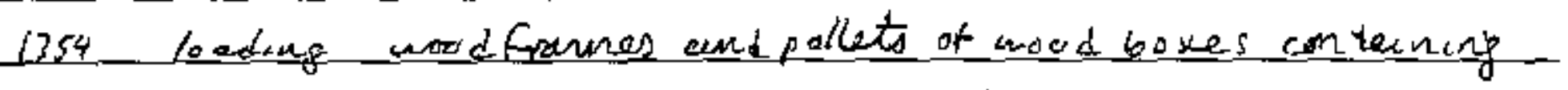
hear y cable into Don Quaking's end dump

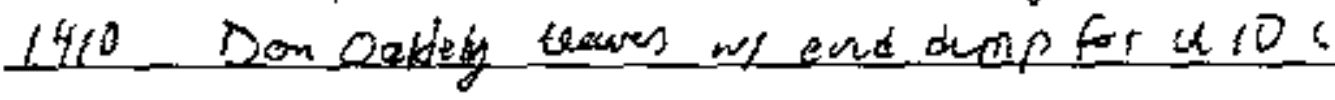

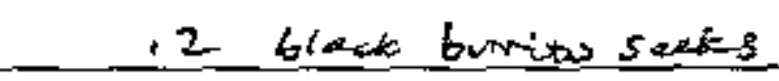

6 blast plaster drums is of whopentop and bungs

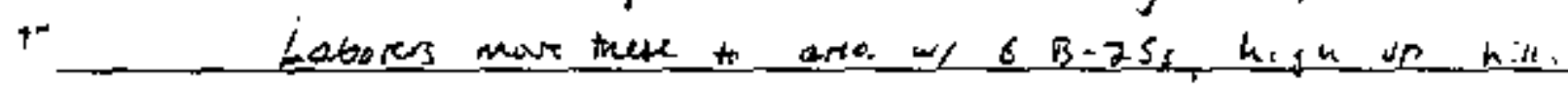

1510 all phones ane down.

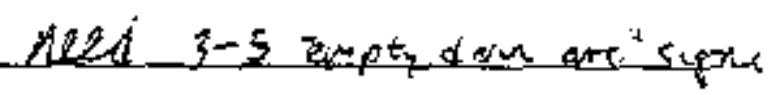
1555 phone up again

20

15

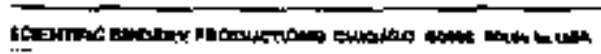

Work continued to Page

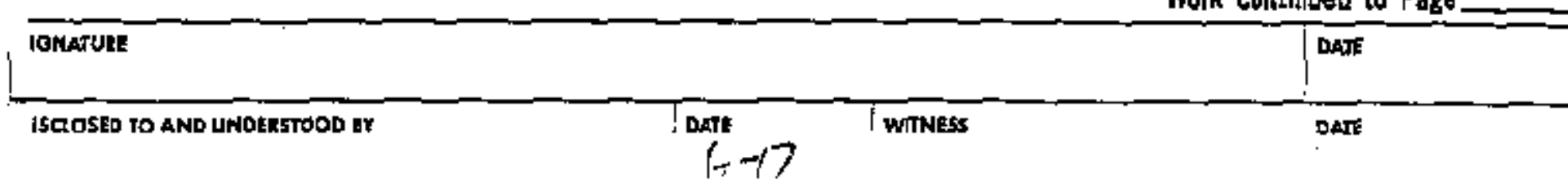


94 TITLE

Work continued from Page
UDENESOAY

MaU 30,200
PROJECT NO.

BOOK No.

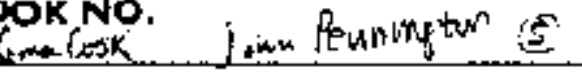

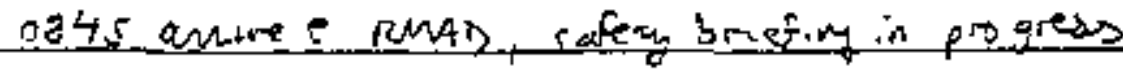
Joham Breacs on David Militigum (E)

Plore of day. Drem finid, set of somfodeng

Tessitlinge ar.

harry towers d (c)

Danios solagni. 0

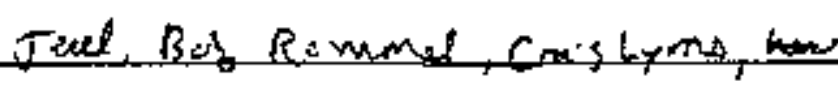

joet pe Millin Girtite:

Gresionce harefor 113 status mis.

white owl nists bay, Gaves

10 cour prep to drain aircompressos o:!

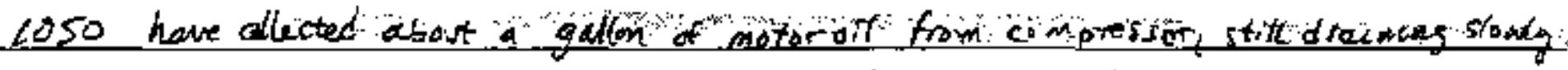

begin (acing end dimp (Don daklog) of wos famed, wod debris,

wood boxes and pallets cable, stal condvit and piping

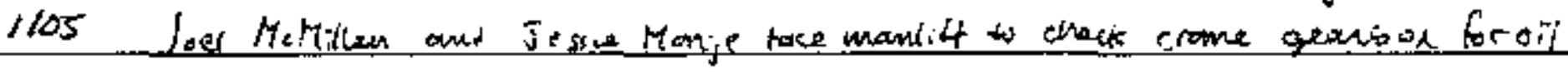

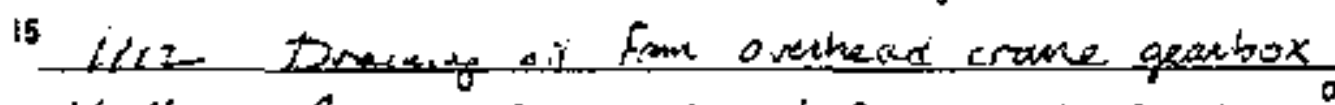

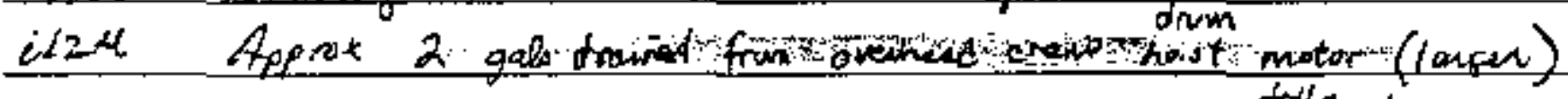

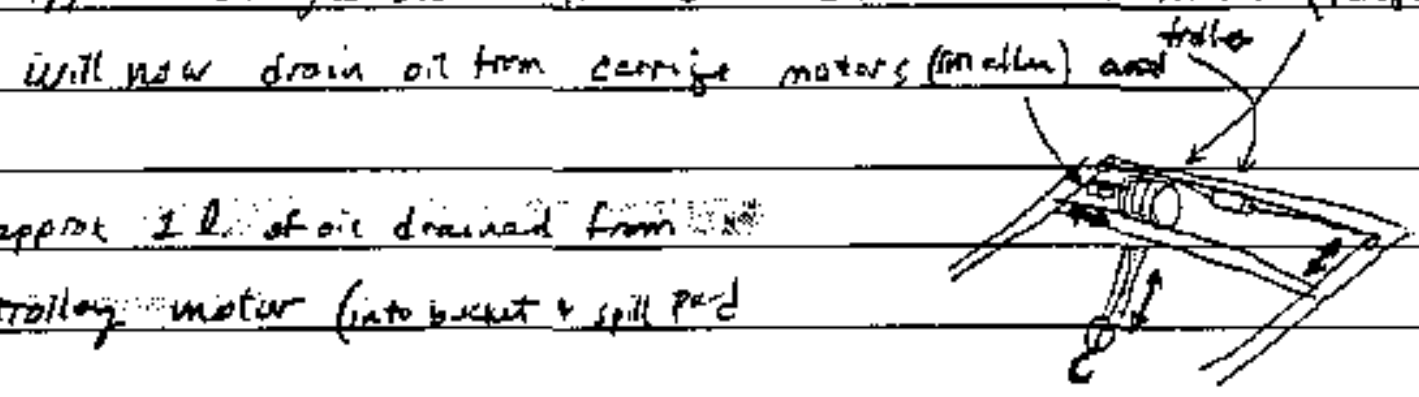

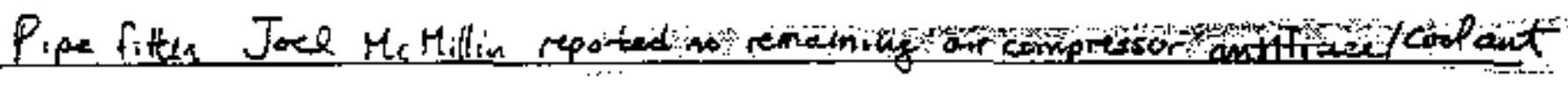
1230 Damoakby jakes end-dump the deris to $410<$

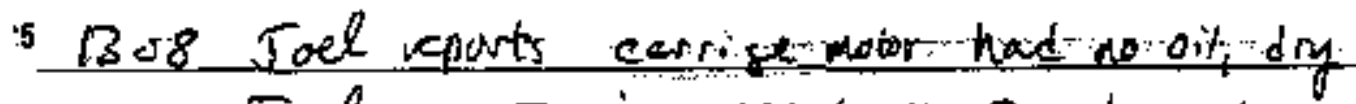

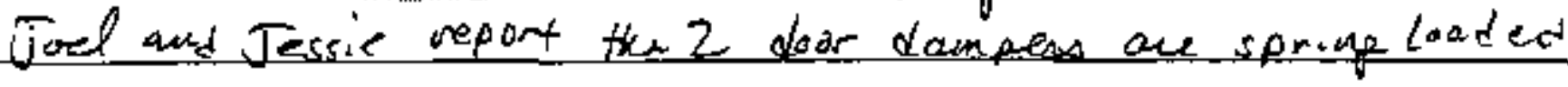
onc, hase no oil.

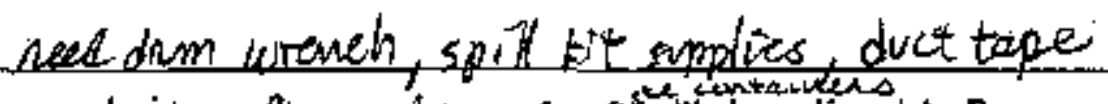

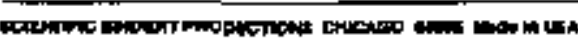
post-its. Plamned ist of wask Work continued to Page

SIGNATURE

heed to wank excewatrar dreas

DISELCSED TO AWD UNDERSTOOO BY

DATE- 18 
TITLE

J19/200 contured PROJECrNO.

95

Work continused from Page _-

1400 creste inm for oit "CaU 254 or $\mathrm{S}^{\circ}$

Containen 1:" Open top 5 gel plestic husket

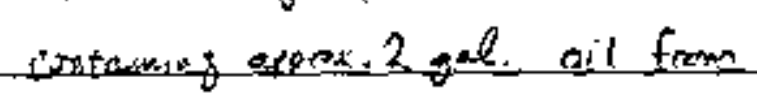
- overbed coans HoIS I motur

Contarin 2 - Closed to is sal plaitic duns

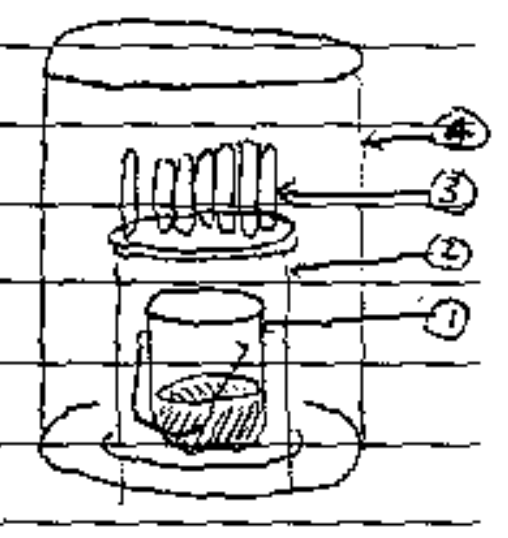
cuntains open-top contesuer 1

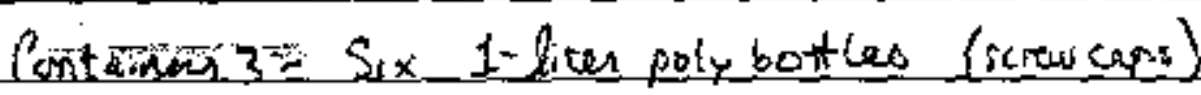
conteining epprox. 6 lites oil from atc compressor oil

One 1 - liten poly bottle (scruceses) conteraing appinx 40.4 lives oil from overhead_crane TRosley mutur

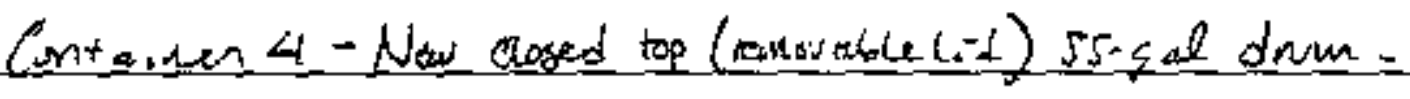
contans contanens 1,2 and 3 .

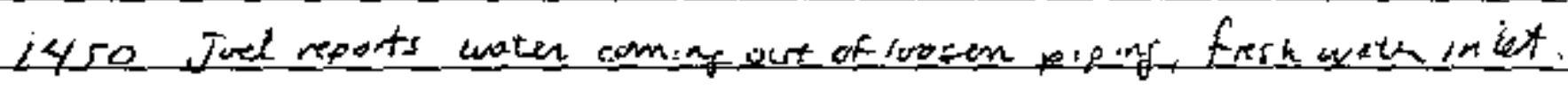
vertic (w) and Lary (L) ass comoving buibs

Rute a bit of waten stordin tank and fiping

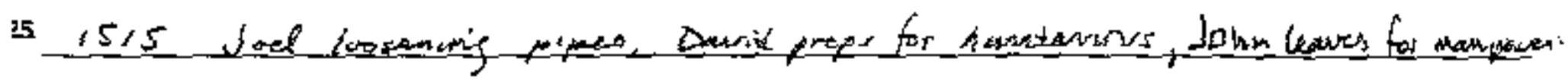

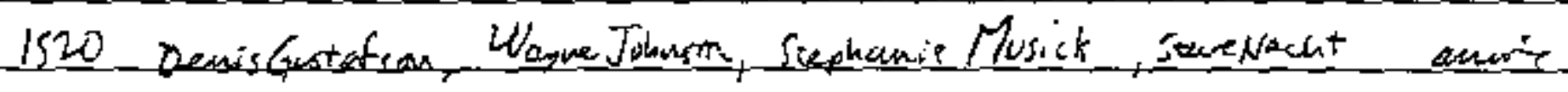
110 reting or Dwrec

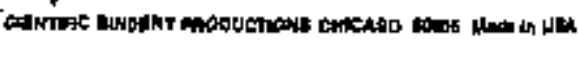
Work continued to Page.

SIBNATURE

DSCLOSED TO AND UNDERSTOOD BY

Dose -19

winkess

DANE

onik 
96 TITLE

THURSDAY

PROJECT NO.

Wok continued from Page

HA: 31,2001

BOOK NO.

0645 andre dorms download pictures

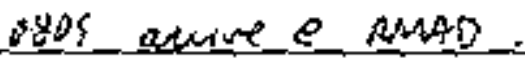

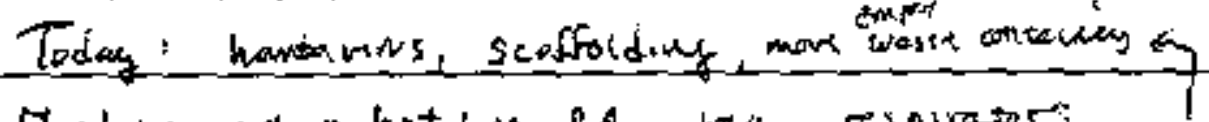

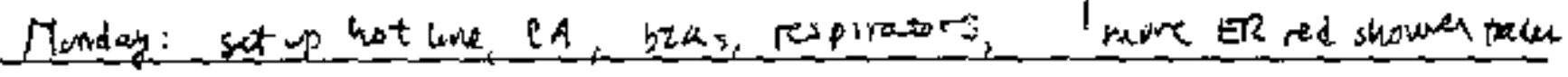
5

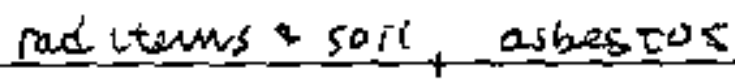

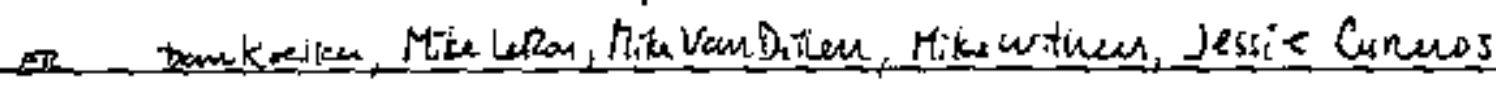

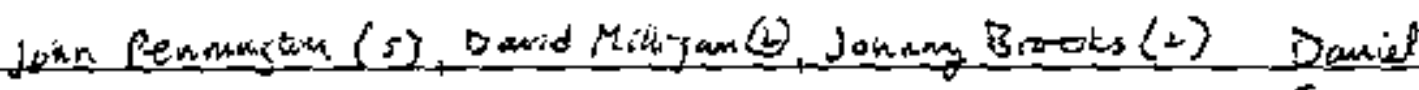
Costs Ob: Resent Bromctein

Soles iv $(0)$

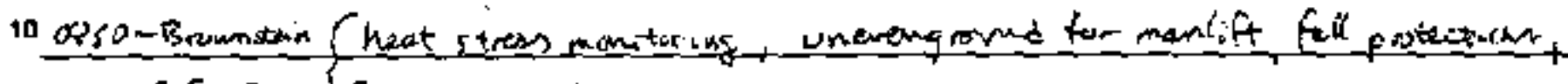

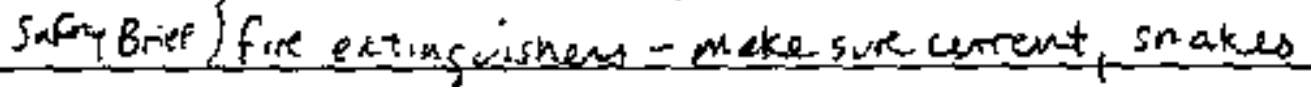

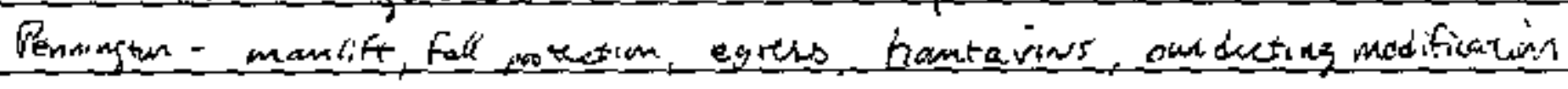
gevenater scatfoctings

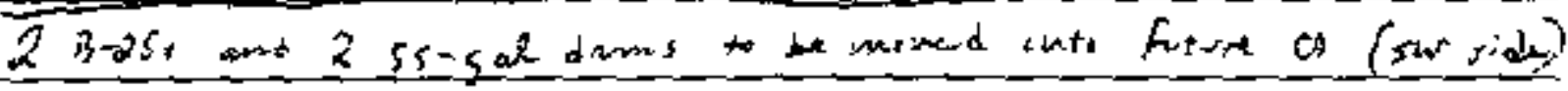
15

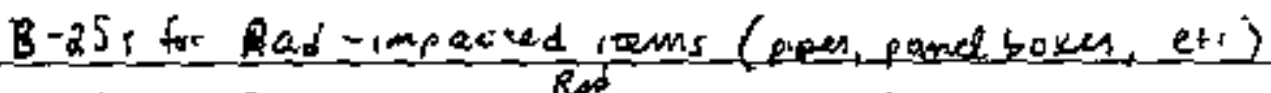

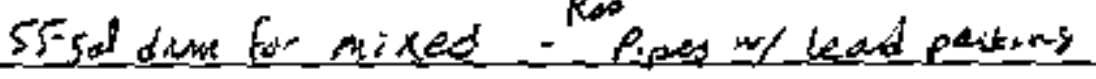

Rus pipes w asbestos

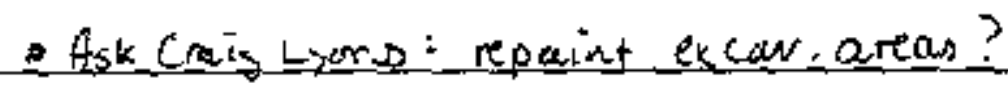

20

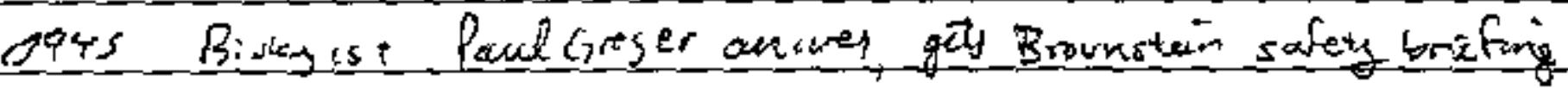
1005 open swed of owlductius, no fowls or nest. Then is an old

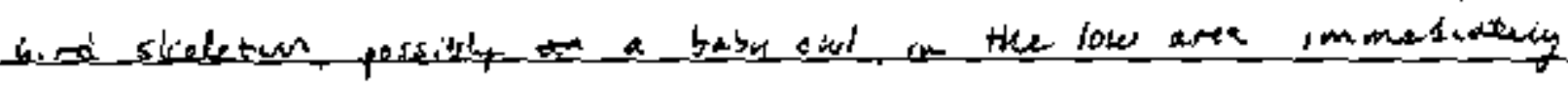
Q bore the vent to the change room.

25 Active nest is occupied, I lancer and 1 gouger ticketing

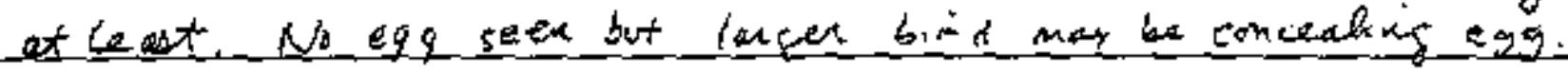
1920 Sound lase more owls in the vel end af ducting

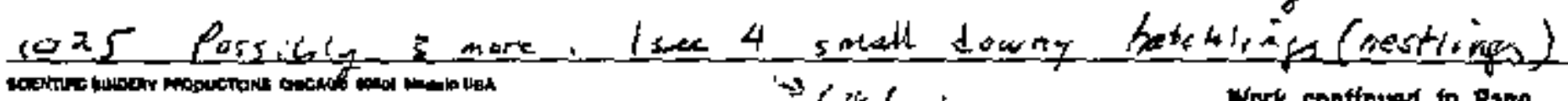

Work continued to Page

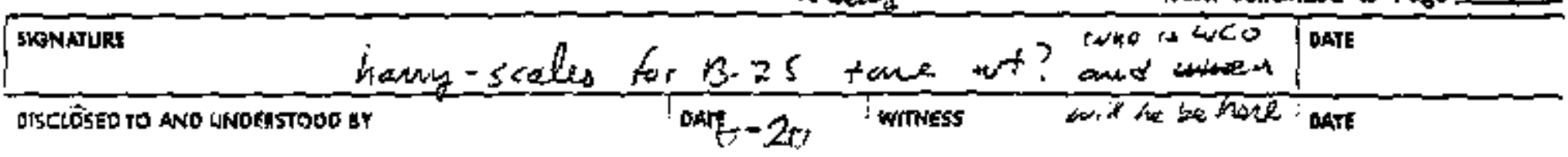


TITLE

Hork continued from Psge__-

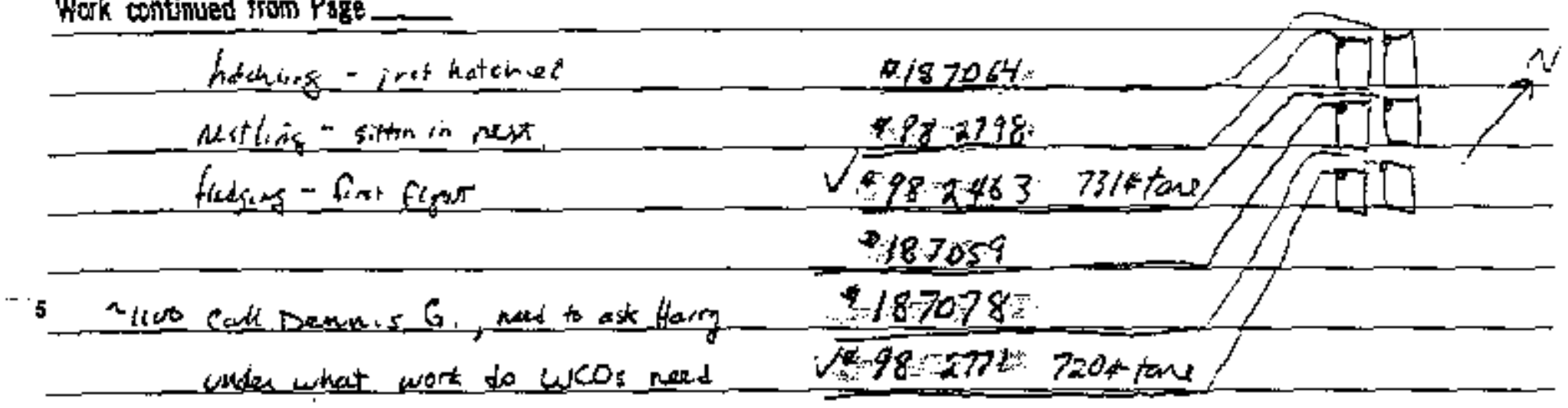

to be inside $C A$ ? and bisksay.

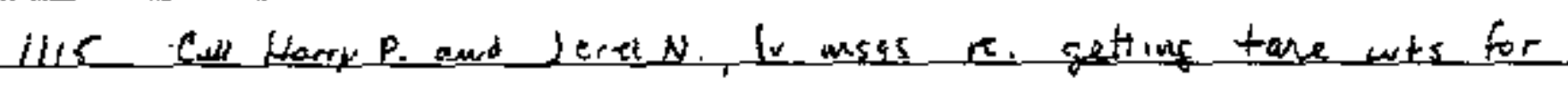
4 of the 6 T3-25'

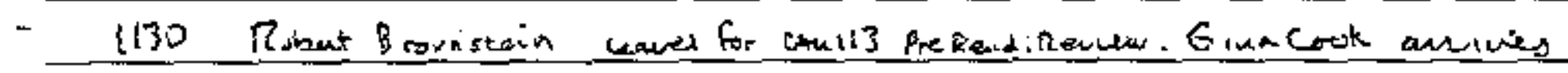

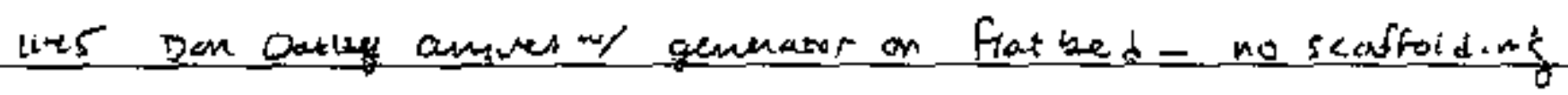

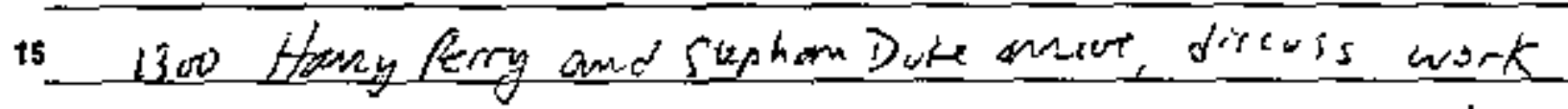

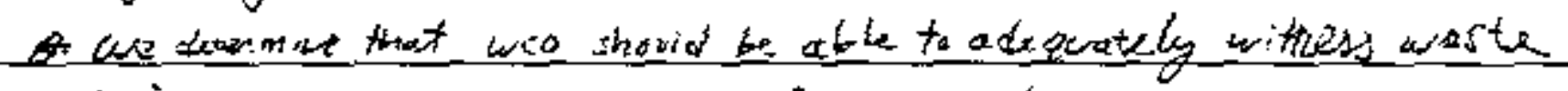

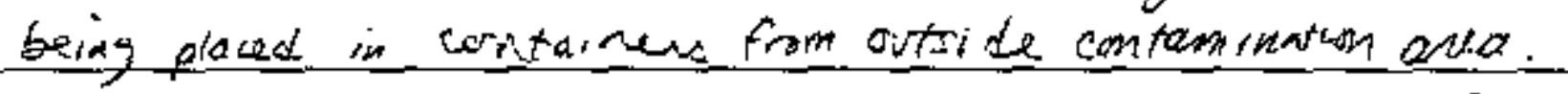

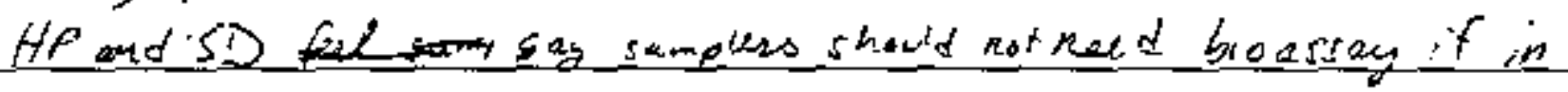

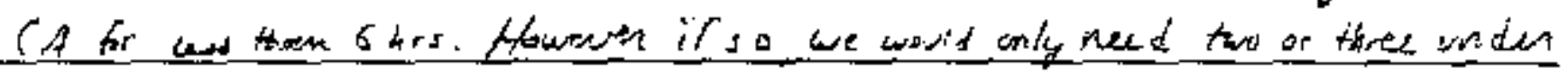
20

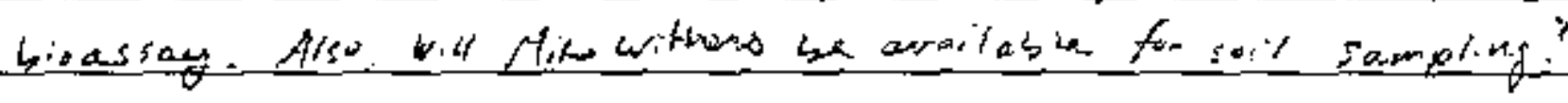

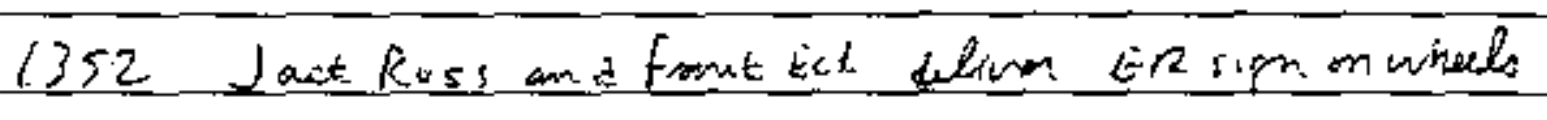

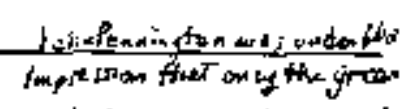

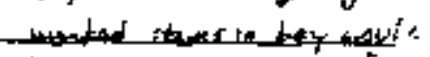

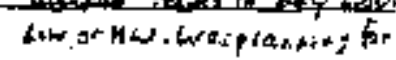

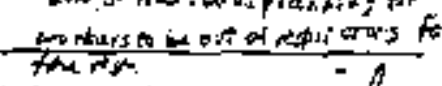

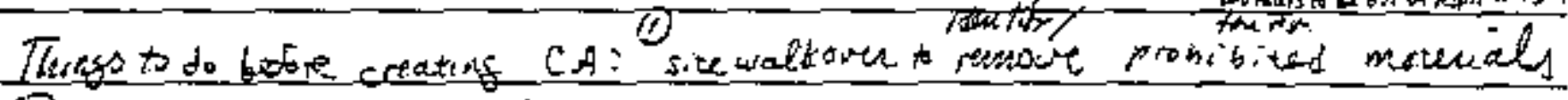
(3) remank rad aceas for exavatean avoresent

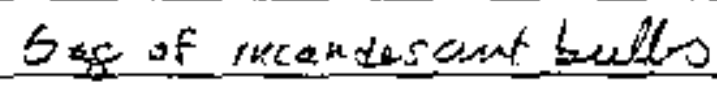

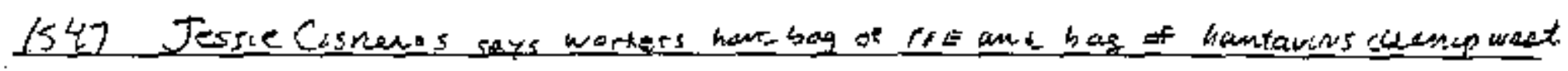
It of Nor rad. Normal prodedure for waste not. Fom-a-CA is fo dume it in the trath.

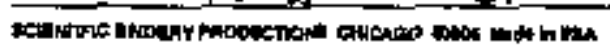

Work ontingred to eage

SIGNavike


98 TITLE

Work comjinded from Page

$$
\left[\begin{array}{l}
\text { MONBAY } \\
\text { Juria } 4,01
\end{array}\right]
$$

PROJECT NO.

BOOK NO.

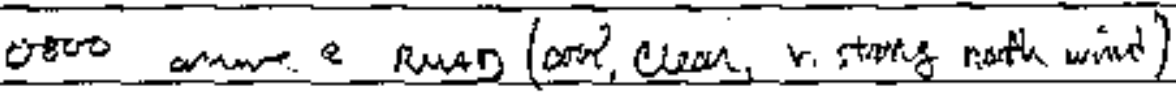

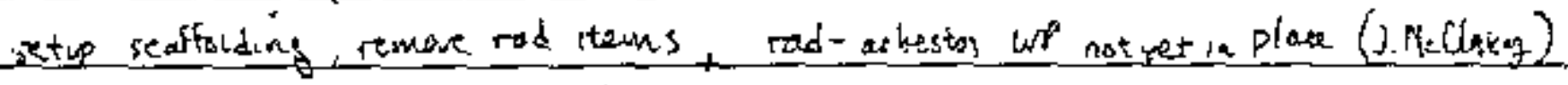

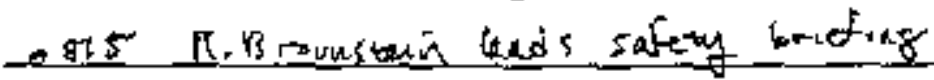

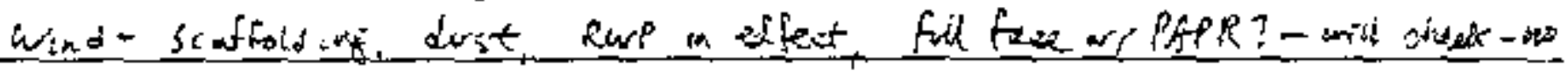

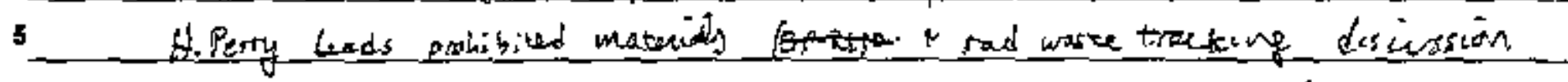

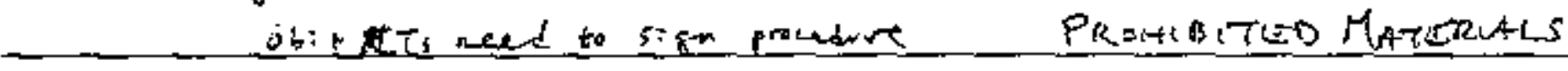

1 Gazindous wester (Lad stab)

Vent inowtorylist - Certis

+ Frecheris

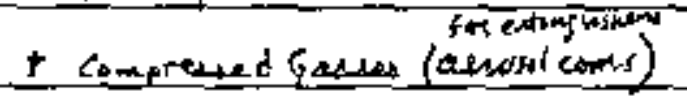

to Issve: dur't have rad-ACM wP dore.

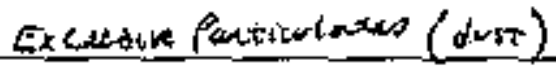

J.Mec says CL is comory out to day.

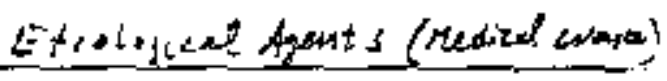

Gave Rod item =enly wir havd. Cnelaturs: Agents (EgTt) Ex,tustwes $(+\omega T, e-4)$

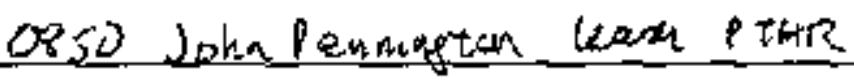
$r$ PCB S (ballosts trumformars)

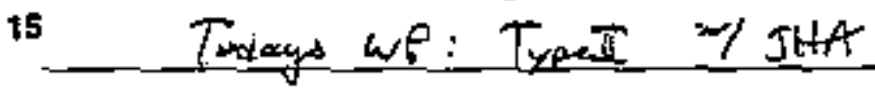

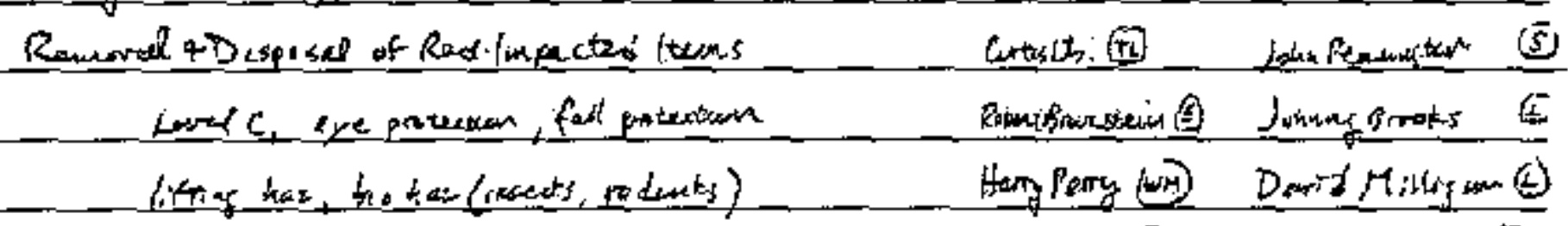

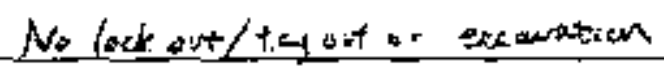

Pliphaldo (wo) Jerrie Nonje (10)

20

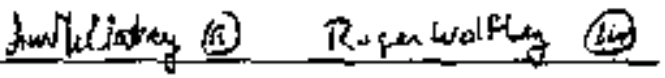

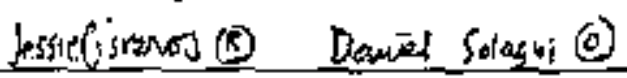

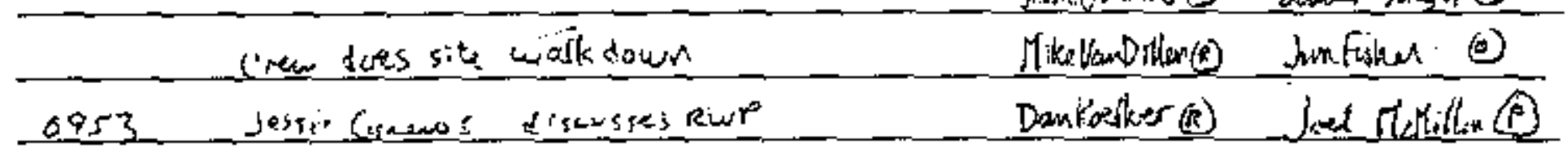

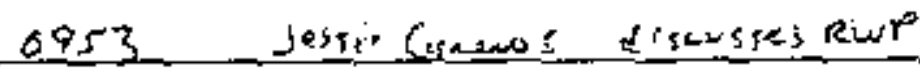

thewathon (R) Raxas $R_{\text {escos }}$

25

witf co jampling to sunfirm to

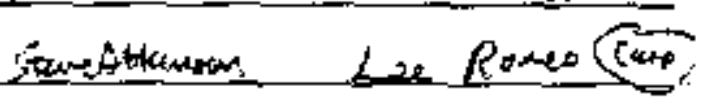

Sepkem Duk _ Doun fore (5)

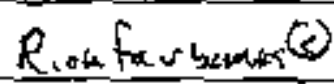

Cheornunteusens

Tenencs 6. Work continued to Page

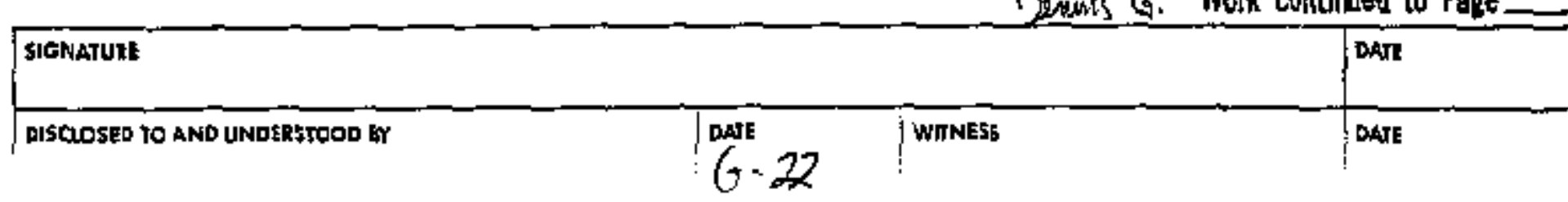


TITLE

Work continued from Page ___ BOOK No.

99

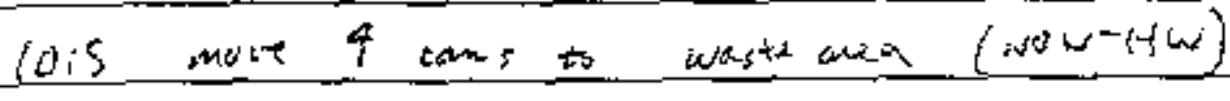

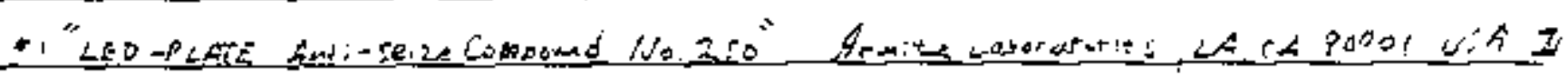

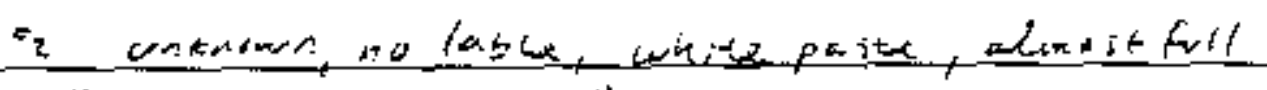

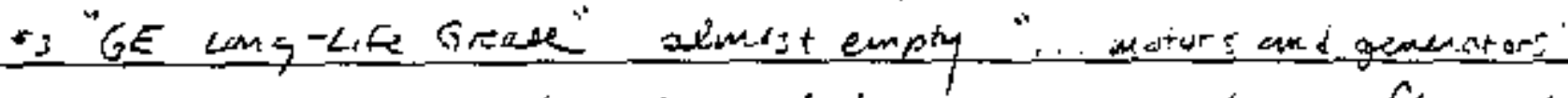

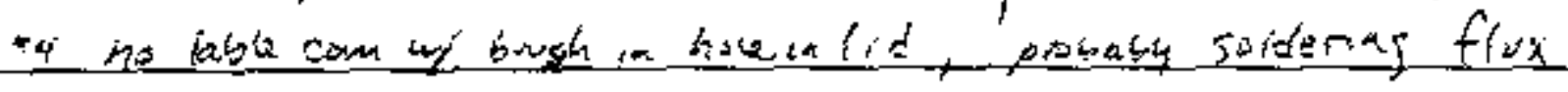

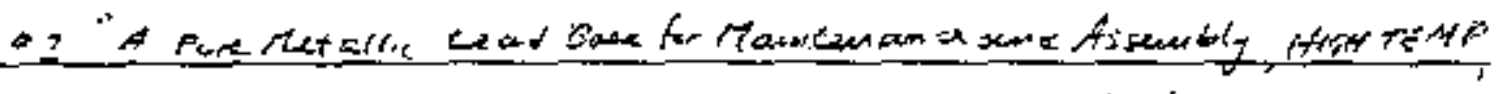

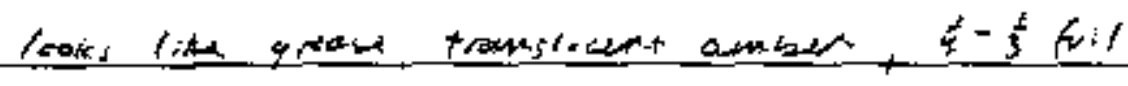

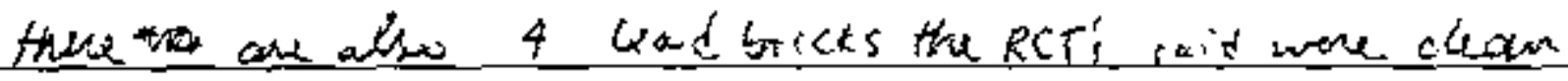

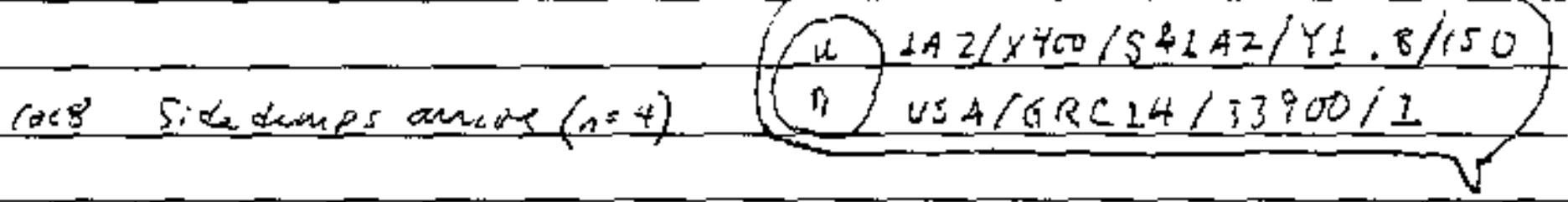

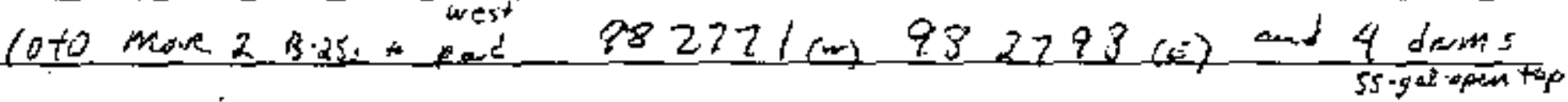

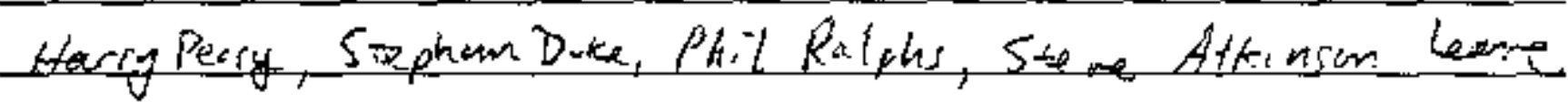

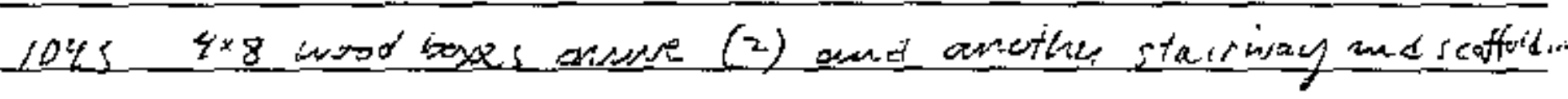

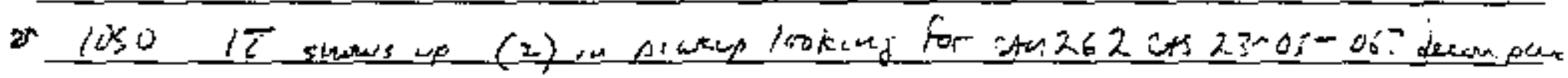

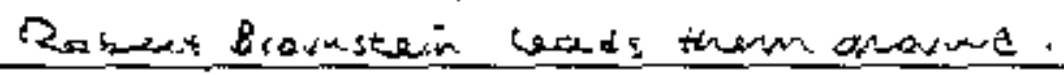

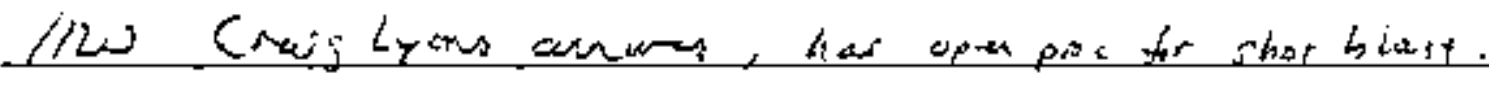

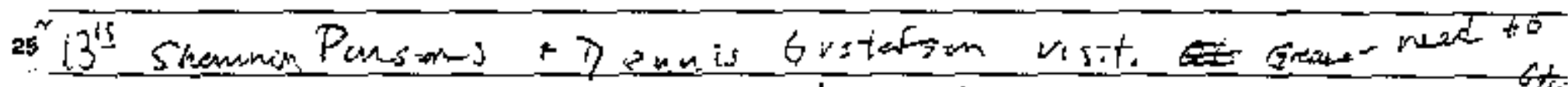

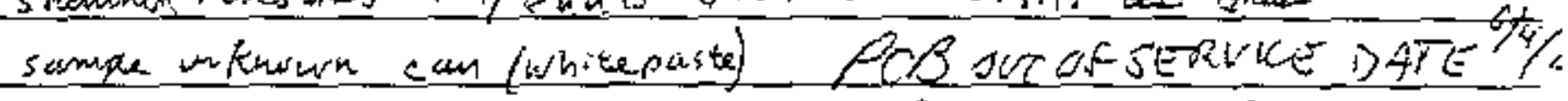

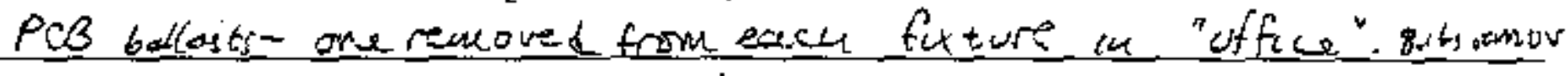

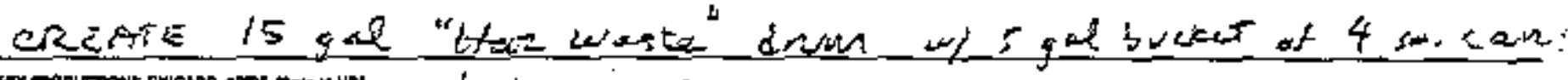

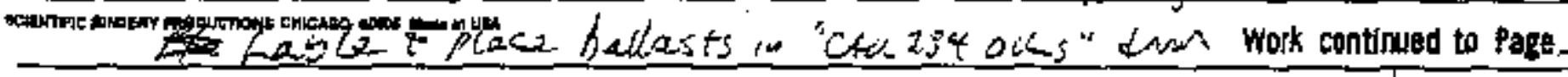
SIOFATUAR

DATE

DISCOED TO AND UNDERSTOOD BY

$6-23$

WITNESS

DATE 
100 TITLE

of 04101 contures

PRÓJECT NO. से

Work continued from Page

l6ts Shavern't Dewnis depent

Tite v.D places rad steckers

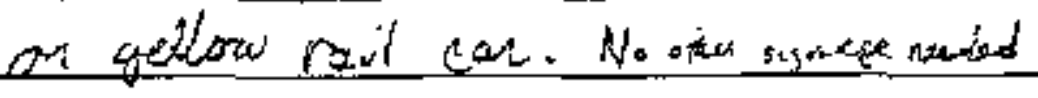

164.6 fied tiract pecomnel drop by

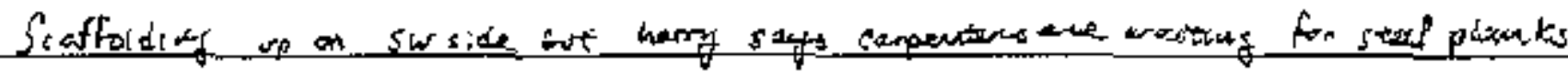

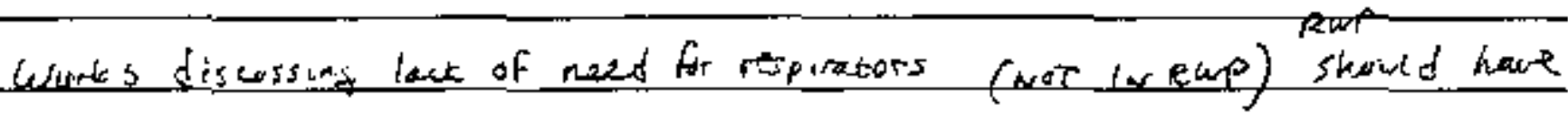
given aptex

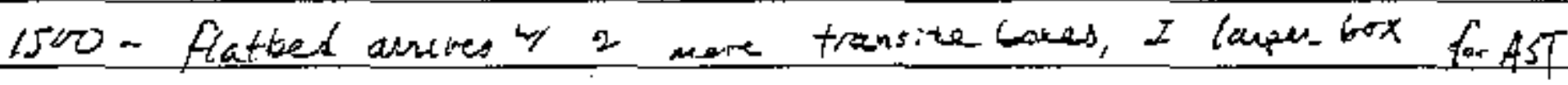

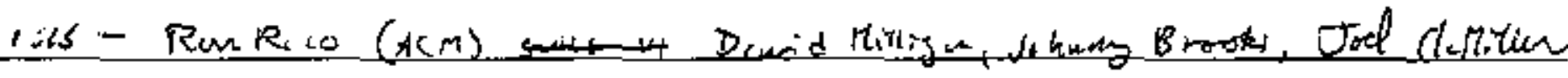
suit.pe

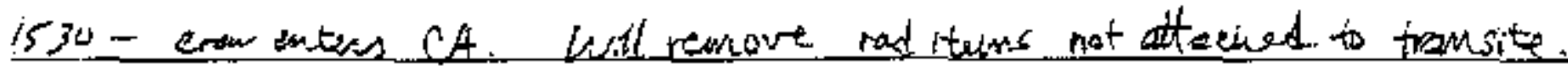

locs crew inares $\mathrm{CA}$

(615 obi Lepanta pundi)

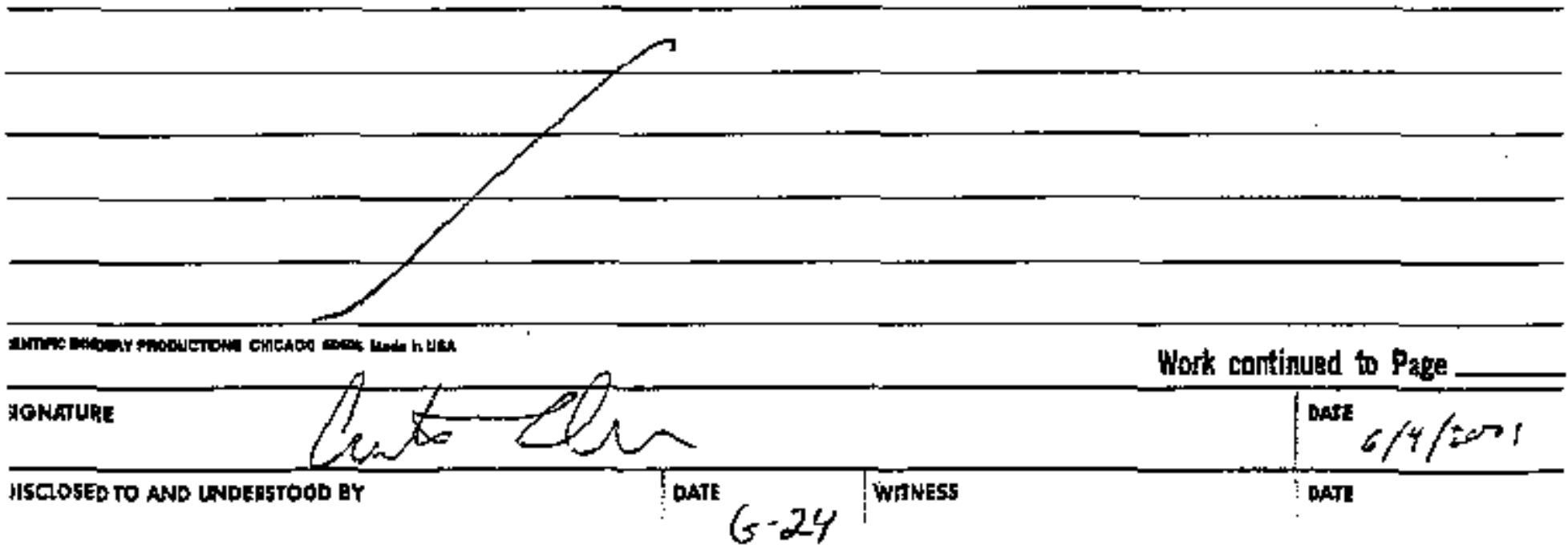




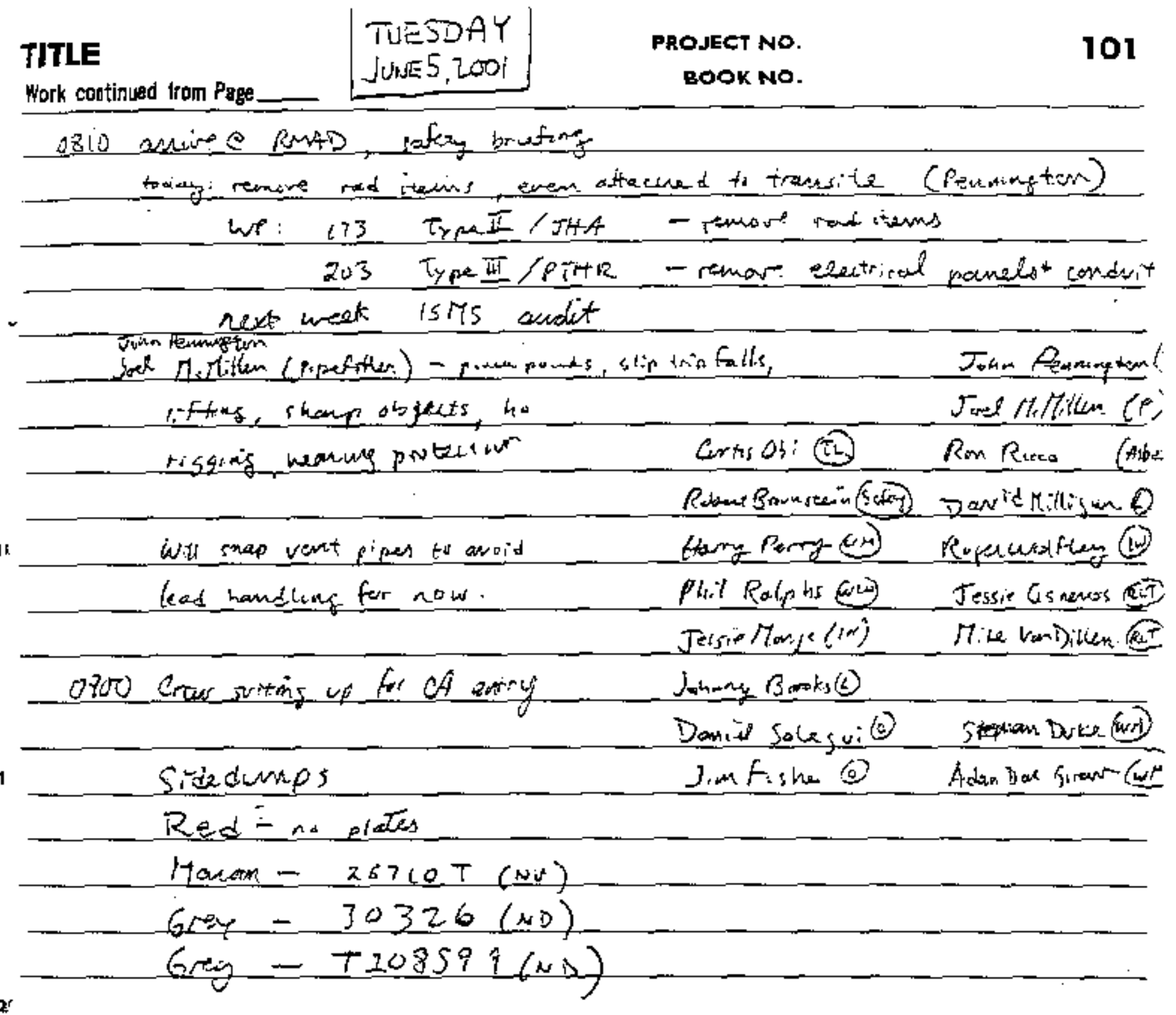

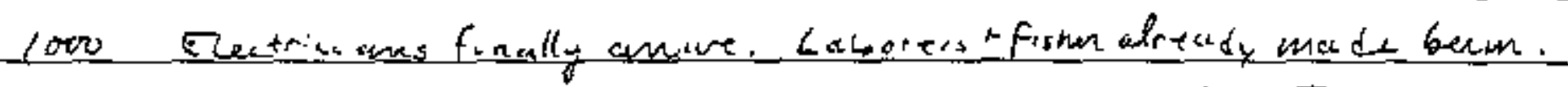

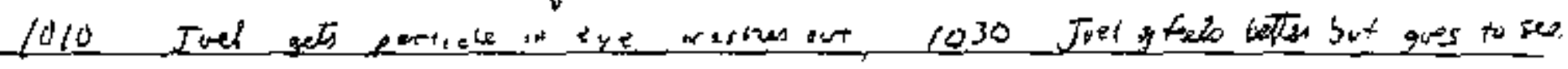
.

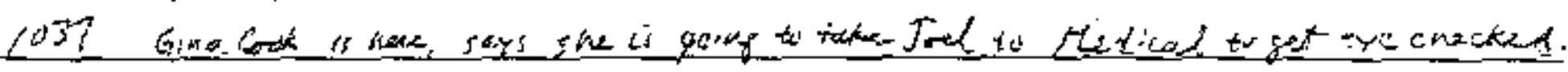
$\mathbf{2 5}$.

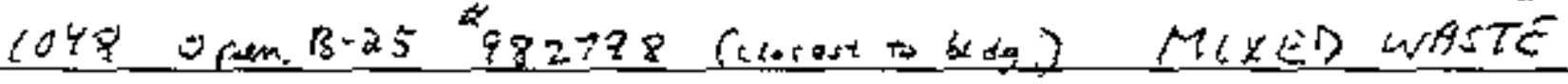

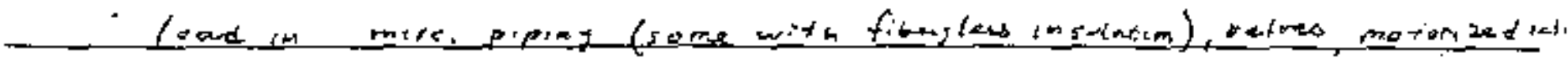

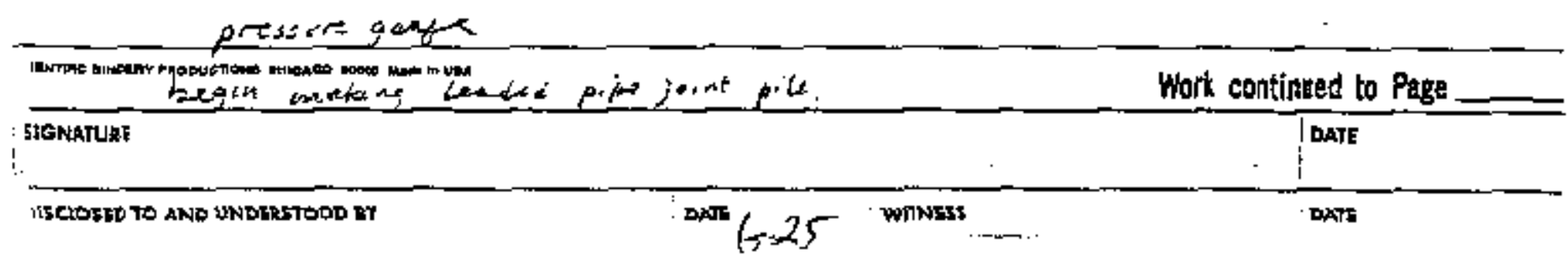


102 TITLE

b s spi continitent

PROJECT NO.

Work continued from Page

BOOK NO.

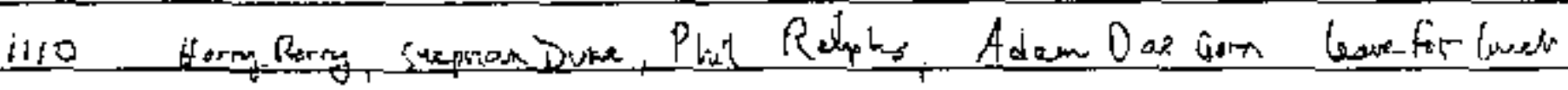
ilis Crew in CA beglif to extr.

1400 quit for Lai, st crow doffs. B-2j is $\frac{1}{3}$ tilit.

5

1410 Pelsibutan Leads daily debriefring

Jel - remond of Bab-impectes iteans

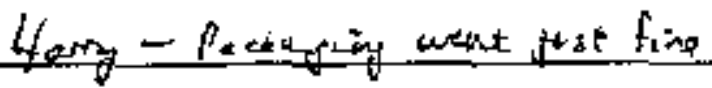

Pontille on eye

Fue - smoldecurg bnak, put out by fire wetich

10

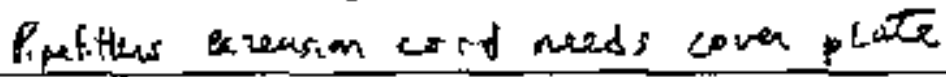

returned 6/4lot dry chen fire ectugusher to fie dest. for

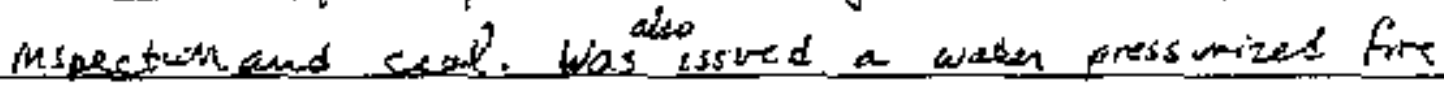
15

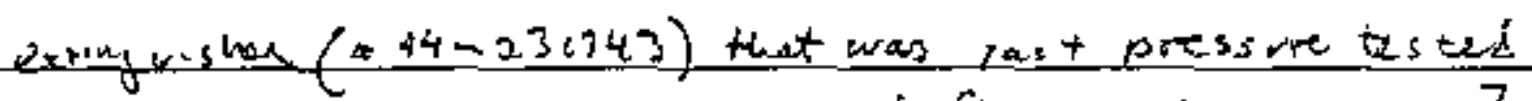

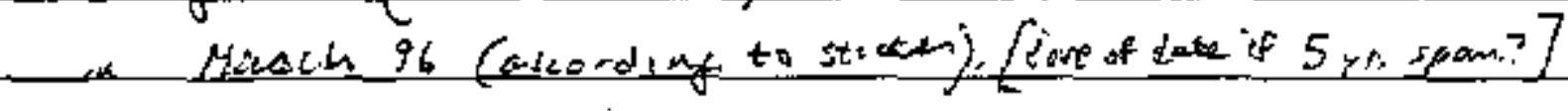

20

25

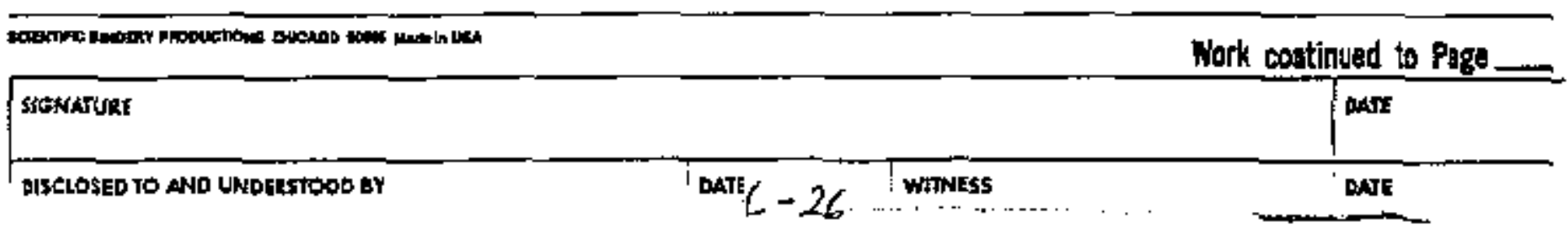




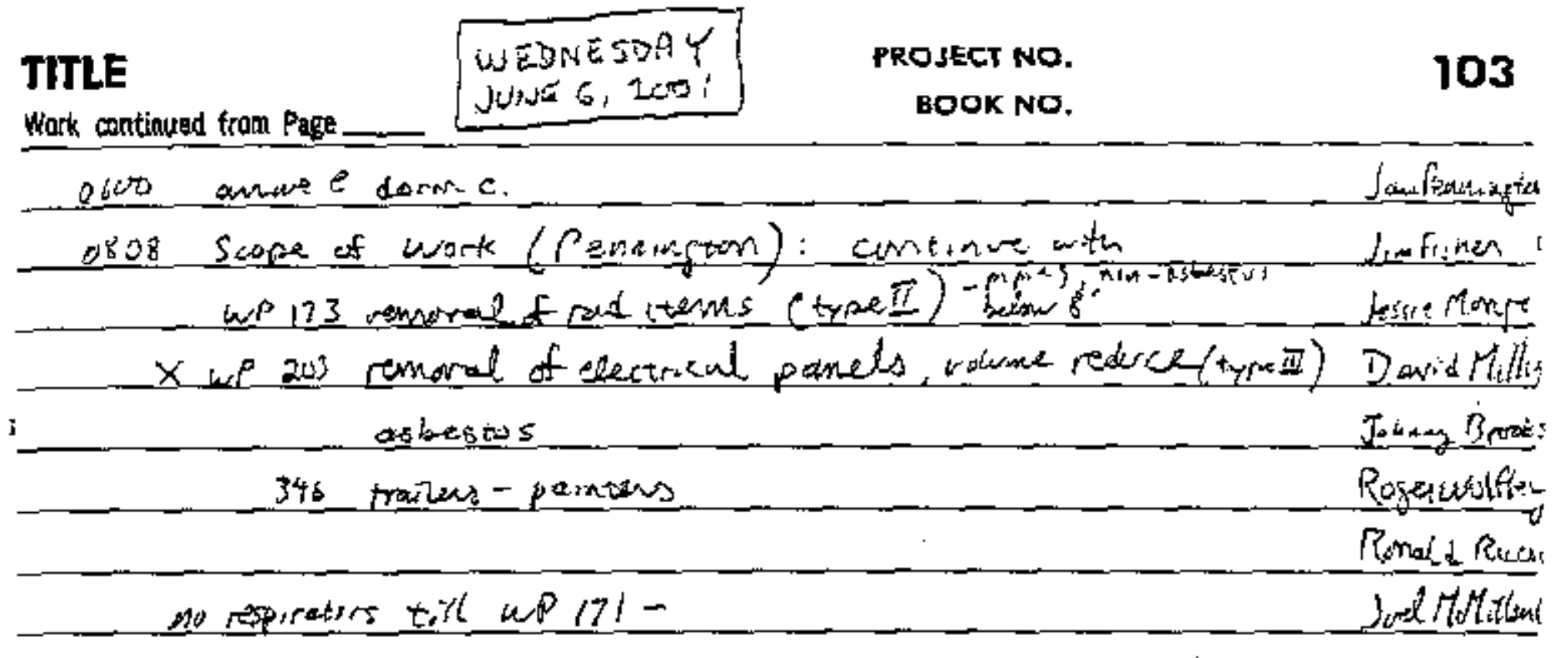

iremuve stars to access wall below toft?

0847 Ginoleck $=C 4 / 52$ no smoke eat, ir.wik

expept at hot line ares sestroy.

Combey for borates inside CA/EZ

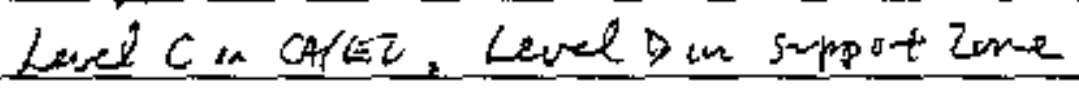

Heat stress = fcoids, cool cunea, eyewash fire exticy.

Heang equipment, - fall probecteon kexing

procicicon L leme of sisht ay openator

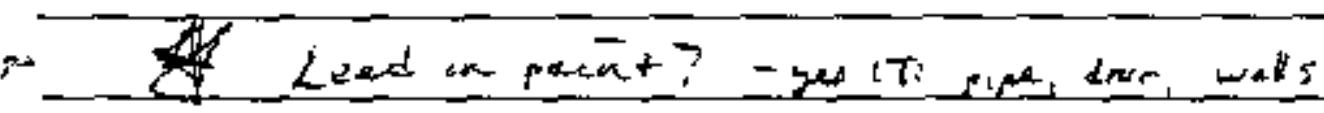

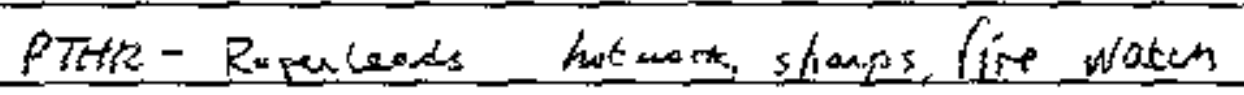

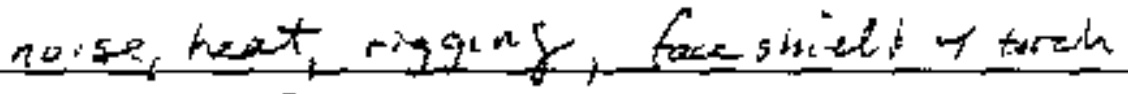
Laved foll proiectom.
Pick Sumitu (es

Gruaceok

Tikerantilen

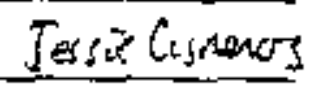

$\operatorname{man} b y$

hytrocrame forkint?

fhit Rolpks Steption Quke.

Angierey

29

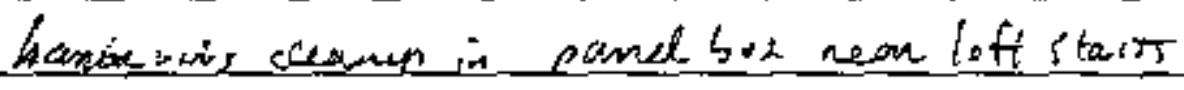

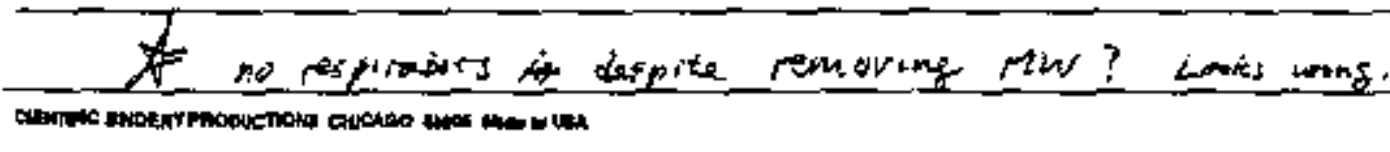

Work ontinued to Page

51GNATLRE

DISCLOSED TO AND UNDERSIDOD ET

i date $6-27$

WITISS

DASE

TDare 
24 TITLE

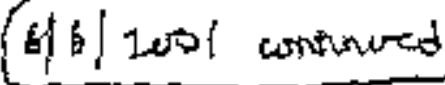

PROJECT NO.

Work continued from Page

BOOK NO.

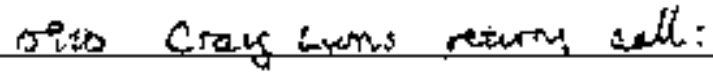

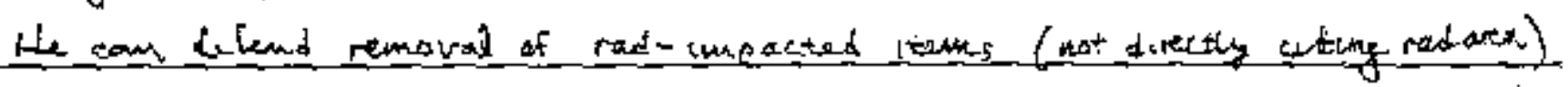

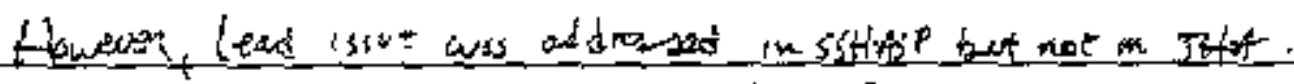

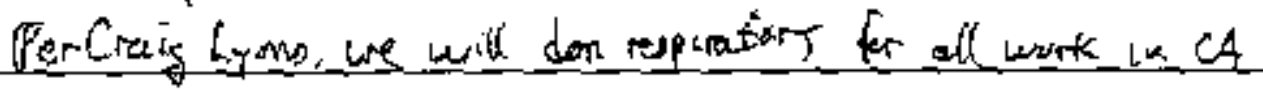

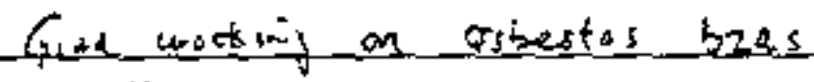

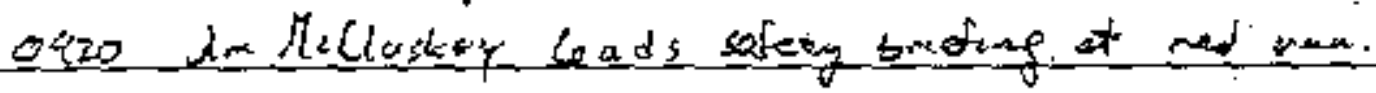

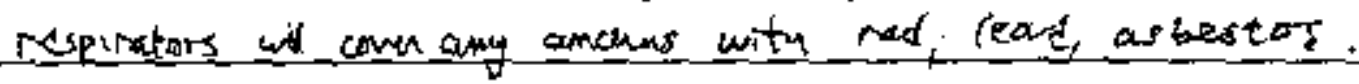

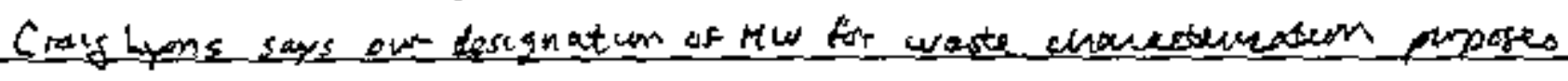

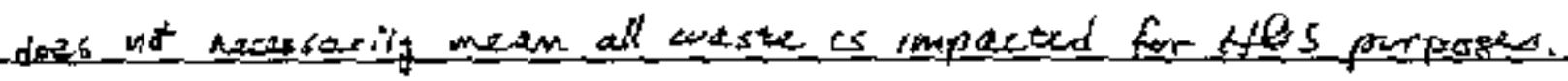

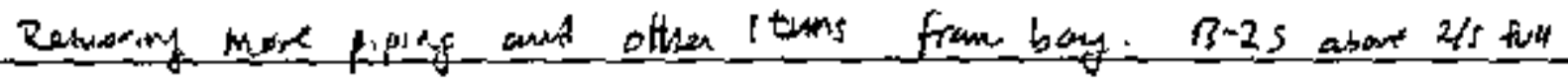

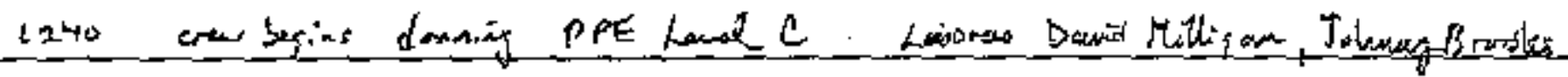

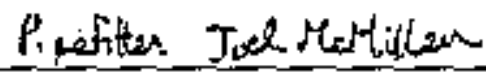

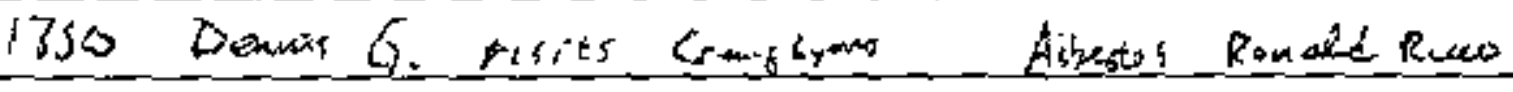

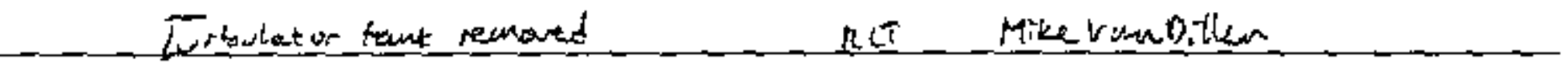

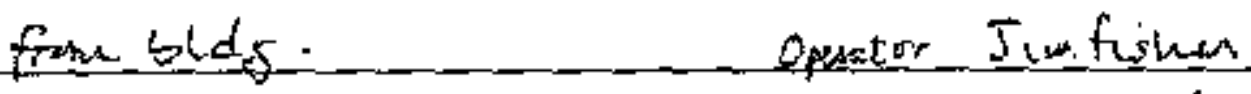

Lonborian Tessie Monde.

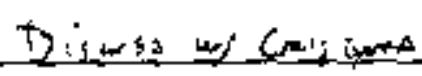

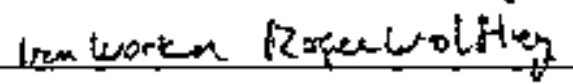

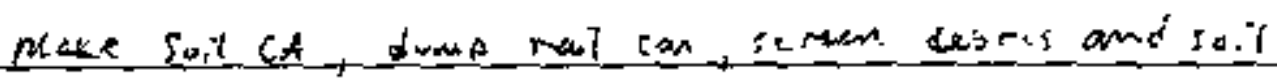

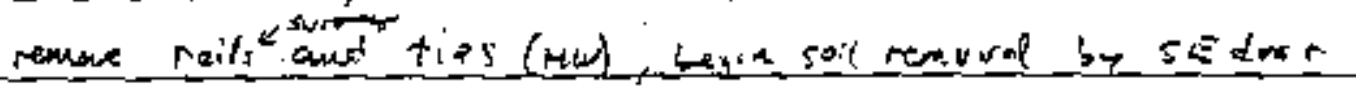

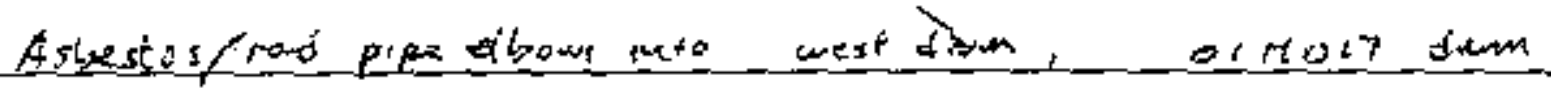

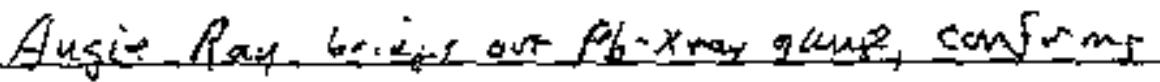

1440 Dermis depots, crow takes break

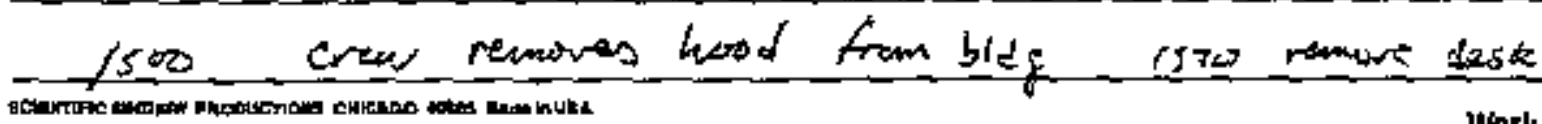

Work continued to Page

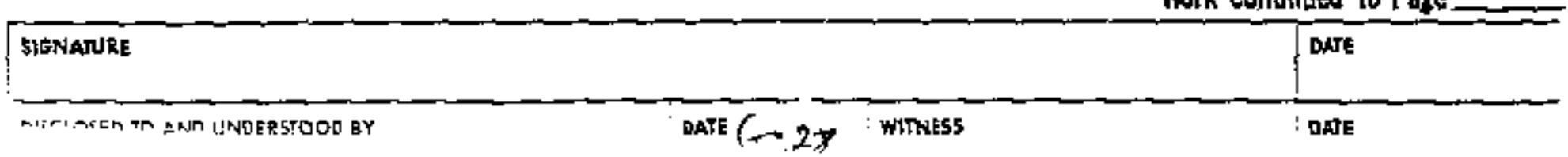


15S5 row bets CA.

1615 Da.j debrief:

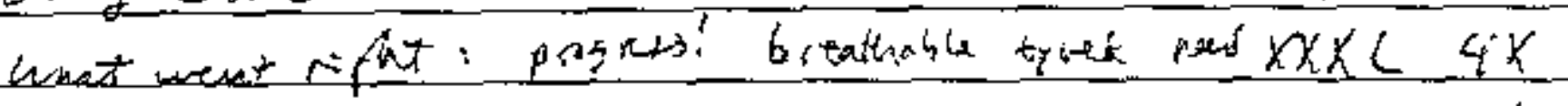

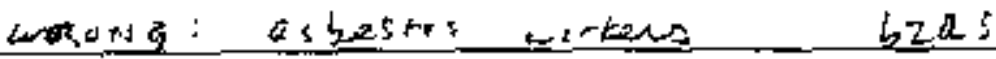

\section{latelen hrik}

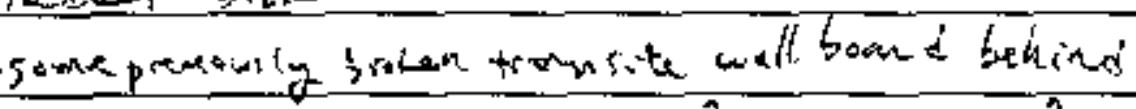

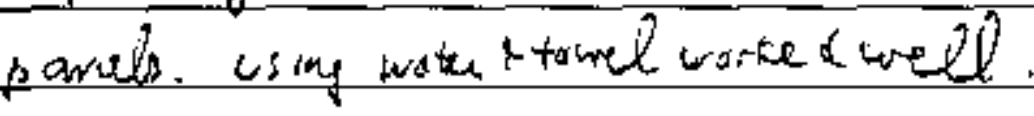




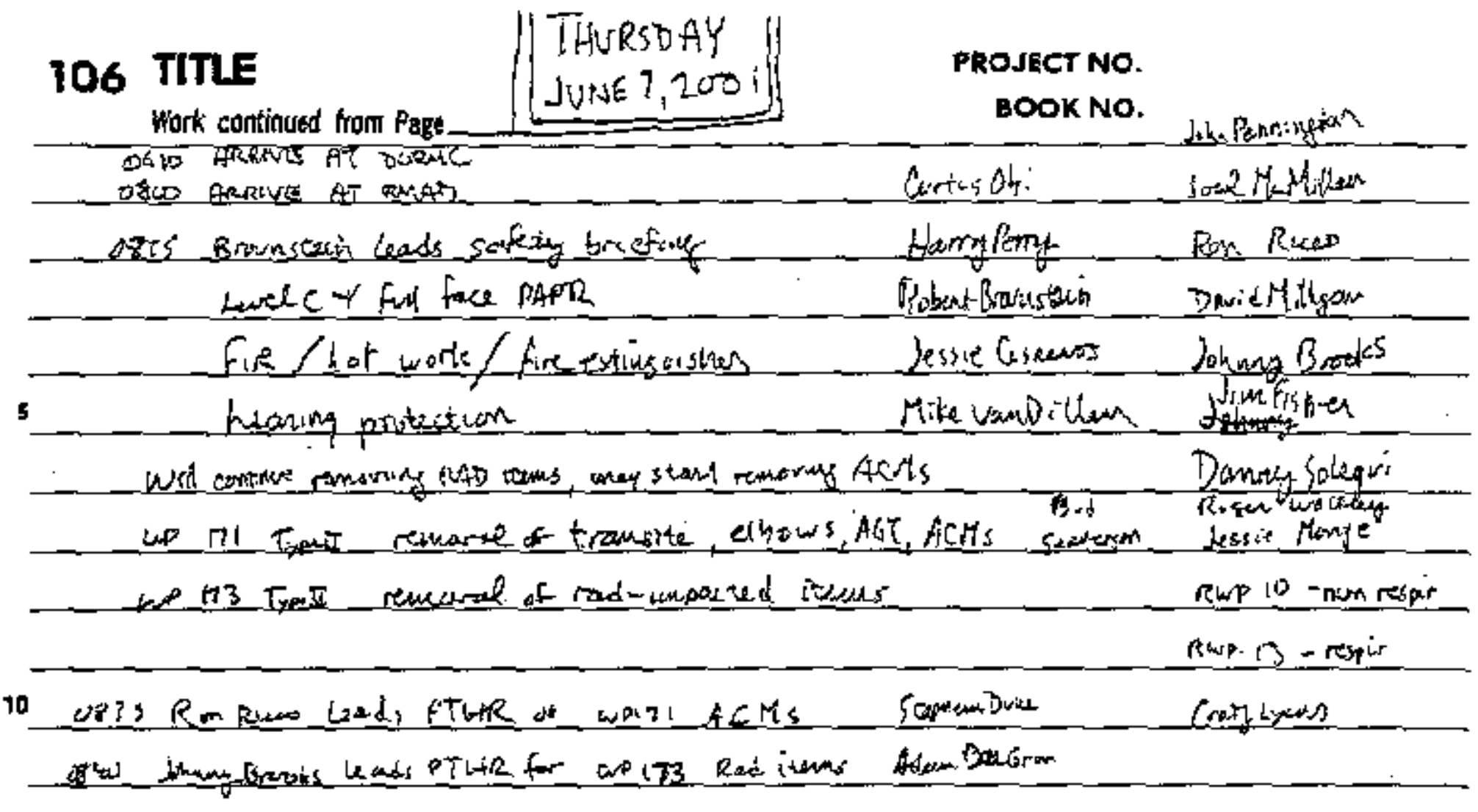

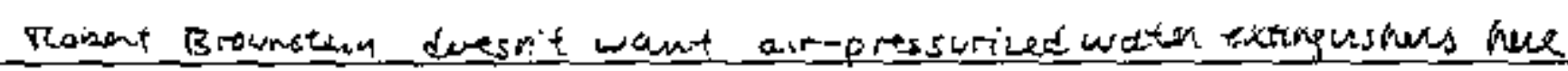

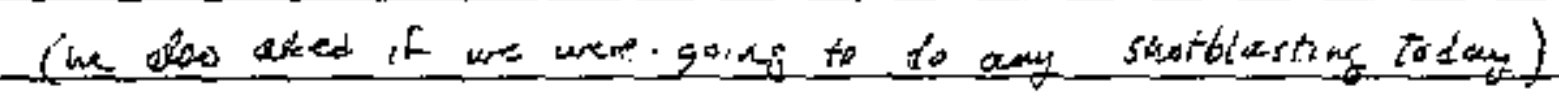

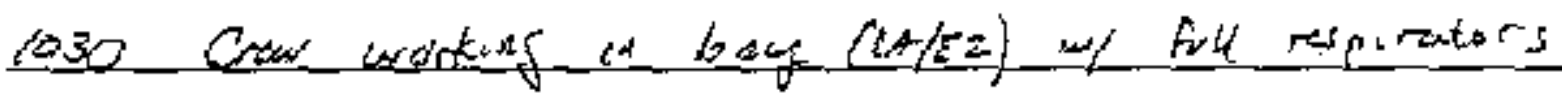

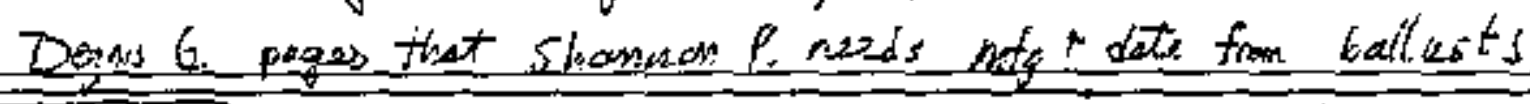

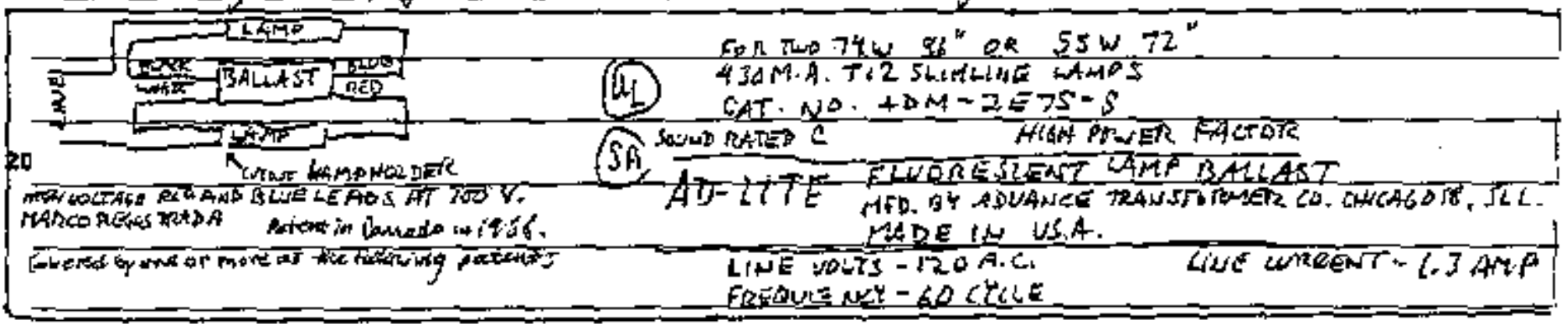
25

Bottoms have stamping

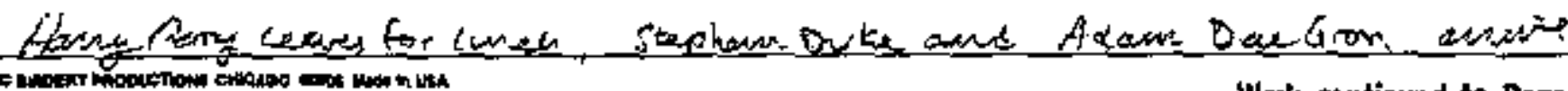
Work continued to Page

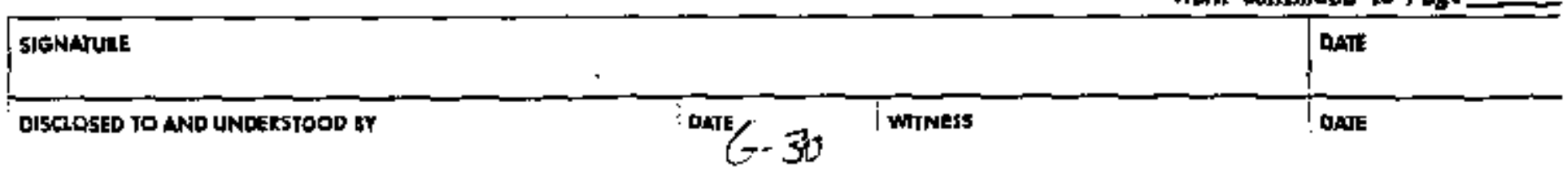


TITLE

$6 / 2001 \cos i \sin 20$

PRÓJECT NO.

107

- idrk continued from Page

BDOK NO.

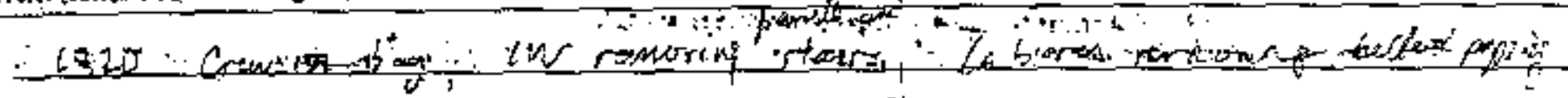

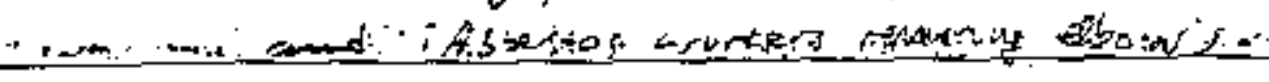

:

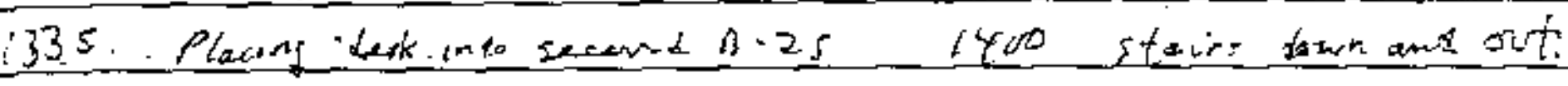

; t...........

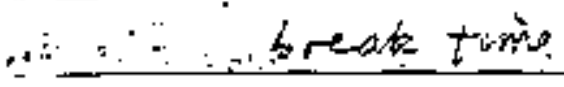

Crator.m.

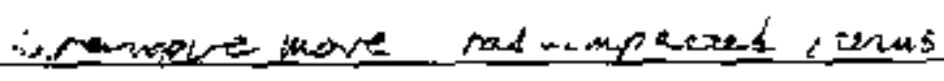

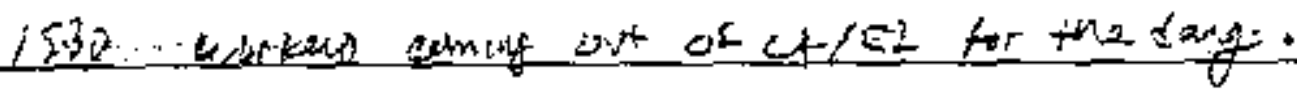

1600 Douty de-buif.

CLCovd - porta-5hade, wo.ste rewoved as planed, no fires hationd mitioned

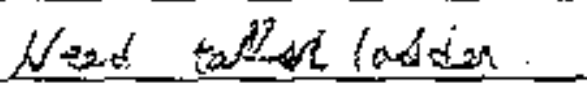

ST ZOSED TO AND UNDERSTOOD BY


108 TITE

Work conţinued from Page
Monday.

Jome $11,200 \mathrm{i}$
PROJECT NO.

DDOK NO.

Jan Peanatens?

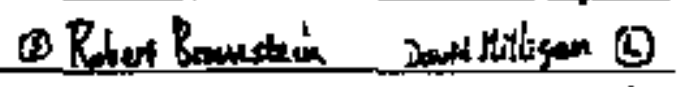

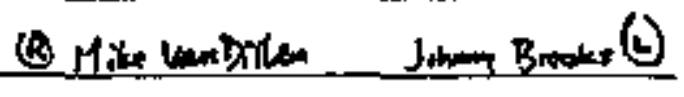

(B) lessitcueres Rogerbolth (10)

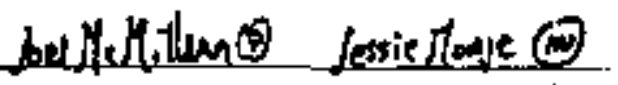

(1) Cortis os:

Lany flowed (C)

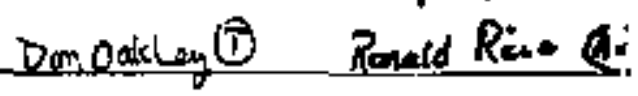

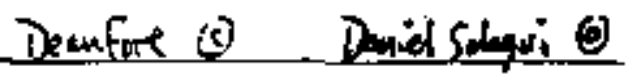

Ponfarbanks

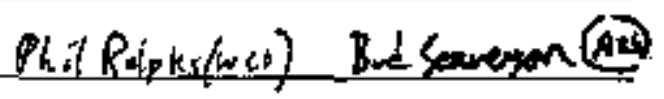

nacio Rome Q

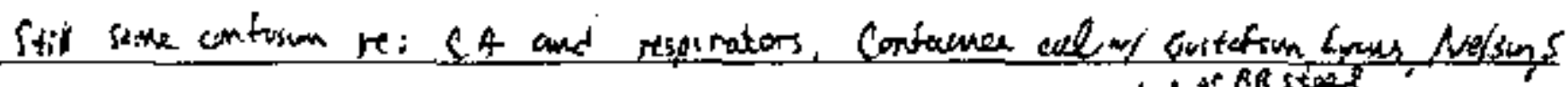

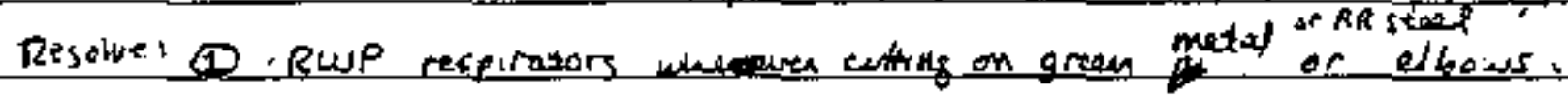

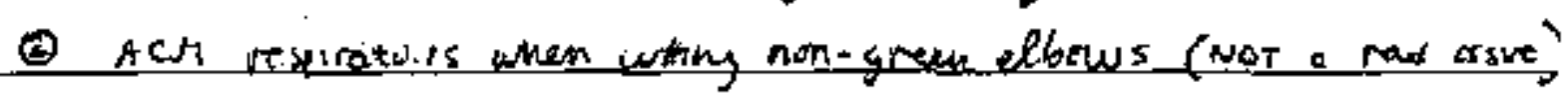

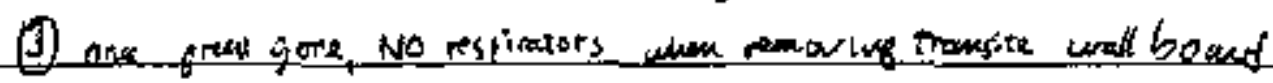

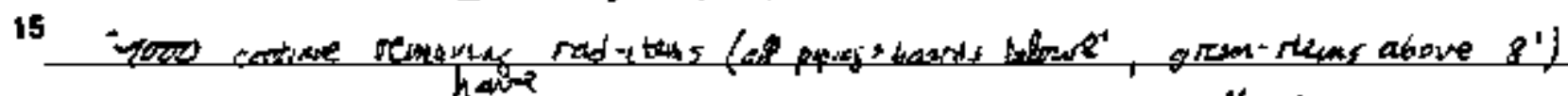

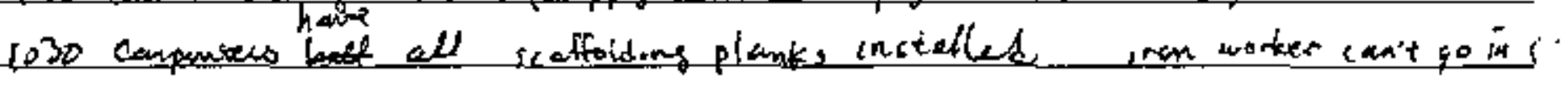

co43 Don Doxley takes water twat anoukd bids.

becous no nore PAPR.

ioso phit Rafels omiven

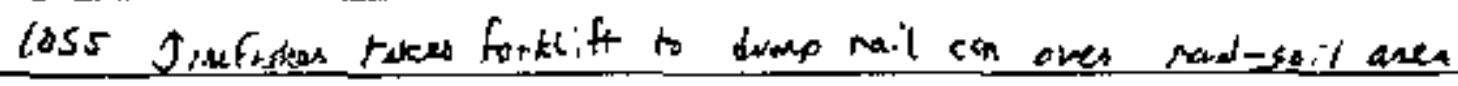

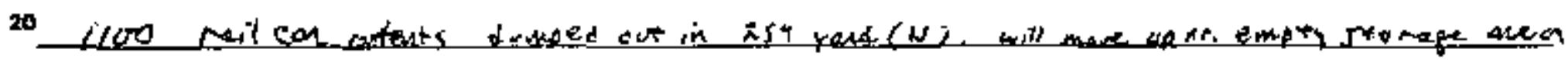

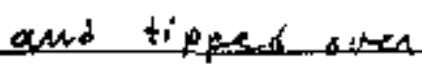
Geporax 1 cy of chairs phyord and (1) io rew comer out trash bos up wored destis and

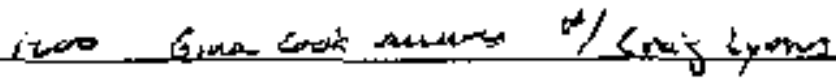

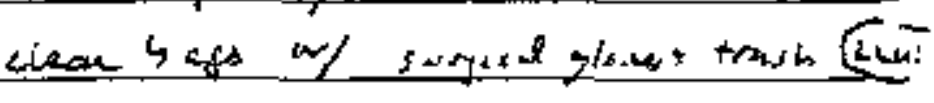

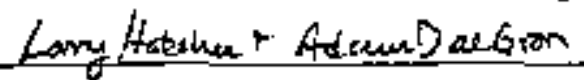
Hike withers init tsot mi can aften imen.

25

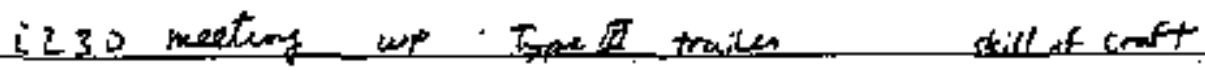

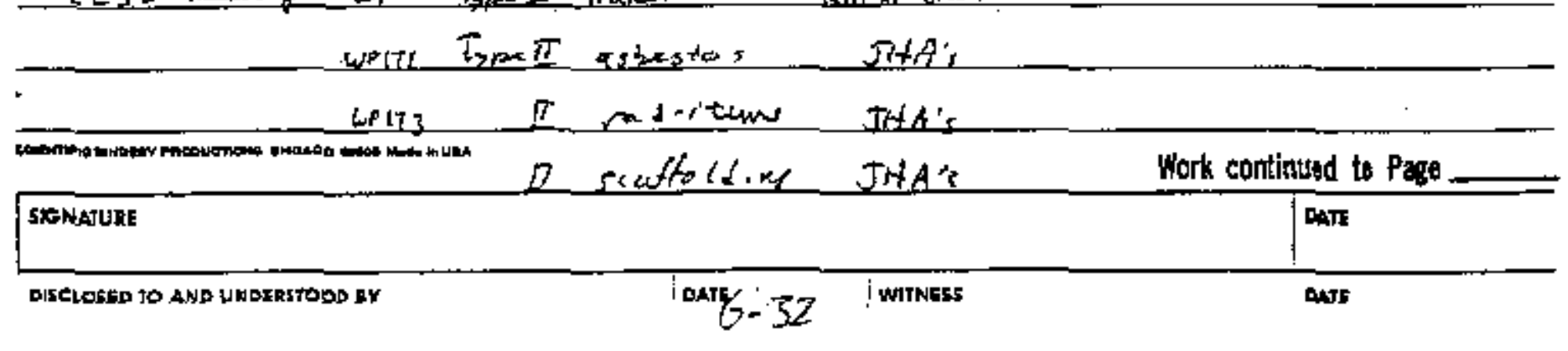


TITLE

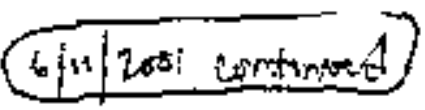

PROJECT NO.

109

. Work continual tron Page

BOOK NO.

1245 - Bob Sk er is un e, Hisenses asbestos

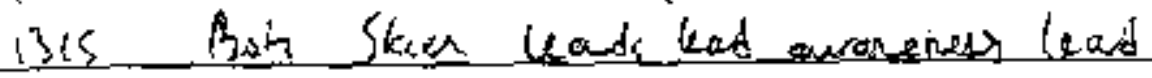

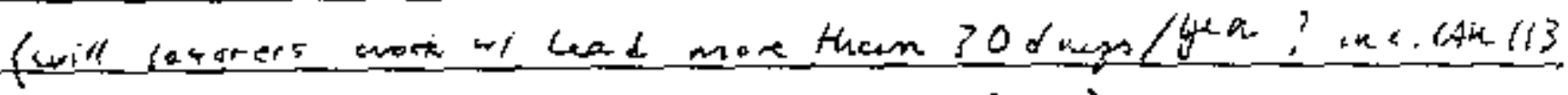

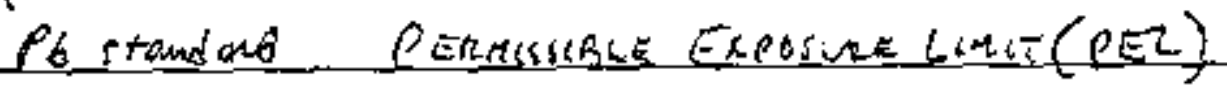

5

$50,25 / \mathrm{m}^{3}$ for 8 hr. 1 eliot

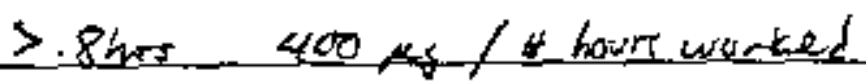

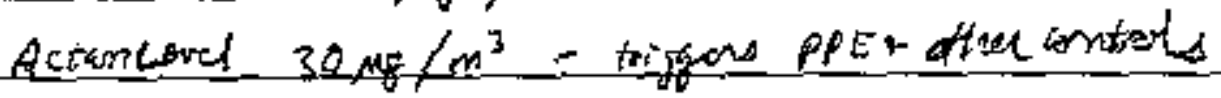

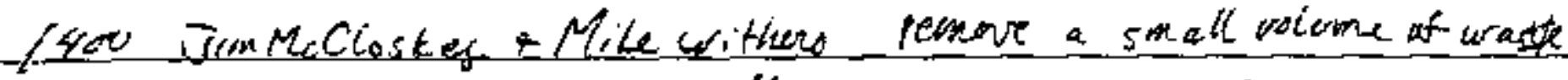
D

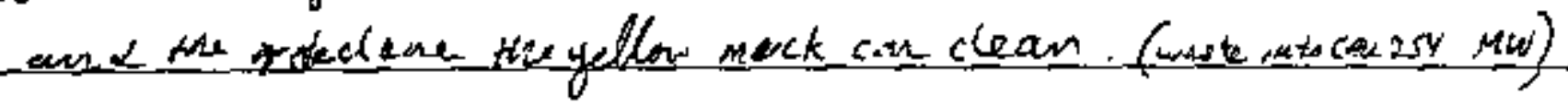

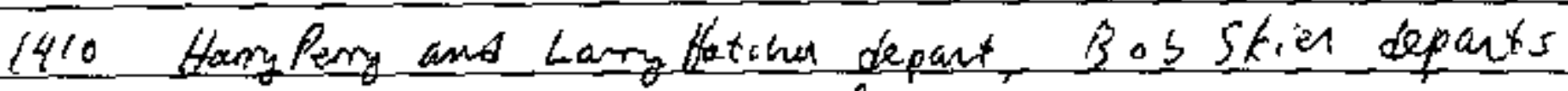
15M inspection planned for $4 R$.

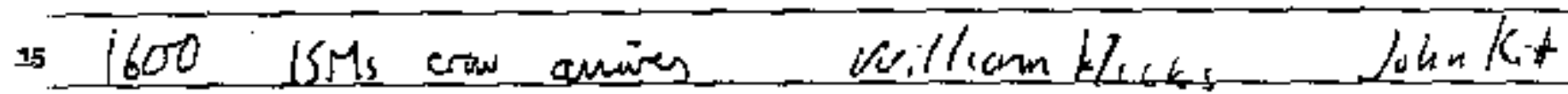

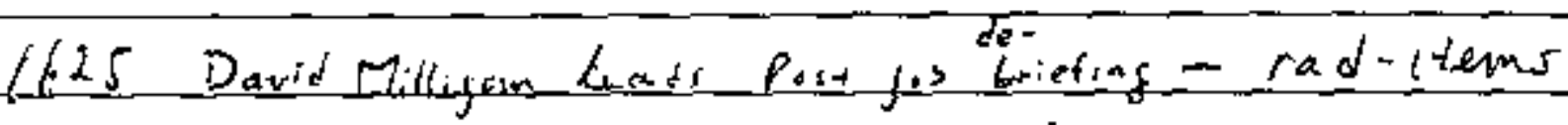

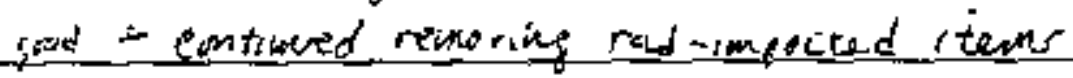

bed - wis on cut_pife snag band saw = remove first from panel 20

$\because$ need more band sow lades and extension cords

1630 Bus Seavasom Gads = a siestas Bud Joel Ron

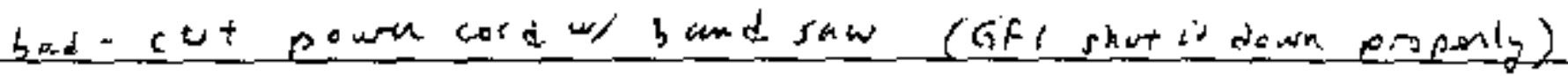

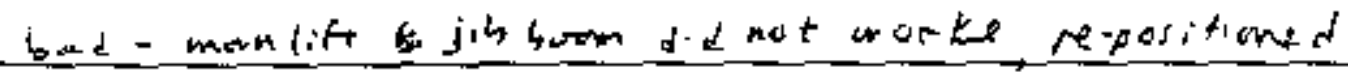

43

- new to fuse socket to hold tor ls and bags

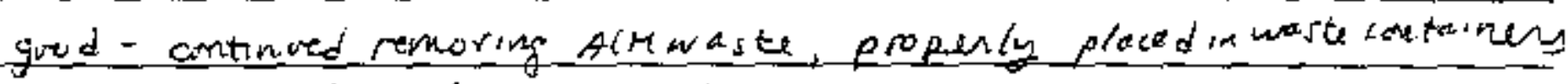
1635-Rienfuirbanks Foam strapping down trailers

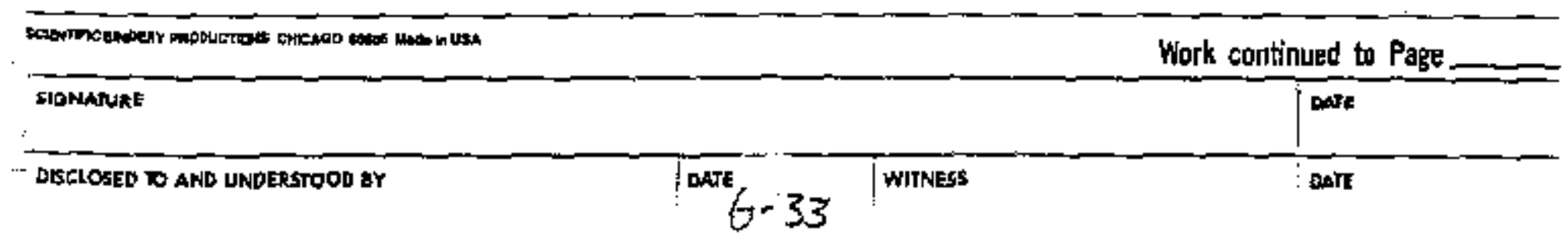


110 TITLE

Whark continued from Page
TUESDAY

WUNE 12,2001
PROJECT NO.

BOOK NO.

(intis obi (Th)

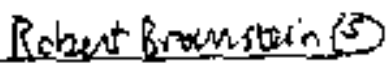

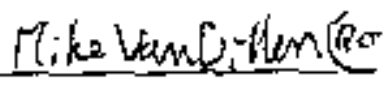

Harypers twat

- cortinue remorad of pad - smpacted ntums

[orry Sunemburses?

5

- continue remaroló absestus tasir

Phil fiphosos

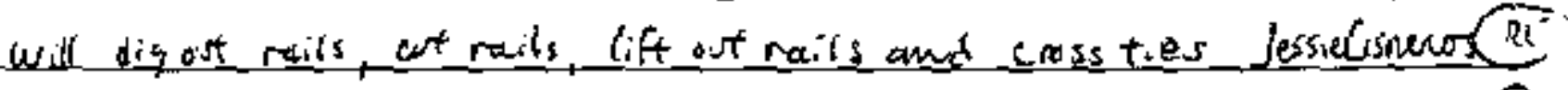

Ginatoros

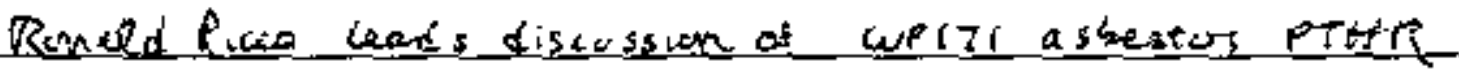

goin Pexpistan (S)

o

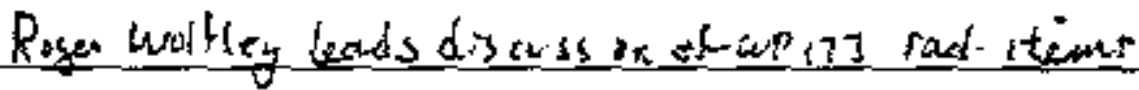

Rosen wolfles (LD)

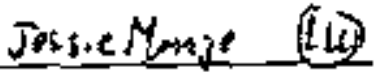

Hetwork permet, shenes, hot/coid surfoces,

Lotryof Howed (L)

Fre watch heat stress (Guid s, breselcs)

Tohingy Broxic: (L)

memlift, fall erotection, eoures tards

Vicior Ramirz (L)

15 rigsing

Deand Hillyear (C)

Desm Solegui (O)

Will probably not remore tramsite today

$\Gamma_{\text {matid Rus }}$ (Asb)

Man renove sell todery

Bud Sermonas $(A s)$

Wese more PAPRS (hara)

Loelchilen (PE)

20

Need more cheirs to dress out

dm Fishin (O)

Will yat rail area before exleuding cA

Marms Grive (2)

Donokis (P)

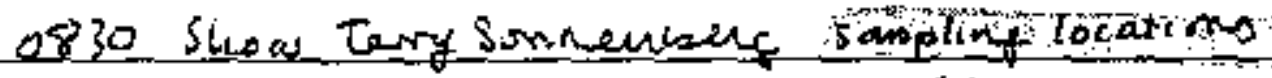

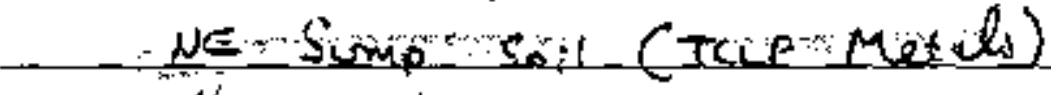

25

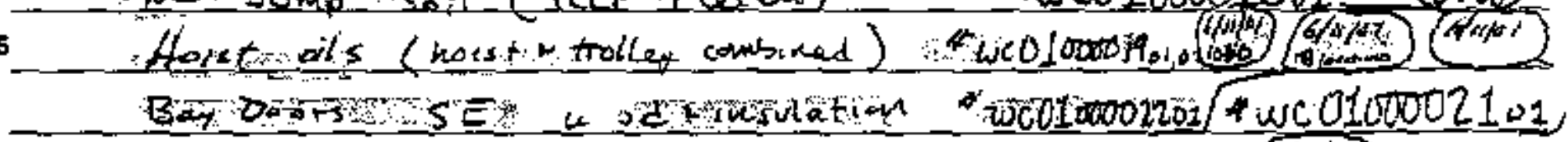

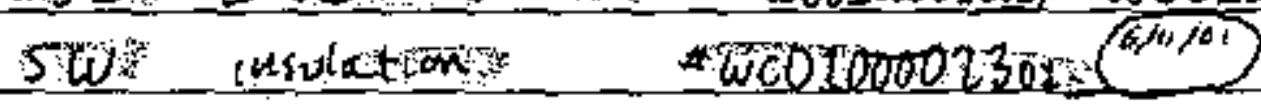

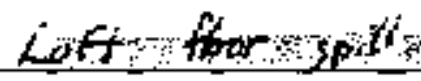

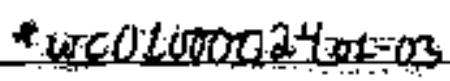

SIONRTUR:


TITLE
Work continued from Page

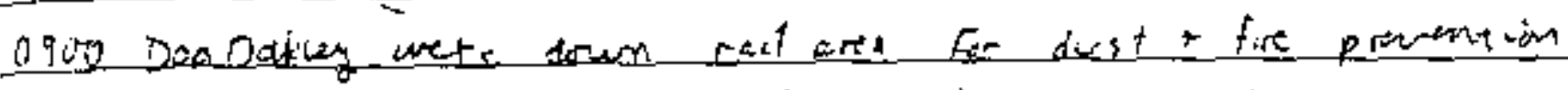

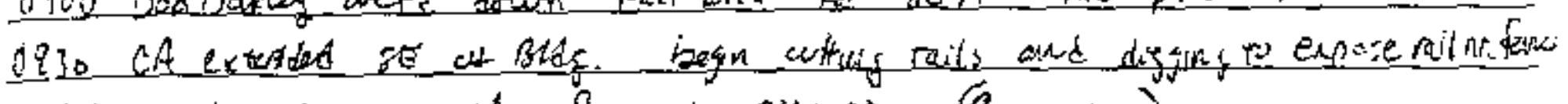

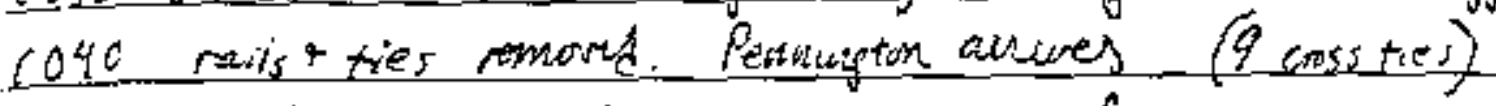

1120 Begin removing first 2025 boxes from area. 1125 secund $8-25005$ 130 More 2 complies of ped

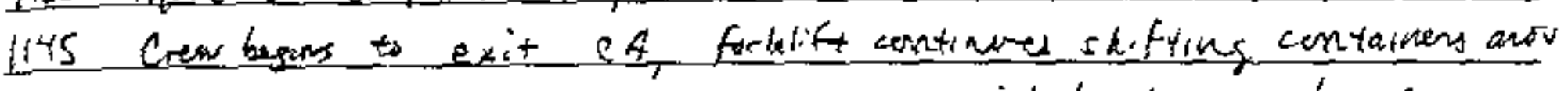
300 sim en from vent has and tabulator acid tank ave clean,

iss culturing rp rails to fit $0-2 s$ w Mw (w/ eros s ties, etc)

Remarry wank bunche sidles from off

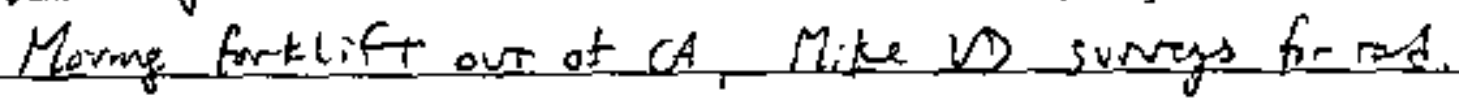

ills ar ap RR rails gs into B-25

435 treat

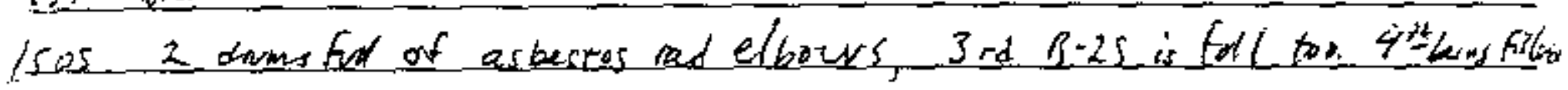

15

20

5

Wot continued to Pg ge

NatURE

DAt:

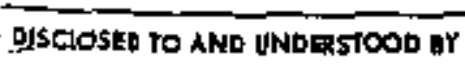

DArE

WINES

Tare

$6=35$ 
112 TITLE

Work continued from Page
WEDNESDAY

13 JUNE 2001
PROJECT NO.

BOOK NO.

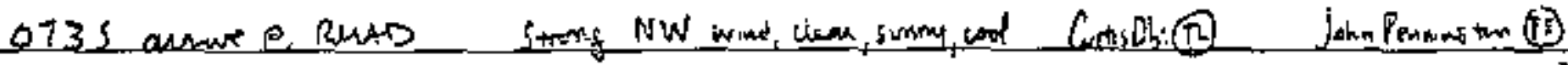

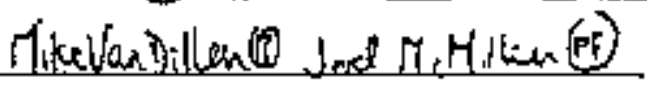

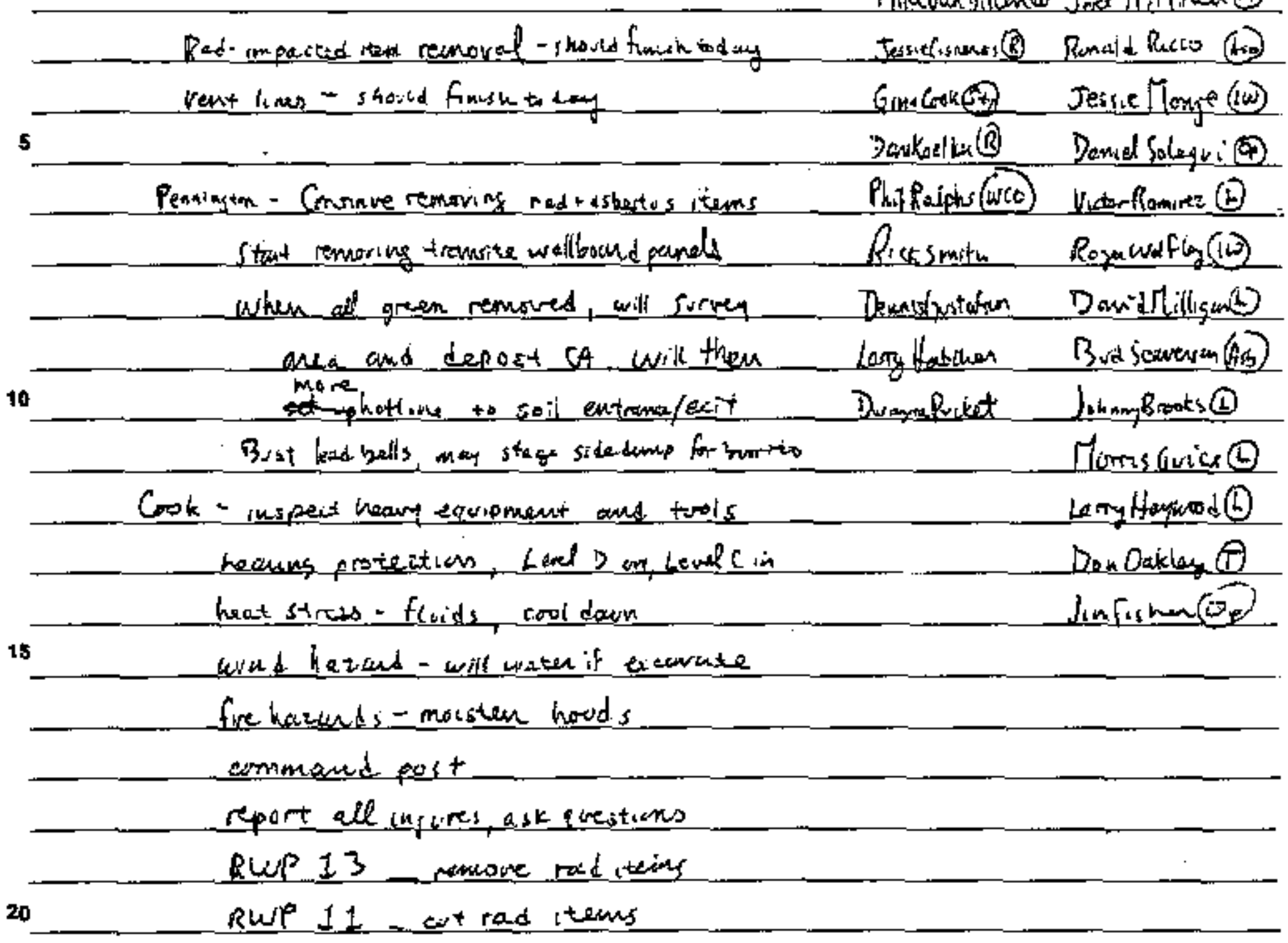

WP 171 removal of asbestos PIt (Joel)

wiptiz removal of rod items PTHAR (Roger)

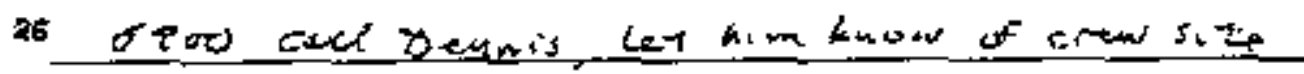

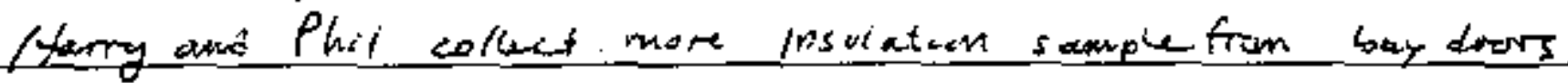

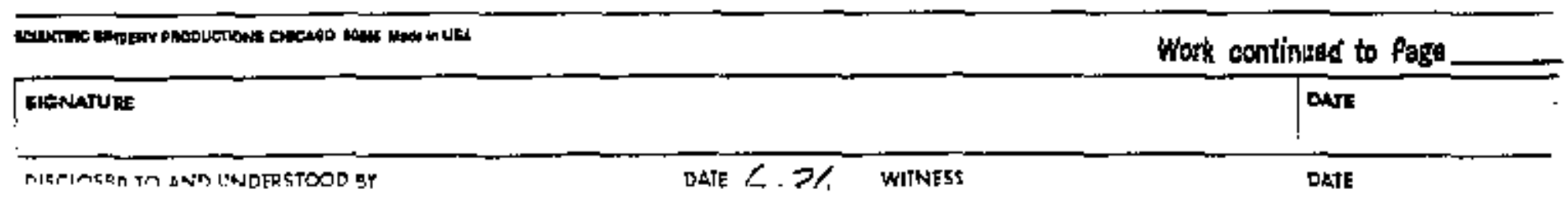


TIE

$6 / 13 \sqrt{2001}$ continued

113

work continue from Page

PROJECT NO.
BOOK NO.

Morns and Victor break beaded-hed vent pies from below 8'

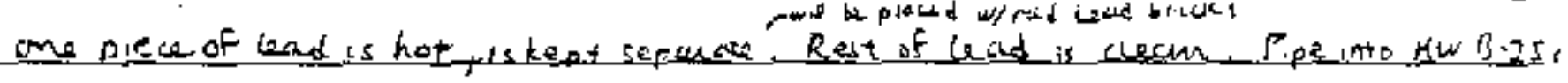

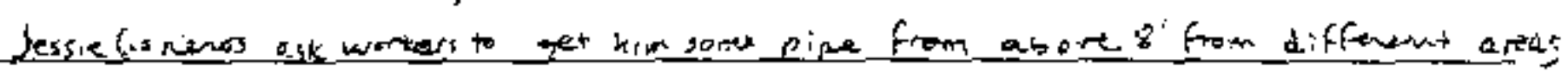
will che ike ter Rad before deporting bay as CA.

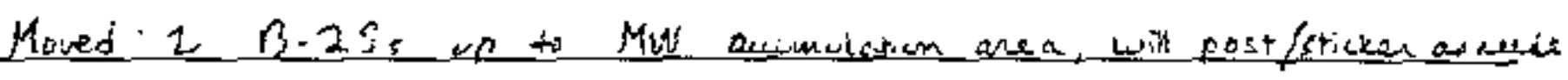
Almost dome removing rad items, began removing transit.

izod Lucre

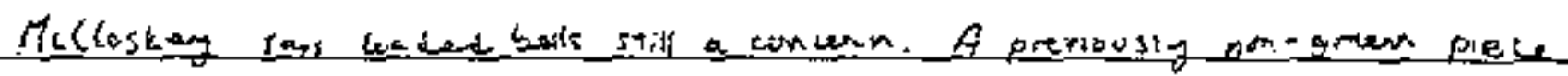

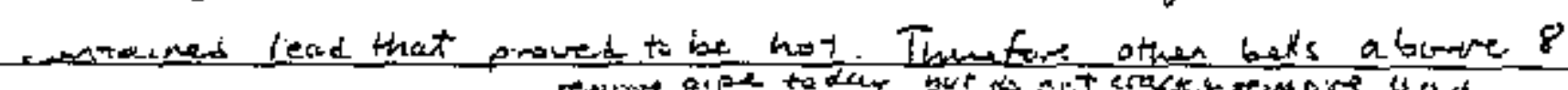

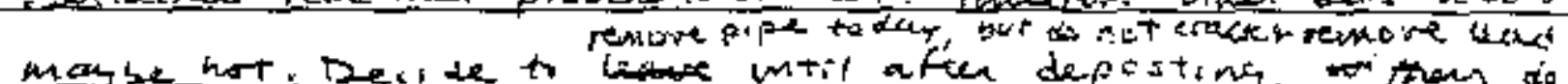

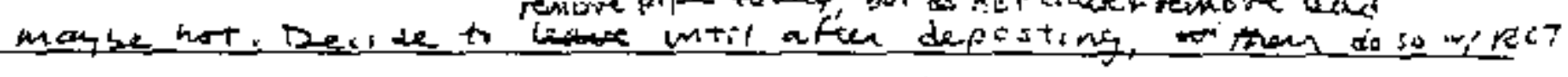
if rad them may have to report CA at that thine.

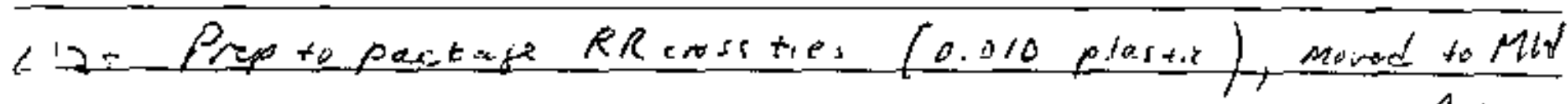
Waste Ares.

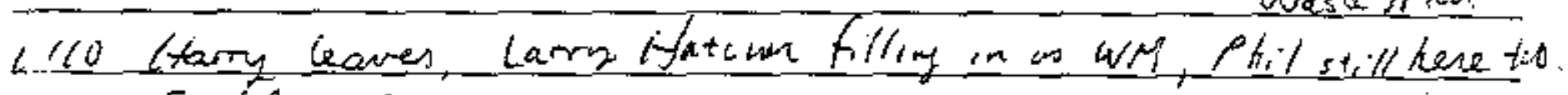

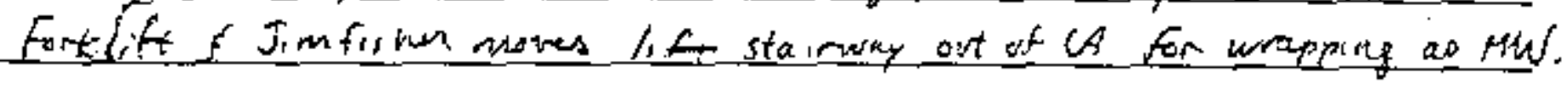

H so HW and MW and LLW asimilatimartas posted for $r o d$ and haze waste.

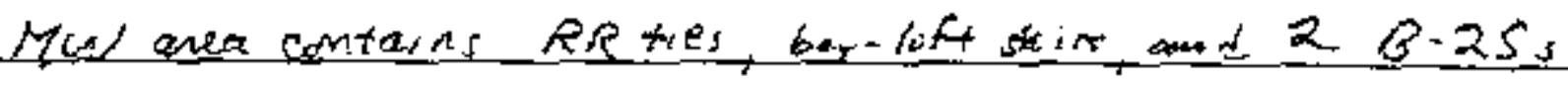

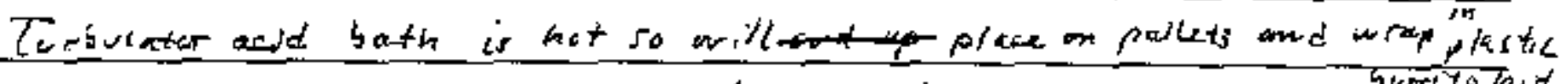

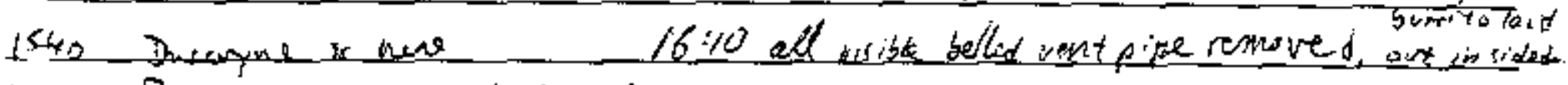

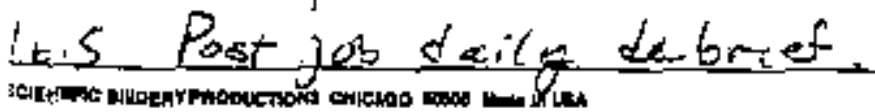

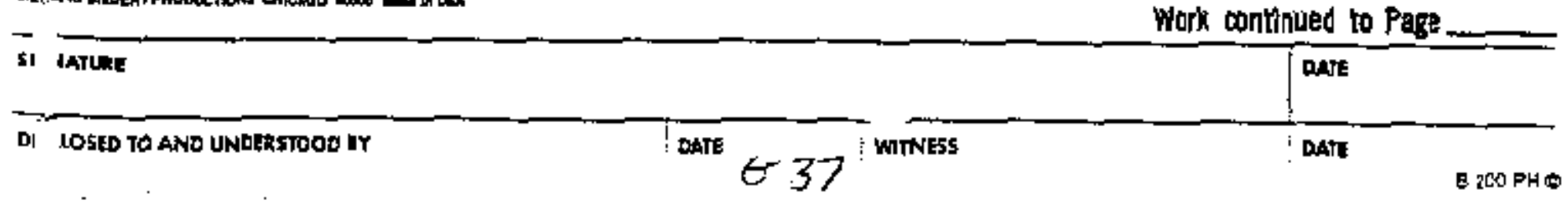


114 TITLE

Work continugd from Page

- g7w ande e RMAD
PROJECT NO.

BOOK NO.

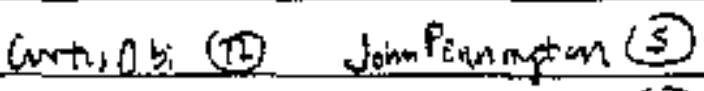

Ginalook (s) Rogawoifley (Tw)

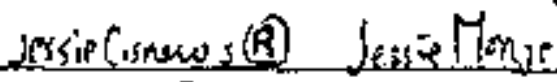

(16)

$122-$ - remored of rad-sail

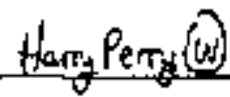

Damid Solegri

(o)

5 _ 1 . ranoval of askestrs

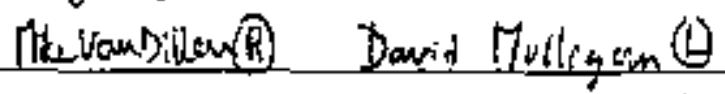

flerieguse (b)

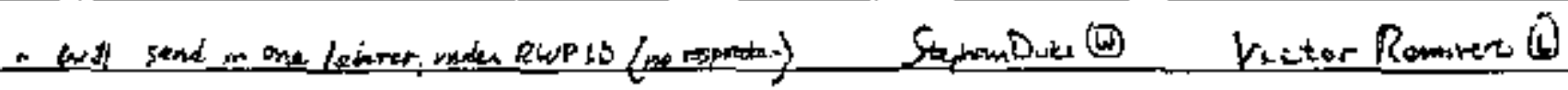

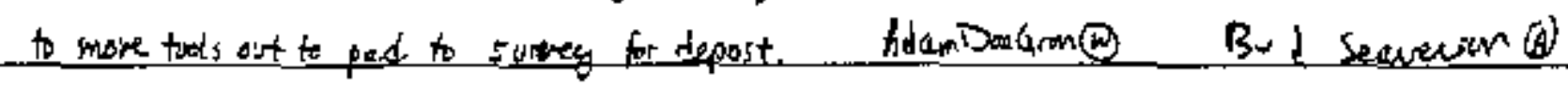

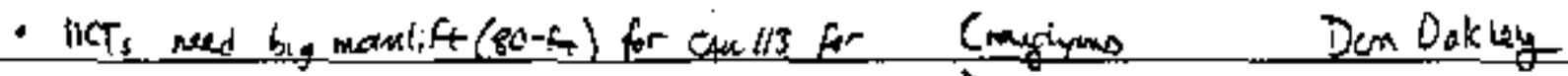

10

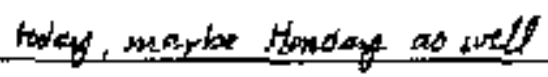

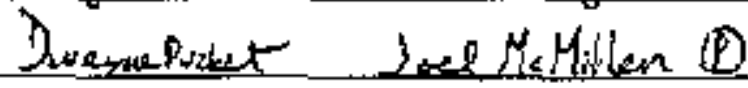

- Stup rad -sait hatline

Rended Rowes

(A)

Boingy Dolens $(?)$

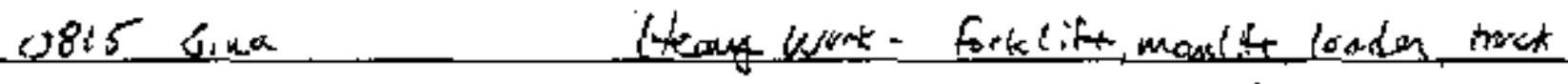

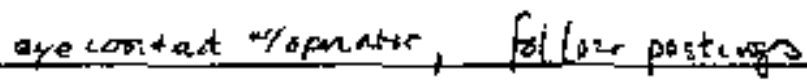

15

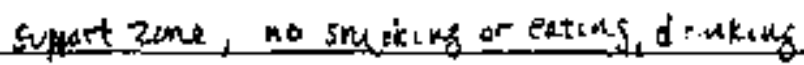

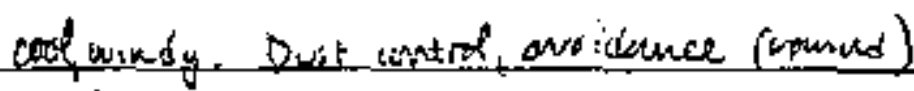

scaffolding sabty, only essential perconncl,

Repart atl acsidents, thijuries to super t. SHSO

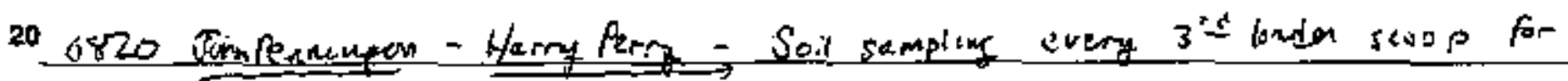

fa composite sample representing each side. dump

$P T H R=0$ suid Mill ifion for soil remorol

Typeritup

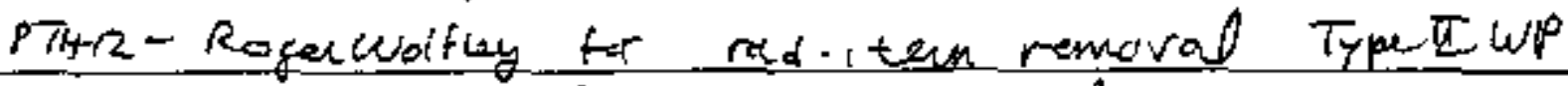

PTHR - Rmald Rico for askestos remoral

25

iO30-RCTs depost ras-item CA (bay and sw padtycurs)

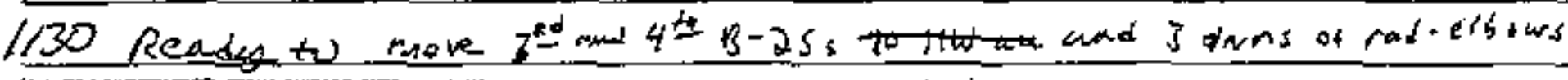

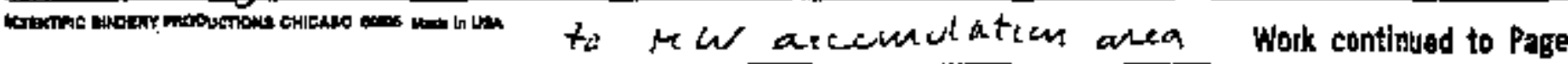

SHGNATURE

DISCLOSED TO AND UNDERSTOOO BY

aloo: plastic-umped traty mator assmbty.

DA:!

DATE/ $>$ WTRESS

DATE 
TITLE

Hork continued from Pagt
$6 / 14 / 2001$ onstrined
PROJECT NO.

BOOK NO.

115

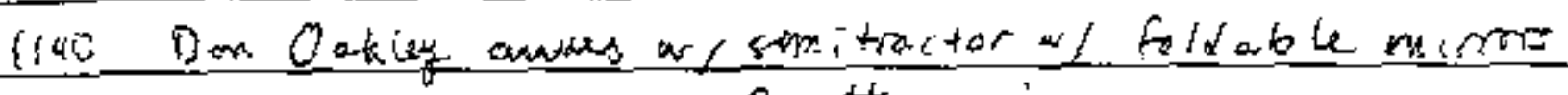

1305 Can Leons of D warre Protet and

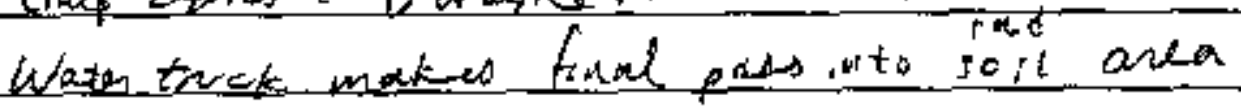

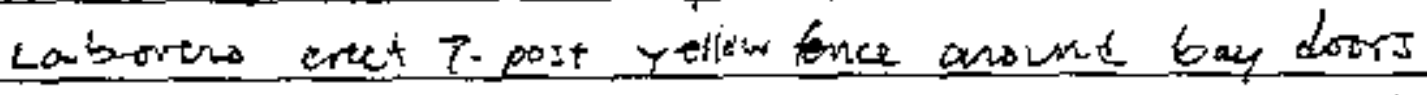

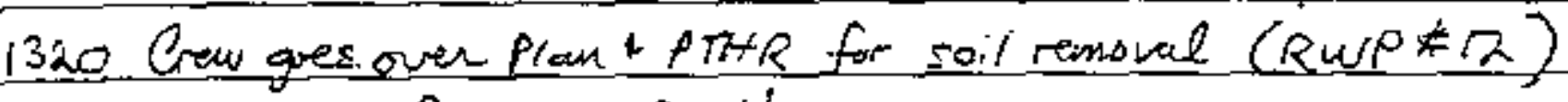

sampine Procadure for Haty.

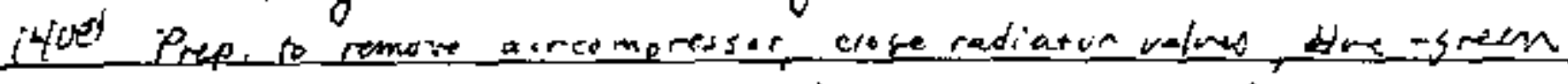

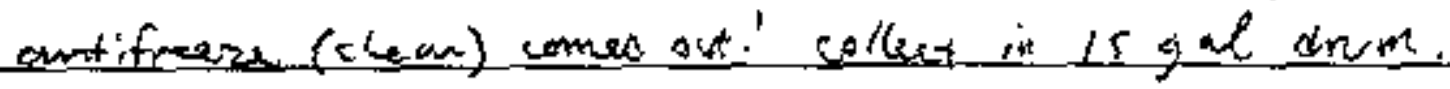

Reper estimates 4 gals coolant

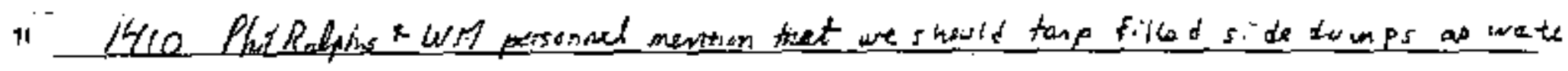

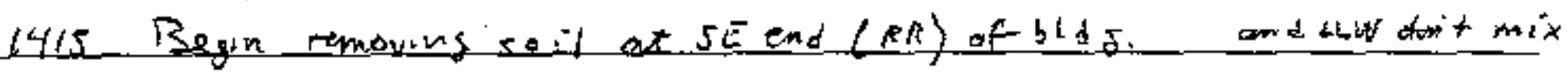

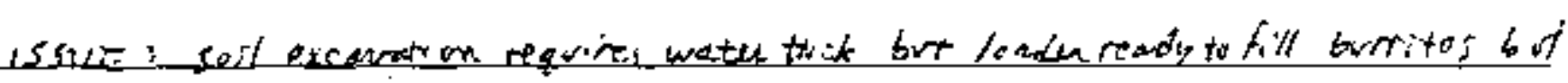
teansten meedsto stay in cabin $C A$. OAly one teame riese.

$1=$

1455 Bud and Rom in manch remoung non-rad estestos elbours

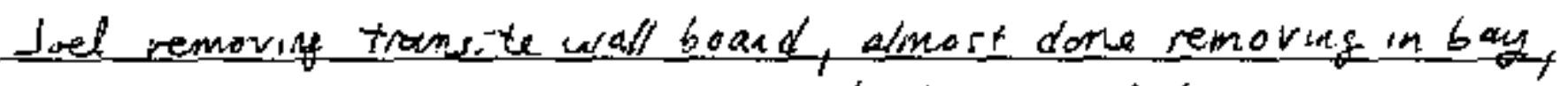
boesiss notyet placed in pladic-linced $60 x 20$

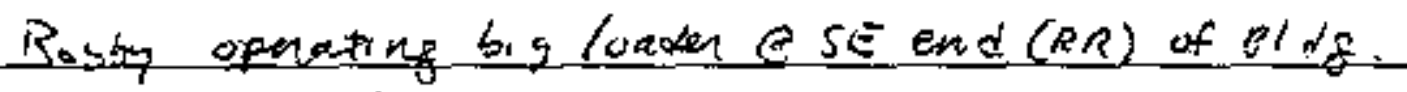

20

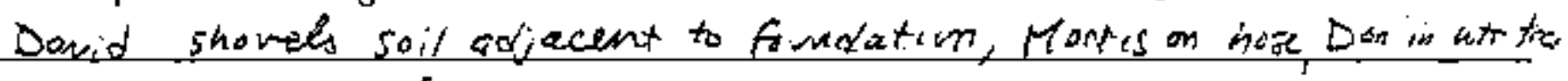
Mike $v-p$ enecks for hat spots.

Danit waits te epenate small trotar.

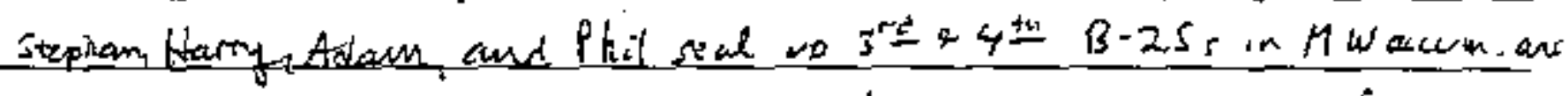

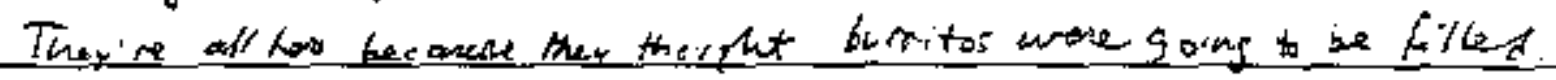

351540 End for ory Soil at se end of blo's:

None logesed into burritos stokkfiled, wated down.

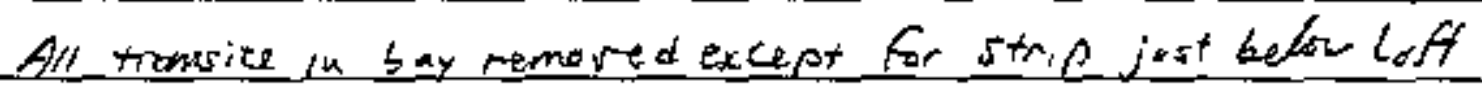

Etbaustin bay : t fare, probably need two days. Not mondus

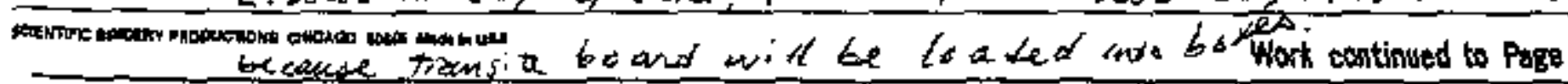

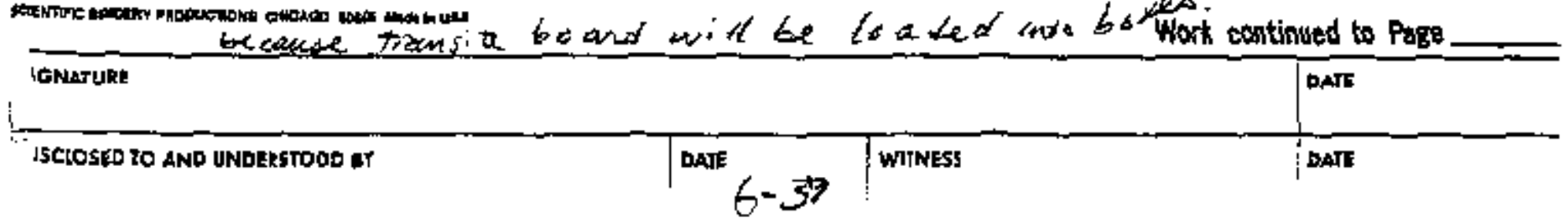


116 TITLE

PRO.JECT NO.

Work continued from Page

BOOK NO.

osts frove $\mathrm{e}$ dormc

0.45 Peminition.

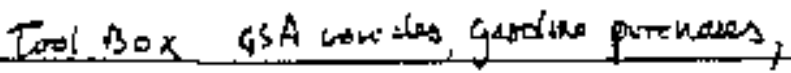

Congem Monoride

$507 \leqslant 7$ Barawchin

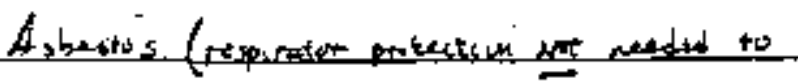
renuer waboard), removal at lead from pipe-gells (respiedturs wit he revired)

land-hazued an scoffolding
Cutusob.

Roine Brmmin (5) Dans Milligin

Jessiegrinios

(Q) Martis finte

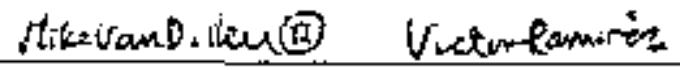

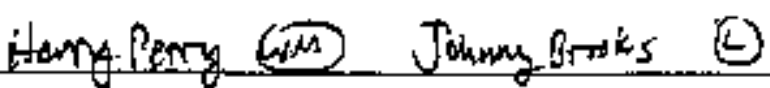

Phichalpintiwa Jellikilem (PE)

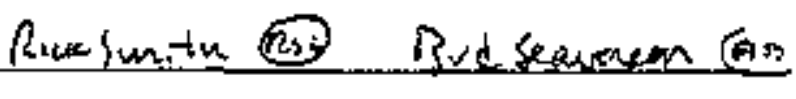

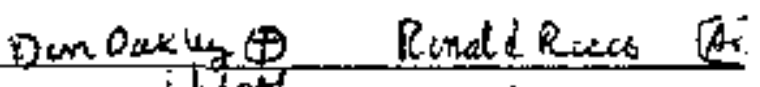

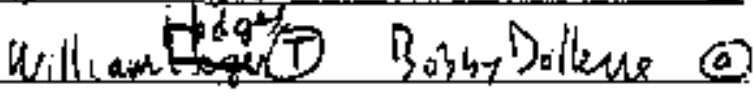

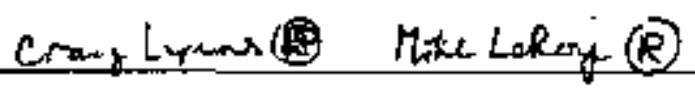

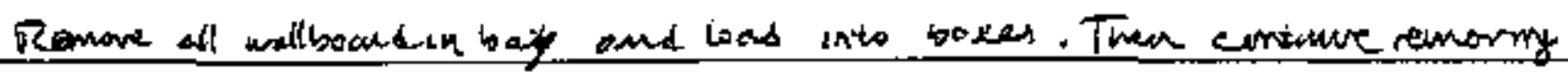
cuskertas elbowis

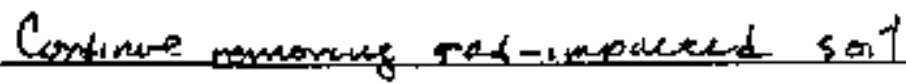

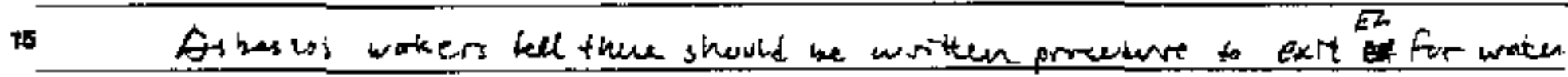

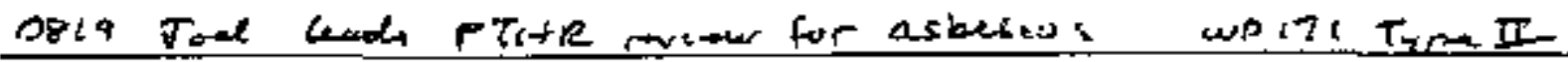

Shamps, hot surfecess. fire enteng eye wash, heat stres, manlift, rigsiag

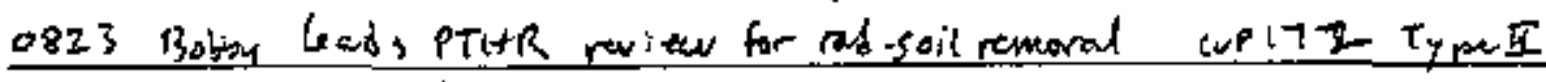

20

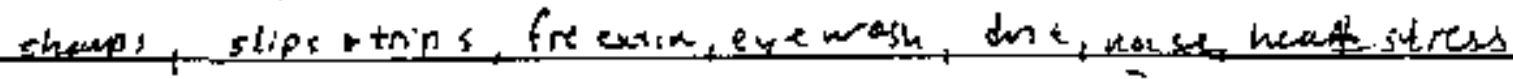

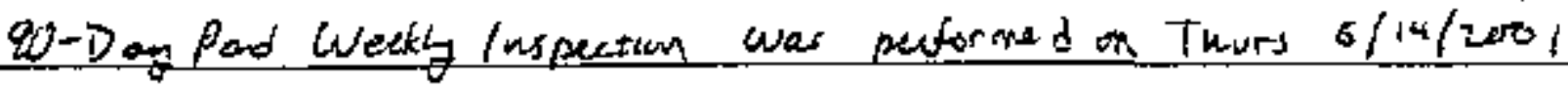

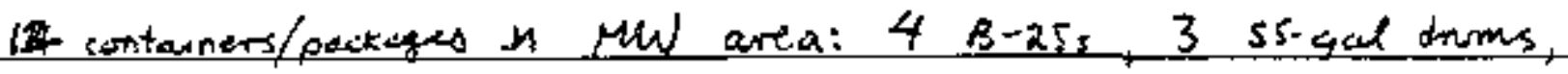
5 bulk plastce-wmpped packafed (starway, crosties, trailey motor, turioulator tamk, metal door)

2 contaners in HW area (butn $15 . \mathrm{g}$ h biack-plastic doms)

Fist $x$ grease, lead cam pound, second is air comprest or coolant

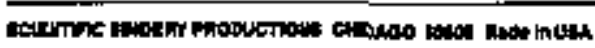

Hork cortinged to Page

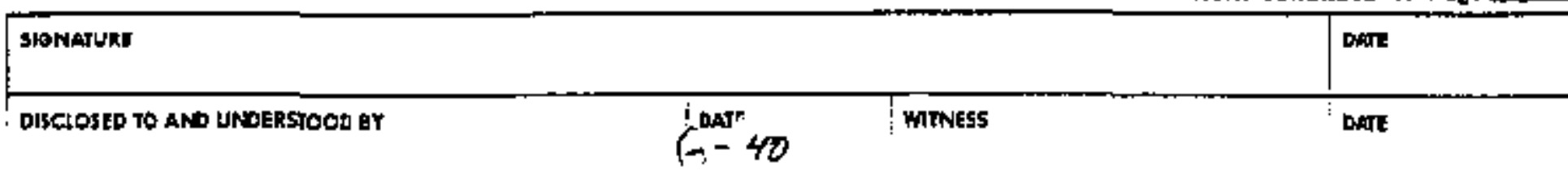


Work contisued from Page

$1+1$

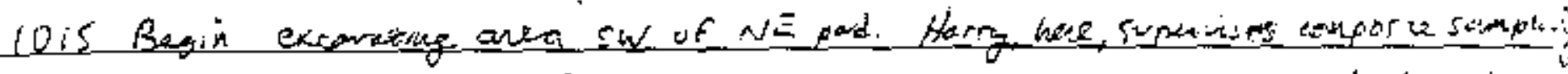

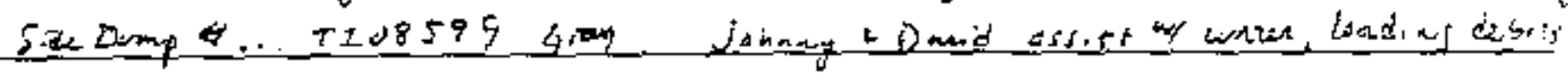

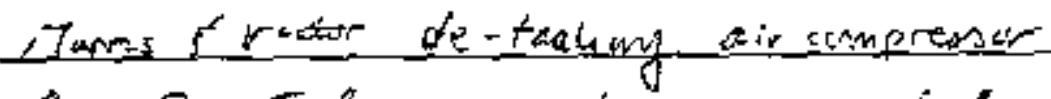

5

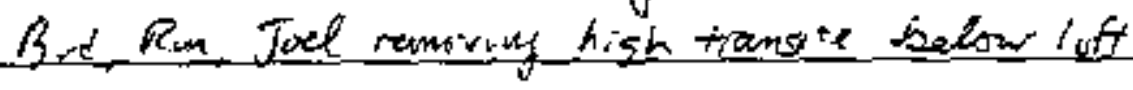

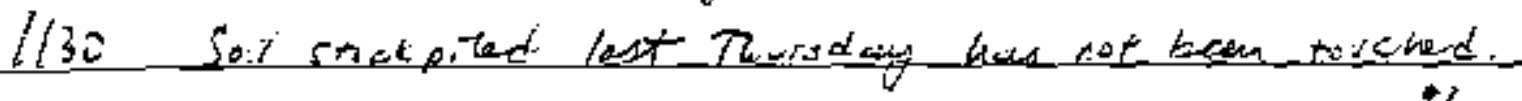

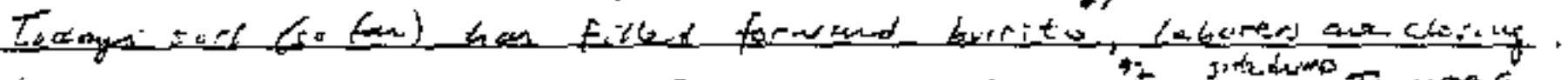

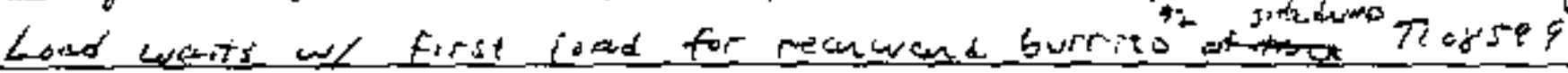

fo All tromsite in 5 an cemored.

LIo R.ek Smith anmon

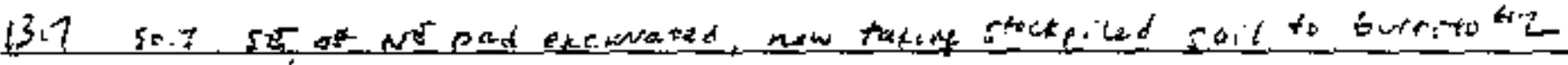

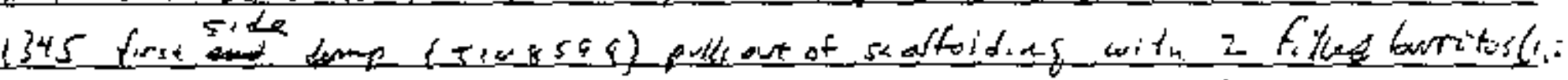

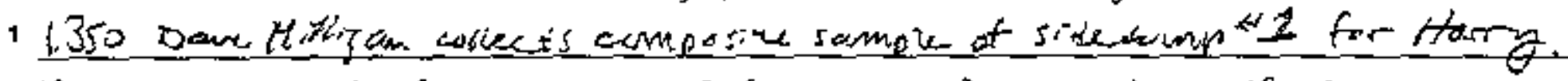

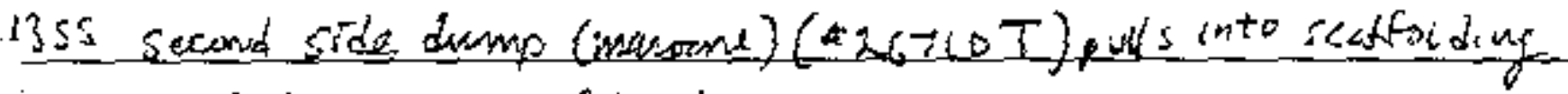
Crois Lient and Rite LeRoy mant

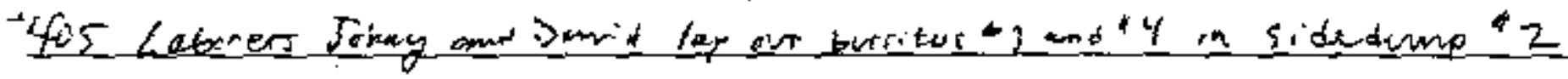
ax

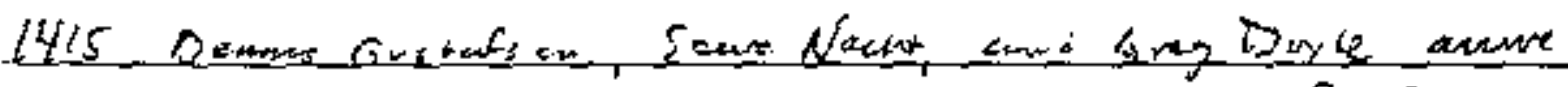

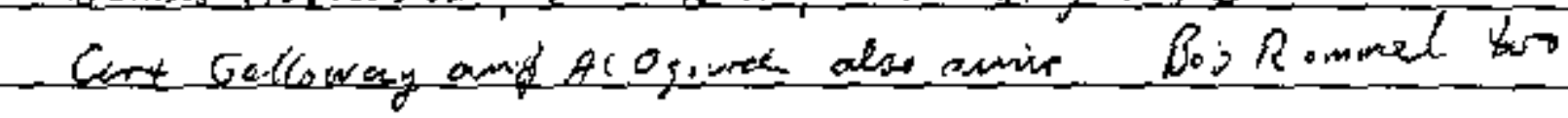

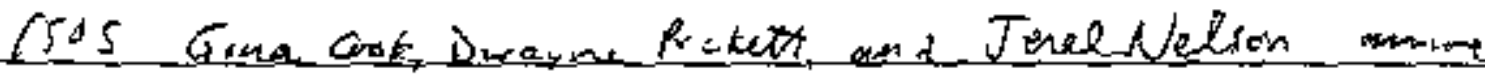
5.

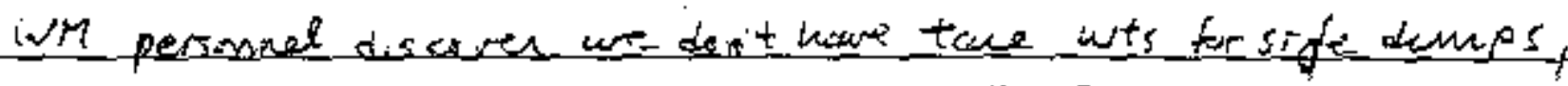

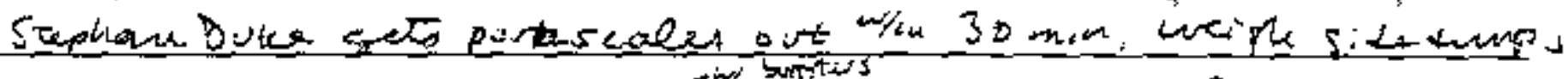

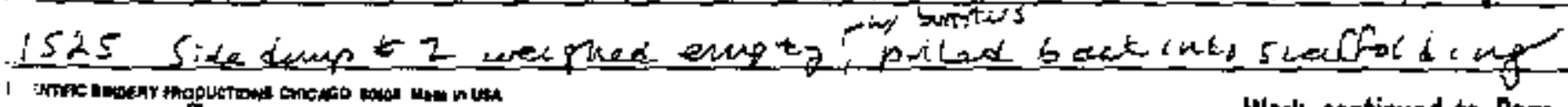

STGMATIRE




\section{TITLE \\ Work continued from Page

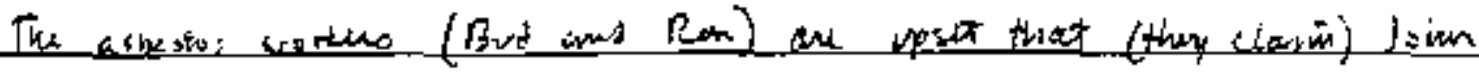

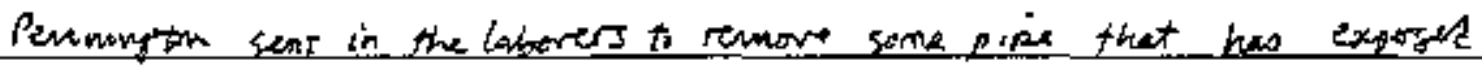

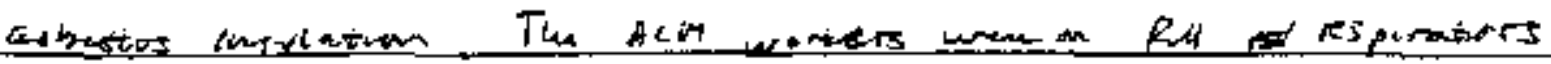

but taberers laven nort.

Brounsesin sems to have all ato re: thes matter

10

15

25

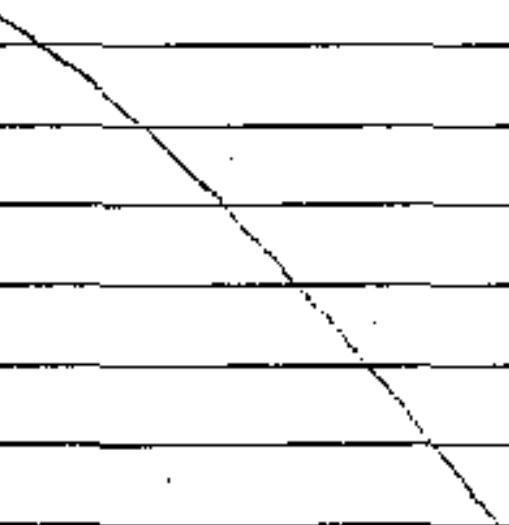

20

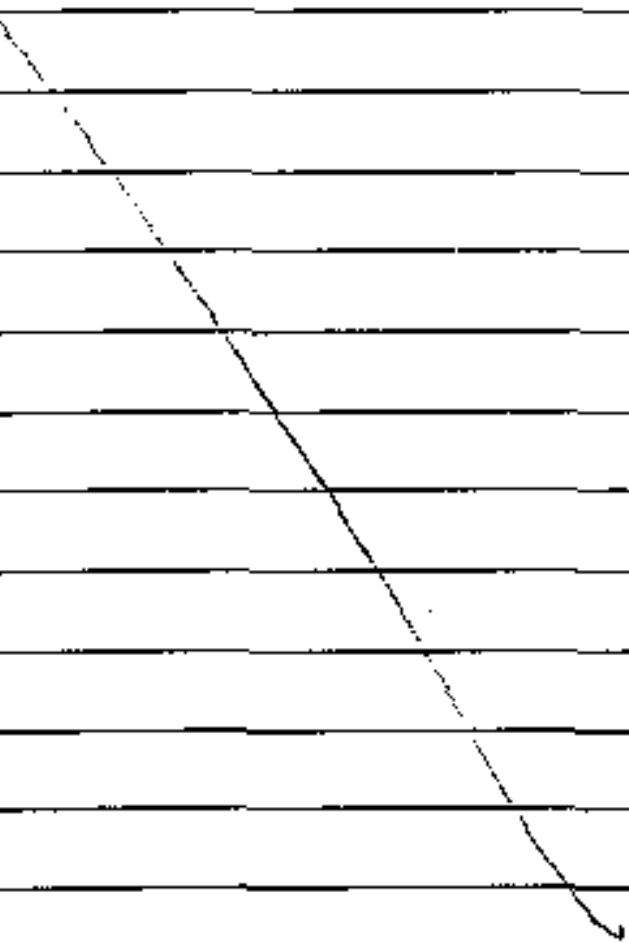

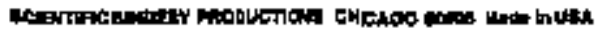

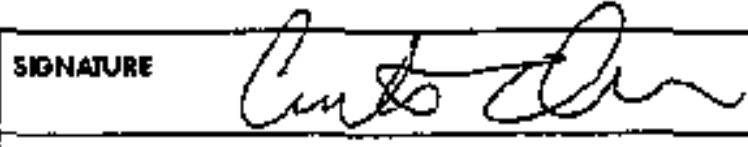




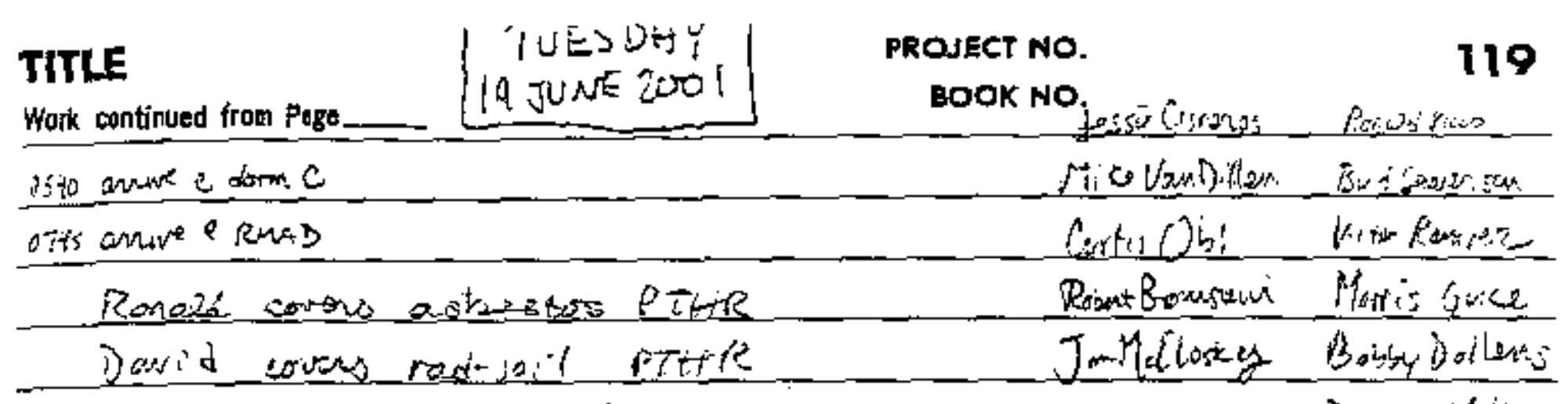

i. Gati's conducts safesu briefing

Denendilieger

Jahumg grook-s

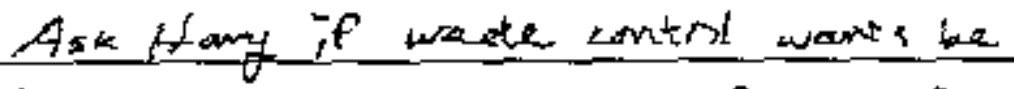

Dot oakley.

be here derig sintblast. Pont time?

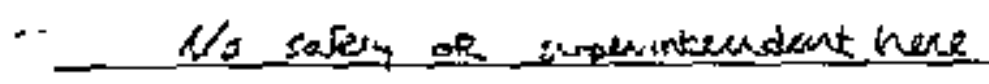

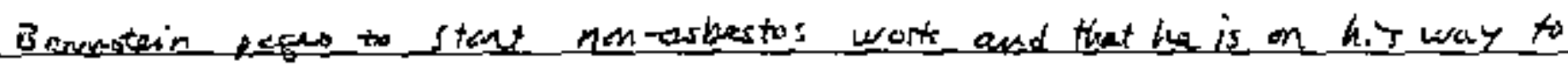

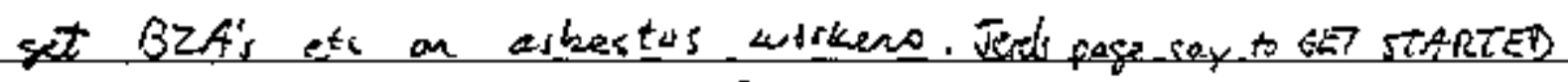

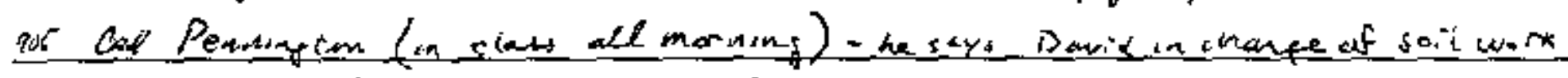
15_... and Rom in chane of arbestis verk.

Don Oakiany waikers disw yard, then gres to refill

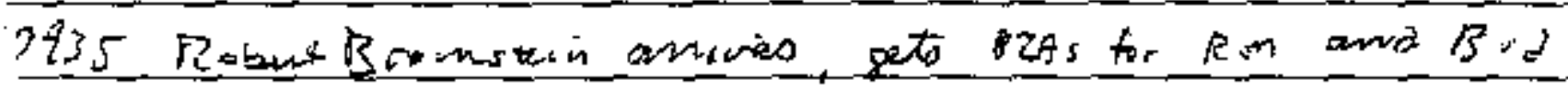

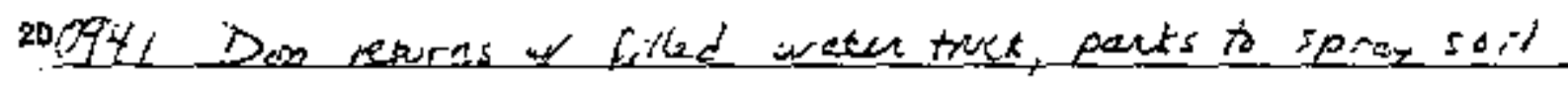

tis 5 seransit.

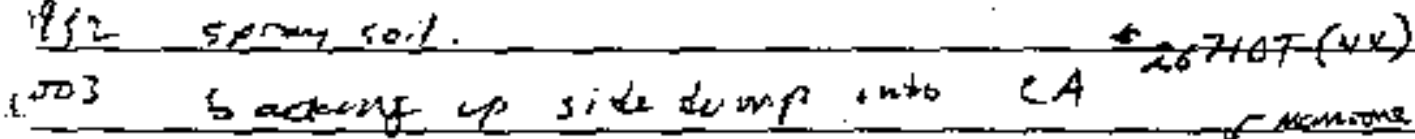

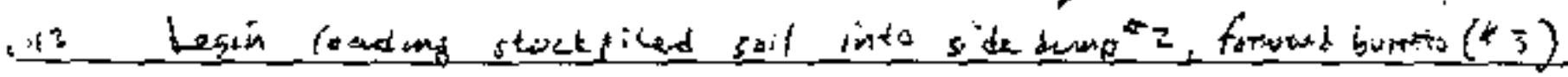

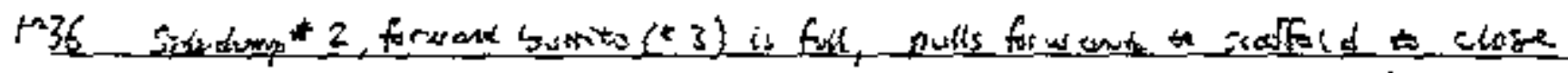

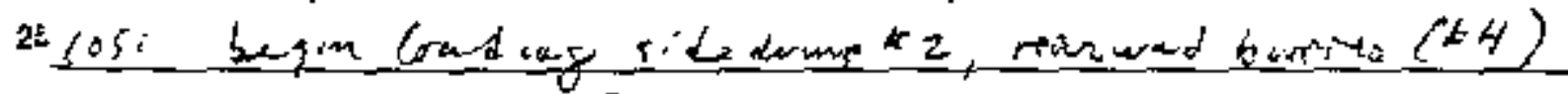

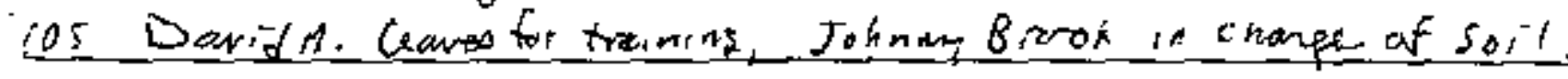

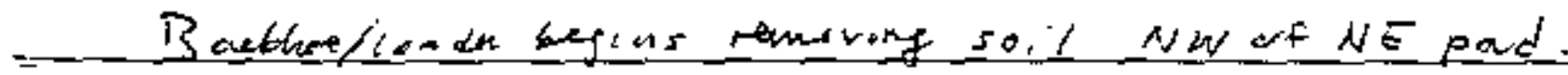

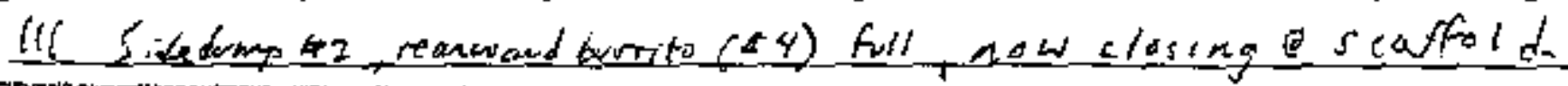

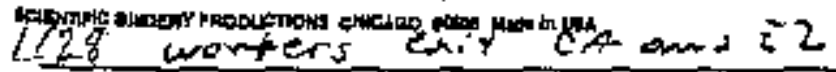

Work contiasted to Page
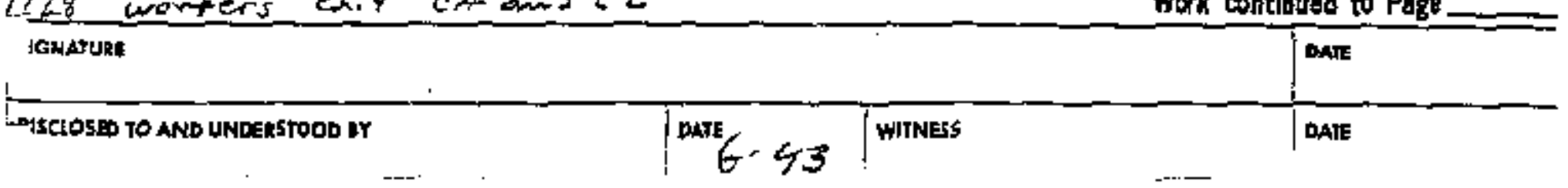
120 TITLE

Work continsed from Page

1230 - Reventater ritans

Sidesump 3 lames sowids,

rady for burrtos $(a r a y+30326(N 0))$
PROJECT NO.

BOOK NO.

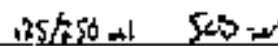

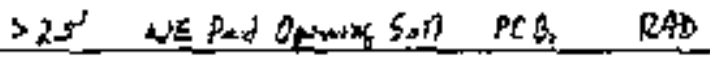

$>1,5$ SW Pad Opening SA PCE BAS

Nw(owg of:

$P C B_{3}$

PAD

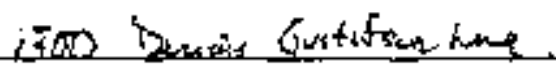

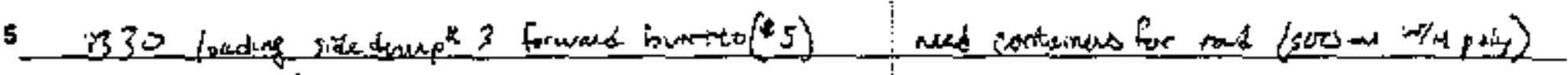

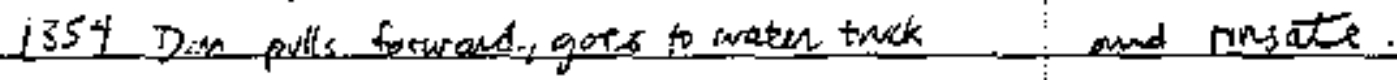

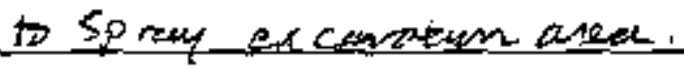

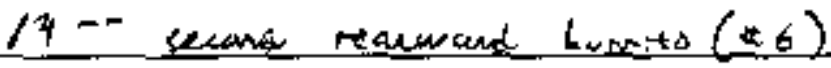

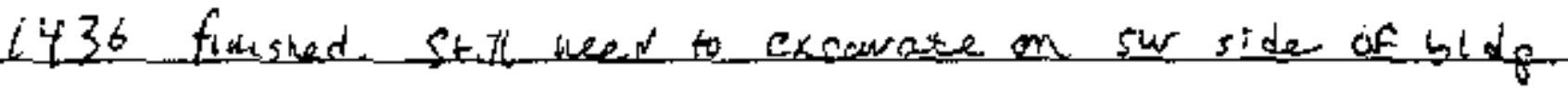

10 cise bursto 6

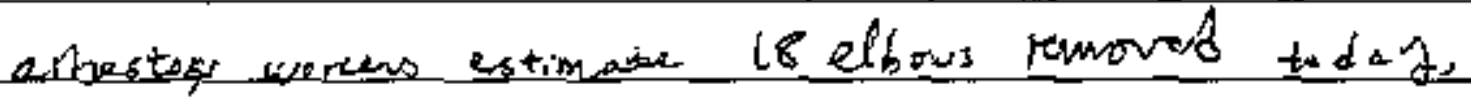
$29+8$

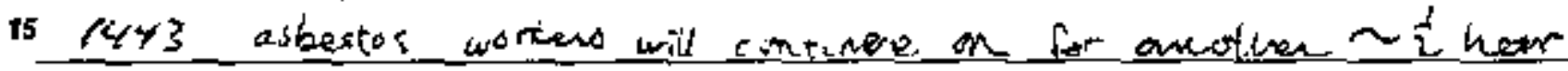

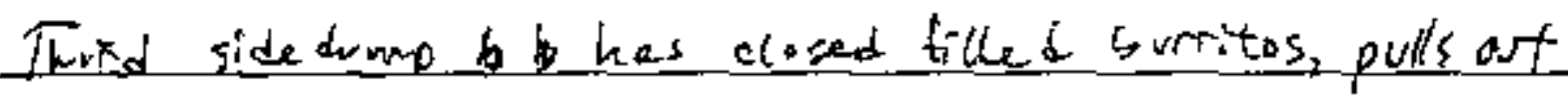

tarme wilact 1 cample, soil crew exts

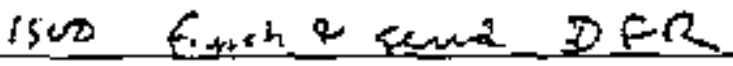

20

25

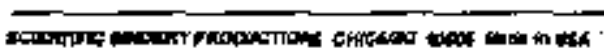

Work continues to Page

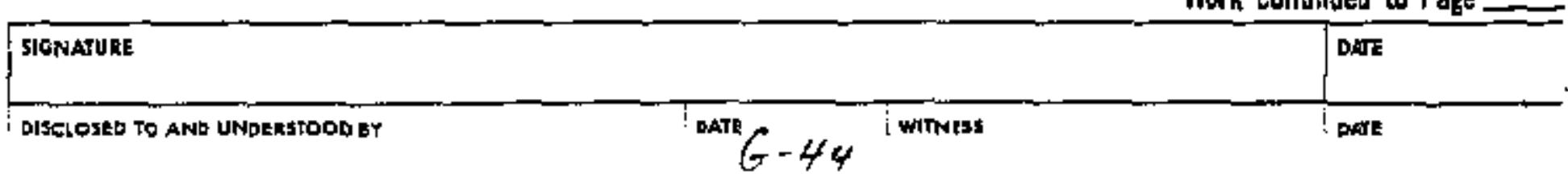


TITLE

Work continuad from Page-_
LOJUNEVOOI। PROJECT NO.

BOOK NO.

121

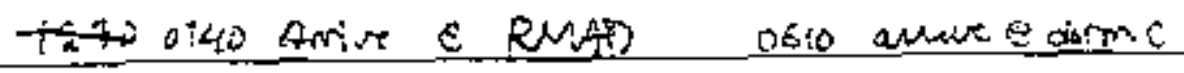

move full box of transite MW

0750 Thensa conkizs sately brefine

slip sip folls

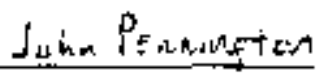

Auricsuce. Vucter Resmetiz

davidrilliges

R.mated Raco

PiCs

B.teflanders

Bobby Dollens

acetplone

Custis Obi

Farklitt, momlift, daity chackli it

Tuen Mizam

Loader

jesre Curens:

Creilizand Mike vanpillen

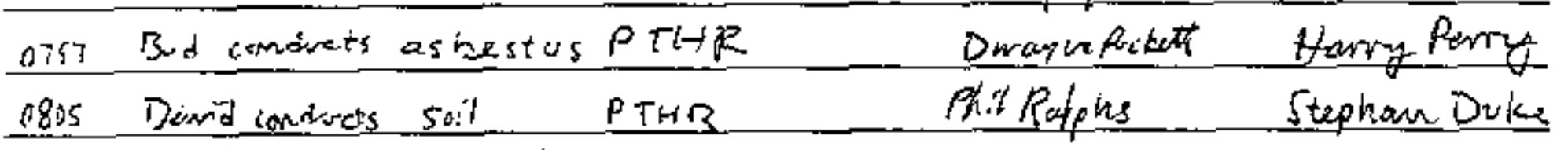

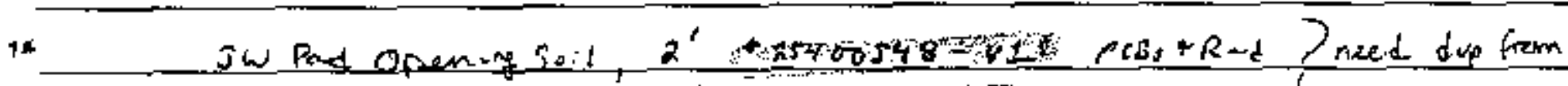

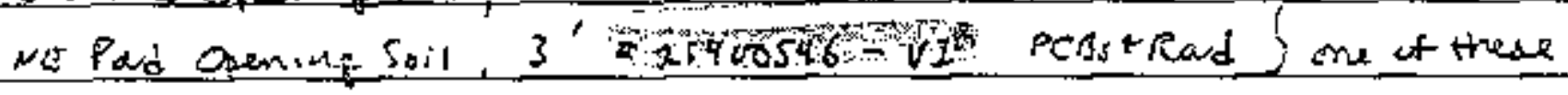

agp corew preps to worix, lube twck antires

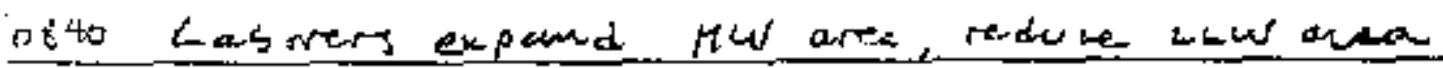

20

2853 Q Bed Ren ans cising Mw bot of trens te

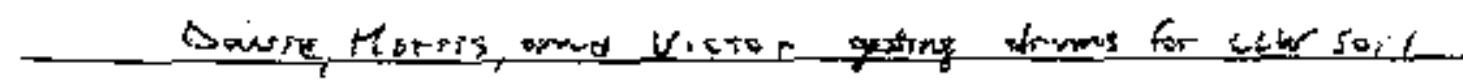

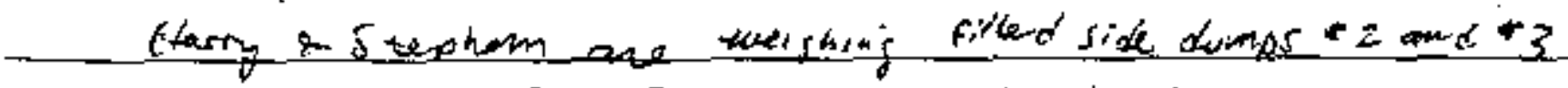

- Bobion getng forkift senvicaby lube trock.

25

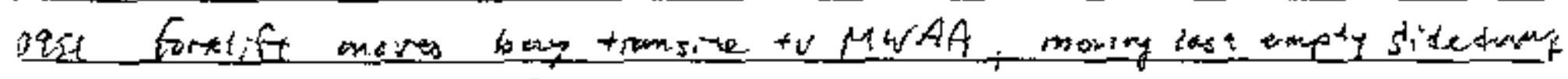
ints scaffaid anen for bureito get up.

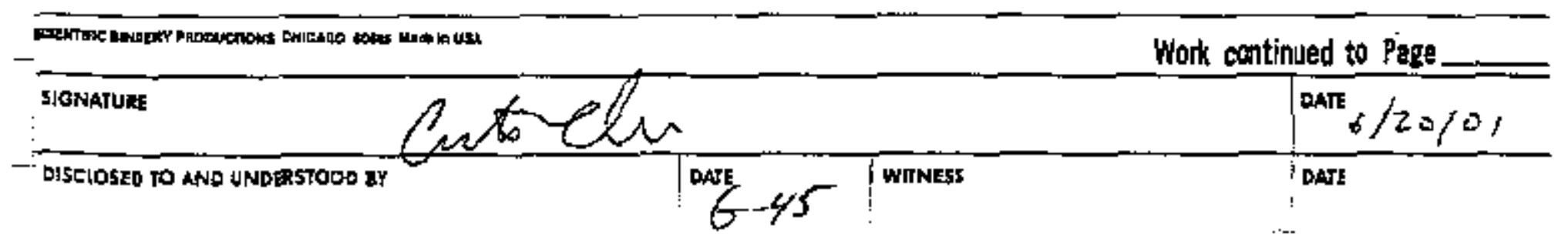


122 TITLE

Work continued from Page_ $6 / 20 / 20 \mathrm{~d}$ contrined
PROJECT NO.
BOOK NO.

1015 begin digging 521 ovf af sw Pad Openuts.

So:! wires, lebris

1050 colloct s.il from sw ped $Q_{\text {pening at }} 2^{\prime}$ b.tionsil $25400578 \%$

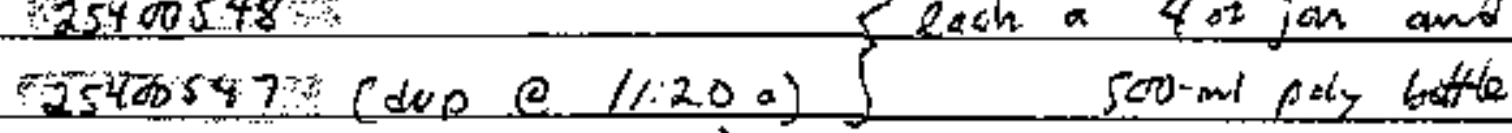

fillod dnom $01<0.293 / 4$ full w mostly soil, small amount of wires, plastic, defiris

$(4-4$

${ }^{10}$ Begin disgun $4^{\prime} \times 4^{\prime}$ anea s5of sucant - actol area ¿ less becouse of concrets pad.

$1 / 25$ burrito 7 astalled in rean of sidedwomp 4 , backed up, reafin

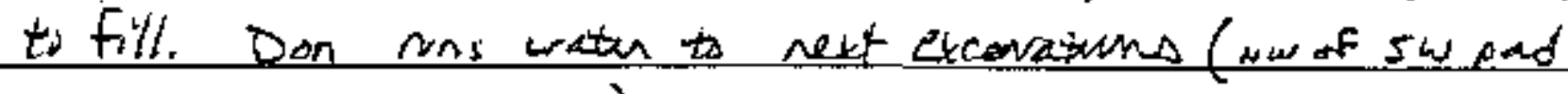
and anoind NE padi).

1308 cre prafy to movedirt. No warte control yet

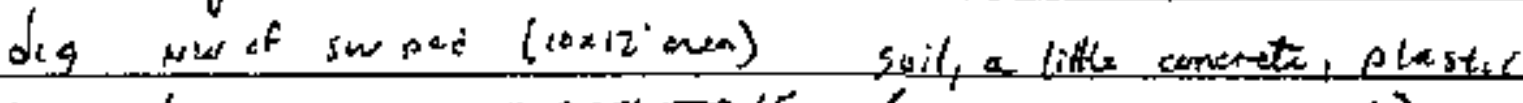
dig $z^{\prime}$ excar.e $254000 / 5$ (no sample nesded)

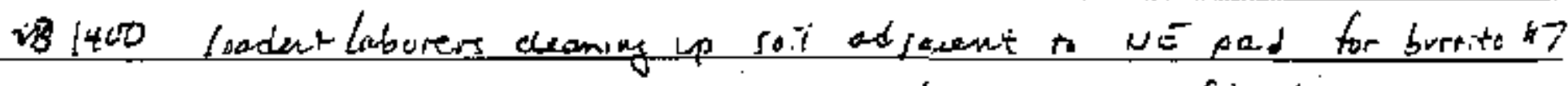
i430 locetion istorosy excevared to $2^{\prime}$ then backfilled.

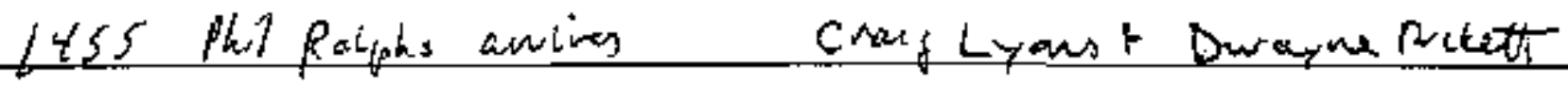
1500 Dave tharis begin dissing e 254000546 to $3^{\prime}$

5 vector washen off loaden

Horry says Craj said all sact will be dirposed as LcW regand less

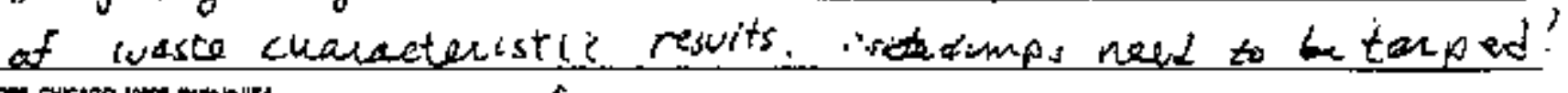

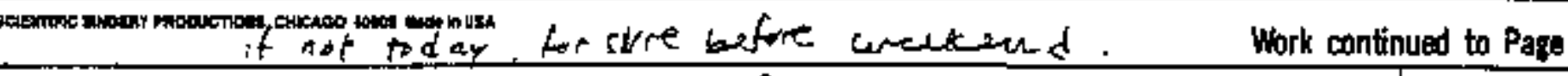
SIENATURE

DISCLOSED TO AND UNDERSFOOD BY

$\operatorname{lon} \mathrm{c}$

WATE $6 / 20 / 0 ;$

DATE $\angle .4 \%$ WITNESS 
TITE

$6 / 20 / 205$

PROJECI NO.

123

Work continused from Page

BODK NO.

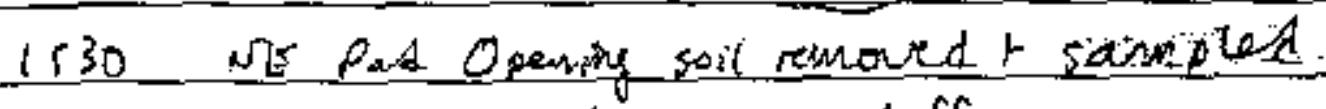
iloo burvto wropped, laborers doffinf.

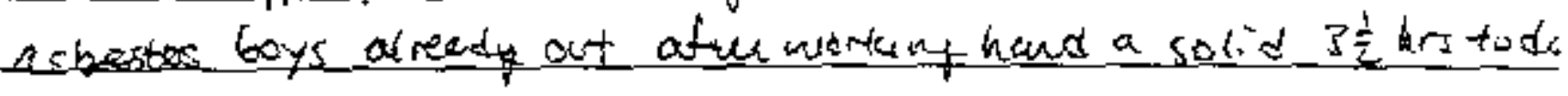

$\mathbf{5}$

$$
\begin{array}{r}
10 \\
25 \\
25 \\
25 \\
\end{array}
$$
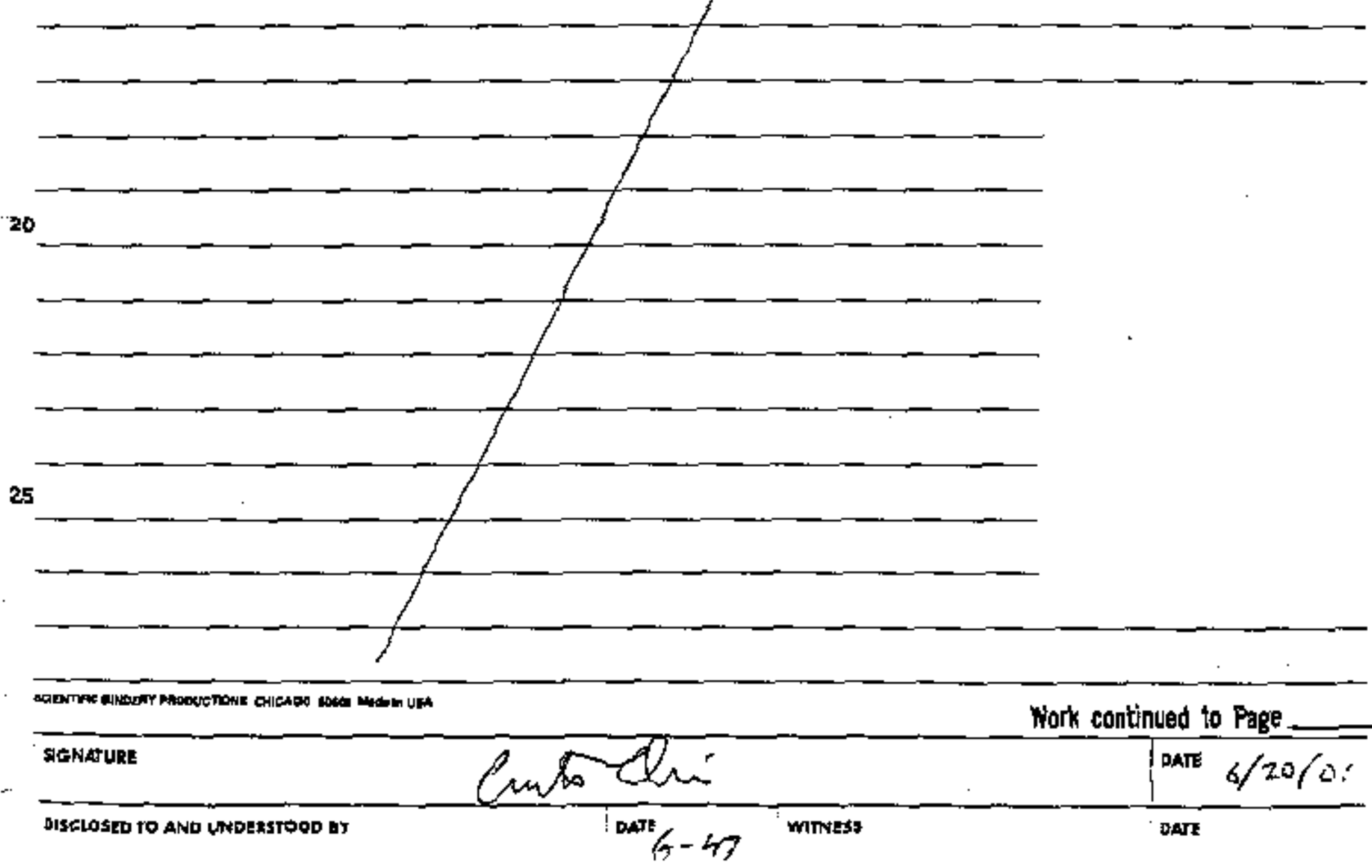


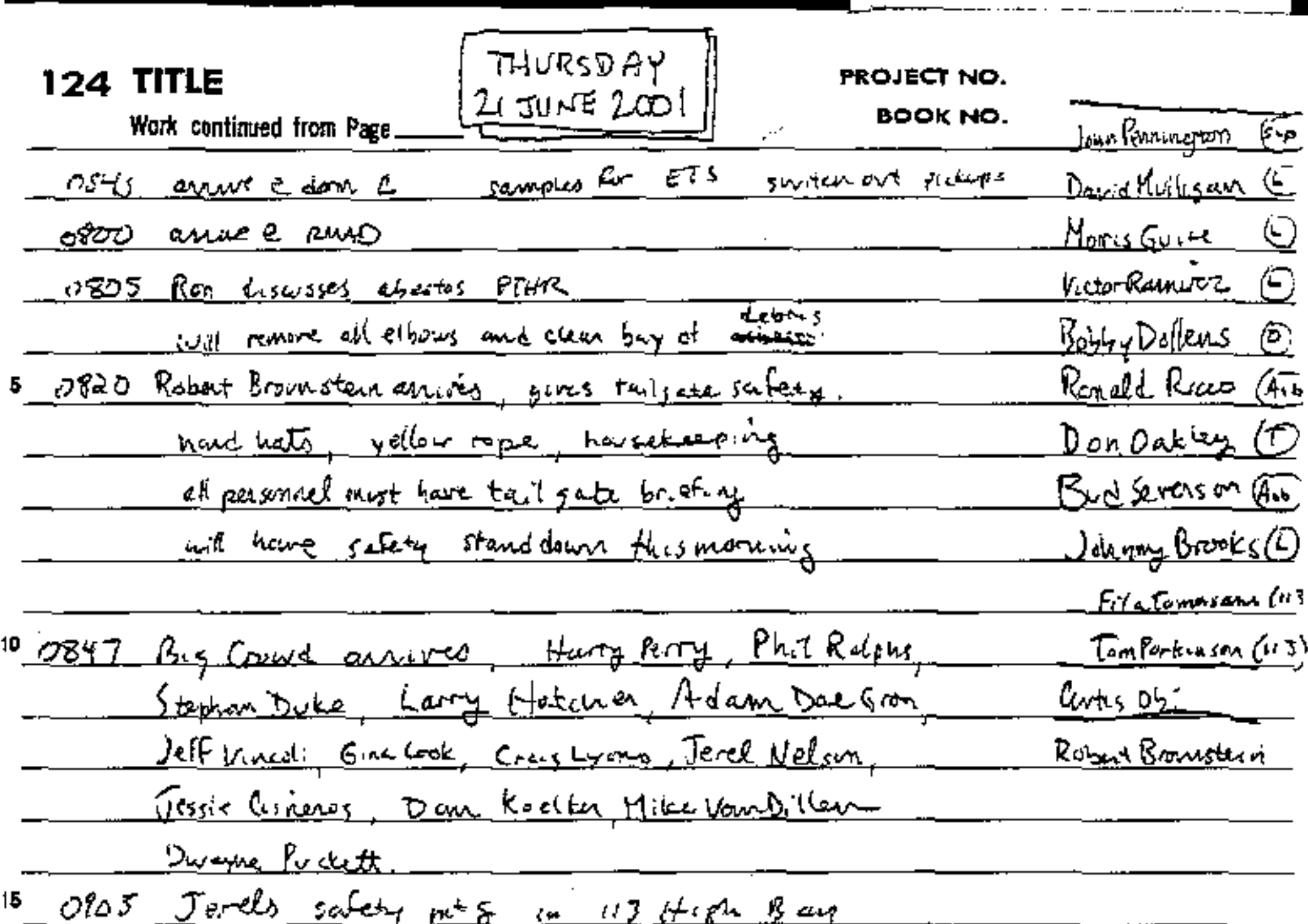

0905 Jerels sabety $n=8$ in 113 itiph Ban

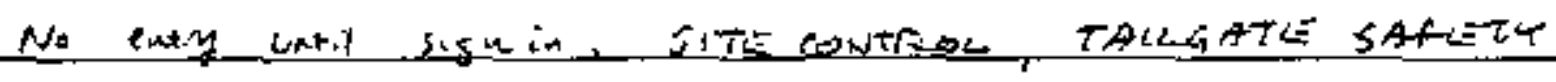

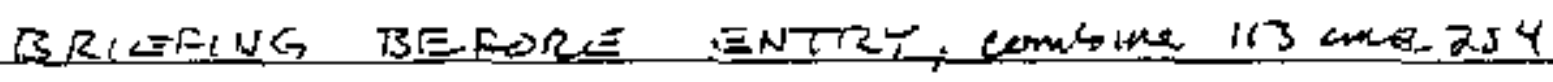

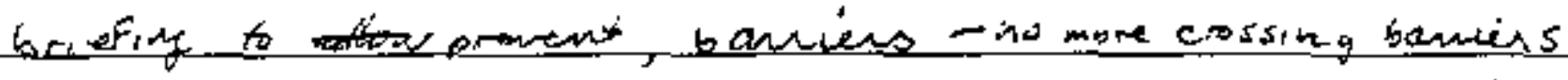

20 1/35 Labarers doubling top rope barrers

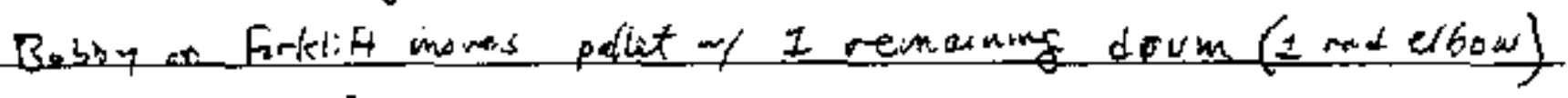
to HUSAA. Dave spots

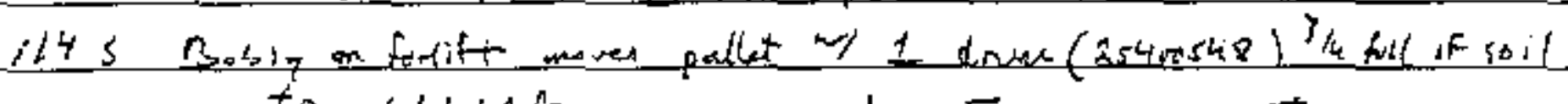
to $C L W A$

Jim Trous as sree.

1317 GC bors weight peckages fortiff.

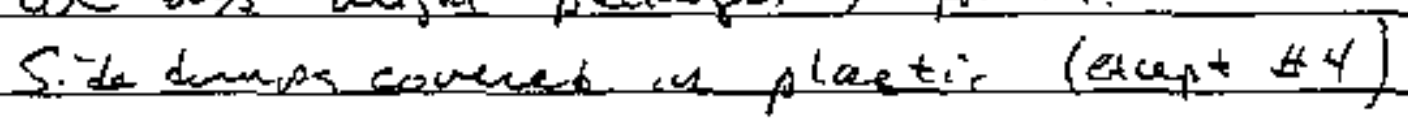

SIISNatukg


TITLE

Eisinool continutes

PROJECT NO.

125

Wotk continued fror Page

BOOK NO.

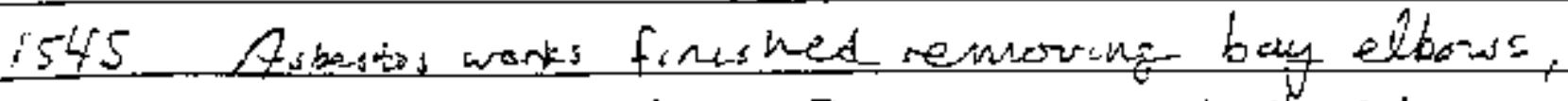

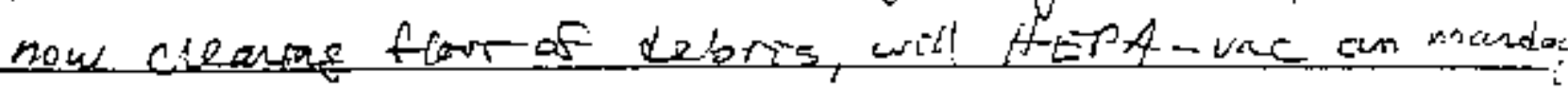

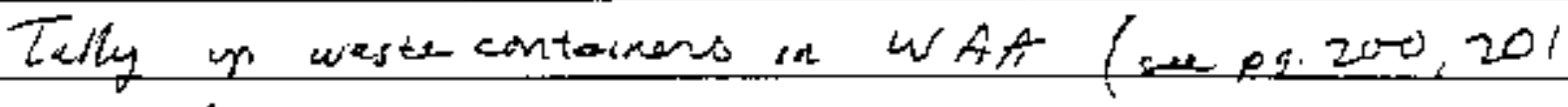
LLWAA I itam

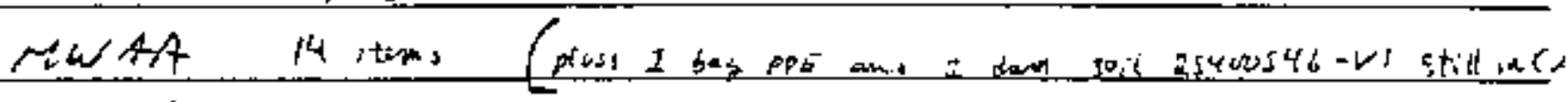
$1-f W+4 \quad 2$ itims

non HWhA, 8 items

4 site dumas covened in plastift placanded.

1608 dandy deraif

20

25

7884

co ver sided-umps

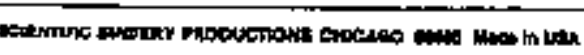
un intign interiva

SIGNATURE

CA rioletion

DISCLOSED TO AND UNDEKSTOOO QY

Sisuces on Sodzdimps

I DASR

$6-49$ 
126 TITLE

Work continued from Fage

It a equre $e$ dom $C$

ii a. annte a ruat

Penongetm Reande

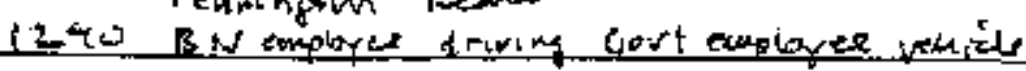
5 inder cutherizer woth. (WSURED

024 Bromstern leads talyote sakiy brieting.

shorbest - foterift, move is Can $25^{4}$ 15. anange $C A$ for Burienrom acess

Soi CA has heen cuared

10

ACM worke - dean oft bay begin boilu room

Let up light potherang in CAM 113

cuan sulety glasses

Sholplast needs dasm dicconnected hofore moring

(300 Rourer pterRs

15

- Evemup asheosos - (WPLTi)

- pop to skotblait - houklesping - (wp 178)

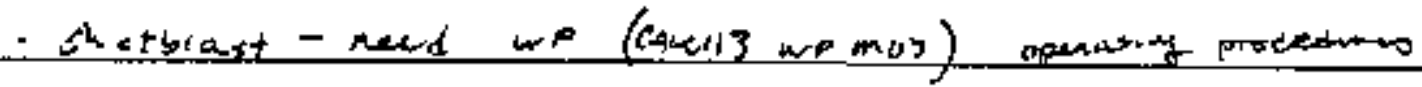

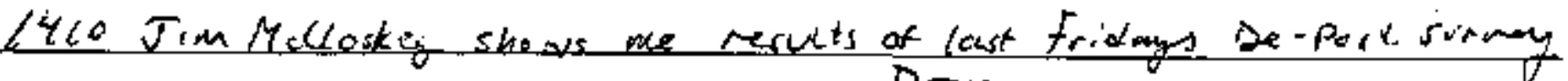
20

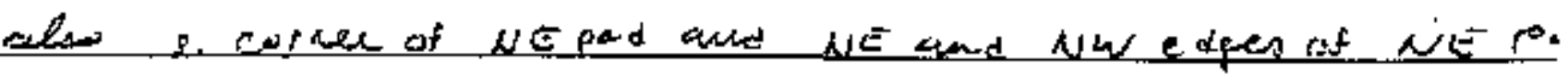

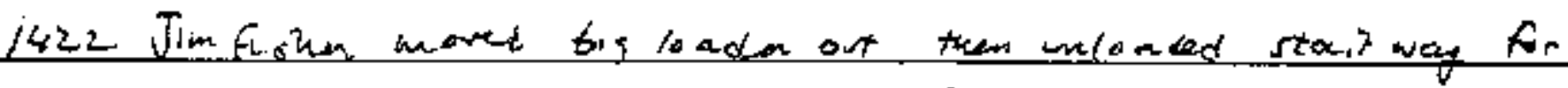

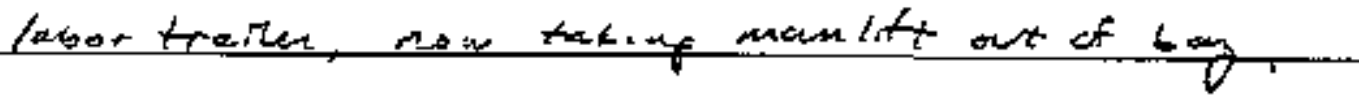

25

Thes $i$. Shotblast of read, twes oftumean

1. Ian prativis on Sw pest

i. lan remore luat pipe, remare lear

4. Com rembers $46 T$

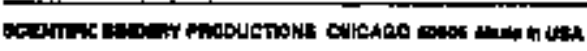

5. Shomion PC Bs Work contenusd to Page

somaruk:

Dat:

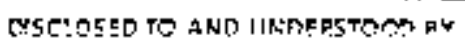

$n$ nete $1-2 \pi$

i. 


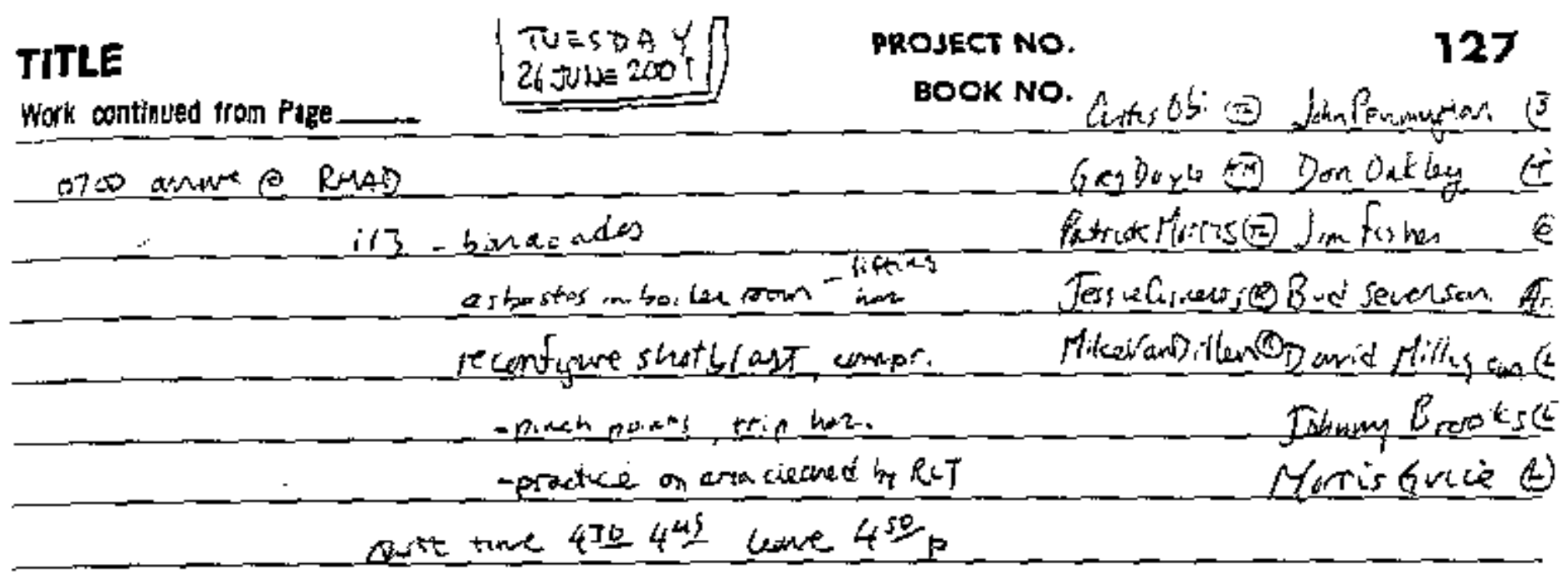

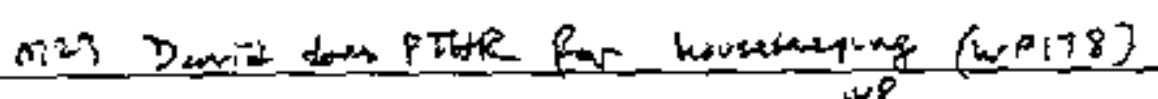

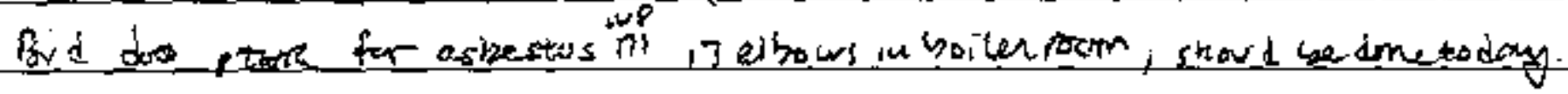

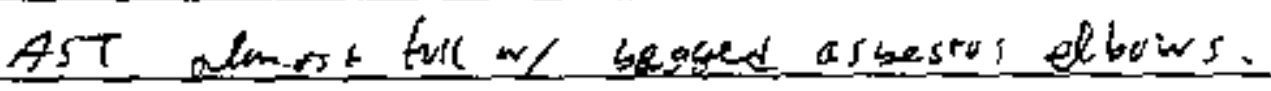

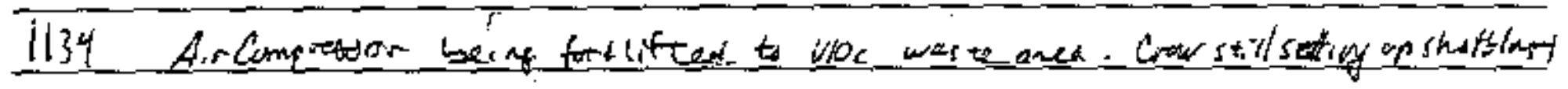

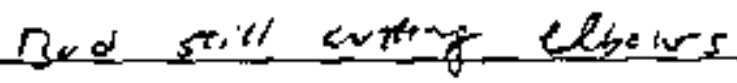

15 Jiesfir tokes manlift into buy to check on ow letts Jim on lempe lo ader remures compresolor conr pad.

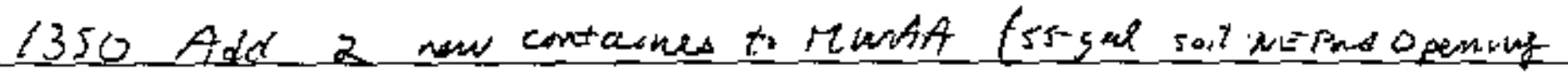
Fen 0800

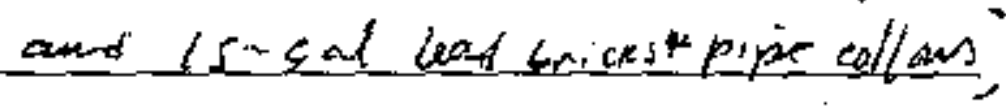

20

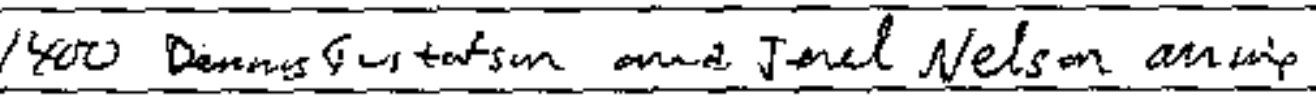

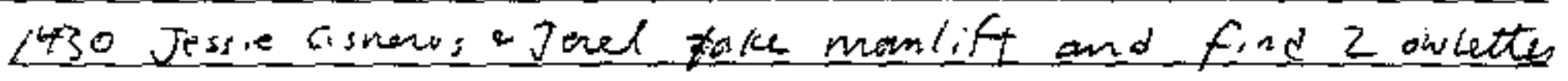
at ray end of ductiry.

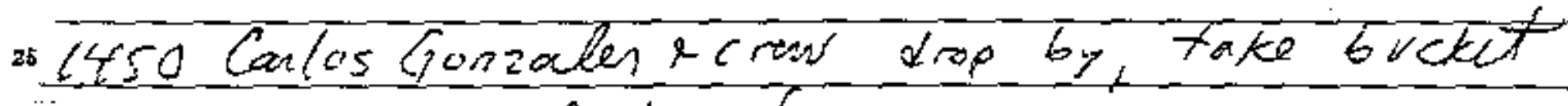
of 2 - $P B$ transtormes

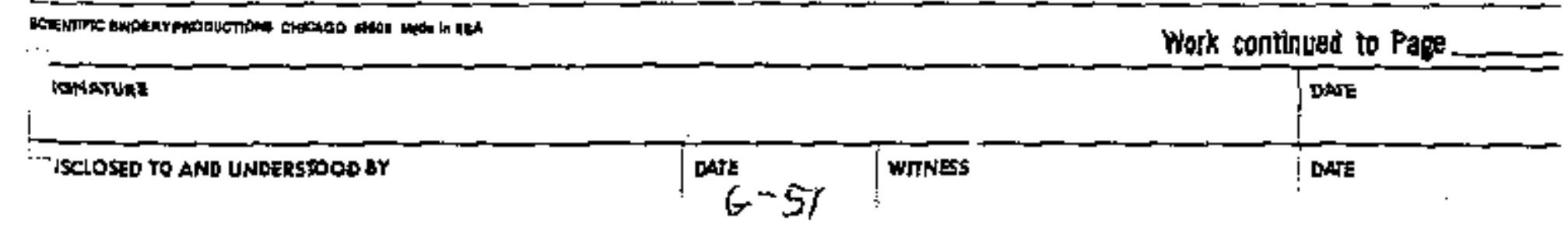


128 TITLE

Wack continued from Page
WEDNESDEY

$27 J$ INE 240
PROJECT NO.

BOOK NO.

O930 amue e cNiso

Rubertbrinstoen

Jimengiser

Qear Rervatuein quzes solety brefing $25 / 13$

Qutosobi

Rogerworifley

$A S T$ - removal, lead collar remorat

Tennesboustafsen

Jessie Minj"

bancins - do not cross, CA/EZ

Stave Noent

Vidar Ramine

$\mathbf{5}$

Led DQPE.

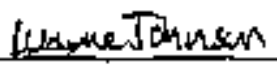

Maristivet

heut stress = flids

Jend Nelison

Bud Seve sont

GesDorke

Dawid fulligon

Bobsketr

ficos Comstnation selesty mty

Slite veritilen.

10

13- gateo, fencias, ros

Jinilc(losken

Shew fuarag inside 11 ?

Patrackinoms

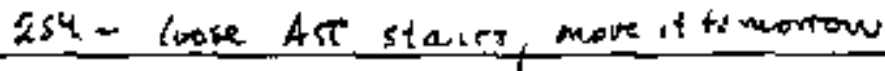

Stepenturese

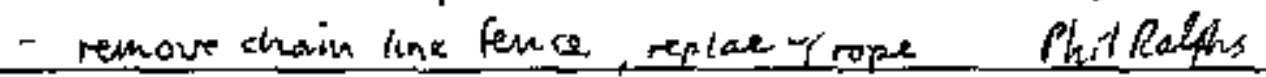

- Sustart cead collans

15

1130 Do wakly inspeetion of $90-d a y$ HWAA and $M W A A^{I(6)}\left(L W^{(1)}\right)$

1330 flury of actwity.

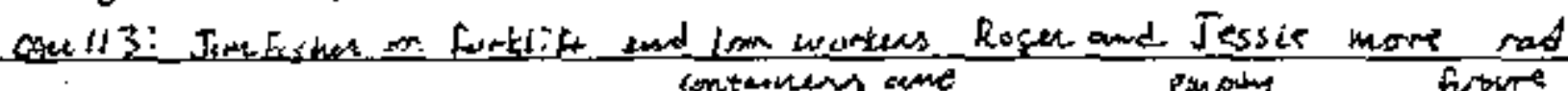
as

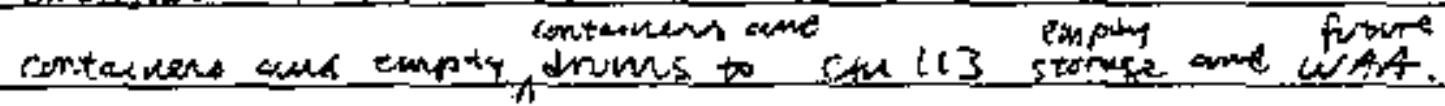

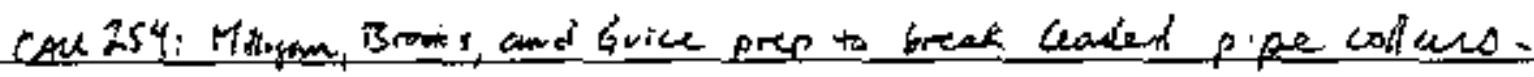

Bud and Vutar prep to on boits on staurway, comdunt in

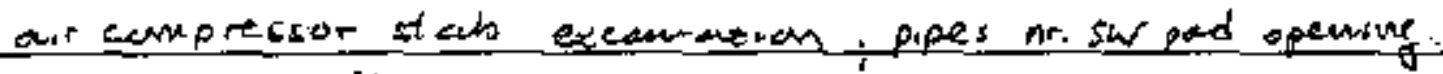

1430 Saphan Duke aud Phit Ralphs anive, hope somple loft flow

20 loft insulation, arrcompretsor walcant and who paske Torziceon LSD imen forkliff moves AST and wod box to loat

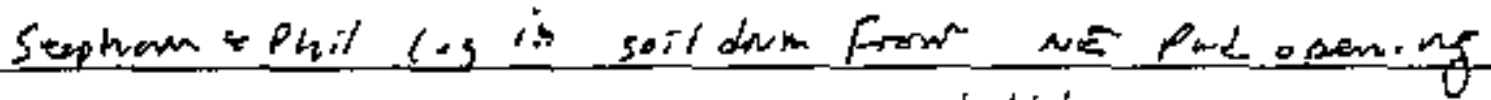

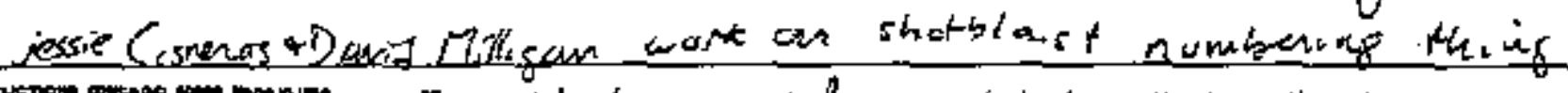

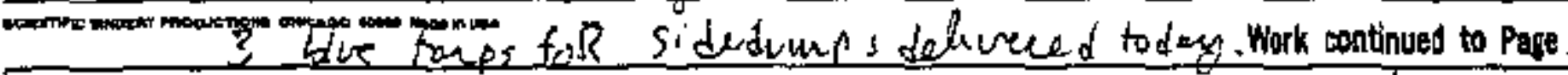

STENATUKE

nare

DISCLOSED TO AND UNDERSTOOD BY

i parg $y=92$

wrisiss

Dart 
TITLE

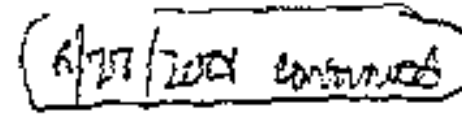

PROJECT NO.

129

fork continued from Page

BOOK NO.

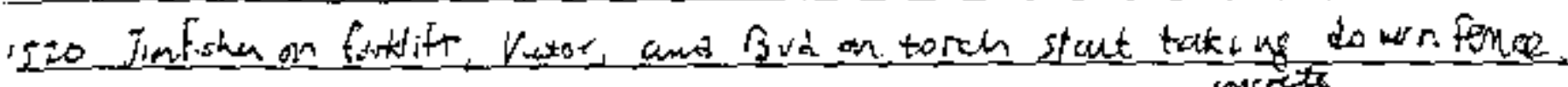

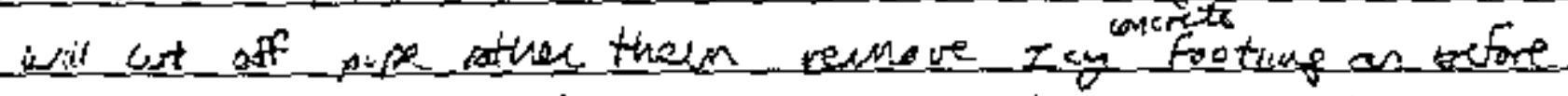

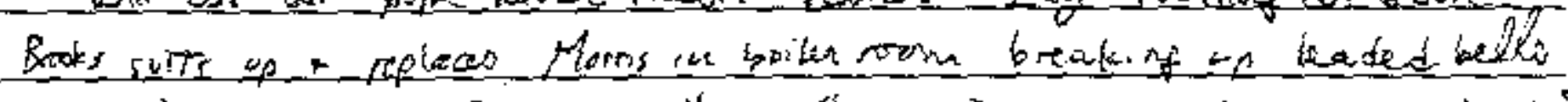

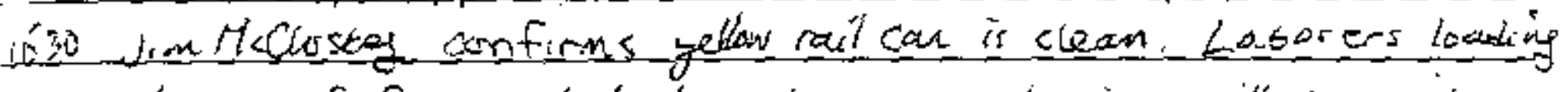
bu chat of fornt-ence loader w/ Box -rad pipe, will dump wits reseal.

Jessie Cosneros de David M Lifisan having a very hand - time ut procedures labeled values connections.

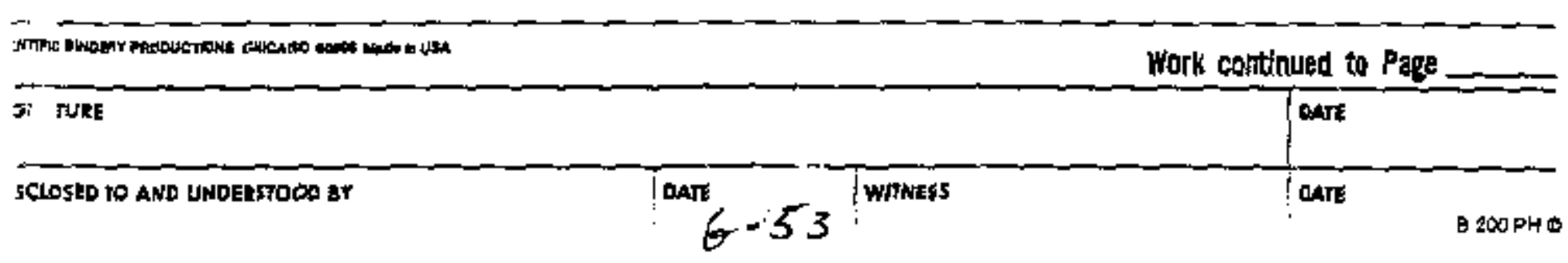


130 TITLE

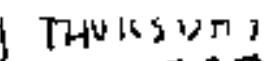

PROJECT NO.

Work continued fron Page

28 JUNE 2001

BOOK NO.

06.0 anuse e simc

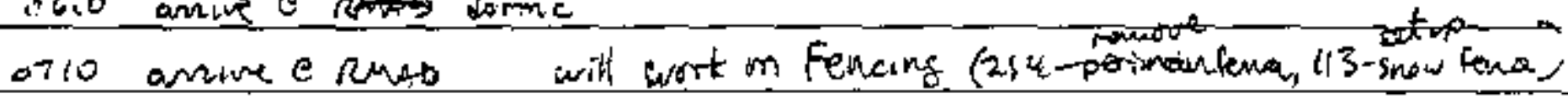

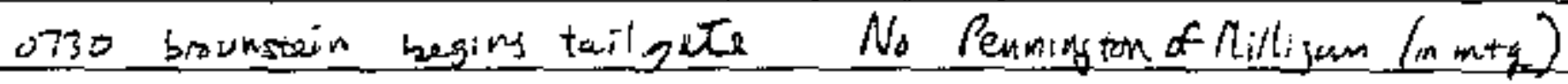

- rimore rma fena, replace w/ rope cuts, buras (wear gloves)

$\mathbf{5}$ vept all aceidents sinjurces, ne maten how slyot

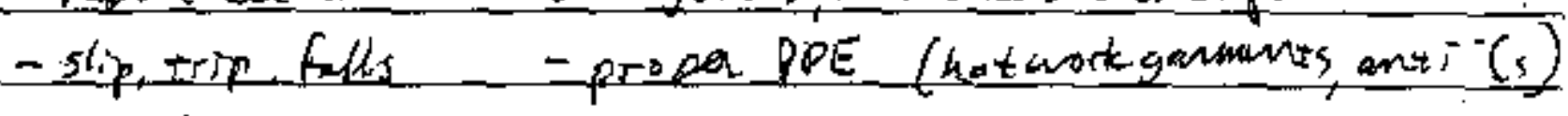

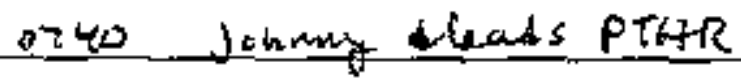

general ho setaping and disposal of debrics (254)

$a_{i+1, j} b h_{i}^{\prime}$

Patrick Murrs

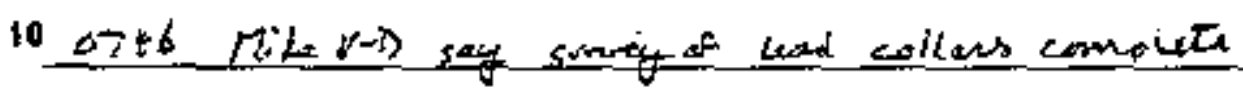

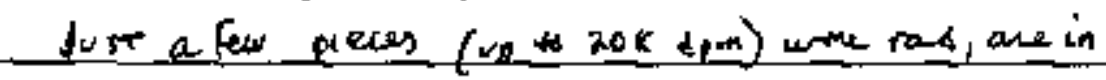
marked plstuc bag.
Robest Brounstein

Domkoelten

Lessecigions

Hike Vom Dillen

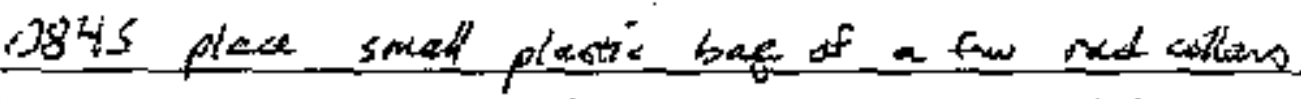

15

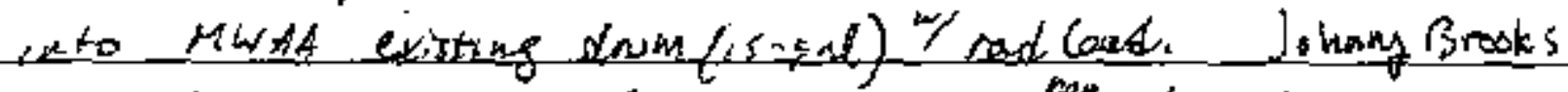

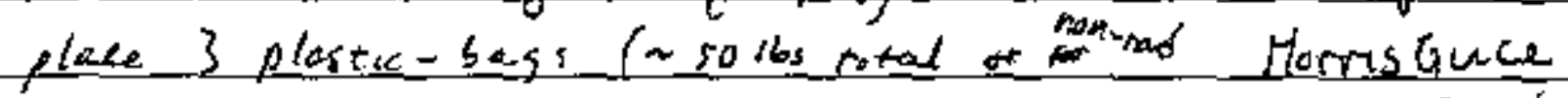

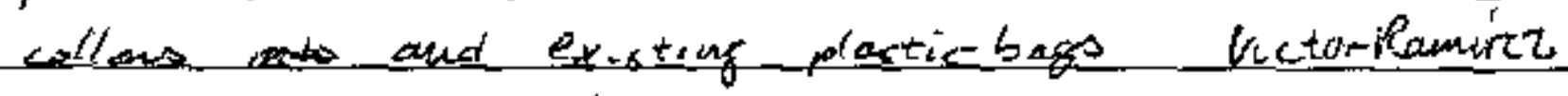

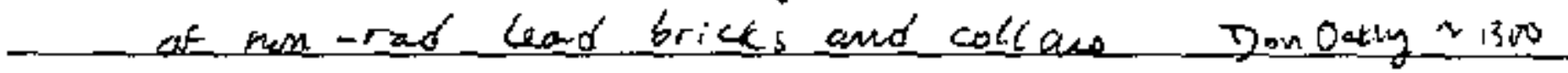

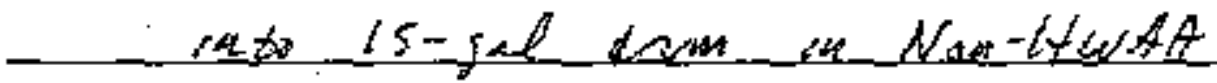

20

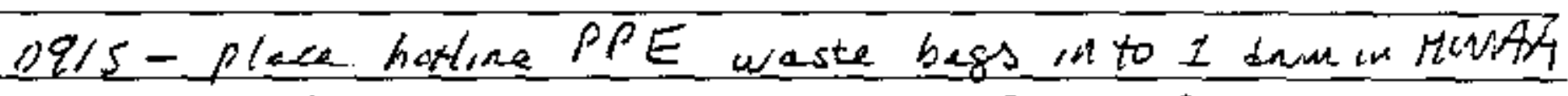
ursed a recucled thp grout drom for the forse time .

Bedtem reads: UN/1A2/Y1 2/200/94

$M N / \pm A^{2} / \times 346 / S / 94$

25

QSA $4 B C \perp 1 \mathrm{MM}$

New Drumbatous: UN $1 \mathrm{~A} 2 / Y 1.8 / 150 / 00$ UN 1 A2/ $\times 400 / 5100$

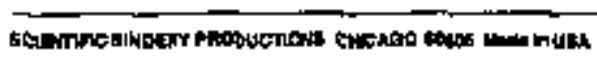

sionutitiat
1.2

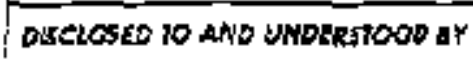

Work continued to Pejpe

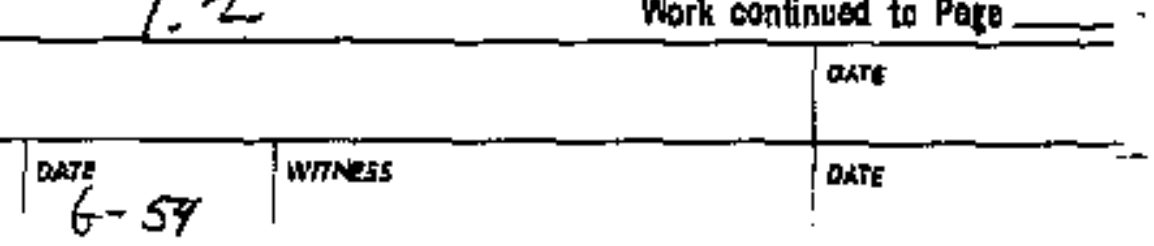


\% TLE

Work continued from Page

ito Brounstein yjur safes

Patrick was assistingt

Serel says there in

- T. Jen s-ayn last weed

tuic encraing. $\sqrt{6}$

131

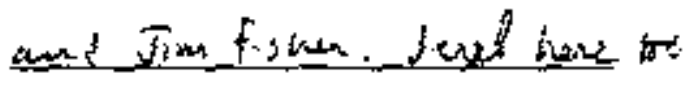

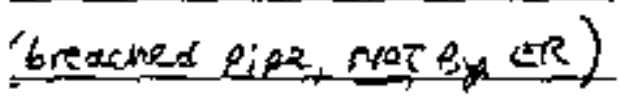

pha become a IAA4 volation

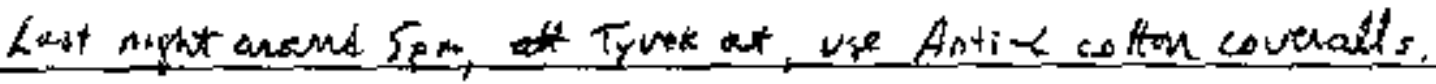

No decision gat reiuding what to wean for hotwork.

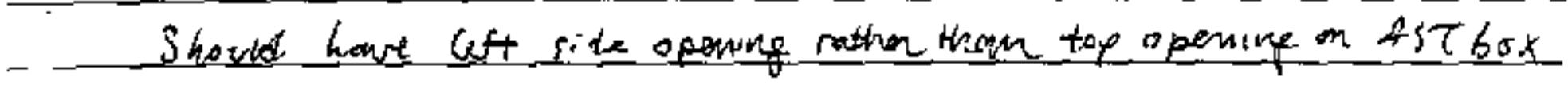

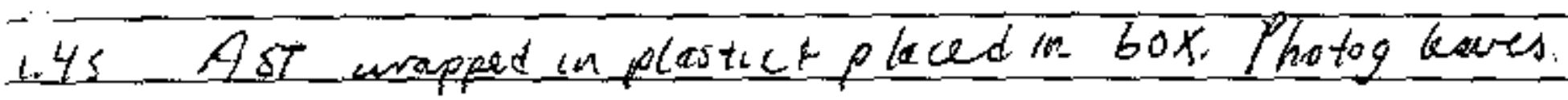

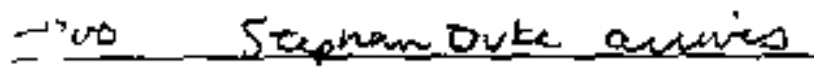

LSO Terny Semen bens anves

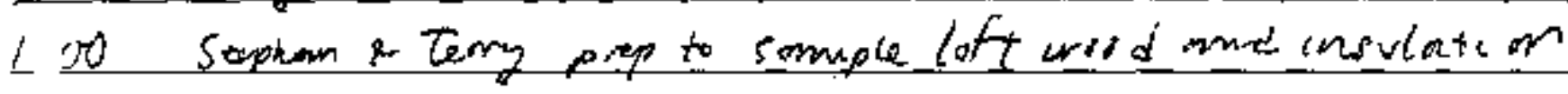

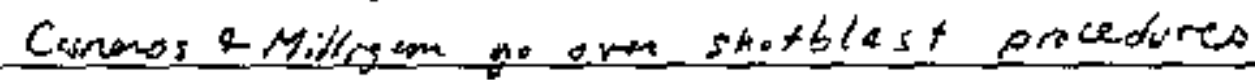

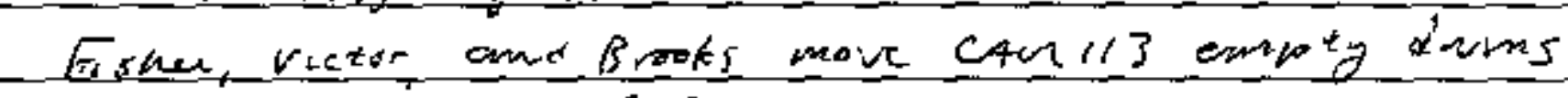

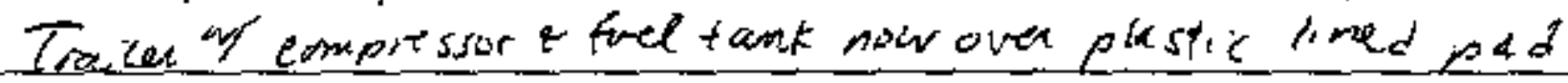
imanedady 5 of $5 w$ pad.

100 Complete samplyy: white pase (samped away, no natesial bet)

coolant

Lift masuateon

continue samplini: (aff sood

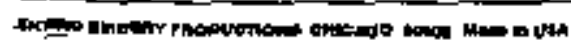

Work continued to Page

IG. mituke

Is

inetr

$6-55$

! MATNess

ante 


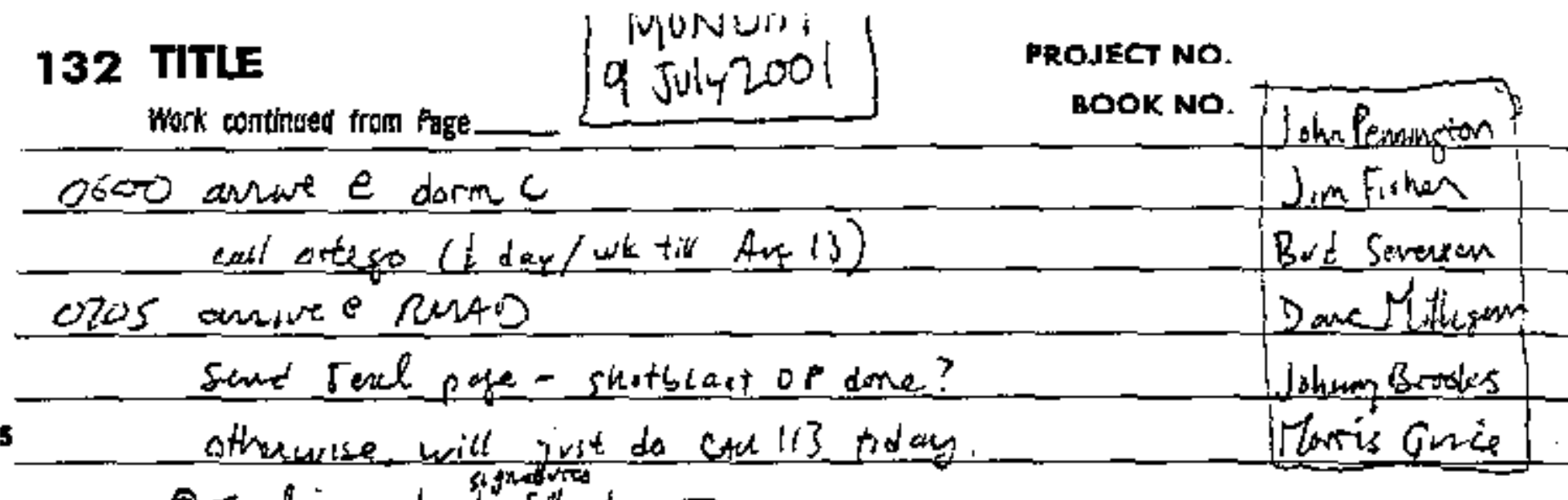

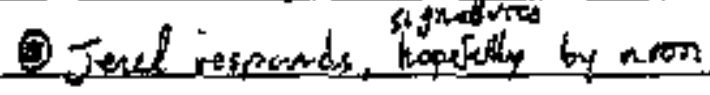

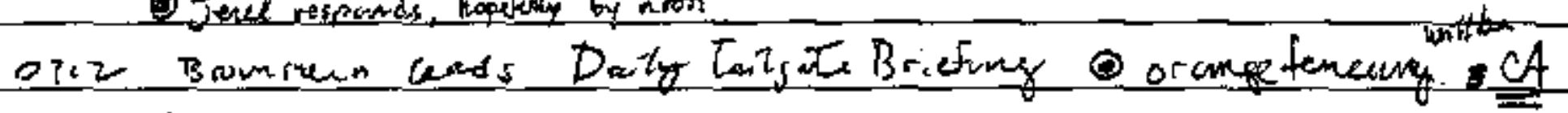

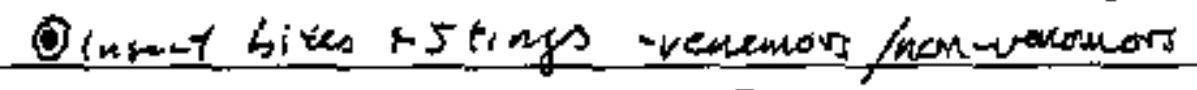

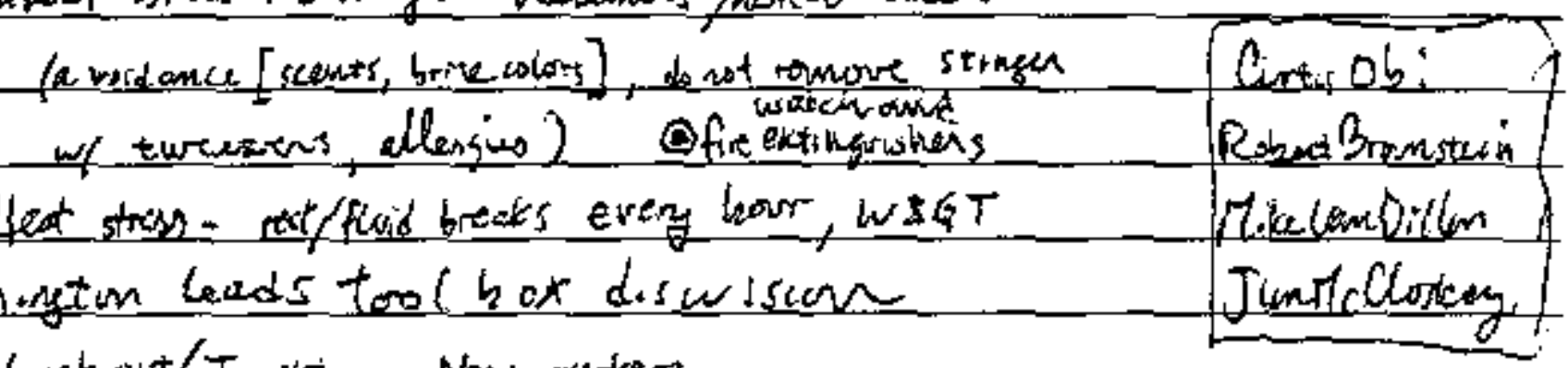

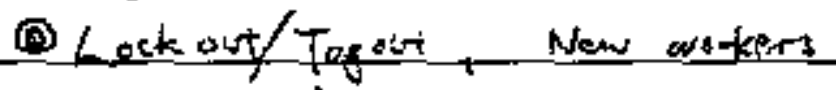

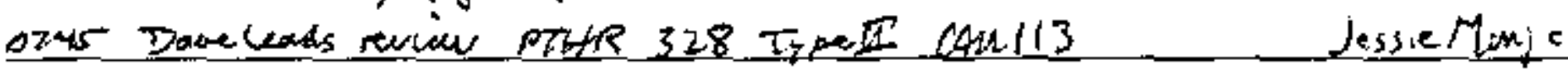

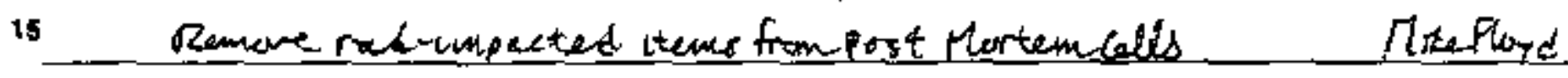

DenOakleng

Shathlest Egurase I caburat openator

Dennesfinney

ogoo Perfarm weatly inspecture of $90-$ Day Pad

20

$$
\begin{aligned}
& \text { LLLU - } 1 \text { torth }
\end{aligned}
$$

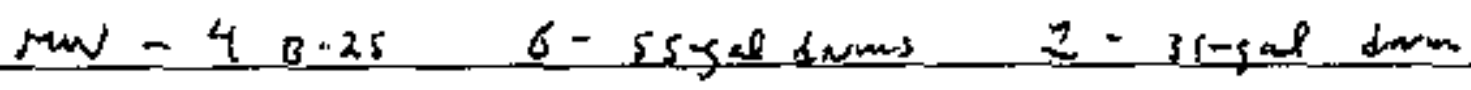

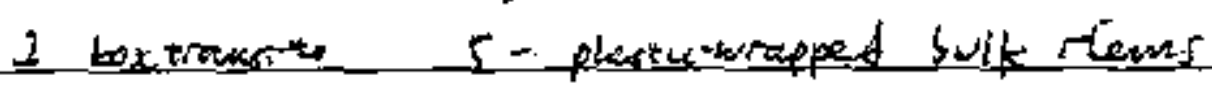

HW- 2 3s-sul baus

25

All 4 side dimps have visfrem

plastic sovering. 3 sidedermes

alon houre bive tands securet.

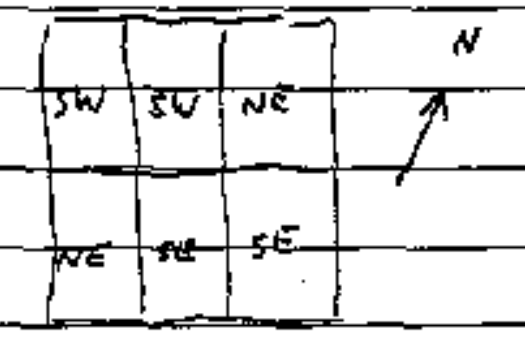

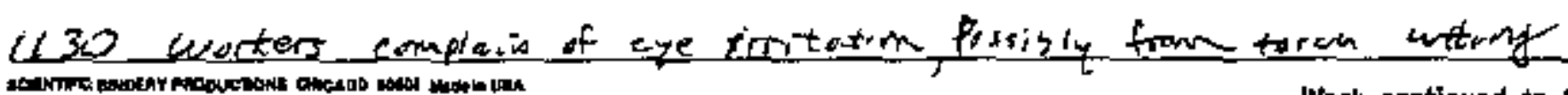

Work costinued to Page

FIGNATURE

DISCLOSED TO AND UNDELSTOOD BY

$6-56$

WIINES5

DATE 
I LE

Jork continaed from Fage

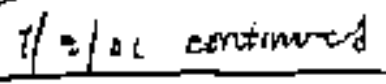

PROJECT NO.

BOOK NO.

133

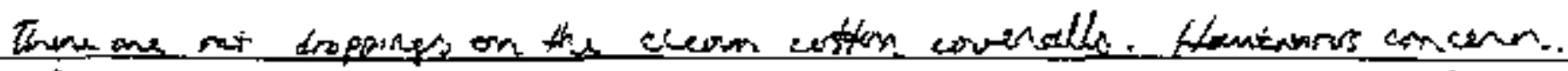

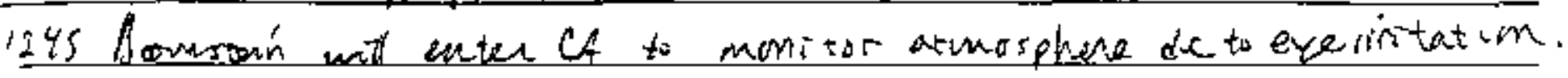

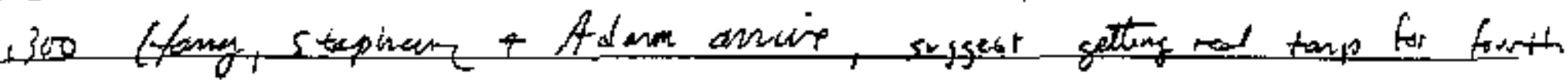
sale dmup. At least needt remove panded watin.

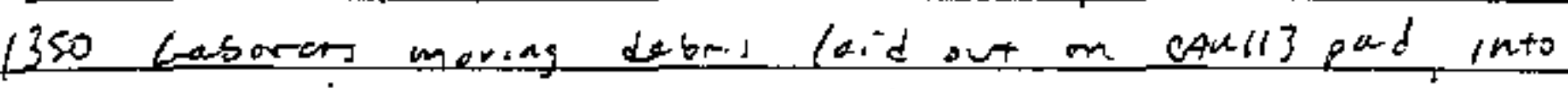

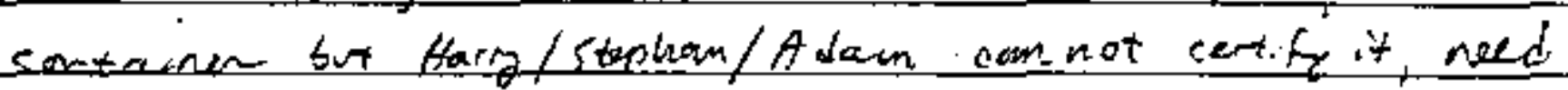

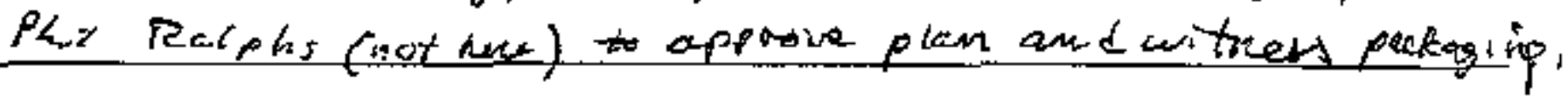

Thuran starn aporoacheo from NW

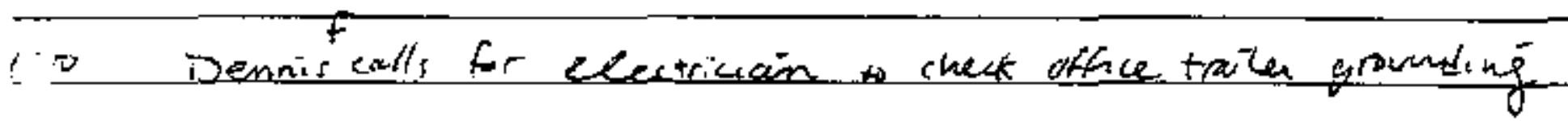

is Denmis takes off.

4s depani RuAP

is aninis dorme

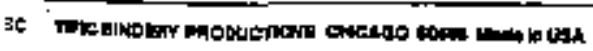

Worh continued to Pare

STRAluRE

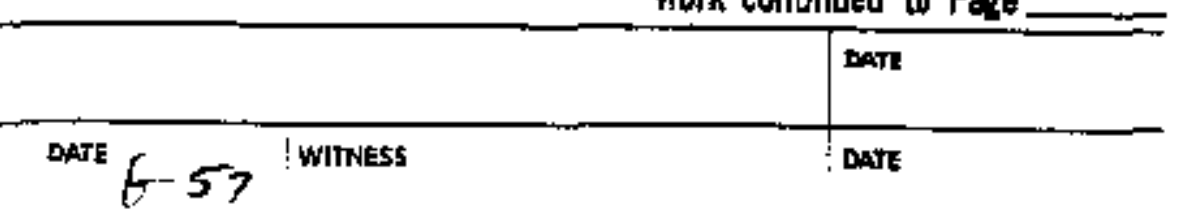


134 TITLE

Work contigued from Page 10 JuLY 2006

PROJECT NO.

BOOK NO.

asss anve e dorm $c$

CAL13 $07 M 08 E 12$

Bipg Rementel

Qtoo arrive e puAt?

Jimfusher

God Seruson

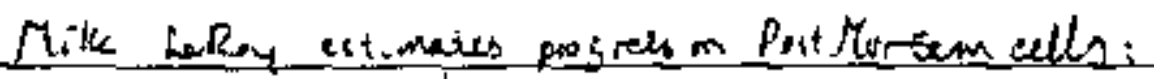

Merisgulce

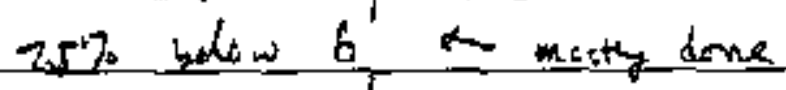

Roser wollity

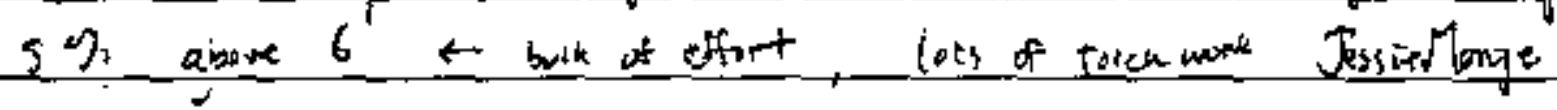

Boinastern

Diluss yestendego naviea + eye uritat on problems

Robestiranitein

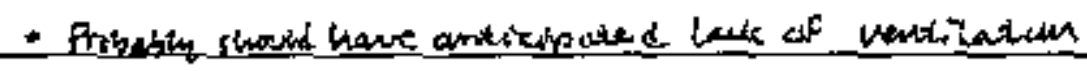

Cuntas 0 :

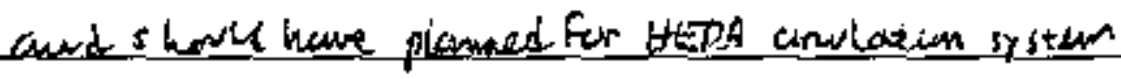

Miketerig

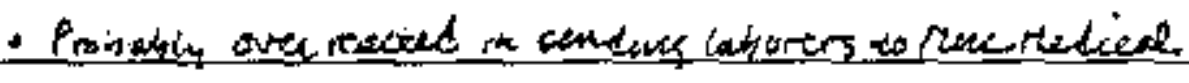

jessiécosmion.

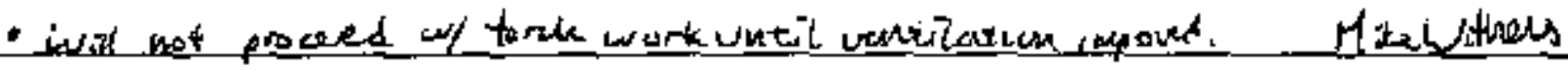

PTHR Ee 113 remaval of rab ctem,

Dure Miliyam

Itheng Growks

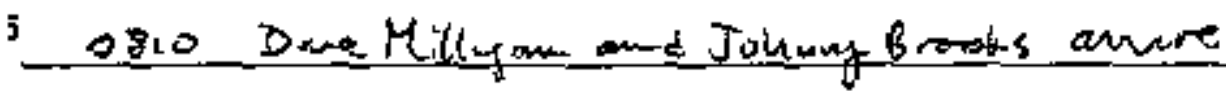

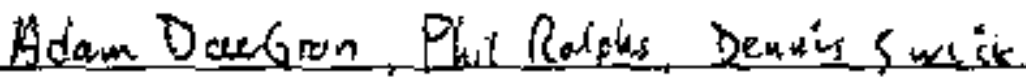

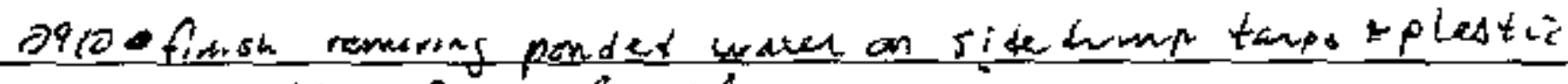

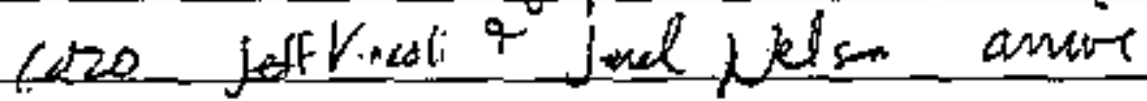

1030 - Laboras place piasii ova hok of transere ( $\mathrm{mal}$ )

1230 Depent site for uste trining

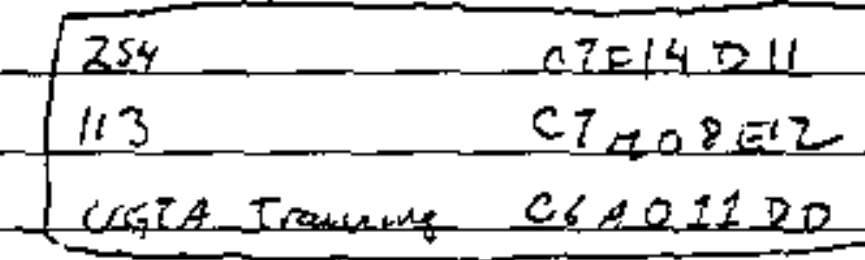

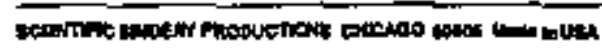

Work continued to Parse

SISMANURE

DATE

DECLOSED TO ANO UNDERSTODO AY

Date -.56

MIrrikss

bure 


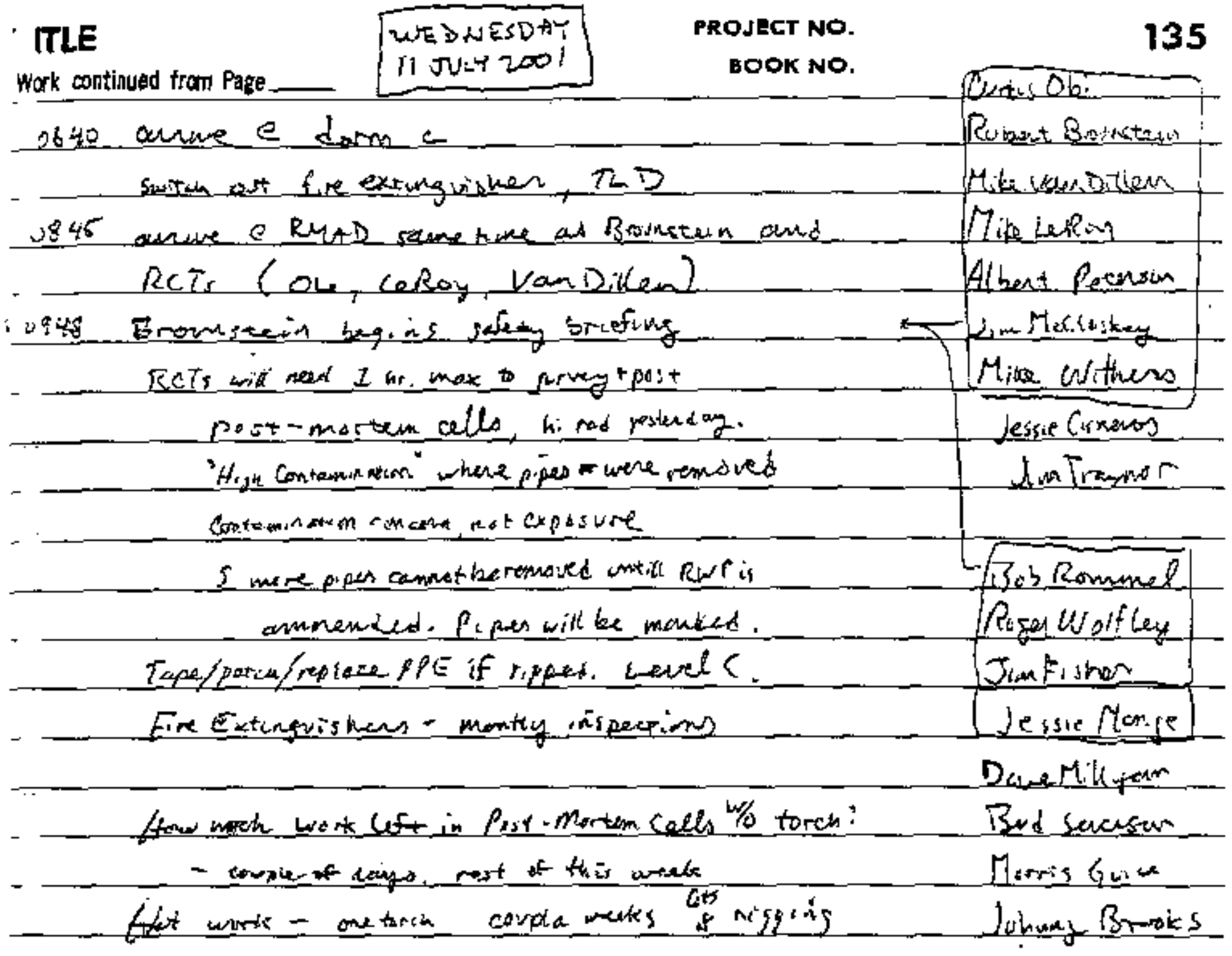

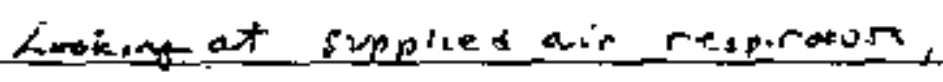

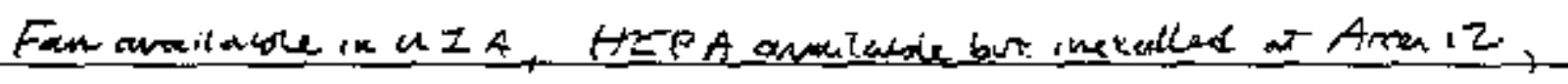

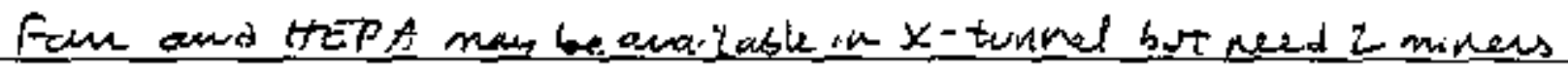

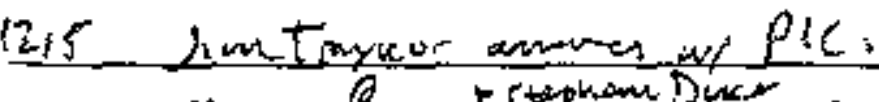

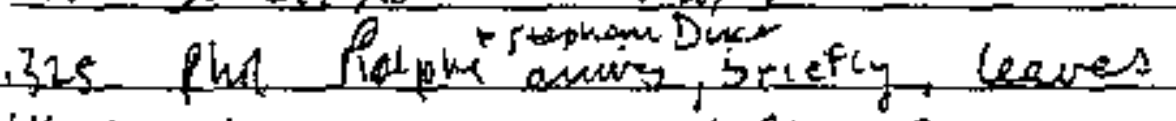

1435 Jessir Cisnus tried PICS for an hour, Browstein checker ean

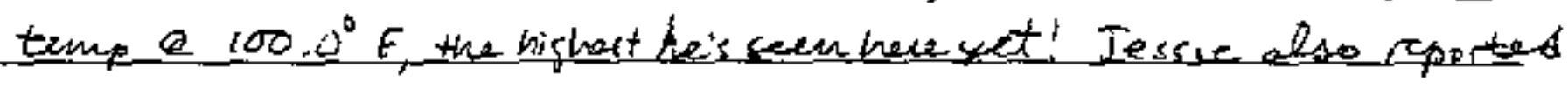

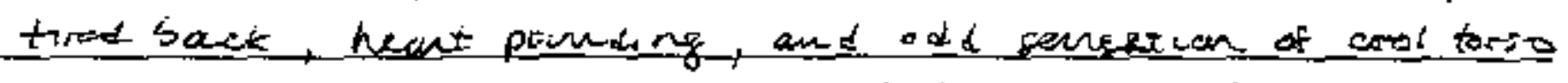

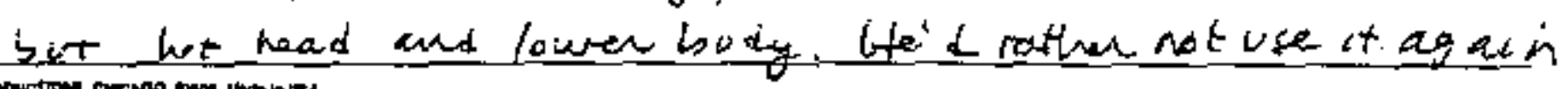

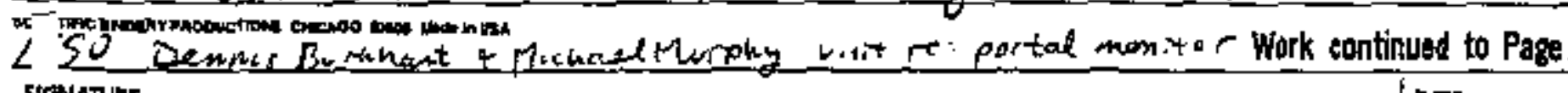
STONATUKE

1 STOSto TO AND UNDeRSTOOD BY

Ears 54

i wrimess

(aAf

DARE 
136 TITLE

Work continuer from Pag
THURSOAY

12- 3is? 2001
PROJEET NO.

BOOK NO.

osts anume derm $C$

Wras Obi

Rogen Wotithe

b7io anue e RMate

o7no Dennis finney disuses lust negits

Rubert Branstain

Jeisic Momje

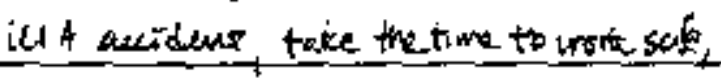

Tike lekpy

Brd Senosin

kssis Giruenos

Dewdith jem

s

p:ach-ponts, inomps, yloves, we help.

Alent Pienen

Johing Broves

0722 Bronsen

Craigtyess

Mams Gues

NS DoE yist tadul _ _ _____ Eurt Galloway

Tieristuren.

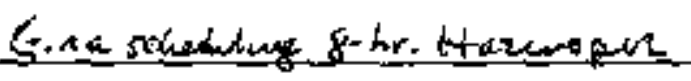

Deninistinrey.

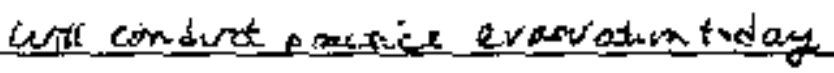

0 workers in cA will just exit if real ompengy.

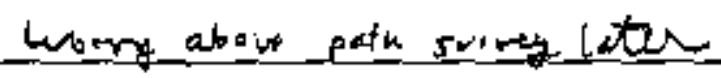

PICS - will ds ad triday stan lunch

wet fun fr piysicel itress

watin sperd on red

5 _._. Same work ab yesterdact, no hot work

ISSUES

srill lowing at vantilation

orso $R_{7}$ deres ptitn - 113 rad ceens

Need ventiletion for kor war.

Sto get wow that shriblove ol has been ispined.

Sy Mondry. Rommal

20

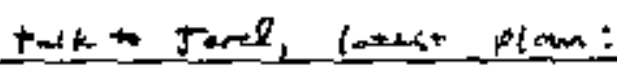

Jene LeRey, etic

$-6(34)$

Hon drain als from_craved on

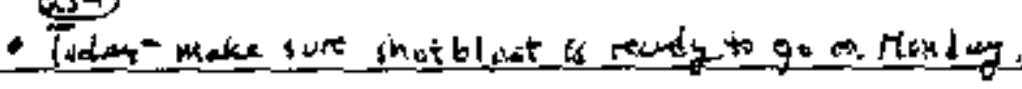

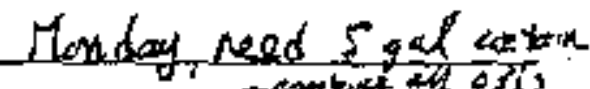

100 and and $0 \pi$

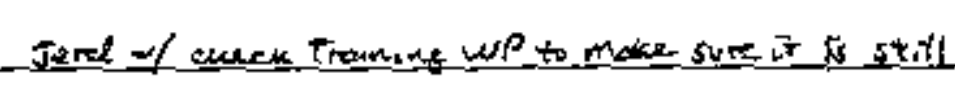

Josic Criveres is niming 254

(iit)

25

- NbA-bot-inori- rempral of rad temes will

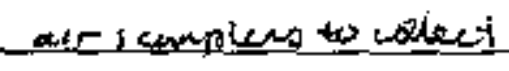

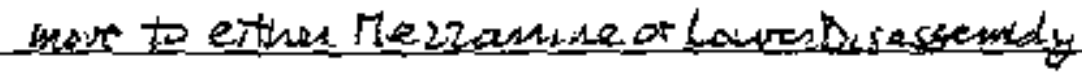

Bay-

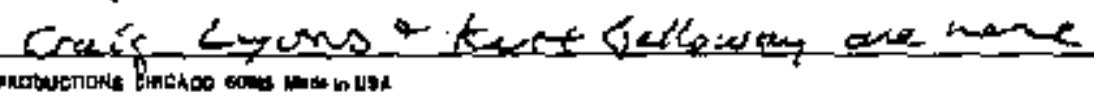

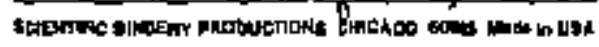
backspound dopa

51GNATURE

Work continued to Page

MISC:OSED TO SNO UNDERSTODOHY

DAIE $L / A$ WIINESS

कAare

DAFE 
TITLE

7/. W 2 201 Continved ProJect No.

BOOK No.

137

Work continued irom Page

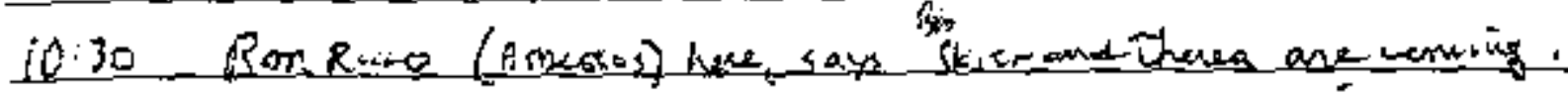

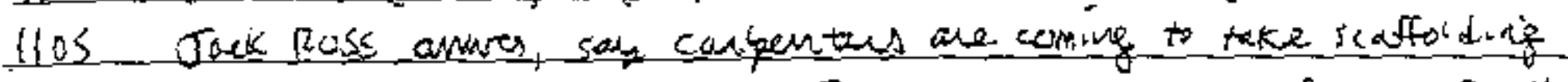

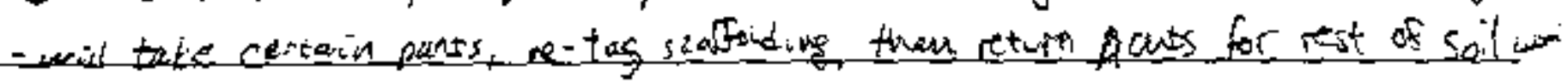

Cog Dexle and Demint Gustatson anine

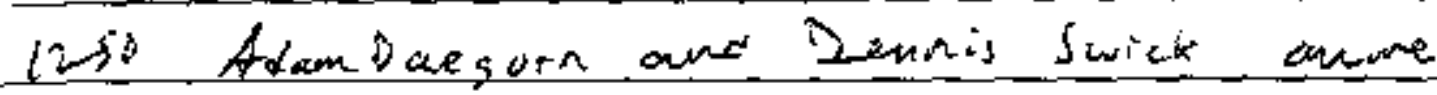

Stapen 2 Plit on these wey sherty

Wo tak Dare Mer Med

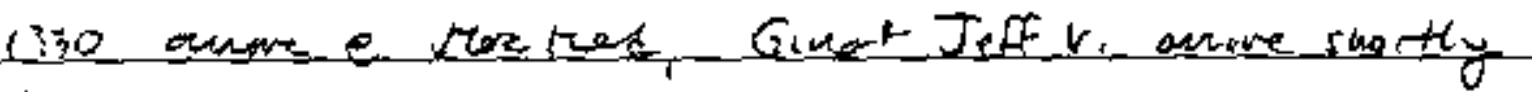

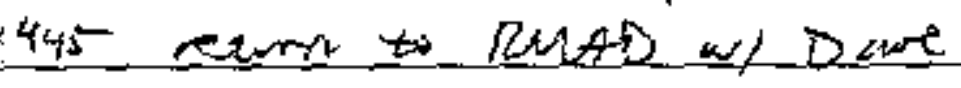

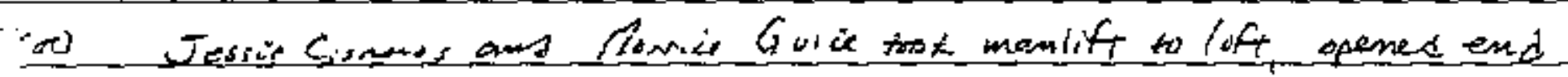

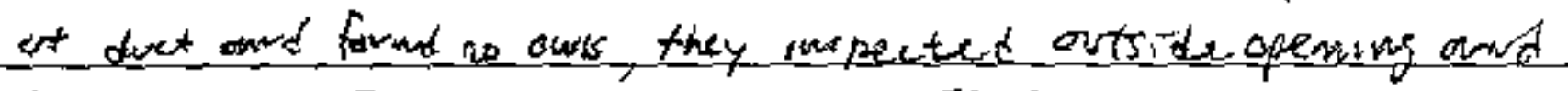

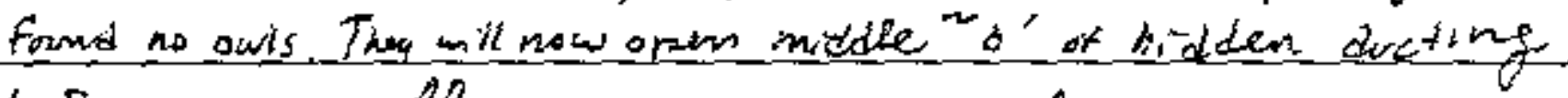

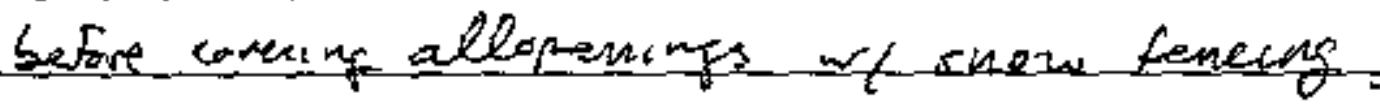

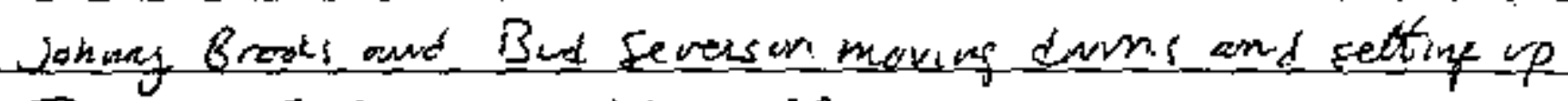
Topets of futur o thetblasy CA

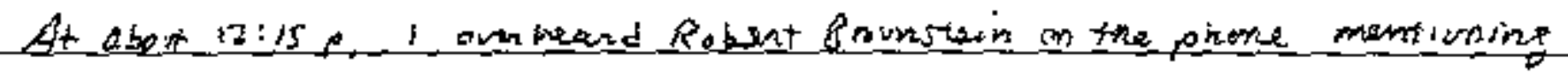
Dave Milligum had reported I light "Wooziness". I lawen bemo this hopped at aboot 9:30 afen being in the CA for abor am bom.

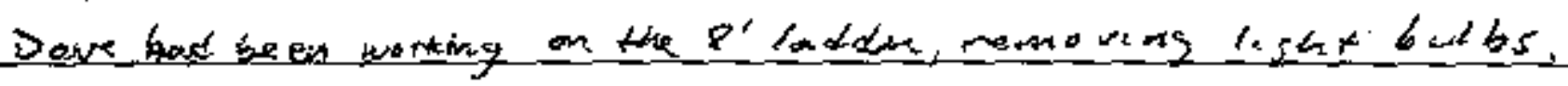

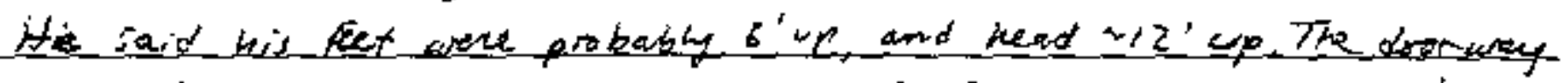

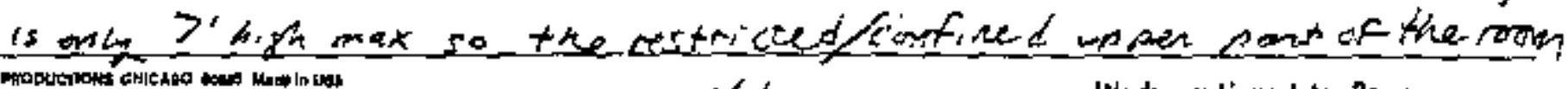
S. Narvise C SLOSFD TO AND UNDERTTOOD BY

DAIE

WrNESS

$6=6 /$

DAF: 
138 TITLE

Wak continued fron Paxe.
PROJECT NO.

BOOK NO.

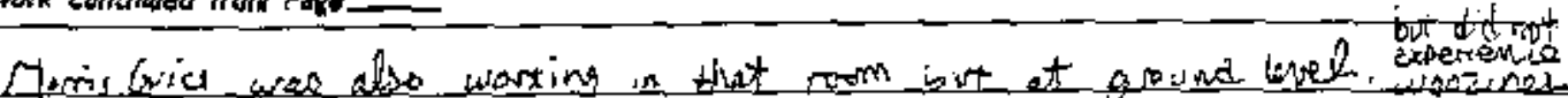
Dave wentimed he was reachiag up a fot to move loght bulb: et and neded to rest hus arms sevenal times. All the areskens. (Dave, Hows, Buid, Johmy) agree it was hot and staffy in the

5 post-mortem cells. The doctor at the rens. Mes. gan he feit it was milt heat stress, noted Dave have forly re-hodred sinie then and relesed Dave Guin Toff as read no more work, rest the remaining day w a wol area Dare said hod profer to do this at RMAD = Dave said he falt fine often a sharif break but complesed w/ES\&H ordeno 
TITLE

Work continute from Page
PROHECT NO.

BOOK NO.
139

Lortig ob:

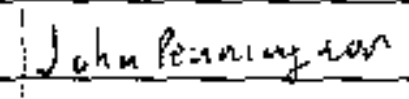

Lat tis ter

IPoren wolifory

Jin Mclogiszy

Dempolken

Tesserkorst

Crait Lyons

David Molligam

lGixa cok

Monts biuge

Mikewithers

Tounny $\beta_{\text {rows }}$

Mike Leley

Donald Lerren

Mikevantillen

Victor Ranarez

Jitunasi

Kestectents

Eexen is = oromge snow femeris.

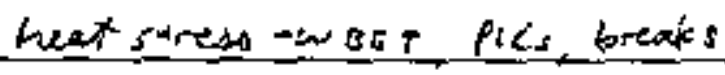

jody sutem waten exen othen

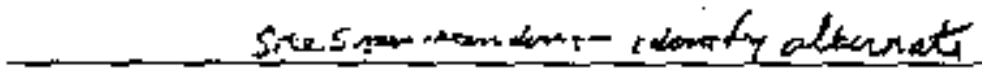

15.

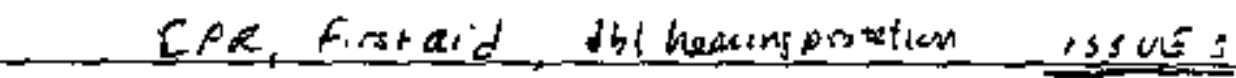

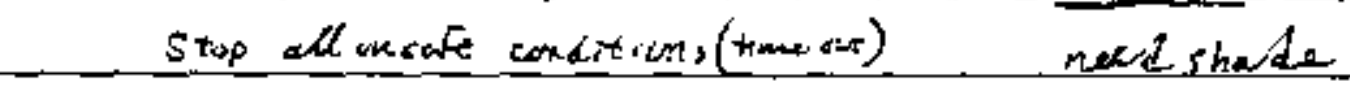

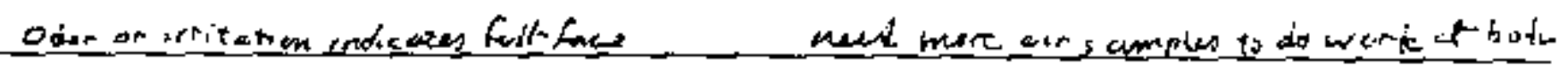
rapes are net suoting.

IIf a are $l i$.

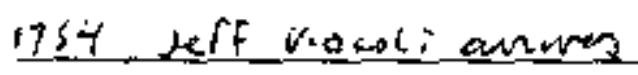
need HETA VOG

!

Jinkfenangter.

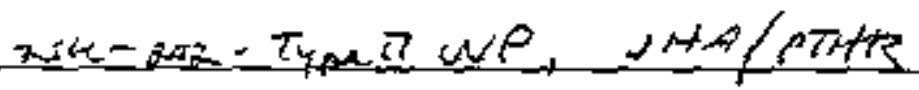

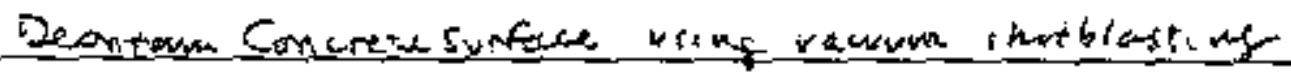

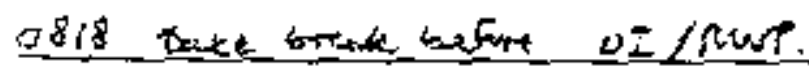

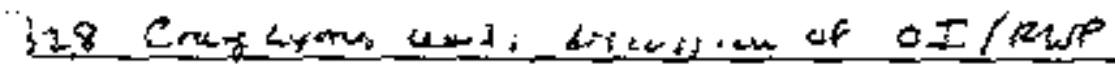

5

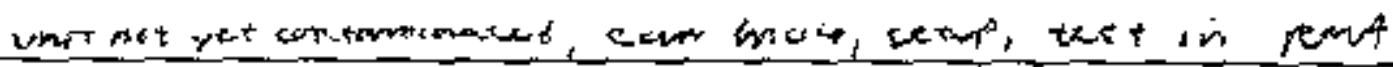

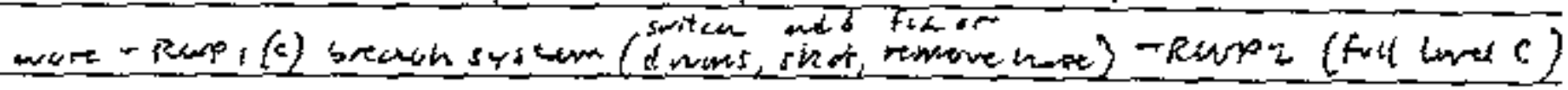

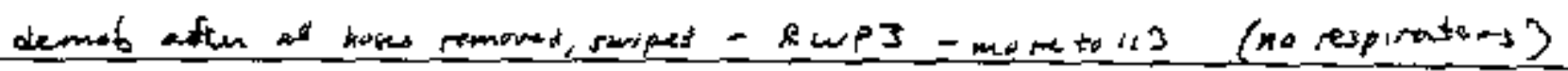

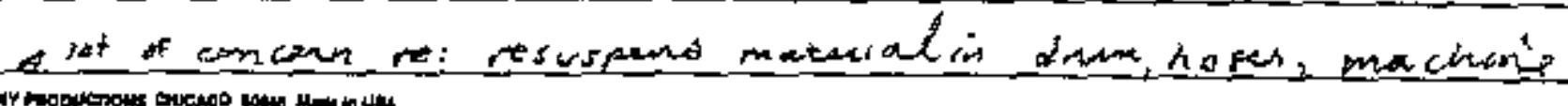

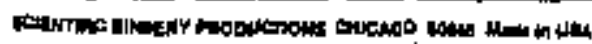

Work continusd to Page

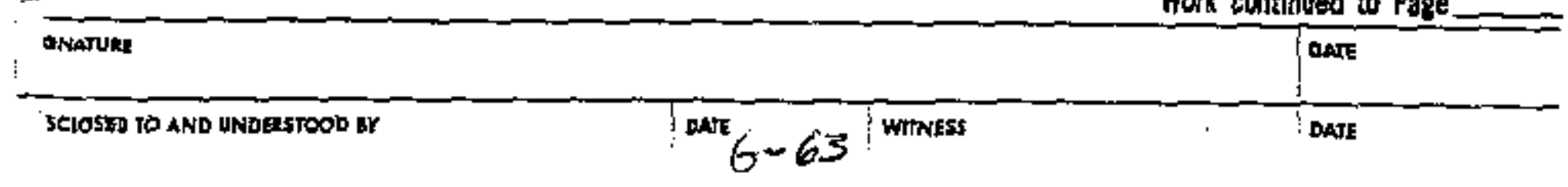


140 TITLE

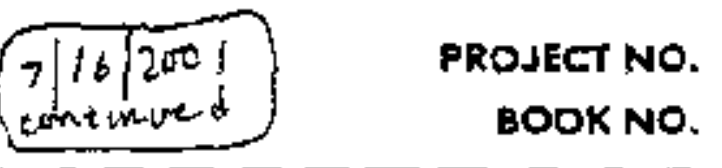

Work conkinued from Page

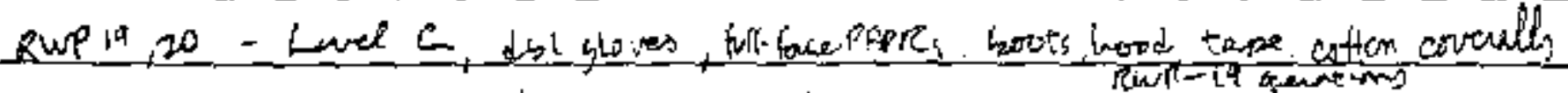

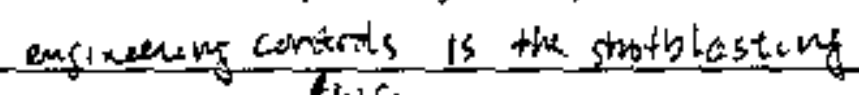

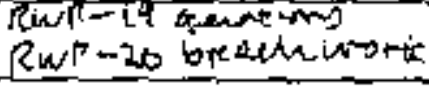
check air sumpiens wery fint, every hove if esssibie.

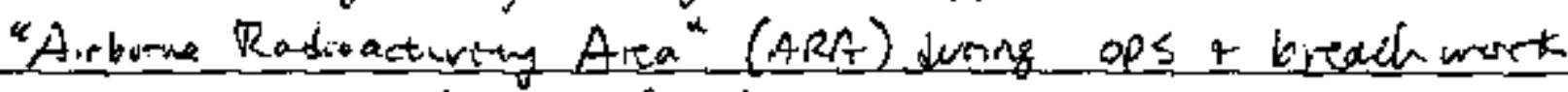
"Contanination Areen" (CA ) during demob

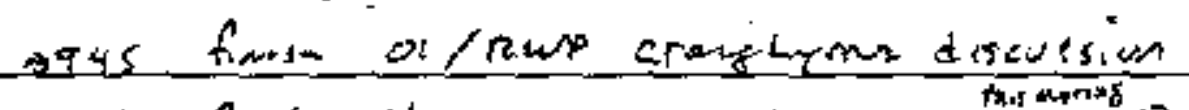

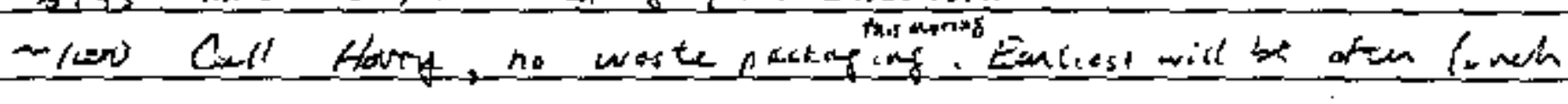

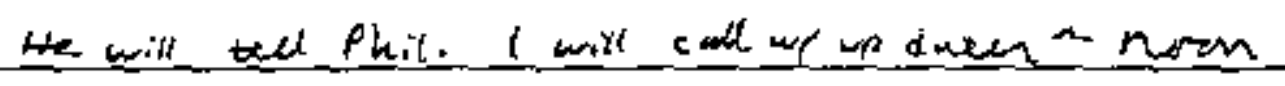

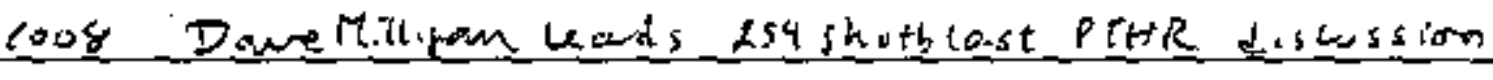

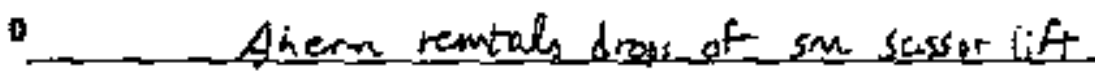

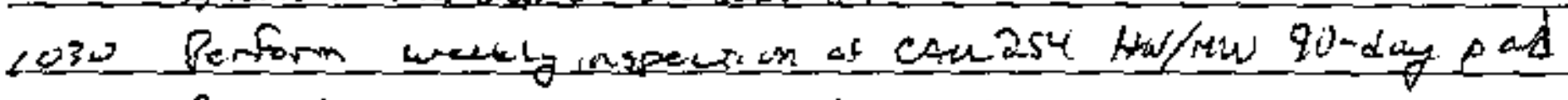

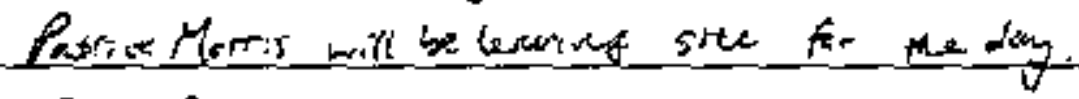

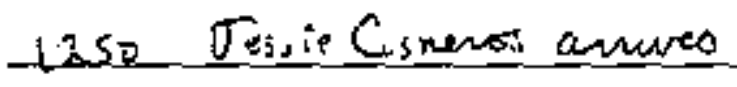

5 is is workens tust huad held shatblast pozel on sir pad cok)

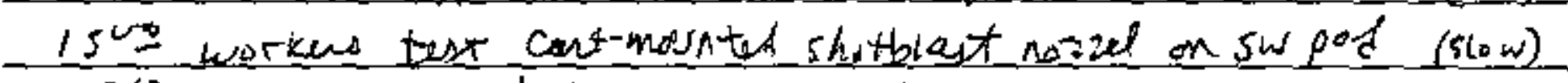
$15^{20}$ waters tont botin noziols at scume tine

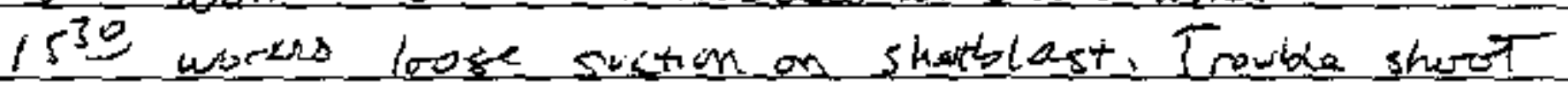

20 jerel sends pogs. waw aesinc. net

$$
1-800-536-7211
$$

1720 cents thenc

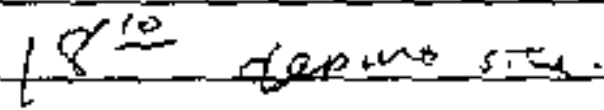

25

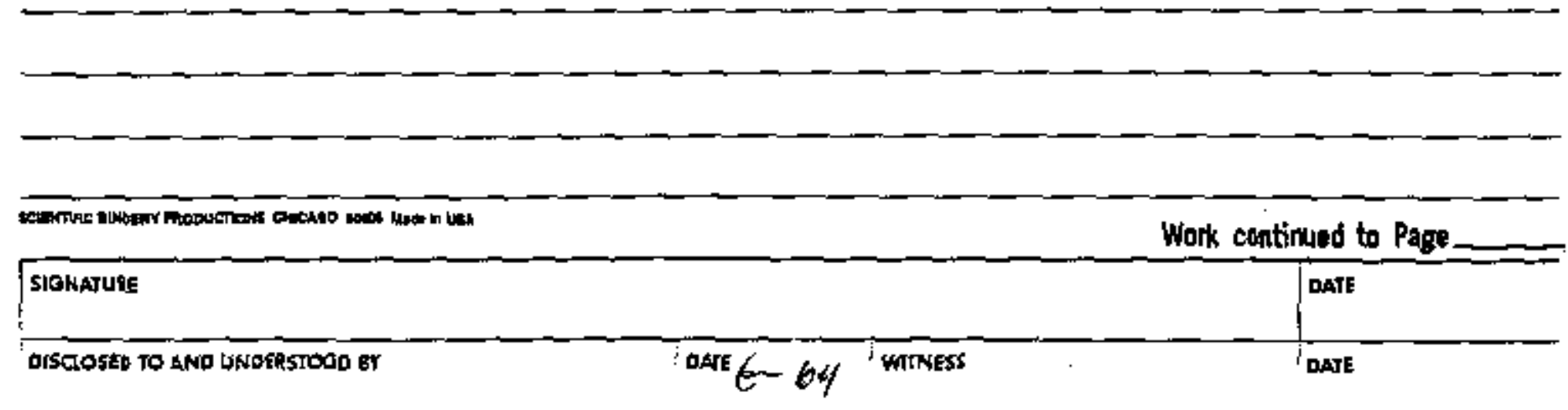


TITLE

ていシรののフ

PROJECT NO.

141

Work continued from Page

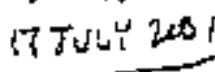

BOOK NO.

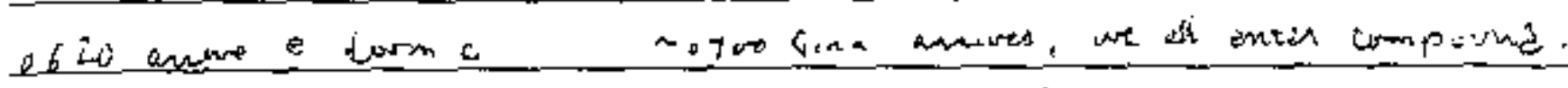

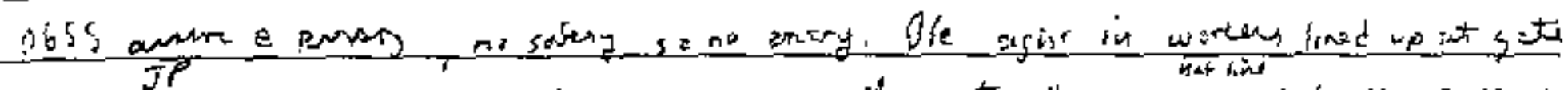

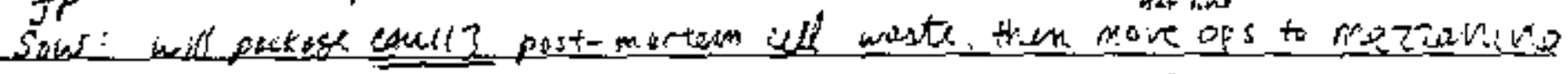

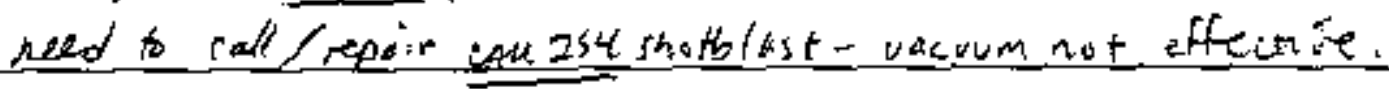

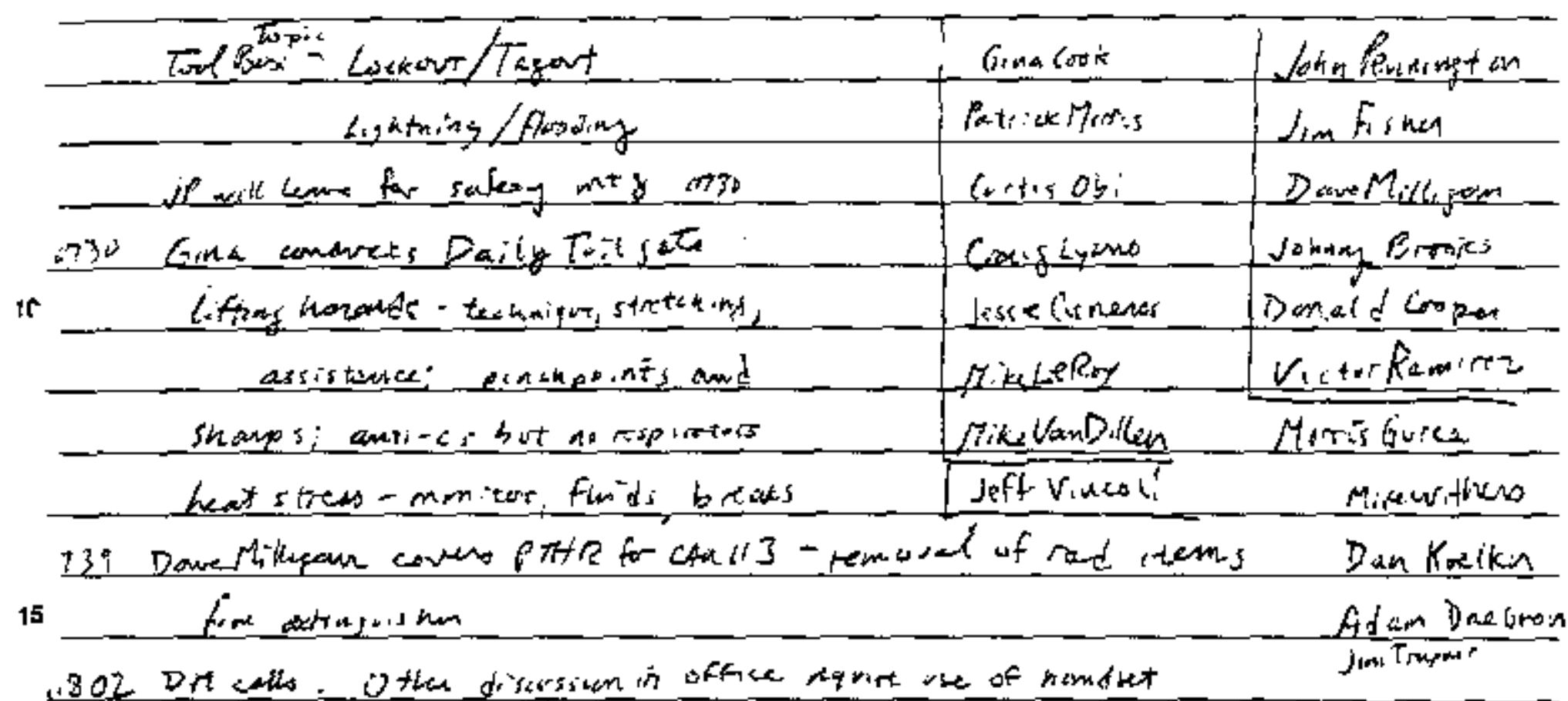

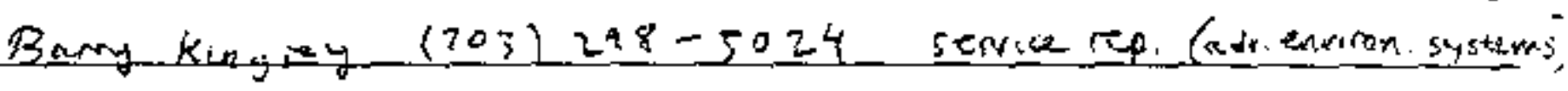

cevenab ruscestions focteack out

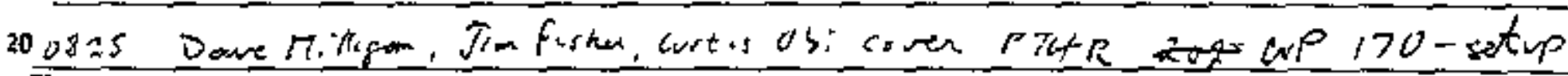

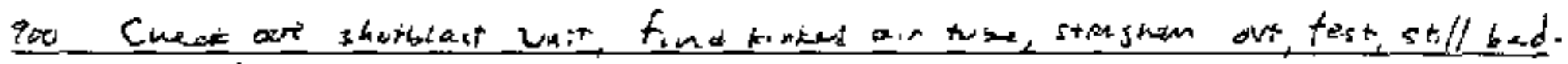

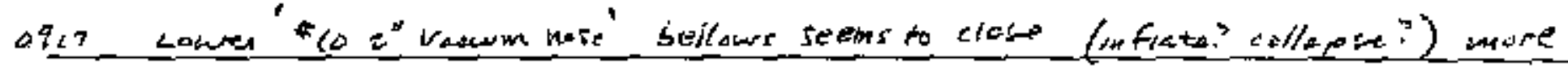

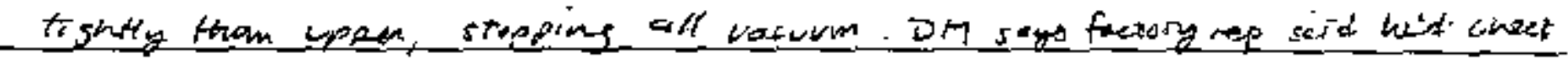
for unseated bellows.

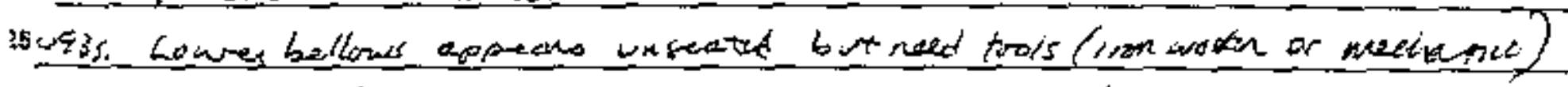

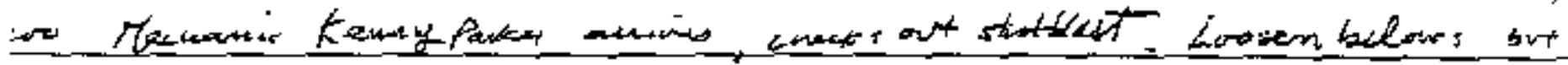

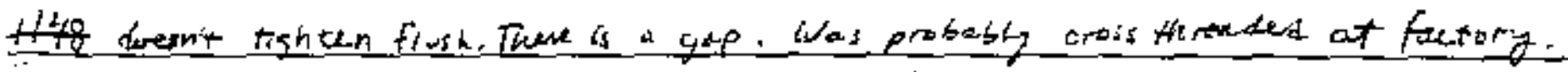
Sac tore is retted the rein thinks this will fie it

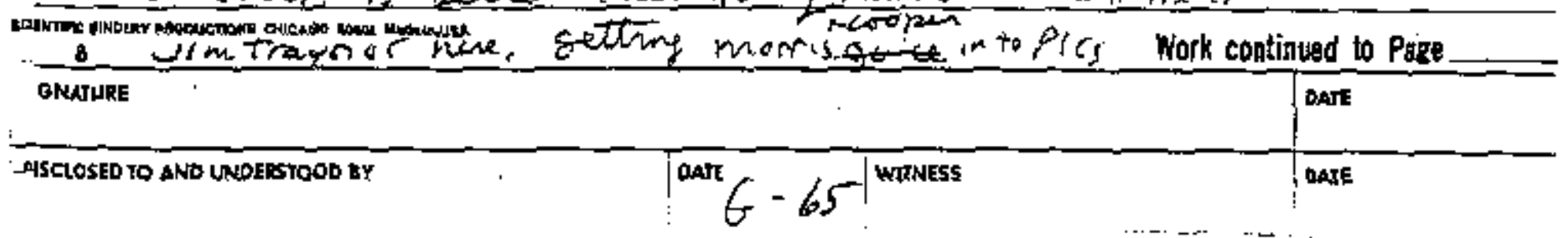


142 TITLE

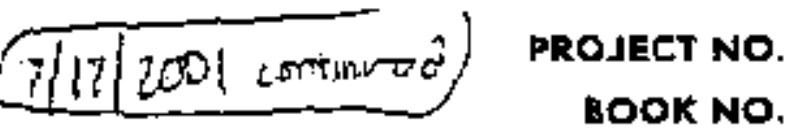

Wowk continued from Page

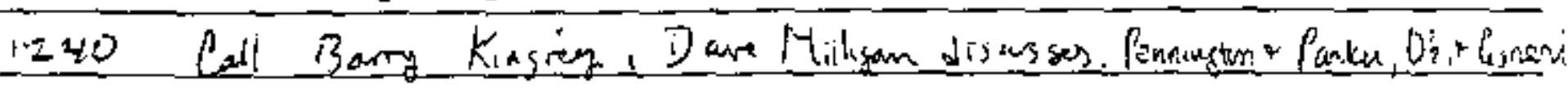

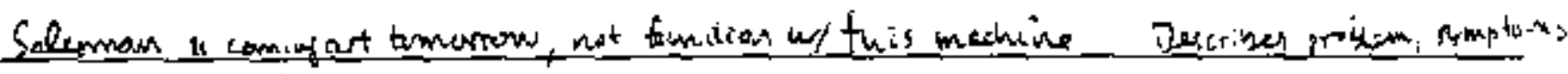

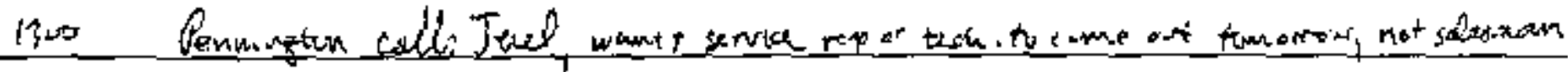

5

Adranced Enr.ronimentol Systems (800) $\$ 36-7111$

$-\frac{1508) 949-2430}{(508) 949-2473}$

Gax $(508) 949-2473$

wwo a sinc. net

Bang kingry (semulene (103) $298-5014$ cell phone 10

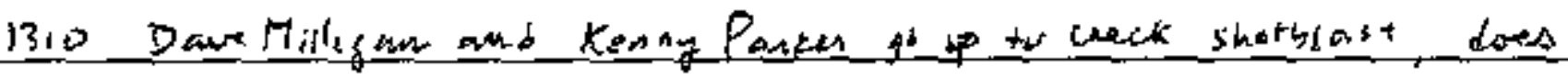
small tuning draw racurom whem unit is ex rasurm.

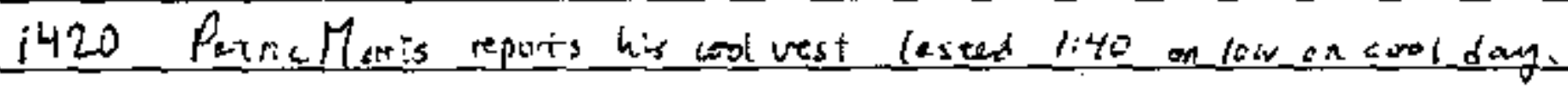
15

Duvid_reports as - sal dow $\frac{1}{2}$ fuil

20

25

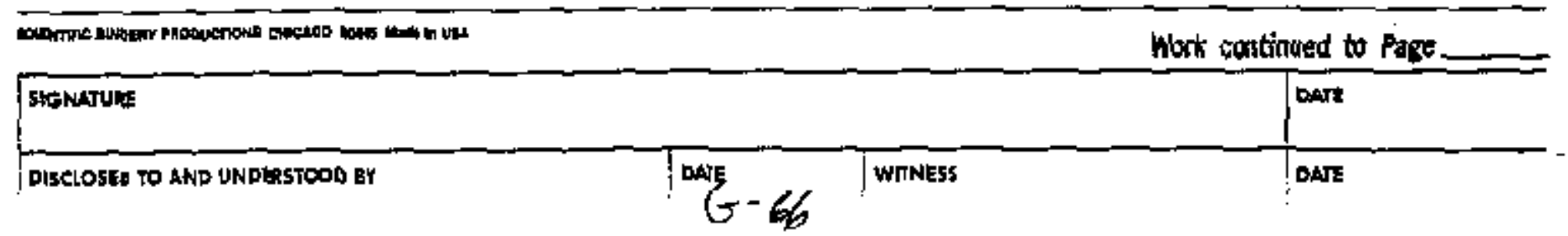


- TLE

WEDNEDAY

PROJECT NO.

143

york continued from Page

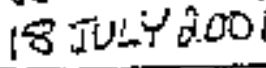
BOOK NO.

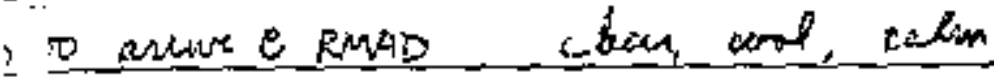

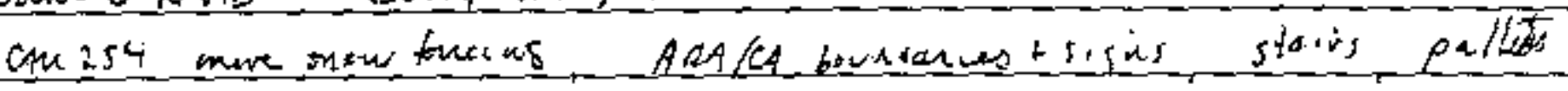

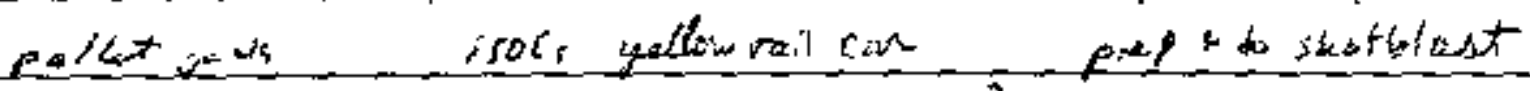

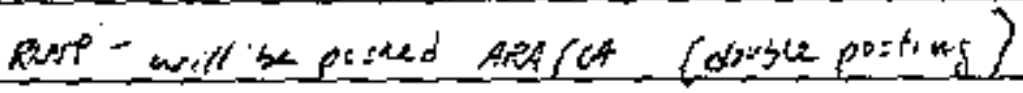

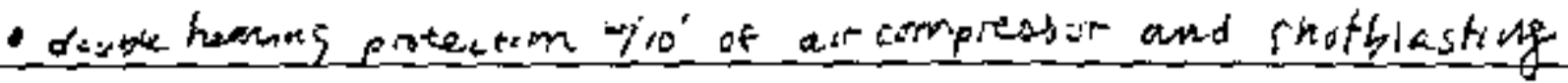
- Picisunsarem isols got in ARA/CL

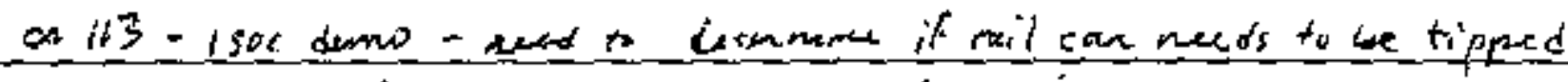

- Pusentuol visit - homderait fo gtairs

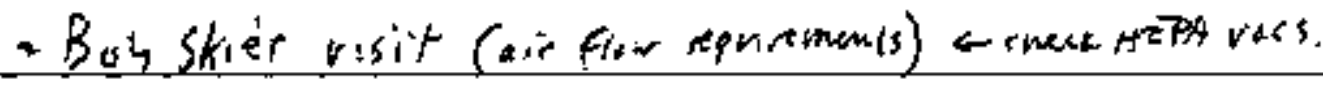

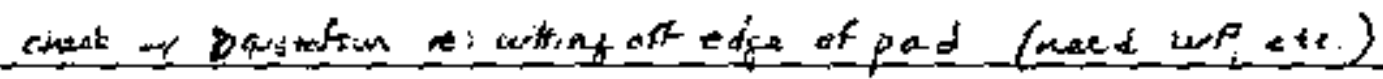

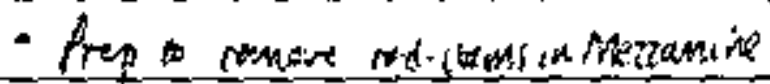

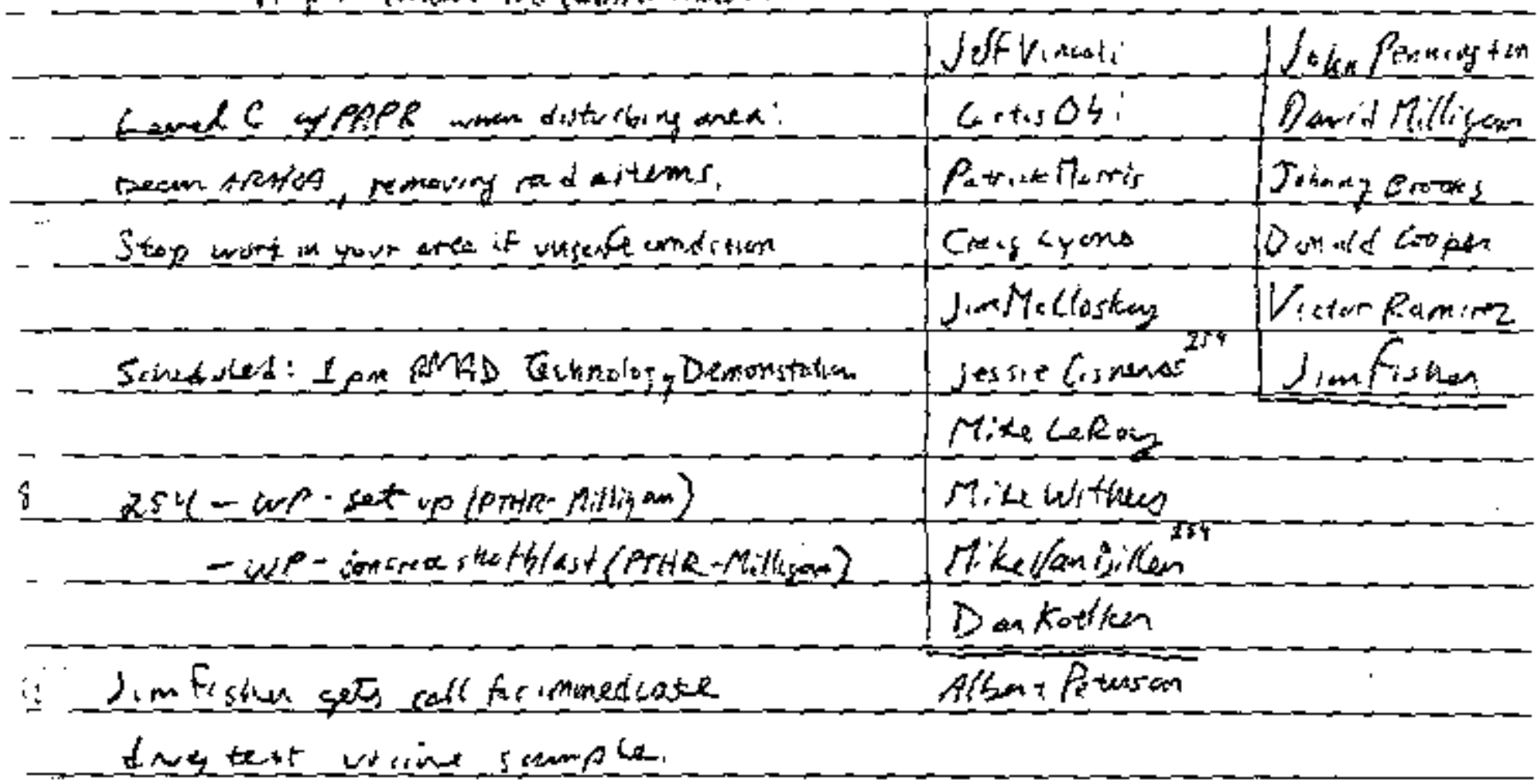

Tiser e fro ros ros

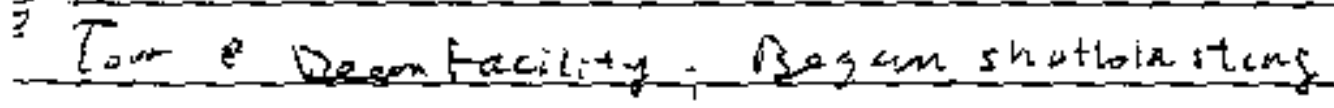

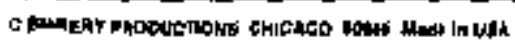

TWW

Work continued to Page

$\overline{35}$

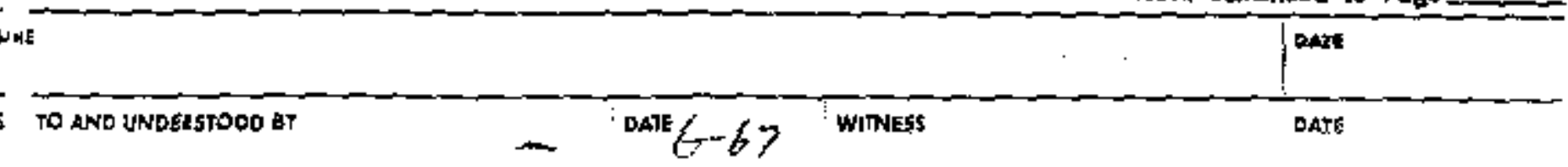


144 TITLE

Work continued from Page

THURSDAT

If Jut $200 \mathrm{i}$

OTos anno R RMD

j.Peuning gion

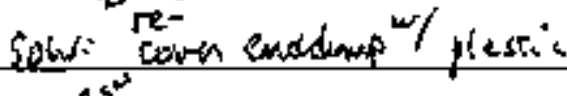

5

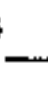

PROJECT NO.

BOOK NO.

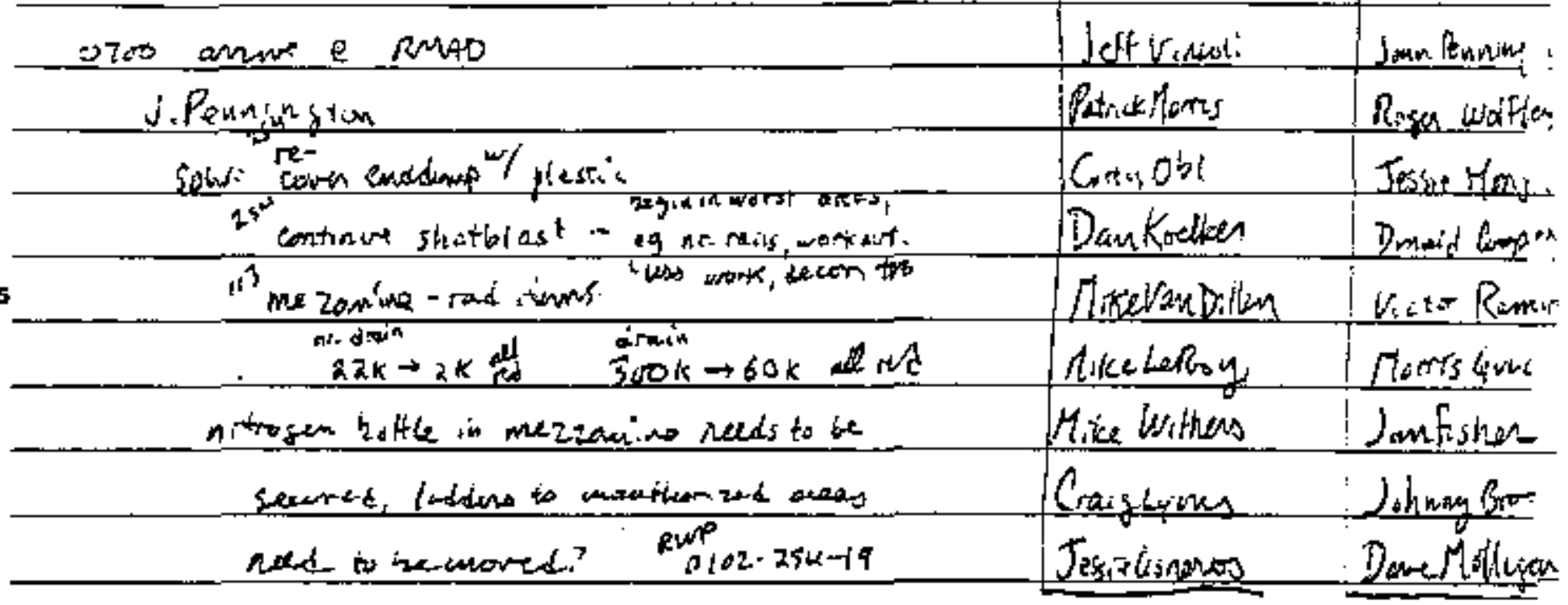

110 need to more out if fol doms

Riont Brombtak

azis 3. viucoi: decily safeby brefing

Boi Skter

- ripea Ez ca anolot borudinies

Thwor Morgan

- Level I W/agor insidey laved D outsides

Jeff min $_{1}+n$

- westhen - likergestentay ot less wind

Jerry

15

- trippeng hazands - pellots hoses

- hovriy breaks, shade options

- anstomien harnerts

isiut

- presmlegintanto

every vist to Heiched. seems

20

- havend ratis freed

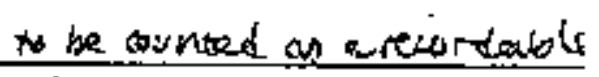

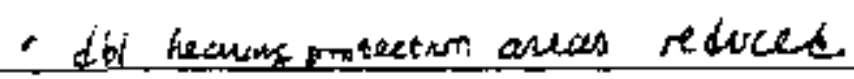

PA systim for comarriense

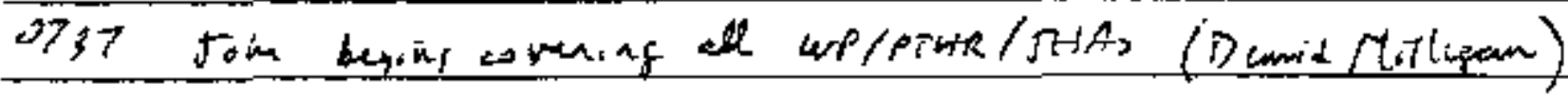

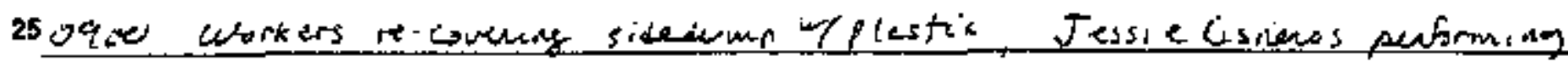

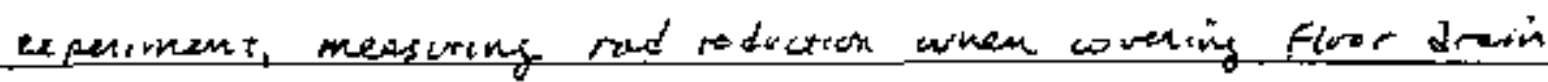
with ceuc and with wath-filled buckt.

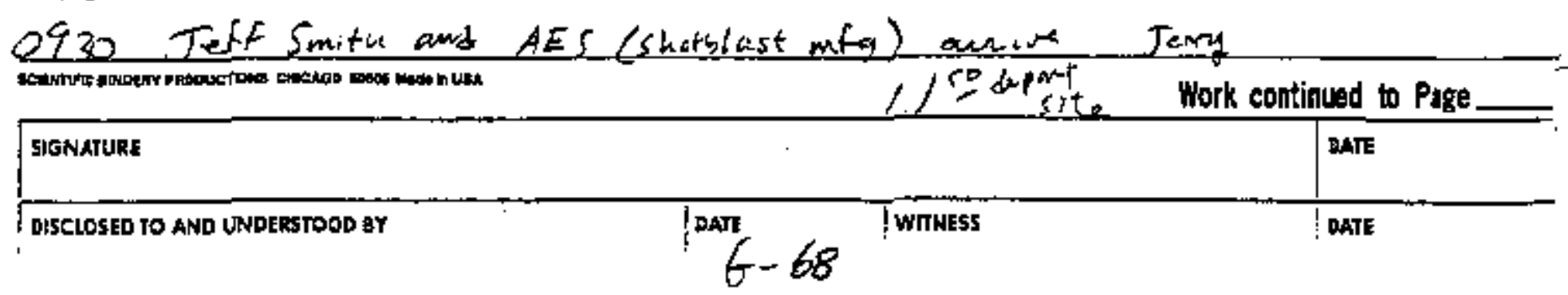


$a \rightarrow$

$2330-2000 \mid$

145

rik continued from Page___ BOOK NO.

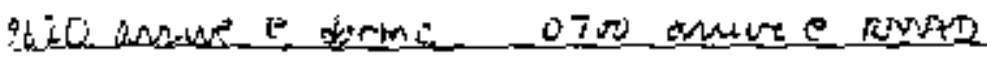

Jim fenmoger discerses row for to day jeff brawi:

curtis obi

Patrisitforis

Darikiket

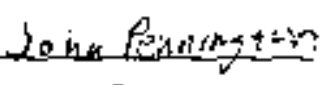

Jim firiten

Johny 8 rowicis

Dnald toones Eroiglyias Victum Rimires.

beace ong 1 openser

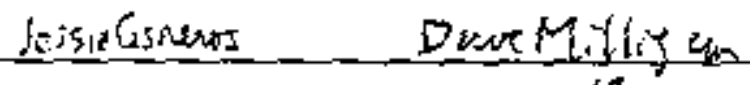

1 tran womicus

Mikevanditlen.. Jessiellom-re.

4 lebirets

jim ligkiskey

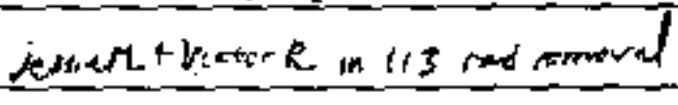

Tike Lerey

likewithen

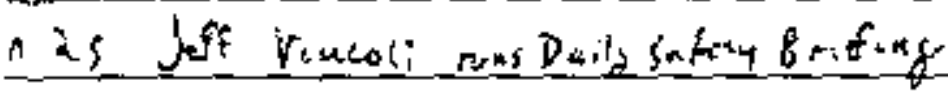

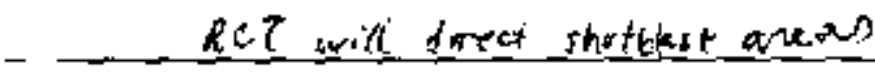

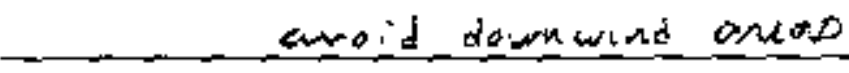

minimiza 4ciomitating shof

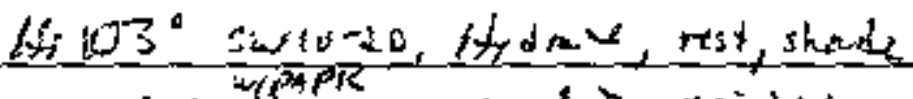

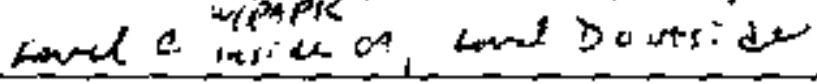

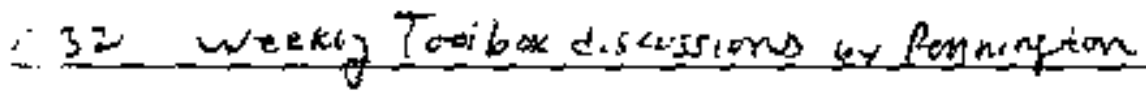

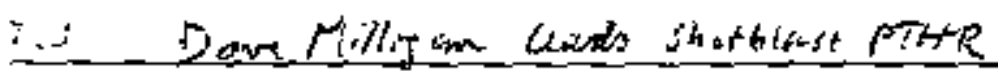

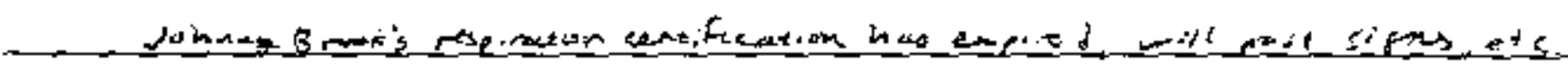

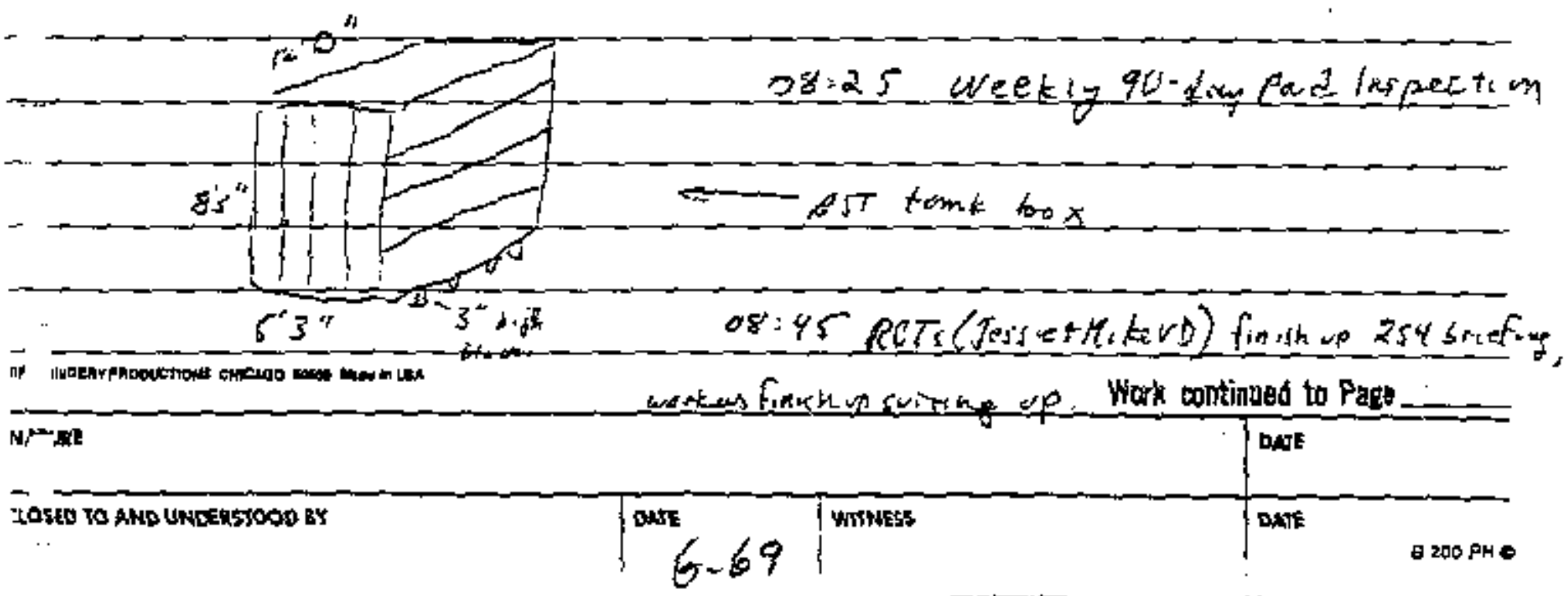


146 TITLE

Work continued from Page
$7 \sqrt{23}+01$ contoured

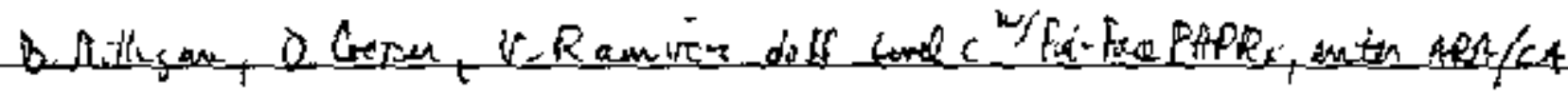

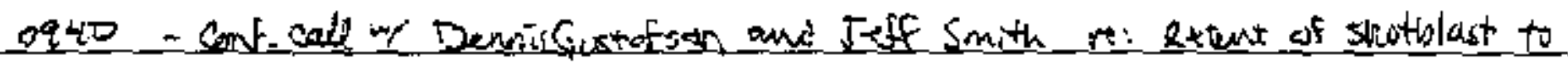

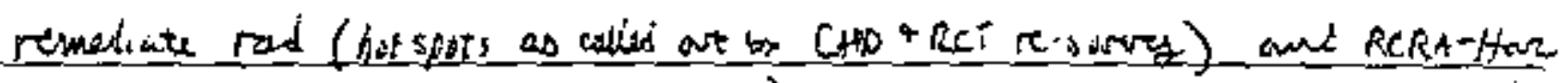

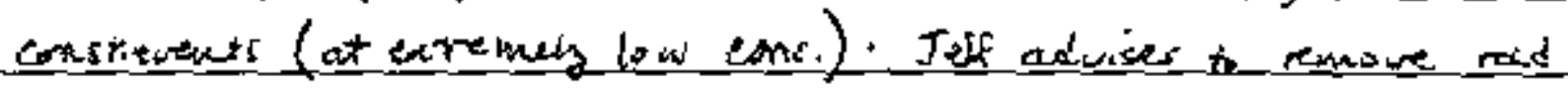

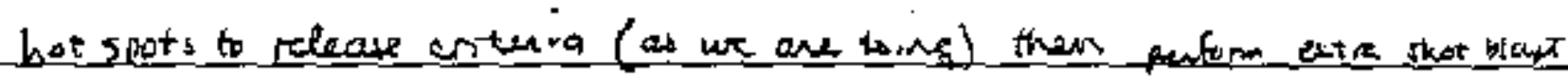

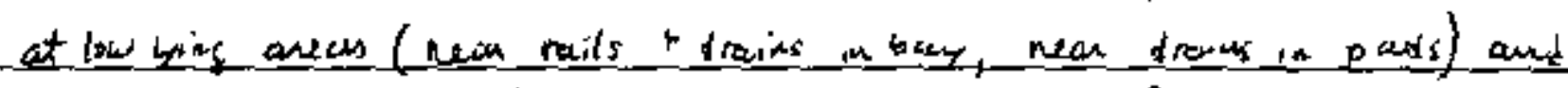
Where II compiles indicate rt imtaminapoun was found.

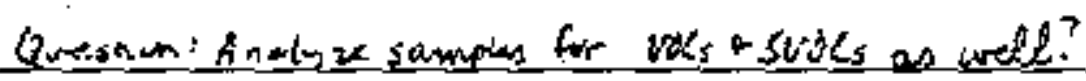

10

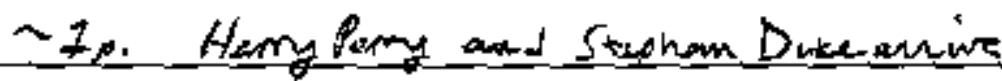

$14^{*}:$

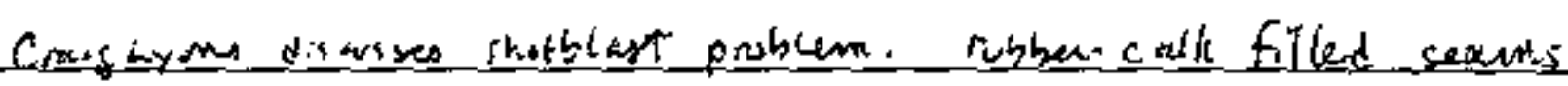

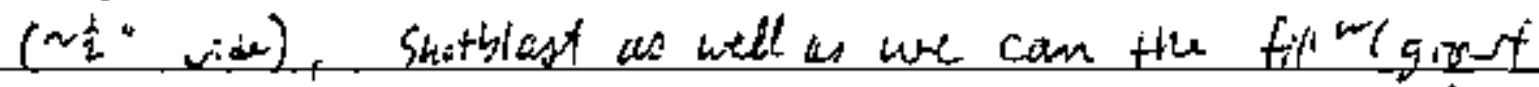

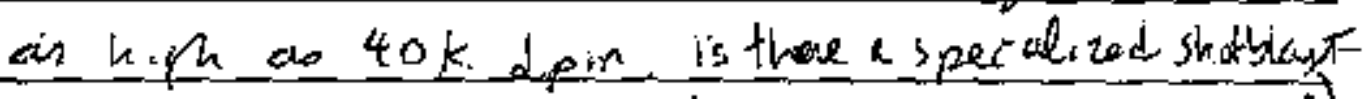
remove vols ter? head for crack s lowish to of)

20

how far can we go into slab loud stay in slopes?

$1500=\operatorname{col} 12 \mathrm{anars}$ Gustation

25

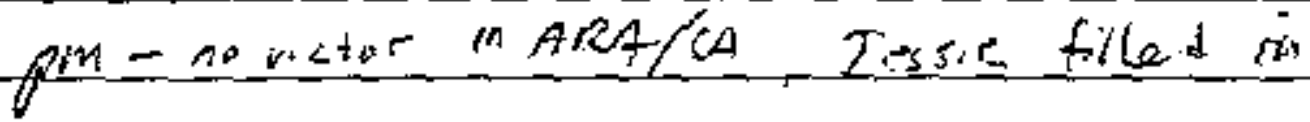

Shothiat 300 if to dray

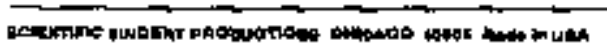

Work continued to Page

SIGNATURE

oat:

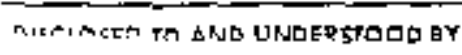

DATE $<=7$

Winters

Date 


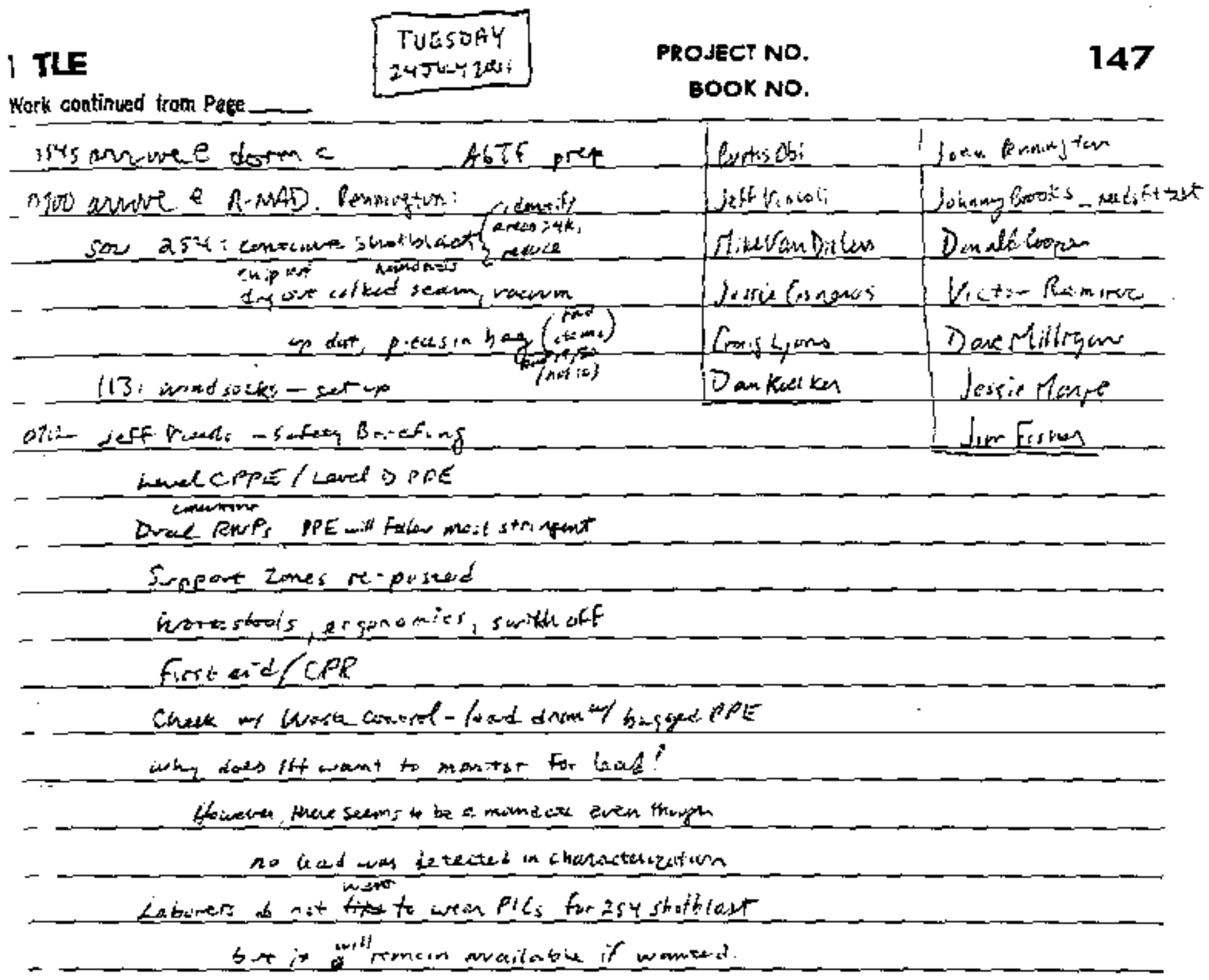

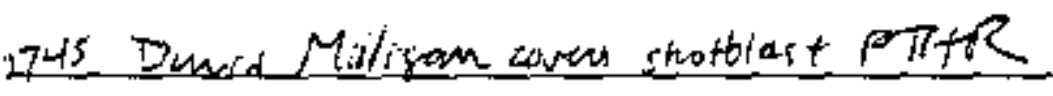

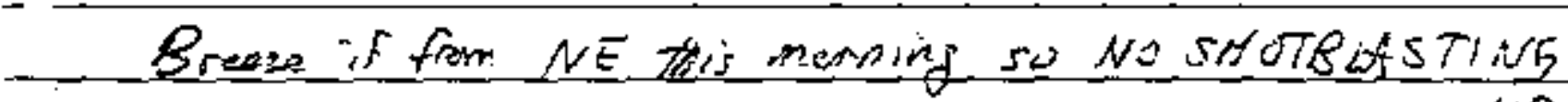

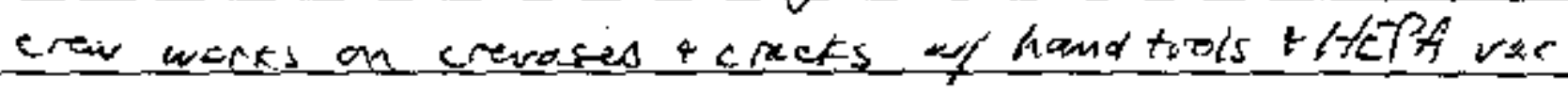

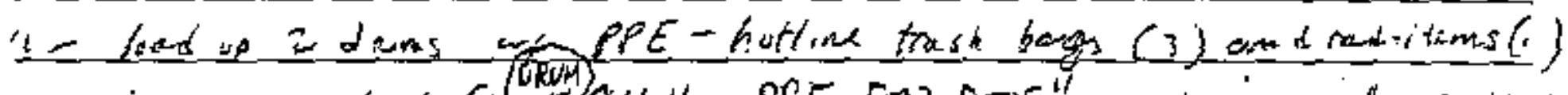

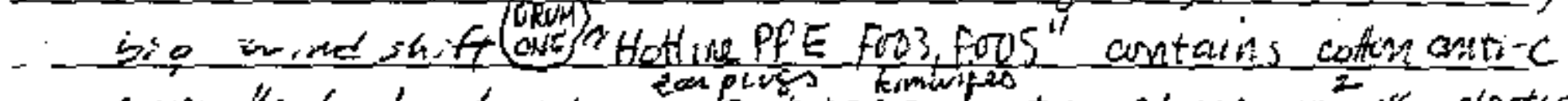

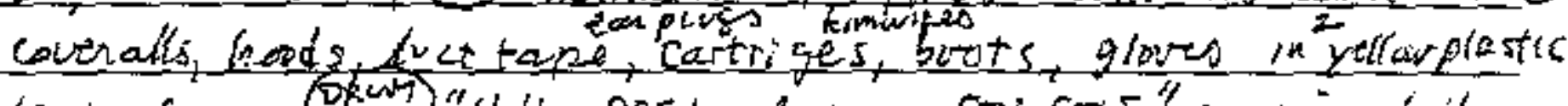

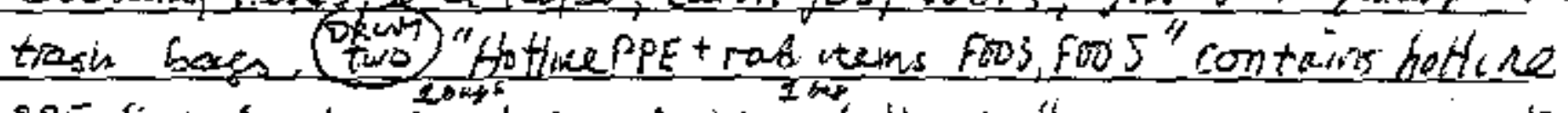

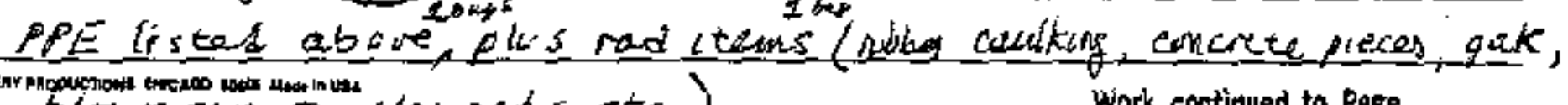
warios Work continued to Page UT TTO AND UNDERSTDDD ET

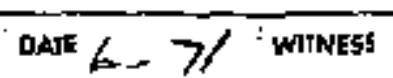

ons 
148 TITLE

PROJECT NO.

Work continued from Page___ BOOK NO.

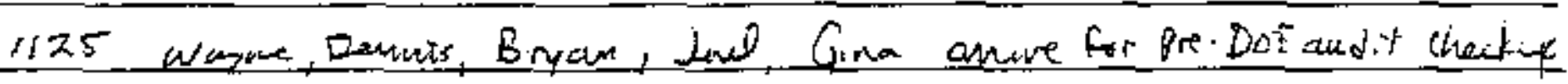

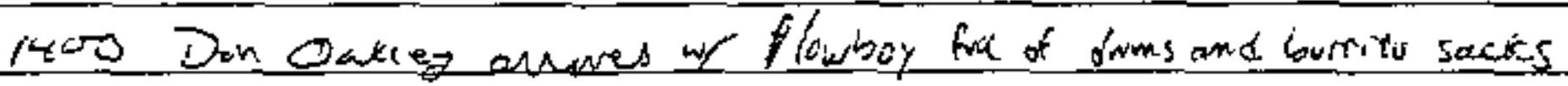

(tod) backers report 4 creases in concrete /f to tres ts ane 2.25/4 dine (just own half.)

First waste dram is aby out $1 / 3$ full

10

15

20

25

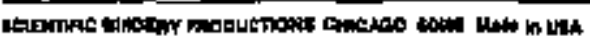

SHELTER:

Wok continued to Page

DISCLOSE TO AND UNDERSTOOD IT

DAT $\angle-77$

WhTNE55...

tart: 


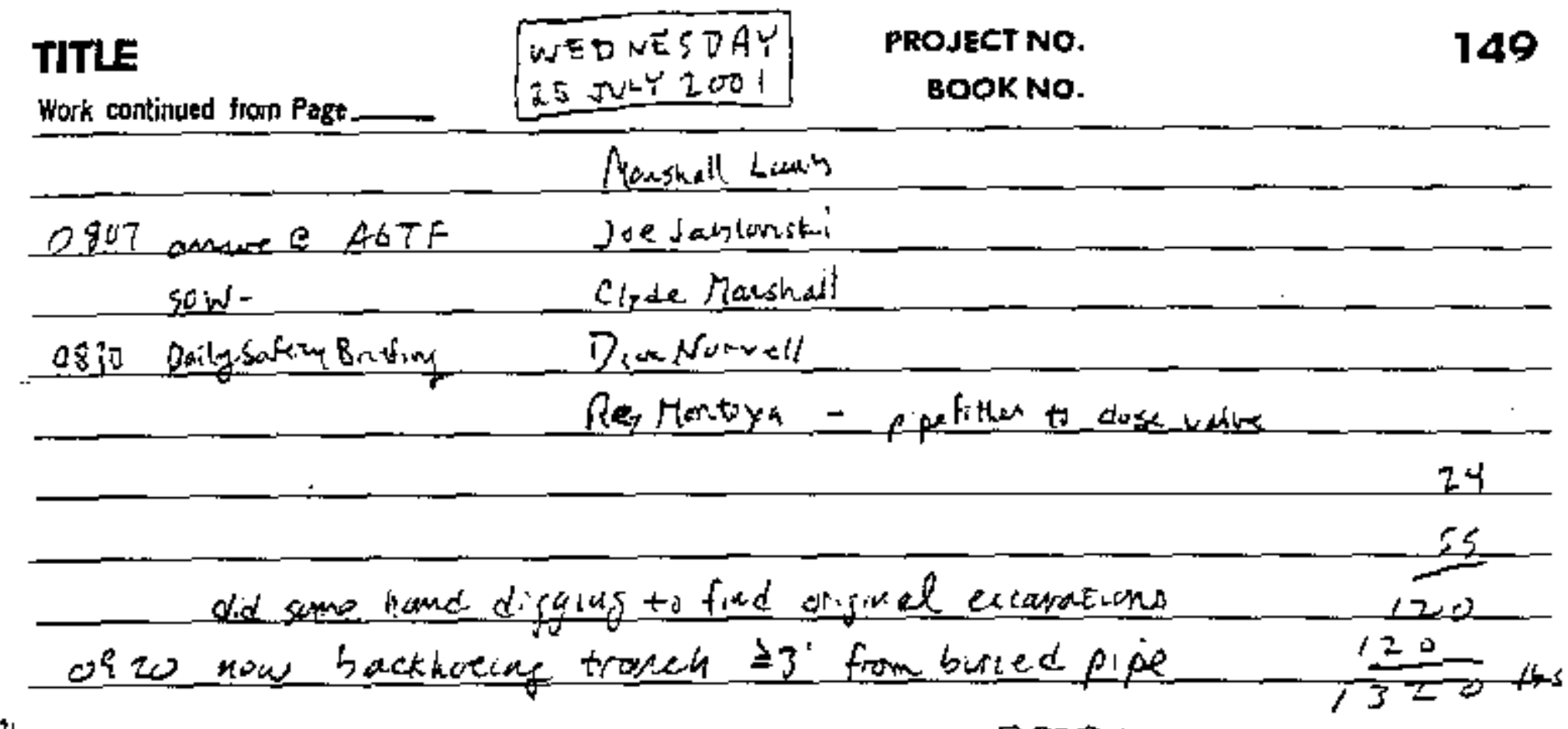

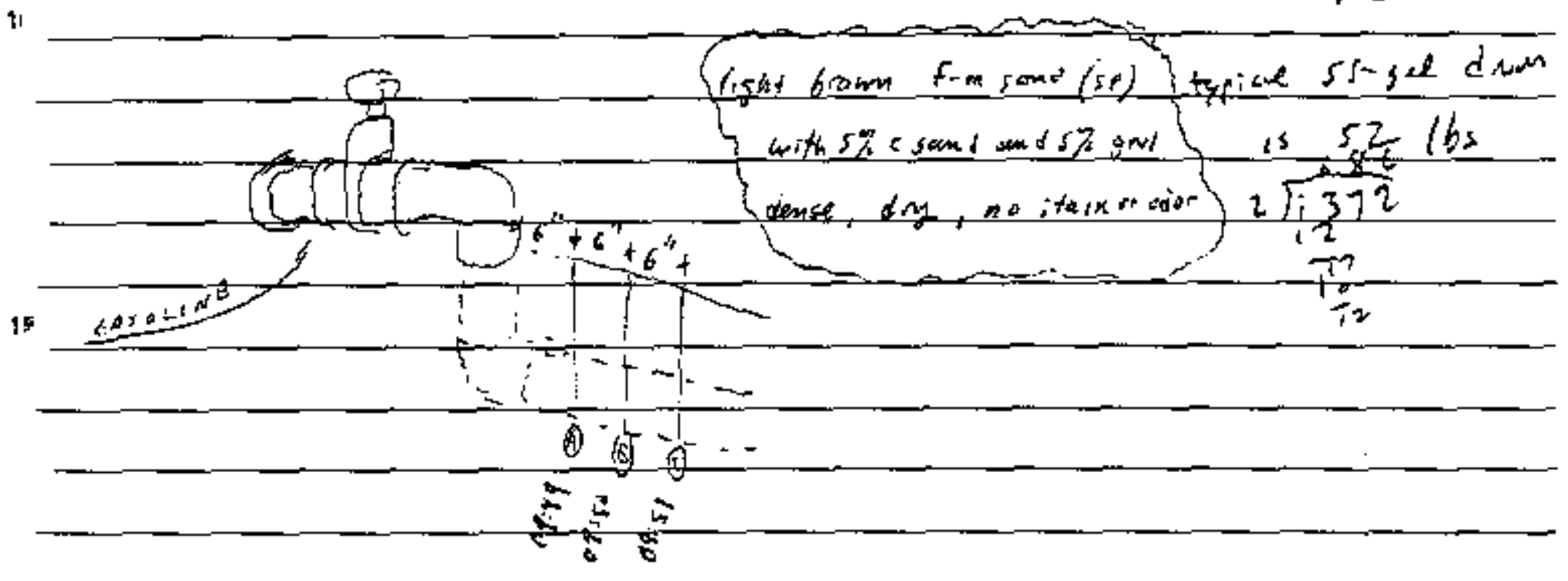

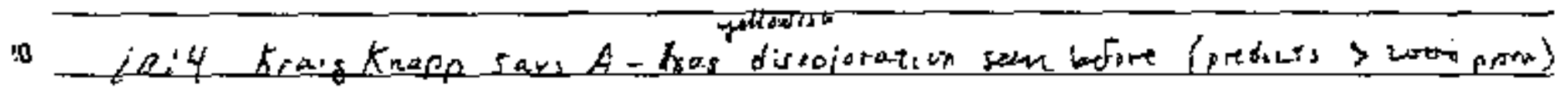

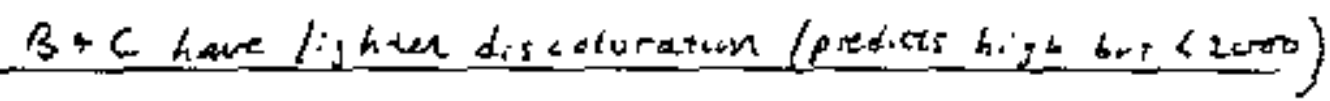

$-2=0$ B/omk calis ritht on

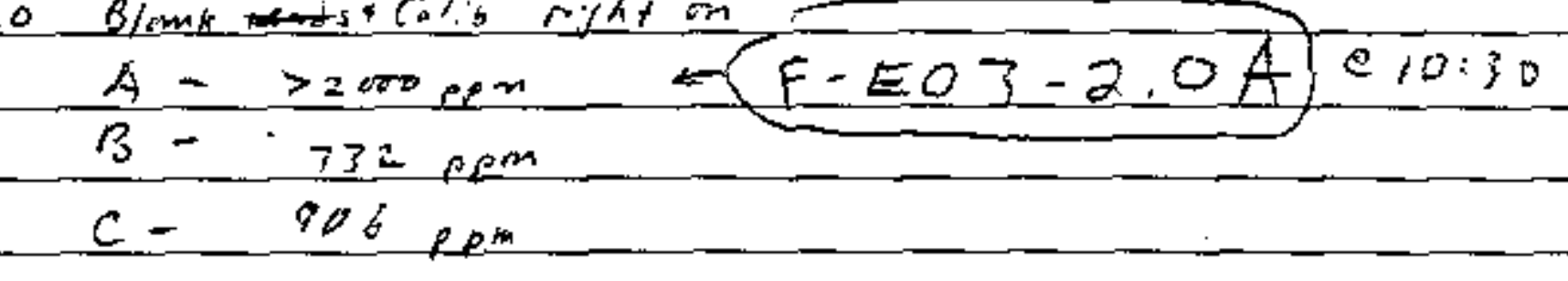

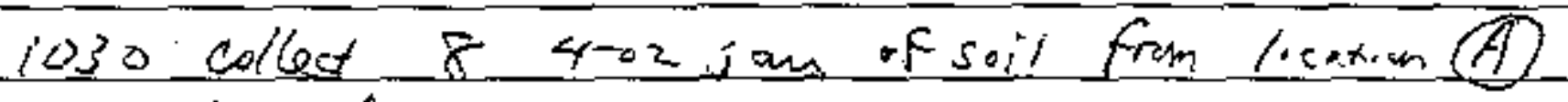
coto skek fill excouration

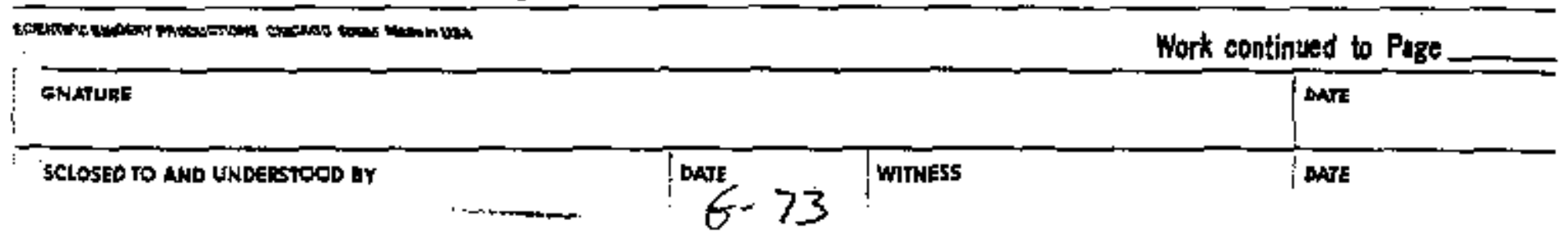


150 TITLE

Work continued fron Pabe

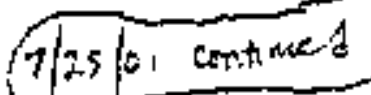

PROJECI NO.

BOOK NO.

1100 back fillug complete, workers prop to leave A6IF IIIl Rey turns raive back on lire and leaves

M2s dopout $96 \overrightarrow{I E}$

$T B+0 C-03(2 \pi, 6060)$

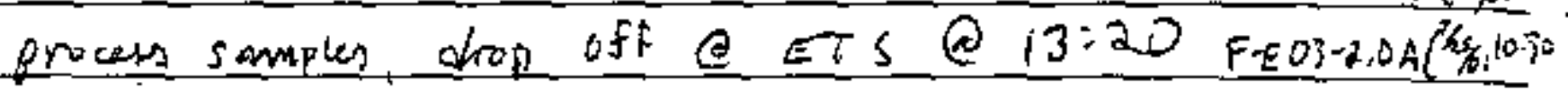

14 ande $e$ RMAD wedredicty

$$
7=2 e \quad 7 \text { her } \text { ArTF }
$$

$2-s_{r} \quad 3$ wass 254

Sow contrume shothlasting

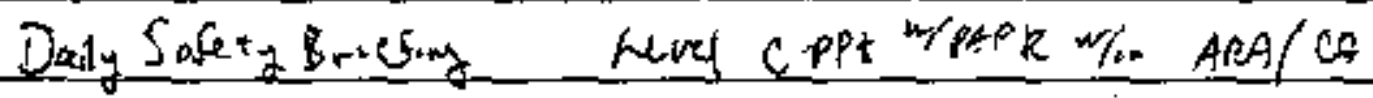

Db! hean protaction during shotblist

254

Heat stress - hydria eang 9 often, work/rst mob,setop demos _CPR/Firstaind

decon conseresta $2 c^{2}$

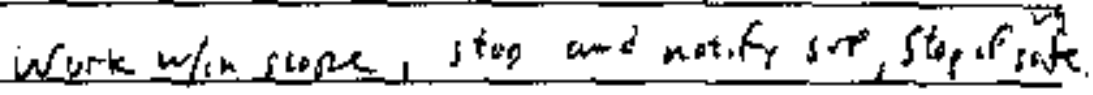

I__ reditans 03 reat work air sompieg nagetive

jeff Viugli:

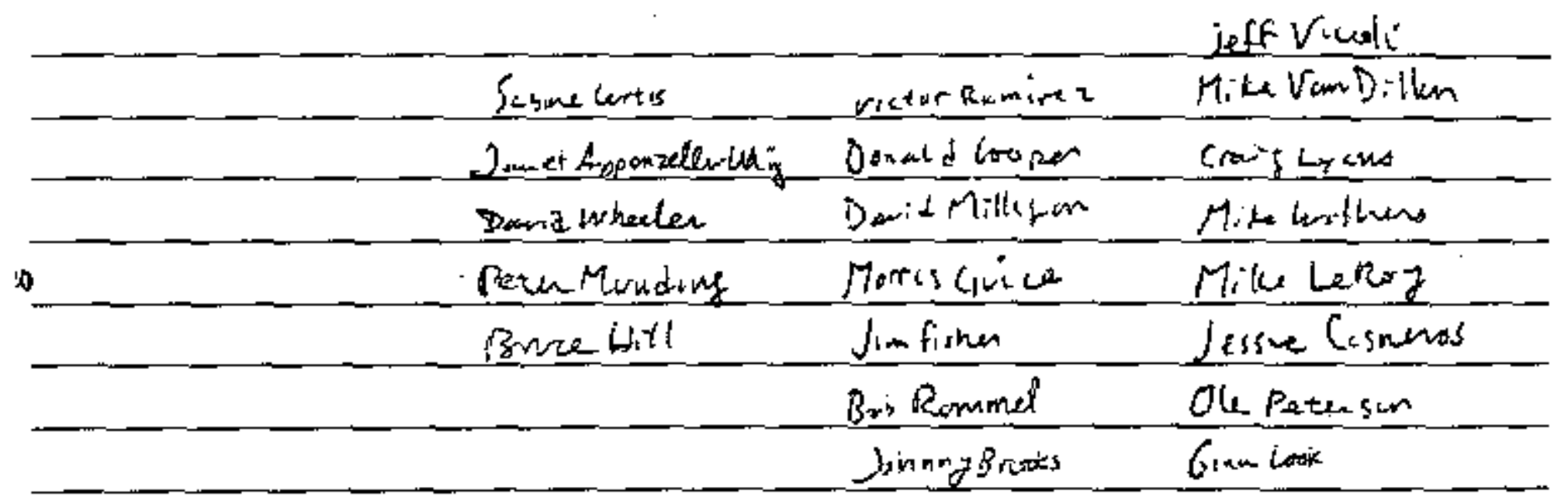

Mhis morning wind was initadly wrows____ Briamkenrad

15

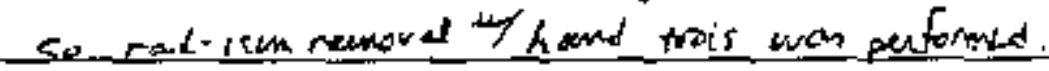
lanel Ne/son

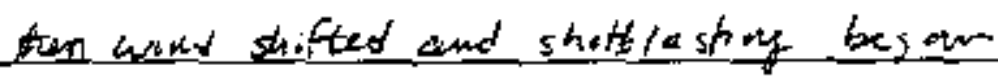
Dennes Gustorsion

thesmominges Corts Ob;

DoE andit was sucess fult John Penningaw Mork continued to Page

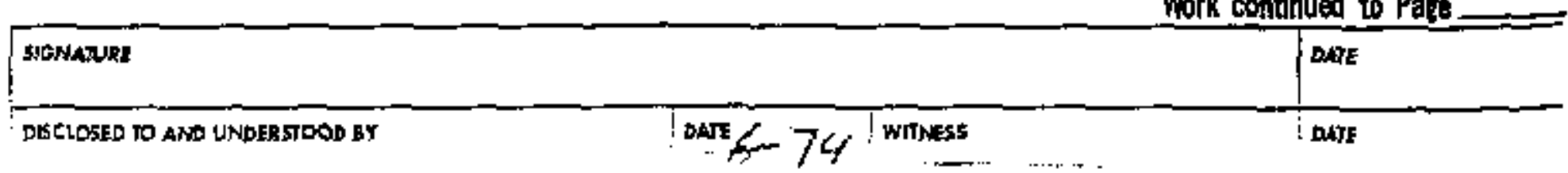


ISLE

Work continued from Page

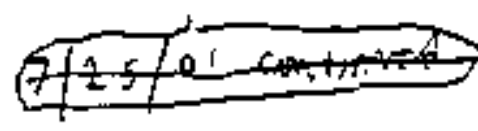

PROJECT NO. Man 7-5?

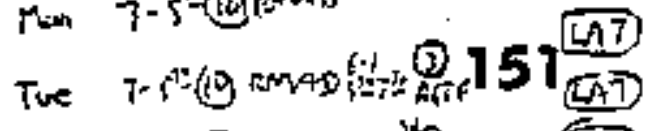

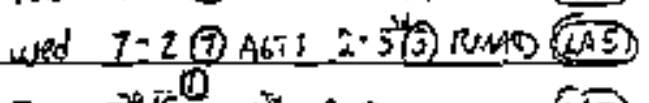$$
\text { Tum } 5060 \text { A }
$$

THURSDAY, JULY 26,2001

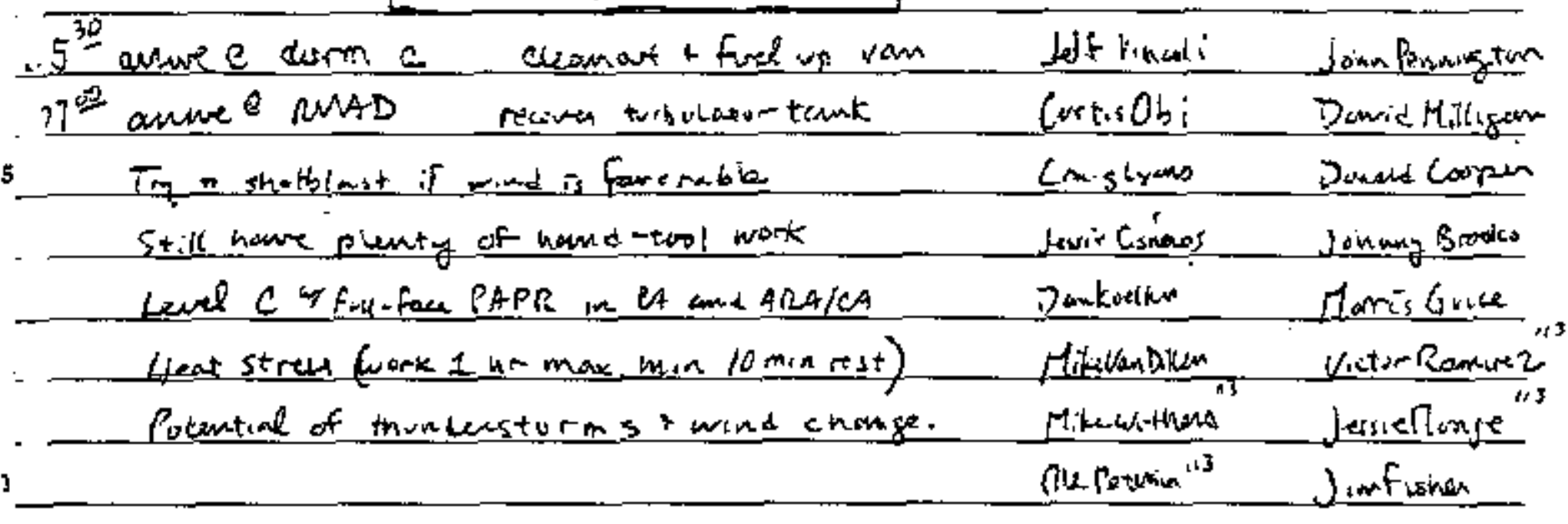

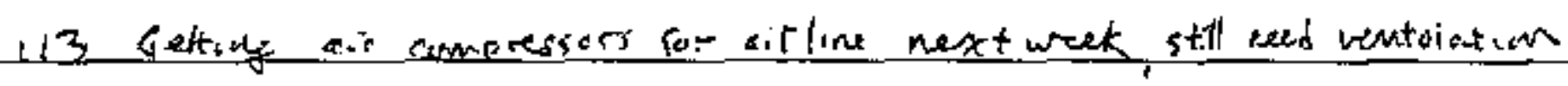
Stay in work scope

-2745 David Millesom reads $p \pi+R$.

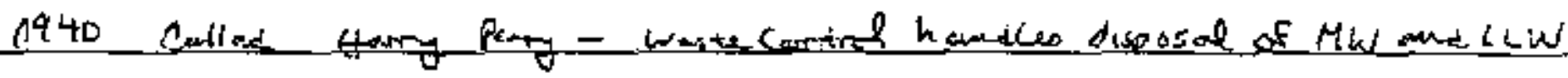
and the enter their ware into HAztrsk

- I should coordinate HW with Sham ono

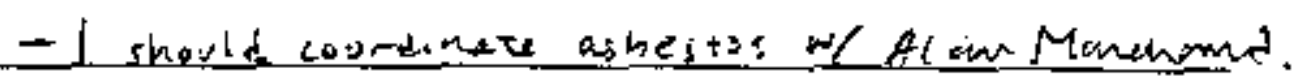

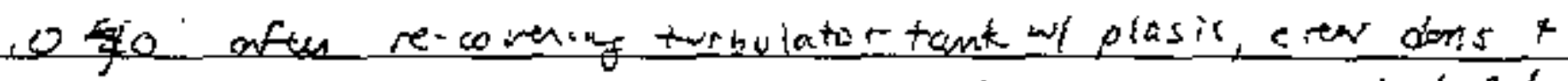

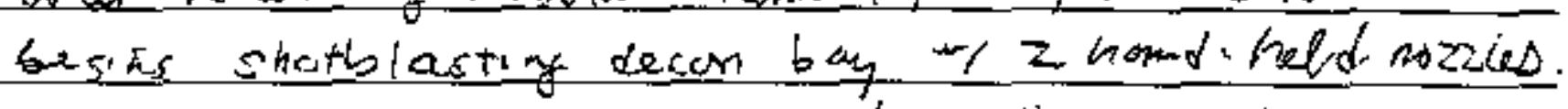

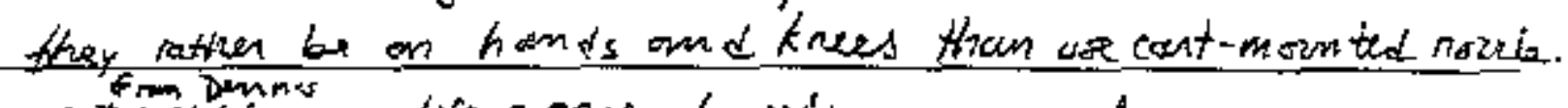

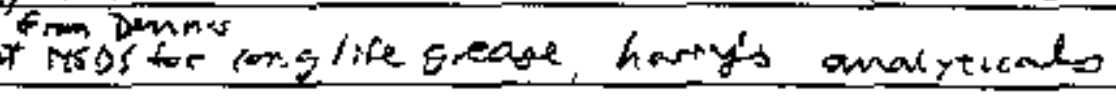

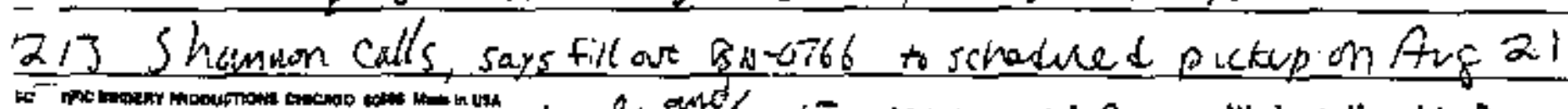

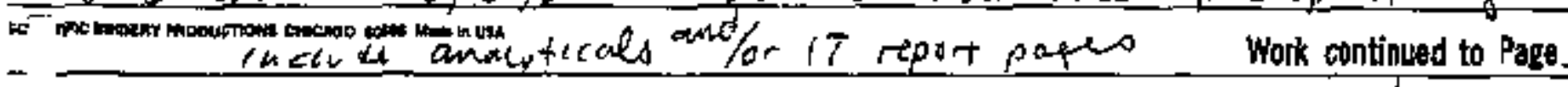
SIGHATukt

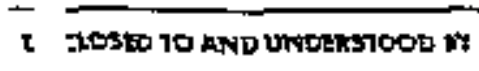

that

DATE 
52 TITLE

PROJECT NO.

Work continued from Page

BOOK NO.

isuo Call Houry $r^{2}$

prope un codes for dirims

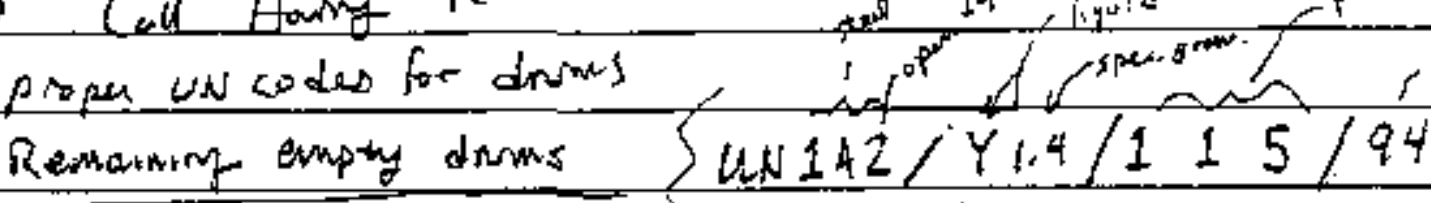

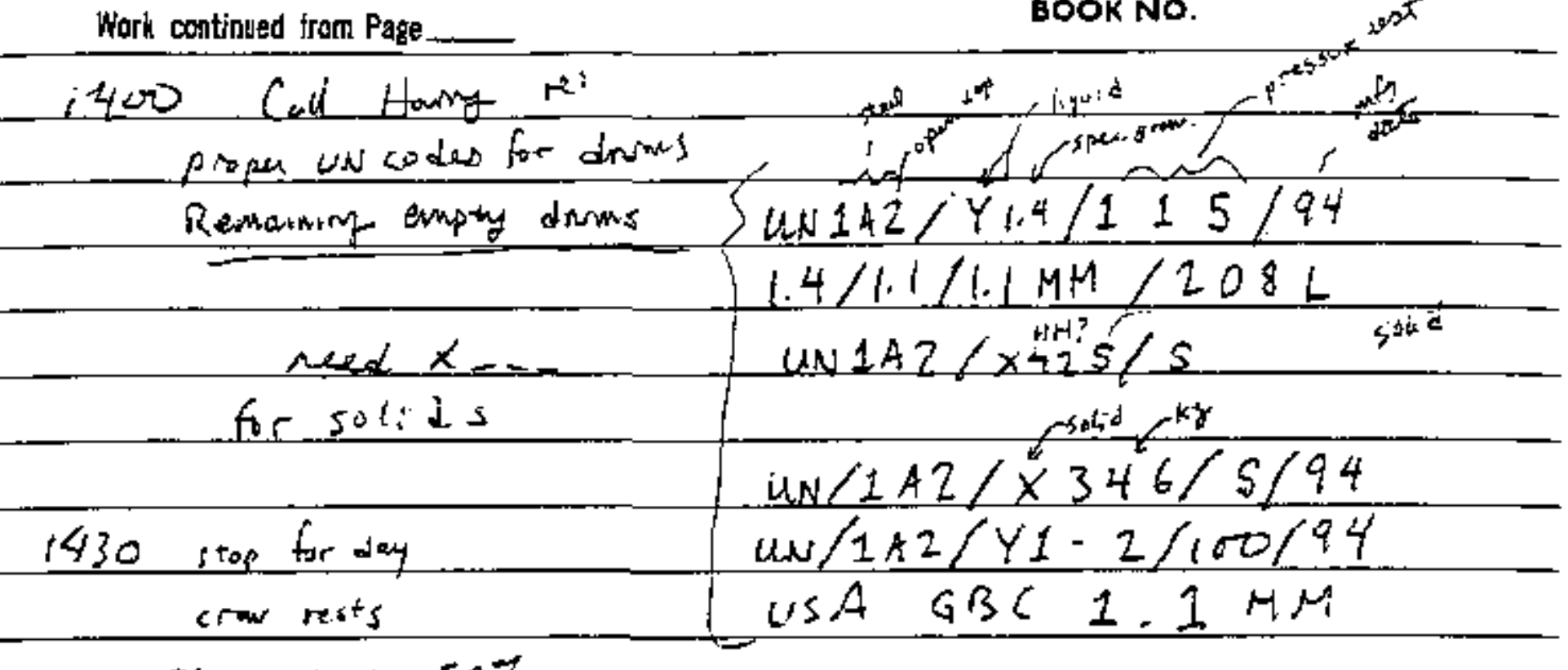

RCTs estimate $50 \%$

shoblest completion

CS22 packagerp bagged PPE \& rad t tems mto 2 droms

1sol I ss-gal int "Hatlineple, Rad Items fro 3 foos"

$$
j u \operatorname{lig} 26,2001
$$

i si-gal in "Hothin PPE Foo 3 foos

why 26,2001

Devid Milligm got avord end of day thet he hais

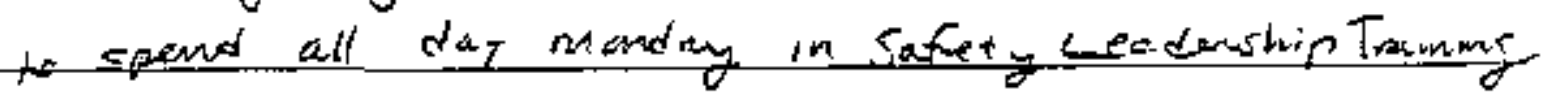

FCT reed to $\frac{1}{2} b a j$ up PPE every othen bag to

helo filly fill waste drums

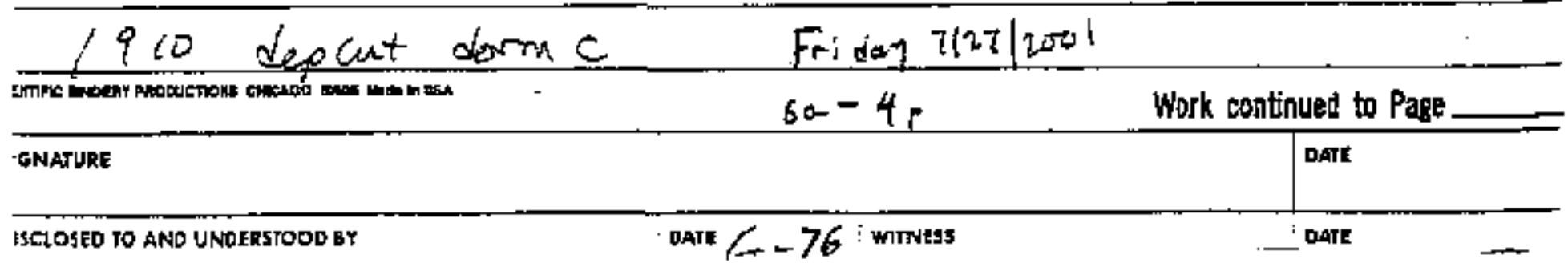




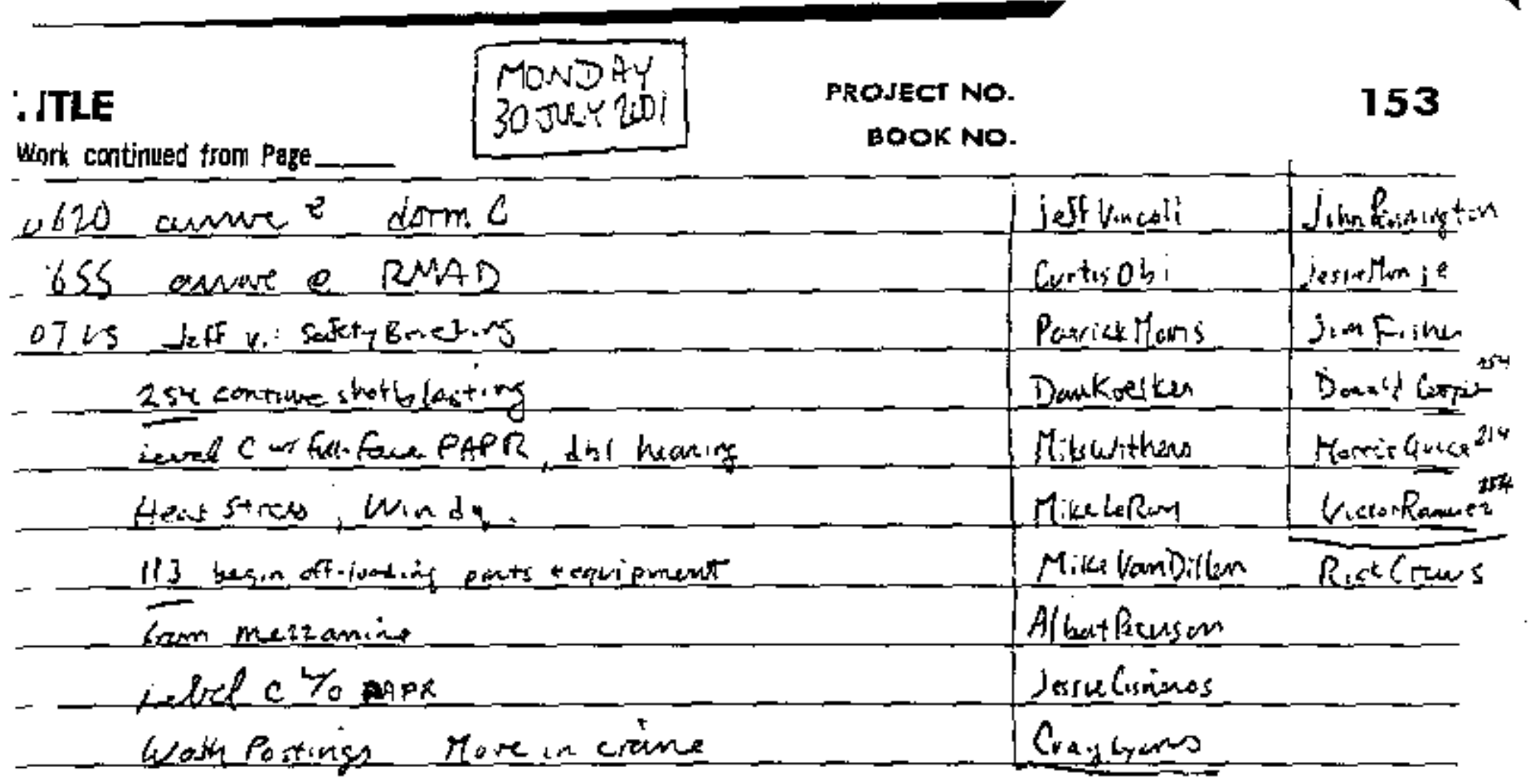

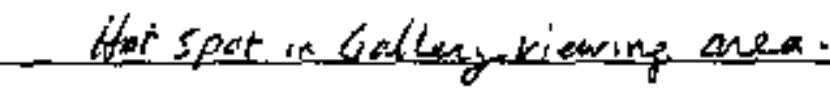

Pouten-actrated tob changes. W water

230 Toul Box top :c for were k (Pennington)

- Lack art l tog ont

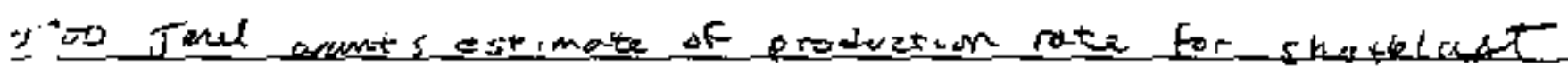

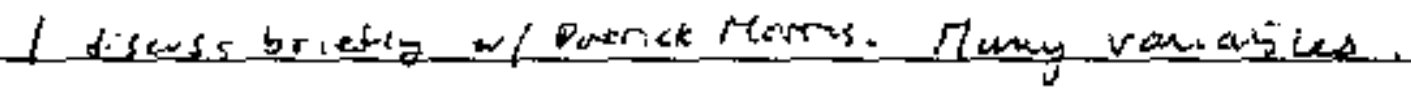

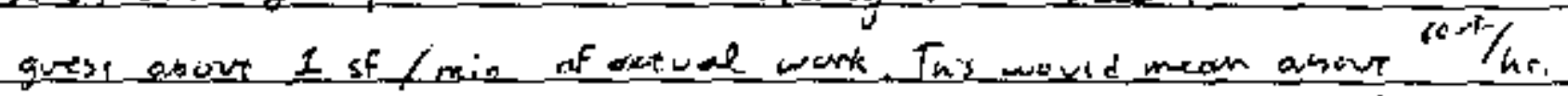

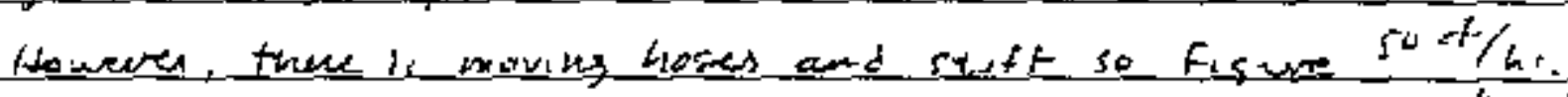

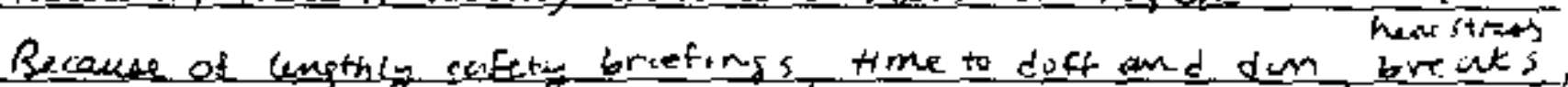

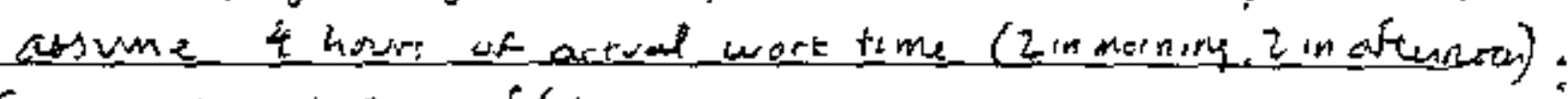

$\therefore$ five about zoo if/ da

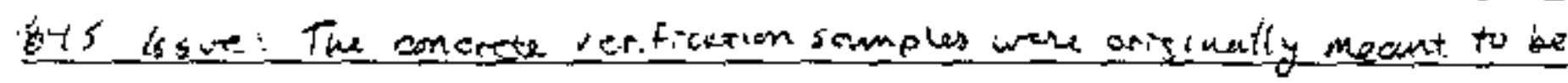

- Indicates of shotblacting complete ness. Now howeva the plow ts to

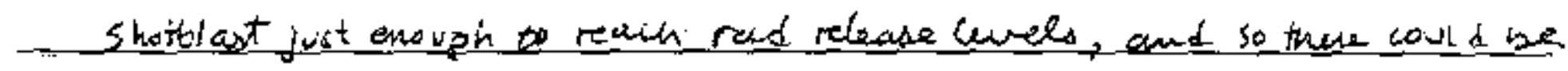
- a los of pain lot on the concrete We might te able to inothlant just the IT CADD locating a ms sample these. if so, rain we then dispose: the east pad as $L L W ?$ ? Need to ark Jeff. Work continued to Page NATURE

EIOSFO 10 स MO UNOESTOOO BY

tours

Jars $2-7 \rightarrow$

Withies 
154 TITLE

73010 i continued

PROJECT NO.

Work continued from Page

BOOK NO.

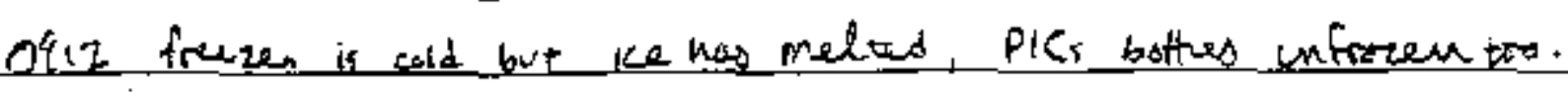

Find a in withy tHese caps locations al

$$
25400\{25 \text { NEAT }
$$

when e is 28400562 is clement

Thotblast workers switches out first drum this morning

10

VEST, $T P H P C B_{S}$ RAD

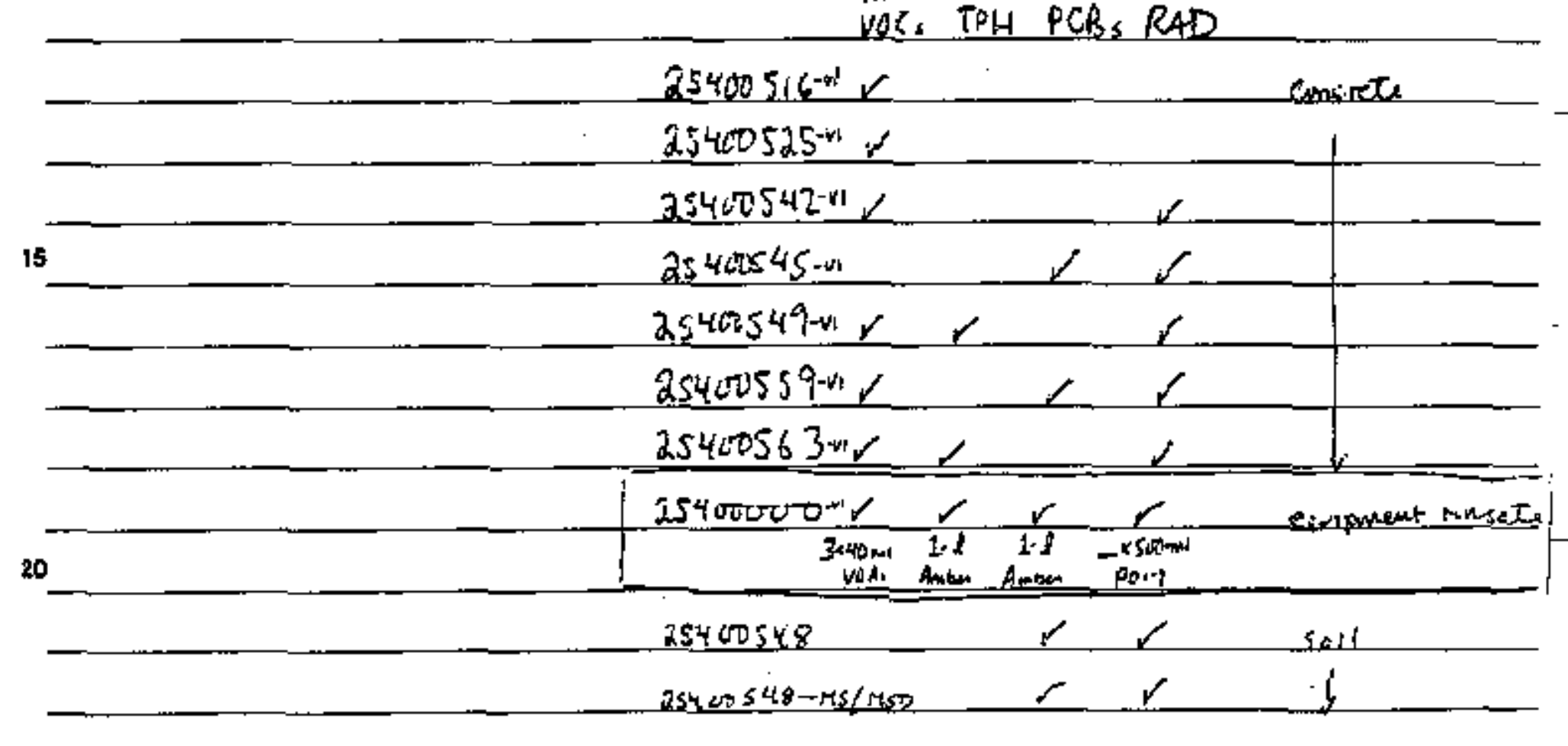

25

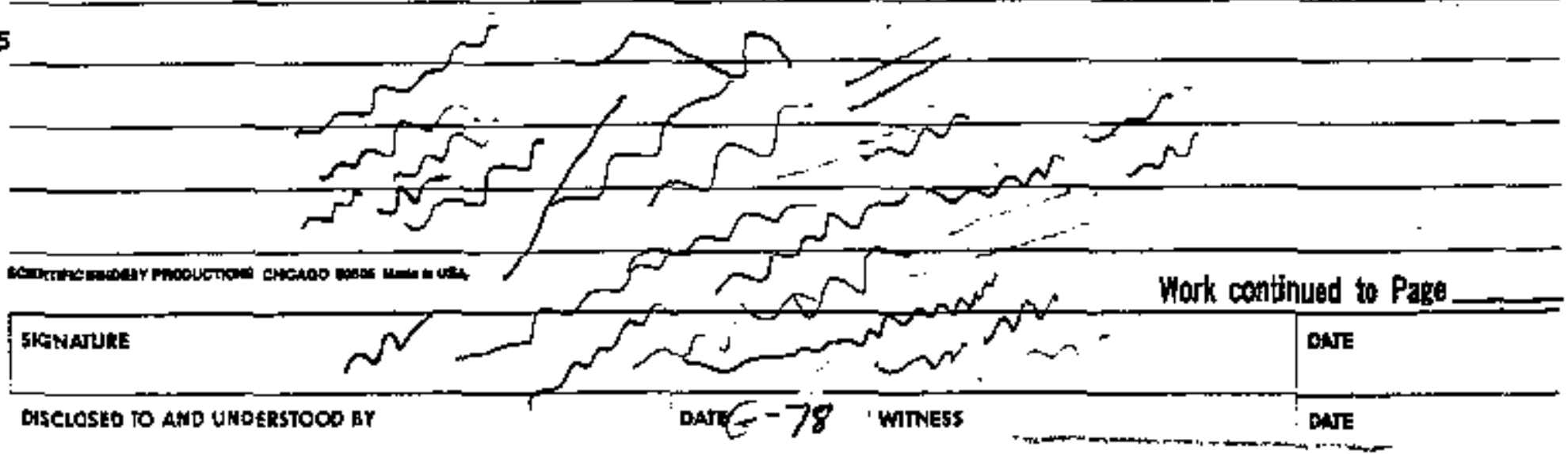




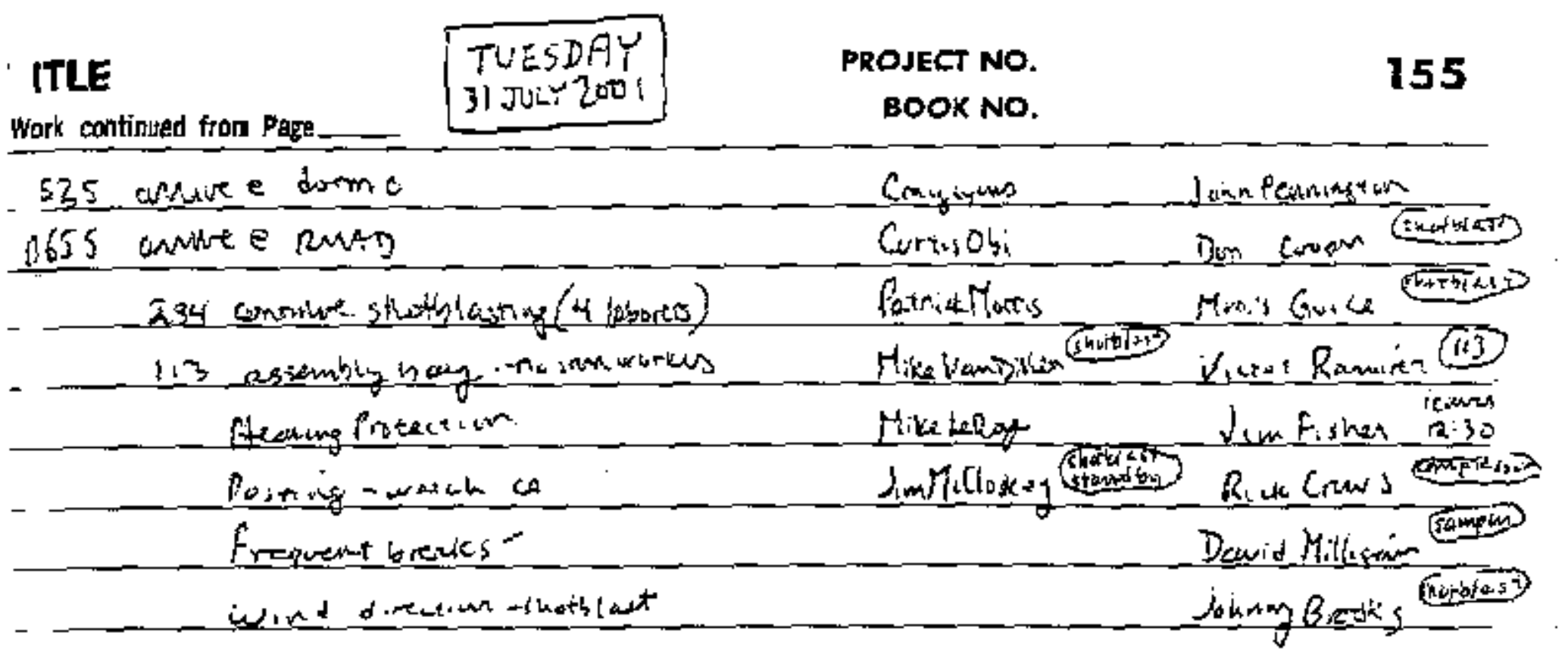

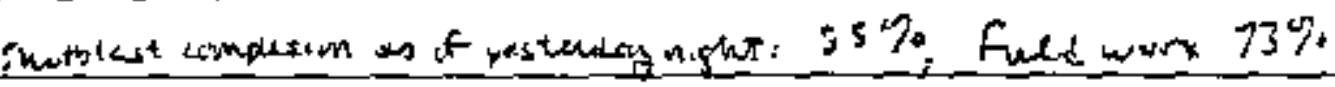
2830 Perforin weakly 90Day HW/MW Pad luspection

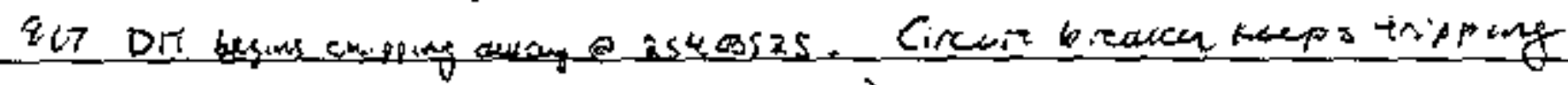

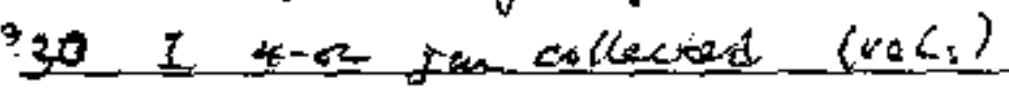

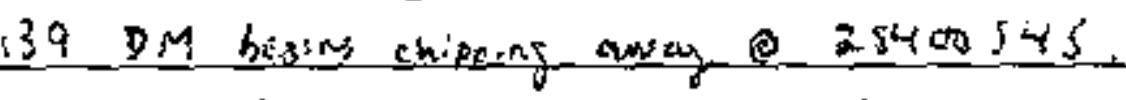

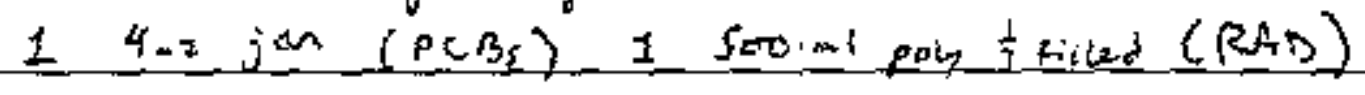

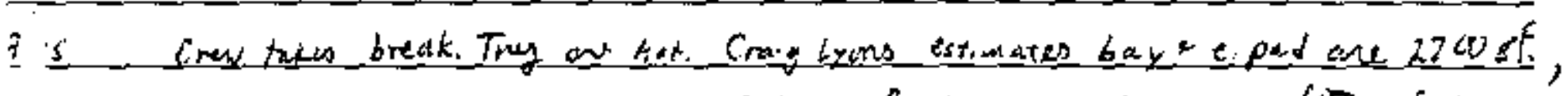

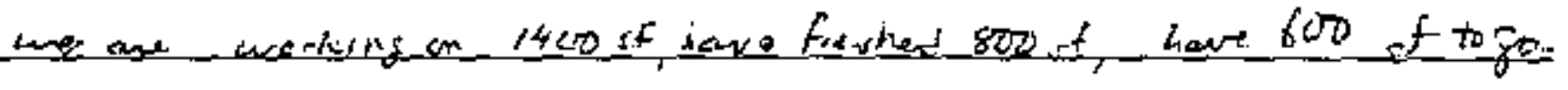

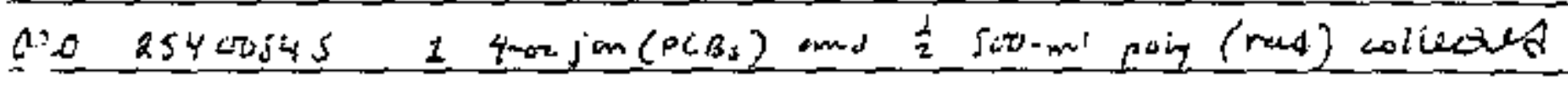

$\therefore$ bagin chipeng ar 254005s9

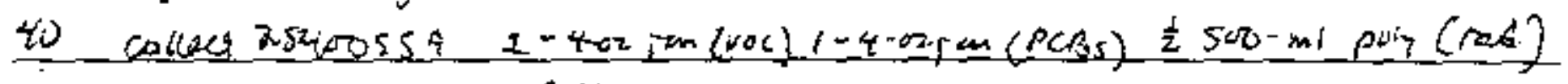
$\therefore s$ bosin_chippingiat 25400542

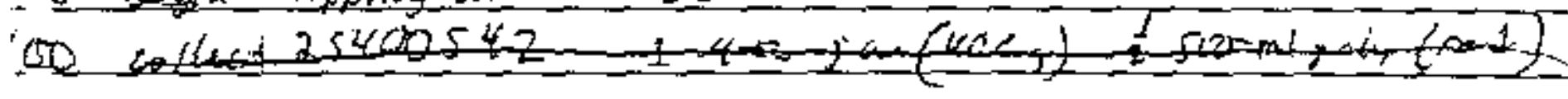

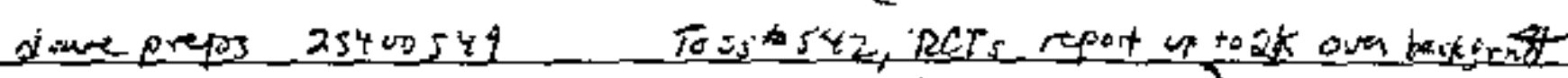

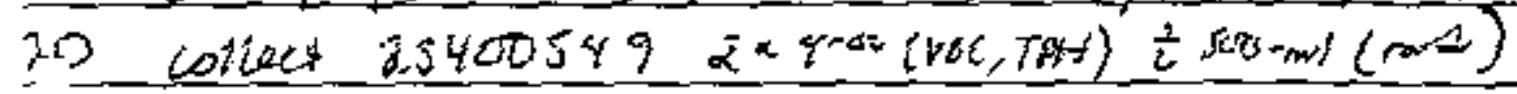

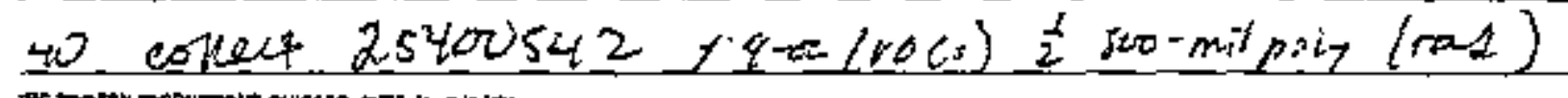

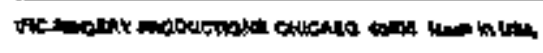

Work contimued to Page tmunte

V. EDTO ANB UNDERSZCOD EY

Butetir

bart $7 / 31 / 0 /$

OATE $6-79$ i WHESS

DATE 
56 TITLE

$0 / 31 / 01$ continued

PROJECT NO.

Work continued from Page

BOOK No.

350 Dare Minizzzom props to sample 25400516

14000 25400516 collected: 1 4 -or $\left(\mathrm{VOC}_{2}\right)$

1430 Cine Cook resits w/ Q Q id Jensen awe John Davies

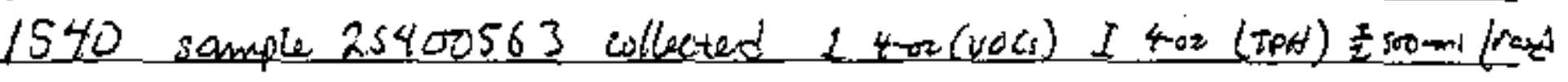

1720 return to form $\mathrm{C}$, process samples

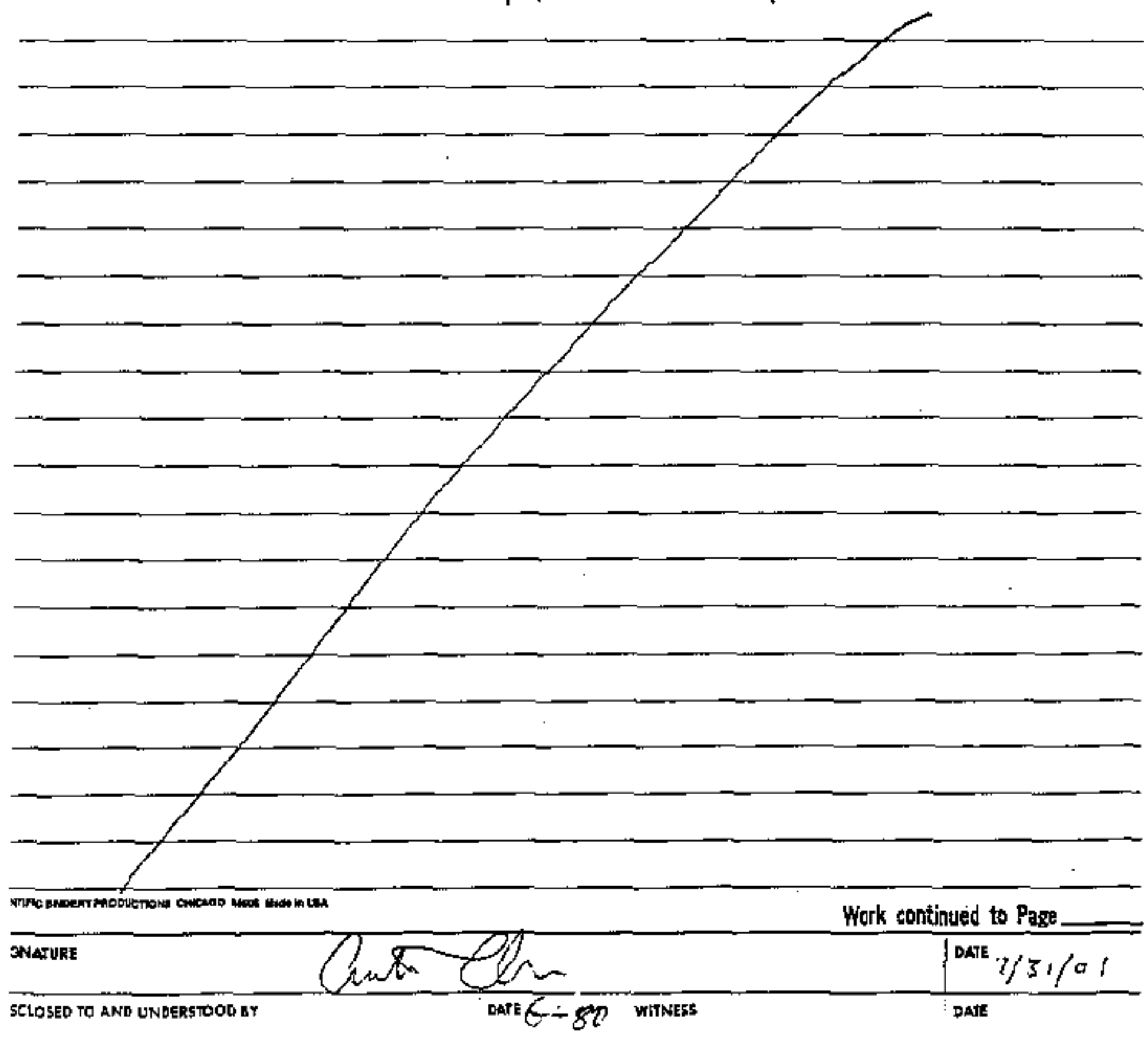




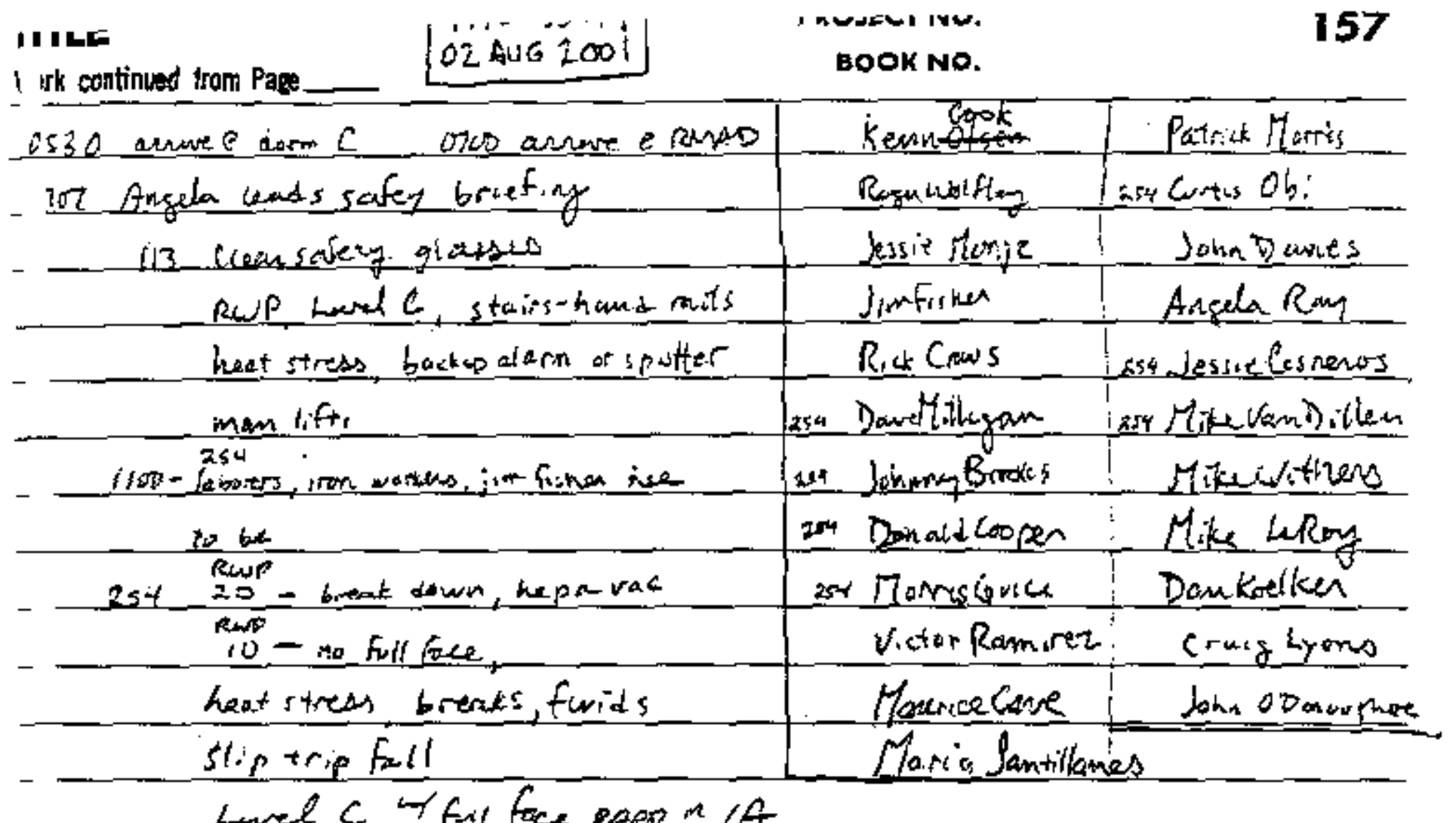

buel $C$ if fit face parain IA

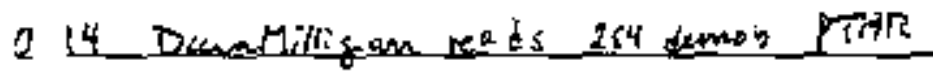

Rizen waifly rads II J P IftR

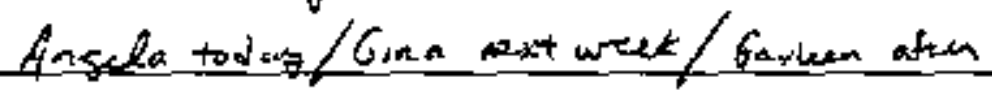
254 Plan - Suitup

Find vibrate

Ches. " C Craing

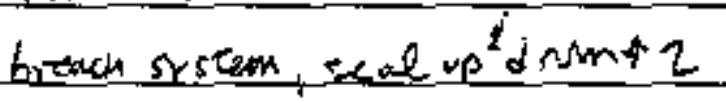

femove treal heres

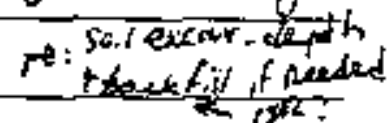

ghase wi Hastes

Sweepup thepa vac

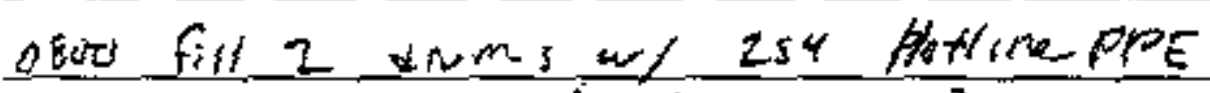

mure to $M W A A$ (swat 200$)$

2835 remove can af GE Cons-te grease

move non-rad lead to Hw relable

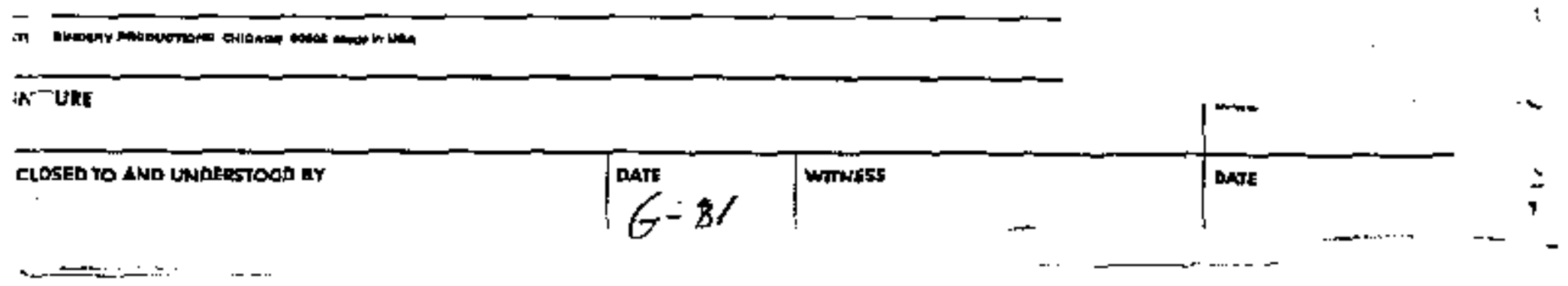


158 TITLE

Work continued from Page

$3 / 2 / 2001$ Ontwed

PROJECT NO.

BOOK NO.

is -gallom capacty black plastie trom

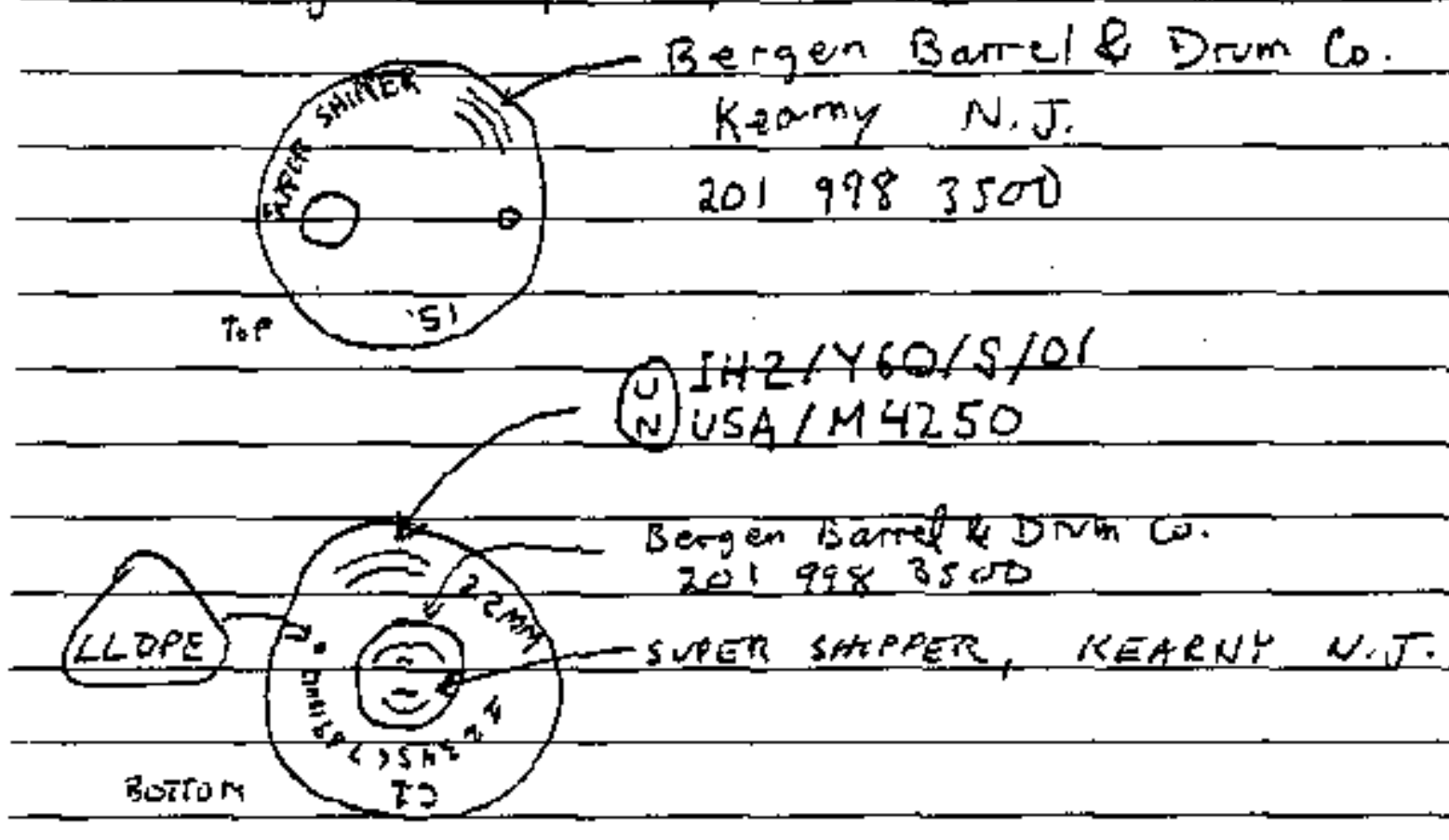

There ane 3-15-9al Cep DNms in t-1WAA

"G/14/2001 A.rS isiur Coolemt DoO4" $24 \mathrm{cal}$

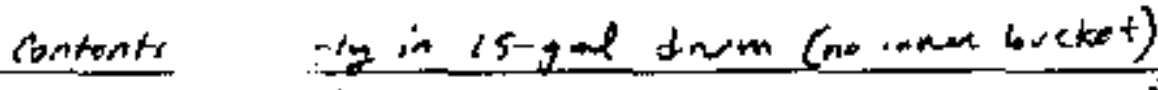

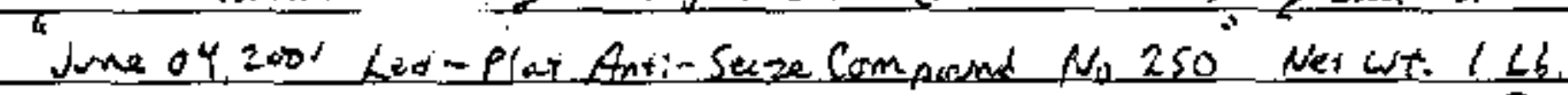

Contents in an open-top (nd lid) white s-yed busket (no (D) code) a betlf-filled 1-16.tin can (approk th pini ar l cup culf)

August 02,2001 Nm-rad head (Brisks, Pipe Coll ans)

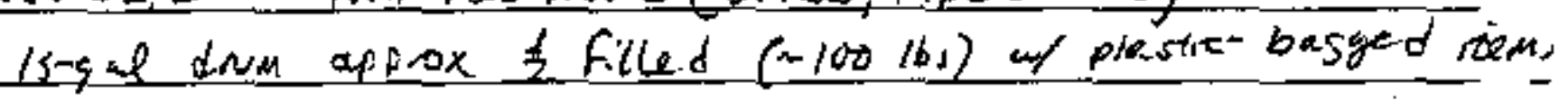

there is 1 5s-gal lap. Drom in non-haz $A A$

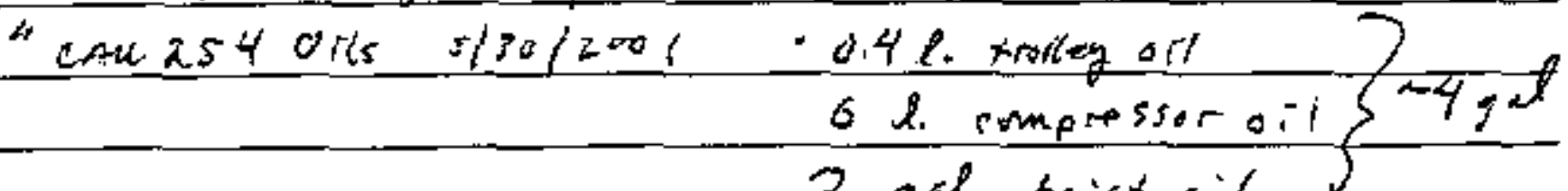

2 gal haist oil

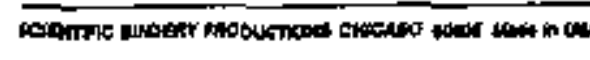

SIGNATURE

Work continued to Page

otsctosed ig and undotsitrod ar

Dare 92

WTiniss

ante 
PROJECT NO.

BOOK NO.

159

I E

* continued from Page

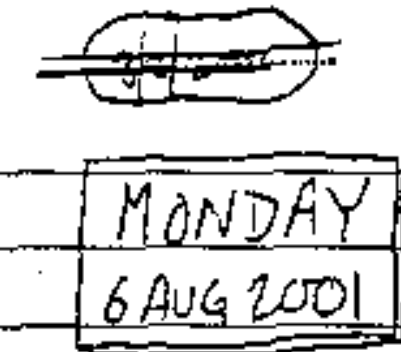

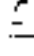

:

:

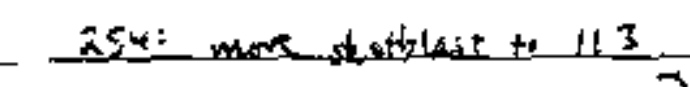

$-$

$-$

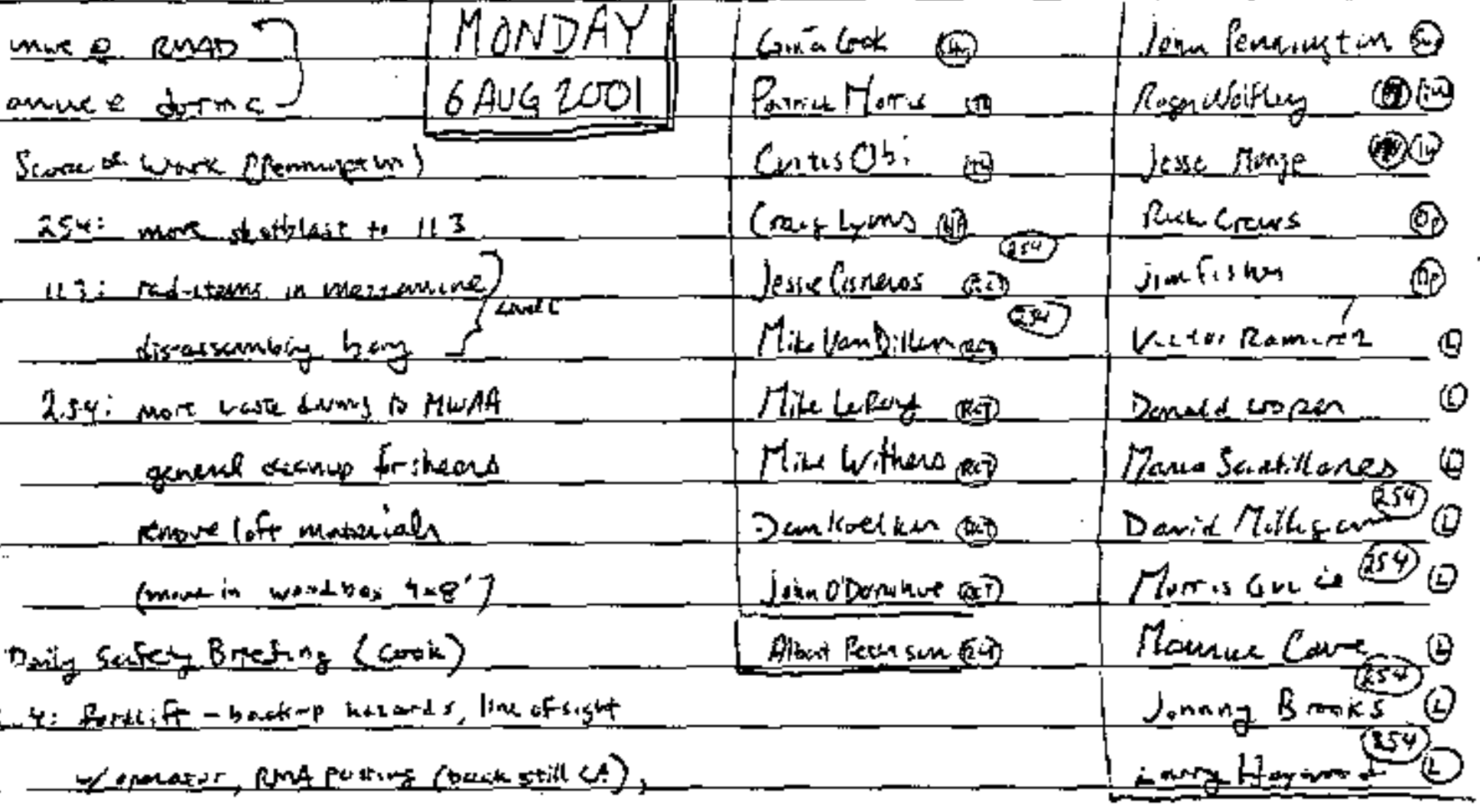

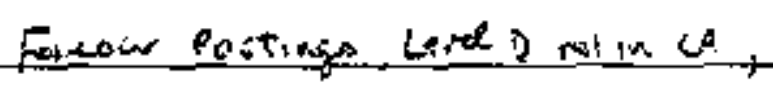

- Weabian hurand-lughinins, hout itress,

- CPIZ/F.rT-aid.

I contume movary high rand trein

scossur fiff, PPE cavel $C$.

wed $8 / 8$ 12-is FMaD traning

follow paxtivgn, heat stress,

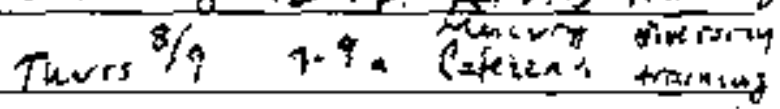

B. medication

3 bor bex repert (Pennimeron)

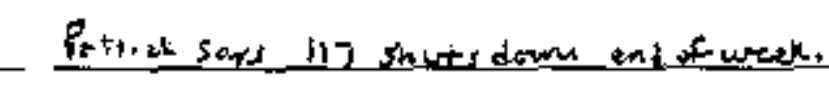

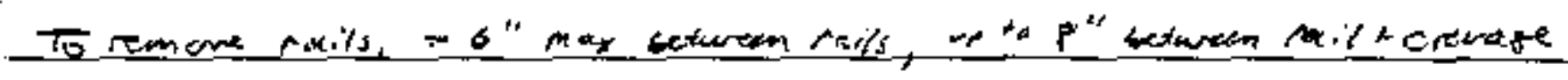

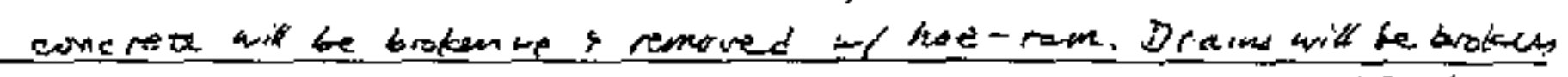

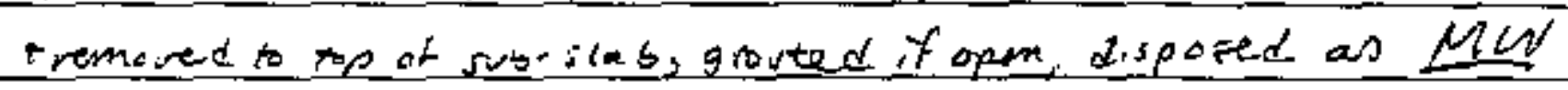

Liep to mave $255-5$ ad arme and 2.255 al awms to MUSA

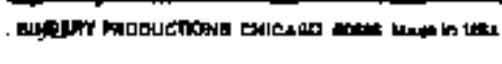

TU...

Work continued to Page

To AND UNDerstoon ar

! 60.83

Date $8 / 6 / 21$

ISt TO AND UNDERSTOOD ar

WITESs

I AATE

5
0
5
0
0
0
0 
SO TITL

Work continued from Page____

$8 / 6 / 0 ;$ contriated

cqso diams mored to MWAA, fortift (rescows) now moving shotblast to 113 .

1300 Howy fery and Adaw Dagarn ansue

Letre insulation is of for $P C B_{s}$, no ad jet

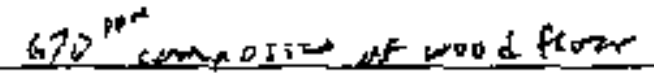

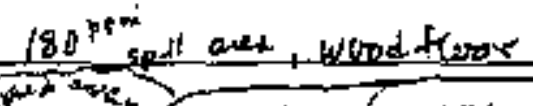

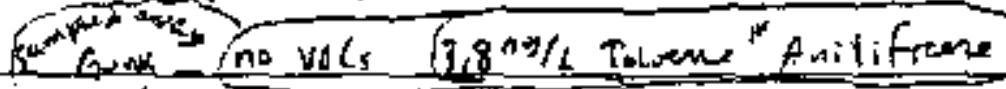

$$
\text { nesvals. }
$$

PROJECT NO.

BOOK NO. 
TITLE

rork continued fron Page

$$
\text { IVESDAY }
$$

PROJECT NO.

BOOK NO.

161

0535 anne e $100 \pi$.

0700 arrare \& Maro
Join penningt on

Rick creus

Rugu walflan

Jessich $1 \mathrm{~cm}$ le

Masis Santillanes

Yasuice Aars

$V_{1}$ tur Ramirz

David Mitisan

Momsquice

Jimfirinen

Damad loopes
Gina Cok

Patriek Moris

Curtes obi

Cragetyons

jesse itinews

fire ram trilen

Mike LeRoy

Mike withers

Dan Kuelken

3 on 25 Cook: 254 Da.ity Satity Brefing

Drst contal, Leve D, tong steeres)

Do not walk wade forielif load.

Wash op hinds, arm, face, afenwands

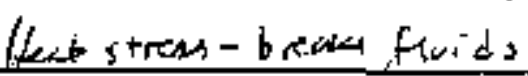

5 .

RMA may change to $A$ doc to

changing scope, be avione of

re-posting of ances.

1830 Pck rinth anives

1

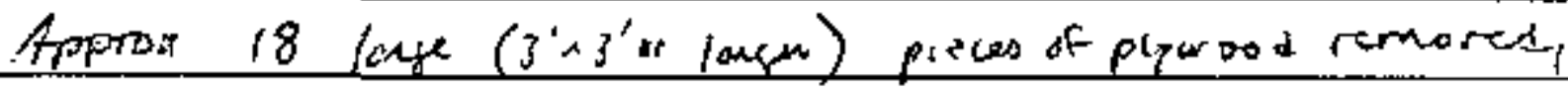

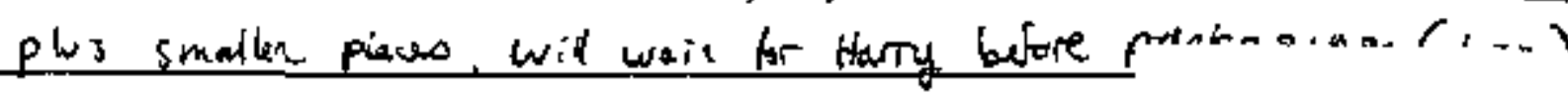

$\therefore$ soo done, srew moves on to other tasks

5 weshup then do PTitR to do gix setap, erc.

SHATURE

SCLESED TO AND UNDERSTOQD IY

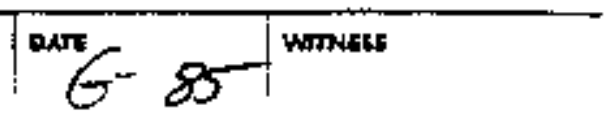


62 TITLE

8) plo, continued

PROJECT NO.

Work continued from Page

BOOK NO.

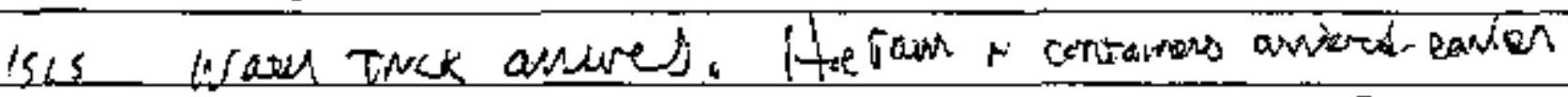
1530 . Move pleasing frappes bundle of Loft floor wood to Nan -han AA, Patrick and forty wild consider then PCB as applied product pea 260 . Rad is nomusue for $N \rightarrow 3$ landfill if below sum of fraction

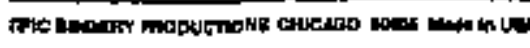

Work continineed to Page

NATURE

i HINESE

! DATE

OSES TO AND UNDERSTOOD BY

$6-86$

( 
$\because \xi$

$\left.\begin{array}{l}\text { WENESOAL } \\ 3 \text { AUE } 2001\end{array}\right]$

PROJECT NO.

163

continued from Pagt

BOOKNO.

T

2) asnue 0 dormb

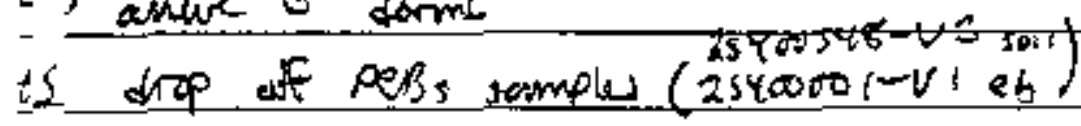

X. anwer e mad

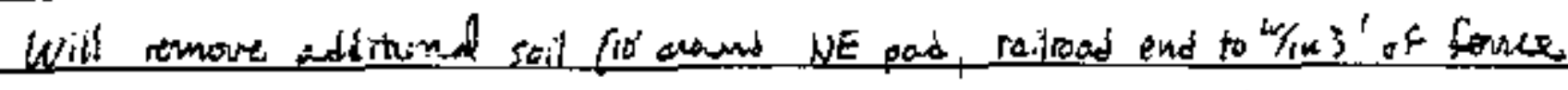
Will remone un-needed fencing at wert and of compound.

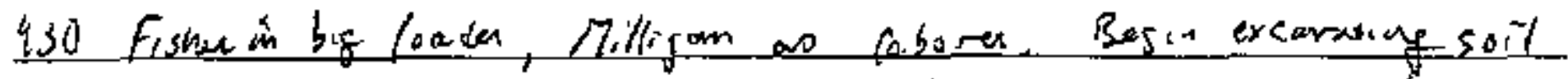
Crang tyons has expend ereas nir. ME Pad, recosed anea 0 ro end.

2E Etheis Training

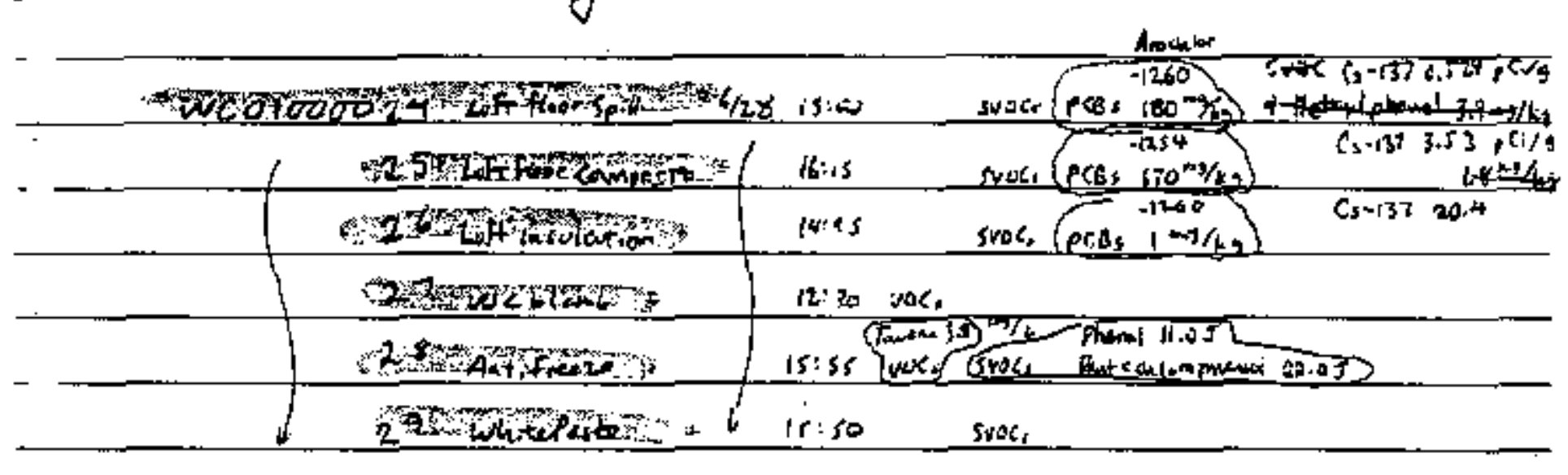

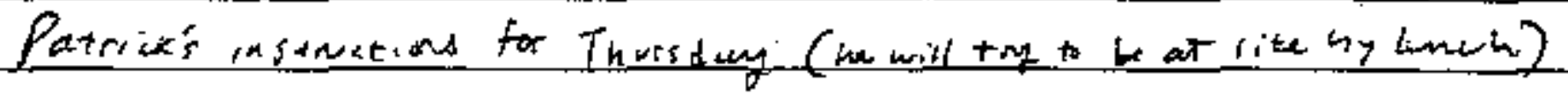

Cmtime remone of tems from mezamnins of drasseming bay De-Post CA t RMA for outen areas (repost CA at inven dours)

Test Descon of remevable rad under plates.

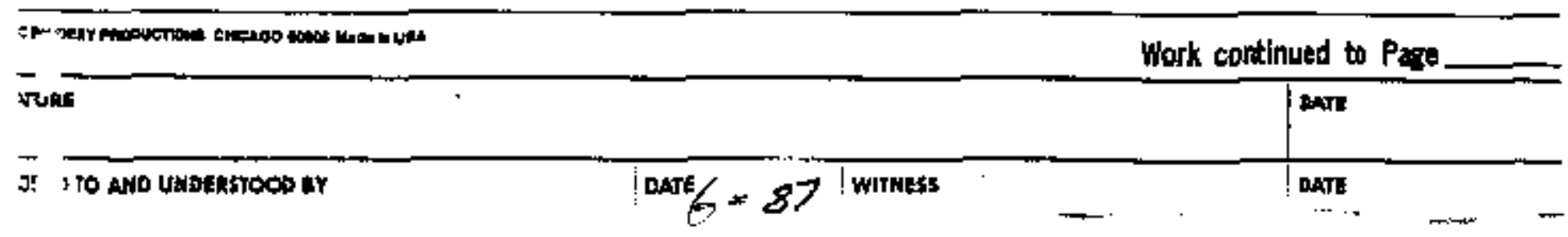


164 TITLE

Work coutinued Irom Page
THURSDAV

IAUG 200
PROJECT NO.

BOOK NO.

ds3s anvere $e$ ists

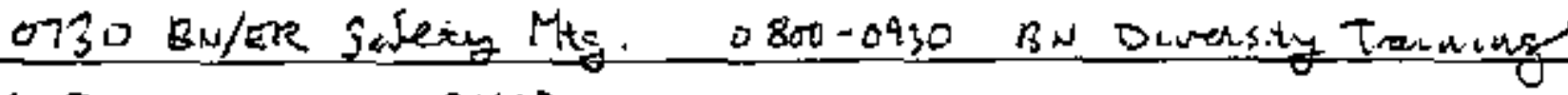

1030 anwe e RMAD

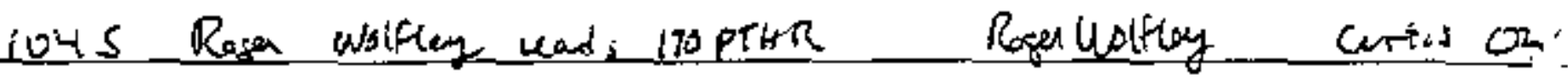

5 wiz drain water From tanps jessin lionge.

Ginawok

100 Vusorthoned lave for-Area 6

Jien fosher

Crighern

Rack Grews Dankelke

1120 Gina ans keity safery briefing

Larry Laywood

nikeletw

2S5: Irein wate from tomes

Denatd Coones

10

coventing sidecumps,

Vitor Ramets

install un blvetarp.

Maunce Cave

113: rencere redictions "rese.

Marie Samtillames

remure toois $*$ cords \% resp.

remere rots fon traps

15

Ladder safeing, went zoned

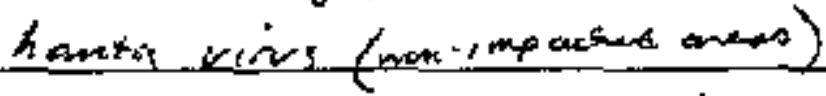

Oyleir has when wetanng boroties

seek assistance if therded.

20 inork-brek regiming

25

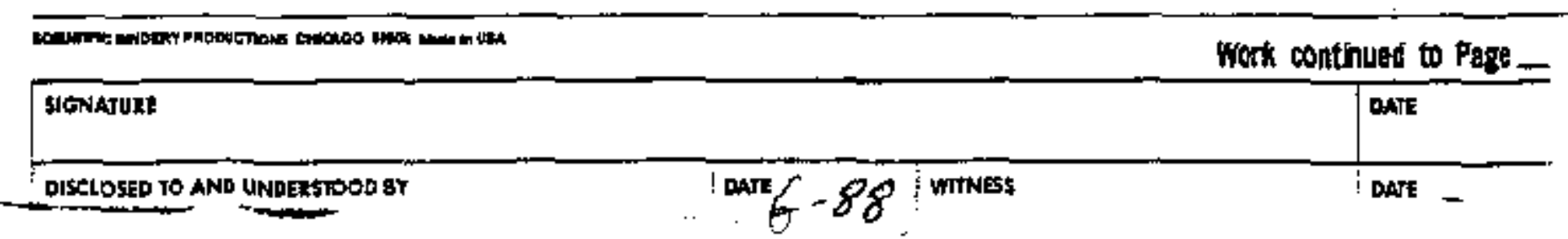


TITLE

mowjel Mw.

61

lork continaed from

BOOK NO.

$10-31-0)$

Solveritertur somptory of Cso 254 .

ton 1320 remp $70^{\circ}$ shirs clew sol fomptren Ewh en hriecus deg.

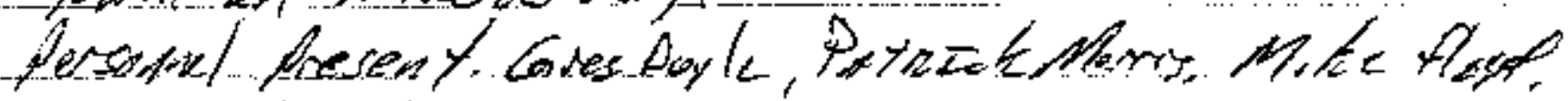
Inionthenst

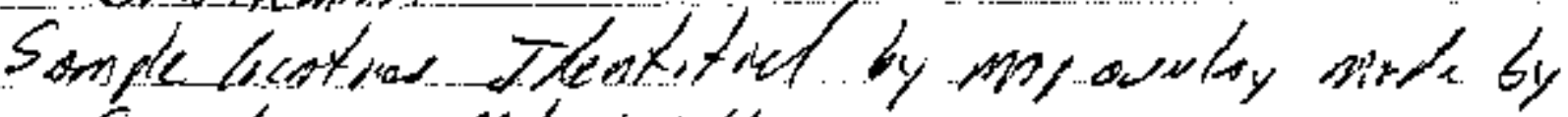

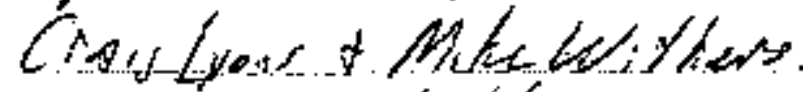

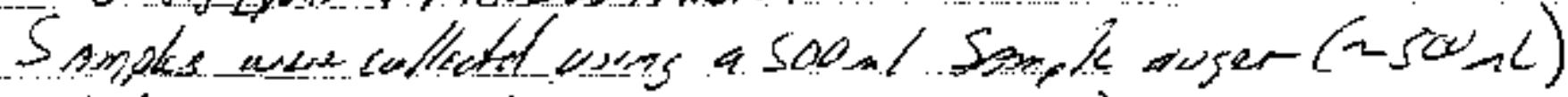

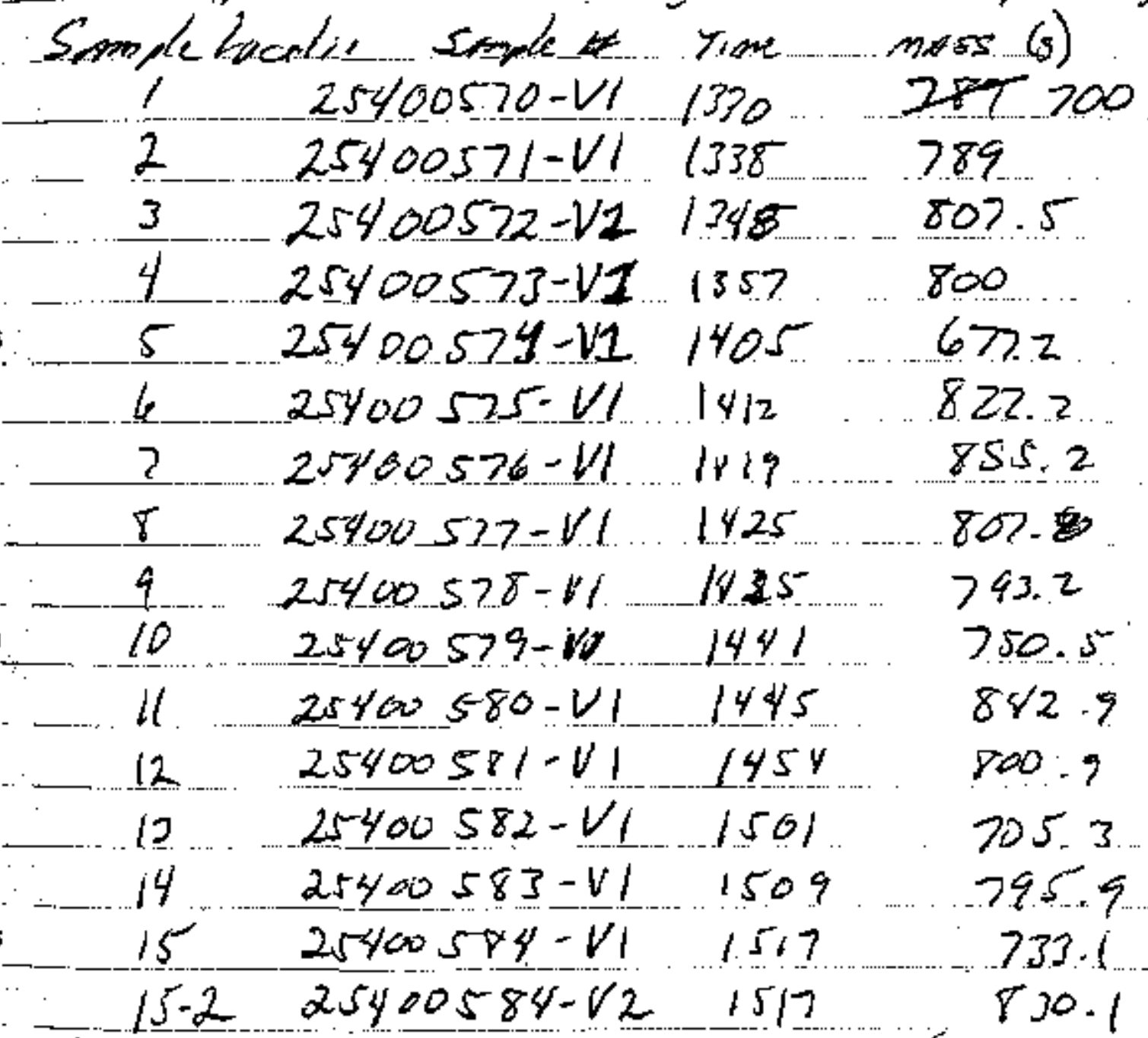

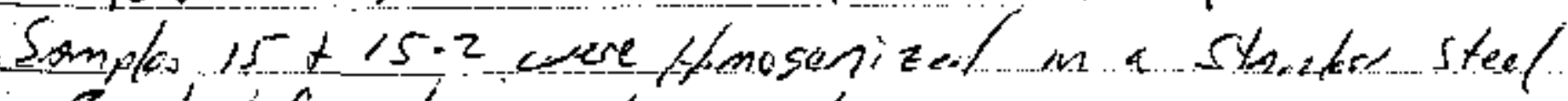

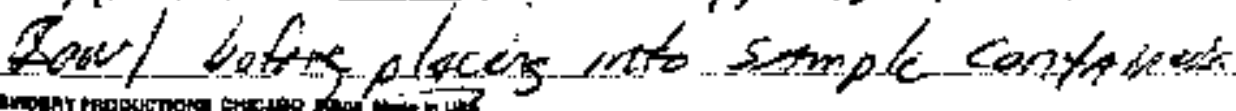

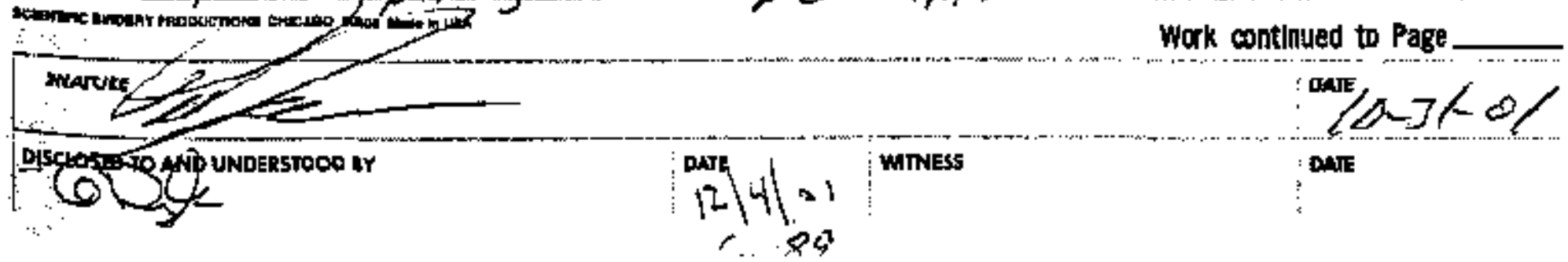


APPENDIX H

\section{PROJECT ORGANIZATION}


THIS PAGE LEFT INTENTIONALIYY BLANK

H-ii 


\section{APPENDIX H}

\section{TABLE OF CONTENTS}

Project Organization $\ldots \ldots \ldots \ldots \ldots \ldots \ldots \ldots \ldots \ldots \ldots$ 
THIS PAGE LEFT INTENTIONALIY BLANK

H-iv 


\section{PROJECT ORGANIZATION}

The U.S. Department of Energy, National Nuclcar Sectrily Administration Nevada Operations Office (NNSANV) Project Manager or Task Manager will serve as the primary point of contact for all activities conducted for this project. The NNSANV Project Manager is responsible for seeing that all activities conducted during the project fulfil] the obligations of NNSANV as described in the Federal Facility Agrement and Consent Order (FFACO) (FFACO, 1996) and the Nevada Division of Environmental Protection (NDEP) approved work plan. The NNSANV Project Manager will plan, authorize, and contro] project work so that activitics afc completed in accordance with the work plan on schedule and within budget. The NNSAVNV Project Manager will be the primary point of contact with the NDEP. The NNSANV points of contact for this project are as follows:

Project Manager: Janet Appenzeller-Wing

Telephone Number: (702) 295-0461

Task Manager: Sabine Curtis

Telephone Number: (702) 295-0542

The identification of the project Health and Safety Officer and the Quality Assuramce Officer can be found in both the Field Management Plan and the Site-Specific Health and Safery Plan. However, personnel are subject to change and it is suggested that the Project Manager be contacted for further informalion. 
THIS PAGE NTENTIONALIY LEFT BLANK 


\section{APPENDIX I}

\section{COMMENT RESPONSE DOCUMENTATION}


THIS PAGE LEFT INTENTIONALlY BLANK

I-ii 


\section{APPENDIX I}

\section{TABLE OF CONTENTS}

Comment Response Documentation $\ldots \ldots \ldots \ldots \ldots \ldots \ldots \ldots$ 1-5 
THIS PAGE LEFT INTENTIONALLY BLANK 


\section{NEVADA ENVIRONMENTAL RESTORATION PROJECT DOCUMENT REVIEW SHEET}

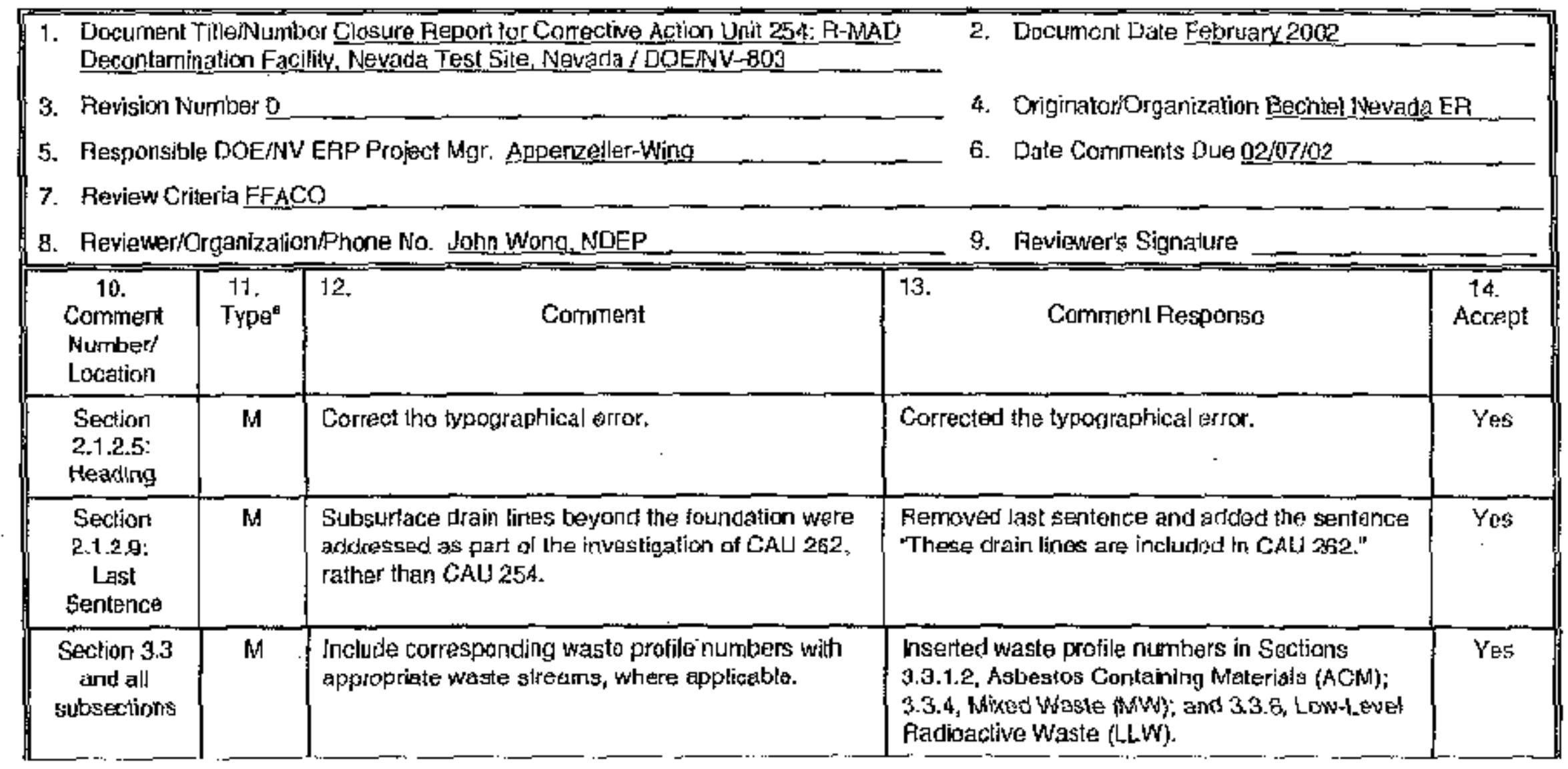




\section{NEVADA ENVIRONMENTAL RESTORATION PROJECT DOCUMENT REVIEW SHEET}

Docurnent Tille/Number

Revision Number

Aeviewer/Organization

\begin{tabular}{|c|c|c|c|c|}
\hline $\begin{array}{c}10 . \\
\text { Comment } \\
\text { Numbert } \\
\text { Locatkun }\end{array}$ & $\begin{array}{l}11 . \\
\text { Type }\end{array}$ & Comment & Comment Rosponse & $\begin{array}{c}14, \\
\text { Accept }\end{array}$ \\
\hline Section 4.0 & M & 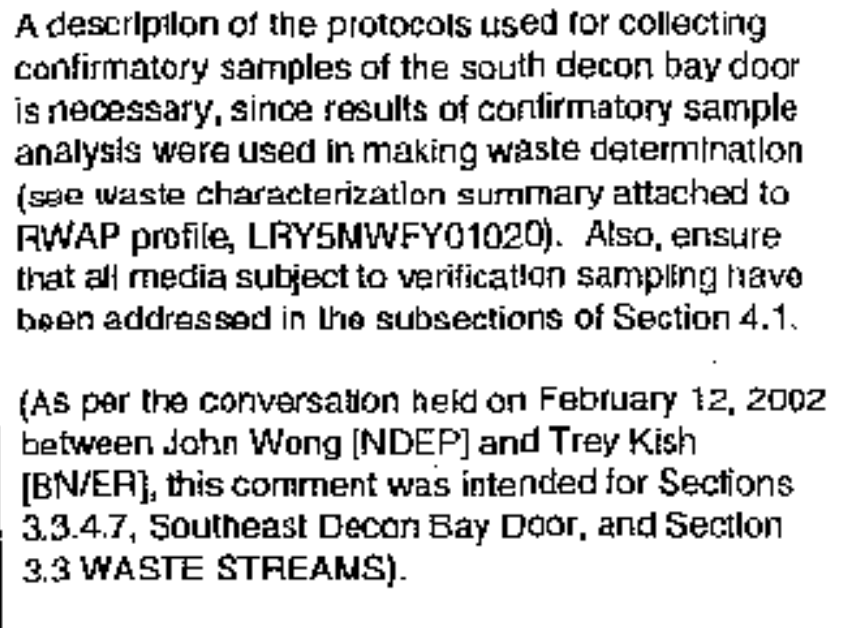 & 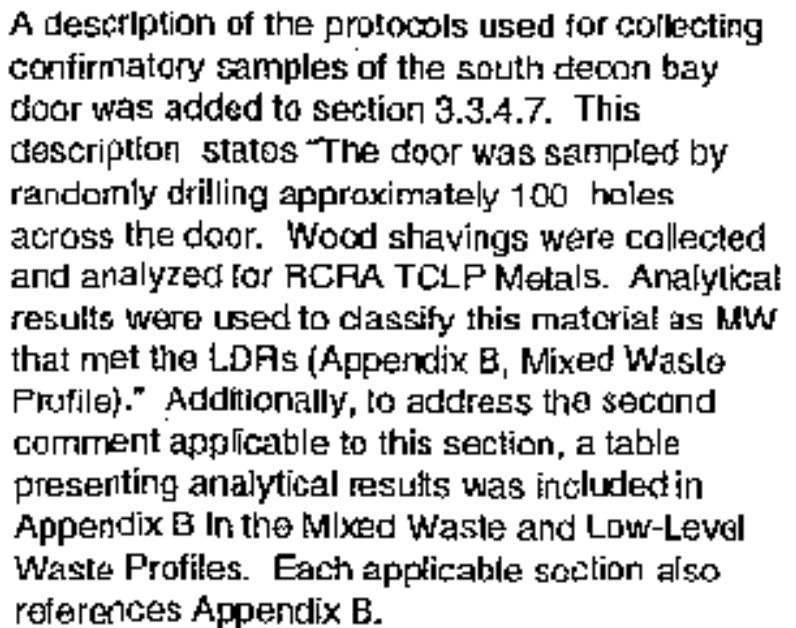 & Yes \\
\hline
\end{tabular}

a " Comment Types: $M=$ Mándatory, $S=$ Suggested.

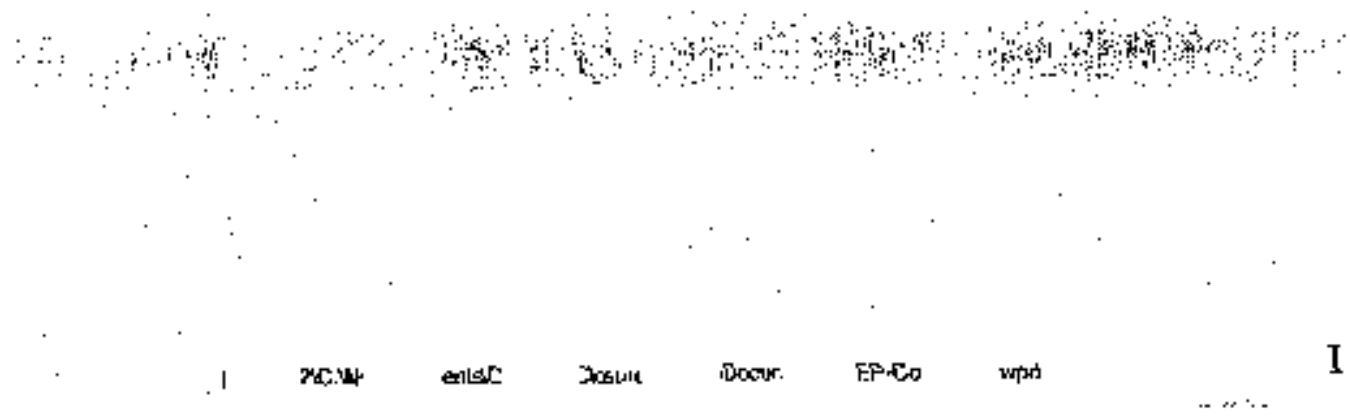




\section{DISTRIBUT1ON LIST}

$-$

$\rightarrow$

-

$-$ 
THIS PAGE LEFT DNTENTIONALLY BLANK 


\section{DISTRIBUTION LIST}

*Provide cepy of initial distribution or Revision 0; remainder of list gets Revision 0 if appowed witinout changes. The entine list receives Revision 1, if issued.

\section{Nevarla Divisison of Envlronnental Protection}

Paul Licbendorter

Burcau of Federal Facillitie:

Division of Envirommental Protcetion

333 W. Nye Late, Room I3B

Carson Ciry, NV 89706-0866

Supervisor, Las Vegas Office

Bureau of Federal Facilities

Division of Environmental Protection

Sawyer State Building

555 E. Washington, Suite 4300

Las Yegas, NV B9101-1049

\section{U.S. Department of Enerwy}

Janet Appenzeller-Wing

Project Manager

Enwironmental Restoralion Division

U.S. Department of Energy

Vational Vuclear Security Administration

Nicvada Operations Office

P.O. Box 98518 MVS 505

Las Vegas, NV B9193-8518

Sabine Curtis

1 (Uncontrolied)*

1 (Lincontrolled)*

Envivummentall Restoracran Di vision

U..S. Depurtment of Energy

Nitional Nuciear Security Administration

Nevada Operations Dftice

P.O. Box $98518 \mathrm{M} / \mathrm{S} 505$

Las Vegas, NV 89193-7518 


\section{DISTRIBUTION LIST (Continued)}

\section{L.S. Department of Energy (Continued)}

Sabrina Lawience

1 (Cintrolled)*

Ervironmental Restoration Division

L.S. Department of Energy

National Nuclear Security Administration

Newada Operations Office

P.O. Box $98518 \mathrm{M} / \mathrm{S} 505$

las Vegas, NV 89193-8518

L.S. Department of Energy

2 (Uincontrolled,

Office of Scientific and Technical In Tormalion

electronic copy)

P.O. Box 62

Qak Ridge, TN 37831-0062

U.S. Department of Energy

1 (Uncontrolled)

National Nuclear Sesurity Adrninistration

Nevada Operations Office

Technical Intormation Resource Center

P.O. Box 98521 M/S 5015

Las Vegas, NV 89193-8521

U.S. Department of Energy

2 (Controlled \&

National Nuclear Securily Administration

Uncontrolled)b

Nevada Operations Office

Public Reading Facility

P.O. Box $98521 \mathrm{M} / \mathrm{S}$ NLV040

Las Yegas, NV $89193-8521$

\section{Rechtel Nevada}

Correspundence Control

1 (Creontrolled)*

Bechtel Nevada

P.O. Box $98521 \mathrm{M} / \mathrm{S}$ NLV608

Lu3 regas, NV $83193-8521$ 


\section{DISTRIBUTION LIST (Continued)}

\section{Bechtel Neyada (Continued)}

Envirotimental Maragertent Library

1 (Lincontrolled) ${ }^{*}$

Bechtel Nevada

P.O. Box 98521, W/S NLV080

Lits Veges, NV 89193-8521

Greg Doyle

I (Lincontrolled)*

Bechtel Nevada

P.O. Box 9852 I MS NTS306

Las Vegas, NV 89193-852L

Anл Heiclema

1 (Uncontrolled)*

Bechtel Nevada

P.O. Box 98521 M/S NLV022

I.us Vegas, KV 89193-852!

Wayne Johrson

1 (Uncontrolled)*

Bechtel Nevada

P.O. Box 98521 MSS NTS306

Las Vegas, VV 89193-8521

Craig Lyons

1 (Uncontrolled) ${ }^{*}$

Bechtel Nevada

P.O. Box $98521 \mathrm{M} / \mathrm{S}$ NTS306

Las Vegas, NV 69193-852]

Patrick Morris

1 (Uncontrolled) ${ }^{*}$

Bechtel Nevada

P.O. Box 98521 M/S NTS306

Las Yegas, NV B9193-8521 


\section{DISTRIBUTION LIST (Continued)}

\section{Bechtel Nevada (Continued)}

Steve Nacht

I (Lincontrolled)*

Bechiel Nevada

P.O. Box 9852 L MS NTS306

Las Vegas, NV 89193-852 I

\section{IT Corporation}

Lупл Kidman

1 (Uncontrolled)*

IT Corporation

P.O. Box $93838 \mathrm{M} / \mathrm{S} 439$

Las Vcgas, NV 89193-8521

Gary Romano

1 (Controlled)

1' FFACO Support Office

IT Corporation

P.O. Box $93838 \mathrm{M} / \mathrm{S} 439$

Las Vegas, NV g9193-8521

\section{State Of Nevada}

Manager, Nouthers Nevada

FiACO Public Reading Facility

Nevada State Library and Archives Federal Publicntions

100 North Stewart Strcct

Curson Ciry, Nv 89701-4285
2 (Uncontrolled

(Controlled \& 